$$
\begin{aligned}
& I 19.3: 2053 \\
& 620
\end{aligned}
$$

\title{
Tertiary Stratigraphy of
}

\section{Highly Extended Terranes,}

\section{California, Arizona, and Nevada}

\section{3}

\section{U.S. GEOLOGICAL SURVEY BULLETIN 2053}

Mr।

?

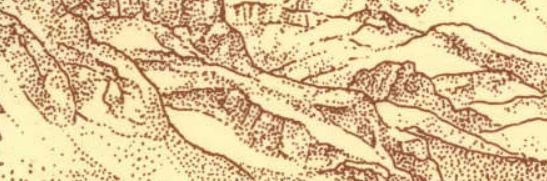





\section{Tertiary Stratigraphy of \\ Highly Extended Terranes, \\ California, Arizona, and Nevada}

David R. Sherrod and Jane E. Nielson, Editors

U.S. GEOLOGICAL SURVEY BULLETIN 2053

Proceedings of a workshop held at the Desert Research Center,

Soda Springs (Zzyzx), California, February 9-12, 1990

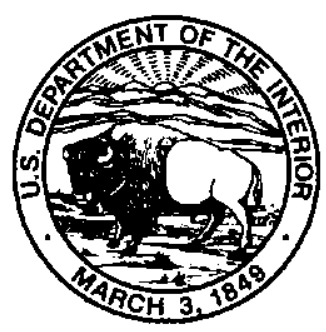

UNITED STATES GOVERNMENT PRINTING OFFICE, WASHINGTON : 1993 


\title{
U.S. DEPARTMENT OF THE INTERIOR BRUCE BABBITT, Secretary
}

\author{
U.S. GEOLOGICAL SURVEY \\ Robert M. Hirsch, Acting Director
}

For sale by the Books and Open-File Report Sales

U.S. Geological Survey

Federal Center, Box 25286

Denver, CO 80225

Any use of trade, product, or firm names in this publication is for descriptive purposes only and does not imply endorsement by the U.S. Government

Manuscript approved for publication December 4, 1992

Library of Congress Cataloging in Publication Data

Tertiary stratigraphy of highly extended terranes, California, Arizona, and Nevada : proceedings of a workshop held at the Deser Research Center, Soda Springs (Zzyzx) California, February 9-12, 1990 / edited by David R. Sherrod and Jane E. Nielson.

p. $\quad$ cm. - (U.S. Geological Survey bulletin; 2053) Includes bibliographical references.

Supt. of Docs. no.: I 19.3:2053

1. Geology, Stratigraphic-Tertiary-Congresses. 2. Geology-California-Congresses. 3. Geology-Nevada-Congresses.

4. Geology-Arizona-Congresses. I. Sherrod, David R. II. Nielson-Pike, Jane E. III. Series.

QE75.B9 no, 2053

[QE691]

$557.3 \mathrm{~s}-\mathrm{dc} 20$

93-20080

[551.8'8'0979 


\title{
FOREWORD
}

\author{
By Ivo Lucchitta ${ }^{1}$
}

\section{THE ORIGIN}

This volume is a collection of stratigraphic data and interpretation that was presented at a workshop held in February 1990 called "Tertiary Stratigraphy of Highly Extended Terranes, Southem Basin and Range," at the Desert Research Center of the California State University System, Soda Springs, near Baker, California (this site is also called Zzyzx). The workshop was convened by a consortium of organizers chaired by Richard W. Hazlett (Pomona College). Besides myself, the consortium included Kathi K. Beratan (now at the University of Pittsburgh), Neil H. Suneson (Oklahoma Geological Survey), Gerald F. Brem (California State University, Fullerton), and Jane E. Nielson (U.S. Geological Survey).

The collaboration of all contributors has made this volume possible. Additional burdens were shared by authors of the introductory articles, and special thanks are owed to numerous technical reviewers; every one of the authors and reviewers contributed significantly to the quality and internal consistency of the volume. Most papers were reviewed in groups that form the volume chapters: Chapter 1, K.K. Beratan and J.P. Calzia; Chapter 2, E.T. Wallin and L.S. Beard; Chapter 3, N.H. Suneson and R.J. Miller; Chapter 4, J.C. Yarnold and M.E. Tennyson. Reviews of individual papers were done by A.F. Glazner, G.B. Haxel, W. Hildreth, K.A. Howard, N.K. Huber, Jill McCarthy, D.M. Miller, A.M. Sarna-Wojcicki, and H.G. Wilshire.

\section{THE MOTIVATION}

Insights that followed the development of plate-tectonic theory have enabled earth scientists to improve greatly their understanding of tectonic processes that operate within ocean basins and at the interface between oceans and continents. In contrast, a satisfactory understanding of the processes that operate within continents has lagged, not because of inadequate effort but because of the character of continents themselves. Continents are a kind of palimpsest in which the record of each new geologic event is superposed on records of earlier events. The superposition modifies and even erases parts of the record. Moreover, this record is not a passive inventory of geologic features that have accumulated over time but an active ingredient that can influence successive events. To coin an aphorism, the present reflects the past and influences the future.

Continental extensional processes have been the focus of studies in terranes of the U.S. Cordillera over the past decade. Most studies have focused on the structural and tectonic aspects of the extended terranes, building on and expanding such earlier work as that by Davis (1925) and Nolan (1943). These studies have led to the formulation of inquiries into how the crust extends and to many useful insights; for example, that the causes and effects of extension probably involve the deep crust and upper mantle.

Studies in zones of extension show that such terranes characteristically feature one or more low-angle normal faults, known as detachment faults, that separate horizontally stacked crustal plates. Normal faulting and basin formation occurred as a result of detachment fault displacement and dismemberment of the upper plate on high-angle normal faults, which terminate at or merge with the underlying detachment faults. Displacement on the detachment faults locally juxtaposed upper-crustal rocks, including syntectonic surface deposits, against plutonic and metamorphic middle-crustal rocks. Thus, middle Tertiary sedimentary and volcanic rocks commonly are preserved above the higher-level detachment faults, in blocks bounded by high-angle normal faults.

\footnotetext{
'U.S. Geological Survey, 2255 N. Gemini Drive, Flagstaff, AZ 86001
} 
Most research has focused on structure; these studies described the plates and detachments and applied field observations to the wider question of how the continental lithosphere behaves during extension. Until recently, local and regional stratigraphy of the syntectonic deposits has been relatively neglected. Yet it is precisely these deposits that contain perhaps the most complete record of structural events that define the extension. Consequently, the information contained in the syntectonic deposits is a powerful tool for understanding the process of extension and should be valued accordingly.

The great value of stratigraphic data that had been accumulated over the last decade of work in metamorphic core complexes led us to organize the Zzyzx workshop and caused the organizers to intentionally focus it narrowly on the stratigraphy of highly extended terranes. We chose to start with the general area of the lower Colorado River extensional corridor in the southern Basin and Range province of the Western U.S., which is currently of great interest and increasingly well studied. Information from surrounding, geologically related regions was also included. The workshop was attended by many of the researchers active in the region, so that pooling of the information resulted in new and, in some cases, surprising insights.

The aim of the workshop was to synthesize information on the following topics, as applied to the Tertiary rocks in the area of interest:

-Preextension paleogeography

-Location, size, and depth of basins

-Age of basin formation

- Diachroneity of basin formation

-Source areas for basin sediments, and changes in source areas through time

-Age, diachroneity, and location of volcanism

-Environment of deposition and paleoclimate

In preparation for the workshop, participants assembled and presented stratigraphic columns of their study areas. These columns formed the data base for numerous discussions at the workshop and preliminary syntheses that were drawn from them.

Knowing that the information is of interest to researchers involved directly in studies of the particular region, besides those who were able to attend the workshop, we have compiled the columns and summaries in this volume. We expect that the data will be useful to many other researchers with a general interest in highly extended terranes beyond the borders of the southern Basin and Range.

\section{REFERENCES CITED}

Davis, W.M., 1925, The Basin and Range problem: National Academy of Science Proceedings, v. 11, p. 387-392.

Nolan, T.B., 1943, The Basin and Range province in Utah, Nevada, and California: U.S. Geological Survey Professional Paper 197-D, p. 141-196. 


\title{
PREFACE
}

\author{
By David R. Sherrod ${ }^{1}$ and Jane E. Nielson ${ }^{2}$
}

\section{INTRODUCTION}

This volume presents stratigraphic information for Tertiary rocks exposed in highly extended terrane of the southern Basin and Range province, southwestern United States (fig. 1). The information is arranged as a series of stratigraphic columns (pls. 1-3). The lithologic details for each column, and interpretations of them, are found in papers that form the volume text (chapters 1-4). To aid presentation, the columns and chapters have been grouped by geographic areas; arbitrary boundaries of the areas generally correspond to routes of the U.S. Interstate Highway system (fig. 1). From north to south these areas are the (1) northern area, north of Interstate Highway 40, (2) central area, part of the region between Inter-

'U.S. Geological Survey, 5400 MacArthur Blvd., Vancouver, WA 98661

${ }^{2}$ U.S. Geological Survey, Mail Stop 975, 345 Middlefield Road, Menlo Park, CA 94025

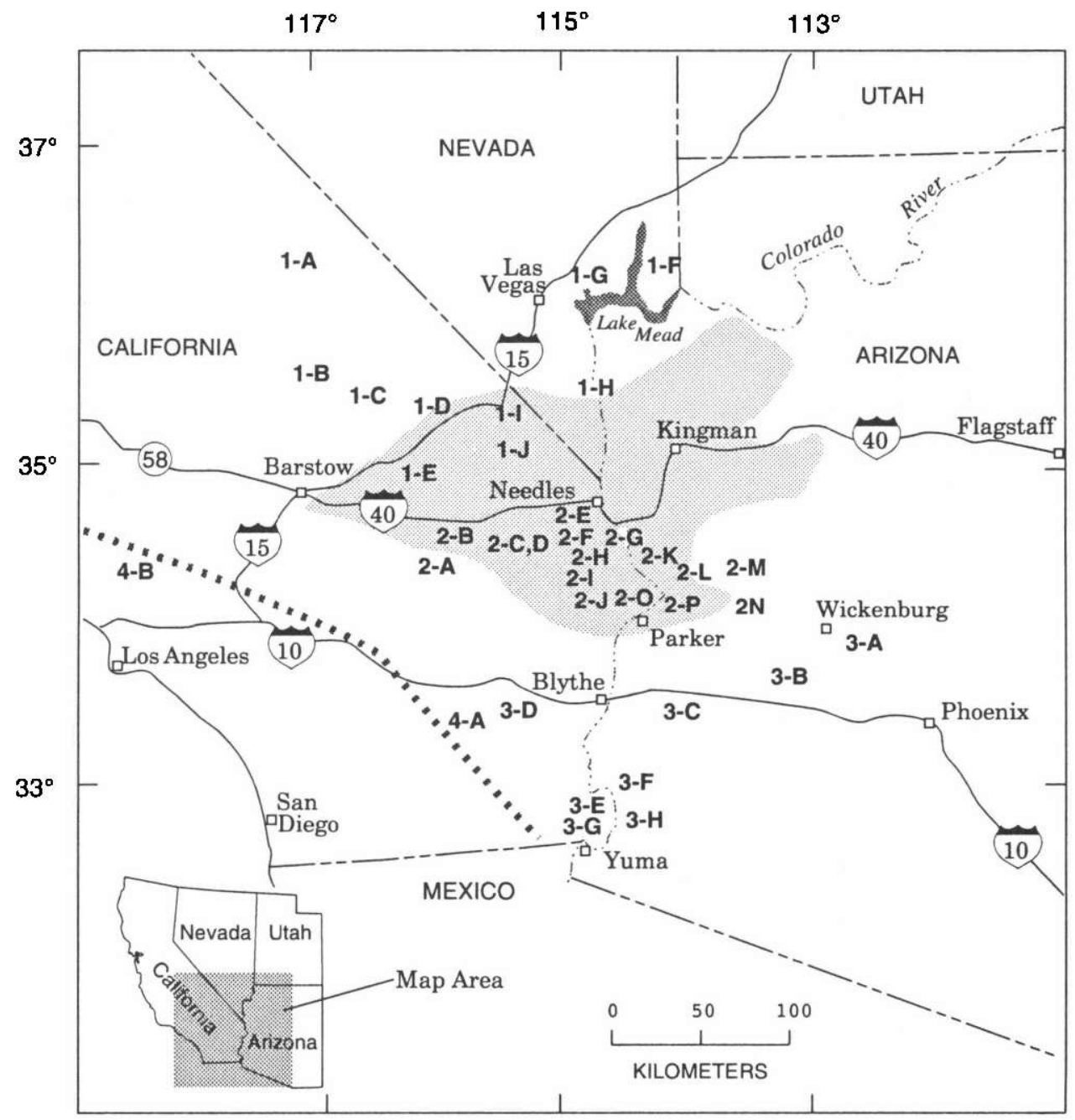

Figure 1. Map showing location of Tertiary stratigraphic sequences discussed in this volume. Shaded area is currently known extent of outcrops of the Peach Springs Tuff of Young and Brennan (1974; see Buesch, this volume). Broken line is San Andreas fault zone. 
state Highways 40 and 10, (3) southern area, part of the region between Interstate Highway 10 and the Mexican border (this third grouping includes two columns north of I-10 near Wickenburg), and (4) far western area, columns from two areas along the San Andreas fault zone in southern California.

Time, not thickness, is represented on the vertical axis of the stratigraphic columns. This technique emphasizes the timing of events; it is perhaps most widely used on charts showing the Correlation of Stratigraphic Units of North America (COSUNA), which were published by the American Association of Petroleum Geologists. Any horizontal line drawn to connect columns becomes a temporal datum. For example, the Peach Springs Tuff of Young and Brennan (1974), which is a widespread 18.5-Ma pyroclastic flow deposited in many of the areas studied, will appear at the same vertical position on columns that depict it. So, too, will widespread erosional hiatuses and region-wide tectonic events.

Lost by this presentational style is the visual impact of depositional thickness. For example, a graben that formed and filled rapidly will be represented by a relatively thin band of rocks on the stratigraphic column regardless of how thick the infilling deposits may be; a thick caldera-fill unit that forms an entire mountain range but that was deposited by caldera eruptions over a few decades would appear vanishingly thin. The time extent of such units may require exaggeration to be shown on a time-based column.

\section{HOW THE COLUMNS WERE ASSEMBLED}

Individual stratigraphic columns were drafted by authors at a vertical scale of 1 inch $=1$ million years for presentation at the Zzyzx conference held in February 1990 (see "Foreword"). The columns were later reduced by 50 percent and edited to establish consistent use of lithologic terms, drafting patterns, and line conventions. At that time the individual authors prepared manuscripts in order to minimize the amount of descriptive text accompanying the columns and to fully reference the sources of information used. All isotopic and paleontologic ages are presented with the columns to indicate the number of dated horizons, and the sources of age information are included with the articles. The columns are presented on plates 1, 2, and 3 (in pocket) and are keyed to their corresponding articles.

\section{INTERPRETING THE COLUMNS: SOME EXAMPLES}

\section{LITHOLOGIC PATTERNS, BRIEF DESCRIPTIVE NAMES, AND AGES}

An explanation for the lithologic patterns is included on each plate. Rocks are grouped according to conventional field criteria, such as grain size or roundness in clastic rocks (sandstone versus siltstone; conglomerate versus breccia), or composition in volcanic rocks (mafic, intermediate, silicic). Areally or stratigraphically significant pyroclastic flows have their own pattern (ash-flow or welded tuff). Shown merely as tuff (undivided) are ash-rich stratigraphic sequences that include air-fall deposits, epiclastic volcanic rocks, and individual pyroclastic-flow deposits of limited usefulness as stratigraphic markers.

Numerous other distinctions are shown in brief title lines on the right side of each column. Whether a sandstone is volcaniclastic or arkosic may be highlighted there. Formal and informal stratigraphic names also are listed on the right side where applicable. Age criteria are shown on the left side of the column. Numerical ages (for example, "13.2 \pm 0.5 ") indicate the results of isotopic methods, chiefly potassiumargon dating. Ages determined by other techniques are indicated in text. Land mammal ages (for example, "Clarendonian") indicate paleontologic age assignments based on fossils. See the articles for discussions of age criteria.

\section{CONFORMITIES, DISCONFORMITIES, AND UNCONFORMITIES}

Pattemed areas on the stratigraphic columns indicate rock units, and where separated by horizontal lines, the units represented are concordantly layered and presumably deposited without significant time or structural breaks. Any diagonal line represents a time-transgressive contact or event. Rock units that were 
deposited instantaneously, such as ash-flow tuff or basalt flows, are shown with exaggerated thickness because of the uncertainties in isotopic ages.

Unpatterned areas indicate the passage of time without deposition. If the bounding lines are straight, the gap is a disconformity or what some workers call an erosional or parallel unconformity. The amount of time that elapsed between deposition of units is indicated by the vertical extent of the unpatterned area. Wavy lines indicate angular unconformities, which in the extended terranes of the southern Basin and Range commonly are seen in the field as tilted stratigraphic units overlain by gently dipping or flat-lying units.

An interesting example that illustrates these relations comes from the Lake Mead area. The informally named red sandstone unit of Bohannon (1984) is locally bounded by angular unconformities with the underlying Horse Spring Formation and the overlying Muddy Creek Formation (Wallin and others, this volume). The red sandstone unit is interbedded with variably tilted components of the basaltic andesite of Callville Mesa, which was erupted sporadically in late Miocene time (fig. 2). Potassium-argon ages and field relations indicate that tilting of the red sandstone unit and extrusion of the basaltic andesite of Callville Mesa occurred synchronously over 2 million years (Duebendorfer and Wallin, 1991; Feuerback and others, 1991), creating internal disconformities.

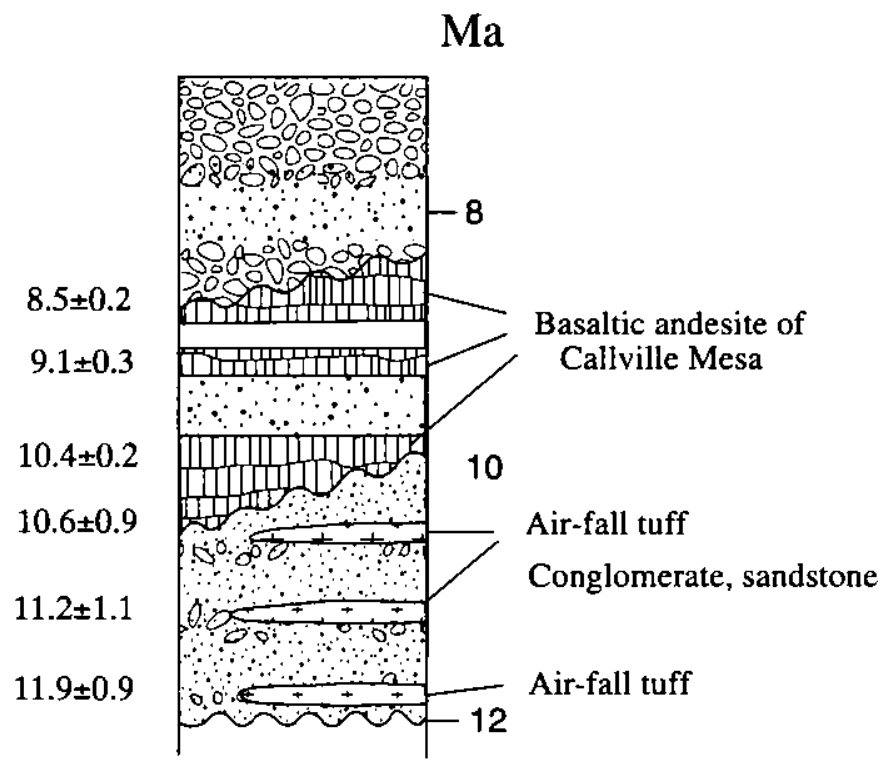

\section{EXPLANATION}

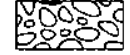

$\because \because: ?$

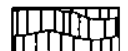

$+\div++$

$\sim \sim$

\section{Conglomerate}

Sandstone

Basalt and basaltic andesite

Tuff

Angular unconformity

Figure 2. Stratigraphic column showing Miocene basaltic andesite of Callville Mesa and its relation to adjacent units (from Wallin and others, this vol.). A disconformity within the unit of basaltic andesite and sedimentary rocks is indicated by the unpatterned area (nondeposition) and its bounding horizontal lines; unconformities are shown by wavy lines that bound the upper and lower parts of the basaltic andesite unit. Isotopic age determinations (in Ma) on left side of column; linear time scale on right. 
Many unconformities developed during very short time intervals. For example, figure 3 shows unconformities bounding both the top and bottom of the Peach Springs Tuff deposit in the Chemehuevi Mountains (Miller and John, this volume), yet the represented interim may be as short as 0.5 million years. In this example, previously deposited rocks probably were undergoing tilting at the time the Peach Springs Tuff was erupted, and tilting continued after the tuff was emplaced. Queries on unconformities and disconformities indicate uncertain age of development. Some unconformities are of uncertain interpretation because of poor exposures, and these problems are discussed in the articles.

Faults are shown as bold horizontal or inclined lines on a few columns in order to indicate that some contacts have no depositional significance. Many large and small blocks in the southern Basin and Range are fault bounded, and intricate fault patterns can be mapped at nearly any scale of field study; however, the columns emphasize stratigraphic relations. The evidence for depositional relations between Tertiary stratigraphic sequences and their underlying pre-Tertiary rocks can be determined for most areas studied.

$\mathrm{Ma}$

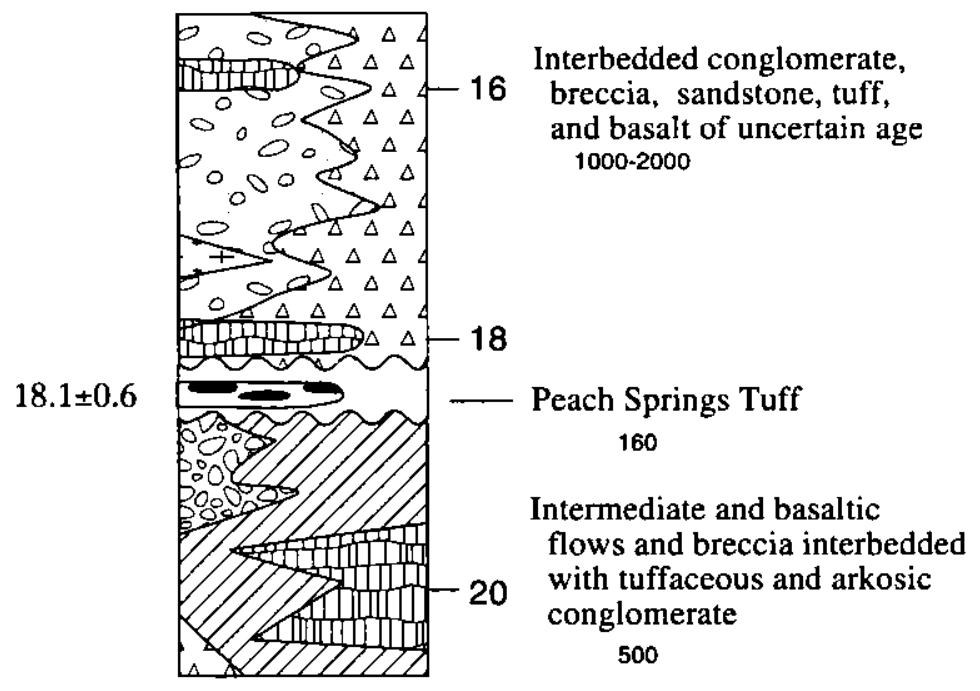

EXPLANATION

\begin{tabular}{|c|c|}
\hline 60 & Conglomerate and sandstone \\
\hline$\Delta \Delta \Delta \Delta$ & Breccia \\
\hline 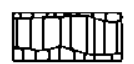 & Basalt and basaltic andesite \\
\hline++++ & Tuff \\
\hline & Ash-flow tuff \\
\hline 30004 & Conglomerate \\
\hline BDPA & Intermediate lava \\
\hline 500 & Unit thickness, in meters \\
\hline
\end{tabular}

Figure 3. Stratigraphic column showing Peach Springs Tuff and its unconformable relation to adjacent units in the Chemehuevi Mountains, as indicated by the wavy lines (from Miller and John, this vol.). Thickness of units (in meters) shown after each unit description. Isotopic age determination from Chemehuevi Mountains shown on left side of column; linear time scale on right. 


\section{REFERENCES CITED}

Bohannon, R.G., 1984, Nonmarine sedimentary rocks of Tertiary age in the Lake Mead region, southeastern Nevada and northwestem Arizona: U.S. Geological Survey Professional Paper 1259, 72 p.

Duebendorfer, E.M., and Wallin, E.T., 1991, Basin development and syntectonic sedimentation associated with kinematically coupled strike-slip and detachment faulting, southem Nevada: Geology, v. 19, no. 1, p. 87-90.

Feuerbach, D.L., Smith, E.I., Shafiqullah, M., and Damon, P.E., 1991, New K-Ar dates for late Miocene to early Pliocene mafic volcanic rocks in the Lake Mead area, Nevada and Arizona: Isochron/West, no. 57, p. 17-20.

Young, R.A., and Brennan, W.J., 1974, Peach Springs Tuff: its bearing on structural evolution of the Colorado Plateau and development of Cenozoic drainage in Mohave County, Arizona: Geological Society of America Bulletin, v. 85 , no. 1 , p. 83-90. 


\section{CONTENTS}

Foreword, by Ivo Lucchitta.

III

Preface, by David R. Sherrod and Jane E. Nielson

CHAPTER 1, NORTHERN AREA, CALIFORNIA, ARIZONA, AND NEVADA

Introduction to the Area North of I-40: Between Lake Mead, Nev. and Needles, Calif., by Ernest M. Duebendorfer, Eugene I. Smith, and James E. Faulds

Columns

1-A. Tertiary Strata of the Ubehebe Basin and Northern Cottonwood Mountains, Death Valley Region, Calif., by J. Kent Snow.

1-B. Neogene Sedimentary Rocks in the Southern Owlshead Mountains: Constraint on Displacement of the Eastern Garlock Fault Zone, by Roland H. Brady, III

1-C. Stratigraphy of the Avawatz Formation, Southern Death Valley Region, Southeastern Calif., by Jon E. Spencer.

1-D. Erosion, Deposition, and Detachment: The Halloran Hills Area, Calif., by Robert E. Reynolds.

1-E. Cenozoic Stratigraphy and Structure of the Northern Bristol Mountains, Calif., by Roland H. Brady, III

1-F. Tertiary Stratigraphy of the South Virgin Mountains, Southeast Nev., and the Grand Wash Trough, Northwest Ariz., by Sue L. Beard

1-G. Tertiary Stratigraphy of the Lake Mead Region, by E. Timothy Wallin, Ernest M. Duebendorfer, and Eugene I. Smith

1-H. Miocene Stratigraphy of the Central Black Mountains, Northwestern Ariz.: Variations Across a Major Accommodation Zone, by James E. Faulds

1-I. Tertiary Stratigraphy and Structure of the Castle Mountains and Castle Peaks, Calif. and Nev., by Jane E. Nielson, Ryan D. Turner, and Allen F. Glazner ..

1-J. Tertiary Stratigraphy and Structure of the Piute Range, Calif. and Nev., by Jane E. Nielson and John K. Nakata

Topical Paper: Feldspar Geochemistry of Four Miocene Ignimbrites in Southeastern Calif. and Western Ariz., by David C. Buesch.

\section{CHAPTER 2, CENTRAL AREA, CALIFORNIA AND ARIZONA}

Introduction to the Area South of I-40 and North of I-10, Calif. and Ariz., by Jane E. Nielson, Keith A. Howard, and Allen F. Glazner.

Columns

2-A. Cenozoic Stratigraphy of the Lead Mountain and Valley Mountain Areas, Eastern Bullion Mountains, Southeastern Calif., by Keith A. Howard.

2-B. Cenozoic Deposits in the Lava Hills and Southern Bristol Mountains, Southeastern Calif., by David M. Miller .

2-C, D. Stratigraphy of the Southern Ship Mountains and Little Piute Mountains, Southeastern Calif., by Martin A. Knoll.

2-E. Geologic Framework of Middle Tertiary Strata, Northern Sacramento Mountains, Southeastern Calif., by Christopher M. Fedo.

2-F. Tertiary Stratigraphy of the Central Sacramento Mountains, Southeastern Calif., by Julia M.G. Miller and Brad R. Leach.

2-G. Tertiary Stratigraphy of the Chemehuevi Mountains, Southeastern Calif. and Western Ariz., by Julia M.G. Miller and Barbara E. John 
CHAPTER 2-Continued

Columns

2-H. Cenozoic Stratigraphy of Northern Chemehuevi Valley and

Flanking Stepladder Mountains and Sawtooth Range, Southeastern Calif., by Keith A. Howard, Peter P. Christiansen, and Barbara E. John

2-I. Tertiary Stratigraphy and Structure of the Northern Turtle Mountains, Calif,, by Jane E. Nielson and John K. Nakata

2-J. Stratigraphic Section of the Central Mopah Range, Calif., by Richard W. Hazlett

2-K. Stratigraphic and Structural Correlation of Tertiary Strata of the Mohave Mountains and Aubrey Hills, Ariz., by Jane E. Nielson.

2-L. Stratigraphic Section of the Castaneda Hills-Signal Area, Arizona, by Ivo Lucchitto and Neil $H$. Suneson

2-M. Middle Tertiary Stratigraphy of the Northem Rawhide Mountains and Artillery Mountains, Ariz., by John C. Yarnold.

2-N. Stratigraphy of Middle Tertiary Rocks in the Central and Eastern Buckskin Mountains, West-Central Ariz., by Jon E. Spencer and Stephen J. Reynolds

2-O. Tertiary Stratigraphy of the Southern Whipple Mountains, Southeastern Calif., by Kathi K. Beratan

2-P. Preliminary Stratigraphic Reevaluation of Upper Tertiary Units, Osborne Wash Area, La Paz County, Ariz., by Anna V. Buising and Kathi K. Beratan.

Topical Paper: Stratigraphic Overview of the Bouse Formation and Gravels of the Colorado River, Riverside Mountains, Eastern Vidal Valley, and Mesquite Mountain Areas, Calif. and Ariz., by Anna V. Buising

\section{CHAPTER 3, SOUTHERN AREA, ARIZONA AND CALIFORNIA}

Introduction to Tertiary Stratigraphy of the Area South of I-10, Ariz. and Calif., by Stephen M. Richard and David R. Sherrod.

Columns

3-A, B. Tertiary Stratigraphy of a Transect from the Hieroglyphic to the Big Horn Mountains, West-Central Ariz., by Stephen M. Richard.

3-C. Tertiary Stratigraphy of the New Water Mountains, Ariz., by David R. Sherrod

3-D. Tertiary Stratigraphy of the Little Chuckwalla Mountains, Southeastern Calif., by David P. Mayo.

3-E. Tertiary Stratigraphy of the Southern Trigo Mountains, Ariz., and Eastern Chocolate Mountains, Calif.: Picacho State Park Area, by David R. Sherrod and Kathleen M. Hughes.

3-F. Tertiary Stratigraphy of the Middle and Chocolate Mountains of Southwestern Ariz., by Stephen M. Richard.

3-G. Stratigraphy of the Ferguson Wash Area, Southeastern Calif., and Adjacent Parts of Southwestern Ariz., by Stephen M. Richard

3-H. Tertiary Stratigraphy of the Laguna Mountains, Yuma County, Ariz., by James P. Lombard .

Topical Paper: The Conglomerate of Bear Canyon (Miocene), Chocolate Mountains, Southeastern Calif., by Kathleen M. Hughes

Topical Paper: Tertiary Basin Structure Revealed in Seismic Reflection Profiles
from Milpitas Wash, Southeastern Calif., by Rebecca S. Morris............... 


\section{CHAPTER 4, WESTERN AREA NEAR THE SAN ANDREAS FAULT ZONE, CALIFORNIA}

Introduction to Tertiary Rocks of the Far West Basins, by John C. Crowell.

Columns

4-A. The Diligencia Formation, Orocopia Mountains, Southeastern Calif., by John C. Crowell....................................................................... 239

4-B. Soledad Basin, Central Transverse Ranges, Calif., by Eric D. Hendrix... 243

\section{PLATES}

[In pocket]

1. Stratigraphic columns for chapter 1 from the area north of I-40 in Calif., Ariz., and Nev., between Lake Mead, Nev., and Needles, Calif.

2. Stratigraphic columns for chapter 2 from the central area, south of I-40 and north of I-10, Calif. and Ariz.

3. Stratigraphic columns for chapter 3 from the area south of I-10, Ariz. and Calif., and chapter 4 from the area near the San Andreas fault zone, Calif. 


\title{
Introduction to the Area North of I-40: Between Lake Mead, Nev., and Needles, Calif.
}

\author{
By Ernest M. Duebendorfer ${ }^{1}$, Eugene I. Smith ${ }^{2}$, and James E. Faulds ${ }^{3}$
}

The region between Lake Mead, Nevada, and Needles, California, contains parts of the Mojave, Great Basin, and southern Basin and Range physiographic provinces. The area, which lies north of U.S. Interstate Highway 40 , includes parts of the Death Valley pull-apart system (Wernicke and others, 1988), the eastern Mojave extensional belt (Dokka, 1989) and the northern Colorado River extensional corridor (Howard and John, 1987; Faulds and others, 1990).

\section{STRUCTURAL SETTING}

The principal Tertiary structures between Lake Mead and Needles include an east-dipping detachment fault system in the south (Davis and others, 1980; Spencer, 1985; Howard and John, 1987; John, 1987), a west-dipping detachment fault system in the north (Wernicke, 1985; Weber and Smith, 1987; Wernicke and others, 1988), the Black Mountains accommodation zone between them (Faulds and others, 1990), and the Lake Mead, Las Vegas Valley, and Garlock strike-slip fault systems (Anderson, 1973; Bohannon, 1979; 1984; Longwell, 1960; 1974; Burchfiel, 1965; Burchfiel and others, 1974; Smith, 1962) (fig. 1).

The east-northeast-dipping detachment system in the southern part of the region is exposed on Homer Mountain and in the neighboring Newberry, Sacramento, and Dead Mountains (Spencer, 1985). Initiation of extension in this area is poorly constrained, but had ended by about 14.6 Ma (Spencer, 1985). The west-dipping detachment system in the north may be composed of several low-angle normal faults that were active at different times. Faults of this system are exposed in the South Virgin Mountains (Wernicke and Axen, 1988; Fryxell and others, 1992), in the western Lake Mead area at Saddle Island (Smith, 1982; Choukroune and Smith, 1985; Duebendorfer and others, 1990), and in the Death Valley region (Burchfiel and others, 1987; Wernicke and others, 1988). Detachment fault-

\footnotetext{
'Department of Geology, Northern Arizona University, Flagstaff, AZ 86011 89154

${ }^{2}$ Department of Geosciences, University of Nevada, Las Vegas, NV

${ }^{3}$ Department of Geology, University of Iowa, Iowa City, IA 52242
}

ing in this system is loosely constrained between about 16 and $9 \mathrm{Ma}$ in the Lake Mead region and occurred from late Miocene to present in the Death Valley region.

The most likely join between the east- and westdipping detachment fault systems is the 40 -km-long Black Mountains accommodation zone, which separates an area $\left(15,000 \mathrm{~km}^{2}\right)$ of east-tilted fault blocks to the north from one $\left(25,000 \mathrm{~km}^{2}\right)$ of dominantly west-tilted blocks to the south (Faulds and others, 1990). This east-striking zone is exposed as a 10-km-wide belt of intermeshing conjugate normal faults. The lack of strike-slip displacement along transverse segments of the zone indicates little relative movement between the upper-plate rocks of opposing detachment terranes. In areas close to the accommodation zone, tilting in both the west- and east-tilted domains occurred primarily between 16.4 and 13.1 Ma (Faulds and others, 1990).

The Lake Mead fault system is a complex zone of northeast-striking left-slip faults that accumulated $65 \mathrm{~km}$ of slip between 17 and $10 \mathrm{Ma}$ (Anderson, 1973; Bohannon, 1979). The northwest-striking Las Vegas Valley shear zone accommodated an estimated $50-65 \mathrm{~km}$ of right slip movement between 15 and 10.7 Ma (Longwell, 1960, 1974; Burchfiel, 1965; Fleck, 1970; Burchfiel and others, 1974; Deibert, 1989). The east-striking Garlock fault exhibits evidence of about $65 \mathrm{~km}$ of left slip during Tertiary time (Smith, 1962). Strike-slip faulting in the Lake Mead and Death Valley regions appears to be kinematically coupled to the west-dipping detachment system (for example, Wernicke and others, 1984; Burchfiel and others, 1987; Weber and Smith, 1987; Duebendorfer and Wallin, 1991).

\section{TERTIARY STRATIGRAPHY}

The Tertiary sedimentary and volcanic sections described in this chapter were mostly deposited in physically separate basins that ranged in size from tens to thousands of square kilometers. Despite significant differences between individual basins in terms of lithologic sequence, time of deposition, and deformational history, several general features are common to many of the stratigraphic sections described in the following chapters. These similarities include 


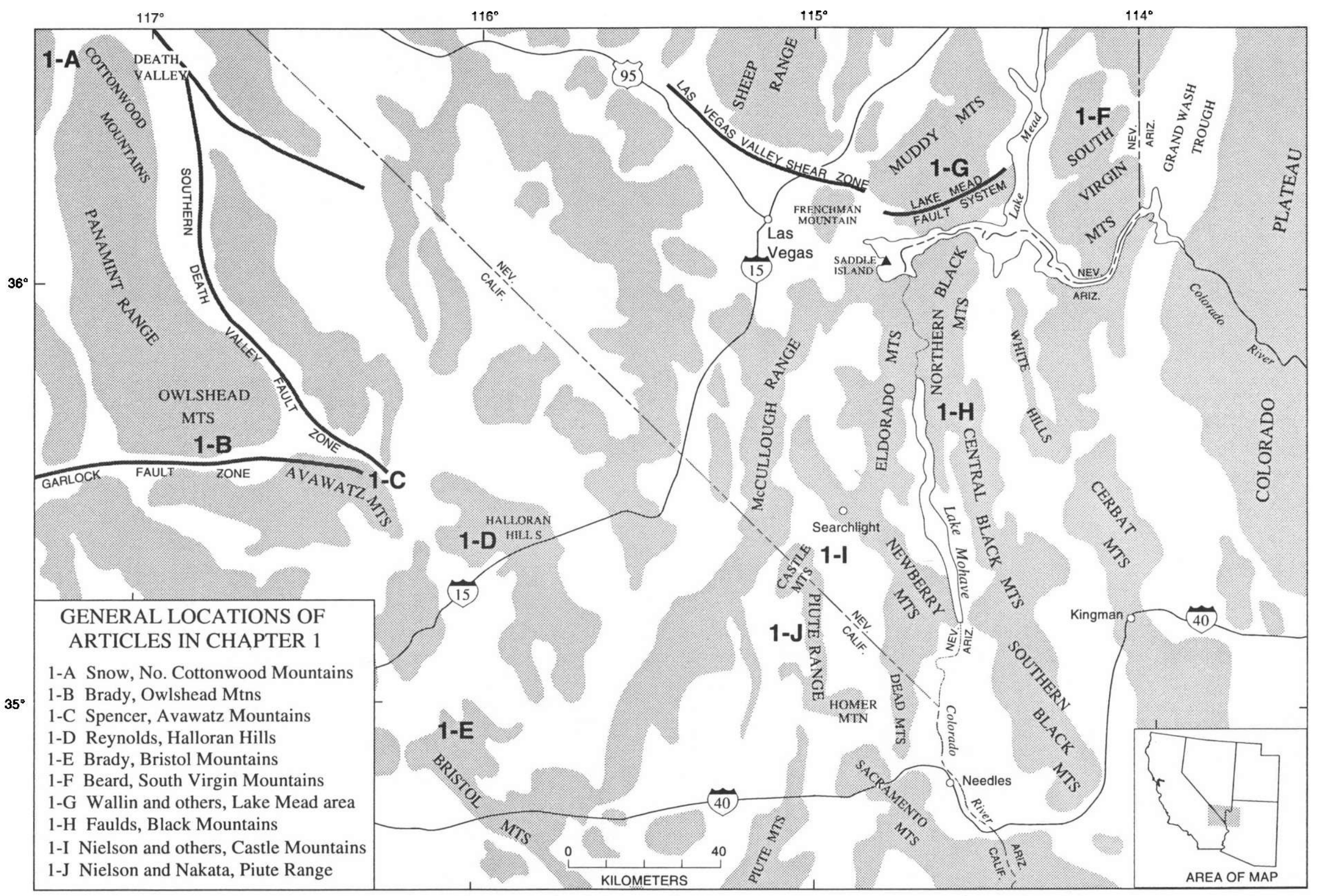

Figure 1. Map showing geologic and geographic features and study areas discussed in chapter 1. Distribution of Peach Springs Tuff shown in topical paper by Buesch (this vol.) 
(1) a nearly ubiquitous, but not necessarily time-correlative, upper Oligocene to lower Miocene basal conglomerate or arkosic sandstone; (2) a systematic decrease in stratal tilt upsection in several basins; (3) coarse sedimentary (landslide?) breccia deposits, and (4) pronounced along-strike variations in lithofacies and (or) abrupt changes in stratigraphic thickness, especially near faults.

\section{SEDIMENTARY ROCKS}

In the Death Valley-eastern Mojave area, Tertiary sedimentary and volcanic rocks overlie a variable association of Precambrian and Mesozoic crystalline and volcanic rocks. Upper Oligocene to upper Pliocene rocks in the northern Cottonwood Mountains, northern Death Valley, compose five unconformity-bounded sequences (Snow, this volume). These sequences are dominated by coarse clastic sedimentary deposits but also contain lacustrine limestone and intercalated tuffaceous rocks. The lower to middle Miocene section in the Avawatz Mountains is dominated by coarse clastic sedimentary rocks (Spencer, this volume). The Halloran Hills preserve a remarkably complete section of finegrained clastic sedimentary rocks that range in age from 19 Ma to at least as young as $12 \mathrm{Ma}$ (Reynolds, this volume). An upper Miocene to lower Pliocene clastic and evaporite succession occurs within a small basin between the southern Owlshead and Avawatz Mountains (Brady, this volume). Intermediate and mafic volcanic rocks and tuff are volumetrically subordinate constituents of the eastern Mojave Tertiary sections described in this volume.

In the northern Colorado River extensional corridor there is a marked northeast-trending discontinuity in the distribution of pre-Tertiary rocks and character of Tertiary sections. This discontinuity extends from the northern McCullough Range to the South Virgin Mountains (Anderson and others, 1972). Tertiary sections north of the discontinuity comprise three unconformity-bounded sequences that consist primarily of nonmarine clastic, nonclastic, and tuffaceous rocks of early Miocene to Pliocene(?) age (Bohannon, 1984; Beard, this volume; Wallin and others, this volume), which rest on thick sections of Paleozoic and Mesozoic strata. To the south, Tertiary sections of the same age are dominated by volcanic rocks, intercalated with less abundant nonmarine clastic and reworked tuffaceous rocks (Faulds, this volume; Nielson and Nakata, this volume; Nielson and others, this volume). The sections directly overlie Proterozoic and Mesozoic plutonic and metamorphic complexes.

\section{VOLCANIC ROCKS}

North of Interstate 40 lower and middle Miocene volcanic rocks, which are broadly contemporaneous with ex- tension, are calc-alkalic or alkali-calcic, with basaltic andesite, andesite, and dacite compositions predominating. Voluminous basalt and lesser amounts of rhyolite erupted principally after the main period of extension (post-9 Ma), but these rock types also occur locally in older volcanic sequences (for example, the Peach Springs Tuff of Young and Brennan, 1974; see Buesch, this volume). This pattern of extension-related intermediate volcanism followed by postextension basaltic volcanism is recognized in many areas of the Great Basin (Anderson, 1973; Elston and Bomhorst, 1979; Eaton, 1982; Otton, 1982; Smith, 1982; Glazner and Ussler, 1989; Glazner, 1990).

\section{PLUTONIC ROCKS}

Early to middle Miocene diorite to quartz monzonite plutons, which are in part cogenetic with the volcanic rocks, are well exposed in the northern Colorado River trough. Plutons include the Newberry (Volborth, 1964; Mathis, 1982), Nelson (Anderson and others, 1972), Mount Perkins (Faulds and others, 1990), Searchlight (P.E. Proctor, unpublished mapping, 1950 to present), Boulder City (Anderson, 1969), and Wilson Ridge (Anderson and others, 1972; Larsen and Smith, 1990; Smith and others, 1990).

\section{RELATIONSHIP OF SEDIMENTARY AND VOLCANIC ROCKS TO TERTIARY EXTENSION}

The Tertiary sedimentary and volcanic rocks record subsidence associated with the onset of extensional tectonism. In the Colorado River extensional corridor, the major pulse of extension occurred during early to middle Miocene time, which is indicated by lower Miocene strata that are very highly tilted and by middle Miocene sedimentary and volcanic sequences with tilts that change upsection from steep to shallow. Tilt variations of the middle Miocene strata indicate deposition in active growth-fault basins (for example, Faulds, this volume; Wallin and others, this volume). However, the original configuration of the early basins has been obscured by severe structural disruption during the main pulse of extension.

Upper Miocene rocks are, in general, much less deformed than the older rocks, and they appear to reflect the waning stages of detachment faulting. These relations document a marked decrease in the magnitude of extensional strain in the region after middle Miocene time throughout the Colorado River extensional corridor.

Extension in the eastern Mojave-Death Valley region is at least in part younger than that in the Colorado River extensional corridor, as shown by the appreciable tilting of 
upper Miocene conglomerates in the North Bristol Mountains (Brady, this volume) and syntectonic upper Miocene to upper Pliocene deposits of northern Death Valley (Snow, this volume). Active extension in the Death Valley region may provide a modern analog for many of the structurally fragmented middle to late Tertiary basins elsewhere in the southern Basin and Range.

\section{REFERENCES CITED}

Anderson, R.E., 1969, Notes on the geology and paleohydrology of the Boulder City pluton, southem Nevada: U.S. Geological Survey Professional Paper 650-B, p. B35-B40.

1973, Large-magnitude late Tertiary strike-slip faulting north of Lake Mead, Nevada: U.S. Geological Survey Professional Paper 794, $18 \mathrm{p}$.

Anderson, R.E., Longwell, C.R., Armstrong, R.L., and Marvin, R.F., 1972, Significance of K-Ar ages of Tertiary rocks from the Lake Mead region, Nevada-Arizona: Geological Society of America Bulletin, v. 83, no. 2, p. 273-288.

Bohannon, R.G., 1979, Strike-slip faults of the Lake Mead region of southern Nevada, in Armentrout, J.M., Cole, M.R., and TerBest, Harry, Jr., eds., Cenozoic paleogeography of the western United States: Los Angeles, Calif., Pacific Section, Society of Economic Paleontologists and Mineralogists, Pacific Coast Paleogeography Symposium 3, p. 129-139.

1984, Nonmarine sedimentary rocks of Tertiary age in the Lake Mead region, southeastern Nevada and northwestern Arizona: U.S. Geological Survey Professional Paper 1259, 72 p.

Burchfiel, B.C., 1965, Structural geology of the Spector Range quadrangle, Nevada, and its regional significance: Geological Society of America Bulletin, v. 76, no. 2, p. 175-192.

Burchfiel, B.C., Fleck, R.J., Secor, D.T., Vincelette, R.R., and Davis, G.A., 1974, Geology of the Spring Mountains, Nevada: Geological Society of America Bulletin, v. 85, no. 7 , p. $1,013-1,022$.

Burchfiel, B.C., Hodges, K.V., and Royden, L.H., 1987, Geology of Panamint Valley-Saline Valley pull-apart system, California: palinspastic evidence for low-angle geometry of a Neogene range-bounding fault: Journal of Geophysical Research, v. 92, no. B10, p. 10,422-10,426.

Choukroune, Pierre, and Smith, E.I., 1985, Detachment faulting and its relationship to older structural events on Saddle Island, River Mountains, Clark County, Nevada: Geology, v. 13 , no. 6 , p. $421-424$.

Davis, G.A., Anderson, J.L., Frost, E.G., and Shackelford, T.J., 1980, Mylonitization and detachment faulting in the Whipple-Buckskin-Rawhide Mountains terrane, southeastern California and western Arizona, in Crittenden, M.D., Jr., Coney, P.J., and Davis, G.H., eds., Cordilleran metamorphic core complexes: Geological Society of America Memoir 153 , p. $79-129$.

Deiber, J.E., 1989, Sedimentological constraints on middle Miocene extensional tectonism of the southern Las Vegas Valley Range, southern Nevada: Las Vegas, University of Nevada, M.S. thesis, $83 \mathrm{p}$.

Dokka, R.K., 1989, The Mojave extensional belt of southern California: Tectonics, v. 8 , no. 2, p. 363-390.
Duebendorfer, E.M., Sewall, A.J., and Smith, E.I., 1990, The Saddle Island detachment; an evolving shear zone in the Lake Mead area, Nevada, in Wernicke, B.P., ed., Basin and Range extensional tectonics near the latitude of Las Vegas, Nevada: Geological Society of America Memoir 176, 77 97.

Duebendorfer, E.M., and Wallin, E.T., 1991, Basin development and syntectonic sedimentation associated with kinematically coupled strike-slip and detachment faulting, southern Nevada: Geology, v. 19, no. I, p. 87-90.

Eaton, G.P., 1982, The Basin and Range province: origin and tectonic significance: Annual Review of Earth and Planetary Sciences, v. 10, p. $409-440$.

Elston, W.E. and Bornhorst, T.J., 1979, The Rio Grande rift in context of regional post-40 m.y. volcanic and tectonic events, in Riecker, R.E., ed., Rio Grande Rift: tectonics and magmatism: Washington, D.C., American Geophysical Union, p. 416-438.

Faulds, J.E., Geissman, J.W., and Mawer, C.K., 1990, Structural development of a major extensional accommodation zone in the Basin and Range province, northwestern Arizona and southern Nevada; implications for kinematic models of continental extension, in Wernicke, B.P., ed., Basin and Range extensional tectonics near the latitude of Las Vegas, Nevada: Geological Society of America Memoir 176, p. 37-76.

Fleck, R.J., 1970, Age and possible origin of the Las Vegas Valley shear zone, Clark and Nye Counties, Nevada [abs.]: Geological Society of America Abstracts with Programs, v. 2, no. 5, p. 333.

Fryxell, J.E., Salton, G.G., Selverstone, Jane, and Wernicke, Brian, 1992, Gold Butte crustal section, south Virgin Mountains, Nevada: Tectonics, v. 11, no. 6, p. 1,099-1,120.

Glazner, A.F., 1990, Recycling of continental crust in Miocene volcanic rocks from the Mojave block, southern California, in Anderson, J.L., ed., The nature and origin of Cordilleran magmatism: Geological Society of America Memoir 174, p. $147-168$.

Glazner, A.F. and Ussler, William, III, 1989, Crustal extension, crustal density, and the evolution of Cenozoic magmatism in the Basin and Range of the western United States: Journal of Geophysical Research, v. 94, no. B6, p. 7,952-7,960.

Howard, K.A., and John, B.E., 1987, Crustal extension along a rooted system of imbricate low-angle faults, Colorado River extensional corridor, California and Arizona, in Coward, M.P., Dewey, J.F., and Hancock, P.L., eds., Continental extensional tectonics: Geological Society of London Special Publication 28, p. 299-311.

John, B.E., 1987, Geometry and evolution of a mid-crustal extensional fault system: Chemehuevi Mountains, southeastern California, in Coward, M.P., Dewey, J.F. and Hancock, P.L., eds., Continental extensional tectonics: Geological Society of London Special Publication 28, p. 312-333.

Larsen, L.L. and Smith, E.I., 1990, Mafic enclaves in the Wilson Ridge pluton, northwestern Arizona: implications for the generation of a calc-alkaline intermediate pluton in an extensional environment: Journal of Geophysical Research, v. 95, no. B11, p. 17,693-17,716.

Longwell, C.R., 1960, Possible explanation of diverse structural patterns in southern Nevada: American Journal of Science, v. 258-A (Bradley Volume), p. 192-203. 
1974, Measure and date of movement on Las Vegas Valley shear zone, Clark County, Nevada: Geological Society of America Bulletin, v. 85, no. 6, p. 985-989.

Mathis, R.S., 1982, Mid-Tertiary detachment faulting in the southeastern Newberry mountains, Clark County, Nevada, in Frost, E.G., and Martin, D.L., eds., Mesozoic-Cenozoic tectonic evolution of the Colorado River region, Califomia, Arizona, and Nevada (Anderson-Hamilton Volume): San Diego, Calif., Cordilleran Publishers, p. 326-340.

Otton, J.K., 1982, Tertiary extensional tectonics and associated volcanism in west-central Arizona, in Frost, E.G., and Martin, D.L., eds., Mesozoic-Cenozoic tectonic evolution of the Colorado River region, California, Arizona, and Nevada (Anderson-Hamilton Volume): San Diego, Calif., Cordilleran Publishers, p. 143-157.

Smith, E.I., 1982, Geology and geochemistry of the volcanic rocks in the River Mountains, Clark County, Nevada and comparisons with volcanic rocks in nearby areas, in Frost, E.G., and Martin, D.L., eds., Mesozoic-Cenozoic tectonic evolution of the Colorado River region, California, Arizona, and Nevada (Anderson-Hamilton Volume): San Diego, Calif., Cordilleran Publishers, p. 41-54.

Smith, E.I., Feuerbach, D.L., Naumann, T.R., and Mills, J.G., 1990, Mid-Miocene volcanic and plutonic rocks in the Lake Mead area of Nevada and Arizona: Production of intermediate igneous rocks in an extensional environment, in Anderson, J.L., ed., The nature and origin of Cordilleran magmatism: Geological Society of America Memoir 174, p. 164-194.

Smith, G.I., 1962, Large lateral displacement on the Garlock fault, California, as measured from offset dike swarm: American Association of Petroleum Geologists Bulletin, v. 46 , no. 1 , p. 85-104.
Spencer, J.E., 1985, Miocene low-angle normal faulting and dike emplacement, Homer Mountain and surrounding areas, southeastern California and southernmost Nevada: Geological Society of America Bulletin, v. 96, no. 9, p. 1,140-1,155.

Volborth, Alexis, 1964, Geology of the granite complex of the Eldorado, Newberry, and northern Dead Mountains, Clark County, Nevada: Nevada Bureau of Mines and Geology Bulletin, v. 80,40 p.

Weber, M.E., and Smith, E.I. 1987, Structural and geochemical constraints on the reassembly of disrupted mid-Miocene volcanoes in the Lake Mead-Eldorado Valley area of southern Nevada: Geology, v. 15 , no. 6, p. 553-556.

Wernicke, Brian, 1985, Uniform-sense normal simple shear of the continental lithosphere: Canadian Journal of Earth Sciences, v. 22, no. 1, p. 108-125.

Wernicke, Brian, and Axen, G.J., 1988, On the role of isostasy in the evolution of normal fault systems: Geology, v. 16, no. 9, p. 848-851.

Wernicke, Brian, Axen, G.J., and Snow, J.K., 1988, Basin and range extensional tectonics at the latitude of Las Vegas, Nevada: Geological Society of America Bulletin, v. 100, no. 11, p. 1,738-1,757.

Wernicke, Brian, Guth, P.L., and Axen, G.J., 1984, Tertiary extensional tectonics in the Sevier thrust belt of southem Nevada, in Lintz, J., Jr., Western Geological Excursions: Geological Society of America, Annual Meeting, Reno, Nev., November 1984 Field Trip Guidebook, v. 4. p. 473510.

Young, R.A., and Brennan, W.J., 1974, Peach Springs Tuff: its bearing on structural evolution of the Colorado Plateau and development of Cenozoic drainage in Mohave County, Arizona: Geological Society of America Bulletin, v. 85, no. 1, p. 83-90. 



\title{
Tertiary Strata of the Ubehebe Basin and Northern Cottonwood Mountains, Death Valley Region, Calif.
}

\author{
By J. Kent Snow ${ }^{1}$
}

\section{INTRODUCTION}

The Cottonwood Mountains are located within the highly extended Death Valley region of southeastern Califomia (fig. 1; Wernicke and others, 1988a). Tertiary strata are discontinuously exposed throughout the range and were in part deposited while the Cottonwood Mountains crustal block separated from structurally lower blocks during extension (Snow, 1990; Snow and White, 1990). This report summarizes the Tertiary stratigraphy of the northern Cottonwood Mountains (col. 1-A, pl. 1) from detailed mapping (Snow, 1990), lithostratigraphic correlations between measured sections (Snow and White, 1990), and ${ }^{40} \mathrm{Ar} /{ }^{39} \mathrm{Ar}$ ages of interstratified volcanic rocks (table 1 ). Data are primarily from the Ubehebe basin in the northernmost part of the range, where the most complete exposures are preserved. The original proximity of the now widely separated Ubehebe, Titus Canyon, and Furnace Creek basins (fig. 1) suggests additional age constraints based on regional correlations of strata between these basins (Snow, 1990).

\section{REGIONAL GEOLOGIC FRAMEWORK}

The Tertiary structure of the northern Cottonwood Mountains is dominated by an east-facing monoclinal flexure, or rollover (Snow, 1990; Snow and White, 1990). Syntectonic strata in the Ubehebe basin record progressive tilting during formation of the rollover by movement on the listric detachment fault that separates the Cottonwood Mountains from ranges to the east (Snow and White, 1990). Tertiary strata older than about $9 \mathrm{Ma}$ in the Ubehebe basin apparently were deposited prior to most largemagnitude extension in the northern Death Valley area, as discussed below, and represent a displaced fragment of an earlier basin.

Several lines of evidence suggest that Paleozoic miogeoclinal strata subjacent to the Ubehebe, Titus Canyon, and Furnace Creek basins were in proximity prior to large-

\footnotetext{
'Division of Geology and Planetary Sciences 170-25, Califomia lnstitute of Technology, Pasadena, CA, 91125
}

magnitude extension. Offset stratigraphic trends of miogeoclinal rocks suggest that the Cottonwood and Panamint Mountains restore to the area immediately south of the Funeral Mountains and structurally above the Black Mountains (fig. 1; Stewart, 1983). Offset remnants of a fossil alluvial fan also suggest that Tucki Mountain (fig. 1) restores immediately south of the eastern Funeral Mountains (Wernicke and others, 1988b, Snow and others, 1989). Reconstructions based on correlations of offset Cordilleran contractile structures suggest similar pre-Tertiary positions for the Funeral, Panamint, and Cottonwood Mountains and

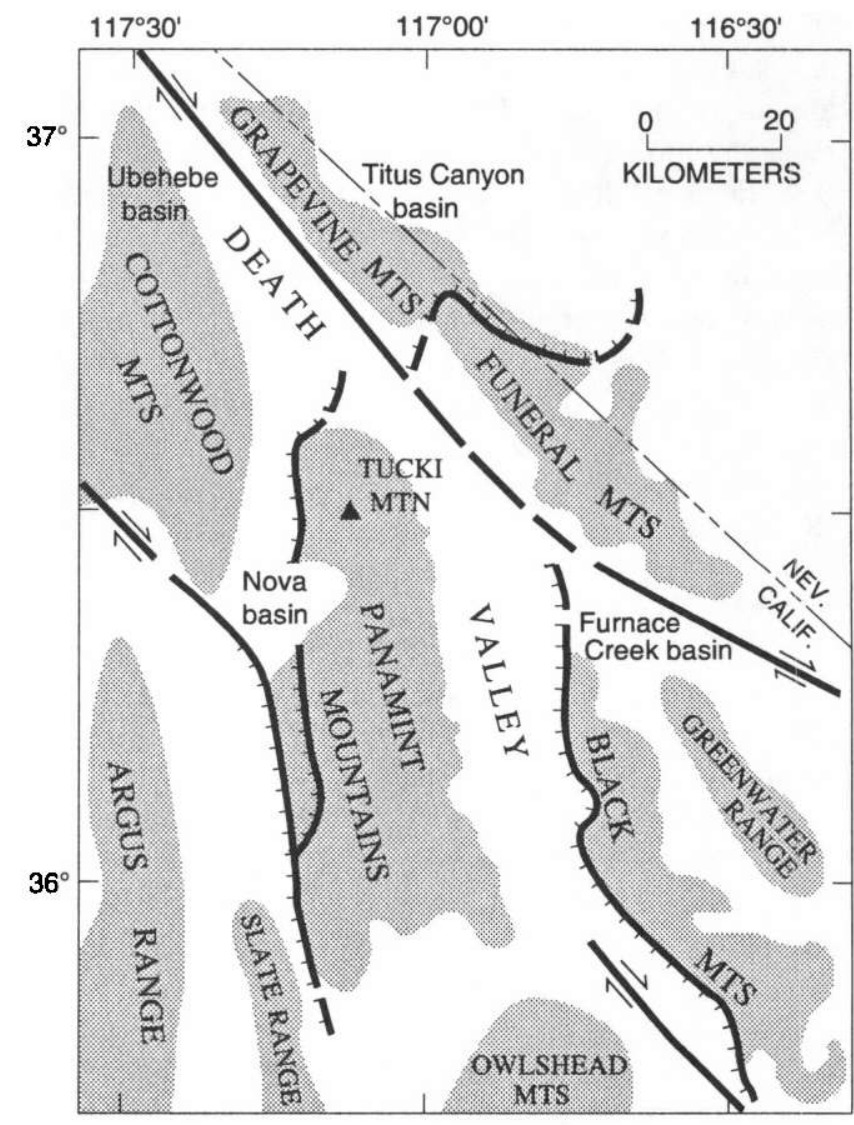

Figure 1. Map showing location of major Tertiary faults, sedimentary basins, and some geographic features named in text. Arrows show sense of strike-slip displacement; hachures on upper plate of normal faults; dashed where approximately located. 
Table $1 .{ }^{40} \mathrm{Ar} /{ }^{39} \mathrm{Ar}$ plateau ages for Tertiary volcanic strata in the northem Cottonwood Mountains.

[See Snow (1990) for isotopic data, sample descriptions, and locations]

\begin{tabular}{llll}
\hline \multicolumn{1}{c}{ Unit } & Sample & \multicolumn{1}{c}{ Mineral } & Age (Ma) \\
\hline $\begin{array}{l}\text { Sequence } 4 \\
\text { Tuff of Mesquite Spring }\end{array}$ & $\begin{array}{l}587-1 \mathrm{AK} 4 \\
\text { 988-11K3 }\end{array}$ & $\begin{array}{l}\text { Sanidine } \\
\text { Sanidine }\end{array}$ & $3.28 \pm 0.07$ \\
Basalt & $687-5 \mathrm{P} 1$ & Plagioclase & $3.65 \pm 0.05$ \\
& & & \\
Sequence 2 & & & \\
Tuff & $1287-3 \mathrm{~K} 2$ & Sanidine & $16.03 \pm 0.27$ \\
Sequence 1 & & & \\
Tuff of Bighom & $487-2 \mathrm{~B} 1$ & Biotite & $22.73 \pm 0.31$ \\
$\quad$ Gorge & $1087-1 \mathrm{~K} 1$ & Sanidine & $23.02 \pm 0.27$ \\
& $1087-1 \mathrm{~B} 1$ & Biotite & $22.93 \pm 0.41$ \\
Tuff & $687-4 \mathrm{~K} 2$ & Sanidine & $22.78 \pm 0.22$ \\
& $687-4 \mathrm{~B} 2$ & Biotite & $23.09 \pm 0.62$ \\
Tuff & $487-1 \mathrm{~K} 2$ & Sanidine & $23.71 \pm 0.22$ \\
& $487-1 \mathrm{~B} 1$ & Biotite & $23.60 \pm 0.51$ \\
& $1287-2 \mathrm{~K} 2$ & Sanidine & $23.87 \pm 0.23$ \\
\hline
\end{tabular}

also suggest that the Grapevine Mountains restore structurally above the western Funeral Mountains and north of the Panamint Mountains (Snow and Wemicke, 1989).

The uplift history of crystalline rocks in the Black Mountains supports the previously discussed reconstructions and constrains the age of large-magnitude extension. Within the core of the range, the 12-Ma Willow Spring Diorite of Asmerom and others (1990) was intruded at greater than $9 \mathrm{~km}$ depth (Holm and Wernicke, 1990) and an adjacent 8.7-Ma quartz monzonite was intruded at greater than $8 \mathrm{~km}$ depth (Holm and others, 1992). Critical outcrops show these crystalline rocks in contact with moderately to steeply tilted, 8- to 9-Ma strata of the Shoshone volcanics of Wright and Troxel (1984) across a dipping, subplanar fault (Holm and Wernicke, 1990; D.K. Holm, unpublished mapping; compare with Drewes, 1963). ${ }^{40} \mathrm{Ar} /{ }^{39} \mathrm{Ar}$ cooling ages suggest that some uplift of the range occurred at around $9 \mathrm{Ma}$ and rapid unroofing began at about $6 \mathrm{Ma}$ (Holm and others, 1989; D.K. Holm, written commun., 1989). Uplift was completed prior to deposition of diorite cobbles in the Copper Canyon Formation at about $5 \mathrm{Ma}$ (Holm and Lux, 1990). Eastward tilting of the Panamint Mountains block, and its movement from a pre-Tertiary position overlying the Black Mountains, was probably underway by about $8 \mathrm{Ma}$ (see Snow and others, 1989), roughly coeval with initial uplift of the Black Mountains. Sedimentation rates within the Fumace Creek basin increased by at least an order of magnitude at about $6 \mathrm{Ma}$ (Cemen and others, 1985), synchronously with rapid unroofing of the Black Mountains.
Large-magnitude extension between other range-sized blocks in the northern Death Valley area is also younger than about $9 \mathrm{Ma}$. Westward transport of the Grapevine Mountains from above the Funeral Mountains is thought to have occurred between about 9 and $5 \mathrm{Ma}$ (Reynolds and others, 1986) during uplift of the Black Mountains. Separation of the Panamint and Cottonwood Mountains is recorded by syntectonic deposits of the Nova basin (fig. 1; Hodges and others, 1989), most of which are younger than 3.3 Ma (Snow, 1990).

\section{TERTIARY STRATIGRAPHY}

Cenozoic deposits in the northern Cottonwood Mountains form five unconformity-bounded sequences that can be further divided into pretectonic, syntectonic, and posttectonic phases of sedimentation by two major angular unconformities (col. 1-A, pl. 1; Snow, 1990).

\section{SEQUENCE 1}

Stratigraphic sections measured within the Ubehebe basin (fig. 1) of the northern Cottonwood Mountains (including units $\mathrm{Tc}_{1}, \mathrm{Tu}_{1}, \mathrm{Tu}_{2}$, and $\mathrm{Tu}_{3}$ of Snow and White, 1990) form a composite section for the Ubehebe unit of Snow (1990) and its two subunits. The lower subunit is a conglomerate composed of poorly sorted, subangular cobbles that appear to be locally derived, predominantly from Paleozoic carbonate units that underlie it beneath an unconformity with less than $5^{\circ}$ discordance. The conglomerate is resistant, weathers pale grayish red (5R 5/2) to light brown (5YR 5/6), and includes interbedded pebble conglomerate and pebbly sandstone toward its top.

The upper subunit, a sequence of lithic wacke and volcanic rocks, is predominantly composed of poorly sorted, subangular, medium sand with subordinate silty mudstone, pebbly sandstone, and cobble conglomerate. Interbedded coarse sandy or pebbly layers are common. The upper subunit contains two white tuff beds that are approximately 24 and $23 \mathrm{Ma}$ (table 1). A third interstratified volcanic unit, the 23-Ma tuff of Bighorn Gorge (Snow, 1990), forms a prominent, grayish orange pink (5YR 7/2) marker bed throughout the Cottonwood Mountains. The upper subunit appears to interfinger with silty mudstone toward the east within the Ubehebe basin and with conglomerate toward the west in the central Cottonwood Mountains.

Correlatives of the Ubehebe unit can be recognized over at least $4,000 \mathrm{~km}^{2}$ within the northern Death Valley area by the occurrence of similar strata and coeval tuff beds (Snow, 1990). Exposures of pre-24- to 20-Ma strata in the Funeral Mountains (Cemen and others, 1985) and 22- to 20-Ma strata in the Grapevine Mountains, which 
unconformably overlie the Titus Canyon Formation (Reynolds, 1969, 1974), are probably correlative with the Ubehebe unit. The lower part of the Ubehebe unit may be time-correlative with the upper part of the Titus Canyon Formation (Snow, 1990), although these strata appear to be lithologically distinct (M.W. Reynolds, oral commun., 1986). The original proximity of these Tertiary basinal deposits, inferred from their reconstructed positions prior to large-magnitude extension, suggests that the Ubehebe unit and its correlatives are parts of a single depositional basin.

Given the reconstructed proximity of the Ubehebe, Titus Canyon, and Furnace Creek basins prior to Tertiary extension and the lateral persistence of exposed tuff beds, the absence of a particular tuff bed in any area is probably due to Tertiary erosion rather than nondeposition. A 27-Ma tuff is exposed in the Titus Canyon Formation (Reynolds, 1974), but no tuff this old is exposed in the Cottonwood Mountains, even in the most complete sections. This tuff was probably eroded from the Cottonwood Mountains prior to deposition of units that now overlie the basal unconformity. Its presence in an originally nearby section suggests a maximum age of $27 \mathrm{Ma}$ for strata in the Ubehebe basin. Similarly, a 20-Ma tuff in the Funeral Mountains is not found in the Cottonwood Mountains. It was probably removed by erosion that formed the disconformity above the Ubehebe unit and thus suggests a minimum age of $20 \mathrm{Ma}$ for the Ubehebe unit.

\section{SEQUENCE 2}

Strata of sequence 2 are lithologically identical to the lithic wackes in the Ubehebe unit except for clasts of mudstone and tuff that are especially abundant in the basal conglomerate and were apparently derived from disconformably underlying strata (Snow and White, 1990, unit $\mathrm{Tu}_{4}$ ). A 16-Ma white tuff (table 1), distinguished by the presence of hornblende phenocrysts, is present about $30 \mathrm{~m}$ above the basal disconformity.

Sequence 2 within the Cottonwood Mountains is probably correlative (Snow, 1990) with part of the Artist Drive Formation of McAllister (1970). A conformable sequence of 16- to 11-Ma strata in the Titus Canyon basin (Reynolds, 1969, 1974) contains tuff beds equivalent to ones in the lower part of the Artist Drive Formation, which have ages between 14 and $11 \mathrm{Ma}$ within the Furnace Creek basin (Cemen and others, 1985). The original proximity of rocks within these coeval sequences supports their correlation and suggests that the base of the Artist Drive Formation is time-transgressive and locally includes strata as old as $16 \mathrm{Ma}$ (Snow, 1990). Because only the 16-Ma tuff bed is exposed in the Cottonwood Mountains and a 14-Ma tuff unit exposed in the now-distant Furnace Creek basin is missing, strata of sequence 2 are probably older than $14 \mathrm{Ma}$.

\section{SEQUENCE 3}

Moderately east-dipping conglomeratic strata of sequence 3 unconformably overlie steeply east-dipping older Tertiary strata and underlying Paleozoic units, typically with $15^{\circ}$ to $20^{\circ}$ discordance. Deposition of sequence 3 is thus inferred to be synchronous with development of the Cottonwood Mountains rollover during large-magnitude extension in the northern Death Valley area (Snow and White, 1990).

Sequence 3 contains two subunits that are differentiated by average clast size and color (Snow, 1990; Snow and White, 1990). The lower subunit is a moderate reddish orange (10R 6/6) to reddish brown (10R 4/4), poorly bedded cobble conglomerate with a matrix of moderately sorted coarse sand and granules. Distinctive spherical cobbles, which are diagnostic of basal strata in the lower unit, were derived from upper Proterozoic to lower Cambrian clastic rocks, mudstones of unknown origin, and granitoids unlike any locally exposed intrusions. These exotic clasts resemble cobbles in conglomerate of the Titus Canyon Formation, and they were probably derived from it when the Ubehebe and Titus Canyon basins were much closer (Snow and White, 1990). Moderately rounded clasts that are representative of locally exposed Paleozoic units greatly increase in proportion upsection to become the dominant clast type in the conglomerate. Also increasing upsection is the proportion of moderately to well sorted sandstone beds with coarse, subrounded clasts interbedded with the conglomerate. The upper subunit is interstratified dusky yellow (5Y 6/4), medium-bedded, poorly sorted cobble conglomerate with subrounded clasts and similar, poorly sorted, pebbly sandstone with coarse, subangular clasts.

The age of sequence 3 is constrained between 16 and 3.7 Ma (table 1) by volcanic units in the Ubehebe basin. Regional considerations suggest that the conglomerates are probably younger than about 9 or $8 \mathrm{Ma}$ and possibly younger than $6 \mathrm{Ma}$. The angular unconformity below sequence 3 records significant rotation of strata along the eastern flank of the Cottonwood Mountains that is kinematically linked to motion of the range away from the Furnace Creek basin area and uplift of the underlying Black Mountains at this time.

\section{SEQUENCE 4}

Strata of sequence 4 unconformably overlie strata of sequence 3 with $15^{\circ}$ to $20^{\circ}$ discordance and overlie older Tertiary or underlying Paleozoic strata with discordance of more than $35^{\circ}$. Although strata of sequence 4 are mildly tilted and cut by some faults in the Ubehebe basin, deposition of these strata largely postdates major extensional tectonism in the northern Cottonwood Mountains (Snow and White, 1990). 
Strata of sequence 4 are dominantly grayish-brown (5YR 4/2), medium to thickly bedded, well-lithified conglomerate composed of poorly sorted, subangular to wellrounded cobbles in a poorly sorted matrix of coarse sand. They are distinguished by the presence of basalt boulders and breccia, spherical cobbles derived from the basal part of sequence 3, and rare cobbles of conglomerate apparently locally derived from older Tertiary strata.

The conglomerate interfingers toward the east with marl that is light gray, irregularly thin to medium bedded, typically porous, and locally contains plant fossils. The marl is associated with beds of fine grained muddy or tuffaceous limestone, coarse grained sandy limestone, and calcareous tuffaceous wacke. Discontinuous caliche horizons lithologically similar to the marl are interstratified within the conglomerate. The complex stratigraphic relationships between conglomerate and marl suggest a paleogeography characterized by the progradation of alluvial fans into a playa lake.

Flows of a 3.65-Ma olivine basalt are present near the base of sequence 4 (table 1). The basalt is only locally exposed in the northern Cottonwood Mountains area and appears to have a source immediately to the west in the Saline Range area (B.C. Burchfiel, oral commun., 1989; Snow, 1990). The 3.2-Ma tuff of Mesquite Spring (Snow, 1990) (table 1) overlies the basalt and forms an important marker bed throughout the northern Death Valley area. This distinctive, white, pumice-lapilli tuff varies from friable to moderately indurated and blocky. It consistently contains biotite and sanidine phenocrysts. Where it is best exposed, the tuff appears zoned; sedimentary lithic clasts dominate at the base but are absent in the upper part. In the northern Cottonwood Mountains the tuff grades continuously from tuffaceous marl to slightly altered tuff, probably indicating eruption into a shallow playa lake (Snow and White, 1990).

The basalt overlies sequence 3 above an angular unconformity in western parts of the Ubehebe basin but overlies as much as $10 \mathrm{~m}$ of conglomerate to the east. Thus, deposition above the unconformity may be slightly time transgressive. Strata overlying the tuff of Mesquite Spring are presumably late Pliocene in age, but an upper age limit is not available.

\section{SEQUENCE 5}

Quaternary(?) strata of sequence 5 are undifferentiated alluvium and poorly indurated conglomerate. They locally overlie strata of sequence 4 with slight angular unconformity, although the contact is typically disconformable where it can be identified.

\section{REFERENCES CITED}

Asmerom, Yemane, Snow, J.K., Holm, D.K., Jacobsen, S.B., Wernicke, B.P., and Lux, D.R., 1990, Rapid uplift and crustal growth in extensional environments; an isotopic study from the Death Valley region, California: Geology, v. 18, no. 3, p. 223-226.

Cemen, Ibrahim, Wright, L.A., Drake, R.E., and Johnson, F.C., 1985. Cenozoic sedimentation and sequence of deformational events at the southeastern end of the Furnace Creek strike-slip fault zone, Death Valley region, Califomia, in Biddle, K.T. and Christie-Blick, Nicholas, eds., Strike-slip deformation, basin formation, and sedimentation: Tulsa, Okla., Society of Economic Paleontologists and Mineralogists Special Publication 37, p. 127-141.

Drewes, Harald, 1963, Geology of the Funeral Peak quadrangle, California, on the east flank of Death Valley: U.S. Geological Survey Professional Paper 413, $78 \mathrm{p}$.

Hodges, K.V., McKenna, L.W., Stock, J., Knapp, J., Page, L., Sternlof, K., Silverburg, D., Wüst, G., and Walker, J.D., 1989, Evolution of extensional basins and Basin and Range topography west of Death Valley, Califomia: Tectonics, v. 8, no. 3, p. 453-467.

Holm, D.K, and Lux, D.R., 1990, The Copper Canyon Formation: A record of unroofing and Tertiary folding of the Death Valley Turtleback surfaces [abs.]: Geological Society of America Abstracts with Programs, v. 23, no. 2, p. 35.

Holm, D.K., Snow, J.K., and Lux, D.R., 1989, Uplift history of the Black Mountains crystalline terrain, Death Valley region, California [abs.]: Eos (American Geophysical Union, Transactions), v. 70 , no. 43 , p. 1,335 .

Holm, D.K., Snow, J.K., and Lux, D.R., 1992, Thermal and barometric constraints on the intrusive and unroofing history of the Black Mountains: Implications for timing, initial dip, and kinematics of detachment faulting in the Death Valley region, California: Tectonics, v. 11, no. 3, p. 507-522.

Holm, D.K. and Wernicke, Brian, 1990, Black Mountains crustal section, Death Valley extended terrain, California: Geology, v. 18 , no. 6 , p. $520-523$.

McAllister, J.F., 1970, Geology of the Furnace Creek borate area, Death Valley, Inyo County, California: California Division of Mines and Geology Map Sheet 14, scale 1:24,000.

Reynolds, M.W., 1969, Stratigraphy and structural geology of the Titus and Titanothere Canyons area, Death Valley, California: Berkeley, University of Califomia, Ph.D. dissertation, $310 \mathrm{p}$.

1974, Recurrent middle and late Cenozoic deformation, northeastem Death Valley, California-Nevada [abs.]: Geological Society of America Abstracts with Programs, v. 6, no. 3, p. 241-242.

Reynolds, M.W., Wright, L.A., Troxel, B.W., 1986, Geology and chronology of late Cenozoic detachment faulting, Funeral and Grapevine Mountains, Death Valley, California [abs.]: Geological Society of America Abstracts, v. 18, no. 2, p. 175.

Snow, J.K., 1990, Cordilleran orogenesis, extensional tectonics, and geology of the Cottonwood Mountains area, Death Val- 
ley region, California and Nevada: Cambridge, Mass., Harvard University, Ph.D. dissertation, $533 \mathrm{p}$.

Snow, J.K. and Wernicke, Brian, 1989, Uniqueness of geological correlations: an example from the Death Valley extended terrain: Geological Society of America Bulletin, v. 101, no. 11, p. $1,351-1,362$.

Snow, J.K., Wernicke, B.P., Burchfiel, B.C., and Hodges, K.V., 1989, Day 8: Neogene extension between the Grapevine Mountains and Spring Mountains, California and Nevada, in Wernicke, B.P., Snow, J.K., Axen G.J., Burchfiel, B.C., Hodges, K.V., Walker, J.D., and Guth, P.L., Extensional tectonics in the Basin and Range province between the southem Sierra Nevada and the Colorado Plateau: Washington, D.C., American Geophysical Union, 28th International Geological Congress Field Trip Guide T-138, p. 67-75.

Snow, J.K., and White, Carolyn, 1990, Listric normal faulting and synorogenic sedimentation, northem Cottonwood Mountains, Death Valley region, California, in Wernicke, B.P., ed., Basin and Range extensional tectonics near the latitude of Las Vegas, Nevada: Geological Society of America Memoir 176, p. 413-445.
Stewart, J.H., 1983, Extensional tectonics in the Death Valley area, California; transport of the Panamint Range structural block $80 \mathrm{~km}$ northwestward: Geology, v. 11 , no. 3, p. 153157.

Wernicke, Brian, Axen, G.J., and Snow, J.K., 1988a, Basin and Range extensional tectonics at the latitude of Las Vegas, Nevada: Geological Society of America Bulletin, v. 100, no. 11, p. $1,738-1,757$.

Wernicke, Brian, Walker, J.D., and Hodges, K.V., 1988b, Field guide to the northern part of the Tucki Mountain fault system, Death Valley region, California, in Weide, D.L. and Faber, M.L., eds., This extended land: geological journeys in the southern Basin and Range: Las Vegas, University of Nevada Department of Geosciences Special Publication 2 (Geological Society of America, Cordilleran Section, Las Vegas, Nev., March 1988, Field Trip Guidebook), p. 255-267.

Wright, L.A., and Troxel, B.W., 1984, Geology of the northem half of the Confidence Hills 15-minute quadrangle, Death Valley region, eastern California: The area of the Amargosa Chaos: California Division of Mines and Geology Map Sheet 34 , scale $1: 24,000$. 



\title{
Neogene Sedimentary Rocks in the Southern Owlshead Mountains: Constraint on Displacement of the Eastern Garlock Fault Zone
}

\author{
By Roland H. Brady, III ${ }^{1}$
}

\section{INTRODUCTION}

The active Garlock fault zone of southeastern California is a major left-lateral system that appears to form a structural boundary between two highly extended terranes in the southem Basin and Range physiographic province. The fault zone may accommodate different times and styles of extension between these terranes (Davis and Burchfiel, 1973). Sedimentation in depositional basins along the Garlock fault is no doubt related to the extensional processes on either side.

The part of the Basin and Range that lies north of the Garlock fault zone represents shallow crustal levels; there Paleozoic and Mesozoic rocks are widespread and steeply dipping normal faults are characteristic. South of the fault zone in the Mojave Desert, crystalline rocks that represent deeper crustal levels crop out widely. The presumably low-angle normal faults, which accommodated extension in the Mojave Desert region, are largely eroded away and northwest-striking, right-lateral faults are the most prominent structures (Hewett, 1954; Burchfiel and Davis, 1981; Dokka and others, 1988). Constraining the extent and displacement on the Garlock fault is important to a clear understanding of the structural evolution of the adjacent extensional terranes.

Although 64 to $67 \mathrm{~km}$ of Neogene and Quaternary displacement has been recognized on the central Garlock fault (Smith, 1962; Carter, 1980; Davis and Burchfiel, 1973), the displacement and easternmost termination are uncertain. Davis and Burchfiel (1973) and Plescia and Henyey (1982) suggested that the fault extends some 60 $\mathrm{km}$ east of the Owlshead Mountains and has a minimum offset of $56 \mathrm{~km}$; however, this report presents stratigraphic evidence that the post-late Miocene offset on the eastern Garlock fault is less than $5 \mathrm{~km}$ and that the fault probably does not extend significantly east of the Owlshead Mountains.

\footnotetext{
'Department of Geology, California State University, Fresno, CA
}

A sequence of Neogene sedimentary rocks is discontinuously exposed over an area of about $50 \mathrm{~km}^{2}$ along the eastern Garlock fault zone between the Avawatz and Owlshead Mountains near southern Death Valley, California. The most complete section is exposed at Owl Hole Spring, on the southem flank of the Owlshead Mountains (fig. 1). Although the top of the section is eroded and the rocks are faulted and folded, the unit is stratigraphically coherent and tectonically in place.

The section at Owl Hole Spring is $700 \mathrm{~m}$ thick. Overall it coarsens upward from fine-grained, evaporite-rich playa and lacustrine beds in the lower two-thirds, to boulder conglomerate (col. 1-B, pl. 1) representing mid- to upper-fan deposits. The deposits accumulated in a tectonically controlled depocenter along the Garlock fault; they consist of sediment eroded from sources on opposite sides of the Garlock fault: the Owlshead Mountains on the north and the Avawatz Mountains on the south. The strata are still physically contiguous with these source areas.

The age, provenance, and structural position of strata in the Owlshead Mountains constrain the maximum slip on the part of Garlock fault between the Avawatz and Owlshead Mountains to less than $5 \mathrm{~km}$ during the last 8.5 million years. This relationship indicates that Neogene slip on the Garlock fault zone east of the Owlshead Mountains is not tectonically significant.

\section{LITHOLOGY}

The sedimentary rocks at Owl Hole Spring are divided into a lower member containing primarily fine-grained clastic rocks, evaporite deposits, and limestone and an upper member of cobble to boulder conglomerate. Due to erosion and faulting, neither the complete thickness nor the geometry of the Owl Hole Spring unit is known.

The basal contact of the section is exposed in only a few small outcrops. It is an angular unconformity on red conglomerate of the Military Canyon Formation of Brady (1990), which contains an 11.3 $\pm 0.6-\mathrm{Ma}$ andesite agglomerate (Brady, 1984). The Military Canyon Formation crops out at several locations in the Avawatz Mountains and 
overall is a coarse clastic unit derived from granite and gneiss sources not presently exposed in the range. It is petrographically identical to strata of similar age in the Halloran Hills, $28 \mathrm{~km}$ southeast of the Avawatz Mountains (Reynolds, this vol.).

\section{LOWER MEMBER}

The lower member of the sedimentary rocks at Owl Hole Spring is approximately $250 \mathrm{~m}$ thick and consists of silty and pure halite overlain by several varieties of gypsum and anhydrite, limestone, celestite $\left(\mathrm{SrSO}_{4}\right)$, bedded manganese oxides, pebble to cobble conglomerate, and monolithologic breccia. Evaporite is abundant mainly in the lower part of the sequence. Throughout the section are interbeds of bentonitic claystone, siltstone, tuff, and medium- to fine-grained sandstone, which vary in structure from massive to laminated.

Halite forms irregularly shaped bodies several tens of meters long and 1 to $2 \mathrm{~m}$ thick within the claystone and siltstone. Locally, the halite has migrated upward, obliterating the bedding in the host rock. Solution in halite-rich zones caused small-scale collapse above interconnected, subterranean channels, forming "pseudo-microkarst" topography.
Gypsum occurs in massive and laminated beds and also forms nodules and veins indicating both primary and secondary deposition. Throughout most of the evaporiteclastic part of the section, bedded gypsum overlies haliterich zones, although halitic and gypsiferous layers are interbedded near the top of the evaporite-rich lowest part. Gypsum is commonly altered to anhydrite, where it is associated with varicolored, nodular chert and manganese oxides.

The gypsiferous zone grades up into calcareous beds that consist of limy sandstone and various forms of primary and secondary limestone, including porous-sparry, dense-micritic, and nodular varieties. The micritic beds commonly are laminated and contain abundant bundles of hollow or crystal-lined tubes ranging from 2 to $5 \mathrm{~mm}$ in diameter and from 1 to $35 \mathrm{~cm}$ in length, which probably are root casts. The upper, carbonate-rich part of the lower member is thickest-approximately $100 \mathrm{~m}$ thick-in the northwestern part of the area.

Beds of medium- to fine-grained, equigranular and pebbly arkosic sandstone increase in abundance upward. They range from several millimeters to $0.5 \mathrm{~m}$ thick and are generally parallel bedded. Low-angie cross stratification and graded beds are common.

Beds of water-laid vitric tuff are found in several places in the upper part of the lower member. The most promi-

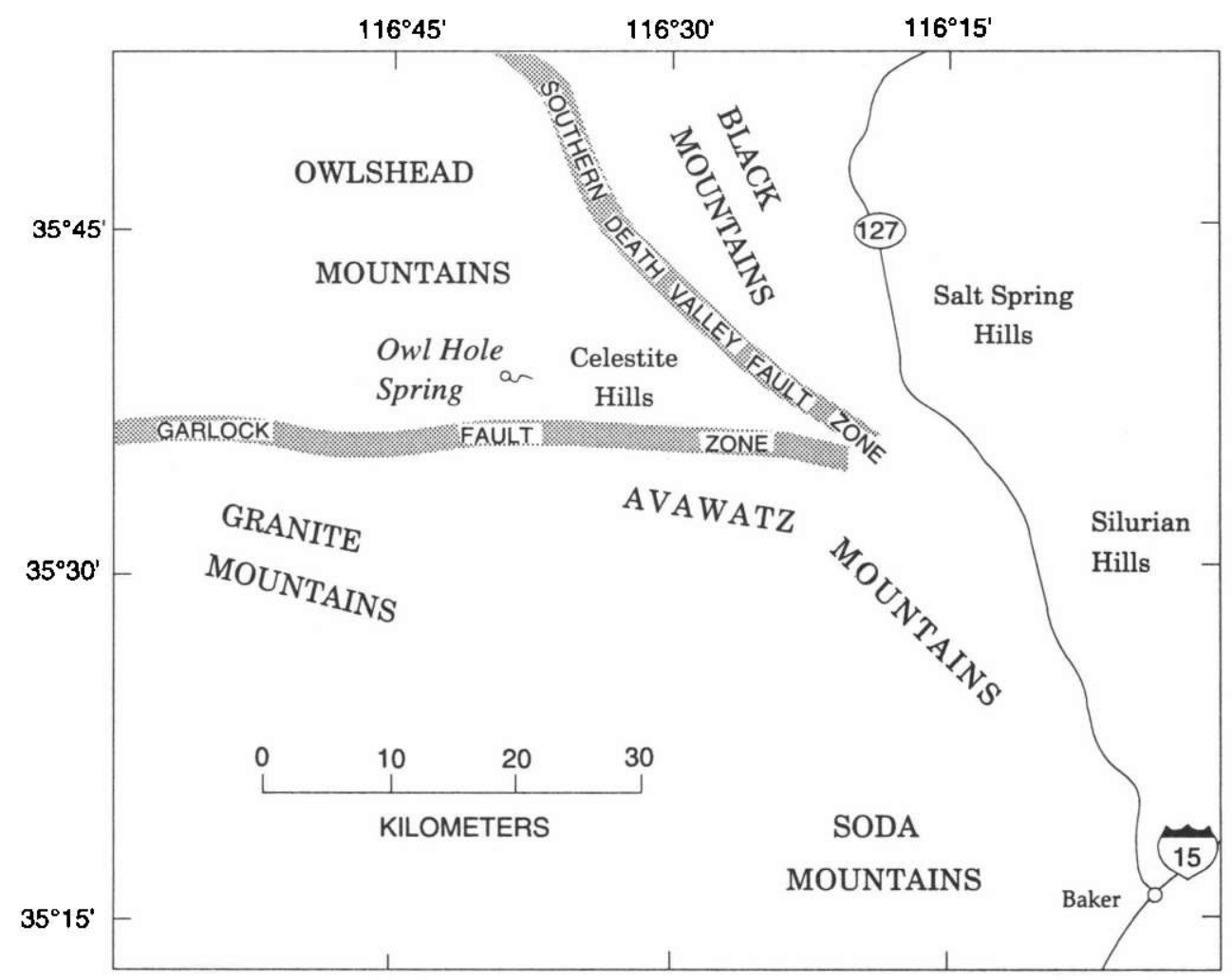

Figure 1. Map showing location of some geologic and geographic features discussed in text. 
Table 1. Potassium-argon ages from vitric tuff beds in the sedimentary rocks at Ow! Hole Spring in the Avawatz Mountains.

\begin{tabular}{|c|c|c|c|c|c|}
\hline $\begin{array}{l}\text { Sample } \\
\text { number }{ }^{1}\end{array}$ & $\begin{array}{c}\text { Material } \\
\text { dated }\end{array}$ & $\begin{array}{c}\mathrm{K}_{2} \mathrm{O} \\
(\mathrm{wt} \mathrm{pct})^{2}\end{array}$ & $\begin{array}{c}{ }^{40} \mathrm{Ar}_{\mathrm{rad}} \\
\left(10^{-11} \mathrm{~mol} / \mathrm{g}\right)^{2}\end{array}$ & $\begin{array}{l}\text { Percent } \\
{ }^{40} \mathrm{Ar}_{\mathrm{rad}}{ }^{2}\end{array}$ & $\begin{array}{l}\text { Calculated age } \\
(\mathrm{Ma})^{3}\end{array}$ \\
\hline \multirow[t]{6}{*}{ OHS-87-10 } & Biotite & $(8.044)$ & $(7.309)$ & $(35.1)$ & $6.31 \pm 0.21$ \\
\hline & & 8.046 & 7.268 & 34.9 & \\
\hline & & 8.008 & 7.077 & 33.8 & \\
\hline & & 8.078 & 7.504 & 35.6 & \\
\hline & & & 7.409 & 35.2 & \\
\hline & & & 7.289 & 35.9 & \\
\hline \multirow[t]{5}{*}{ OHS-1 } & Whole rock & $(3.157)$ & (3.495) & $(52.4)$ & $7.68 \pm 0.18$ \\
\hline & (vitric tuff) & 3.168 & 3.511 & 53.0 & \\
\hline & & 3.139 & 3.506 & 53.1 & \\
\hline & & 3.164 & 3.453 & 51.3 & \\
\hline & & & 3.510 & 52.1 & \\
\hline \multirow[t]{5}{*}{ OHS-2 } & Biotite & (8.392) & $(10.27)$ & $(41.4)$ & $8.49 \pm 0.24$ \\
\hline & & 8.437 & 10.57 & 42.5 & \\
\hline & & 8.422 & 10.42 & 42.1 & \\
\hline & & 8.412 & 10.09 & 40.6 & \\
\hline & & 8.295 & 10.00 & 40.2 & \\
\hline
\end{tabular}

\footnotetext{
'Dating was done by M. Shafiqullah, University of Arizona Geochronology Lab, Tucson, Ariz. Location of samples: $35^{\circ} 38^{\prime} 17^{\prime \prime} \mathrm{N}$. lat, $116^{\circ} 41^{\prime} 37^{\prime \prime} \mathrm{W}$. long.

${ }^{2}$ Value in parentheses is arithmetic mean used in age calculation.

${ }^{3} \mathrm{~K}$-Ar ages were calculated using the constants for the radioactive decay and abundance of ${ }^{40} \mathrm{~K}$ recommended by the International Union of Geological Sciences Subcommission on Geochronology (Steiger and Jäger, 1977). These constants are: $\lambda_{\varepsilon}=0.580 \times 10^{-10} \mathrm{yr}^{-1}, \lambda_{\beta}=4.962 \times 10^{-10} \mathrm{yr}^{-1}$, and ${ }^{40} \mathrm{~K} / \mathrm{K}_{\text {total }}=1.167 \times 10^{-4} \mathrm{~mol} / \mathrm{mol}$.
}

nent tuff bed is only $13 \mathrm{~cm}$ thick, but several form distinctive marker horizons that can be traced along strike for hundreds of meters. Glass is mostly fresh but is altered to clay or zeolite where tuff is in contact with halite or gypsum. From lower to upper, tuff beds yielded isotopic ages of $8.49 \pm 0.24,7.68 \pm 0.18$, and $6.31 \pm 0.21 \mathrm{Ma}$, respectively (table 1 ; col. 1-B, pl. 1).

Throughout the lower member, thin, discontinuous beds of conglomerate and monolithologic breccia fill shallow channels. Some conglomerate beds contain subrounded clasts of Tertiary volcanic rocks, Paleozoic limestone, and granite; others contain mainly dark- to pale-green, massive metavolcanic rocks. The monolithologic breccia is formed of very angular clasts of these same metavolcanic rocks. The clast content of the breccia differs from that of overlying and underlying sandstone, which are mainly granitic, indicating that the breccia was derived from a separate source terrane.

The lower member is pervasively mineralized by strontium and manganese in the Celestite Hills, $6 \mathrm{~km}$ southeast of Owl Hole Spring (Durrell, 1953), and at Owl Hole Spring. Spectrographic and petrographic analyses show the manganese deposits to be an impure mixture of pyrolusite, psilomelane, and miscellaneous metallic trace elements. The manganese oxides are sooty and spongy on the surface but inside are dense and compact with a sub- metallic luster. In areas of partial replacement, sooty, black manganese oxides fill irregular, interconnected cavities in the massive gypsum bed. The intervening gypsum is fresh, white, and unaltered.

Field and chemical evidence indicates that the celestite and manganese oxides result from low-temperature, secondary replacement reactions. The stratiform geometry of the deposit indicates that mineralizing fluids likely migrated upward along vertical faults, and then along bedding surfaces in the strata-probably confined in part by boundary units of low porosity. These deposits were mined from the late 1800 s to the end of World War II.

In several parts of the manganese oxide deposit, celestite replaced limestone and gypsum. The celestite variously forms massive white beds, dense masses of prismatic tan crystals as long as $3 \mathrm{~mm}$ with wisps and small stringers of psilomelane, and white rounded nodules within a matrix of loose, limy siltstone and free celestite crystals. Spectroscopic analyses of nodular and crystalline celestite show them to be 99.95 percent $\mathrm{SrSO}_{4}$.

\section{UPPER MEMBER}

Overlying the lower member is an interval more than $440 \mathrm{~m}$ thick of interbedded breccia, massive to bedded 
boulder and cobble conglomerate, and subordinate, pebbly to cobbly sandstone. The contact between the lower and upper members is gradational and is due to an increase in clastic detritus over a stratigraphic distance of about $10 \mathrm{~m}$. The top of the upper member is erosionally truncated, and its age is undetermined.

Bedding in the lower part of the upper member is generally thick and planar at outcrop scale. Most commonly, the framework is clast supported. In the upper part of the member, bedding is massive, and matrix-supported framework dominates. Paleocurrent directions based on channel orientation indicate transport from sources on both north and south sides of the depocenter.

The proportions of different clast lithologies in the lower part of the upper member are separated into distinct beds-those containing green, massive, metavolcanic rocks and those containing mostly Tertiary volcanic rocks with lesser granite and trace amounts of red chalcedony, large smoky quartz, and clear quartz crystals. Clasts in the upper part of the upper member are almost entirely metavolcanic rocks.

\section{INTERPRETATION}

The sedimentary rocks at Owl Hole Spring were deposited in a late Miocene to Pliocene basin located along the left-lateral Garlock fault zone. The basin had an east- trending, linear shape with approximate dimensions of 3 $\mathrm{km}$ by $17 \mathrm{~km}$ (fig. 2). Rocks of the lower member (clastic rocks, evaporite deposits, and limestone) are interpreted to represent deposition in a saline playa, synchronous with deformation and tilting. These strata later were overlapped by fluvial, lacustrine-margin deposits.

The sequence of halite beds overlain successively by gypsum and carbonate rocks is the inverse of the solubility sequence that would be expected from progressive desiccation of a saline lake. However, the entire sequence could be produced by progressive, syndepositional southward tilting of a flooded basin. In this way the saline, basincenter deposits would be progressively overlapped by (1) less-soluble, gypsiferous playa deposits, (2) carbonate rocks, lacustrine-margin deposits, and (3) alluvial fan deposits. Similar relationships have been documented in Death Valley (Hunt and Mabey, 1966).

The upper member (cobble to boulder conglomerate) represents alluvial fans that prograded from the Avawatz and Owlshead Mountains, ultimately filling the basin. This pulse of coarse clastic deposition was probably caused by tectonic uplift of the basin margins, owing to oblique slip along the Garlock fault zone.

Conglomerate clast compositions at Owl Hole Spring indicate that sediment was derived from both the Avawatz and Owlshead Mountains. Detritus in the upper part of the upper member was derived solely from the Avawatz Mountains, where the western $10 \mathrm{~km}$ is composed of met-

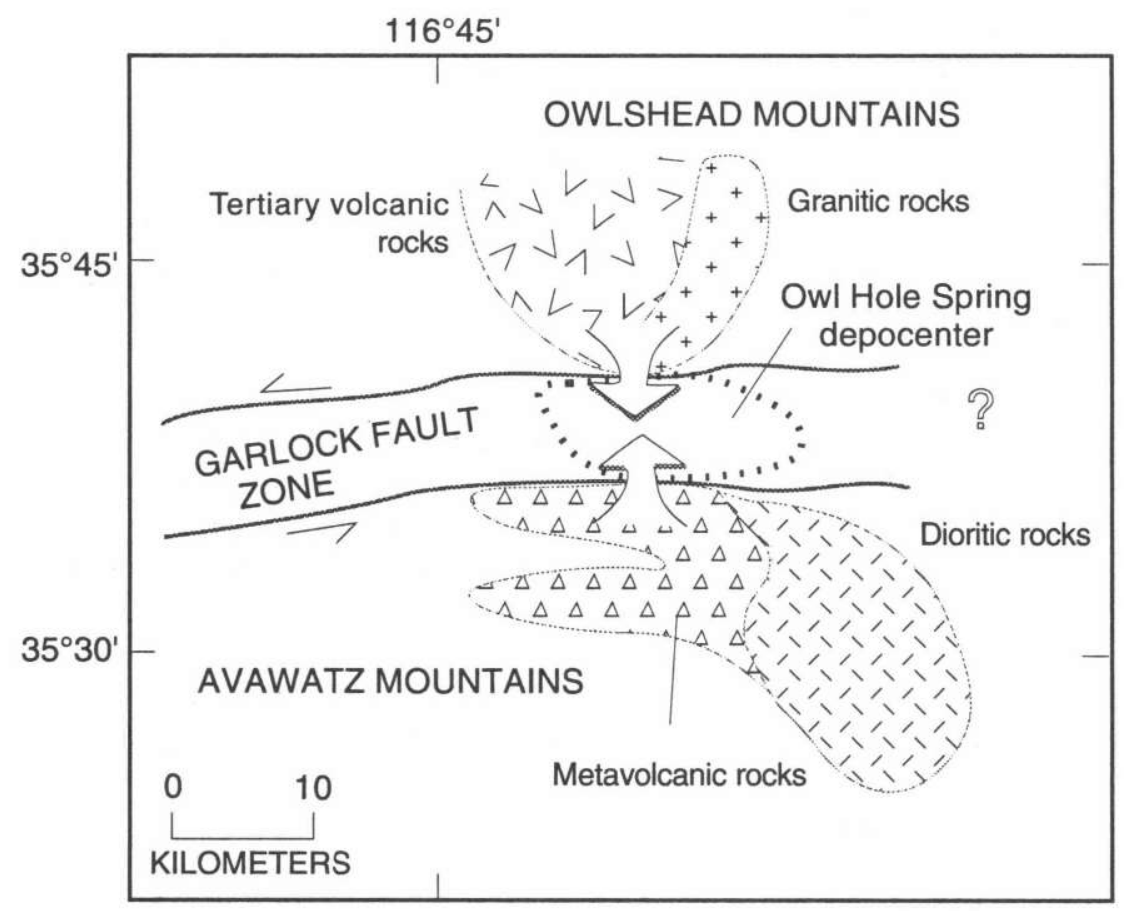

Figure 2. Schematic diagram showing depositional setting of the sedimentary rocks at Owl Hole Spring. Transport of sediment from both sides of the basin is shown by large arrows. Dotted line shows the present extent of Tertiary deposits. Query indicates uncertain extent of Garlock fault zone in late Miocene and Pliocene time. 
avolcanic rocks and minor granite, and the eastern part is mainly dioritic rocks; younger dikes indicate that Tertiary volcanic rocks may have been present at one time. An arcuate belt in the southern Owlshead Mountains is the likely source terrane for associated vesicular basalt, red chalcedony, and large crystals of both clear and smoky quartz in the lower member and the lower part of the upper member of sedimentary rocks at Owl Hole Spring. The belt is approximately $5 \mathrm{~km}$ across, mainly composed of granitic and carbonate bedrock on the east and widespread outcrops of Tertiary volcanic rocks on the west (Jennings and others, 1962).

The sedimentary rocks at Owl Hole Spring place important constraints on Neogene slip along the eastern Garlock fault zone. Because beds of coarse clastic detritus derived from the Owlshead and Avawatz Mountains are interlayered as discrete beds, the sources of that sediment must have been on opposite sides of the basin during deposition. Specifically, the granitic clasts likely were derived mainly from the 5-km-wide belt of older rocks in the eastem Owlshead Mountains. That source must have been situated north of the belt of metavolcanic rocks in the Avawatz Mountains, which is approximately $10 \mathrm{~km}$ across (fig. 2). Because these two source terranes are still opposite one another (fig. 1), the amount of left slip that has occurred since deposition of lower parts of the Owl Hole Spring unit about $8.5 \mathrm{Ma}$ is constrained to be less than 5 $\mathrm{km}$ - the width of the granitic belt in the Owlshead Mountains. This constraint indicates that large amounts of Neogene slip (about $64 \mathrm{~km}$ ) proposed to have occurred along the western Garlock fault zone cannot be documented for the time since about $8.5 \mathrm{Ma}$, in the vicinity of the southern Owlshead Mountains.

\section{ACKNOWLEDGMENTS}

This project benefited greatly from conversations with Jon Spencer. Research was supported by National Aeronautics and Space Administration contract NAS5-28754.

\section{REFERENCES CITED}

Brady, R.H. III, 1984, Neogene stratigraphy of the Avawatz Mountains between the Garlock and Death Valley fault zones, southern Death Valley, California: Implications as to late Cenozoic tectonism: Sedimentary Geology, v. 38, nos. 1-4, p. 127-157.
1990 , Stratigraphy and structure at the intersection of the Garlock and Death Valley fault zones, northern Avawatz Mountains, California, in Reynolds, R.E., Wells, S.G., and Brady, R.H. III, compilers, At the end of the Mojave: Quaternary studies in the eastern Mojave Desert: Redlands, Calif., San Bernardino County Museum Association Special Publication, Mojave Desert Research Symposium Field Trip Guide, p. 119-128.

Burchfiel, B.C., and Davis, G.A., 1981, Mojave Desert and environs, in Emst, W.G., ed., The geotectonic development of California (Rubey Volume 1): Englewood Cliffs, N.J., Prentice-Hall, p. 217-252.

Carter, B.A., 1980, Quaternary displacement on the Garlock fault, California, in Fife, D.L., and Brown, A.R., eds., Geology and mineral wealth of the California desert: Santa Ana, Calif., South Coast Geological Society (Dibblee Volume), p. $457-465$.

Davis, G.A., and Burchfiel, B.C., 1973, Garlock fault, an intercratonic transform structure, southern California: Geological Society of America Bulletin, v. 84, no. 4, p. 1,407-1,422.

Dokka, R.K., McCurry, Michael, Woodburne, M.O., Frost, E.G., and Okaya, D.A., 1988, A field guide to the Cenozoic crustal structure of the Mojave Desert, in Weide, D.L., and Faber, M.L., eds., This extended land: geological journeys in the southern Basin and Range: Las Vegas, University of Nevada Department of Geosciences Special Publication 2 (Geological Society of America, Cordilleran Section, Las Vegas, Nev., March 1988, Field Trip Guidebook), p. 21-44.

Durrell, Cordell, 1953, Celestite deposits near the southern end of Death Valley, San Bernardino County, California: California Division of Mines Special Report 32, p. 15-21.

Hewett, D.F., 1954, General geology of the Mojave Desert region, California, in Jahns, R.H., ed., Geology of southern California: California Division of Mines and Geology Bulletin 170 , p. $5-20$.

Hunt, C.B., and Mabey, D.R., 1966, Stratigraphy and structure, Death Valley, California: U.S. Geologic Survey Professional Paper 494-A, 162 p.

Jennings, C.W., Burnett, J.L., and Troxel, B.W., compilers, 1962, Trona sheet, Geologic atlas of California: California Division of Mines and Geology, scale 1:250,000.

Plescia, J.B., and Henyey, Thomas, 1982, Geophysical character of the proposed eastern extension of the Garlock fault and adjacent areas, eastern California: Geology, v. 10, no. 4, p. 202-208.

Smith, G.I., 1962, Large lateral displacement on the Garlock fault, California, as measured from offset dike swarm: American Association of Petroleum Geologists Bulletin, v. 46, no. 1, p. 85-104.

Steiger, R.H., and Jäger, E., 1977, Subcommission on geochronology: Convention on the use of decay constants in geoand cosmochronology: Earth and Planetary Science Letters, v. 36 , no. 3 , p. $359-362$. 



\title{
Stratigraphy of the Avawatz Formation, Southern Death Valley Region, Southeastern Calif.
}

\author{
By Jon E. Spencer ${ }^{1}$
}

The Avawatz Mountains are located in San Bernardino County in the northeastern Mojave Desert region of southeastern California (fig. 1). Quatemary uplift due to reverse faulting along the north and east flanks of the range is largely responsible for the rugged morphology and excellent rock exposures in the Avawatz Mountains. Pre-Tertiary bedrock in the range consists primarily of roof pendants of Proterozoic and Paleozoic metasedimen-

\footnotetext{
'Arizona Geological Survey, 845 N. Park Avenue, Tucson, AZ 85719
}

tary rocks and Mesozoic metavolcanic rocks intruded by Mesozoic granitic rocks (Spencer, 1990a). The Miocene to Pliocene(?) Avawatz Formation of Henshaw (1939) is well exposed in the southern Avawatz Mountains along the northwest-striking Arrastre Spring fault. The Arrastre Spring fault bifurcates southward into east and west branches, and clastic rocks at the base of the Avawatz Formation rest depositionally on pre-Tertiary bedrock on both sides of both branches of the fault. The Avawatz Formation is tentatively regarded as Miocene in age over most of its exposure area; however, it might also possibly

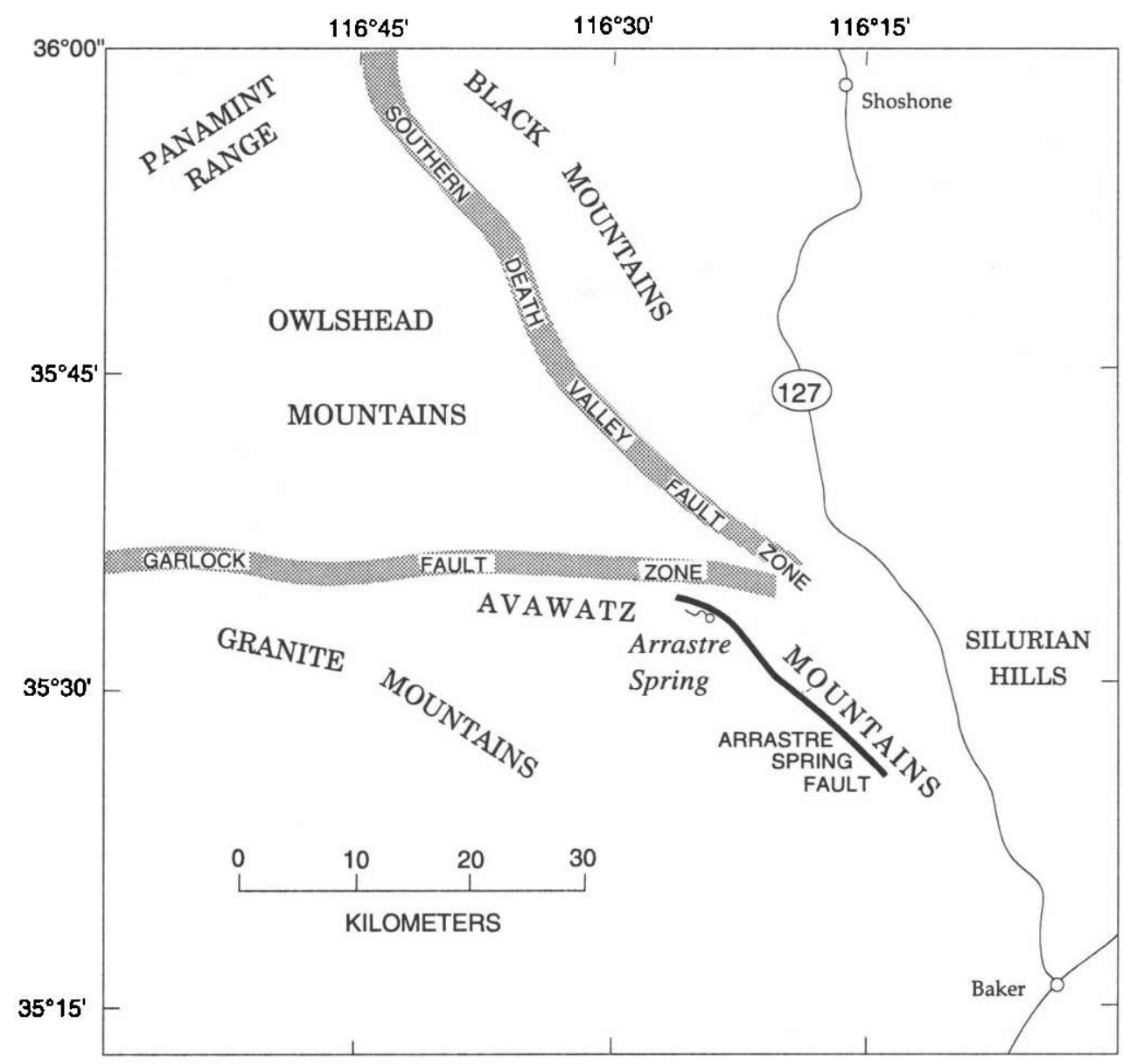

Figure 1. Map showing location of some geographic and geologic features discussed in text. 
include some Pliocene rocks in its southwesternmost outcrops.

The thickest part of the Avawatz Formation is southwest of the southwestern branch of the Arrastre Spring fault and is shown schematically in the accompanying stratigraphic column (col. 1-C, pl. 1). Fine-grained clastic rocks that make up the lower $750 \mathrm{~m}$ of the section record initial basin formation adjacent to the Arrastre Spring fault (Spencer, 1990b). These clastic rocks consist primarily of poorly sorted sandstone and local conglomeratic sandstone with less abundant silty sandstone, siltstone, and mudstone near the base of the section. An interbedded tuff near the base has a $\mathrm{K}$-Ar age of $20.9 \pm 0.2 \mathrm{Ma}$ (biotite; Spencer, 1990b). Eastward lateral increase in grain size toward the Arrastre Spring fault is apparent in the upper part of this 750-m-thick sequence.

Fine-grained basal strata grade upward into approximately $3,000 \mathrm{~m}$ of coarse conglomerate and sedimentary breccia that were derived from bedrock northeast of the Arrastre Spring fault. Individual breccia sheets typically range from 2 to $20 \mathrm{~m}$ thick but are locally much thicker (perhaps more than $100 \mathrm{~m}$ ). Clast size and clast-size ranges are highly variable. In some breccia sheets all clasts are less than about $20 \mathrm{~cm}$ in diameter, whereas in others the maximum clast diameter approaches $5 \mathrm{~m}$. The sedimentary breccia sheets represent catastrophic debris avalanches of the type described by Shreve (1968). The conglomerate grades laterally westward away from the Arrastre Spring fault into sandstone and is interpreted as representing alluvial fan deposits shed from the uplifted northeast side of the Arrastre Spring fault (Brady, 1984; Spencer, 1990b). Coarse clastic strata eventually transgressed eastward across both branches of the Arrastre Spring fault and buried it. The conglomerate and breccia fine upward into sandstone with locally interbedded conglomerate, sedimentary breccia, and white air-fall tuff. This stratigraphically highest part of the section is complicated by folding and unconformities but appears to be more than $1,000 \mathrm{~m}$ thick. A tuff from this upper part of the section, well above the conglomerate, yielded K-Ar ages of 11.0 and 11.3 $\mathrm{Ma}$ (sandine) (Evernden and others, 1964). (Their samples were originally reported as 10.7 and $11.0 \mathrm{Ma}$ but are slightly older when recalculated using method of Dalrymple (1979); no error range was reported for these ages.)

The Avawatz Formation is interpreted to have been deposited in a basin formed by southwest-side-down nor- mal movement on the Arrastre Spring fault in middle Miocene time. The basin was apparently a half-graben and sediments within it probably thinned gradually to the southwest. Movement on the fault had begun by $21 \mathrm{Ma}$ and was over by approximately $12 \mathrm{Ma}$ (Spencer, 1990b). Most faulting and conglomerate deposition in the basin probably occurred between approximately 21 and $15 \mathrm{Ma}$, within a Cenozoic extensional tectonic environment that affected the Mojave region and southern Basin and Range province. The upper, finer grained strata in the sequence were probably deposited in a broad, shallow basin inherited from the earlier period of extension, but also underwent deformation associated with movement on the Garlock and Death Valley faults (Spencer, 1990b) or with regional north-south shortening (Bartley and others, 1990).

\section{REFERENCES CITED}

Bartley, J.M., Glazner, A.F., and Schermer, E.R., 1990, Northsouth contraction of the Mojave block and strike-slip tectonics in southern California: Science, v. 248, p. 1,398-1,401.

Brady, R.H., III, 1984, Neogene stratigraphy of the Avawatz Mountains between the Garlock and Death Valley fault zones, southem Death Valley, California: Implications as to late Cenozoic tectonism: Sedimentary Geology, v. 38, nos. 1-4, p. 127-157.

Dalrymple, G.B., 1979, Critical tables for conversion of $\mathrm{K}-\mathrm{Ar}$ ages from old to new constants: Geology, v. 7, no. 11, p. $558-560$.

Evernden, J.F., Savage, D.E., Curtis, G.H., and James, G.T., 1964, Potassium-argon dates and the Cenozoic mammalian chronology of North America: American Journal of Science, v. 262 , no. 2 , p. $145-198$.

Henshaw, P.C., 1939, A Tertiary mammalian fauna from the Avawatz Mountains, San Bernardino Mountains, California: Carnegie Institution of Washington Publication 514, p. 1-30.

Shreve, R.L., 1968, The Blackhawk landslide: Geological Society of America Special Paper 108, 47 p.

Spencer, J.E., 1990a, Geologic map of the southem Avawatz Mountains, northeastern Mojave Desert region, San Bernardino County, Califomia: U.S. Geological Survey Miscellaneous Field Studies Map MF-2117, scale 1:24,000.

1990b, Late Cenozoic extensional and compressional tectonism in the southern and western Avawatz Mountains, southeastern California, in Wernicke, B.P., ed., Basin and Range extensional tectonics near the latitude of Las Vegas, Nevada: Geological Society of America Memoir 176, p. 317-333. 


\title{
Erosion, Deposition, and Detachment: The Halloran Hills Area, Calif.
}

\author{
By Robert E. Reynolds ${ }^{1}$
}

\section{SETTING}

The Halloran Hills ${ }^{2}$ are in the eastern Mojave Desert, southeast of the Avawatz Mountains and east of the Death Valley fault zone, north of the Cima volcanic field, and west of Clark Mountain (fig. 1). The Cenozoic strata exposed there record depositional and structural history that spans approximately 25 million years from middle Tertiary to late Pleistocene time.

Prior to Cenozoic time, middle Mesozoic thrusting emplaced Paleozoic carbonate rocks over Triassic and Jurassic clastic rocks and Jurassic volcanic rocks between 172 and $167 \mathrm{Ma}$ (Busby-Spera, 1988). The Teutonia batholith was then emplaced between Late Jurassic and Early Cretaceous time, from 137 to $92 \mathrm{Ma}$ (Beckerman and others, 1982). During early Tertiary time, the thrust sheets of Paleozoic rocks were stripped from over much of the Teutonia batholith, and an extensive erosional surface on granitic rocks, known as the Ivanpah upland of Hewett (1956), was formed in the area that is presently the Halloran Hills.

The Shadow Valley basin (Hewett, 1956) in the Ivanpah upland is a Tertiary structural depression that was filled by lacustrine sediment, landslide debris, and gravityslide blocks. The basin was subsequently extended by westward movement of the upper plate of a detachment fault. The sediment of Shadow Valley basin and the erosional surface upon which it was deposited are exposed over $700 \mathrm{~km}^{2}$.

\section{BASIN FORMATION}

The deeply weathered, hematite-stained erosional surface that developed about $20 \mathrm{Ma}$ produced rounded granitic blocks, including some large spheroidal granitic boulders. The swales and areas of low relief in this surface were

\footnotetext{
${ }^{1}$ Division of Earth Sciences, San Bemardino County Museum, 2024 Orange Tree Lane, Redlands, CA 92374

2“"Halloran Hills" is an informal geographic name applied to hills north of Interstate Highway 15 near Halloran Springs, Calif. The area includes Turquoise Mountain, Squaw Peak, and other lower summits [eds.]
}

covered with a conglomerate containing rounded clasts of quartzite derived from the Cambrian Wood Canyon Formation and the Cambrian Zabriskie Quartzite (col. 1-D, pl. 1). Such lag deposits may be time transgressive. The deeply weathered erosional surface and overlying conglomerate represent a period of structural stability that presumably spanned a significant amount of time.

Subsidence and sedimentation into Shadow Valley basin are recorded by fine-grained lacustrine sedimentary rocks north of the Francis Spring-Squaw Mountain area. Coarse-grained arkosic fanglomerate grades from Halloran Spring northward into the uppermost part of these lacustrine sedimentary rocks. Near the base of the lacustrine sequence is a sphene-bearing tuff that resembles and has the paleomagnetic polarity of the Peach Springs Tuff of Young and Brennan (1974) (paleomagnetic data of J.W. Hillhouse, U.S. Geological Survey, oral commun., 1991). A sample of this tuff collected $3 \mathrm{~km}$ west of Francis Spring has a K-Ar age of $19.05 \pm 0.11 \mathrm{Ma}$ (sanidine) (Carl Swisher, U.C. Berkeley, oral commun., 1989). This is within the range of conventional K-Ar ages for the Peach Springs Tuff, which has an accepted age of $18.5 \pm 0.2 \mathrm{Ma}$, determined by two ${ }^{40} \mathrm{Ar} /{ }^{39} \mathrm{Ar}$ methods (Nielson and others, 1990).

A unit of pyroxene andesite breccia and lava flows is interbedded with the lower basin sedimentary deposits. At Halloran Spring, the pyroxene andesite breccia overlies a brecciated mass of crystalline rock derived from Mountain Pass and underlies a 1.6-km-thick sequence of arkosic sandstone and conglomerate. A K-Ar age of $12.8 \pm 0.5 \mathrm{Ma}$ (whole rock) was obtained from a pyroxene andesite flow collected southwest of Halloran Summit (H.G. Wilshire, U.S. Geological Survey, oral commun., 1988). At Squaw Mountain, breccia of the pyroxene andesite unit is located in the middle part of the unit of the lacustrine sedimentary rocks. Siltstone that overlies the pyroxene andesite breccia contains a fossil rodent assemblage (Reynolds, 1988) with taxa in common with the early Clarendonian land-mammal age (Reynolds and Whistler, 1990) of the Avawatz Formation (Spencer, 1990). The Avawatz Formation contains a tuff that yielded $\mathrm{K}-\mathrm{Ar}$ ages of 11.0 and $11.3 \mathrm{Ma}$ (sanidine) (Evernden and others, 1964, their samples KA 1275 and KA 1365 herein recalculated using method of Dalrymple, 1979; no error ranges were reported for these ages). 


\section{SYNTECTONIC DEPOSITION}

Faulting and folding deformed the fine-grained lacustrine rocks that are between 18.5 and $11 \mathrm{Ma}$. An erosional surface formed across the sedimentary rocks and, in places, exposed the older erosional surface of the Ivanpah upland. The development of the erosional surface on the lacustrine rocks exposed in Shadow Valley may have been contemporaneous with a structural event that later led to the deposition of landslide blocks, landslide breccias, and fanglomerate in the Shadow Valley basin. The basin was filled with coarse debris from the southeast, northeast, and south.

Some landslide blocks have sources to the southeast. In contrast, some fanglomerate beds contain distinctive clasts of syenite, garnet gneiss, and Jurassic clastic and volcanic rocks associated with Paleozoic limestone. This association indicates a source to the east near Mountain Pass. Fanglomerate beds in the northem part of the basin were derived from the northeast and contain clasts of predominantly metamorphic rocks, no Mountain Pass rocks, and only one percent Paleozoic carbonate rocks. These granitic fanglomerate deposits may indicate relative uplift of the terrain south of the inferred east-striking Halloran fault (Jennings, 1961).

\section{DETACHMENT FAULTING}

Normal-fault-bounded blocks in the Shadow Valley basin were tilted southeastward, probably above a detachment surface with upper-plate displacement to the northwest. Mapped relations indicate that the Shadow Valley detachment surface is not exposed in the area but probably lies below the Tertiary sedimentary rocks and within the Mesozoic granitic and metamorphic rocks. An alternative interpretation of Parke and Davis (1990) postulates that a "Halloran Hills detachment fault" is exposed in the area.

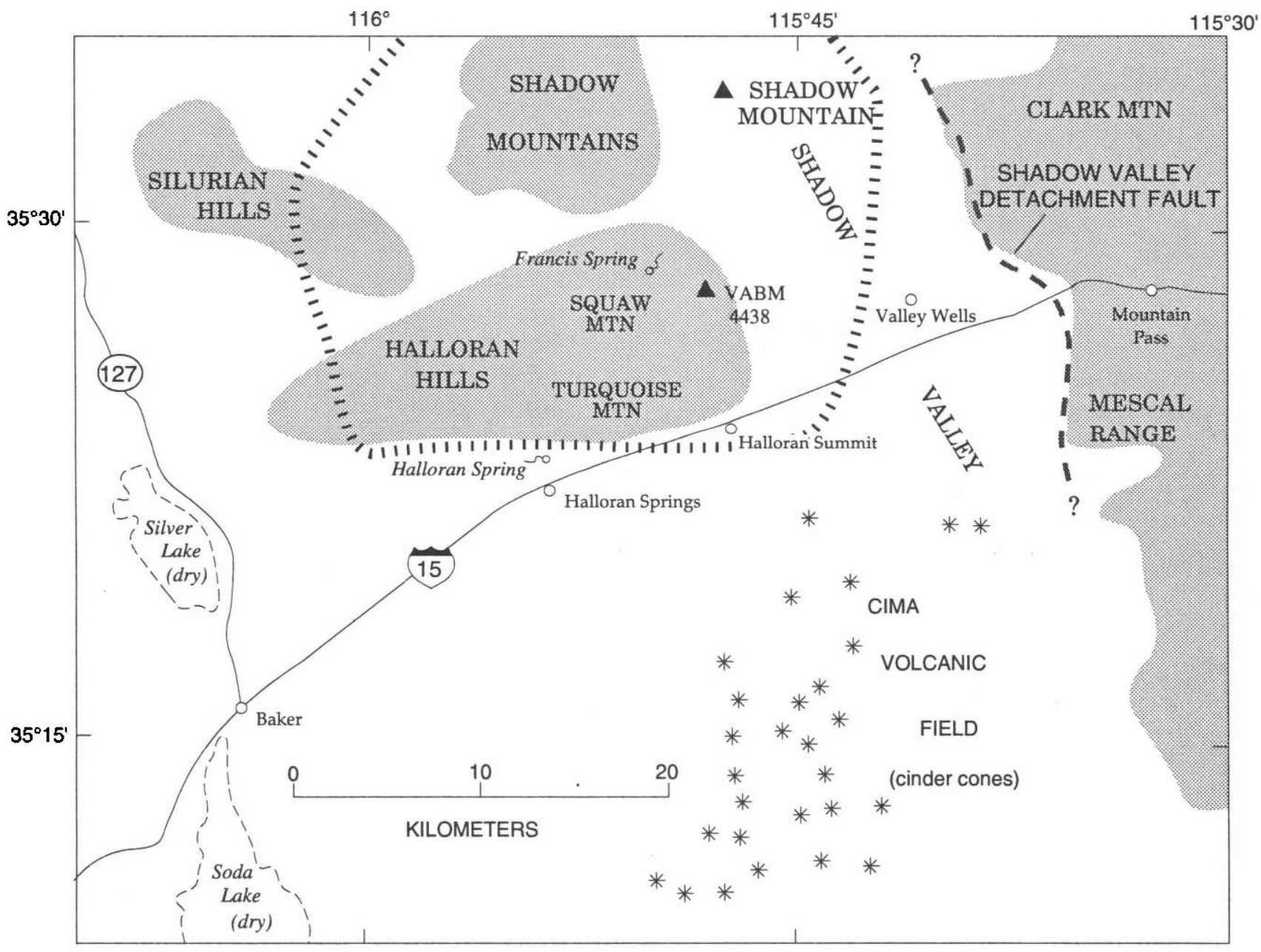

Figure 1. Map showing location of geographic features named in text. "Halloran Hills" is an informal geographic name. Broken line shows approximate limit of Tertiary Shadow Valley basin. Vents for Cima volcanic field (late Tertiary and Quaternary) from Jennings (1975). 
Whatever the structural level of the fault, it probably was active in middle or late Miocene time.

A third, probably time-transgressive, erosional surface developed across the east-tilted strata that had been deposited in the Shadow Valley basin. Upper Miocene and Pliocene basalt lava overlies this surface. The flow directions of the lava on the erosional surface indicate that a topographic divide had formed in the Shadow Valley basin area by this time. Basalt was erupted near or along the divide and flowed into basins that had already formed to the east and west of the divide: the Valley Wells basin to the east, and the Soda Lake basin to the west (fig. 1). In the southern Cima volcanic field, one of these lavas has a $\mathrm{K}$-Ar age of $6.47 \pm 0.18 \mathrm{Ma}$ (whole rock; Turrin and others, 1985); in the Halloran Hills a flow has an age of $5.12 \pm 0.16 \mathrm{Ma}$ (whole rock, Turrin and others, 1985). West-flowing basalt flows at Halloran Spring range in age from $5.12 \pm 0.16 \mathrm{Ma}$ to $4.24 \pm 0.17 \mathrm{Ma}$ (whole rock, Turin and others, 1985). Northeast-flowing basalt lava in the eastern Halloran Hills has a K-Ar age of $4.48 \pm 0.15 \mathrm{Ma}$ (whole rock; Turrin and others, 1985).

\section{LATE TERTIARY AND QUATERNARY TECTONIC ACTIVITY}

North-striking normal faults east of Turquoise Mountain and in the Valley Wells basin have east-side-up relative displacement. West of topographic location VABM 4438 (Halloran Spring 15-minute quadrangle; fig. 1), this movement predated the 5.12-Ma basalt flow. In the Valley Wells basin, the sense of movement appears to be reversed (westside-up) since the emplacement of basalt from about 4.5 and 3.3 Ma (ages previously cited from Turrin and others, 1985).

The Pliocene and Quaternary lacustrine sedimentary sequence in Valley Wells basin contains vertebrate fossils near its base that represent the late Blancan land-mammal age of late Pleistocene time (approximately $2.4 \mathrm{Ma}$ ) (Reynolds and others, 1991). Different species of mammoth indicate that deposition spans the 0.4-Ma Irvingtonian-Rancholabrean land-mammal stage boundary (Woodburne, 1987; Savage and Russell, 1983). Thus, lacustrine deposition started prior to $2 \mathrm{Ma}$ and continued until after $0.4 \mathrm{Ma}$. Stratigraphic relations indicate east-side-up movement early in the Pleistocene depositional history. If sedimentary sections can be correlated, the western part of the basin was uplifted 55 meters after late Pleistocene time (approximately 0.4 Ma).

\section{REFERENCES CITED}

Beckerman, G.M., Robinson, J.P., and Anderson, J.L., 1982, The Teutonia batholith: A large intrusive complex of Juras- sic and Cretaceous age in the eastem Mojave Desert, California, in Frost, E.G., and Martin, D.L., eds., MesozoicCenozoic tectonic evolution of the Colorado River region, Califomia, Arizona, and Nevada (Anderson-Hamilton Volume): San Diego, Calif., Cordilleran Publishers, p. 205221.

Busby-Spera, C.J., 1988, Speculative tectonic model for the early Mesozoic arc of the southwest Cordilleran United States: Geology, v. 16, no. 12, p. 1,121-1,125.

Dalrymple, G.B., 1979, Critical tables for conversion of $\mathbf{K}-\mathrm{Ar}$ ages from old to new constants: Geology, v. 7, no. 11, p. $558-560$.

Evernden, J.F., Savage, D.E., Curtis, G.H., and James, G.T., 1964, Potassium-argon dates and the Cenozoic mammalian chronology of North America: American Journal of Science, v. 262, no. 2, p. 145-198.

Hewett, D.F., 1956, Geology and mineral resources of the Ivanpah quadrangle, Califomia and Nevada: U.S. Geological Survey Professional Paper 257, 172 p.

Jennings, C.W., compiler, 1961, Kingman sheet, Geologic atlas of Califomia: California Division of Mines and Geology, scale 1:250,000.

Jennings, C.W., 1975, Fault map of California, with locations of volcanoes, thermal springs, and thermal wells: California Division of Mines and Geology Map 1, scale 1:750,000.

Nielson, J.E., Lux, D.R., Dalrymple, G.B., and Glazner, A.F., 1990, Age of the Peach Springs Tuff, southeastern California and western Arizona: Journal of Geophysical Research, v. 95 , no. B1, p. 571-580.

Parke, Mary and Davis, G.A., 1990, Gravity gliding in the eastern Mojave Desert? Only the Shadows know [abs.]: Geological Society of America Abstracts with Programs, v. 22, no. 3 , p. 74 .

Reynolds, R.E., 1988, Timing of deposition and deformation in Pleistocene sediments at Valley Wells, eastern San Bernardino County, Califomia [abs.]: Geological Society of America Abstracts with Programs, v. 20, no. 3, p. 223-224.

Reynolds, R.E. and Whistler, D.P., 1990, Early Clarendonian faunas of the eastern Mojave Desert, San Bernardino County, California, in Reynolds, R.E., Wells, S.G., and Brady, R.H., III, compilers, At the end of the Mojave: Quaternary studies in the eastem Mojave Desert: Redlands, Calif., San Bernardino County Museum Association Special Publication, Mojave Desert Research Symposium Field Trip Guide 90, p. 105-109.

Reynolds, R.E., Jefferson, G.T., and Reynolds, R.L, 1991, The sequence of vertebrates from Plio-Pleistocene sediments at Valley Wells, San Bemardino County, California, in Crossing the borders: Quaternary studies in eastern California and southwestern Nevada: Redlands, Calif., San Bernardino County Museum Special Publication, Mojave Desert Quaternary Research Symposium Field Guide 91, p. 72-77.

Savage, D.E., and Russell, D.E., 1983, Mammalian paleofaunas of the world: Reading, Mass., Addison-Wesley, $432 \mathrm{p}$.

Spencer, J.E., 1990, Geologic map of the southern Avawatz Mountains, northeastern Mojave Desert region, San Bernardino County, California: U.S. Geological Survey Miscellaneous Field Studies Map MF-2117, scale 1:24,000.

Turrin, B.D., Dohrenwend, J.C., Drake, R.E., and Curtis, G.H., 
1985, K-Ar ages from the Cima volcanic field, eastern Mojave Desert, California: Isochron/West, no. 44, p. 9-16.

Woodburne, M.O., 1987, Mammal ages, stages, and zones, in Woodburne, M.O., ed., Cenozoic mammals of North America: Berkeley, Calif., University of Califomia Press, p. 18-24.
Young, R.A., and Brennan, W.J., 1974, Peach Springs Tuff: its bearing on structural evolution of the Colorado Plateau and development of Cenozoic drainage in Mohave County, Arizona: Geological Society of America Bulletin, v. 85, no. 1, p. 83-90. 


\section{Cenozoic Stratigraphy and Structure of the Northern Bristol Mountains, Calif.}

\section{INTRODUCTION}

The northern Bristol Mountains lie at the southeastern edge of Soda Lake, approximately $30 \mathrm{~km}$ southeast of Baker, Calif. (fig. 1). The range is composed mainly of Mesozoic granitic rocks, but older gneiss is exposed on the west margin (Kupfer and Bassett, 1962). On the west, thick fanglomerate and Quaternary sand dunes partly cover exposures of older units.

This paper describes and interprets three fault-bounded sections of syntectonic Tertiary sedimentary strata within the northern Bristol Mountains area. The sections exposed are small (each less than $0.5 \mathrm{~km}^{2}$ ) but are geologically important because they record the evolution of a system of subparallel northwest-striking lateral faults, called the Bristol Mountains fault zone (fig. 1; Brady and others, 1989).

The Bristol Mountains fault zone lies within a belt of lateral faults that extends from Death Valley to southeasternmost California (Hamilton and Meyers, 1966; Brady 1988) and are probably part of the Eastern California shear zone. At the latitude of the Bristol Mountains, this major zone is believed to separate structural terranes having differing tectonic styles: the Mojave Desert block on the west, and the Basin and Range extensional terrane on the east (Brady and Dokka, 1989; Dokka and Travis, 1990). The Mojave Desert block is characterized by early Miocene (22-17 Ma) northwest-directed extension followed by dextral faulting and related rotation of faultbounded blocks after $13 \mathrm{Ma}$ (Dokka and Travis, 1990). In the Basin and Range terrane, intense northeast-directed extension and detachment faulting occurred between 20 to $18 \mathrm{Ma}$ and has continued to Holocene time (Davis and Lister, 1988). Strata in the northern Bristol Mountains that are coeval with these episodes of faulting bear directly on the evolution of the boundary between these two terranes.

The northern Bristol Mountains are rarely visited, and geographic place names are sparse. Access to the area is chiefly by four-wheel-drive vehicle across rough roads and dry washes, the largest of which drains northward from the core of the mountains toward Soda Lake, crossing the

\footnotetext{
'Department of Geology, Califomia State University, Fresno, CA
}

Union Pacific Railroad tracks at Balch siding (fig. 1). Exposed in the upper part of that wash is a sequence of Tertiary sedimentary and volcanic rocks, which represents the most extensive of the three sections of Cenozoic deposits that crop out in the northernmost Bristol Mountains.

The sequence of sedimentary and volcanic rocks lies in a wedge-shaped basin surrounded by Mesozoic plutonic rocks and consists of two units totaling more than $225 \mathrm{~m}$

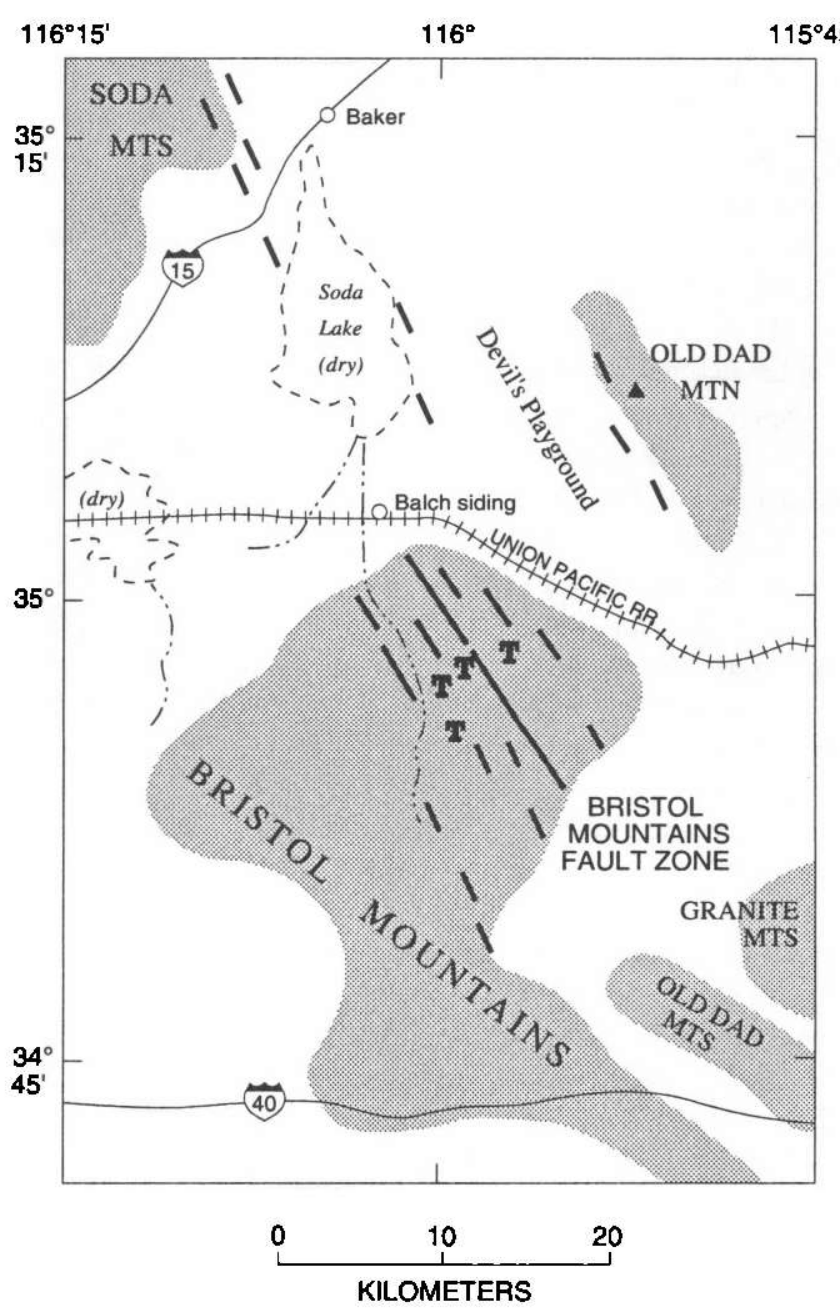

Figure 1. Map showing location of some features discussed in text. T, outcrops of Tertiary volcanic and sedimentary sequences. 
in thickness. The lower unit of volcanogenic and clastic strata is overlain on an angular unconformity by an upper unit composed of fanglomerate. The top of the fanglomerate is eroded and covered by unconsolidated gravel and eolian sand that contains Stage II-III pedogenic carbonate and a moderately developed cambic $\mathrm{B}$ (Bw) horizon with thin clay films. These features are similar to upper Pleistocene $(36,600-15,500$ yr B.P.) soils in the eastern Soda Mountains area, $40 \mathrm{~km}$ to the north (Wells and others, 1984; S.G. Wells, oral commun., 1988). The soil and underlying bedrock are cut by faults of the Bristol Mountains fault zone.

\section{LITHOLOGY}

\section{LOWER UNIT}

The lower unit of the sedimentary and volcanic sequence is composed of arkosic conglomerate, metavolcanic-clast conglomerate, arkosic sandstone, sandy siltstone, and basalt and lapilli tuff, in decreasing order of abundance (col. 1-E, pl. 1). The unit totals $20 \mathrm{~m}$ in exposed thickness and probably unconformably overlies Mesozoic plutonic rocks, although the contact is concealed. The unit is everywhere faulted and tilted from $15^{\circ}$ to nearly vertical.

The lowest exposed strata are pale-colored pebbly sandstone and pebble conglomerate. Bedding is distinct and planar. The conglomerate contains mainly subrounded clasts of Tertiary volcanic rocks in a matrix of well-sorted arkosic sand. The sandstone and conglomerate are overlain by black basaltic lapillistone and breccia (agglomerate?), which includes clasts as much as $30 \mathrm{~cm}$ in diameter. Plagioclase from clasts in the breccia yielded a K-Ar age of 26.7 $\pm 0.6 \mathrm{Ma}$ (table 1). Pink, coarse-grained arkose with scattered basalt cobbles fills channels up to $50 \mathrm{~cm}$ deep that are cut into the basaltic rocks.

Thinly bedded sandy tuff and tuffaceous sandstone overlie the arkose on a sharp contact. Sand grains in both the tuff and sandstone are mainly of granitic derivation. Channels as deep as $4 \mathrm{~m}$ in the tuff and tuffaceous sandstone are infilled by a tan, monolithologic mudflow breccia, which includes volcanic clasts of Tertiary purple and red andesite porphyry, gray felsite, and tan tuff. Upsection the breccia becomes tuffaceous and forms crude, massive beds 20 to $30 \mathrm{~cm}$ thick. Abruptly overlying the breccia, and occupying channels eroded into it, is a white, biotitehomblende vitric tuff, which yielded a $\mathrm{K}$-Ar age of 26.0 $\pm 0.6 \mathrm{Ma}$ (homblende) (table 1). This deposit is rarely exposed and probably was eroded from most areas.

The filling of channels that are cut into the underlying volcanic units is a pink to lavender, massive, pebble-tocobble breccia at least $8 \mathrm{~m}$ thick. This upper breccia also is monolithologic, with a matrix of fine-grained ashy mud and
Table 1. Potassium-argon ages from the sedimentary and volcanic rocks of the northeastern Bristol Mountains.

\begin{tabular}{lccccc}
\hline $\begin{array}{l}\text { Sample } \\
\text { number }{ }^{1}\end{array}$ & $\begin{array}{c}\text { Material } \\
\text { dated }\end{array}$ & $\begin{array}{c}\mathrm{K}_{2} \mathrm{O} \\
(\mathrm{wt} \mathrm{pct})^{2}\end{array}$ & $\begin{array}{c}{ }^{40} \mathrm{Ar}_{\mathrm{rad}} \\
\left(10^{-11} \mathrm{~mol}_{\mathrm{g}}\right)^{2}\end{array}$ & $\begin{array}{c}\text { Percent } \\
{ }^{40} \mathrm{Ar}_{\mathrm{rad}}{ }^{2}\end{array}$ & $\begin{array}{c}\text { Calculated age } \\
(\mathrm{Ma})^{3}\end{array}$ \\
\hline BSW-1 & Biotite & $(8.097)$ & $(10.50)$ & $(73.6)$ & $8.99 \pm 0.21$ \\
& & 8.098 & 10.32 & 72.7 & \\
& & 8.012 & 10.49 & 73.0 & \\
& & 8.182 & 10.52 & 73.6 & \\
& & & 10.68 & 74.9 & \\
BM-88-6B & Hornblende & $(0.513)$ & $(1.931)$ & $(80.8)$ & $26.0 \pm 0.6$ \\
& & 0.509 & 1.938 & 83.7 & \\
& & 0.517 & 1.930 & 79.7 & \\
& & 0.512 & 1.938 & 80.1 & \\
BM-88-13 & & & 1.919 & 79.7 & \\
& & & & & \\
& & & & & \\
& & $1.836)$ & $(7.096)$ & $(71.1)$ & $26.7 \pm 0.6$ \\
& & 1.818 & 7.134 & 71.1 & \\
& & 1.845 & 7.060 & 71.2 & \\
\hline
\end{tabular}

\footnotetext{
${ }^{1}$ Dating by M. Shafiqullah, University of Arizona Geochronology Lab, Tucson, Ariz. Sample locations and lithology:

BSW-1, $35^{\circ} 00^{\prime} 34^{\prime \prime} \mathrm{N}$. lat, $115^{\circ} 59^{\prime} 30^{\prime \prime} \mathrm{W}$. long, rhyolite clast in fanglomerate;

BM-88-6B, $35^{\circ} 00^{\prime} 60^{\prime \prime}$ N. lat, $116^{\circ} 00^{\prime} 32^{\prime \prime} \mathrm{W}$. long, rhyolite tuff; BM-88-13, $35^{\circ} 00^{\prime} 20^{\prime \prime} \mathrm{N}$. lat, $116^{\circ} 00^{\prime} 62^{\prime \prime} \mathrm{W}$. long, basalt clast in pyroclastic(?) breccia.

${ }^{2}$ Value in parentheses is arithmetic mean used in age calculation.

${ }^{3} \mathrm{~K}$-Ar ages were calculated using the constants for the radioactive decay and abundance of ${ }^{40} \mathrm{~K}$ recommended by the International Union of Geological Sciences Subcommission on Geochronology (Steiger and Jäger, 1977). These constants are: $\lambda_{\mathrm{E}}=0.580 \times 10^{-10} \mathrm{yr}^{-1}$, $\lambda_{\beta}=4.962 \times 10^{-10} \mathrm{yr}^{-1}$, and ${ }^{40} \mathrm{~K} / \mathrm{K}_{\text {total }}=1.167 \times 10^{-4} \mathrm{~mol} / \mathrm{mol}$.
}

clasts similar to those in the breccia beneath the 26-Ma tuff. The upper breccia is deeply channeled, and it is overlain by tan, poorly sorted conglomerate and sandy conglomerate of mainly granitic clasts. The breccia deposit fines upward across $30 \mathrm{~cm}$ to beds of pebbly sandstone, silty sandstone, and laminated, bentonitic claystone and sandy claystone; many of these beds contain granitic pebbles.

The uppermost part of the lower unit is marked by approximately $1 \mathrm{~m}$ of massive to thickly bedded conglomeratic granule sandstone of mainly granitic detritus. The bases of the beds are graded and channeled, and the beds have an open framework.

\section{UPPER UNIT}

Fanglomerate forms the upper unit of the Tertiary sequence. It is more than $200 \mathrm{~m}$ thick and overlies the lower unit on an angular unconformity of $10^{\circ}$ to $20^{\circ}$. Beds dip $35^{\circ}$ to $40^{\circ}$ at the base of the unit and decrease in dip to less than $10^{\circ}$ upsection. 
Most of the fanglomerate consists of massive to thickly bedded, pebble to cobble conglomerate and breccia, containing sparse boulders as much as $75 \mathrm{~cm}$ in diameter. Matrix support is dominant and, in some places, beds are reversely graded. Laterally discontinuous beds of openframework conglomerate are common. Overall, the fanglomerate fines and thins upward; shallow channels (15-75 $\mathrm{cm}$ ) filled with nomally graded beds and lenses of wellsorted, coarse-grained sand appear throughout but are most abundant in the upper part.

Clasts are generally angular to subrounded and consist almost entirely of medium- and coarse-grained granitic rocks, Tertiary volcanic rocks, and minor amounts of finegrained mafic rocks probably derived from Mesozoic dikes. Biotite from a rhyolite clast near the base of the fanglomerate provides a maximum age for the unit of $8.99 \pm 0.21 \mathrm{Ma}$ (table 1).

\section{STRUCTURAL RELATIONS}

The Bristol Mountains fault zone is a system of subparallel, vertical faults that extend the entire length of the range (Brady and others, 1989). This zone forms the prominent structural grain of the mountain range. Several of the faults bound sections of Tertiary continental deposits. The most pronounced fault in the zone bounds the sequence of sedimentary and volcanic rocks on its east side, placing it against highly sheared, pink granitic rocks. The fault varies from several discrete well-defined branches to a diffuse mass of sheared and mineralized rocks nearly $45 \mathrm{~m}$ across. Statistical analyses of slickenline orientations and minor fractures suggest that the dominant shear sense is left lateral; the minimum estimated strike separation on this fault is $8 \mathrm{~km}$. Where the sequence crops out within $50 \mathrm{~m}$ of the fault, it is broadly to tightly folded and cut by a complex of minor high- and low-angle faults. In several places, fault-bounded slabs of granitic bedrock are tectonically intersheaved with the sedimentary rocks. Other minor faults separate beds by only a few tens of meters.

\section{INTERPRETATION}

The lower unit of the Tertiary sequence near Balch siding is interpreted to represent braid plain deposits. Ages of the tuff and basalt breccia in the lower unit indicate that a pulse of bimodal volcanism occurred in late Oligocene time, approximately $26 \mathrm{Ma}$. Clasts of Tertiary volcanic rocks in conglomerate of the lower unit probably were shed from local, now-eroded, sources. The presence of such sources is indicated by dikes of Tertiary age that cut pre-Tertiary rocks and by the presence in the lower unit of the proximal Oligocene breccia and tuff deposits.
The fanglomeratic upper unit probably represents a regressive alluvial fan deposit that grades vertically from upper- to mid- or outer-fan fringe deposits. Debris-flow deposits, deep channeling, and coarser sized sediment decrease in abundance upsection. Both lower and upper units contain detritus that most likely was derived from the suite of Mesozoic granite and mafic dikes in the Bristol Mountains.

The sedimentary and volcanic rocks were deposited in a syntectonic basin that underwent faulting throughout a long period of time. Deformation and possibly uplift and erosion of the lower unit occurred after about $26 \mathrm{Ma}$ (the age of the basalt and tuff) but before about $9 \mathrm{Ma}$ (the age of a rhyolite clast in the upper unit). Thus, the onset of fanglomerate deposition, which followed a hiatus of perhaps $18 \mathrm{~m} . \mathrm{y}$. , may have resulted from renewed tectonic activity. The upward-decreasing dip of the fanglomerate beds indicates that growth faulting occurred synchronously with deposition, and erosional truncation of the fanglomerate may also have been due to fault-related uplift. Finally, following formation of the Pleistocene soil, the sequence was faulted again.

Tertiary deposits of probably similar age are found in four places across the Bristol Mountains fault zone at approximately the same elevation (fig. 1). Both elevations, and the nearly horizontal slickenlines on fault surfaces, indicate that strike-slip rather than dip-slip motion on the Bristol Mountains fault zone has predominated. The close correspondence between sediment provenance and bedrock types in the range indicates that lateral displacement is distributed across the fault zone and that offset on any one fault in the Bristol Mountains fault zone is not greater than the length of the range (about $15 \mathrm{~km}$ ).

The upward-decreasing deformation in the sequence of sedimentary and volcanic rocks suggests that tectonism along the Bristol Mountains fault zone was most intense during the time between deposition of the lower unit (approximately $26 \mathrm{Ma}$ ) and deposition of the fanglomeratic upper unit (after $9 \mathrm{Ma}$, but pre-Pleistocene), although faulting continued into Pleistocene and, perhaps, Holocene time.

\section{REFERENCES CITED}

Brady, R.H. III, 1988, Southward continuation of the southern Death Valley fault zone from the Avawatz to the Bristol Mountains, San Bernardino County, California [abs.]: Geological Society of America Abstracts with Programs, v. 20 , no. 4 , p. 145.

Brady, R.H. III, and Dokka, R.K., 1989, The eastern Mojave shear zone: a major Tertiary tectonic boundary in the southwestern Cordillera [abs.]: Geological Society of America Abstracts with Programs, v. 21, no. 5, p. 59.

Brady, R.H. III, Clayton, Jeff, Troxel, B.W., Verosub, K.L., Cregan, Alan, and Abrams, Michael, 1989, Thematic mapper 
and field investigations at the intersection of the Death Valley and Garlock fault zones, California: Remote Sensing of Environment, v. 208, p. 207-217.

Davis, G.A., and Lister, G.S., 1988, Detachment faulting in continental extension: perspectives from the southwestern U.S. Cordillera, in Clark, S.P., Jr., Burchfiel, B.C., and Suppe, J., eds., Processes in continental lithospheric deformation: Geological Society of America Special Paper 218, p. 133-159.

Dokka, R.K., and Travis, C.J., 1990, Late Cenozoic strike-slip faulting in the Mojave Desert, California: Tectonics, v. 9, no. 2 , p. 311-340.

Hamilton, Warren, and Meyers, W.B., 1966, Cenozoic tectonics of the western United States: Review of Geophysics, v. 4, no. 4 , p. 509-549.
Kupfer, D.H., and Bassett, A.M., 1962, Geologic reconnaissance map of part of the southeastern Mojave Desert, Califomia: U.S. Geological Survey Miscellaneous Mineral Investigations Field Studies Map MF-205, scale 1:125,000.

Steiger, R.H., and Jäger, E., 1977, Subcommission on geochronology: Convention on the use of decay constants in geoand cosmochronology: Earth and Planetary Science Letters, v. 36 , no. 3 , p. $359-362$.

Wells, S.G., McFadden, L.D., Dohrenwend, J.C., Bullard, T.F., Feilberg, B.F., Ford, R.L., Grimm, J.P., Miller, J.R., Orbock, S.M., and Pickle, J.D., 1984, Late Quaternary geomorphic history of Soda Mountains piedmont and Silver Lake playa area: Geological Society of America, Annual Meeting, Reno Nev., November 1984, Field Trip 14 Guidebook, p. 69-87. 


\title{
Tertiary Stratigraphy of the South Virgin Mountains, Southeast Nev., and the Grand Wash Trough, Northwest Ariz.
}

\author{
By L. Sue Beard ${ }^{1}$
}

\section{INTRODUCTION}

The South Virgin Mountains ${ }^{2}$ and Grand Wash trough area of the Basin and Range province is an extended terrane west of the Colorado Plateau margin, in northwest Arizona and southeast Nevada (fig. 1). The South Virgin Mountains contain Precambrian, Paleozoic, and Mesozoic rocks exposed in structural blocks that are mostly east-tilted, as well as Tertiary sedimentary rocks that both predate and postdate the tilting. The structural blocks are bounded by northeast-striking, left-separation faults of the Lake Mead fault system and north-striking normal faults with low- to high-angle dips. The Grand Wash trough is a Tertiary basin that lies east of the South Virgin Mountains and is separated from the Colorado Plateau by the northstriking Grand Wash fault. Exposed in the trough are mostly flat-lying Tertiary sedimentary strata that were deposited against both east-tilted blocks on the west and south sides of the trough and nearly horizontal Paleozoic rocks of the Colorado Plateau on the east.

Tertiary sedimentary rocks in the Grand Wash trough have been studied by Lucchitta $(1966,1972,1979)$ and in the Grand Wash trough and South Virgin Mountains by Bohannon $(1979,1984)$. The rocks are divided into two packages (col, 1-F, pl. 1). The Horse Spring Formation crops out in the South Virgin Mountains and in the northwest comer of the trough and is exposed generally in north-striking, east-tilted ridges offset by strike-slip faults (also see Wallin and others, this volume). Unconformably overlapping the Horse Spring Formation are the mostly flat-lying rocks of the Grand Wash trough (Bohannon, 1984), also called the Muddy Creek Formation by Lucchitta $(1966,1972,1979)$.

'U.S. Geological Survey-MS 9540, 2255 N. Gemini Drive, Flagstaff, AZ 86001-1698

"2uouth Virgin Mountains" is an informal geographic name applied to the mountains east of the Overton arm of Lake Mead, west of Grand Wash trough, north of the Colorado River arm of Lake Mead, and south of Whitney Pocket (Longwell and others, 1965). The area discussed in this chapter also includes the Wechech basin [eds.]

\section{SOUTH VIRGIN MOUNTAINS}

Only the lower two members of the Horse Spring Formation, the Rainbow Gardens and Thumb Members as defined by Bohannon (1984), were deposited in the South Virgin Mountains, and only the lowermost, the Rainbow Gardens Member, is exposed in the trough, although the Thumb Member may occur in the subsurface. The Horse Spring Formation is late Oligocene to middle Miocene in age in this area: a tuff in the middle part of the Rainbow Gardens Member has a K-Ar age of $24.3 \mathrm{Ma}$ (biotite, Carpenter and others, 1989), and tuffs in the Thumb Member yield fission track ages of $16.3 \pm 1.9$ and $15.9 \pm 1.0 \mathrm{Ma}$ (Bohannon, 1984).

The Rainbow Gardens Member is a widespread unit in southeastern Nevada. The scattered outcrops are inferred to represent deposits of a single shallow sag that became dismembered by strike-slip and low-angle normal faults (Bohannon, 1984). In the area of the South Virgin Mountains the Rainbow Gardens Member typically contains a ubiquitous, lower unit of resistant conglomerate, a middle unit of diverse clastic rocks, and an upper unit of resistant carbonate rocks (Bohannon, 1984; Beard, unpub. mapping, 1989). The basal conglomerate is a very distinctive darkweathering unit composed mostly of subangular carbonate and sandstone clasts derived from Paleozoic rocks that are set in a sandy, carbonate-cemented matrix. The basal conglomerate overlies a gentle regional unconformity of low relief that truncates the upper Paleozoic and Mesozoic sections southward so that the conglomerate is deposited on Cretaceous rocks at the northernmost exposures and on Permian Kaibab Limestone at the southernmost exposures (Bohannon, 1979, 1984). This low-relief surface may correlate with the Paleocene erosion surface exposed to the southeast on the Colorado Plateau (Young, 1985). Bohannon (1984) interpreted the conglomerate as a braided stream and pediment-veneer deposit.

At the north end of the South Virgin Mountains, just south of Whitney Pocket (fig. 1), the basal conglomerate consists of a stack of monolithologic layers of angular Paleozoic clasts interbedded with channel-filling lenses of dark-red, hematitic pebbly sandstone; these pebbles include rounded chert, quartzite, and distinctive silicified litharenite 
and radiolarian-bearing argillite. Litharenite and agillite clasts, which were derived originally from the Mississippian Eleana Formation in southern Nevada (P.M. Goldstrand, oral commun., 1990), also occur in the immediately underlying Cretaceous rocks. At this location the conglomerate grades directly upward into the upper (carbonate rocks) unit. To the south the transition from conglomerate to carbonate rocks is represented by the middle unit, a slopeforming assemblage of claystone, sandstone, thyolitic tuff, tuffaceous sandstone, rounded pebble conglomerate, and thin platy limestone. At the southernmost exposures, conglomerate is absent in the middle unit, and fine-grained tuff and carbonate rocks dominate the section. The middle slope-forming unit probably represents a transition from fluvial to lacustrine settings, culminating in the lacustrine deposits of the upper (carbonate rocks) unit. The maximum thickness of the Rainbow Gardens Member is about $400 \mathrm{~m}$, indicating deposition without great subsidence into a broad shallow basin. Facies relations suggest that the northernmost exposures in the South Virgin Mountains were probably near the northern end of the basin.

The Thumb Member is present throughout the South Virgin Mountains but is well exposed only in the northern part. The Wechech basin section (fig. 1) (Bohannon, 1984) consists of $1.2 \mathrm{~km}$ of lacustrine deposits of parallel-bedded sittstone and sandstone, gypsiferous siltstone, claystone, and massive bedded gypsum, overlain by conglomerate. Tuff units interbedded in the lacustrine section are dated at 16.3 and $15.9 \mathrm{Ma}$. The basal $3-10 \mathrm{~m}$ of the conglomerate at the north end of the Wechech basin is composed almost entirely of material derived from Precambrian crystalline rocks similar to those exposed on Whitney Ridge to the east. Upward and southward the conglomerate is dominated by clasts of Paleozoic car-bonate rocks and sandstone. To the north and east the lacustrine deposits undergo a change into sandstone, conglomeratic sandstone, and con-

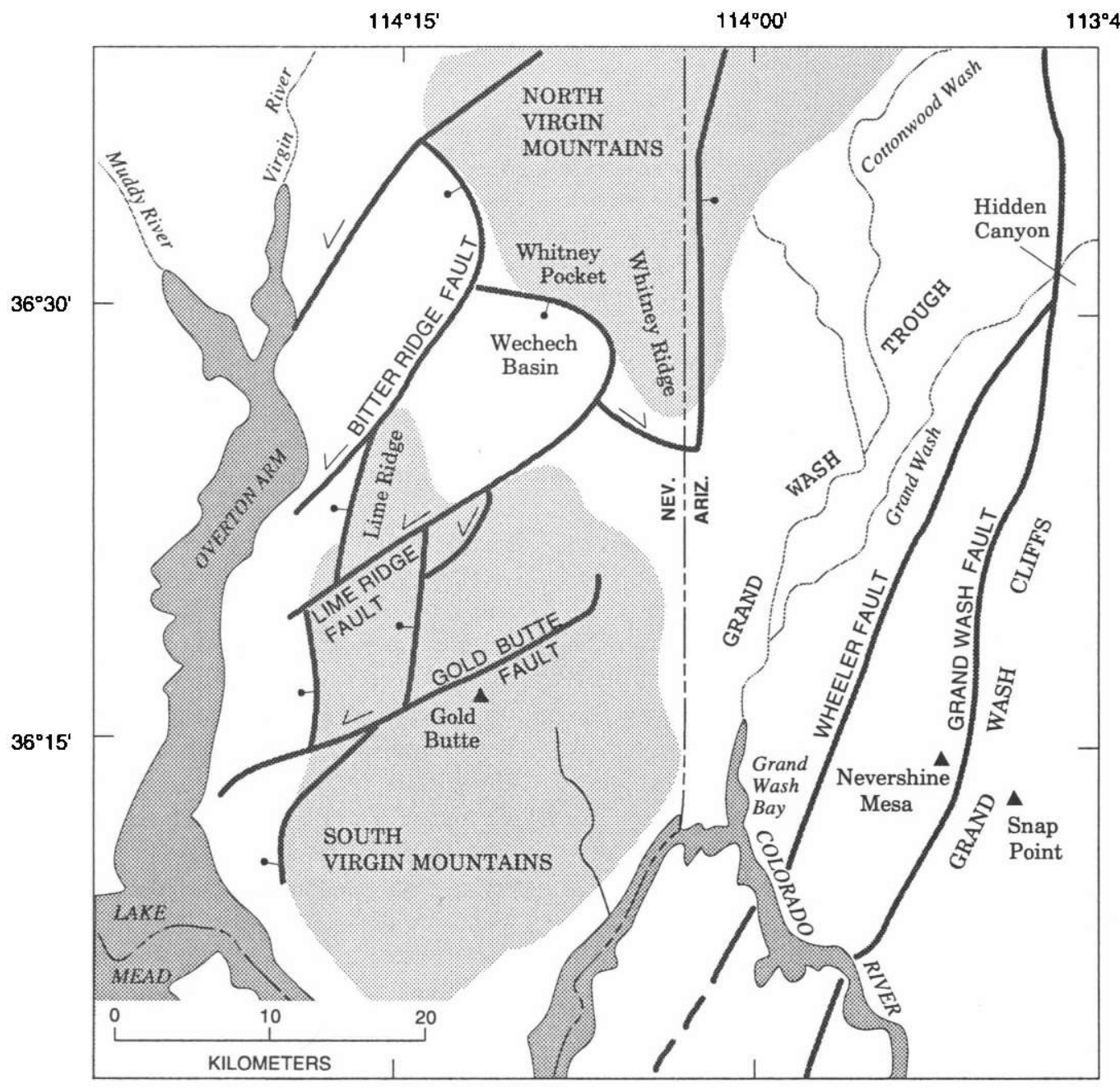

Figure 1. Map showing location of some geographic and geologic features named in text. Faults modified from Longwell and others (1965), Bohannon (1984), Beard and Campagna (1991), Beard (1992), and L. Sue Beard (unpub. data, 1991-92). Ball and bar on downthrown blocks; half arrows show relative direction of movement. 
glomerate of probable marginal lake and alluvial fan origin. Southward, toward the Lime Ridge fault (fig. 1), the Thumb Member is poorly exposed and faulted and folded; it is lithologically similar but thinner than in the north. It is unclear whether this lateral variation is due to depositional thinning, erosional truncation, structural attenuation, or a complex interaction of all three processes.

In the southemmost exposures in the South Virgin Mountains the interval above the Rainbow Gardens Member is a thick unbedded sedimentary breccia composed mostly of clasts of Precambrian rocks. The clasts are derived from bedrock exposures just to the south across the Gold Butte fault, one of the northeast-striking left-separation faults. Bohannon (1984) inferred that the breccia is equivalent to the Thumb Member, although the outcrops cannot be traced directly into dated Thumb exposures. This breccia, and the Precambrian-clast conglomerate at the Wechech Basin, indicate that terranes of older rocks were exposed at both the northern and southem ends of the basin during or late in the deposition of Thumb strata.

\section{GRAND WASH TROUGH}

Middle and upper Miocene interior-basin deposits filling the Grand Wash trough have been studied and described by Lucchitta (1966, 1972, 1979). The deposits were correlated to the type locality of the Muddy Creek Formation to the west by Longwell (1936) and Lucchitta (1966, 1972, 1979). Bohannon (1984), however, argued that these deposits are not physically connected to those that contain the type locality of the Muddy Creek Formation, are of somewhat different age, and are lithologically dissimilar; he preferred to informally name them rocks of the Grand Wash trough.

The Grand Wash trough is an asymmetric basin, resembling a half-graben, that formed by motion on the Grand Wash fault. The Grand Wash fault is a vertical to steeply dipping normal fault that may be listric at depth; it separates tilted crustal blocks on the west from untilted Paleozoic rocks of the Colorado Plateau. The trough contains fine-grained strata deposited in playas and lakes in the axis of the basin, which was on the east side near the fault. The fine-grained rocks interfinger to the east with conglomerates derived from Paleozoic rocks exposed in the Grand Wash Cliffs and to the west with Precambrian clast-bearing conglomerates derived from the Gold Butte area in the South Virgin Mountains (Lucchitta, 1966, 1972). These units also unconformably overlap east-tilted strata of the Rainbow Gardens Member in the southern part of the Grand Wash trough, a few kilometers north of the Colorado River.

Deep-basin deposition in the Grand Wash trough culminated in the Hualapai Limestone, a widespread unit of variable thickness. This unit has variously been defined as a member of the Muddy Creek Formation (Lucchitta, 1972) and also designated a separate formation (Bohannon, 1984). A K-Ar age of $8.66 \pm 2.2 \mathrm{Ma}$ was obtained from basaltic glass shards in an air-fall tuff from the lower part of the Hualapai Limestone (Blair and Armstrong, 1979). Air-fall tuff beds below the Hualapai Limestone yielded fission track ages of $10.8 \pm 0.8,11.1 \pm 1.3$, and 11.6 $\pm 1.2 \mathrm{Ma}$ (Bohannon, 1984). In addition, a basalt fiow is interbedded at Nevershine Mesa with the upper part of the easterly derived conglomerate. This flow can be traced by remnant outcrops to a basalt on the Grand Wash Cliffs at Snap Point, which has a K-Ar age of

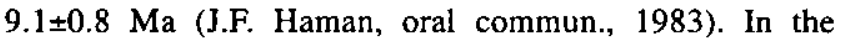
northwest end of the trough, east-tilted Rainbow Gardens strata are unconformably overlain by flat-lying red clastic rocks and flows of the informally named Grand Wash basalt of Best and Brimhall (1970).

Basalt lava flows blanket much of the surface and fill drainages that are cut into the rocks of the Grand Wash trough. The drainages are graded to the Colorado River, which issues from the Grand Canyon through the Grand Wash Cliffs at the southern end of the trough. The flows of the Cottonwood Wash sequence in the northern trough have ages ranging from $6.87 \pm 0.20 \mathrm{Ma}$ (lowest flow) (Best and others, 1980) to $4.73 \pm 0.18$ (uppermost flow) (P.E. Damon, in Reynolds and others, 1986); at Hidden Canyon the uppermost flow has an age of $3.8 \pm 0.2 \mathrm{Ma}$ (R.J. Miller, written commun., 1989). In addition, a 3.80 \pm 0.11 -Ma basalt at Grand Wash Bay (Shafiqullah and others, 1980), which is exposed on the shore of Lake Mead, rests on eroded basin-fill deposits and on fluvial gravel deposited by the Colorado River. These relations indicate that interior basin deposition ended and throughgoing drainage began perhaps by $6.9 \mathrm{Ma}$ and certainly by $3.8 \mathrm{Ma}$.

\section{AGE CONSTRAINTS ON CRUSTAL TILTING}

Crustal tilting and faulting, both normal and strikeslip, in the South Virgin Mountains and Grand Wash trough began after deposition of the Rainbow Gardens Member of the Horse Spring Formation. Extensional faulting may have begun as early as Rainbow Gardens time, but little subsidence and no crustal tilting is recorded. The lower part of Thumb Member also is conformable with the Rainbow Gardens Member; angular discordance is observed only in areas where the conglomeratic facies dominates the stratigraphy of the Thumb Member. Dips of Tertiary rocks range from less than $10^{\circ}$ to as much as $50^{\circ}$; average dips are about $35^{\circ}$. In the Grand Wash trough, the interior-basin deposits (post-11.6 Ma) are mostly flat lying. Therefore, crustal 
tilting is not reflected in the stratigraphic record until sometime after $15.9 \mathrm{Ma}$ and is ended by $11.6 \mathrm{Ma}$. Motion along some of the strike-slip faults, however, continued at least into Muddy Creek time (D.J. Campagna, written commun., 1990).

\section{REFERENCES CITED}

Beard, L. Sue, 1992, Preliminary geologic map of the St. Thomas Gap 7.5-minute quadrangle, Clark County, Nevada, and Mohave County, Arizona: U.S. Geological Survey Open-File Report 92-326, scale 1:24,000.

Beard, L. Sue, and Campagna, David J., 1991, Preliminary geologic map of the Devil's Throat 7.5-minute quadrangle, Clark County, Nevada: U.S. Geological Survey Open-File Report 91-132, scale 1:24,000.

Best, M.G., and Brimhall, W.H., 1970, Late Cenozoic basalt types in the western Grand Canyon region, in Hamblin, W.K., and Best, M.G., eds., The western Grand Canyon district: Salt Lake City, Utah Geological Society Guidebook, no. 23 , p. 57-74.

Best, M.G., McKee, E.H., and Damon, P.E., 1980, Space-timecomposition pattems of late Cenozoic mafic volcanism, southwestern Utah and adjoining areas: American Journal of Science, v. 280 , no. 10, p. 1,035-1,050.

Blair, W.N., and Armstrong, A.K., 1979, Hualapai Limestone member of the Muddy Creek Formation: the youngest deposit predating the Grand Canyon, southeastern Nevada and northwestern Arizona: U.S. Geological Survey Professional Paper 1111, 14 p.

Bohannon, R.G., 1979, Strike-slip faults of the Lake Mead region of southern Nevada, in Armentrout, J.M., Cole, M.R., and TerBest, Harry, Jr., eds., Cenozoic paleogeography of the western United States: Los Angeles, Calif., Pacific Section, Society of Economic Paleontologists and Mineralogists, Pacific Coast Paleogeography Symposium 3, p. 129-139.

1984, Nonmarine sedimentary rocks of Tertiary age in the Lake Mead region, southeastern Nevada and northwestern
Arizona: U.S. Geological Survey Professional Paper 1259, $72 \mathrm{p}$.

Carpenter, D.G., Carpenter, J.A., Bradley, M.D., Franz, U.A., and Spence, J.R., 1989, Comment on "On the role of isostasy in the evolution of normal fault systems": Geology, v. 17 , no. 8, p. 774-775.

Longwell, C.R., 1936, Geology of the Boulder Reservoir floor, Arizona-Nevada: Geological Society of American Bulletin, v. 47 , no. 9 , p. $1,393-1,476$.

Longwell, C.R., Pampeyan, E.H., Bowyer, Ben, and Roberts, R.J., 1965, Geology and mineral deposits of Clark County, Nevada: Nevada Bureau of Mines and Geology Bulletin 62, $218 \mathrm{p}$.

Lucchitta, Ivo, 1966, Cenozoic geology of the upper Lake Mead area adjacent to the Grand Wash Cliffs, Arizona: University Park, Pennsylvania State University, Ph.D. dissertation, $218 \mathrm{p}$.

1972, Early history of the Colorado River in the Basin and Range province: Geological Society of America Bulletin, v. 83 , no. 7 , p. 1,933-1,948.

1979, Late Cenozoic uplift of the southwestem Colorado Plateau and adjacent lower Colorado River region: Tectonophysics, v. 61, nos. 1-3, p. 63-95.

Reynolds, S.J., Florence, F.P., Welty, J.W., Roddy, M.S., Currier, D.A., Anderson, A.V., and Keith, S.B., 1986, Compilation of radiometric age determinations in Arizona: Arizona Bureau of Geology and Mineral Technology Bulletin 197, $258 \mathrm{p}$.

Shafiqullah, M., Damon, P.E., Lynch, D.J., Reynolds, S.J., Rehrig, W.A., and Raymond, R.H., 1980, K-Ar geochronology and geologic history of southwestern Arizona and adjacent areas, in Jenney, J.P., and Stone, Claudia, eds., Studies in western Arizona: Arizona Geological Society Digest, v. 12, p. 201-260.

Young, R.A., 1985, Geomorphic evolution of the Colorado Plateau margin in west-central Arizona; a tectonic model to distinguish between the causes of rapid symmetrical scarp retreat and scarp dissection, in Morisawa, Marie, and Hack, J.T., eds., Tectonic geomorphology: London, Allen and Unwin, Binghamton Symposia in Geomorphology, International Series 15, p. 261-278. 


\title{
Tertiary Stratigraphy of the Lake Mead Region
}

\author{
By E. Timothy Wallin ${ }^{1}$, Ernest M. Duebendorfer ${ }^{2}$, and Eugene I. Smith ${ }^{1}$
}

\section{INTRODUCTION}

The Lake Mead region falls within a highly extended terrane along the Nevada-Arizona border (fig. 1). This terrane is bounded to the east by the Colorado Plateau, to the west by the unextended Spring Mountains block, to the south by the Colorado River extensional corridor, and to the north by a complex structural zone that coincides approximately with the Las Vegas Valley shear zone and Lake Mead fault system (Duebendorfer and others, this

\footnotetext{
'Department of Geoscience, University of Nevada, Las Vegas, NV 89154

${ }^{2}$ Department of Geology, Northem Arizona University, Flagstaff, AZ 86011
}

volume). Miocene sedimentary rocks crop out widely north of Lake Mead and south of the Muddy Mountains (Bohannon, 1984). Smaller, less well studied remnants of these Miocene strata also crop out south and east of Lake Mead (Beard, this volume).

Miocene strata in the Lake Mead region are in excess of $2 \mathrm{~km}$ thick and comprise three nonmarine, unconformity-bounded sequences, namely the Horse Spring Formation, the informally named red sandstone unit of Bohannon (1984), and the Muddy Creek Formation (col. 1-G, pl. 1). The Horse Spring Formation unconformably overlies Paleozoic and Mesozoic sedimentary rocks and consists of the Rainbow Gardens, Thumb, Bitter Ridge Limestone, and Lovell Wash Members (Bohannon, 1984).

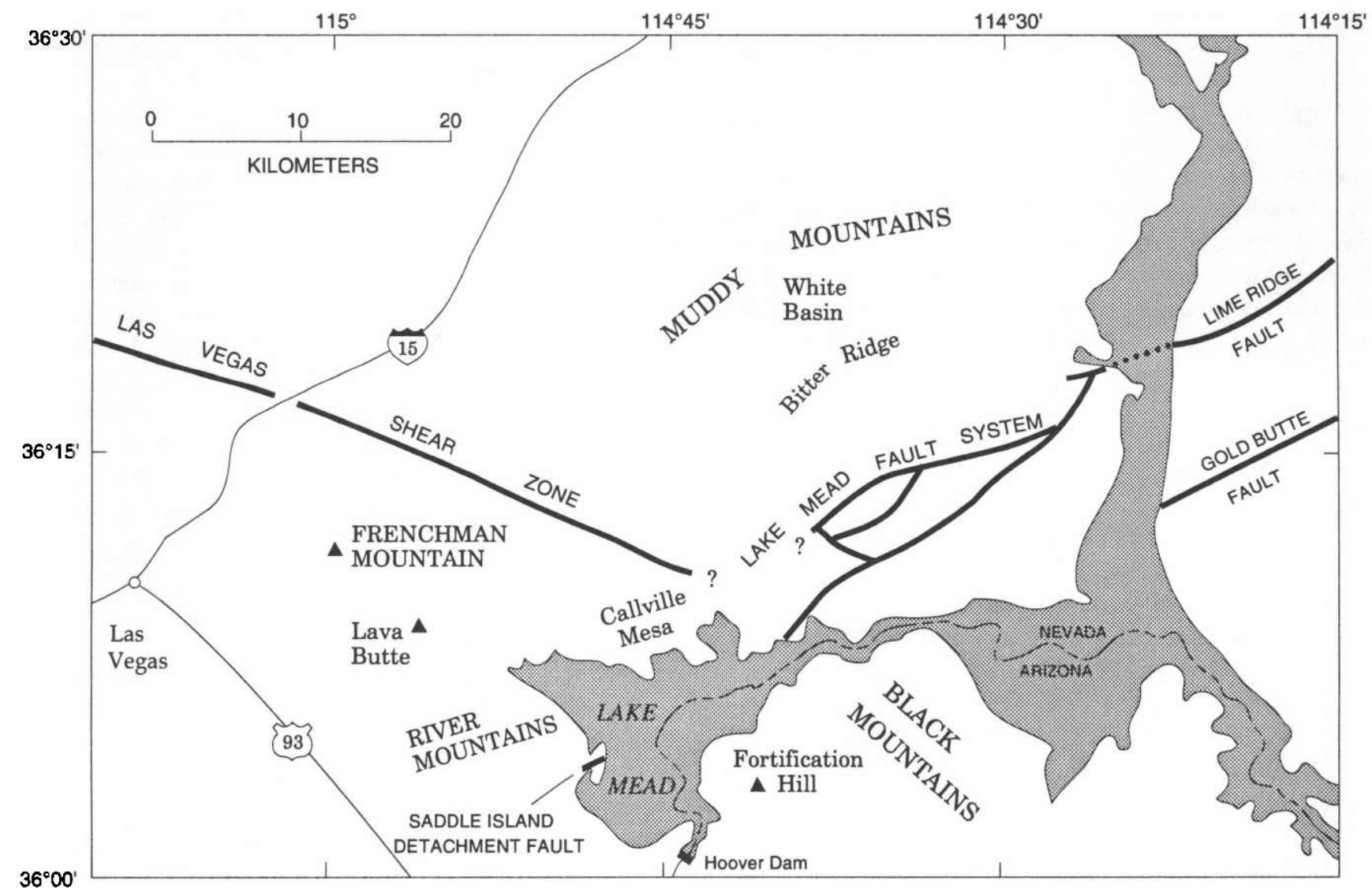

Figure 1. Map showing location of some geologic and geographic features named in text. Faults generalized from Anderson (1973). 
In the Lake Mead area, the Horse Spring Formation ranges in age from early(?) to middle Miocene (Anderson and others, 1972; Bohannon, 1984), although locally it may be Oligocene in age. Carpenter and others (1989) reported a K-Ar age of $24.3 \pm 1.0$ Ma for a tuff interbedded with the Tertiary Cottonwood Wash Formation in the Virgin Mountains. Thus, the Rainbow Gardens member may be as old as late Oligocene, if it is lithostratigraphically equivalent to the Cottonwood Wash Formation as suggested by Bohannon and others (1983).

According to Bohannon (1984), deposition of the Rainbow Gardens Member began in a broad sag basin prior to the onset of Miocene extension in the area. Both the configuration of the Horse Spring basin and stratigraphy of the later basin-fill units were strongly influenced by the surface expressions of major Miocene structures, including the Gold Butte fault, Lake Mead fault system, and Las Vegas Valley shear zone. Strata of the Horse Spring Formation were disrupted both during and after deposition by sinistral displacement on the Lake Mead fault system, dextral displacement on the Las Vegas Valley shear zone, and by both high- and low-angle normal faults (Anderson, 1973; Bohannon, 1984; Duebendorfer and Wallin, 1991).

\section{UNIT DESCRIPTIONS}

The Rainbow Gardens Member becomes finer upward overall and consists of a basal conglomerate that is overlain by complexly interfingering terrigenous clastic and carbonate rocks, and minor chert; the upper part is dominated by carbonate rocks. The Rainbow Gardens Member was deposited principally in alluvial and lacustrine depositional environments (Bohannon, 1984). The timing of the onset of sedimentation of the Rainbow Gardens Member is poorly constrained due to a lack of datable rocks. Although Bohannon (1984) estimated an age of about 20 to $18 \mathrm{Ma}$ for the Rainbow Gardens Member, it may be as old as Oligocene.

The Thumb Member conformably overlies the Rainbow Gardens Member and comprises gypsiferous sandstone and siltstone with subordinate conglomerate, breccia and megabreccia, and volumetrically minor carbonate rocks, tuff, and basaltic andesite flows deposited in lacustrine and alluvial depositional environments (Bohannon, 1984). Anderson and others (1972) reported a K-Ar age of $17.7 \pm 3.0 \mathrm{Ma}$ (whole rock) for basaltic andesite in the lower part of the Thumb Member (originally reported as 17.2 $\pm 3.0 \mathrm{Ma}$ but recalculated using modern decay constants). Bohannon (1984) reported fission-track ages that range from $16.2 \pm 0.8$ to $13.2 \pm 0.9 \mathrm{Ma}$ (zircon) for air-fall tuff within the Thumb Member. However, he interpreted the 13.2-Ma age to be anomalously young and inferred an age range of $17.2(17.7)$ to $13.5 \mathrm{Ma}$ for the member. Clast- and matrix-supported megabreccia deposits presum- ably represent episodic and catastrophic rock avalanches or debris flows. Some breccia units within the Thumb Member contain large blocks of distinctive Precambrian crystalline rocks that have been used by many authors to constrain displacement on either or both the Las Vegas Valley shear zone and Lake Mead fault system (Longwell, 1960, 1974; Anderson, 1973; Bohannon, 1984; Rowland and others, 1990). Several of these workers proposed that boulders of rapakivi granite and aluminous high-grade metamorphic rocks were derived from the Gold Butte area south of the Gold Butte fault (fig. 1).

The Bitter Ridge Limestone Member of the Horse Spring Formation is confined largely to an area northwest of the Las Vegas Valley shear zone and Lake Mead fault system and consists principally of porous limestone with volumetrically minor sandstone in its uppermost part near Bitter Ridge. In an isolated exposure near Lava Butte, the Bitter Ridge Limestone Member also contains intraformational limestone breccia and clasts of the dacite of Lava Butte. The age of the Bitter Ridge Limestone Member is constrained by a $\mathrm{K}-\mathrm{Ar}$ age of $13.7 \pm 0.7 \mathrm{Ma}$ (whole rock) (Anderson and others, 1972) for the dacite of Lava Butte (originally reported as $13.4 \pm 0.7$ but recalculated using modern decay constants). A minimum age for the unit is provided by a fission-track age of $13.0 \pm 0.8 \mathrm{Ma}$ (zircon) from an air-fall tuff in the conformably overlying Lovell Wash Member (Bohannon, 1984).

The Lovell Wash Member of the Horse Spring Formation is confined to the area northwest of the Lake Mead fault system but occurs both north and south of the Las Vegas Valley shear zone. The Lovell Wash Member consists principally of limestone, dolomite, claystone, tuff, arenaceous tuff, and tuffaceous sandstone. The age of the Lovell Wash Member is constrained by the $13.0 \pm 0.8-\mathrm{Ma}$ age of the interstratified air-fall tuff mentioned above. Both the Bitter Ridge Limestone and Lovell Wash Members were deposited in lacustrine depositional environments (Bohannon, 1984).

The red sandstone unit of Bohannon (1984) unconformably overlies the Horse Spring Formation. Documented surface exposures of the red sandstone unit are restricted to White Basin and the area immediately northwest of Lake Mead (Bohannon, 1984; Duebendorfer and Wallin, 1991). It consists principally of sandstone and conglomerate with subordinate siltstone, claystone, and both air-fall and reworked tuff. All of these units were deposited in alluvial fan and playa-lake paleoenvironments (Bohannon, 1984).

Locally, the red sandstone unit is overlain by and interbedded with basaltic andesite flows near Callville Mesa (fig. 1). These flows contain phenocrysts of iddingsitized olivine (1-5 percent), plagioclase (10-30 percent), augite (2-9 percent), and minor orthopyroxene. Quartz and alkali feldspar form xenocrysts that are rimmed by glass and acicular clinopyroxene. Rare pyroxenite xenoliths are found locally. The flows range in age from $10.4 \pm 0.2$ to $8.5 \pm 0.2$ 
Ma (K-Ar, plagioclase) (Feuerbach and Smith, 1988; Feuerbach and others, 1991). Lavas in the Callville Mesa area erupted from a complex cinder cone located there and from scattered additional vents. The 500-m-diameter cone is located on the footwall of an east-striking, down-to-thesouth normal fault.

The red sandstone unit is lithologically similar to both the underlying Horse Spring Formation and the overlying Muddy Creek Formation. Similar units in the area are considered equivalent in age to the red sandstone unit if they are overlain unconformably by the Muddy Creek Formation or the basaltic andesite of Callville Mesa and (1) overlie the Horse Spring Formation with angular discordance, (2) contain clasts of the youngest rocks of the Horse Spring Formation, or (3) contain clasts of the oldest rocks of the basaltic andesite of Callville Mesa (Duebendorfer and Wallin, 1991).

The youngest unconformity-bounded unit, the Muddy Creek Formation, crops out widely at low elevations in the Lake Mead region. This unit consists of conglomerate, sandstone, siltstone, claystone, gypsum, and halite. Conglomerate is especially abundant near the basin margins. The age of the Muddy Creek Formation ranges from about 10.4 Ma or younger near Callville Mesa, where it overlies the red sandstone unit, to at least as young as $5.9 \pm 0.2 \mathrm{Ma}$ (K-Ar, plagioclase, Feuerbach and others, 1991) where it is intruded by basalt at Fortification Hill. Although it is cut by numerous faults, the Muddy Creek Formation appears to be largely posttectonic relative to significant earlier Miocene extension.

\section{TIME OF TILTING}

In most areas of the Lake Mead Region, the Horse Spring Formation overlies the Paleozoic and Mesozoic section with angular discordance of less than $10^{\circ}$. Furthermore, the amount of tilting within the Horse Spring Formation is essentially constant upsection. These observations suggest that most of the stratal tilting associated with Miocene extension occurred after deposition of the Horse Spring Formation.

The red sandstone unit is steeply tilted near the basin margins and slightly tilted to horizontal elsewhere in the basin, except near faults. The lack of substantial tilting of many surface exposures of the red sandstone indicates that much of the tilting exhibited by the Horse Spring Formation occurred either prior to or during deposition of the red sandstone unit (Duebendorfer and Wallin, 1991). Locally, the magnitude of tilting of both the Horse Spring Forma- tion and the red sandstone unit is nearly identical. Together, these observations indicate that the red sandstone unit represents syntectonic sedimentation that occurred during tilting of older rocks.

\section{REFERENCES CITED}

Anderson, R.E., 1973, Large-magnitude late Tertiary strike-slip faulting north of Lake Mead, Nevada: U.S. Geological Survey Professional Paper 794, 18 p.

Anderson, R.E., Longwell, C.R., Armstrong, R.L., and Marvin, R.F., 1972, Significance of K-Ar ages of Tertiary rocks from the Lake Mead region, Nevada-Arizona: Geological Society of American Bulletin, v. 83, no. 2, p. 273-288.

Bohannon, R.G., 1984, Nonmarine sedimentary rocks of Tertiary age in the Lake Mead region, southeastern Nevada and northwestern Arizona: U.S. Geological Survey Professional Paper 1259, 72 p.

Bohannon, R.G., Antweiler, J.C., Lucchitta, Ivo, Anderson, R.E., Beard, L.S., Hovorka, D.S., and Briggs, J.P., 1983, Geology and mineral resource potential of the Narrows (AZ-010135), Lime Hills (AZ-010-135), and Sand Cove (AZ-010128) Wilderness Study Areas, Mohave County, Ariz.: U.S. Geological Survey Open-File Report 83-887, 10 p.

Carpenter, D.G., Carpenter, J.A., Bradley, M.D., Franz, U.A., and Spence, J.R., 1989, Comment on "On the role of isostasy in the evolution of normal fault systems": Geology, v. 17, no. 8, p. 774-775.

Duebendorfer, E.M., and Wallin, E.T., 1991, Basin development and syntectonic sedimentation associated with kinematically coupled strike-slip and detachment faulting, southern Nevada: Geology, v. 19, no. 1, p. 87-90.

Feuerbach, D.L., and Smith, E.I., 1988, Changes in volcanism during declining stages of regional extension in the Lake Mead area, Nevada and Arizona [abs.]: Geological Society of America Abstracts with Programs, v. 20, no. 7, p. A114.

Feuerbach, D.L., Smith, E.I., Shafiqullah, M., and Damon, P.E., 1991, New K-Ar dates for late Miocene to early Pliocene mafic volcanic rocks in the Lake Mead area, Nevada and Arizona: Isochron/West, no. 57, p. 17-20.

Longwell, C.R., 1960, Possible explanation of diverse structural patterns in southern Nevada: American Journal of Science, v. 258-A (Bradley Volume), p. 192-203.

1974, Measure and date of movement on Las Vegas Valley shear zone, Clark County, Nevada: Geological Society of America Bulletin, v. 85 , no. 6, p. 985-990.

Rowland, S.M., Parolini, J.R., Eschner, Edward, McAllister, A.J., and Rice, J.A., 1990, Sedimentologic and stratigraphic constraints on the Neogene translation and rotation of the Frenchman Mountain structural block, Clark County, Neva$\mathrm{da}$, in Wernicke, B.P., ed., Basin and Range extensional tectonics near the latitude of Las Vegas, Nevada: Geological Society of America Memoir 176, p. 99-122. 



\title{
Miocene Stratigraphy of the Central Black Mountains, Northwestern Ariz.: Variations Across a Major Accommodation Zone
}

\author{
By James E. Faulds ${ }^{1}$
}

\section{INTRODUCTION}

Miocene extension fragmented the central Black Mountains into a complex array of tilted fault blocks (Longwell, 1963; Anderson, 1971; Faulds and others, 1988, 1990). Extension was directed east-west or eastnortheast-west-southwest, as inferred from the average strike of major normal faults and of layering in tilted fault blocks. Fault block tilting, as indicated by dips of layered strata in Tertiary volcanic and sedimentary rocks, commonly exceeds $60^{\circ}$ and locally surpasses $90^{\circ}$ (beds overturned).

A major accommodation zone in the central Black Mountains, northwestern Arizona, and adjacent Eldorado Mountains, southern Nevada, separates about $15,000 \mathrm{~km}^{2}$ of east-tilted fault blocks to the north from more than $25,000 \mathrm{~km}^{2}$ of dominantly west-tilted blocks to the south (fig. 1). In upper-plate rocks, the east-trending accommodation zone corresponds to a $10-\mathrm{km}$-wide belt of intermeshing conjugate normal faults (Faulds and others, 1990). East-dipping normal faults dominate the west-tilted domain, whereas west-dipping normal faults characterize the east-tilted domain (fig. 2). East- and west-dipping faults are about equally common within the accommodation zone. The zone also represents the most likely join between a west-dipping detachment system under the easttilted domain (Wemicke, 1985; Weber and Smith, 1987; Duebendorfer and others, 1990) and east-dipping detachment system beneath the west-tilted domain (Davis and others, 1980; Spencer, 1985; Spencer and Reynolds, 1989). The displacement on major normal faults and magnitude of tilting of fault blocks progressively decrease toward the axial part of the zone. The actual tilt reversal is facilitated by en echelon, transversely oriented, obliqueslip scissor faults on transverse segments of the zone (orthogonal to strike of tilted fault blocks) and minor folding on along-strike segments (parallel to strike of tilted blocks). The deformational style along the zone is discussed in greater detail in Faulds and others (1990).

\footnotetext{
'Department of Geology, University of Iowa, Jowa City, LA 52242
}

Tertiary strata in the Black and Eldorado Mountains (col. 1-H, pl. 1) range in age from early Miocene to early Pliocene(?) and consist of andesite lava flows and flow breccia, basaltic andesite flows, tuffaceous sedimentary rocks, flow-banded rhyolite, minor ash-flow tuff, megabreccia, conglomerate, and basalt flows. Much of the Tertiary section was deposited in half grabens produced by Miocene extension. Tertiary strata locally exceed $4 \mathrm{~km}$ in thickness in some major half grabens.

The purpose of this paper is to compare Tertiary sections across the accommodation zone in the central Black Mountains and discuss the implications of observed variations. The stratigraphic sections described here are from the southern part of the Eldorado Canyon basin in the easttilted domain, northern part of the Mount Perkins basin in the west-tilted domain, and axial part of the accommodation zone. The Eldorado Canyon basin extends from the northern part of the accommodation zone to the Malpais Mesa area and possibly to the western Lake Mead region (fig. 1). A west-dipping normal fault, here referred to as the Bighorn fault, borders the Eldorado Canyon basin on the east. The Mount Perkins basin continues at least $40 \mathrm{~km}$ southward from the southern part of the accommodation zone (fig. 1). The east-dipping Mount Davis fault (Faulds and others, 1990) bounds the Mount Perkins basin on the west. As displacement on their bounding normal faults decreases, the Mount Perkins and Eldorado Canyon basins merge into several smaller half grabens within the accommodation zone and therefore terminate as major depocenters.

\section{TIMING OF DEFORMATION}

Stratigraphic relations, discordant tilts, and $\mathrm{K}$-Ar ages indicate that the major episode of extension in the vicinity of the accommodation zone occurred during middle Miocene time. Potassium-argon ages from a tuff tilted $85^{\circ}$ and basalt flow tilted approximately $25^{\circ}$ constrain approximately 70 percent of the west-tilting in the Mount Perkins growth-fault basin to between approximately 16.4 and 14.1 Ma (table 1). A gently west-tilted $\left(15^{\circ}\right), 13.13 \pm 0.27-\mathrm{Ma}$ basalt flow (table 1) just to the west of the Mount Perkins 
growth-fault basin demonstrates that extension in the westtilted domain continued until about $13 \mathrm{Ma}$. Potassiumargon ages from a moderately tilted (about $45^{\circ}$ ) tuff and gently tilted (approximately $15^{\circ}$ ) basalt flow bracket more than 65 percent of the east-tilting in the Eldorado Canyon basin to between approximately 15.9 and $13.7 \mathrm{Ma}$ (table 1). The K-Ar ages indicate that, in the vicinity of the accommodation zone, most of the extension in the west- and east- tilted domains was approximately simultaneous and that the zone facilitated penecontemporaneous block tilting in opposite directions. In both the east- and west-tilted domains, the timing of the last increment of tilting (15-35 percent of total) is poorly constrained. Some tilting may be as young as latest Miocene or early Pliocene, as evidenced by gently tilted $\left(5^{\circ}-10^{\circ}\right)$ upper Miocene basalt flows and sedimentary rocks that crop out about $15 \mathrm{~km}$ north of the accommoda-

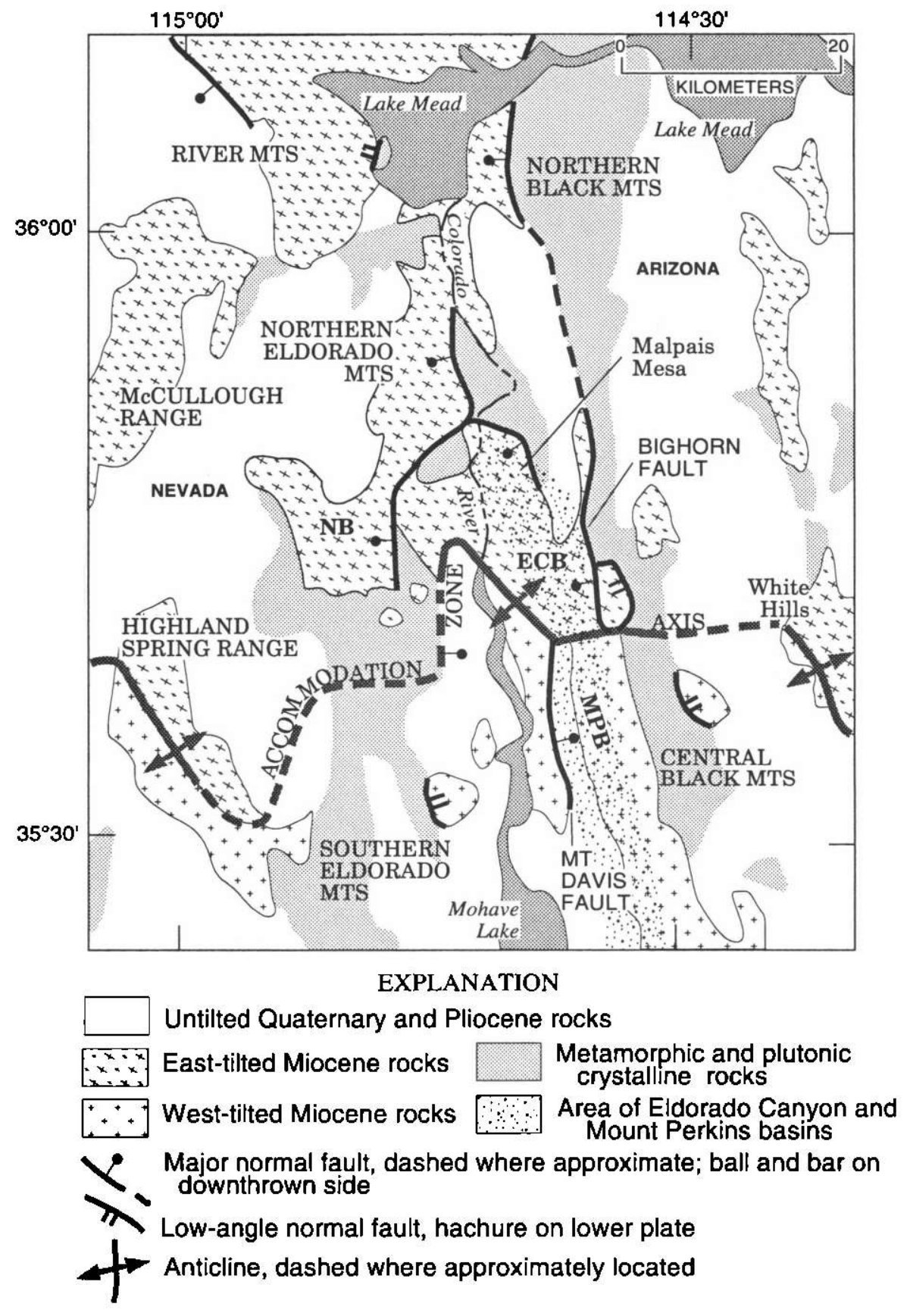

Figure 1. Generalized geologic map of the Black and Eldorado Mountains accommodation zone and nearby regions. ECB, Eldorado Canyon basin; MPB, Mount Perkins basin, NB, Nelson basin. Geology from Anderson (1977, 1978), Stewart and Carlson (1978), Davis (1984), Reynolds (1988), and Faulds (1989). 
tion zone (fig. 1, Malpais Mesa area) in an apparent extension of the Eldorado Canyon basin. Generally undeformed, upper Miocene to lower Pliocene basalt flows in the northern Black Mountains (Anderson and others, 1972) imply that extension had ceased by early Pliocene time near the accommodation zone.

Because the development of large half grabens in middle Miocene time greatly affected the distribution of Tertiary deposits, the Tertiary section was divided into three intervals on the basis of age relative to the main pulse of tilting in middle Miocene time: (1) prior to approximately $16 \mathrm{Ma}$ (before major tilting); (2) 16 to $13 \mathrm{Ma}$ (coincidental with major tilting); and (3) post-13 Ma (after major tilting).

\section{MIOCENE STRATIGRAPHY}

\section{PRE-16 MA}

Tertiary volcanic and sedimentary strata in the central Black Mountains accumulated on a surface of low relief cut into Late Cretaceous quartz monzonite, weakly foliated granodiorite of unknown age, and Proterozoic gneiss, amphibolite, and mylonite. The 1.5-km-thick, pre-16-Ma section consists of, in ascending order: (1) a basal arkosic sandstone and conglomerate that predates the onset of volcanism, (2) thin (less than $20 \mathrm{~m}$ thick) rhyolite tuff, which may be correlative with the Peach Springs Tuff of Young and Brennan (1974), (3) a complex section of intercalated homblende andesite flows, pyroxene-olivine basaltic ande- site flows, volcanic breccia, and subordinate dacite and rhyodacite flows and volcaniclastic sandstone, (4) volcanic breccia, volcaniclastic conglomerate and sandstone, and lesser basaltic andesite flows, and (5) a thick sequence $(600$ $\mathrm{m}$ ) of pyroxene-olivine basaltic andesite flows (col. 1- $\mathrm{H}, \mathrm{pl}$. 1). The thickness and overall constitution of the pre-16-Ma section is fairly uniform across the central Black Mountains. However, the sequence of volcanic breccia, volcaniclastic conglomerate, and sandstone is much thicker and more widespread in the Eldorado Canyon basin. Although major unconformities were not observed in the pre-16-Ma section, significant disconformities cannot be ruled out.

The age of the pre-16-Ma section in the central Black Mountains is not well documented. However, Anderson and others (1972) obtained K-Ar ages ranging from 19.1 to 15.7 Ma (corrected using constants of Dalrymple, 1979) from probable correlatives in the northern Black and northern Eldorado Mountains and suggested a 20-Ma age for the base of the Tertiary section. With the exception of the hornblende andesite lava, the pre-16-Ma section in the central Black Mountains closely resembles the Patsy Mine Volcanics (Anderson, 1971, 1977, 1978) in areas to the north. Propylitic alteration and potassium metasomatism commonly hampers isotopic dating of the pre-16-Ma section.

\section{TO 13 MA}

The 16- to 13-Ma volcanic and sedimentary rocks rest conformably on pre-16-Ma rocks. The 16- to 13-Ma strata

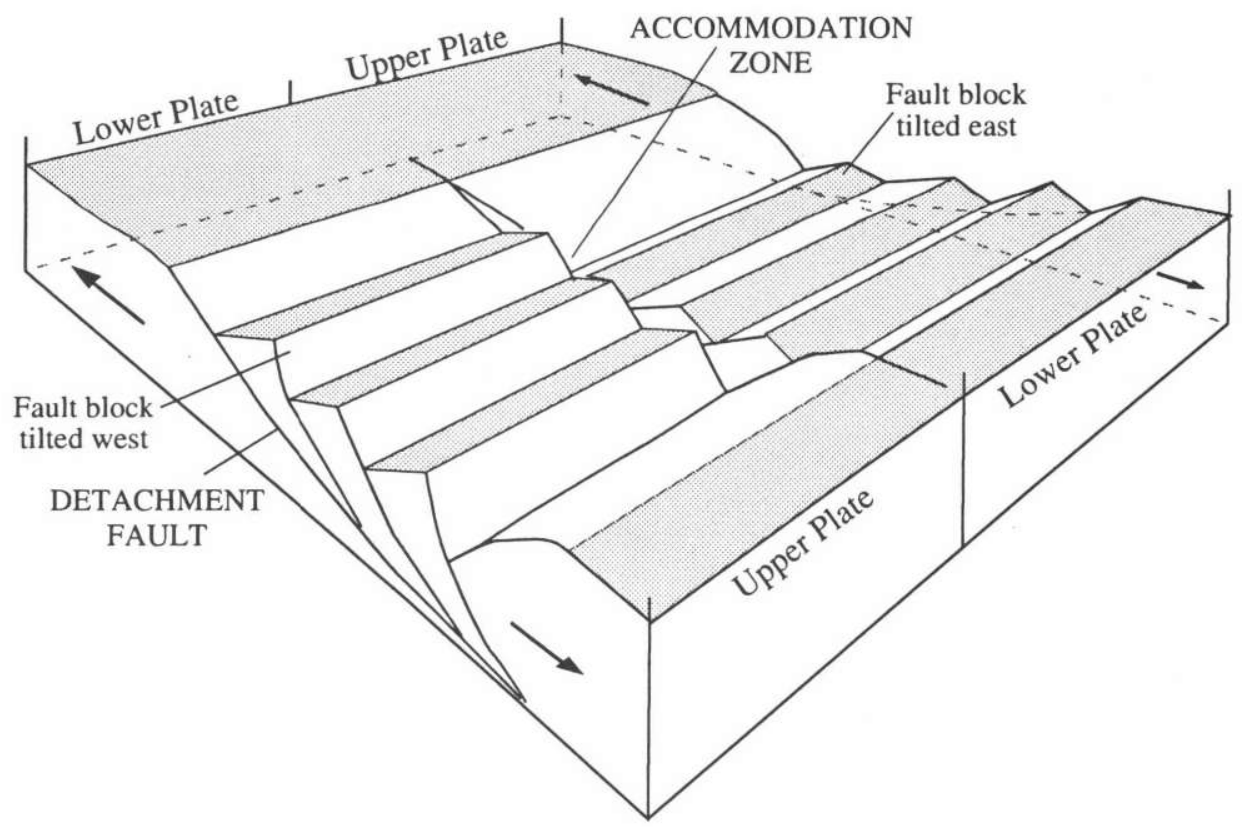

Figure 2. Schematic block diagram of accommodation zone in Black and Eldorado Mountains. Zone facilitates reversals in both dominant direction of block tilting and dip direction of major normal fault systems. 
Table 1. New K-Ar ages from the central Black Mountains, Arizona.

\begin{tabular}{|c|c|c|c|c|c|c|}
\hline $\begin{array}{l}\text { Sample } \\
\text { number }^{1}\end{array}$ & $\begin{array}{c}\text { Material } \\
\text { dated }\end{array}$ & $\begin{array}{c}\mathrm{K}_{2} \mathrm{O} \\
(\mathrm{wl} \mathrm{pct})^{2}\end{array}$ & $\begin{array}{c}{ }^{40} \mathrm{Ar}_{\mathrm{rad}} \\
\left(10^{-11} \mathrm{~mol} / \mathrm{g}\right)\end{array}$ & $\begin{array}{l}\text { Percent } \\
{ }^{40} \mathrm{Ar}_{\mathrm{rad}}\end{array}$ & Tilt & $\begin{array}{c}\text { Assigned age } \\
\text { (Ma) }\end{array}$ \\
\hline \multicolumn{7}{|c|}{ Mount Perkins basin } \\
\hline \multirow[t]{5}{*}{$88-177$} & Feldspar & $(1.125)$ & (2.133) & $(22.2)$ & $15^{\circ}$ West & $13.13 \pm 0.27$ \\
\hline & concentrate & 1.104 & 2.139 & 21.8 & & \\
\hline & & 1.119 & 2.128 & 22.1 & & \\
\hline & & 1.130 & 2.137 & 22.2 & & \\
\hline & & 1.147 & 2.127 & 22.5 & & \\
\hline \multirow[t]{5}{*}{$88-065$} & Feldspar & (1.369) & $(2.830)$ & $(27.7)$ & $25^{\circ}$ West & $14.32 \pm 0.36$ \\
\hline & concentrate & 1.412 & 2.825 & 27.5 & & \\
\hline & & 1.351 & 2.819 & 28.1 & & \\
\hline & & 1.334 & 2.834 & 27.4 & & \\
\hline & & 1.377 & 2.843 & 27.8 & & \\
\hline \multirow[t]{5}{*}{$88-063$} & Feldspar & $(1.468)$ & $(2.983)$ & $(15.7)$ & $44^{\circ}$ West & $14.10 \pm 0.37$ \\
\hline & concentrate & 1.510 & 3.006 & 16.1 & & \\
\hline & & 1.447 & 3.038 & 15.1 & & \\
\hline & & 1.454 & 3.010 & 15.8 & & \\
\hline & & 1.459 & 2.878 & 15.7 & & \\
\hline \multirow[t]{5}{*}{$88-066$} & Biotite & $(8.769)$ & $(20.82)$ & (7.7) & $85^{\circ}$ West & $16.43 \pm 0.36$ \\
\hline & & 8.780 & 20.71 & 7.9 & & \\
\hline & & 8.765 & 20.83 & 7.7 & & \\
\hline & & 8.763 & 20.80 & 7.8 & & \\
\hline & & & 20.93 & 7.4 & & \\
\hline \multicolumn{7}{|c|}{ Eldorado Canyon basin } \\
\hline \multirow[t]{5}{*}{$88-176$} & Feldspar & (1.936) & $(3.831)$ & $(24.3)$ & $15^{\circ}$ East & $13.71 \pm 0.29$ \\
\hline & concentrate & 1.935 & 3.849 & 24.1 & & \\
\hline & & 1.942 & 3.831 & 24.1 & & \\
\hline & & 1.929 & 3.825 & 24.3 & & \\
\hline & & & 3.820 & 24.5 & & \\
\hline \multirow[t]{5}{*}{$88-067$} & Biotite & $(8.316)$ & (19.13) & $(42.2)$ & $40^{\circ}$ East & $15.92 \pm 0.36$ \\
\hline & & 8.364 & 19.03 & 41.6 & & \\
\hline & & 8.299 & 19.23 & 41.4 & & \\
\hline & & 8.286 & 19.42 & 41.8 & & \\
\hline & & & 18.85 & 44.1 & & \\
\hline
\end{tabular}

'Dating was done by M. Shafiqullah, University of Arizona Geochronology Lab, Tucson, Ariz. Sample location and lithology:

$88-177,35^{\circ} 33^{\prime} 45^{\prime \prime} \mathrm{N}$. lat, $114^{\circ} 42^{\prime} 30^{\prime \prime} \mathrm{W}$. long, basalt lava $88-065,35^{\circ} 39^{\prime} 00^{\prime \prime} \mathrm{N}$. lat, $114^{\circ} 35^{\prime} 30^{\prime \prime} \mathrm{W}$. long, basalt lava $88-063,35^{\circ} 40^{\circ} 00^{\prime \prime} \mathrm{N}$. lat, $114^{\circ} 35^{\prime} 00^{\prime \prime} \mathrm{W}$. long, basalt lava $88-066,35^{\circ} 39^{\prime} 30^{\prime \prime} \mathrm{N}$. lat, $114^{\circ} 35^{\prime} 05^{\prime \prime} \mathrm{W}$. long, tuff $88-176,35^{\circ} 43^{\prime} 00^{\prime \prime} \mathrm{N}$. lat, $114^{\circ} 36^{\prime} 00^{\prime \prime} \mathrm{W}$. long, basalt lava $88-067,35^{\circ} 42^{\prime} 30^{\prime \prime} \mathrm{N}$. lat, $114^{\circ} 35^{\prime} 30^{\prime \prime} \mathrm{W}$. long, tuff

${ }^{2}$ Value in parentheses is arithmetic mean used in age calculation.

${ }^{3} \mathrm{~K}$-Ar ages were calculated using the constants for the radioactive decay and abundance of ${ }^{40} \mathrm{~K}$ recommended by the International Union of Geological Sciences Subcommission on Geochronology (Steiger and Jäger, 1977). These constants are: $\lambda_{\mathrm{E}}=0.580 \times 10^{-10} \mathrm{yr}^{-1}, \lambda_{\beta}=4.962 \times 10^{-10} \mathrm{yr}^{-1}$, and ${ }^{40} \mathrm{~K} / \mathrm{K}_{\text {total }}=1.167 \times 10^{-4} \mathrm{~mol} / \mathrm{mol}$.

in the central Black Mountains generally correlate with the Mount Davis Volcanics (Anderson, 1978) in the northern Black Mountains. These strata were largely deposited in developing half grabens, as evidenced by progressively gentler tilts up section. Significant variations in thickness and composition occur across the accommodation zone.
In the Mount Perkins basin, the 16- to 13-Ma section consists of a lower sequence of intercalated tuffaceous rocks, rhyolite flows, and volcaniclastic conglomerate and an upper sequence of basalt flows. Both units are as thick as $1,000 \mathrm{~m}$. The tuffaceous rocks dominate the lower part of the 16- to 13-Ma section in much of the Mount Perkins 
basin but give way northward near the southern margin of the accommodation zone to volcaniclastic conglomerate. Widespread unconformities were not observed in the Mount Perkins basin. However, an angular unconformity is locally developed between the uppermost basalt flows and older, more steeply tilted strata. The tuffaceous rocks and basalt flows are bracketed between 16.4 to $14.1 \mathrm{Ma}$ and 14.3 to $13.1 \mathrm{Ma}$, respectively (table 1).

The 16- to 13-Ma section in the southern Eldorado Canyon basin is composed of, in ascending order, a thin veneer of tuffaceous rocks, megabreccia deposits of probable landslide origin, conglomerate and subordinate sandstone, and basalt flows. No major unconformities were observed in the Eldorado Canyon basin. In contrast to the Mount Perkins basin, clasts of pre-Miocene plutonic and metamorphic rocks commonly dominate conglomerate beds in the 16- to 13-Ma section in the Eldorado Canyon basin. The change of predominant clast types between the two basins occurs in the axial part of the accommodation zone. The megabreccia deposits in the Eldorado Canyon basin also are largely composed of metamorphic and plutonic crystalline rocks, and occupy the same stratigraphic interval as the basal part of the thick tuffaceous sequence in the Mount Perkins basin. The megabreccia and conglomerate in the Eldorado Canyon basin are bracketed between approximately 15.9 and 13.7 Ma (table 1). Although thin in the east-tilted domain, the middle Miocene tuffaceous sequence represents an important stratigraphic and structural marker throughout the central Black Mountains, inasmuch as its base is the youngest unit of maximum tilt and thus records the onset of major extension in both the Mount Perkins and Eldorado Canyon basins.

As displacement along the Mount Davis and Bighorn faults and block tilting both decrease, the 16- to 13-Ma sections in the Mount Perkins and Eldorado Canyon basins thin appreciably toward the axial part of the accommodation zone. For example, the conglomerate and tuffaceous rocks, which generally exceed $500 \mathrm{~m}$ in thickness in both the Mount Perkins and Eldorado Canyon basins, thin to less than $30 \mathrm{~m}$ and locally pinch out in the axial part of the accommodation zone. The overlying basalt unit shows a similar, but less pronounced, trend. Relatively thick sequences of basalt flows occur locally within the accommodation zone in the vicinity of probable volcanic centers.

\section{POST-13 MA}

The post-13-Ma section was largely deposited during the waning stages of extension. In both the Mount Perkins and Eldorado Canyon basins, the section consists primarily of conglomerate and sandstone. As in the 16- to 13-Ma section, volcanic clasts dominate post-13-Ma sedimentary rocks in the Mount Perkins basin, whereas clasts of meta- morphic and plutonic rocks are common in the Eldorado Canyon basin. The conglomerates and sandstone generally rest conformably on or interfinger with the subjacent middle Miocene basalt flows. Upper Miocene to lower Pliocene basalt flows unconformably overlie the conglomerate and sandstone in the Malpais Mesa area of the Eldorado Canyon basin (fig. 1). A K-Ar age of 6.0 1.0 -Ma (wholerock; age corrected using constants of Dalrymple, 1979) was obtained from a capping basalt flow at Malpais Mesa (reported in Anderson and others, 1972). These capping basalt flows have yielded, however, preliminary wholerock ${ }^{40} \mathrm{Ar} /{ }^{39} \mathrm{Ar}$ ages that range from $9.7 \pm 0.5$ to $10.5 \pm 0.5$ Ma (J.E. Faulds and P.B. Gans, unpub. data, 1992). Parts of the Mount Perkins and Eldorado Canyon basins contain essentially flat-lying sedimentary deposits of probable Quaternary age, including gravel deposited by the Colorado River and locally derived alluvium. Post-13-Ma deposits within the accommodation zone are generally limited to thin veneers of Quaternary alluvium in active drainages.

\section{DISCUSSION}

Major variations in thickness and composition of Miocene strata are related to structural variations across the accommodation zone. The stratal variations are: significant thinning of the 16- to 13-Ma sections, from more than 500 $\mathrm{m}$ to less than $30 \mathrm{~m}$ toward the axial part of the zone, and change in the dominant clasts, from volcanic to crystalline rock types, northward across the zone. Reductions in both the magnitude of tilting and displacement along major normal faults toward the axial part of the zone probably caused the corresponding thinning of the 16- to $13-\mathrm{Ma}$ section. Gentler tilts, less displacement along major normal faults, and intermeshing of conjugate normal faults produced shallow and narrow half grabens within the accommodation zone, which in turn prevented accumulation of thick "syn-tilt" deposits. Larger and deeper half grabens permitted accumulation of thicker deposits in more highly tilted parts of the east- and west-tilted domains. Relatively thin syntectonic strata probably characterize accommodation zones that correspond to belts of intermeshing conjugate normal faults.

The transition from volcanic to crystalline rocks as the dominant clast type northward across the accommodation zone is related to a corresponding change in source areas. The volcanic clasts in the Mount Perkins basin were presumably derived from a thick volcanic mantle on the upthrown eastern part of the west-tilted Mount Perkins block, as well as from local volcanic centers. On the other hand, the crystalline source area that shed detritus and megabreccias into the Eldorado Canyon basin probably corresponded to the upthrown western escarpment of an east-tilted fault block, which presently makes up the southernmost part of the northern Black 
Mountains crystalline terrane (fig. 1). Paleomagnetic data from a 73.3-Ma quartz monzonite pluton suggest that the southernmost part of the northern Black Mountains terrane of metamorphic and plutonic crystalline rocks is tilted approximately $60^{\circ}$ to the east (Faulds, 1989). Catastrophic failure of oversteepened mountain fronts probably produced the megabreccia deposits. The abundance of crystalline material in the megabreccia and conglomerate at or near the base of the growth-fault sequence indicates that extensive source areas of the crystalline rocks were exposed essentially at the onset of major extension and block tilting. Curiously, the megabreccia and conglomerate overlie $1.5 \mathrm{~km}$ of Tertiary strata that lack clasts of crystalline rocks.

The sharp transition from solely volcanic to mixed volcanic and crystalline source areas coincident with the onset of measurable tilting may suggest that, prior to the inception of major extension, lower Miocene strata (20 to $16 \mathrm{Ma}$ ) were deposited in broad grabens or half grabens. Initial stages of extension may have coincided with the outbreak of volcanism in early Miocene time. During the early stages of extension, graben subsidence probably did not keep pace with volcanic construction, which prevented a major influx of detritus from the upthrown parts of tilted fault blocks. A thin volcanic cover may have mantled the horsts in early Miocene time. With the onset of major extension and block tilting in middle Miocene time, however, the upthrown margins of the original horsts were quickly tectonically denuded and crystalline material was shed into rapidly subsiding half-grabens. Altematively, the lower Miocene strata may not have been deposited in grabens but instead formed constructional volcanic piles atop a little-deformed, regionally extensive erosion surface of relatively low relief. An influx of crystalline material above $1.5 \mathrm{~km}$ of volcanic and volcaniclastic strata at the onset of major extension in middle Miocene time could occur where major middle Miocene normal faults dipped toward and developed near the periphery of volcanic edifices. I favor the former explanation because early Miocene volcanism in the central Black Mountains approximately coincided with the development of large sedimentary basins in the Lake Mead area (for example, Horse Spring Formation of Bohannon, 1984; also see Wallin and others, this volume, and Beard, this volume).

A change in dominant clast type also occurs across the accommodation zone in the Eldorado Mountains but contrary in sense to that in the central Black Mountains. In the Eldorado Mountains, volcanic clasts dominate middle Miocene strata in the east-tilted Nelson half graben, whereas crystalline clasts are common in Miocene strata within a west-tilted half graben directly south of the accommodation zone. The upthrown eastem edge of a westtilted fault block, which eventually evolved into the southern Eldorado Mountains crystalline terrane, was the probable source area for the clasts of crystalline rocks in the west-tilted half graben (fig. 1). Paleomagnetic data from Miocene(?) dikes suggest that the southern Eldorado Mountains crystalline terrane is tilted $45^{\circ}$ to $60^{\circ}$ to the west (Faulds, 1989).

The abundance, depositional age, and distribution of clasts and megabreccia of crystalline rocks indicate that the crystalline terranes of the southem Eldorado Mountains and much of the northern Black Mountains were unroofed during the early stages of Miocene extension. The variations in dominant clast types across the accommodation zone also reflect corresponding changes in the configuration of major basins and fault blocks, as strain is partitioned differently in the east- and west-tilted domains (fig. 1).

\section{REFERENCES CITED}

Anderson, R.E., 1971, Thin skin distension in Tertiary rocks of southeastern Nevada: Geological Society of America Bulletin, v. 82 , no. 1, p. 43-58.

1977, Geologic map of the Boulder City 15-minute quadrangle, Clark County, Nevada: U.S. Geological Survey Geologic Quadrangle Map GQ-1395, scale 1:62,500.

1978, Geologic map of the Black Canyon 15-minute quadrangle, Mohave County, Arizona, and Clark County, Nevada: U.S. Geological Survey Geologic Quadrangle Map GQ-1394, scale 1:62,500.

Anderson, R.E., Longwell, C.R., Amstrong, R.L., and Marvin, R.F., 1972, Significance of K-Ar ages of Tertiary rocks from the Lake Mead region, Nevada-Arizona: Geological Society of America Bulletin, v. 83, no. 2, p. 273-288.

Bohannon, R.G., 1984, Nonmarine sedimentary rocks of Tertiary age in the Lake Mead region, southeastern Nevada and northwestern Arizona: U.S. Geological Survey Professional Paper 1259, 72 p.

Dalrymple, G.B., 1979, Critical tables for conversion of K-Ar ages from old to new constants: Geology, v. 7, no. 11, p. $558-560$.

Davis, S.O., 1984, Structural geology of the central portion of the Highland Spring Range, Clark County, Nevada: Los Angeles, University of Southern California, M.S. thesis, 190 p.

Davis, G.A., Anderson, J.L., Frost, E.G., and Shackelford, T.J., 1980 , Mylonitization and detachment faulting in the Whipple-Buckskin-Rawhide Mountains terrane, southeastern California and western Arizona, in Crittenden, M.D., Jr., Coney, P.J., and Davis, G.H., eds., Cordilleran metamorphic core complexes: Geological Society of America Memoir 153, p. 79-129.

Duebendorfer, E.M., Sewall, A.J., and Smith, E.I., 1990, The Saddle Island detachment; an evolving shear zone in the Lake Mead area, Nevada, in Wemicke, B.P., ed., Basin and Range extensional tectonics near the latitude of Las Vegas, Nevada: Geological Society of America Memoir 176, p. 7797.

Faulds, J.E., 1989, Structural development of a major extensional accommodation zone in the Basin and Range province, northwestern Arizona and southern Nevada: Implications for 
kinematic models of continental extension: Albuquerque, University of New Mexico, Ph.D. dissertation, 266 p.

Faulds, J.E., Geissman, J.W., and Mawer, C.K., 1990, Structural development of a major extensional accommodation zone in the Basin and Range province, northwestern Arizona and southem Nevada; implications for kinematic models of continental extension, in Wernicke, B.P., ed., Basin and Range extensional tectonics near the latitude of Las Vegas, Nevada: Geological Society of America Memoir 176, p. 37-76.

Faulds, J.E., Hillemeyer, F.L., and Smith, E.I., 1988, Geometry and kinematics of a Miocene "accommodation zone" in the central Black and southem Eldorado Mountains, Arizona and Nevada, in Weide, D.L. and Faber, M.L., eds., This extended land: geological journeys in the southern Basin and Range: Las Vegas, University of Nevada Department of Geosciences Special Publication 2 (Geological Society of America, Cordilleran Section, Las Vegas, Nev., March 1988, Field Trip Guidebook), p. 293-310.

Longwell, C.R., 1963, Reconnaissance geology between Lake Mead and Davis Dam, Arizona-Nevada: U.S. Geological Survey Professional Paper 374-E, 51 p.

Reynolds, S.J., 1988, Geologic map of Arizona: Arizona Geological Survey Map 26, scale 1:1,000,000.

Spencer, J.E., 1985, Miocene low-angle normal faulting and dike emplacement, Homer Mountain and surrounding areas, southeastern California and southernmost Nevada: Geological Society of America Bulletin, v. 96, no. 9, p. 1,140-1,155.

Spencer, J.E., and Reynolds, S.J., 1989, Middle Tertiary tectonics of Arizona and adjacent areas, in Jenney, J.P., and Reynolds, S.J., eds., Geologic evolution of Arizona: Arizona Geological Society Digest 17, p. 539-574.

Steiger, R.H., and Jäger, E., 1977, Subcommission on geochronology: Convention on the use of decay constants in geoand cosmochronology: Earth and Planetary Science Letters, v. 36 , no. 3 , p. $359-362$.

Stewart, J.H., and Carlson, J.E., 1978, Geologic map of Nevada: U.S. Geological Survey and Nevada Bureau of Mines and Geology, scale 1:500,000.

Weber, M.E., and Smith, E.I., 1987, Structural and geochemical constraints on the reassembly of disrupted mid-Miocene volcanoes in the Lake Mead-Eldorado Valley area of southern Nevada: Geology, v. 15, no. 6, p. 553-556.

Wemicke, Brian, 1985, Uniform-sense normal simple shear of the continental lithosphere: Canadian Journal of Earth Sciences, v. 22, no. 1, p. 108-125.

Young, R.A., and Brennan, W.J., 1974, Peach Springs Tuff: its bearing on structural evolution of the Colorado Plateau and development of Cenozoic drainage in Mohave County, Arizona: Geological Society of America Bulletin, v. 85, no. 1 , p. 83-90. 



\title{
Tertiary Stratigraphy and Structure of the Castle Mountains and Castle Peaks, Calif. and Nev.
}

\author{
By Jane E. Nielson ${ }^{1}$, Ryan D. Turner ${ }^{2}$, and Allen F. Glazner ${ }^{3}$
}

\section{SETTING}

The Castle Mountains and Castle Peaks are adjacent ranges that straddle the California-Nevada state line, about $90 \mathrm{~km}$ south of Las Vegas, Nevada (fig. 1; Duebendorfer and others, this volume; col. 1-I, pl. 1). The Castle Peaks are located at the northeastern end of a series of northeasttrending ranges that include, from south to north, the Providence Mountains, Mid Hills, and New York Mountains. The Castle Mountains lie between the Castle Peaks and the north-trending Piute Range (fig. 1) (Nielson and Nakata, this volume, col. 1-J, pl. 1). Pre-Tertiary rocks of the Castle Mountains and Castle Peaks are Proterozoic gneiss and granite and minor Mesozoic (Cretaceous?) granite. Nonconformably overlying Tertiary sections comprise predominantly volcanic and less abundant interbedded sedimentary units of late early to middle Miocene age. Rhyolite plugs and dikes and basalt dikes intruded both Miocene strata and older rocks.

Regional mapping by Hewett (1956) and Bingler and Bonham (1973) included these ranges or parts of them, and detailed mapping and rock descriptions are found in masters theses by Medall (1964) on the southern Castle Mountains and Balkwill (1964) on the Castle Peaks. Mapping and geochronology of the northern Castle Mountains in Nevada reported by Turner (1985; also Turner and Glazner, 1990) provide a time-stratigraphic framework for the Miocene rocks of these ranges. Recent mapping by Capps and Moore (1991) have better defined rocks that underlie the volcanic section in the Castle Mountains. Wilderness inventory mapping in the Castle Peaks (Miller and others, 1986) and Piute Range (Nielson and others, 1987) and more recent detailed mapping in the southem Castle Mountains have supplied part of the stratigraphy reported here.

\section{STRATIGRAPHY}

The stratigraphic sections of the Castle Mountains and Castle Peaks are shown on the right and left-hand sides,

\footnotetext{
'U.S Geological Survey, Mail Stop 975, 345 Middlefield Road, Menlo Park, CA 94025

${ }^{2}$ Environmental Investigations, Durham, NC 27713

${ }^{3}$ Department of Geology, University of North Carolina, Chapel Hill, NC 27514
}

respectively, of col. 1-I (pl. 1). The Miocene section in the Castle Mountains was defined by Turner (1985), who related the units he distinguished to nomenclature of Bingler and Bonham (1973). Capps and Moore (1991) established a nomenclature, which they called the "Castle Mountains Volcanic Rocks," unrelated to older usage or the units defined by Turner for the Miocene section.

\section{LOWER AND MIDDLE MIOCENE ROCKS OF THE CASTLE MOUNTAINS}

In the Castle Mountains, Miocene strata consist mostly of mafic volcanic and volcaniclastic sedimentary rocks that nonconformably overlie a complex of Proterozoic gneiss; one outcrop of Paleozoic limestone faulted against gneiss has been reported (Capps and Moore, 1991). At rare locations arkosic conglomerate of Miocene or older age directly overlies the nonconformity. The volcanic section has a maximum thickness of about $1 \mathrm{~km}$ on the west side of the range and thins to about $0.3 \mathrm{~km}$ on the east side where the Castle Mountains adjoin and are overlain by rocks of the Piute Range, a distance of about $1 \mathrm{~km}$. These thickness variations probably are due both to faulting and to shoaling of the depositional basin from west to east.

The basal Miocene volcanic unit is a sanidine-rich, sphene-bearing ash-flow tuff, which produced $\mathrm{K}$-Ar ages of $18.5 \pm 0.5 \mathrm{Ma}$ (biotite) and 17.5 $\pm 0.4 \mathrm{Ma}$ (sanidine) (Turner and Glazner, 1990) Capps and Moore (1991) reported K-Ar ages from this unit, where it underlies rocks of the Piute Range, of $22.3 \pm 0.5$ and $21.8 \pm 0.7 \mathrm{Ma}$ on biotite and sanidine, respectively, from the same sample. However, sanidine from the same tuff outcrop sampled by Capps produced an age of $18.79 \pm 0.04$ using the singlecrystal laser fusion ${ }^{40} \mathrm{Ar} /{ }^{39} \mathrm{Ar}$ technique (Turrin, written commun., 1991; Nielson and Nakata, this volume); thus it is most likely the Peach Springs Tuff of Young and Brennan (1974). Turrin found feldspar of greater age in the laser fusion sample, even though it had been hand-picked for purity. This supports the conclusion of Nielson and others (1990) that dating of bulk samples commonly yields spuriousiy old ages because the tuff probably incorporated minerals of older rocks as it flowed across surface regolith or alluvial detritus. 
Rocks that immediately overlie the Peach Springs Tuff consist of andesitic to basaltic flows and breccias of late early Miocene age, which are interbedded with sedimentary rocks derived principally from mafic volcanic sources. These strata are coeval and have similar lithology to the Patsy Mine Volcanics (Longwell, 1963; Anderson and others, 1972; Bingler and Bonham, 1973; the rocks are part of a unit that Capps and Moore, 1991, call "Jacks Well member" of the "Castle Mountains Volcanic Rocks"). The lower Miocene section in the Castle Mountains contains some rhyolitic rocks, especially rhyolitic dikes, that may be related to later Miocene volcanism and intrusion. Basaltic dikes also occur in the section.

In the northernmost Castle Mountains the lower Miocene volcanic rocks are conformably overlain by an upwardly fining fluvial to lacustrine unit of varicolored sedimentary rocks, composed of mixed volcaniclastic and arkosic detritus. The unit of lacustrine sedimentary rocks is overlain by a partly welded ash-flow tuff that has $\mathrm{K}-\mathrm{Ar}$ ages of $16.1 \pm 0.4 \mathrm{Ma}$ (biotite) and $16.2 \pm 0.4 \mathrm{Ma}$ (sanidine) (Tumer and Glazner, 1990). This tuff apparently was included in the "Jacks Well member" by Capps and Moore (1991). It is overlain by a thick sequence of leucocratic silicic volcanic rocks, including bedded surge deposits, lithic air-fall tuff, massive pumice breccia, flow breccia, and local rhyolite lava flows. Basalt flows are interbedded with rhyolite units in the uppermost part of the sequence (this rhyolitic eruptive section was divided into two units by Capps and Moore, 1991). In the northern part of the range the interbedded basalt flows are thick and abundant, compared to rare thin flows in the southern part of the range. No single eruptive unit in this sequence can be traced along strike more than one kilometer.

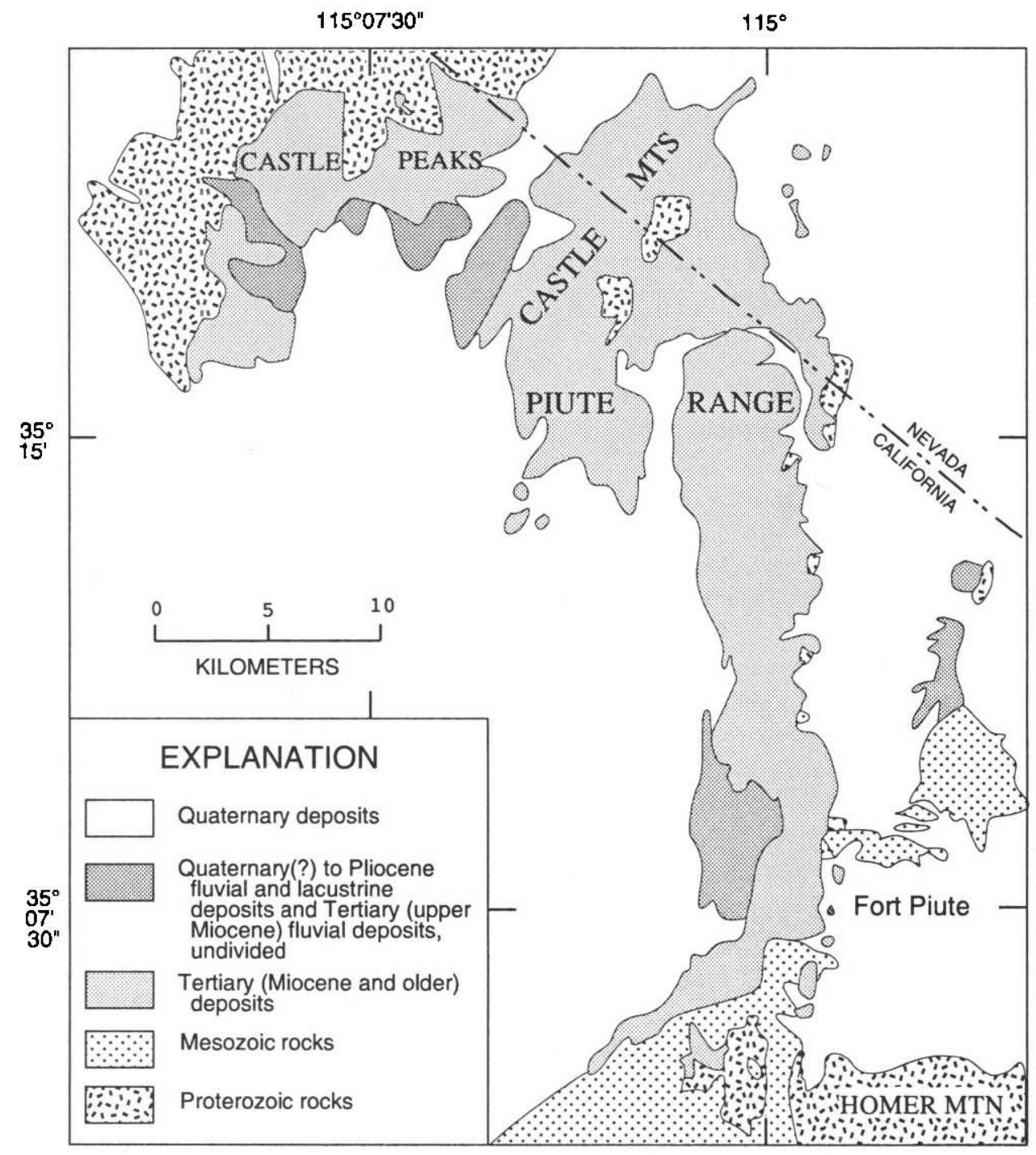

Figure 1. Generalized geology of Castle Mountains, Castle Peaks, and Piute Range, California and Nevada. 
The rhyolitic eruptive section is thickest $(400 \mathrm{~m})$ and forms the dominant exposures in the southern Castle Mountains. The sequence of silicic eruptive rocks contains rhyolite intrusions that vary from narrow dikes to plugs up to $500 \mathrm{~m}$ in maximum dimension. Overlapping strata of the rhyolitic section represent early eruptions of lava that later solidified to form these dikes and plugs. About 50 plugs larger than $75 \mathrm{~m}$ diameter are exposed along a generally linear northeast trend on the west side of the range. The concentration of plugs is greatest at the southwest end of this trend, coincident with the thickest rhyolitic section. In the northern part of the range the rhyolite flows are overlain by a local welded ash-flow tuff, which yielded a K-Ar age of $14.4 \pm 0.2$ Ma (biotite; Turner and Glazner, 1990). Latitic intrusions in the southern part of the range have $\mathrm{K}-\mathrm{Ar}$ ages of $14.5 \pm 0.5$ and $15.1 \pm 0.4 \mathrm{Ma}$ on biotite, as reported by Capps and Moore (1991).

Intrusions related to the middle Miocene rhyolitic volcanism occur throughout the underlying strata, and some of these intrusions cut the nonconformable contact between Proterozoic and Tertiary rocks. The rhyolitic intrusions are most voluminous at the southwestern end of the range, where the lower Miocene andesitic section is overwhelmed by rhyolite dikes and small plugs, and multiple intrusive events are indicated by plugs that intrude each other. One rhyolite plug with approximately vertical flowbanding has an age of $12.8 \pm 0.2 \mathrm{Ma}$ (sanidine; Turner and Glazner, 1990).

\section{LOWER AND MIDDLE MIOCENE ROCKS OF THE CASTLE PEAKS}

Tertiary volcanic and sedimentary rocks in the Castle Peaks nonconformably overlie banded Proterozoic gneiss, which is intruded by foliated to nonfoliated Proterozoic granite (Miller and others, 1986). The lowest Tertiary unit is fine- to medium-grained arkosic sandstone of Miocene or older age that filled stream channels (locally steep-sided canyons) in an area of considerable relief. The lowest volcanic unit is the Peach Springs Tuff (Wells and Hillhouse, 1989). A section of coarse monolithologic to heterolithologic eruptive breccia units that are dacitic to andesitic in composition overlies this regionally extensive unit. The breccia section is locally interbedded with finer grained volcaniclastic eruptive rocks and sedimentary deposits. Within the breccia units are sills and dikes that may be related to feeders of the overlying andesite flows.

The eruptive breccia units are separated from a thick section of brecciated to massive andesite flows by an interval of up to four white lithic tuff beds. Interbedded within the upper part of the andesite flows is a silicic welded ash-flow tuff with an oxide-rich suite of heavy minerals (Gusa and others, 1987) similar to subunits of the Wild Horse Mesa Tuff of McCurry (1988) dated by $\mathrm{K}-\mathrm{Ar}$ at 15.8 $\pm 0.4 \mathrm{Ma}$ (McCurry, 1988). The andesite flows are overlain by conglomerate described below. Thus, Miocene volcanic rocks of the Castle Peaks appear to be temporally equivalent to, but lithologically distinct from, those beneath the rhyolitic eruptive section in the Castle Mountains.

\section{UPPER MIOCENE(?) AND YOUNGER DEPOSITS}

The uppermost unit in the Castle Mountains and Castle Peaks is predominantly sandstone and conglomerate. The age of this untilted unit is believed to be late Miocene(?) and younger. In the Castle Mountains the topmost units of the eruptive rhyolite section grade into a poorly exposed clay-rich horizon that may be a paleosol developed on tuff and volcanic breccia units. Crystal-rich sandstone, with coarse conglomerate lenses, overlies this presumed paleosol. The sedimentary unit coarsens upsection, to predominantly conglomerate with coarse sandstone matrix. Basalt lava flows (and sills?) are interbedded in the unit. In the Castle Peaks, the sandstone overlies andesite flows; coarse channel conglomerate locally rests directly on andesite (S.M. Thompson, written commun., 1990). Clasts in the conglomerate are mostly Proterozoic granite and gneiss, Paleozoic limestone, and variable-generally minor-amounts of volcanic rocks. At one locality a silicified rhyolite ash-flow(?) tuff is interbedded with the conglomerate. Conglomerate directly overlying the tuff is dominated by mafic volcanic clasts derived from andesite flows in the Castle Peaks.

\section{STRUCTURE}

Miocene strata in the Castle Peaks dip southeast toward the northwestern part of the Castle Mountains. There are no distinct unconformities within the lower and middle Miocene sections of either range. Dips of Miocene units on the northwest side of the Castle Mountains are highly variable; the Peach Springs Tuff and immediately adjacent units have dips up to $65^{\circ}$. Rhyolite flows and volcaniclastic units have dips that vary locally between $36^{\circ}$ and $25^{\circ}$. The steeply dipping rocks appear to form the nose of a highly faulted anticlinal fold with northeast trend (Turner and Glazner, 1990). The equivalent, but dramatically thinner strata on the eastern side of the supposed anticline (Nielson and Nakata, this volume), are relatively undeformed, and exposures of the Peach Springs Tuff have dips no greater than $25^{\circ}$. Miocene strata in the Castle Peaks generally have gentle dips, although locally beds are steeply tilted near numerous closely spaced faults. 
The apparent anticline in the Castle Mountains can be interpreted as an extensional, rather than a compressional structure. Steep tilting of older units occurs only where the rhyolite units of middle Miocene age are thickest and rhyolite plugs are most concentrated; also, the plugs trend approximately parallel to the supposed anticlinal axis. Subsidence of the older units into a small volcano-tectonic depression that was created by eruption of upper-crustal rhyolitic melts may have caused the tilting of the underlying section. This depression might be considered a linear trap-door caldera, but of relatively diminutive size. The much shallower dips of equivalent, but much thinner, strata east of the supposed anticlinal core thus would represent parts of the section that lapped across a ramp of tilted crust, which was lowered on a northeast-striking fault or faults now buried beneath the rhyolite section and overlying sedimentary units.

Faulting in the Castle Mountains is complex and includes east-dipping low-angle normal faults and highangle strike- and oblique-slip faults. High-angle faults generally cut low-angle faults, although a major highangle, oblique-slip fault turns into a low-angle fault as the strike changes from northeast to north. Displacement on these faults is relatively small, and the ranges do not appear to be as extended as are the neighboring Eldorado and Black Mountains of the Lake Mead region (Anderson, 1971; Anderson and others, 1972; Bohannon, 1979).

Miocene faults in the Castle Peaks strike northeast to northwest (Miller and others, 1986). The northeaststriking faults are mostly normal dip-slip faults, which dip northwest. No low-angle faults of Miocene age are known in the range.

In the Castle Peaks, upper Miocene(?) and younger conglomerate overlies the volcanic section on a distinct angular unconformity. Although the younger rocks apparently are undeformed and probably represent continuous deposition from late Tertiary into Quaternary time, some major exposures are topographically much higher than laterally equivalent rocks that crop out at the margins of the adjacent Lanfair and Ivanpah Valleys. Thus, considerable erosion must have occurred since the time of deposition, and local uplifting may be required to explain these relations.

\section{REFERENCES CITED}

Anderson, R.E., 1971, Thin skin distension in Tertiary rocks of southeastern Nevada: Geological Society of America Bulletin, v. 82 , no. 1, p. $43-58$.

Anderson, R.E., Longwell, C.R., Armstrong, R.L., and Marvin, R.F., 1972, Significance of K-Ar ages of Tertiary rocks from the Lake Mead region, Nevada-Arizona: Geological Society of America Bulletin, v. 83, no. 2, p. 273-288.
Balkwill, H.R., 1964, Geology of the central New York Mountains, California: Los Angeles, University of Southem California, M.S. thesis, 93 p.

Bingler, E.C., and Bonham, H.F., 1973, Reconnaissance geologic map of the McCullough Range and adjacent areas, Clark County, Nevada: Nevada Bureau of Mines and Geology Map 45 , scale $1: 125,000$.

Bohannon, R.G., 1979, Strike-slip faults of the Lake Mead region of southem Nevada, in Amentrout, J.M., Cole, M.R., and Terbest, Harry, Jr., eds., Cenozoic paleogeography of the western United States: Pacific Section, Society of Economic Paleontologists and Mineralogists, Pacific Coast Paleogeography Symposium 3, p. 129-140.

Capps, R.C., and Moore, J.A., 1991, Geologic setting of midMiocene gold deposits in the Castle Mountains, San Bernardino County, California and Clark County, Nevada, in Raines, G.L., Lisle, R.E., Shafer, R.W., and Wilkinson, W.H., eds., Geology and ore deposits of the Great Basin: Geological Society of Nevada, Symposium Proceedings, v. 2, p. 1,1951,219 .

Gusa, Sharon, Howard, K.A., and Nielson, J.E., 1987, Heavymineral suites confirm the wide extent of the Peach Springs Tuff in California and Arizona, U.S.A.: Journal of Volcanology and Geothermal Research, v. 33, no. 4, p. 343-347.

Hewett, D.F., 1956, Geology and mineral resources of the Ivanpah quadrangle, California and Nevada: U.S. Geological Survey Professional Paper 275, 172 p.

Longwell, C.R., 1963, Reconnaissance geology between Lake Mead and Davis Dam, Arizona-Nevada: U.S. Geological Survey Professional Paper 374-E, 51 p.

McCurry, Michael, 1988, Geology and petrology of the Woods Mountains volcanic center, southeastern California: Implications for the genesis of peralkaline rhyolite ash flow tuffs: Journal of Geophysical Research, v. 93, no. B12, p. 14,38514,855 .

Medall, S.E., 1964, Geology of the Castle Mountains, California: Los Angeles, University of Southem California, M.S. thesis, $107 \mathrm{p}$.

Miller, D.M., Frisken, J.G., Jachens, R.C., and Gese, D.D., 1986, Mineral resources of the Castle Peaks Wildemess Study Area, San Bernardino County, California: U.S. Geological Survey Bulletin 1713-A, 17 p.

Nielson, J.E., Frisken, J.G., Jachens, R.C., and McDonnell, J.R., Jr., 1987, Mineral resources of the Fort Piute Wilderness Study Area, San Bernardino County, California: U.S. Geological Survey Bulletin 1713-C, 12 p.

Nielson, J.E., Lux, D.R., Dalrymple, G.B., and Glazner, A.F., 1990, Age of the Peach Springs Tuff, southeastern California and western Arizona: Joumal of Geophysical Research, v. 95, no. B1, p. 571-580.

Tumer, R.D., 1985, Miocene folding and faulting of an evolving volcanic center in the Castle Mountains, southeastern California and southern Nevada: Chapel Hill, University of North Carolina, M.S. thesis, $56 \mathrm{p}$.

Turner, R.D., and Glazner, A.F., 1990, Miocene volcanism, folding, and faulting in the Castle Mountains, southem Nevada and eastern California, in Wernicke, B.P., ed., Basin and Range extensional tectonics near the latitude of Las Vegas, Nevada: Geological Society of America Memoir 176, p. 2335 . 
Wells, R.E., and Hillhouse, J.W., 1989, Paleomagnetism and tectonic rotation of the lower Miocene Peach Springs Tuff: Colorado Plateau, Arizona to Barstow, California: Geological Society of America Bulletin, v. 101, no. 6, p. 846-863.
Young, R.A., and Brennan, W.J., 1974, Peach Springs Tuff: its bearing on structural evolution of the Colorado Plateau and development of Cenozoic drainage in Mohave County, Arizona: Geological Society of America Bulletin, v. 85 , no. 1 , p. 83-90. 



\title{
Tertiary Stratigraphy and Structure of the Piute Range, Calif. and Nev.
}

\author{
By Jane E. Nielson ${ }^{1}$ and John K. Nakata ${ }^{1}$
}

\section{SETTING}

The Piute Range lies at the north end of a series of north-south-trending Mojave Desert mountain ranges that include, from south to north, the Old Woman, Little Piute, and Piute Mountains. The north end of the Piute Range straddles the California-Nevada state line, about $90 \mathrm{~km}$ south of Las Vegas, Nev., and abuts the eastern side of the Castle Mountains (fig. 1 in Duebendorfer and others, this volume; Nielson and others, this volume). The south end of the range adjoins Homer Mountain (Spencer, 1985).

Pre-Tertiary rocks exposed at the north end of the Piute Range are mostly Proterozoic granitic augen gneiss that give uranium-lead ages of 1,720 to $1,660 \mathrm{Ma}$ (Wooden and others, 1986). Mylonitic zones in these rocks are cut by dikelets of foliated leucocratic Proterozoic granite. In the south-central part of the range, Proterozoic rocks are intruded by undeformed plutons of Mesozoic (Cretaceous?) granite and diorite, similar to relations exposed in Homer Mountain (Spencer, 1985). At the south end of the Piute Range, the exposed older rocks are Cretaceous(?) leucogranite varieties. A section of Tertiary (predominantly Miocene) volcanic and sedimentary rocks as much as $700 \mathrm{~m}$ thick, overlies the suite of older rocks on an irregular nonconformity with as much as $125 \mathrm{~m}$ of exposed relief.

Regional mapping by Hewett (1956) and Bingler and Bonham (1973) included the Piute Range or parts of it. Wilderness inventory mapping in the Piute Range (Nielson and others, 1987) is the basis for the stratigraphy reported here. Discovery of the Peach Springs Tuff of Young and Brennan (1974) in the range, and work in the adjacent Castle Mountains, Nev., by Tumer (1985; Turner and Glazner, 1990), also provide an approximate time-stratigraphic framework for Miocene rocks of the Piute Range.

\section{STRATIGRAPHY}

Tertiary stratigraphy of the Piute Range varies from north to south, parallel to the strike of beds; composite

\footnotetext{
${ }^{1}$ U.S. Geological Survey, Mail Stop 975, 345 Middlefield Road, Menlo Park, CA 94025
}

relations are shown on plate 1 (col. 1-J). The lowest Miocene unit everywhere in the Piute Range is arkosic sandstone and (or) conglomerate, composed entirely of clasts derived from subjacent older rocks. The lowest volcanic unit in the section at the north end of the range is a sanidine- and sphene-bearing tuff, dated at $18.79 \pm 0.04 \mathrm{Ma}$ (B.D. Turrin, written commun., 1991) using the single-crystal laser fusion ${ }^{40} \mathrm{Ar} /{ }^{39} \mathrm{Ar}$ technique. This highly precise age is indistinguishable from one of $18.5 \pm 0.5 \mathrm{Ma}$ reported by Nielson and others (1990) for the Peach Springs Tuff of Young and Brennan (1974), and we believe that the basal tuff unit in the Piute Range is the Peach Springs Tuff.

The oldest volcanic unit at the south end of the range, near Civil War-era Fort Piute, is a basalt flow, with a $\mathrm{K}-\mathrm{Ar}$ age of $19.8 \pm 0.5 \mathrm{Ma}$ (table 1 ), that directly overlies Cretaceous(?) granite. Relations between this flow and the basal arkose are not exposed. Except for the Peach Springs Tuff, Miocene volcanic units in the Piute Range are not distinctive and (or) are of limited distribution. The Miocene section appears to be composed of numerous interfingering piles of short, stubby flows (mostly brecciated) and lenticular interbeds of sedimentary rocks.

In the north part of the Piute Range, in Nevada, the Peach Springs Tuff is conformably overlain by andesitic flow breccia, reworked tuff, and air-fall tuff. These rocks are overlain unconformably by a section composed of dark-colored basaltic to dacitic flow and brecciated flow units interspersed with fluvial channel gravel. Rocks beneath the unconformity are here referred to as the lower Miocene section, and the overlying rocks as the upper $\mathrm{Mi}$ ocene section. Clasts in the interbedded gravel include Proterozoic gneiss and granite, Paleozoic limestone (and marble), Mesozoic granite, and Tertiary volcanic rock types. The gneiss clasts include gamet-bearing types that resemble rocks exposed in the New York Mountains, about $25 \mathrm{~km}$ west of the Piute Range.

Volcanic rocks that directly overlie basal arkosic units in the south part of the range are lava flows, flow breccia, volcaniclastic breccia, and local air-fall tuff. Flow compositions range from basalt to rhyodacite. No distinction between the lower and upper Miocene sections is evident in this area. 
Table 1. K-Ar ages of Piute Range rocks.

\begin{tabular}{|c|c|c|c|c|c|c|c|c|c|}
\hline Sample No.' & $\begin{array}{l}\text { Latitude } \\
\text { (N.) }\end{array}$ & $\begin{array}{l}\text { Longitude } \\
\text { (W.) }\end{array}$ & Rock type & Material dated & $\begin{array}{c}\mathrm{K}_{2} \mathrm{O} \\
\text { (wt pct) }\end{array}$ & $\begin{array}{l}{ }^{40} \mathrm{Ar}_{\mathrm{rad}} \\
10^{-11} \mathrm{~mol} / \mathrm{g}\end{array}$ & $\begin{array}{l}\text { Percent } \\
{ }^{40} \mathrm{Ar}_{\mathrm{rad}}\end{array}$ & $\begin{array}{c}\text { Calculated age } \\
\qquad(\mathrm{Ma})^{2}\end{array}$ & Assigned age (Ma) \\
\hline \multicolumn{10}{|c|}{ Upper Miocene section } \\
\hline CA84PR-33a & $35^{\circ} 17^{\prime} 35^{\prime \prime}$ & $115^{\circ} 02^{\prime} 15^{\prime \prime}$ & Dacite flow & Whole rock & 3.85 & $\begin{array}{l}4.81 \\
4.12\end{array}$ & $\begin{array}{l}46.5 \\
46.8\end{array}$ & $\begin{array}{l}8.64 \\
7.41\end{array}$ & $8.0 \pm 0.6$ \\
\hline JN86PR-3 & $35^{\circ} 16^{\prime} 18^{\prime \prime}$ & $114^{\circ} 58^{\prime} 23^{\prime \prime}$ & $\begin{array}{c}\text { Basaltic andesite } \\
\text { flow }\end{array}$ & Whole rock & 2.40 & $\begin{array}{l}3.35 \\
3.72\end{array}$ & $\begin{array}{l}56.8 \\
63.6\end{array}$ & $\begin{array}{c}9.66 \\
10.74\end{array}$ & $10.2 \pm 0.7$ \\
\hline CA84PR-39 & $35^{\circ} 19^{\prime} 12^{\prime \prime}$ & $115^{\circ} 01^{\prime} 44^{\prime \prime}$ & Basalt flow & Whole rock & 1.33 & $\begin{array}{l}2.04 \\
2.02\end{array}$ & $\begin{array}{l}35.2 \\
36.7 \\
\end{array}$ & $\begin{array}{l}10.6 \\
10.7 \\
\end{array}$ & $10.7 \pm 0.3$ \\
\hline \multicolumn{10}{|c|}{ Lower Miocene section } \\
\hline JP84PR-93 & $35^{\circ} 13^{\prime} 00^{\prime \prime}$ & $115^{\circ} 01^{\prime} 50^{\prime \prime}$ & Basalt flow & Whole rock & 2.95 & $\begin{array}{l}5.13 \\
5.28\end{array}$ & $\begin{array}{l}67.0 \\
68.0\end{array}$ & $\begin{array}{l}12.04 \\
12.38\end{array}$ & $12.2 \pm 0.3$ \\
\hline JN86PR-2 & $35^{\circ} 16^{\prime} 18^{\prime \prime}$ & $114^{\circ} 59^{\prime} 43^{\prime \prime}$ & $\begin{array}{c}\text { Pyroxene andesite } \\
\text { flow }\end{array}$ & Whole rock & 3.56 & $\begin{array}{l}5.84 \\
6.88\end{array}$ & $\begin{array}{l}73.4 \\
71.4\end{array}$ & $\begin{array}{l}11.36 \\
13.40\end{array}$ & $12.4 \pm 1.4$ \\
\hline CA84PR-70a & $35^{\circ} 12^{\prime} 00^{\prime \prime}$ & $115^{\circ} 01^{\prime} 06^{\prime \prime}$ & $\begin{array}{l}\text { Olivine-pyroxene } \\
\text { andesite flow }\end{array}$ & Whole rock & 2.74 & $\begin{array}{l}4.69 \\
5.39\end{array}$ & $\begin{array}{l}63.5 \\
78.4\end{array}$ & $\begin{array}{l}11.85 \\
13.60\end{array}$ & $12.7 \pm 0.8$ \\
\hline JP84PR-96 & $35^{\circ} 14^{\prime} 00^{\prime \prime}$ & $115^{\circ} 01^{\prime} 35^{\prime \prime}$ & Rhyolite & Biotite & 8.84 & $\begin{array}{l}1.70 \\
1.70\end{array}$ & $\begin{array}{l}38.3 \\
55.5\end{array}$ & $\begin{array}{l}13.31 \\
13.40\end{array}$ & $13.3 \pm 0.3$ \\
\hline JN84PR-6 & $35^{\circ} 05^{\prime} 31^{\prime \prime}$ & $114^{\circ} 59^{\prime} 02^{\prime \prime}$ & $\begin{array}{c}\text { Basaltic andesite } \\
\text { flow }\end{array}$ & Whole rock & 1.50 & 4.30 & 75.5 & 19.82 & $19.8 \pm 0.5$ \\
\hline
\end{tabular}

\footnotetext{
'Sample preparation and analytical work were done at U.S. Geological Survey, $\mathrm{K}_{2} \mathrm{O}$ analyses by M. Dyslin, L. Espos, P. Klock, S. Macpherson, S. Pribble, and D. Vivit.

${ }^{2} \mathrm{~K}$-Ar ages were calculated using the constants for the radioactive decay and abundance of ${ }^{40} \mathrm{~K}$ recommended by the International Union of Geological Sciences Subcommission on Geochronology (Steiger and Jäger, 1977). These constants are: $\lambda_{\mathrm{e}}=0.580 \times 10^{-10} \mathrm{yr}^{-1}$, $\lambda_{\beta}=4.962 \times 10^{-10} \mathrm{yr}^{-1}$, and ${ }^{40} \mathrm{~K} / \mathrm{K}_{\text {total }}=1.167 \times 10^{-4} \mathrm{~mol} / \mathrm{mol}$.
}

Abundant phyric and aphyric andesitic and basaltic dikes occur throughout the volcanic flows of the Piute Range. In addition, a hornblende andesite plug about 350 $m$ across intrudes volcanic strata of the upper Miocene section in the north part of the range, and three rhyolite intrusions (sills?) within volcanic strata are exposed in cliffs over a distance of about $1.5 \mathrm{~km}$ in the southern half of the range. Except for one medium-gray dacite sill or plug, the silicic intrusions are predominantly dark colored, like all flows in the Piute Range, and are easily distinguished from probably coeval, very light colored rhyolite plugs and dikes of the adjacent Castle Mountains.

Lacustrine deposits crop out in buttress unconformity against the volcanic rocks on the west side of the Piute Range. Lava flows within these beds have been intersected in drill holes. On the east side of the range, playa and interfingering alluvial sandstones lap over the tilted volcanic rocks. These units merge upsection with conformable Pliocene and Quaternary alluvial deposits.

\section{STRATIGRAPHIC INTERPRETATION}

The composite stratigraphic column (col. 1-J, pl. 1) is a tentative interpretation, based on equivocal field relations and problematic geochronologic data. In addition to the Peach Springs Tuff and the basalt of the lower Miocene section mentioned above, ages from one biotite separate and three other whole-rock samples yielded $\mathrm{K}$-Ar ages between $13.3 \pm 0.3$ and $12.2 \pm 0.3 \mathrm{Ma}$ for rocks of the lower section (table 1). These ages were determined on rocks that crop out in a variety of locations, ranging from units with moderate dips that closely overlie the Peach Springs Tuff to nearly horizontal flows that lie at elevations $600 \mathrm{~m}$ above the closest Peach Springs outcrop. Three other dated rocks ascribed here to the upper Miocene section range in age from $10.7 \pm 0.3$ to $8.0 \pm 0.6 \mathrm{Ma}$ (table 1). Most of these samples were collected from slightly tilted flows interbedded with gravel lenses in the north part of the range.

The Peach Springs Tuff occurs at the base of Miocene sections in the Piute Range, Castle Mountains, and Castle Peaks and overlies a suite of older plutonic rocks (Nielson and others, this volume). In addition, $\mathrm{K}-\mathrm{Ar}$ ages from rocks of the Piute Range are equivalent to those of the upper Castle Mountains volcanic section (Turner and Glazner, 1990); thus, the two volcanic sections apparently erupted concurrently. Interfingering relations of units between the two sections are exposed locally in the southern part of the Castle Mountains. These relations indicate that the sections were erupted in close proximity to each other. At this site, only thin units of the upper rhyolitic part of the Castle Mountains section are present; they appar- 
ently lapped across a topographically high ridge of older rocks.

Dark flow breccia of lithology similar to rocks of the Piute Range is found locally in the upper part of the Castle Mountains rhyolitic eruptive section, but no rocks resembling the upper Castle Mountains section are known to crop out anywhere in the Piute Range. Thus, the attenuated eastern part of the Castle Mountains section probably pinches out within the eruptive strata of the Piute Range. Piute Range flows with very young whole rock ages of 8 to $10 \mathrm{Ma}$ may be the lateral equivalents of volcanic rocks that are interbedded with conglomerate units in the upper part of the Castle Mountains and Castle Peaks sections (Nielson and others, this volume).

Playa deposits that overlie and abut the Piute Range volcanic section are tentatively considered to be of Pliocene(?) and younger age, on the basis of vertebrate fossils (R.E. Reynolds, oral commun., 1987).

\section{STRUCTURE}

Volcanic rocks of the lower section in the north part of the Piute Range are broken up by a complex of faults with various strikes. The beds are tilted steeply (up to vertical) to the west, northwest, and southwest by north-, northeast-, and northwest-striking faults. Faults with east-northeast strikes offset the tilted strata and the nonconformity between Proterozoic and Tertiary rocks.

Structural elements are obscured by the numerous indistinguishable volcanic units in the overlying section. The units mostly dip $15^{\circ}$ or less, and low radial dips occur locally in flows that were arched by intrusion of silicic sills(?). In the southern part of the Piute Range, especially south of Fort Piute, flows and breccia of the Miocene section dip to the east up to $45^{\circ}$. These rocks are repeated by northwest-striking normal faults that dropped the section down to the west.

Rocks of the Piute Range overlap the attenuated eastern part of the Castle Mountains Miocene volcanic section. The light-colored rhyolitic rocks of this section dip gently toward the Piute Range, where they are truncated by north-striking faults (Turner, 1985). Proterozoic rocks are exposed at elevations about $350 \mathrm{~m}$ lower on the east side of the Piute Range than on the west. Gravity data suggest that the older rocks are offset by a fault that parallels the west side of the Piute Range (Mariano and others, 1986). East of the fault, the thick section of volcanic rocks have westward dips that project into it, whereas west of the fault, units that resemble Piute Range rocks form thin, generally untilted, caps on Castle Mountains rhyolite flows and breccia deposits. Thus, the fault probably existed in the Miocene as the boundary of a volcano-tectonic basin in which the Piute Range lavas accumulated.

\section{REFERENCES CITED}

Bingler, E.C., and Bonham, H.F., 1973, Reconnaissance geologic map of the McCullough Range and adjacent areas, Clark County, Nevada: Nevada Bureau of Mines and Geology Map 45, scale 1:125,000.

Hewett, D.F., 1956, Geology and mineral resources of the Ivanpah quadrangle, California and Nevada: U.S. Geological Survey Professional Paper 275, 172 p.

Mariano, John, Helferty, M.G., and Gage, T.B., 1986, Bouguer and isostatic residual gravity maps of the Colorado River region, including the Kingman, Needles, Salton Sea, and El Centro quadrangles: U.S. Geological Survey Open File Report 86-347, scale 1:250,000.

Nielson, J.E., Frisken, J.G., Jachens, R.C., and McDonnell, J. Jr., 1987, Mineral resources of the Fort Piute Wilderness Study Area, San Bernardino County, California: U.S. Geological Survey Bulletin 1713-C, 12 p.

Nielson, J.E., Lux, D.R., Dairymple, G.B., and Glazner, A.F., 1990, Age of Peach Springs Tuff, southeastern California and western Arizona: Journal of Geophysical Research, v. 95, no. B1, p. 571-580.

Spencer, J.E., 1985, Miocene low-angle normal faulting and dike emplacement, Homer Mountain and surrounding areas, southeastern California and southemmost Nevada: Geological Society of America Bulletin, v. 96, no. 9, p. 1,1401,155 .

Steiger, R.H., and Jäger, E., 1977, Subcommission on geochronology: Convention on the use of decay constants in geoand cosmochronology: Earth and Planetary Science Letters, v. 36 , no. 3, p. $359-362$.

Turner, R.D., 1985, Miocene folding and faulting of an evolving volcanic center in the Castle Mountains, southeastem California and southern Nevada: Chapel Hill, University of North Carolina, M.S. thesis, $56 \mathrm{p}$.

Tumer, R.D., and Glazner, A.F., 1990, Miocene volcanism, folding, and faulting in the Castle Mountains, southern Nevada and eastern California, in Wernicke, B.P., ed., Basin and Range extensional tectonics near the latitude of Las Vegas, Nevada: Geological Society of America Memoir 176, p. 2335.

Wooden, Joe, Miller, Dave, and Elliot, Geoff, 1986, Early Proterozoic geology of the northem New York Mountains, southeastem California [abs.]: Geological Society of America Abstracts with Programs, v. 18, no. 5, p. 424.

Young, R.A., and Brennan, W.J., 1974, Peach Springs Tuff: its bearing on structural evolution of the Colorado Plateau and development of Cenozoic drainage in Mohave County, Arizona: Geological Society of America Bulletin, v. 85 , no. 1 , p. $83-90$. 



\title{
Feldspar Geochemistry of Four Miocene Ignimbrites in Southeastern Calif. and Western Ariz.
}

\author{
By David C. Buesch ${ }^{1}$
}

\section{INTRODUCTION}

Regional correlations are difficult between exposures of Middle Cenozoic stratigraphic sequences in the southern Basin and Range province of western Arizona, southeastern California, and southem Nevada, because of faulting and abrupt facies changes. However, many sequences contain interbedded tephra layers that are widely distributed. Thus, tephrochronology can be one of the most useful tools for unraveling the stratigraphy and structure of these highly extended terranes. However, correlations between many tephra units have yet to be determined in the region. When correlations of tephra layers are extended throughout their outcrop areas, the lateral variations within each tuff can be evaluated. Developing the tephrochronology for this region is an important step in understanding the sedimentologic, volcanologic, and structural history of these extensional terranes.

The focus of this study is the phenocryst mineralogy and feldspar composition of three Miocene ignimbrites and related fallout tuff deposits, using the same petrographic and electron microprobe analytical techniques for each. These results are used to characterize samples of major tephra deposits that occur at the western margin of the Colorado Plateau and in the eastern Mojave Desert (fig. 1); these are the Peach Springs Tuff of Young and Brennan (1974), the informally named Cook Canyon tuff of Buesch and Valentine (1986), and the Fort Rock Creek rhyodacite unit of Fuis (1973). Fallout tuff deposits that crop out near Kingman, Ariz., also were analyzed for this study. These data and analyses from studies of the widespread Wild Horse Mesa Tuff of McCurry (1988) indicate that the major tephra units are compositionally distinct. The distinctive petrography and feldspar geochemistry of the ignimbrites establishes criteria against which previously interrelated tephra layers can be compared. These data allow the fallout tuff deposits near Kingman to be tentatively correlated with the major units.

A secure tephrostratigraphic correlation commonly requires a multifaceted approach, including geochemical, pa-

'U.S. Geological Survey Yucca Mountain Project, 101 Convention Center Drive, Suite 860, Las Vegas, NV 89109 leomagnetic, and isotopic determinations, because tephra beds of different ages can have similar characteristics (Izett, 1981). Also, the mineral assemblage may be zoned (Hildreth, 1979; Smith, 1979) or constant (Whitney and Stormer, 1985), and phenocryst contents and proportions can vary laterally and vertically within ignimbrite and fallout deposits (Westgate and Gorton, 1981; Sarna-Wojcicki and others, 1985). Correlations using geochemical analyses of phenocrysts and volcanic glass are well documented (Izett, 1981; Westgate and Gorton, 1981, Smith and Leeman, 1982; Izett and others, 1988; Sarna-Wojcicki and Davis, 1991). However, mineral compositions, especially of feldspars, are particularly useful in correlating tuffs and establishing a tephrostratigraphy from rocks with partly or completely altered glass compositions.

\section{IGNIMBRITE UNITS OF THE STUDY AREA}

The Miocene ignimbrites and associated fallout tuff units studied and the sampling locations are listed in table 1. The terminology for pyroclastic flow units follows the usage of Sparks and others (1973) and Fisher and Schmincke (1984); that for zones of welding and crystallization follows Smith (1960) (fig. 2). The petrographic methodology used in transmitted and reflected light follows Warren and others $(1984,1989)$. Point counts were made in reflected light. Modal contents of the felsic minerals (sanidine, plagioclase, and quartz) are based on 400 to 4,000 counts. Volume estimates for mafic minerals, magnetite and ilmenite, and accessory minerals were determined by summing the areas covered by each mineral phase in a thin section (determined in reflected light), and dividing by the area of the section. Petrographic determinations for each of the ignimbrites are summarized in table 2.

\section{PEACH SPRINGS TUFF}

The Peach Springs Tuff crops out at scattered locations across an area of at least $32,000 \mathrm{~km}^{2}$ in southern California, western Arizona, and southern Nevada (fig. 1; 


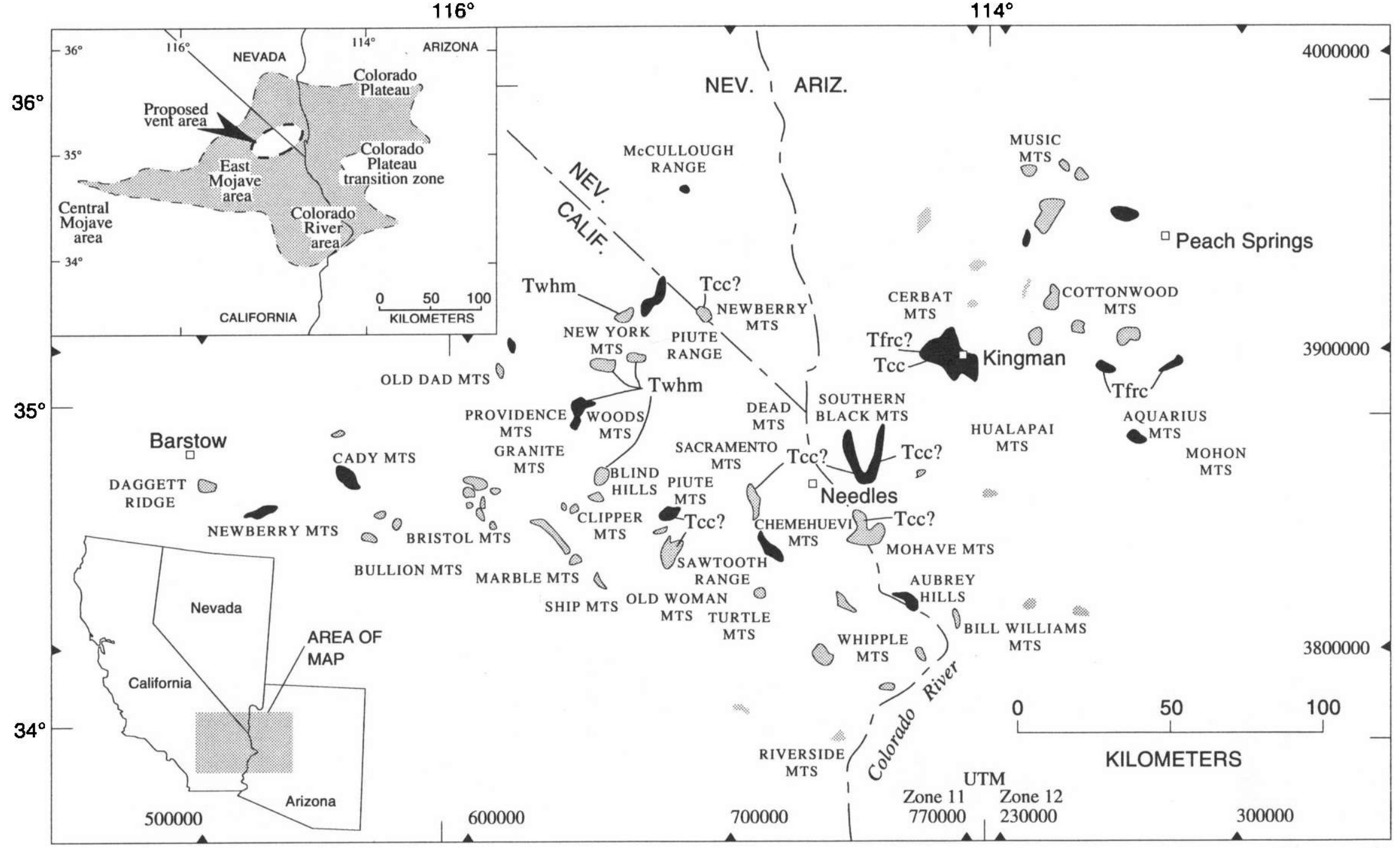

Figure 1. Distribution of Miocene Peach Springs Tuff of Young and Brennan (1974). Exposures in black are correlated by electron microprobe data; exposures in bounded gray are correlated on basis of petrography (Glazner and others, 1986; Buesch, unpub. data) or thermoremanent magnetism (Wells and Hillhouse, 1989); exposures in unbounded gray have been suggested as equivalent to the Peach Springs Tuff, but were not investigated by author. These other exposures may correlate to the informally named Cook Canyon tuff of Buesch and Valentine (1986) (Tcc), Fort Rock Creek rhyodacite unit of Fuis (1973) (Tfrc), and Wild Horse Mesa Tuff of McCurry (1988) (Twhm). Inset map: Minimum distribution of the Peach Springs Tuff (shaded area modified from Glazner and others, 1986); white ellipse is proposed source area (Buesch, 1989; Wells and Hillhouse, 1989; Hillhouse and Wells, 1991). 
Table 1. Locations of tephra units.

\begin{tabular}{|c|c|c|c|c|}
\hline \multirow[t]{2}{*}{ Field No.' } & \multirow[t]{2}{*}{ USGS quadrangle name ${ }^{2}$} & \multirow[t]{2}{*}{ Location (fig. 1) } & \multicolumn{2}{|c|}{ UTM Grid $(m)^{3}$} \\
\hline & & & E. & $\mathrm{N}$ \\
\hline \multicolumn{5}{|c|}{$\begin{array}{c}\text { PEACH SPRINGS TUFF } \\
\text { Central Mojave area }\end{array}$} \\
\hline PST110 & Daggett, CA & Daggett Ridge & 500720 & 3852000 \\
\hline PST117* & Camp Rock Mine, CA & S. Newberry Mtns., Kane Wash & 525800 & 3843660 \\
\hline PST138 & Hidden Valley E., CA & N. Cady Mtns. & 565000 & 3871600 \\
\hline PST119* & Sleeping Beauty, CA & S. Cady Mtns. & 562680 & 3849600 \\
\hline PST139 & Ludlow, CA & Ludlow & 575850 & 3840000 \\
\hline PST149 & Morgans Well, CA & Bullion Mtns. & 576000 & 3828800 \\
\hline PST118 & E. of Broadwell Lake, CA & Bristol Mtn. Wash, Central Bristol Mins. & 590900 & 3852000 \\
\hline PST 148* & Granite Spring, CA & Granite Spring & 610000 & 3901620 \\
\hline PST120 & Siberia, CA & Siberia Wash & 599200 & 3842880 \\
\hline PST140 & E. of Siberia, CA & Orangeblossom Wash & 609300 & 3839600 \\
\hline \multicolumn{5}{|c|}{ East Mojave area } \\
\hline PST131* & Brown Buttes, CA & NW. Marble Mtns. & 624750 & 3838880 \\
\hline PST147 & Pinto Valley, CA & Pinto Mtn. & 650020 & 3892300 \\
\hline PST133* & Columbia Mtn., CA & Providence Mtns., Barber Canyon & 637400 & 3875800 \\
\hline PST134A & Blind Hills, CA & Blind Hills & 649400 & 3853680 \\
\hline PST134B & W. of Blind Hills, CA & Clipper Mtns. & 647900 & 3849000 \\
\hline PST016* & Skeleton Pass, CA & Ship Mtns. & 650380 & 3823180 \\
\hline PST142 & Cadiz Summit, CA & S. Marble Mins. & 638550 & 3827750 \\
\hline PST129 & - & McCulloch Mtns. & 666000 & 3948800 \\
\hline PST145 & Castle Peaks, CA & New York Mtns., Bathtub Springs & 660420 & 3910220 \\
\hline PST109 & do. & New York Mtns., Barnwell & 661800 & 3906500 \\
\hline PST $107^{*}$ & do. & New York Mtns., Dove Spring & 662700 & 3915100 \\
\hline PST 102 & Fenner, CA & Piute Mtns. & 669880 & 3846900 \\
\hline PST103* & do. & do. & 670700 & 3848350 \\
\hline \multicolumn{5}{|c|}{ Colorado River area } \\
\hline$\overline{\text { PST141 }}$ & Essex, CA & Old Woman Mtns. & 670200 & 3834020 \\
\hline PST106 & Painted Rock Wash, CA & Little Piute Mtns. & 676480 & 3831160 \\
\hline PST144 & Searchlight, NV-CA & Piute Range & 682100 & 3902450 \\
\hline PST155 & Flattop Mtn., CA & Sacramento Mtns. & 703500 & 3852000 \\
\hline PST132* & Snaggletooth, CA & Sawtooth Range, Snaggletooth & 715100 & 3830900 \\
\hline PST112 & Havasu Lake, CA-AZ & Chemehuevi Wash & 734860 & 3813260 \\
\hline PST116 & Savahia Peak, CA & Pyramid Butte & 723300 & 3798800 \\
\hline PST111 & Parker, AZ-CA & Moovalya Lake & 752020 & 3785400 \\
\hline PST135 & Castle Rock, CA-AZ & Yucca Mine area & 738900 & 3834650 \\
\hline PST113* & Lake Havasu City S., AZ-CA & Aubrey Hills & 751250 & 3811650 \\
\hline PST114 & Monkeys Head, AZ & Bill Williams Mtns. & 765700 & 3805400 \\
\hline PST150 & Gene Wash, CA-AZ & Parker Dam & 761600 & 3798480 \\
\hline \multicolumn{5}{|c|}{ Colorado Plateau transition zone } \\
\hline PST136* & Warm Springs SE, AZ & SW. Black Mtns. & 747600 & 3861080 \\
\hline PST154A & Yucca, AZ & SE. Black Mtns. & 757080 & 3861740 \\
\hline PST154G* & do. & do. & 757800 & 3858800 \\
\hline PST010 & - & Flat Top & 772500 & 3853000 \\
\hline PST045* & Kingman, $A Z$ & Kingman & 764220 & 3899200 \\
\hline PST084* & do. & do. & 767540 & 3902080 \\
\hline PST095* & do. & do. & 765500 & 3895700 \\
\hline PST101* & do. & do. & 766100 & 3895600 \\
\hline V85-21 & do. & do. & 762800 & 3898800 \\
\hline
\end{tabular}


Table 1. Locations of tephra units-Continued.

\begin{tabular}{llll}
\hline Field No.' & USGS quadrangle name & Location (fig. 1) & \multicolumn{2}{l}{ UTM Grid (m) } \\
& & E. & N. \\
\hline
\end{tabular}

\begin{tabular}{|c|c|c|c|c|}
\hline \multicolumn{5}{|c|}{$\begin{array}{c}\text { PEACH SPRINGS TUFF } \\
\text { Colorado Plateau }\end{array}$} \\
\hline V86-40* & Hackberry, AZ & Hackberry & 253100 & 3916650 \\
\hline V86-34 & Milkweed Canyon, AZ & Milkweed Canyon & 254600 & 3942100 \\
\hline V86-46 & Valentine, $\mathrm{AZ}$ & Valentine & 260800 & 3923100 \\
\hline V86-21 & Hualapai Peak NE., AZ & Peacock Mtns. & 245800 & 3898600 \\
\hline V86-29* & Penitentiary Mtn., AZ & Penitentiary Mtn. & 273800 & 3888100 \\
\hline V86-23* & Gonzales Wash, AZ & Trout Creek & 278900 & 3871900 \\
\hline V86-20* & Bull Spring, AZ & Willows Ranch & 277500 & 3897500 \\
\hline V86-38* & Peach Springs, AZ & Peach Springs Canyon & 280300 & 3937000 \\
\hline \multicolumn{5}{|c|}{ COOK CANYON TUFF } \\
\hline PST008* & Kingman, $\mathrm{AZ}$ & S. Cerbat Mins. & 768250 & 3900200 \\
\hline PST025* & Kingman, AZ & S. Cerbat Mtns., Cook Canyon & 766650 & 3896350 \\
\hline PST154A & Yucca, AZ & SE. Black Mtns. & 757400 & 3862050 \\
\hline PST136+ & Warm Springs SE., AZ & SW. Black Mtns. & 745100 & 3660500 \\
\hline PST102+ & Fenner, CA & Piute Mtns. & 669880 & 3846900 \\
\hline PST103 & do. & do. & 670700 & 3848350 \\
\hline PST135 & Castle Rock, CA-AZ & Tumarion Hills & 740300 & 3833700 \\
\hline PST144 & Searchlight, NV.CA & Piute Range & 682100 & 3902450 \\
\hline \multicolumn{5}{|c|}{$\begin{array}{l}\text { TUFF UNITS ASSOCLATED WITH THE FORT ROCK CREEK RHYODACITE UNIT } \\
\text { Tuff unit A }\end{array}$} \\
\hline PST005* & Bull Spring, AZ & N. Aquarius Mtns. & 279150 & 3896950 \\
\hline \multicolumn{5}{|c|}{ F2 } \\
\hline PST025+ & Kingman, AZ & S. Cerbat Mtns. & 766650 & 3896350 \\
\hline \multicolumn{5}{|c|}{ WILD HORSE MESA TUFF ${ }^{5}$} \\
\hline PST133 & Columbia Mtn., CA & Providence Mtns. & 638150 & 3876600 \\
\hline PST147 & Mid Hills, CA & Pinto Mtn. & 648000 & 3893500 \\
\hline PST134A & Blind Hills, CA & Blind Hills & 649400 & 3853680 \\
\hline $\begin{array}{l}\text { 'Detai } \\
{ }^{2} 1: 24 \\
{ }^{3} \mathrm{UTM} \\
{ }^{4} \text { Locat } \\
{ }^{5} \text { Locat }\end{array}$ & $\begin{array}{l}\text { electron microprobe san } \\
\text { scale. Where maps not } \\
\text { Jniversal Transverse Merc } \\
\text { ns of the Peach Springs T } \\
\text { ns of the Wild Horse Me } \\
\text { sion of locations. }\end{array}$ & $\begin{array}{l}\text { Reconnaissance electron micr } \\
\text { locations determined from } 1: 25 \\
\text { Grid coordinates to the nearest } 2 \\
\text { compiled from many sources. } \\
\text { ff are from the author's mappin }\end{array}$ & $\begin{array}{l}\text { ple }(+) \text {. } \\
\text { maps. }\end{array}$ & 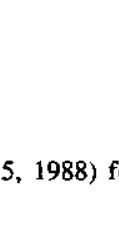 \\
\hline
\end{tabular}

table 1 ). It is the only regional volcanic stratigraphic marker identified in the area (Glazner and others, 1986). It is dated by several isotopic techniques at $18.5 \mathrm{Ma}$ (Nielson and others, 1990). The Peach Springs Tuff was originally described on the Colorado Plateau by Young (1966) and Young and Brennan (1974) and was subsequently studied by Buesch and Valentine (1986, 1989), Buesch (1987a, b, 1989, 1990, 1991a, b), and Valentine and others $(1989,1990)$. Its heavy mineral suite is distinctive (Gusa and others, 1987), and thermoremanent paleomagnetic directions (Wells and Hillhouse, 1989) are different from those normally determined for Miocene rocks. The phenocryst assemblage is sanidine $>>$ plagioclase \pm quartz, with homblende>biotite \pm clinopyroxene, and magnetite \pm ilmenite (table 2). Sphene and perrierite are minor constituents, and sphene is typically visible in hand specimen. Apatite occurs as inclusions in all phenocrysts, whereas pyrrhotite is included in clinopyroxene and hornblende.

The estimated minimum volume of the Peach Springs Tuff is $640 \mathrm{~km}^{3}$ (Buesch 1991a, unpub. data). Its vent location probably was either within or near the margin of the Colorado River extensional corridor (fig. 1; Howard and John, 1987; also see fig. 1 of Nielson and others, "Introduction" to chapter 2 , this volume). This location is based on isopach maps and flow direction indicators (Buesch, 1991b; unpub. data), systematic regional variation of feldspar geochemistry (Buesch, 1989, 1990), and anisotropy of magnetic susceptibility (Hillhouse and Wells, 1991). 
The Peach Springs Tuff is a single cooling unit that locally may display any of three texturally distinct stratigraphic divisions $\left(l_{1}\right.$, layer $1 ; l_{2}$, layer $2 ; l_{3}$, layer 3$)$ typical of pyroclastic flows (Buesch and Valentine, 1986; Valentine and others, 1989, 1990; Buesch, 1991a; fig 2). A complete $\mathrm{l}_{1}-\mathrm{l}_{2}-\mathrm{l}_{3}$ sequence does not occur at any location. Basal layered deposits $\left(I_{1}\right)$ are observed at Arizona localities (Valentine and others, 1989, 1990), at exposures in the New York and Piute Mountains, Califomia, and in the southeastern Black Mountains, Arizona (D.C. Buesch, unpub. data, 1988) (fig. 1). The $l_{1}$ beds are interpreted as surge deposits by Valentine and others (1989, 1990), although Wilson and Self (1990) argue that they are mostly Plinian fallout. Massive to weakly stratified ignimbrite $\left(l_{2}\right)$ is the main component of the Peach Springs Tuff at all locations shown in figure 1. Fine-grained fallout tuff $\left(l_{3}\right)$ is exposed only in the Newberry and Old Woman Mountains, California (Buesch, 1991a; fig. 1).

\section{COOK CANYON TUFF}

The Cook Canyon tuff was informally named by Buesch and Valentine (1986) for exposures near Kingman, Ar- izona (table 1), where it consists of as much as $4 \mathrm{~m}$ of basal fallout deposits and from 3 to $40 \mathrm{~m}$ of nonwelded to partially welded ignimbrite (fig. 3 ). The tuff has a phenocryst assemblage of plagioclase >sanidine, with biotite> clinopyroxenezhomblende, minor amounts of magnetite, and trace amounts of sphene and apatite (table 2). Small amounts of sanidine are found in the early erupted fallout tephra layers and ignimbrite (appendix 1), but not at the top of the exposure near Kingman. Biotite is always the most abundant mafic phenocryst, but the relative abundance of clinopyroxene and homblende varies, with hornblende less abundant in the ignimbrite than in the early erupted fallout tephra. Both light-tan and dark-gray pumice clasts are found in the deposit; the clasts range from 2 to $30 \mathrm{~cm}$ in diameter. The Cook Canyon tuff is undated and its source is unknown.

\section{TUFF UNIT A OF FORT ROCK CREEK RHYODACITE UNIT}

The Fort Rock Creek rhyodacite unit of Fuis (1973) is a sequence of interbedded fallout tuff, nonwelded to partially welded ignimbrite, and locally reworked volcaniclastic
A)

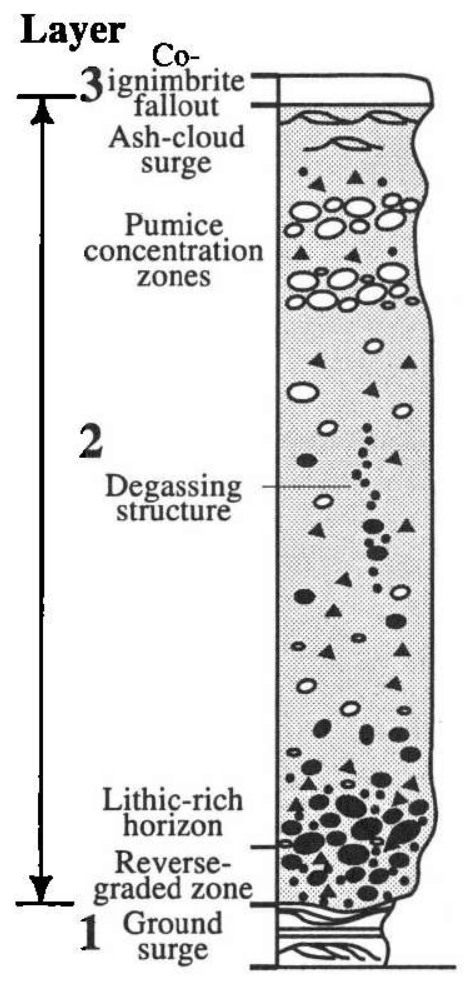

B)

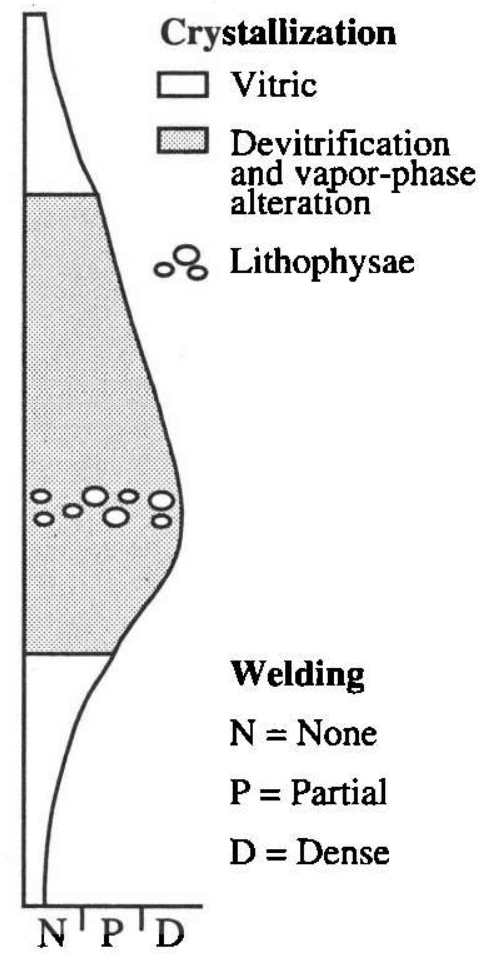

Figure 2. Idealized sections of features related to deposition $(A)$, and welding and crystallization $(B)$ of a pyroclastic flow deposit. $A$ modified from Fisher and Schmincke (1984), and $B$ from Smith (1960). 
Table 2. Petrographic and mineralogic characteristics of Miocene ignimbrites.

\begin{tabular}{|c|c|c|c|c|}
\hline Tuff & $\begin{array}{c}\text { Total crystals } \\
\text { (pet whole rock) }\end{array}$ & $\begin{array}{c}\text { Sanidine:Plagioclase: } \\
\text { Quartz } \\
\text { (nomalized) }\end{array}$ & $\begin{array}{c}\text { Ferromagnesian } \\
\text { phenocrysts }{ }^{2} \\
\text { (pct total phenocrysts) }\end{array}$ & $\operatorname{Minor}(m)$ and trace $(t r)$ minerals ${ }^{3}$ \\
\hline Peach Springs Tuff & $8-20$ & $80: 15: 5$ & $\begin{array}{c}\mathrm{Hb}>\mathrm{Bio} \pm \mathrm{Cpx} \\
\quad(<20)\end{array}$ & $\begin{array}{c}\text { Sph,Perr (m); } \\
\text { Mag } \pm \operatorname{Ilm}(m), A p \\
\text { Pyr (tr) }\end{array}$ \\
\hline Cook Canyon tuff & $5-12$ & 2:98:0 & $\begin{array}{c}\text { Bio }>>C p x \geq H b \\
(10-15)\end{array}$ & $\begin{array}{c}\text { Mag (m); } \\
\text { Sph, Ap (tr) }\end{array}$ \\
\hline $\begin{array}{l}\text { Tuff unit A of } \\
\text { Fort Rock Creek } \\
\text { rhyodacite unit }\end{array}$ & $12-25$ & $40: 50: 10$ & $\begin{array}{c}\mathrm{Hb}>\mathrm{Bio} \pm \mathrm{Cpx} \\
(15-25)\end{array}$ & $\begin{array}{c}\text { Mag (m); } \\
\text { Sph, Zir, Ap (tr); } \\
\text { Perr (tr) }\end{array}$ \\
\hline $\begin{array}{l}\text { Wild Horse Mesa } \\
\text { Tuff }^{4}\end{array}$ & $0-13$ & $97: 1: 2$ & $\begin{array}{c}\text { Bio }>>C p x \pm O p x \pm O l \\
\text { (7) }\end{array}$ & $\begin{array}{c}\text { Mag>Ilm (m); } \\
\text { Sph, Zir, Ap (tr); } \\
\text { Perr, All (tr); Pyr (tr) }\end{array}$ \\
\hline
\end{tabular}

\footnotetext{
'Proportions of felsic and mafic minerals determined by methods described in text; values not corrected to dense rock equivalent. Cook Canyon tuff and tuff unit A of Fort Rock Creek rhyodacite unit vary from nonwelded to partially welded; Peach Springs Tuff and Wild Horse Mesa Tuff vary from nonwelded to densely welded.

${ }^{2} \mathrm{Bio}$, biotite; Cpx, clinopyroxene; $\mathrm{Hb}$, homblende; Ol, olivine; Opx, orthopyroxene.

${ }^{3}$ Mag, magnetite; Ilm, ilmenite; Sph, sphene; Zir, zircon; Ap, apatite; Perr, perrierite; All, allanite; Pyr, pyrhotite.

${ }^{4}$ Data from McCurry (1988). Pyr, either pyrite or pyrrhotite.
}

sedimentary rocks; its age is poorly constrained. The beds of primary volcanic ejecta were erupted from a vent in the Aquarius Mountains (Fuis, 1973; Goff and others, 1983; Amey and others, 1985). In the northern Aquarius Mountains (fig. 1; table 1) the Fort Rock Creek rhyodacite unit is overlain by $5-10 \mathrm{~m}$ of fluvial sandstone and conglomerate, which in turn is overlain by the Peach Springs Tuff. Arney and others (1985) reported a $\mathrm{K}-\mathrm{Ar}$ age of $22.0 \pm 0.7 \mathrm{Ma}$ (whole rock) from a basalt dike that cuts the rhyodacite, whereas Young and McKee (1978) obtained a K-Ar age of $18.2 \pm 1.5 \mathrm{Ma}$ (whole rock) from a basalt that underlies the rhyodacite.

The sample used in this study is from a nonwelded ignimbrite herein referred to as tuff unit $A$; this unit is one of several similar tuff beds within the Fort Rock Creek Rhyodacite. Tuff unit $A$ has a phenocryst assemblage of plagioclasezsanidine >>quartz, with hornblende> biotite \pm clinopyroxene, and minor amounts of magnetite. Sphene and perrierite are found in trace amounts (table 2).

\section{FALLOUT TUFF DEPOSITS NEAR KINGMAN}

Two fallout tuff deposits (labeled $\mathrm{ft}_{1}$ and $\mathrm{ft}_{1}$ in fig. 3) are interstratified with volcaniclastic sandstone in the interval between the Cook Canyon tuff and Peach Springs Tuff near Kingman, Ariz. An incipient paleosoil horizon was locally developed on the sandstone prior to emplace- ment of the Peach Springs Tuff. Fallout tuff unit $\mathrm{ft}_{1}$ has plagioclase as the only felsic phenocryst, and biotite>> clinopyroxenezhornblende. Fallout tuff unit $\mathrm{ft}_{2}$ has sanidinezplagioclase $>>$ quartz, and homblende>biotite $>$ clinopyroxene.

\section{WILD HORSE MESA TUFF}

The Wild Horse Mesa Tuff of McCurry (1988) crops out in five mountain ranges across an area of $600 \mathrm{~km}^{2}$ near the Woods Mountains, California (fig. 1; table 1). It was erupted from a postulated 10-km-diameter caldera in the Woods Mountains volcanic field and has a volume of $80 \mathrm{~km}^{3}$ (McCurry, 1985). The Wild Horse Mesa Tuff forms a compound cooling unit, and each cooling unit contains multiple flow units and fallout tephra layers. The age of the middle member of the Wild Horse Mesa Tuff is $17.75 \pm 0.19 \mathrm{Ma}$ and its upper member is $17.67 \pm 0.15$ $\mathrm{Ma}$, determined by ${ }^{40} \mathrm{Ar} /{ }^{39} \mathrm{Ar}$ plateau ages on sanidine (McCurry and others, 1989; D.R. Lux, oral commun., 1991). Most of the Wild Horse Mesa Tuff is rhyolitic, but the upper parts of the upper two cooling units contain minor amounts of trachytic pumice; thus the magma was compositionally zoned (McCurry, 1988). Phenocrysts in the Wild Horse Mesa Tuff are sanidine>>plagioclase, with biotite >>clinopyroxene \pm orthopyroxene \pm olivine, and trace amounts of sphene, perrierite, and allanite (McCurry, 1985, 1988; table 2). 


\section{FELDSPAR COMPOSITIONS OF THE IGNIMBRITE UNITS}

\section{ANALYTICAL METHODS}

Feldspar grains identified for microanalysis in whole rock thin sections are phenocrysts in pumice, grains with attached glass, phenocrysts in xenoliths, or texturally nondistinct grains; data are listed in appendixes 1 and 2 . Analyses of texturally nondistinct grains are included in this data set, but geochemical characterization of each tuff is limited to grains in pumice or with attached glass. In this paper, "pumice" is identified as a glass clast with at least 10 vesicles, regardless of grain size or size of the vesicles. All chemical analyses represent individual points on grains; thus, the data represent variation both within and between feldspars in the samples selected for this study. Specific locations of analyses were recorded with respect to grain morphology (see appendix 1). Data from the Wild Horse Mesa Tuff are averages of single points analyzed on three or more grains in grain mount samples (McCurry, 1988).

Feldspars were analyzed initially by energy dispersive spectrometry and grouped into sanidine, sodic plagioclase $\left(<A n_{25}\right)$, and sodic-calcic plagioclase $\left(A n_{25}\right.$ to $\left.A n_{55}\right)$. Mineral compositions were determined by wavelength dispersive spectrometry (WDS) on a four-spectrometer Cameca MBX electron microprobe at Los Alamos National Laboratory. All WDS data were corrected by the method of Bence and Albee (1968). The beam current was $15 \mathrm{nA}$ and beam diameter was 5 micrometers. The count time for most elements was 20 seconds, or until a one-sigma standard deviation of 0.5 percent was reached. Extended count times were used for minor components; for example, 90-second counts were used for $\mathrm{Fe}_{2} \mathrm{O}_{3}, 60$ seconds for $\mathrm{MgO}$, and 30 seconds for $\mathrm{SrO}$ determinations. Offpeak backgrounds were determined for each mineral phase. To minimize matrix

\section{EXPLANATION}

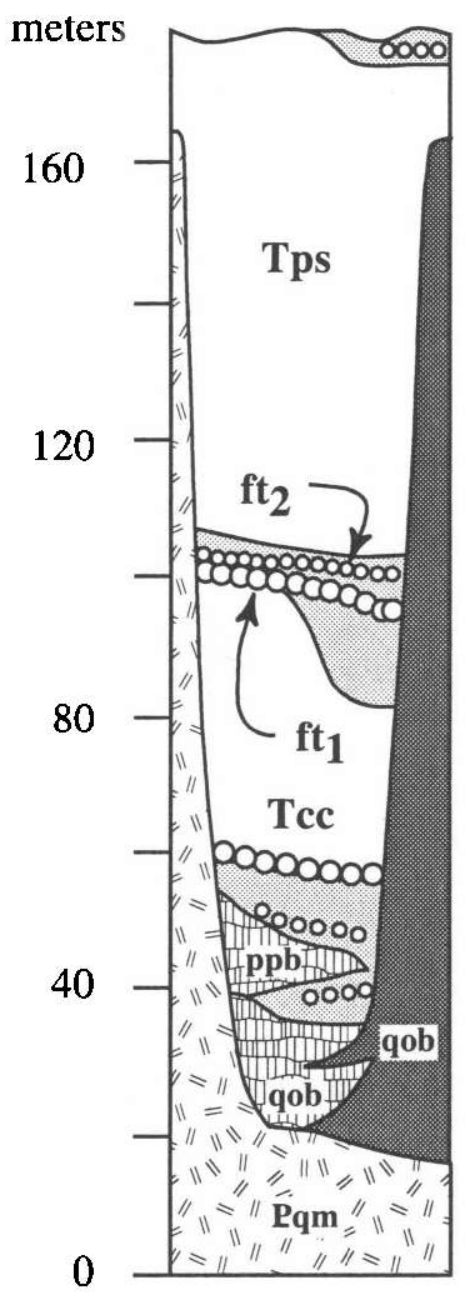

Interbedded epiclastic tuffaceous sandstone and fallout tuff (Miocene)

Tps Peach Springs Tuff of Young and Brennan (1974) (Miocene)-Light-gray to mauve colored non-to densely welded ignimbrite, containing sanidine $>>$ plagioclase $>$ amphibole as major phenocrysts. Peach Springs Tuff varies in thickness from $8 \mathrm{~m}$ at paleovalley margins and over paleotopographic highs, to $90 \mathrm{~m}$ in axial parts of paleovalleys. Locally forms two cliffs

ft2 Pumiceous fallout tuff (Miocene)-Petrographically similar to Fort Rock Creek rhyodacite unit of Fuis (1973) in Aquarius Mountains. As thick as $50 \mathrm{~cm}$

ft1 Plagioclase- and biotite-bearing fallout tuff (Miocene)Petrographically similar to informally named Cook Canyon tuff of Buesch and Valentine (1986). As thick as $1 \mathrm{~m}$

Tcc Cook Canyon tuff of Buesch and Valentine (1986) (Miocene) - Informal unit. Gray, sintered to partly welded ignimbrite; major phenocrysts are plagioclase and biotite. Contains mixed mafic/silicic pumice fragments. Uppermost part locally reworked to epiclastic sandstone. Underlain everywhere by pumiceous fallout tuff

ppb Pyroxene-plagioclase basalt lava flows (Miocene)Includes local interbeds of epiclastic volcaniclastic sandstone and pumiceous fallout tuff

qob Quartz-bearing olivine basalt (Miocene) - Lava flows as thick as $6 \mathrm{~m}$ and cinder cones as high as $150 \mathrm{~m}$. Locally contains xenoliths of underlying rocks

Pqm Quartz monzonite (Proterozoic)-Quartz monzonite, locally porphyritic and foliated, and leuco- and melanocratic gneiss. Paleotopography $>150 \mathrm{~m}$

Figure 3. Columnar section of rocks exposed in Miocene paleovalley at Kingman, Arizona (modified from Buesch and Valentine, 1986). 
variations, compositionally similar grains were used to establish background counts for samples of each tuff.

To minimize interference by the $\mathrm{Si}-\mathrm{K}$ line in analysis for $\mathrm{S} r$, feldspars were grouped into sanidine (64 to 68 weight percent $\mathrm{SiO}_{2}$ ), sodic plagioclase (62 to 66 weight percent $\mathrm{SiO}_{2}$ ), and sodic-calcic plagioclase (53 to 62 weight percent $\mathrm{SiO}_{2}$ ). Grains of intermediate composition in each group were used for backgrounds. By using an extended count time, the effective minimum detection limit of $\mathrm{SrO}$ is probably less than 0.10 weight percent in feldspar; in these analyses, the minimum detection level was 0.055 to 0.061 . Many of the SrO concentrations in appendix 1 are reproducible, even for $\mathrm{SrO}$ concentrations less than 0.10 weight percent. However, trends plotted for such samples should be interpreted with caution. In analyses with the weight percent $\mathrm{SrO}$ greater than 0.10 , variations may represent real differences within or between grains.

\section{ANALYTICAL RESULTS}

Molecular percentages of feldspar end-members anorthite (An), albite (Ab), orthoclase (Or), celsian, and $\mathrm{Sr}$ feldspar were calculated from the analytical compositions. Two-component plots of feldspar end-members can be used to characterize ignimbrites and demonstrate compositional zonations within them (Warren and others, 1989).

A plot of Or versus An end-member compositions in sanidine (fig. $4 A$ ) and plagioclase (fig. $4 B$ ) can be used to differentiate between the three tephra units studied in this paper and the Wild Horse Mesa Tuff. For each unit, the composition of grains overlap regardless of textural context. Figure $4 A$ shows particularly clear distinctions between sanidine compositions for the units analyzed. The ranges of plagioclase compositions for the four units overlap substantially, however, which highlights the importance of using more than one mineral for characterization.

Two compositional regions are defined by plagioclase in the Peach Springs Tuff. For a given Or content, proportionately more analyses with high An values (23 of 102) are from the basal layered deposits, although sparse grains with equally high An occur in the ignimbrite (7 of 122). Thus, the proportion of the two plagioclase compositions changed during eruption of the Peach Springs Tuff, such that the high An component was relatively less abundant in the later erupted magma than in material that erupted initially.

The fallout deposits and ignimbrite of the Cook Canyon tuff have minor to only trace amounts of sanidine, and the few analyses are colinear and have a restricted range. Plagioclase analyses from samples of the initial fallout deposits and the uppermost part of the ignimbrite in the Cook Canyon tuff also are colinear and nearly completely overlap; the fallout deposits have a slightly wider range of pla- gioclase compositions than the ignimbrite. Thus, the composition of feldspars in the Cook Canyon tuff changed only slightly during the eruption. Plagioclase compositions in the Cook Canyon tuff are significantly different from the other tuff units (fig. 4B); in comparison, grains in the Peach Springs Tuff predominantly have higher or lower An contents.

Plagioclase compositions of the Peach Springs Tuff and tuff unit $A$ of the Fort Rock Creek rhyodacite unit show nearly complete overlap, although there is a slight difference in the median plagioclase composition.

The weight percentages of $\mathrm{Fe}_{2} \mathrm{O}_{3}, \mathrm{SrO}$, and $\mathrm{BaO}$ in sanidine and plagioclase show contrasting distribution patterns that help distinguish samples from three of the units studied (fig. 5). With respect to these components, plagioclase and sanidine grains in the Peach Springs Tuff overlap both the Cook Canyon tuff and tuff unit A. Distinctions can be made between the Peach Springs Tuff and the other two tuff units with these minor components only by evaluating all three oxides in both feldspars, but good compositional separations are obtained using plots of An molecular percent versus weight percent $\mathrm{Fe}_{2} \mathrm{O}_{3}, \mathrm{SrO}$, and $\mathrm{BaO}$ (fig. 5). The Cook Canyon tuff and tuff unit $\mathrm{A}$ have plagioclase and sanidine with similar distributions of SrO but contrasting An values. These separations are also clear on the plots for $\mathrm{Fe}_{2} \mathrm{O}_{3}$ and $\mathrm{BaO}$. Sanidine of the Peach Springs Tuff is separated from the other tuff units on these diagrams because of its distinctive An contents (fig. 4A).

In figure 5, plagioclase compositions show a positive correlation between the content of $\mathrm{An}$ and the weight percent of $\mathrm{Fe}_{2} \mathrm{O}_{3}$ and $\mathrm{SrO}$. Plagioclase compositional ranges in both the ignimbrite and layer 1 deposits of the Peach Springs Tuff extend toward high $\mathrm{Fe}_{2} \mathrm{O}_{3}$ and $\mathrm{SrO}$; most of these analyses are from grains with high contents of An ( 225 ; fig. 5; appendix 2 ; unpub. data), which form the highAn trend in figure 4 . These correlations probably result from the substitution of $\mathrm{Fe}_{2} \mathrm{O}_{3}$ and $\mathrm{SrO}$ for $\mathrm{Al}_{2} \mathrm{O}_{3}$ and $\mathrm{CaO}$, respectively. Plagioclase grains in the Cook Canyon tuff and tuff unit $A$ also show a negative correlation between the content of $\mathrm{An}$ and weight percent $\mathrm{BaO}$, but those in the Peach Springs Tuff have a slight positive correlation of these components. Sanidine analyses show weak or no correlation between the minor oxides and An values.

Descriptive statistics also can discriminate between tephra (Westgate and Gorton, 1981), and the data of this study can be used to show differences between the units. Medians and one-sigma standard deviations of the molecular percentages calculated for feldspar end members and the weight percentages of $\mathrm{Fe}_{2} \mathrm{O}_{3}, \mathrm{SrO}$, and $\mathrm{BaO}$ are different for the Peach Springs Tuff, Cook Canyon tuff, tuff unit A of the Fort Rock Creek rhyodacite unit, and Wild Horse Mesa Tuff (table 3). Use of median rather than mean values minimizes the effect of widely dispersed values. 

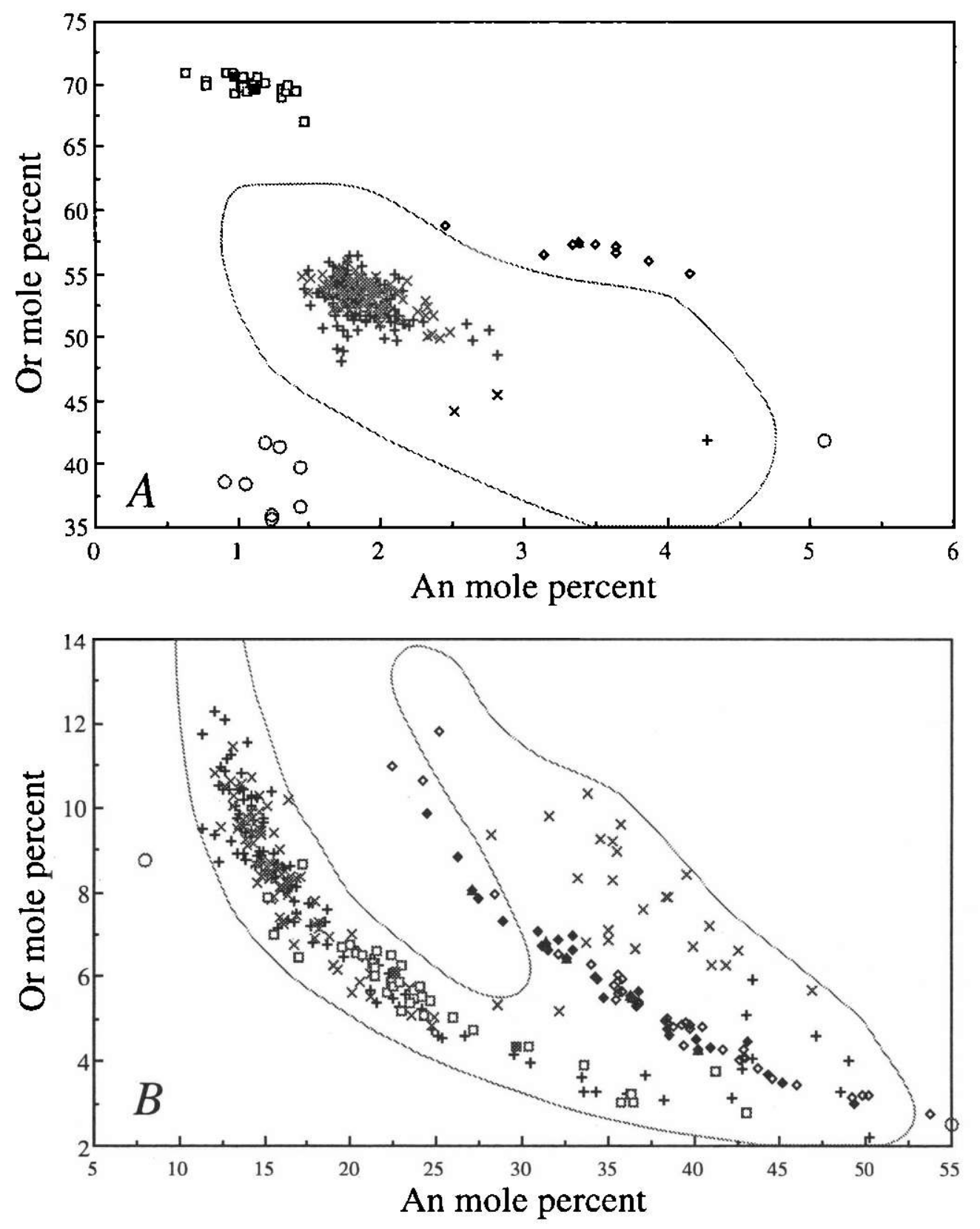

\begin{tabular}{|c|c|}
\hline Twhm & Tuff unit $A$ \\
\hline+ Tpsig & ig? \\
\hline $\begin{array}{ll}\times & \mathrm{Tpsl}_{1} \\
& \mathrm{ft}_{2}\end{array}$ & $\begin{array}{l}-\mathrm{ig} \\
-\mathrm{Tccb}\end{array}$ \\
\hline
\end{tabular}

Figure 4. Plots of feldspar compositions: $(A)$ sanidine and $(B)$ plagioclase. Data are from Peach Springs Tuff of Young and Brennan (1974), informally named Cook Canyon tuff of Buesch and Valentine (1986), tuff unit A of the Fort Rock Creek rhyodacite unit of Fuis (1973), and Wild Horse Mesa Tuff of McCurry (1988); see figures 1 and 3. Symbols: Tpsig, ignimbrite of Peach Springs Tuff; Tps, , layer 1 of Peach Springs Tuff; Tccb, basal fallout deposits of Cook Canyon tuff; ig? and $\mathrm{ig}$, two ignimbrites that probably correlate with the Cook Canyon tuff; $\mathrm{ft}_{2}$, fallout tuff unit, probably equivalent to the Fort Rock Creek rhyodacite unit. Line encloses 98 percent of all feldspar analyses from Peach Springs Tuff (Buesch, unpub. data). Data are in appendixes. 
The one-sigma standard deviation is a numerical representation of the amount of clustering of the data in figures 4 and 5; a small one-sigma standard deviation represents closely clustered data, whereas a large one-sigma standard deviation represents broadly scattered data. Standard deviations of the molecular percentage of Or in sanidine from the ignimbrite of the Peach Springs Tuff and tuff unit A are good examples of the relationship between the numerical and graphical presentation (table 3; figs. 4 and 5). The ranges of the medians and one-sigma standard deviations (table 4) show both the regional variation within the Peach Springs Tuff and distinguish its composition from the other tuffs discussed in this paper.

\section{COMPOSITIONAL ZONING}

Many of the analyses in figure 4 are from grains that have less than 2 molecular percent variation of the feldspar
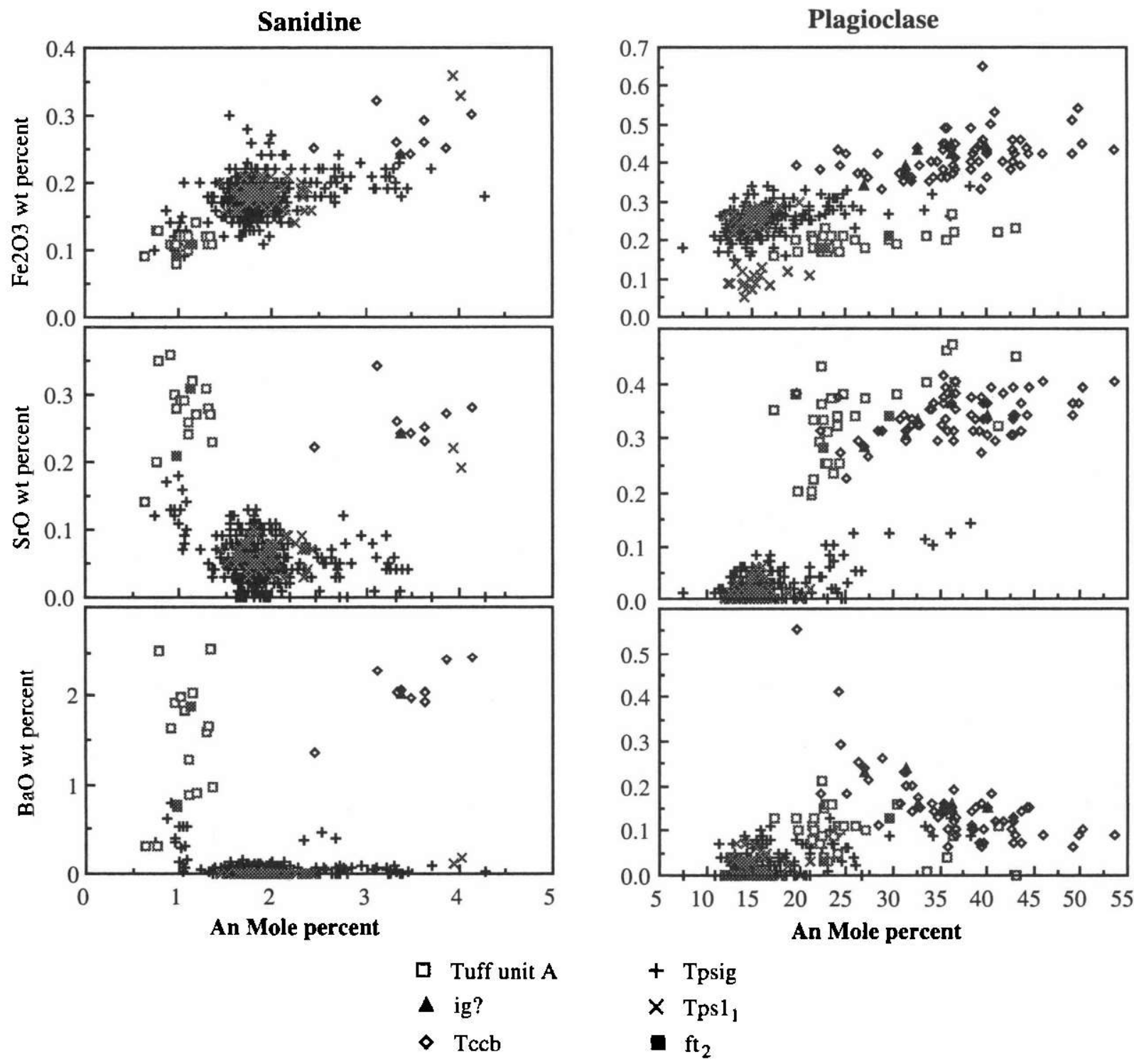

Figure 5. Weight percent $\mathrm{Fe}_{2} \mathrm{O}_{3}, \mathrm{SrO}$, and $\mathrm{BaO}$ versus mole percent $\mathrm{An}$ in plagioclase and sanidine from Peach Springs Tuff of Young and Brennan (1974), informally named Cook Canyon tuff of Buesch and Valentine (1986), and tuff units of Fort Rock Creek rhyodacite unit of Fuis (1973). Number of sanidine analyses for each tuff unit is: Tpsl $1_{1}$, layer 1 of Peach Springs Tuff-53; Tpsig, ignimbrite of Peach Springs Tuff-401; Tccb, basal fallout deposits of Cook Canyon tuff and ignimbrite of Cook Canyon tuff, undivided-9; tuff unit A of Fort Rock Creek rhyodacite unit-17. The number of plagioclase analyses: $\mathrm{Tps}_{1}-44 ; \mathrm{Tpsig}-228$; Tccb-66; tuff unit $\mathrm{A}$ of Fort Rock Creek rhyodacite unit-31. $\mathrm{ft}_{2}$ and ig explained in figure 4. Data are in appendixes. 
Table 3. Statistical variations in compositional parameters of feldspars from tephra units ${ }^{1}$.

\begin{tabular}{|c|c|c|c|c|c|c|c|c|}
\hline Tuff & Mineral & $\begin{array}{l}\text { No. of } \\
\text { analyses }\end{array}$ & $\begin{array}{c}\text { Or } \\
(\mathrm{mol} p c t)\end{array}$ & $\underset{(\mathrm{mol} p c t)}{\text { An }}$ & $\underset{(\mathrm{mol} p \mathrm{pct})}{\mathrm{Ab}}$ & $\begin{array}{c}\mathrm{Fe}_{2} \mathrm{O}_{3} \\
\text { (wt pct) }\end{array}$ & $\begin{array}{c}\text { Sro } \\
\text { (wt pct) }\end{array}$ & $\begin{array}{c}\mathrm{BaO} \\
\text { (wt pct) }\end{array}$ \\
\hline Peach Springs Tuff & Sanidine & 401 & $53.54 \pm 5.17$ & $1.80 \pm 0.84$ & $44.66 \pm 4.60$ & $0.18 \pm 0.03$ & $0.05 \pm 0.03$ & $0.04 \pm 0.09$ \\
\hline (ignimbrite) & Plagioclase & 228 & $8.15 \pm 8.39$ & $16.72 \pm 10.59$ & $75.05 \pm 9.61$ & $0.27 \pm 0.08$ & $0.03 \pm 0.14$ & $0.04 \pm 0.33$ \\
\hline Peach Springs Tuff & Sanidine & 53 & $53.58 \pm 2.12$ & $1.86 \pm 0.44$ & $44.47 \pm 2.27$ & $0.19 \pm 0.03$ & $0.06 \pm 0.04$ & $0.00 \pm 0.03$ \\
\hline (layer 1) & Plagioclase & 44 & $8.97 \pm 10.08$ & $15.83 \pm 10.14$ & $75.42 \pm 10.96$ & $0.27 \pm 0.15$ & $0.02 \pm 0.16$ & $0.03 \pm 0.16$ \\
\hline Cook Canyon tuff & Sanidine & 9 & $57.04 \pm 1.04$ & $3.50 \pm 0.48$ & $39.38 \pm 0.67$ & $0.26 \pm 0.03$ & $0.25 \pm 0.04$ & $2.04 \pm 0.33$ \\
\hline $\begin{array}{l}\text { (ignimbrite and } \\
\text { basal fallout deposits) }\end{array}$ & Plagioclase & 68 & $5.53 \pm 16.69$ & $35.90 \pm 12.66$ & $56.62 \pm 7.29$ & $0.40 \pm 0.07$ & $0.33 \pm 0.05$ & $0.14 \pm 0.63$ \\
\hline Tuff unit A of & Sanidine & 17 & $69.95 \pm 0.59$ & $1.06 \pm 0.21$ & $28.93 \pm 0.50$ & $0.11 \pm 0.01$ & $0.28 \pm 0.06$ & $1.59 \pm 0.70$ \\
\hline $\begin{array}{l}\text { Fort Rock Creek } \\
\text { rhyodacite unit }\end{array}$ & Plagioclase & 31 & $5.64 \pm 1.31$ & $23.46 \pm 6.54$ & $70.85 \pm 5.36$ & $0.20 \pm 0.02$ & $0.34 \pm 0.08$ & $0.10 \pm 0.05$ \\
\hline \multirow[t]{4}{*}{ Wild Horse Mesa Tuff ${ }^{2}$} & Sanidine (r) & 8 & $38.52 \pm 2.32$ & $1.22 \pm 0.18$ & $60.26 \pm 2.32$ & $0.24 \pm 0.10$ & n.d. & n.d. \\
\hline & Sanidine $(t)$ & 1 & 41.92 & 5.10 & 52.99 & 0.30 & n.d. & n.d. \\
\hline & Plagioclase (r) & 1 & 8.75 & 8.05 & 83.20 & 0.12 & n.d. & n.d. \\
\hline & Plagioclase $(t)$ & 1 & 2.48 & 56.26 & 41.27 & 0.55 & n.d. & n.d. \\
\hline
\end{tabular}

\footnotetext{
'Two feldspar calibration standards were also analyzed. Standard deviations for these 916 analyses are: Albiteะ0.41, Anorthite \pm 0.23 , Orthoclase \pm 0.35 , Celsian \pm 0.10 , and $\mathrm{Sr}$ feldspar \pm 0.11 .

${ }^{2}$ Means and standard deviations for the Wild Horse Mesa Tuff calculated from the average compositions in McCurry (1985, 1988). Analyses from the rhyolitic (r) and trachytic (t) part of the tuff. Total Fe is presented as FeO*; n.d., not determined.
}

end members, but some grains are zoned (table 5; appendix 1). Grains from the Peach Springs Tuff show the greatest amount of zoning. The maximum zoning in a single plagioclase grain is 32 molecular percent An and 25 molecular percent Or. The maximum zoning in a single sanidine grain is 2 molecular percent An and 9 molecular percent Or. The rims of plagioclase tend to have lower An and higher Or contents than cores, but there are exceptions.

Three patterns of zoning characterize sanidine in the Peach Springs Tuff: (1) an increase in Or content from core to rim, (2) an increase in An from core to rim, and (3) an increase in An from core toward rim that reaches a maximum in a zone near the rim, and then decreases again from that zone to the rim. Zoning patterns 1 and 3 are the most common.

Oscillatory zoning occurs in some grains of plagioclase and sanidine from the Peach Springs Tuff. The maximum range in each oscillation is approximately 5 molecular percent of $\mathrm{Ab}$ in both plagioclase and sanidine (appendix 1).

\section{DISCUSSION}

\section{TENTATIVE CORRELATIONS OF TEPHRA UNITS}

On the basis of petrographic and geochemical similarities, several tephra beds are tentatively correlated with the
Cook Canyon tuff. Ignimbrites with two colors of pumice, and mineralogy, texture, and welding profile similar to the Cook Canyon tuff, are exposed in the Piute Mountains (Calif.) and southern Black Mountains (Ariz.) (fig. 1; table 1). Limited microprobe analyses from the ignimbrites in these localities are within the range of feldspar analyses of the Cook Canyon tuff and indicate that these deposits may be correlated with the Cook Canyon tuff (figs. 4 and 6; appendix 1). A sequence of slightly altered fallout tuff and ignimbrite 10 to $40 \mathrm{~m}$ thick in the Yucca Mine area (Ariz.) (table 1) is also tentatively correlated with the Cook Canyon tuff. These tuff units in the northern Mohave Mountains are described as "white tuff" by Nielson (this volume). Another 2- to 8-cm-thick plagioclase- and biotite-bearing fallout tuff, tentatively correlated with the Cook Canyon tuff, is locally exposed just below the Peach Springs Tuff in the Piute Range (Searchlight, Nev.-Calif. quadrangle--fig. 1; table 1). The distribution of these tentatively correlated exposures indicate that the vent area of the Cook Canyon tuff was near or within the Colorado River extensional corridor (Howard and John, 1987).

Fallout tuff units $\mathrm{ft}_{1}$ and $\mathrm{ft}_{2}$ (fig. 3 ) from the fallout deposits near Kingman (Ariz.) appear to be related to the same sources that produced the Cook Canyon tuff and Fort Rock Creek rhyodacite unit. Fallout tuff unit $\mathrm{ft}_{1}$ is petrographically similar to the Cook Canyon tuff and probably represents a slightly younger enuption from the same magma chamber. Fallout tephra unit $\mathrm{ft}_{2}$ is 
Table 4. Feldspar analyses from the Peach Springs Tuff: averages and ranges of statistical parameters ${ }^{1}$.

\begin{tabular}{lccccccc}
\hline Feldspar & \multicolumn{4}{c}{ Sanidine } & \multicolumn{3}{c}{ Plagioclase } \\
\cline { 2 - 7 } End member & $\begin{array}{c}\text { Median } \\
\text { (average) }\end{array}$ & $\begin{array}{c}\text { Median } \\
\text { (range) }\end{array}$ & $\begin{array}{c}\text { Std. deviation } \\
\text { (range) }\end{array}$ & $\begin{array}{c}\text { Median } \\
\text { (average) }\end{array}$ & $\begin{array}{c}\text { Median } \\
\text { (range) }\end{array}$ & $\begin{array}{c}\text { Std. deviation } \\
\text { (range) }\end{array}$ \\
\hline Albite & 45.95 & 44.12 to 50.05 & 0.82 to 7.12 & 76.16 & 74.06 to 77.11 & 0.92 to 9.55 \\
Anorthite & 1.97 & 1.66 to 2.74 & 0.11 to 2.18 & 14.84 & 13.07 to 17.96 & 1.96 to 12.40 \\
Orthoclase & 52.18 & 48.75 to 54.10 & 0.92 to 9.61 & 8.79 & 7.34 to 9.93 & 1.15 to 8.38 \\
\hline
\end{tabular}

'Data summarized from samples shown with "*" in table 1.

${ }^{2}$ Standard deviations are one-sigma values.

Table 5. Maximum zoning ranges of calculated feldspar end members in tephra units.

\begin{tabular}{|c|c|c|c|c|c|c|}
\hline Tuff & Mineral & Sample location' & Grain identification ${ }^{2}$ & $\begin{array}{c}\mathrm{Ab} \\
{\text { (range } \mathrm{mol} \mathrm{pct})^{3}}^{3}\end{array}$ & $\begin{array}{c}\mathrm{An} \\
\text { (range } \mathrm{mol} \mathrm{pct})^{3}\end{array}$ & $\begin{array}{c}\text { Or } \\
\text { (range mol pcl) }\end{array}$ \\
\hline \multirow{2}{*}{$\begin{array}{l}\text { Peach Springs Tuff } \\
\text { (ignimbrite and layer 1) }\end{array}$} & Sanidine & PST101m2 & S29MP1PU13 & 7.45 & 2.23 & 9.78 \\
\hline & Plagioclase & $\begin{array}{l}\text { PST045cm5 } \\
\text { (PST101 m2) }\end{array}$ & $\begin{array}{l}\text { P26PU19 } \\
\text { (P19GL27) }\end{array}$ & $\begin{array}{c}6.91 \\
(16.02)\end{array}$ & 32.69 & 25.78 \\
\hline \multirow[t]{2}{*}{ Cook Canyon tuff } & Sanidine & PST008m2 & S2MP2PU4 & 2.05 & 1.70 & 3.75 \\
\hline & Plagioclase & $\begin{array}{l}\text { PST008m2 } \\
\text { (PST008m2) }\end{array}$ & $\begin{array}{c}\text { P6GL2 } \\
\text { (P8MP2PU4) }\end{array}$ & 14.31 & 16.93 & $\begin{array}{c}2.61 \\
(8.40)\end{array}$ \\
\hline \multirow[t]{2}{*}{$\begin{array}{l}\text { Tuff unit A of Fort Rock } \\
\text { Creek rhyodacite unit }\end{array}$} & Sanidine & $\begin{array}{l}\text { PST005 } \\
\text { (PST005) }\end{array}$ & $\begin{array}{c}\text { S5 } \\
\text { (S2GL5) }\end{array}$ & 2.24 & $\begin{array}{c}0.44 \\
(0.54)\end{array}$ & 2.67 \\
\hline & Plagioclase & $\begin{array}{l}\text { PST005 } \\
\text { (PST005) }\end{array}$ & $\begin{array}{l}\text { P19PU21 } \\
\text { (P20PU21) }\end{array}$ & 14.08 & 15.34 & $\begin{array}{c}1.83 \\
(2.27)\end{array}$ \\
\hline
\end{tabular}

\footnotetext{
${ }^{1}$ Sample locations in table 1 and appendixes.

${ }^{2}$ Grain identification is the same as in appendixes; does not include the morphological location.

${ }^{3}$ Maximum zoning of feldspar end members in individual grains; parens indicate sample identification and value of maximum zoning of feldspar end members from all grains, if different from maximum in individual grains.
}

petrographically similar to tuff unit A of the Fort Rock Creek rhyodacite unit, and these two tephra units have similar feldspar compositions (figs. 4 and 5). These petrographic and geochemical similarities, and the stratigraphic position (fig. 3), indicate that fallout tuff unit $\mathrm{ft}_{2}$ probably is an eruptive unit related to emplacement of the Fort Rock Creek rhyodacite unit. However, it is not known where fallout tuff unit $\mathrm{ft}_{2}$ belongs within the stratigraphic section that comprises the Fort Rock Creek rhyodacite unit.

\section{PETROGRAPHIC AND COMPOSITIONAL VARIATIONS WITHIN TUFF UNITS}

Each of the ignimbrites discussed in this paper is laterally and vertically variable in petrography and composition, but the ranges of variation differ. Including the tentatively correlated exposures in the Piute Mountains
(Calif.) and southern Black Mountains (Ariz.), the Cook Canyon tuff is only slightly zoned in abundance of phenocrysts and feldspar compositions. Plagioclase compositions in the early erupted fallout tephra have slightly higher molecular contents of $\mathrm{An}$, lower Or, and broader ranges of $\mathrm{An}$ and Or compared to plagioclase in the uppermost part of the ignimbrite (fig. 4). Petrographic descriptions of the Fort Rock Creek rhyodacite unit by Fuis (1973) and data from this study (table 2) indicate that the sequence of fallout tephra and ignimbrites have vertical variations of felsic and mafic phenocrysts, but more work is needed to document any trends. The Wild Horse Mesa Tuff is vertically zoned with respect to mineral assemblage and whole rock compositions, but lateral variations have not been demonstrated (McCurry, 1985, 1988).

The Peach Springs Tuff is petrographically zoned both vertically and laterally (Buesch, 1987a, b; unpub. data). The ratios of plagioclase to sanidine and homblende to biotite increase toward the top of most stratigraphic sections 
and also tend to increase from the inferred vent area to distal exposures. Clinopyroxene is absent or occurs in minor amounts in western exposures and in the lower parts of exposures to the east and north of Snaggletooth (Sawtooth Range., Calif.; fig. 1, table 1). However, clinopyroxene increases in abundance toward the tops of exposures of the Peach Springs Tuff east and north of Snaggletooth. Ilmenite and pyrrhotite do not occur in exposures west of the southern Black Mountains (Ariz.) but are trace components east of this location. Thus, on the basis of the mineral assemblage there is a difference between the western and eastern exposure areas of the Peach Springs Tuff. In each exposure area the ignimbrite exhibits lateral zonation (Buesch, 1987a, b; unpub. data).

Analytical data for feldspars from Peach Springs exposures near Kingman (Ariz.) are representative of data from all 17 locations studied (fig. 4; data in appendixes; Buesch, unpub. data). The average of medians of the feldspar end-member values for sanidine and plagioclase grains from 38 samples (table 4) plots within the data cluster of the Kingman samples (fig. 4) and is close to the median compositions of data from phenocrysts in pumice and grains attached to glass (table 3). Plagioclase grains with high An values are present in the ignimbrite at Kingman, but the broader range of high An values is only a minor component of the entire ignimbrite (fig. $4 B$ ).

The two compositional ranges of plagioclase in the Peach Springs Tuff (fig. $4 B$ ) are similar to the double trends in some of the large-volume ignimbrites of southwestern Nevada (Warren and others, 1989). The high-An trend in samples from both the basal and uppermost parts of the ignimbrite of the Peach Springs Tuff are defined partly by analysis of phenocryst grains in pumice or attached to glass and thus represent magmatic variations (appendix 2: Buesch, unpub. data). Warren and others (1989) attribute the double compositional trends to rhyolite and quartz latite bulk rock compositions, which resided together in a compositionally zoned magma chamber, and to increasing temperature with depth in the chamber. An alternative possibility is that the two compositional trends represent magmas from different chambers. No petrologic modeling of the Peach Springs magma chamber has yet been done; therefore, distinction between these two possibilities cannot be made. There are only eight whole rock minor- and trace-element data from pumice clasts of the Peach Springs Tuff; all were collected from the basal part of the ignimbrite near Kingman (Ariz.) and all are low-silica rhyolite (David Nealey, 1991 personal commun.)

\section{CONCLUSIONS}

Tephra units are exposed in many of the stratigraphic sequences discussed in this volume, and tephrochronology can be one of the most useful tools for geologists to use in unraveling the stratigraphy and structure of variable and fragmented stratigraphic sections in the highly extended terranes. Phenocryst geochemistry is a rapid and relatively inexpensive method for differentiating the tuff units discussed in this paper. Phenocryst assemblage and mineral chemistry are particularly useful in correlating tephra where the volcanic glass in shards or pumice has been partially or completely altered. On the basis of phenocryst assemblage and feldspar geochemistry, the distribution of the Cook Canyon tuff and a fallout tuff within the Fort Rock Creek rhyodacite unit is tentatively expanded to previously uncorrelated deposits in adjacent mountain ranges. This adds another potentially useful regional datum besides the Peach Springs Tuff and Wild Horse Mesa Tuff, for correlating stratigraphic sections in these extensional terranes.

\section{ACKNOWLEDGMENTS}

Field and technical support for this work were provided by grants from the Geological Society of America, the UCSB Graduate Division, the UCSB Department of Geological Sciences, and NSF Grant EAR-16532 to R.V. Fisher, and the U.S. Geological Survey. Electron microprobe analyses at Los Alamos National Laboratory (LANL) were supported by a Laboratory Fellowship from the Associated Western Universities, and by the Geology and Geochemistry Group at LANL. In particular I thank Richard Warren for sharing codes and expertise, and David Broxton, Roland Hagan, Gary Luedemann, and Peggy Snow, for helpful discussions. Michael McCurry and David Sherrod gave helpful comments on an earlier draft of this manuscript. Reviews by Wes Hildreth and Andrei Sarna-Wojcicki are greatly appreciated. Jane Nielson and R.V. Fisher were always there with questions, answers, and encouragement.

\section{REFERENCES}

Amey, B.H., Goff, F.E., and Eddy, A.C., 1985, Chemical, petrographic, and $\mathrm{K}-\mathrm{Ar}$ age data to accompany reconnaissance geologic strip map from Kingman to south of Bill Williams Mountain, Arizona: Los Alamos, New Mexico, Los Alamos National Laboratory report LA-10409-HDR, 26 p.

Bence, A., and Albee, A., 1968, Empirical correction factors for electron microanalysis of silicates and oxides: Joumal of Geology, v 76, no. 4, p. 382-403.

Buesch, D.C., 1987a, Compositional stratification of the Peach Springs Tuff near Kingman, Arizona [abs.]: Geological Society of America Abstracts with Programs, v. 19, no. 6, p. 362. 1987b, Stratification in Layer 2 deposits in the Peach Springs Tuff, Arizona: Response to topography and lateral variations [abs.]: International Union of Geodesy and Geophysics, XIX General Assembly, Vancouver, Canada, August 9-22, Abstract Volume 2, p. 394. 
-1989, Geochemical variations in ignimbrite phenocrysts: Implications for eruption history and vent location [abs.]: Eos, Transactions of the American Geophysical Union, v. 70, no. 43 , p. 1,413 .

1990, Variations in phenocryst geochemistry: Eruption history, vent location and emplacement mechanisms of a large-volume ignimbrite in southwestem USA [abs.]: Mainz, Federal Republic of Germany, International Association of Volcanology and Chemistry of the Earth's Interior, International Volcanological Congress, p. 17.

1991a, Changes in the depositional environments resulting from emplacement of a large-volume ignimbrite, in Fisher, R.V., and Smith, G.A., eds., Sedimentation in Volcanic Settings: Society of Economic Paleontologists and Mineralogists (Society for Sedimentary Geology) Special Publication No. 45 , p. 139-153.

1991b, Locating the vent area of the lower Miocene Peach Springs Tuff, Arizona, California, and Nevada: Petrofabric and other flow direction indicators [abs.]: Geological Society of America Abstracts with Programs, v. 23, no. 5 , A452.

Buesch, D.C., and Valentine, G.A., 1986, Peach Springs Tuff and volcanic stratigraphy of the southern Cerbat Mountains, Kingman, Arizona, in Cenozoic stratigraphy, structure and mineralization in the Mojave Desert: in Cenozoic stratigraphy, structure and mineralization in the Mojave Desert: Geological Society of America, Cordilleran Section, 82d, Los Angeles, Calif., March 1986, Guidebook and Volume, Field Trips 5 and 6, p. 7-14.

1989. Thickness and flow dynamics as factors controlling welding variations in ignimbrites [abs.], in IAVECI Continental Magmatism General Assembly: Santa Fe, New Mexico Bureau of Mines and Mineral Resources Bulletin 131, p. 32.

Fisher, R.V., and Schmincke, H.-U., 1984, Pyroclastic rocks: Springer-Verlag, $472 \mathrm{p}$.

Fuis, G., 1973, The geology and mechanics of formation of the Fort Rock Dome, Yavapai County, Arizona: Pasadena, California Institute of Technology, Ph.D. dissertation, $386 \mathrm{p}$.

Glazner, A.F., Nielson, J.E., Howard, K.A., and Miller, D.M., 1986, Correlation of the Peach Springs Tuff, a large-volume Miocene ignimbrite sheet in California and Arizona: Geology, v. 14 , no. 10 , p. $840-843$.

Goff, F.E., Eddy, A.C., and Arney, B.H., 1983, Reconnaissance geologic strip map from Kingman to south of Bill Williams Mountain, Arizona: Los Alamos, New Mexico, Los Alamos National Laboratory Report LA-9202-MAP, scale 1:48,000.

Gusa, Sharon, Nielson, J.E., and Howard, K.A., 1987, Heavymineral suites confirm the wide extent of the Peach Springs Tuff in California and Arizona, U.S.A.: Journal of Volcanology and Geothermal Research, v. 33, no. 4, p. 343-347.

Hildreth, W., 1979, The Bishop Tuff: Evidence for the origin of compositional zonation in silicic magma chambers, in Chapin, C.E., and Elston, W.E., eds., Ash-flow tuffs: Geological Society of America Special Paper 180, p. 43-75.

Hillhouse, J.W, and Wells, R.E., 1991, Magnetic fabric and source area of the lower Miocene Peach Springs Tuff in Calif., Nevada, and Arizona: Journal of Geophysical Research, v. 96 , no. B7, p. $12,443-12,460$.

Howard, K.A., and John, B.E., 1987, Crustal extension along a rooted system of imbricate low-angle faults: Colorado River extensional corridor, California and Arizona, in Coward, M.P., Dewey, J.F., and Hancock, P.L., eds., Continental extensional tectonics: Geological Society of London Special Publication 28, p. 299-311.

Izett, G.A., 1981, Volcanic ash beds: Recorders of upper Cenozoic silicic pyroclastic volcanism in the western United States: Journal of Geophysical Research, v. 86, no. B11, p. 10,20010,222 .

Izett, G.A., Obradovich, J.D., and Menhert, H.H., 1988, The Bishop ash bed (middle Pleistocene) and some older (Pliocene and Pleistocene) chemically and mineralogically similar ash beds in California, Nevada, and Utah: U.S. Geological Survey Bulletin 1675, p. 37.

McCurry, M., 1985. The petrology of the Woods Mountains Volcanic Center, San Bernardino County, California: University of California, Los Angeles, Ph.D. dissertation, 403 p.

1988, Geology and petrology of the Woods Mountains volcanic center, southeastern California: Implications for the genesis of peralkaline rhyolitic ash fiows: Journal of Geophysical Research, v. 93, no. B12, p. 14,835-14,855.

McCurry, M., Lux, D.R., and West, D.P., Jr., $1989,{ }^{40} \mathrm{Ar} /{ }^{39} \mathrm{Ar}$ constraints on the age, rates of development, and magmatic processes at the Woods Mountains volcanic center, Mojave Desert, California [abs]: Geological Society of America Abstracts with Programs, v. 21, no. 6, p. A15.

Nielson, J.E., Lux, D.R., Dalrymple, G.B., and Glazner, A.F., 1990, Age of Peach Springs Tuff, southeastern California and western Arizona: Journal of Geophysical Research, v. 95 , no. B1, p. $571-580$.

Sarna-Wojcicki, A.M., and Davis, J.O., 1991, Quaternary tephrochronology, in Morrison, R.B., ed., Quatemary nonglacial geology; conterminous U.S.: Geological Society of America, The Geology of North American Geology, v. K-2, p. 93-116.

Sama-Wojcicki, A.M., Meyer, C.E., Bowman, H.R., Hall, N.T., Russell, P.C., Woodward, M.J., and Slate, J.L., 1985, Correlation of the Rockland ash bed, a 400,000-year old stratigraphic marker in northern California and western Nevada, and implications for Middle Pleistocene paleogeography of central California: Quatemary Research, v. 23, no. 2, p. 236257.

Smith, D.R., and Leeman, W.P., 1982, Mineral and phase chemistry of Mount St. Helens tephra sets $W$ and $Y$ as keys to their identification: Quaternary Research, v. 17 no. 2, p. 211227.

Smith, R.L., 1960, Zones and zonal variations in welded ash flows: U.S. Geological Survey Professional Paper 354-F, p. F149-159.

1979, Ash-flow magmatism, in Chapin, C.E., and Elston, W.E., eds., Ash-flow tuffs: Geological Society of America Special Paper 180, p. 5-27.

Sparks, R.S.J., Self, S., and Walker, G.P.L., 1973, Products of ignimbrite eruptions: Geology, v.1, no. 3, p. 115-118.

Valentine, G.A., Buesch, D.C., and Fisher, R.V., 1989, Basal layered deposits of the Peach Springs Tuff, northwestern Arizona, USA: Bulletin of Volcanology, v. 51, no. 6, p. 395-414.

1990, Response to comment on "Basal layered deposits of the Peach Springs Tuff, northwestern Arizona, USA": Bulletin of Volcanology, v. 52, no. 7, p. 565-569.

Warren, R.G., Byers, F.M., Broxton, D.E., Freeman, S.H., and Hagan, R.C., 1989, Phenocryst abundances and glass and 
phenocryst compositions as indicators of magmatic environments of large-volume ash flow sheets in southwestern Nevada: Journal of Geophysical Research, v. 94, no. B5, p. $5,987-6,020$.

Warren, R.G., Byers, F.M., and Caporuscio, F.A., 1984, Petrography and mineral chemistry of units of the Topopah Spring, Calico Hills, and Crater Flats tuffs, and older volcanic units, with emphasis on samples from drill hole USW G-1, Yucca Mountain, Nevada Test Site: Los Alamos National Laboratory Report, LA-10003-MS, 78 p.

Wells, R.E., and Hillhouse, J.W., 1989, Paleomagnetism and tectonic rotation of the lower Miocene Peach Springs Tuff: Colorado Plateau, Arizona, to Barstow, California: Geological Society of America Bulletin, v. J01, no. 6, p. 846-863.

Westgate, J.A., and Gorton, M.P., 1981, Correlation techniques in tephra studies, in Self, S., and Sparks, R.S.J., eds., Tephra studies: Boston, Mass., D. Reidel Publishing Company, p. 73-94.
Whitney, J.A., and Stormer, J.C., Jr., 1985, Mineralogy, petrology, and magmatic conditions from the Fish Canyon Tuff, central San Juan volcanic field, Colorado: Journal of Petrology, v. 26, no. 3, p. 726-762.

Wilson, C.J.N., and Self, S., 1990, Comment on "Basal layered deposits of the Peach Springs Tuff, northwestern Arizona, USA": Bulletin of Volcanology, v. 52, no. 7, p. 562-565.

Young, R.A., 1966, Cenozoic geology along the edge of the Colorado Plateau in northwestern Arizona: St. Loujs, Missouri, Washington University, Ph.D. dissertation, 167 p.

Young, R.A., and Brennan, W.J., 1974, The Peach Springs Tuff-its bearing on the structural evolution of the Colorado Plateau and development of Cenozoic drainage in Mohave County, Arizona: Geological Society of America Bulletin, v. 85 , no. 1 , p. $83-90$.

Young, R.A., and McKee, E.H., 1978, Early and middle Cenozoic drainage and erosion in west-central Arizona: Geological Society of America Bulletin, v. 89, no. 12, p. 1,745-1,750. 

APPENDIXES 1 AND 2 
APPENDIXES: Analyses of feldspar of tephra units of extensional terranes, southeastern California and western Arizona

Analyses are by electron microprobe; see text for details of procedures. Total Fe is reported as $\mathrm{FeO}$. All analyses are by the author, except those for the Wild Horse Mesa Tuff of McCurry (1988).

Sample designations are numbers of field locations in table 1 with extension indicating stratigraphic height above the base of unit in centimeters $(\mathrm{cm})$ or meters $(\mathrm{m})$.

Location codes for individual electron microprobe analyses designate mineral species-S, sanidine; P, plagioclaseand grain number; textural context and number, and morphological position. Textural context: CC crystal cluster; MP, sanidine overgrowths on plagioclase; MS, sanidine overgrowths on sanidine; PU, phenocrysts in pumice; GL, grains with attached glass; no designation, texturally nondistinct grains. Morphological position for grains with at least one boundary that is a crystal face: R, rim; C, core; for broken grains: E, external; I, internal; MR, MC, ME, MI are used when multiple similar locations (rim, core, external or internal) are analyzed on a single grain. For example, analysis S2PU4R2 is of sanidine grain 2, in pumice sample 4 , second analysis near rim.

Tabulated data from McCurry (1988) represent average of three or more analyses; "nd", oxides not determined. Letters in parentheses designate member: LM, lower; MM, middle; UM, upper; interval at which samples were collected: f, Plinian fallout; l, lower; m, middle; u, upper. Except for samples designated "t" from trachyte pumice, all analyses are from pumice clasts of rhyolitic composition.

Appendix 1. Sanidine compositions.

$\begin{array}{lllllllllllllllll}\begin{array}{l}\text { Oxide wt pet or } \\ \text { feldspar mol pet }\end{array} & \mathrm{SiO}_{2} & \mathrm{~A}_{2} \mathrm{O}_{2} & \mathrm{Fe}_{2} \mathrm{O}_{3} & \mathrm{MgO} & \mathrm{CaO} & \mathrm{SrO} & \mathrm{BaO} & \mathrm{Na}_{2} \mathrm{O} & \mathrm{K}_{2} \mathrm{O} & \text { Total } & \text { Ab } & \text { An } & \text { Or } & \mathrm{Celsian} & \mathrm{Sr}-\mathrm{Feldspar}\end{array}$

Peach Springs Tuff-Layer 1 (Tpsl $\mathbf{~}_{1}$

PST045cm5

\begin{tabular}{|c|c|c|c|c|c|c|c|c|c|c|c|c|c|c|c|}
\hline S11PU6I & 67.21 & 18.85 & 0.19 & 0.00 & 0.36 & 0.06 & 0.00 & 5.15 & 9.08 & 100.90 & 45.48 & 1.76 & 52.76 & 0.00 & 0.16 \\
\hline S11PU6MR & 66.47 & 18.82 & 0.18 & 0.00 & 0.36 & 0.08 & 0.00 & 5.14 & 9.36 & 100.42 & 44.71 & 1.73 & 53.56 & 0.00 & 0.21 \\
\hline S11PU6R & 66.83 & 18.78 & 0.19 & 0.00 & 0.37 & 0.05 & 0.00 & 4.98 & 9.39 & 100.58 & 43.83 & 1.80 & 54.37 & 0.00 & 0.13 \\
\hline S12I & 66.51 & 18.85 & 0.19 & 0.00 & 0.40 & 0.04 & 0.00 & 4.99 & 9.18 & 100.16 & 44.35 & 1.96 & 53.68 & 0.00 & 0.11 \\
\hline S13PU9I & 66.88 & 18.99 & 0.17 & 0.00 & 0.40 & 0.08 & 0.00 & 4.99 & 9.28 & 100.79 & 44.09 & 1.95 & 53.95 & 0.00 & 0.21 \\
\hline S13PU9ME & 66.45 & 19.02 & 0.19 & 0.00 & 0.49 & 0.04 & 0.00 & 5.26 & 8.97 & 100.43 & 46.01 & 2.37 & 51.62 & 0.00 & 0.10 \\
\hline S13PU9MI & 66.15 & 18.86 & 0.14 & 0.00 & 0.47 & 0.08 & 0.00 & 5.29 & 9.10 & 100.10 & 45.85 & 2.25 & 51.90 & 0.00 & 0.21 \\
\hline S13PU9R & 66.54 & 18.78 & 0.16 & 0.00 & 0.50 & 0.07 & 0.00 & 5.57 & 8.94 & 100.56 & 47.49 & 2.36 & 50.15 & 0.00 & 0.18 \\
\hline S15GL16I & 66.19 & 18.89 & 0.18 & 0.00 & 0.35 & 0.08 & 0.00 & 4.97 & 9.47 & 100.13 & 43.62 & 1.70 & 54.68 & 0.00 & 0.21 \\
\hline S15GL16R & 66.49 & 18.70 & 0.16 & 0.00 & 0.33 & 0.06 & 0.00 & 5.01 & 9.28 & 100.03 & 44.34 & 1.61 & 54.04 & 0.00 & 0.16 \\
\hline S17GL26E & 66.55 & 19.01 & 0.16 & 0.00 & 0.50 & 0.07 & 0.01 & 5.49 & 8.69 & 100.49 & 47.81 & 2.41 & 49.79 & 0.02 & 0.18 \\
\hline S17GL26I & 66.53 & 18.94 & 0.18 & 0.00 & 0.48 & 0.03 & 0.00 & 5.17 & 9.06 & 100.40 & 45.37 & 2.33 & 52.31 & 0.00 & 0.08 \\
\hline S17GL26ME & 66.47 & 18.93 & 0.19 & 0.00 & 0.48 & 0.07 & 0.00 & 5.28 & 8.99 & 100.42 & 46.07 & 2.31 & 51.61 & 0.00 & 0.18 \\
\hline S21PU14I & 65.99 & 18.80 & 0.19 & 0.00 & 0.40 & 0.07 & 0.00 & 5.03 & 9.51 & 99.99 & 43.71 & 1.92 & 54.37 & 0.00 & 0.18 \\
\hline S21PU14R & 66.26 & 18.89 & 0.19 & 0.00 & 0.33 & 0.05 & 0.00 & 4.96 & 9.49 & 100.16 & 43.56 & 1.60 & 54.84 & 0.00 & 0.13 \\
\hline S22PU14C & 66.49 & 18.83 & 0.17 & 0.00 & 0.42 & 0.05 & 0.00 & 5.17 & 9.11 & 100.24 & 45.37 & 2.04 & 52.60 & 0.00 & 0.13 \\
\hline S22PU14R & 66.30 & 18.70 & 0.20 & 0.00 & 0.48 & 0.09 & 0.00 & 5.15 & 9.22 & 100.15 & 44.86 & 2.31 & 52.83 & 0.00 & 0.23 \\
\hline S27GL37E & 66.71 & 18.73 & 0.18 & 0.00 & 0.43 & 0.08 & 0.00 & 5.17 & 9.45 & 100.74 & 44.47 & 2.04 & 53.48 & 0.00 & 0.21 \\
\hline S27GL37I & 66.02 & 18.83 & 0.21 & 0.00 & 0.39 & 0.06 & 0.00 & 5.01 & 9.21 & 99.72 & 44.39 & 1.91 & 53.70 & 0.00 & 0.16 \\
\hline S2PU2I & 65.73 & 19.09 & 0.19 & 0.00 & 0.40 & 0.07 & 0.00 & 5.12 & 9.20 & 99.81 & 44.94 & 1.94 & 53.12 & 0.00 & 0.18 \\
\hline S2PU2MR & 66.74 & 18.88 & 0.19 & 0.00 & 0.41 & 0.05 & 0.00 & 5.16 & 9.37 & 100.81 & 44.67 & 1.96 & 53.37 & 0.00 & 0.13 \\
\hline S2PU2R & 66.66 & 18.69 & 0.16 & 0.00 & 0.44 & 0.09 & 0.00 & 5.06 & 9.33 & 100.43 & 44.22 & 2.13 & 53.65 & 0.00 & 0.24 \\
\hline S3OPU12E & 65.60 & 19.06 & 0.36 & 0.01 & 0.80 & 0.22 & 0.10 & 3.75 & 10.70 & 100.61 & 33.39 & 3.94 & 62.68 & 0.18 & 0.59 \\
\hline S30PU12E2 & 64.91 & 18.99 & 0.33 & 0.00 & 0.81 & 0.19 & 0.17 & 3.85 & 10.35 & 99.61 & 34.66 & 4.03 & 61.31 & 0.31 & 0.51 \\
\hline S3PU2R & 66.18 & 18.82 & 0.19 & 0.00 & 0.44 & 0.03 & 0.00 & 5.12 & 9.37 & 100.16 & 44.41 & 2.11 & 53.48 & 0.00 & 0.08 \\
\hline S4PU3I & 66.72 & 18.73 & 0.19 & 0.00 & 0.37 & 0.09 & 0.00 & 4.83 & 9.43 & 100.36 & 42.98 & 1.82 & 55.20 & 0.00 & 0.24 \\
\hline S4PU3R & 66.79 & 18.73 & 0.17 & 0.00 & 0.36 & 0.09 & 0.00 & 4.78 & 9.60 & 100.52 & 42.32 & 1.76 & 55.92 & 0.00 & 0.24 \\
\hline S5GL2I & 66.20 & 18.82 & 0.18 & 0.00 & 0.40 & 0.07 & 0.00 & 4.90 & 9.40 & 99.99 & 43.34 & 1.96 & 54.70 & 0.00 & 0.19 \\
\hline S5GL2MR & 66.68 & 18.83 & 0.18 & 0.00 & 0.38 & 0.05 & 0.00 & 4.96 & 9.34 & 100.42 & 43.84 & 1.86 & 54.31 & 0.00 & 0.13 \\
\hline S5GL2R & 66.87 & 18.67 & 0.19 & 0.00 & 0.35 & 0.06 & 0.00 & 4.86 & 9.56 & 100.56 & 42.84 & 1.71 & 55.45 & 0.00 & 0.16 \\
\hline S6PU4E & 66.46 & 19.19 & 0.21 & 0.00 & 0.45 & 0.09 & 0.00 & 5.17 & 9.27 & 100.84 & 44.89 & 2.16 & 52.95 & 0.00 & 0.23 \\
\hline
\end{tabular}


Appendix 1. Sanidine compositions-Continued.

$\begin{array}{lllllllllllllll}\text { Oxide w1 pel or } & \mathrm{SiO}_{2} & \mathrm{~A}_{2} \mathrm{O}_{2} & \mathrm{Fe}_{2} \mathrm{O}_{3} & \mathrm{MgO} & \mathrm{CaO} & \mathrm{SrO} & \mathrm{BaO} & \mathrm{Na}_{2} \mathrm{O} & \mathrm{K}_{2} \mathrm{O} & \text { Total } & \text { Ab } & \text { An } & \text { Or } & \mathrm{Ce}\end{array}$

Peach Springs Tuff-Layer $1\left(\mathrm{Tpsl}_{1}\right)$-Continued

PST045cm5-Continued

\begin{tabular}{|c|c|c|c|c|c|c|c|c|c|c|c|c|c|c|c|}
\hline S6PU4I & 66.56 & 18.77 & 0.19 & 0.00 & 0.37 & 0.10 & 0.00 & 5.07 & 9.19 & 100.24 & 44.78 & 1.81 & 53.41 & 0.00 & 0.26 \\
\hline S8MS1E & 66.44 & 18.84 & 0.18 & 0.00 & 0.45 & 0.07 & 0.00 & 4.94 & 9.44 & 100.35 & 43.33 & 2.18 & 54.48 & 0.00 & 0.18 \\
\hline S8MS1I & 67.11 & 18.68 & 0.19 & 0.00 & 0.35 & 0.06 & 0.01 & 4.88 & 9.38 & 100.66 & 43.40 & 1.72 & 54.88 & 0.02 & 0.16 \\
\hline S9MS1E & 66.34 & 18.88 & 0.18 & 0.00 & 0.42 & 0.05 & 0.00 & 4.92 & 9.21 & 100.01 & 43.88 & 2.07 & 54.05 & 0.00 & 0.13 \\
\hline S9MS1I & 66.96 & 18.82 & 0.16 & 0.00 & 0.37 & 0.07 & 0.00 & 4.99 & 9.39 & 100.76 & 43.88 & 1.80 & 54.32 & 0.00 & 0.18 \\
\hline \multicolumn{16}{|l|}{ PST045cm45 } \\
\hline S16E & 65.50 & 18.89 & 0.28 & 0.00 & 0.37 & 0.08 & 0.00 & 5.00 & 9.35 & 99.47 & 44.03 & 1.80 & 54.17 & 0.00 & 0.21 \\
\hline S16I & 66.38 & 18.81 & 0.16 & 0.00 & 0.39 & 0.05 & 0.00 & 5.03 & 9.45 & 100.27 & 43.88 & 1.88 & 54.24 & 0.00 & 0.13 \\
\hline S16ME & 66.14 & 18.84 & 0.21 & 0.00 & 0.41 & 0.07 & 0.00 & 5.06 & 9.41 & 100.13 & 44.09 & 1.97 & 53.94 & 0.00 & 0.18 \\
\hline Sl6MI & 66.16 & 18.92 & 0.18 & 0.00 & 0.40 & 0.03 & 0.07 & 5.03 & 9.30 & 100.09 & 44.24 & 1.94 & 53.82 & 0.12 & 0.08 \\
\hline $\mathrm{S} 16 \mathrm{MI} 2$ & 65.96 & 18.85 & 0.20 & 0.00 & 0.40 & 0.05 & 0.02 & 5.12 & 9.48 & 100.07 & 44.22 & 1.91 & 53.87 & 0.03 & 0.13 \\
\hline S18E & 66.36 & 18.88 & 0.17 & 0.00 & 0.41 & 0.04 & 0.00 & 5.28 & 8.97 & 100.11 & 46.28 & 1.99 & 51.73 & 0.00 & 0.10 \\
\hline S18I & 65.97 & 18.87 & 0.19 & 0.00 & 0.42 & 0.07 & 0.00 & 5.34 & 9.11 & 99.96 & 46.17 & 2.01 & 51.82 & 0.00 & 0.18 \\
\hline S18ME & 66.15 & 19.15 & 0.17 & 0.00 & 0.49 & 0.00 & 0.00 & 5.56 & 8.89 & 100.41 & 47.60 & 2.32 & 50.08 & 0.00 & 0.00 \\
\hline S18MI & 66.68 & 19.01 & 0.18 & 0.00 & 0.44 & 0.04 & 0.01 & 5.30 & 8.88 & 100.54 & 46.55 & 2.14 & 51.31 & 0.02 & 0.11 \\
\hline S19E & 66.60 & 18.54 & 0.19 & 0.00 & 0.33 & 0.06 & 0.00 & 5.12 & 9.36 & 100.20 & 44.67 & 1.59 & 53.73 & 0.00 & 0.16 \\
\hline S19I & 66.83 & 18.97 & 0.17 & 0.00 & 0.40 & 0.07 & 0.00 & 5.28 & 9.10 & 100.82 & 45.96 & 1.92 & 52.12 & 0.00 & 0.18 \\
\hline SIPU1E & 66.30 & 18.93 & 0.18 & 0.00 & 0.34 & 0.07 & 0.01 & 5.06 & 9.39 & 100.27 & 44.29 & 1.64 & 54.07 & 0.02 & 0.18 \\
\hline S1PU1I & 65.49 & 18.86 & 0.18 & 0.00 & 0.36 & 0.03 & 0.00 & 5.13 & 9.39 & 99.43 & 44.58 & 1.73 & 53.69 & 0.00 & 0.08 \\
\hline S20PU7E & 66.77 & 19.03 & 0.18 & 0.00 & 0.34 & 0.06 & 0.00 & 5.11 & 9.43 & 100.91 & 44.43 & 1.63 & 53.94 & 0.00 & 0.16 \\
\hline S20PU7I & 66.43 & 18.79 & 0.20 & 0.00 & 0.30 & 0.07 & 0.00 & 5.01 & 9.53 & 100.31 & 43.77 & 1.45 & 54.78 & 0.00 & 0.18 \\
\hline S21E & 65.70 & 18.48 & 0.21 & 0.00 & 0.31 & 0.02 & 0.00 & 5.14 & 9.29 & 99.16 & 44.99 & 1.50 & 53.51 & 0.00 & 0.05 \\
\hline S22GL32E & 66.39 & 18.88 & 0.18 & 0.00 & 0.34 & 0.07 & 0.00 & 5.22 & 9.32 & 100.42 & 45.23 & 1.63 & 53.14 & 0.00 & 0.18 \\
\hline S22GL32I & 66.16 & 18.95 & 0.18 & 0.00 & 0.39 & 0.06 & 0.00 & 4.95 & 9.31 & 100.01 & 43.84 & 1.91 & 54.25 & 0.00 & 0.16 \\
\hline S22GL32ME & 65.77 & 18.87 & 0.18 & 0.00 & 0.38 & 0.04 & 0.00 & 4.93 & 9.45 & 99.62 & 43.41 & 1.85 & 54.74 & 0.00 & 0.11 \\
\hline S22GL32MI & 66.67 & 19.08 & 0.16 & 0.00 & 0.35 & 0.07 & 0.00 & 5.37 & 9.24 & 100.93 & 46.12 & 1.66 & 52.22 & 0.00 & 0.18 \\
\hline S22GL32MI2 & 65.44 & 18.72 & 0.16 & 0.00 & 0.31 & 0.05 & 0.00 & 5.00 & 9.43 & 99.12 & 43.95 & 1.51 & 54.54 & 0.00 & 0.13 \\
\hline S22GL32MI3 & 66.08 & 18.81 & 0.19 & 0.00 & 0.38 & 0.05 & 0.02 & 5.23 & 9.04 & 99.80 & 45.93 & 1.84 & 52.23 & 0.04 & 0.13 \\
\hline S24PU8C & 66.34 & 19.12 & 0.18 & 0.00 & 0.37 & 0.05 & 0.00 & 5.30 & 9.12 & 100.48 & 46.07 & 1.78 & 52.16 & 0.00 & 0.13 \\
\hline S24PU8MR & 65.66 & 18.97 & 0.17 & 0.00 & 0.39 & 0.05 & 0.00 & 5.26 & 9.22 & 99.73 & 45.57 & 1.87 & 52.56 & 0.00 & 0.13 \\
\hline S24PU8R & 66.37 & 19.09 & 0.21 & 0.00 & 0.36 & 0.08 & 0.00 & 5.34 & 9.23 & 100.69 & 45.99 & 1.71 & 52.30 & 0.00 & 0.21 \\
\hline S26E & 66.35 & 18.71 & 0.18 & 0.00 & 0.36 & 0.02 & 0.00 & 5.16 & 9.22 & 100.00 & 45.16 & 1.74 & 53.10 & 0.00 & 0.05 \\
\hline S26I & 66.84 & 18.89 & 0.17 & 0.00 & 0.36 & 0.06 & 0.00 & 4.94 & 9.35 & 100.61 & 43.75 & 1.76 & 54.48 & 0.00 & 0.16 \\
\hline S2PU1C & 65.85 & 18.96 & 0.16 & 0.00 & 0.40 & 0.05 & 0.01 & 5.14 & 9.17 & 99.73 & 45.11 & 1.94 & 52.95 & 0.02 & 0.13 \\
\hline S2PU1R & 66.00 & 18.70 & 0.21 & 0.00 & 0.39 & 0.06 & 0.00 & 5.18 & 9.36 & 99.91 & 44.83 & 1.87 & 53.30 & 0.00 & 0.16 \\
\hline S30E & 66.32 & 19.06 & 0.19 & 0.00 & 0.52 & 0.01 & 0.00 & 6.11 & 7.66 & 99.88 & 53.42 & 2.51 & 44.07 & 0.00 & 0.03 \\
\hline S30I & 66.29 & 19.07 & 0.18 & 0.00 & 0.52 & 0.05 & 0.01 & 5.47 & 8.86 & 100.47 & 47.21 & 2.48 & 50.31 & 0.02 & 0.13 \\
\hline S30ME & 66.26 & 19.12 & 0.18 & 0.00 & 0.58 & 0.04 & $0.0 \mathrm{~J}$ & 5.89 & 7.89 & 99.98 & 51.66 & 2.81 & 45.53 & 0.02 & 0.10 \\
\hline S3I & 66.82 & 19.14 & 0.17 & 0.00 & 0.39 & 0.07 & 0.00 & 5.15 & 9.09 & 100.82 & 45.39 & 1.90 & 52.71 & 0.00 & 0.18 \\
\hline S3R & 65.91 & 18.88 & 0.17 & 0.00 & 0.38 & 0.09 & 0.00 & 5.08 & 9.29 & 99.79 & 44.55 & 1.84 & 53.61 & 0.00 & 0.24 \\
\hline S4GL4E & 66.77 & 18.81 & 0.21 & 0.00 & 0.35 & 0.06 & 0.00 & 5.13 & 9.34 & 100.65 & 44.73 & 1.69 & 53.58 & 0.00 & 0.16 \\
\hline S4GLAI & 65.88 & 18.88 & 0.17 & 0.00 & 0.36 & 0.04 & 0.00 & 5.15 & 9.35 & 99.82 & 44.78 & 1.73 & 53.49 & 0.00 & 0.10 \\
\hline S5PU3I & 66.32 & 18.88 & 0.19 & 0.00 & 0.41 & 0.06 & 0.01 & 5.20 & 9.07 & 100.13 & 45.64 & 1.99 & 52.37 & 0.02 & 0.16 \\
\hline S5PU3R & 65.81 & 18.97 & 0.21 & 0.00 & 0.42 & 0.03 & 0.00 & 5.44 & 8.99 & 99.86 & 46.95 & 2.00 & 51.05 & 0.00 & 0.08 \\
\hline S6PU3E & 66.38 & 18.87 & 0.18 & 0.00 & 0.36 & 0.06 & 0.03 & 5.01 & 9.23 & 100.11 & 44.41 & 1.76 & 53.83 & 0.05 & 0.16 \\
\hline S8PU4I & 66.07 & 19.15 & 0.19 & 0.00 & 0.42 & 0.07 & 0.00 & 5.24 & 9.11 & 100.25 & 45.70 & 2.02 & 52.27 & 0.00 & 0.18 \\
\hline S8PU4R & 66.26 & 18.90 & 0.18 & 0.00 & 0.40 & 0.05 & 0.00 & 5.09 & 9.26 & 100.15 & 44.64 & 1.94 & 53.43 & 0.00 & 0.13 \\
\hline
\end{tabular}


Appendix 1. Sanidine compositions-Continued.

\begin{tabular}{llllllllllllllllll}
\hline $\begin{array}{l}\text { Oxide wt pet or } \\
\text { feldspar mol pet }\end{array}$ & $\mathrm{SiO}_{2}$ & $\mathrm{~A}_{2} \mathrm{O}_{2}$ & $\mathrm{Fe}_{2} \mathrm{O}_{3}$ & $\mathrm{MgO}$ & $\mathrm{CaO}$ & $\mathrm{SrO}$ & $\mathrm{BaO}$ & $\mathrm{Na}_{2} \mathrm{O}$ & $\mathrm{K}_{2} \mathrm{O}$ & Total & Ab & An & Or & Celsian & Sr-Feldspar
\end{tabular}

Peach Springs Tuff-Ignimbrite (Tpsig)

PST101m2

\begin{tabular}{|c|c|c|c|c|c|c|c|c|c|c|c|c|c|c|c|}
\hline S10E & 67.59 & 18.75 & 0.19 & 0.00 & 0.40 & 0.04 & 0.03 & 5.13 & 8.94 & 101.08 & 45.67 & 1.97 & 52.36 & 0.05 & 0.11 \\
\hline S10E2 & 67.06 & 18.93 & 0.16 & 0.00 & 0.37 & 0.04 & 0.05 & 5.29 & 8.91 & 100.80 & 46.58 & 1.80 & 51.62 & 0.09 & 0.11 \\
\hline S10I & 66.82 & 18.82 & 0.17 & 0.00 & 0.38 & 0.07 & 0.04 & 5.18 & 9.03 & 100.50 & 45.71 & 1.85 & 52.43 & 0.07 & 0.18 \\
\hline S11E & 66.54 & 18.94 & 0.17 & 0.01 & 0.42 & 0.07 & 0.01 & 5.17 & 9.65 & 100.97 & 44.00 & 1.98 & 54.03 & 0.02 & 0.18 \\
\hline S11I & 66.79 & 18.80 & 0.16 & 0.01 & 0.40 & 0.05 & 0.02 & 5.04 & 9.47 & 100.75 & 43.86 & 1.92 & 54.22 & 0.04 & 0.13 \\
\hline$S 12 E$ & 65.82 & 19.11 & 0.24 & 0.00 & 0.56 & 0.03 & 0.00 & 5.58 & 8.85 & 100.18 & 47.64 & 2.64 & 49.72 & 0.00 & 0.08 \\
\hline S12I & 66.17 & 19.22 & 0.19 & 0.02 & 0.59 & 0.06 & 0.00 & 5.65 & 8.56 & 100.45 & 48.67 & 2.81 & 48.52 & 0.00 & 0.15 \\
\hline S13I & 67.03 & 18.97 & 0.14 & 0.01 & 0.37 & 0.04 & 0.00 & 5.09 & 9.41 & 101.06 & 44.32 & 1.78 & 53.90 & 0.00 & 0.10 \\
\hline S13R & 66.86 & 18.87 & 0.17 & 0.03 & 0.37 & 0.03 & 0.00 & 5.11 & 9.56 & 100.99 & 44.04 & 1.76 & 54.20 & 0.00 & 0.08 \\
\hline S14I & 66.97 & 18.70 & 0.17 & 0.02 & 0.38 & 0.03 & 0.00 & 5.03 & 9.60 & 100.91 & 43.53 & 1.82 & 54.66 & 0.00 & 0.08 \\
\hline S14R & 66.43 & 18.68 & 0.14 & 0.00 & 0.38 & 0.05 & 0.00 & 5.01 & 9.45 & 100.14 & 43.80 & 1.84 & 54.36 & 0.00 & 0.13 \\
\hline S15E & 66.38 & 18.87 & 0.16 & 0.01 & 0.36 & 0.08 & 0.00 & 4.99 & 9.60 & 100.45 & 43.37 & 1.73 & 54.90 & 0.00 & 0.21 \\
\hline S15I & 66.21 & 18.81 & 0.18 & 0.00 & 0.57 & 0.05 & 0.00 & 5.36 & 8.81 & 100.00 & 46.72 & 2.75 & 50.53 & 0.00 & 0.13 \\
\hline S15ME & 66.30 & 18.91 & 0.14 & 0.01 & 0.41 & 0.03 & 0.00 & 4.98 & 9.53 & 100.31 & 43.39 & 1.97 & 54.63 & 0.00 & 0.08 \\
\hline S15MI & 65.53 & 18.88 & 0.19 & 0.01 & 0.54 & 0.03 & 0.00 & 5.31 & 8.89 & 99.38 & 46.35 & 2.60 & 51.05 & 0.00 & 0.08 \\
\hline S16E & 66.97 & 18.73 & 0.19 & 0.00 & 0.35 & 0.10 & 0.01 & 5.02 & 9.37 & 100.73 & 44.12 & 1.70 & 54.18 & 0.02 & 0.26 \\
\hline S16I & 66.44 & 18.70 & 0.19 & 0.00 & 0.36 & 0.05 & 0.01 & 4.99 & 9.24 & 99.97 & 44.28 & 1.77 & 53.95 & 0.02 & 0.13 \\
\hline S17E & 66.77 & 18.87 & 0.20 & 0.00 & 0.40 & 0.07 & 0.00 & 5.20 & 9.14 & 100.66 & 45.48 & 1.93 & 52.59 & 0.00 & 0.18 \\
\hline S171 & 66.88 & 18.63 & 0.18 & 0.00 & 0.35 & 0.06 & 0.00 & 5.12 & 9.48 & 100.69 & 44.33 & 1.67 & 54.00 & 0.00 & 0.16 \\
\hline S18GL9I & 66.77 & 18.88 & 0.18 & 0.00 & 0.44 & 0.06 & 0.00 & 5.26 & 8.96 & 100.57 & 46.15 & 2.13 & 51.72 & 0.00 & 0.16 \\
\hline S18GL9MI & 66.37 & 19.07 & 0.19 & 0.00 & 0.45 & 0.08 & 0.00 & 5.35 & 8.87 & 100.38 & 46.79 & 2.17 & 51.04 & 0.00 & 0.21 \\
\hline S18GL9R & 66.82 & 18.74 & 0.19 & 0.00 & 0.38 & 0.06 & 0.00 & 5.27 & 9.16 & 100.62 & 45.80 & 1.82 & 52.38 & 0.00 & 0.16 \\
\hline S22GL28I & 67.32 & 18.82 & 0.18 & 0.01 & 0.41 & 0.02 & 0.05 & 5.03 & 8.75 & 100.59 & 45.67 & 2.06 & 52.27 & 0.09 & 0.05 \\
\hline S22GL28MI & 66.74 & 18.65 & 0.17 & 0.01 & 0.37 & 0.07 & 0.03 & 5.09 & 9.01 & 100.14 & 45.36 & 1.82 & 52.82 & 0.05 & 0.19 \\
\hline S22GL28MR & 66.96 & 18.96 & 0.18 & 0.02 & 0.36 & 0.02 & 0.05 & 5.17 & 8.97 & 100.67 & 45.87 & 1.77 & 52.36 & 0.09 & 0.05 \\
\hline S22GL28MR2 & 66.80 & 19.08 & 0.18 & 0.00 & 0.36 & 0.07 & 0.05 & 5.00 & 8.99 & 100.54 & 44.99 & 1.79 & 53.22 & 0.09 & 0.19 \\
\hline S22GL28R & 67.46 & 18.79 & 0.19 & 0.01 & 0.38 & 0.02 & 0.01 & 5.28 & 8.90 & 101.05 & 46.54 & 1.85 & 51.61 & 0.02 & 0.05 \\
\hline S23GL30I & 66.86 & 18.88 & 0.14 & 0.00 & 0.34 & 0.08 & 0.04 & 5.12 & 8.80 & 100.26 & 46.14 & 1.69 & 52.17 & 0.07 & 0.22 \\
\hline S23GL30I2 & 66.77 & 18.84 & 0.19 & 0.00 & 0.37 & 0.07 & 0.01 & 5.10 & 9.20 & 100.55 & 44.90 & 1.80 & 53.30 & 0.02 & 0.18 \\
\hline S23GL30R & 67.10 & 18.72 & 0.18 & 0.00 & 0.41 & 0.10 & 0.08 & 5.16 & 9.01 & 100.76 & 45.60 & 2.00 & 52.39 & 0.14 & 0.26 \\
\hline S23GL30R2 & 66.48 & 18.80 & 0.19 & 0.00 & 0.39 & 0.10 & 0.00 & 5.12 & 9.36 & 100.43 & 44.55 & 1.88 & 53.58 & 0.00 & 0.26 \\
\hline S24PU12E & 66.78 & 18.70 & 0.18 & 0.00 & 0.36 & 0.05 & 0.04 & 5.19 & 9.20 & 100.51 & 45.36 & 1.74 & 52.90 & 0.07 & 0.13 \\
\hline S25GL31I & 66.98 & 18.72 & 0.20 & 0.00 & 0.33 & 0.08 & 0.04 & 5.22 & 9.43 & 101.02 & 44.97 & 1.57 & 53.45 & 0.07 & 0.21 \\
\hline S25GL31MI & 66.83 & 18.92 & 0.16 & 0.00 & 0.38 & 0.11 & 0.02 & 5.07 & 9.32 & 100.82 & 44.43 & 1.84 & 53.73 & 0.04 & 0.29 \\
\hline S25GL31R & 66.98 & 18.76 & 0.17 & 0.01 & 0.31 & 0.07 & 0.00 & 4.98 & 9.65 & 100.93 & 43.30 & 1.49 & 55.21 & 0.00 & 0.18 \\
\hline S26GL32I & 67.11 & 18.67 & 0.19 & 0.00 & 0.33 & 0.09 & 0.02 & 5.13 & 9.29 & 100.83 & 44.90 & 1.60 & 53.50 & 0.04 & 0.24 \\
\hline S26GL32I2 & 66.92 & 18.80 & 0.18 & 0.00 & 0.36 & 0.07 & 0.00 & 5.19 & 9.09 & 100.62 & 45.65 & 1.75 & 52.60 & 0.00 & 0.18 \\
\hline S26GL32R & 67.03 & 18.66 & 0.20 & 0.00 & 0.32 & 0.11 & 0.00 & 5.12 & 9.27 & 100.70 & 44.93 & 1.55 & 53.52 & 0.00 & 0.29 \\
\hline S26GL32R2 & 66.78 & 18.78 & 0.20 & 0.00 & 0.42 & 0.09 & 0.00 & 5.18 & 9.14 & 100.59 & 45.34 & 2.03 & 52.63 & 0.00 & 0.24 \\
\hline S27GL3312 & 66.77 & 18.69 & 0.16 & 0.01 & 0.41 & 0.04 & 0.03 & 5.02 & 8.90 & 100.04 & 45.22 & 2.04 & 52.74 & 0.05 & 0.11 \\
\hline S27GL33R & 66.77 & 18.51 & 0.18 & 0.01 & 0.38 & 0.09 & 0.03 & 5.06 & 9.02 & 100.06 & 45.16 & 1.87 & 52.97 & 0.05 & 0.24 \\
\hline S28GL2I & 67.06 & 18.87 & 0.17 & 0.01 & 0.39 & 0.02 & 0.05 & 5.17 & 8.75 & 100.50 & 46.40 & 1.93 & 51.67 & 0.09 & 0.05 \\
\hline S28GL2R & 66.90 & 18.82 & 0.19 & 0.01 & 0.33 & 0.08 & 0.08 & 5.42 & 8.77 & 100.60 & 47.66 & 1.60 & 50.74 & 0.14 & 0.21 \\
\hline S29MP1PU13E & 66.60 & 18.85 & 0.20 & 0.01 & 0.44 & 0.04 & 0.00 & 5.52 & 8.94 & 100.60 & 47.40 & 2.09 & 50.51 & 0.00 & 0.10 \\
\hline S29MP1PU131 & 66.47 & 18.86 & 0.21 & 0.01 & 0.41 & 0.04 & 0.01 & 5.38 & 9.12 & 100.51 & 46.35 & 1.95 & 51.70 & 0.02 & 0.10 \\
\hline S29MP1PU13I2 & 66.38 & 19.27 & 0.18 & 0.02 & 0.89 & 0.00 & 0.02 & 6.18 & 7.32 & 100.26 & 53.80 & 4.28 & 41.92 & 0.04 & 0.00 \\
\hline S30GL371 & 66.68 & 19.00 & 0.18 & 0.01 & 0.37 & 0.05 & 0.00 & 5.03 & 9.44 & 100.77 & 43.95 & 1.79 & 54.27 & 0.00 & 0.13 \\
\hline S30GL37R & 67.01 & 18.84 & 0.18 & 0.01 & 0.35 & 0.07 & 0.02 & 5.00 & 9.40 & 100.87 & 43.94 & 1.70 & 54.36 & 0.04 & 0.18 \\
\hline S31PU14C & 66.55 & 18.80 & 0.20 & 0.01 & 0.36 & 0.07 & 0.00 & 4.94 & 9.69 & 100.63 & 42.90 & 1.73 & 55.37 & 0.00 & 0.18 \\
\hline S3IPU14R & 66.67 & 18.80 & 0.16 & 0.01 & 0.39 & 0.03 & 0.00 & 5.00 & 9.67 & 100.72 & 43.19 & 1.86 & 54.95 & 0.00 & 0.08 \\
\hline S32PU14C & 66.14 & 18.86 & 0.19 & 0.01 & 0.46 & 0.02 & 0.00 & 5.46 & 8.97 & 100.11 & 47.00 & 2.19 & 50.81 & 0.00 & 0.05 \\
\hline
\end{tabular}


Appendix 1. Sanidine compositions-Continued.

$\begin{array}{lllllllllllllllll}\text { Oxide wt pcl or } & \mathrm{SiO}_{2} & \mathrm{~A}_{2} \mathrm{O}_{2} & \mathrm{Fe}_{2} \mathrm{O}_{3} & \mathrm{MgO} & \mathrm{CaO} & \mathrm{SrO} & \mathbf{B a O} & \mathrm{Na}_{2} \mathrm{O} & \mathrm{K}_{2} \mathrm{O} & \text { Total } & \mathrm{Ab} & \text { An } & \text { Or } & \text { Celsian } & \mathrm{Sr} \text {-Feldspar }\end{array}$

Peach Springs Tuff-Ignimbrite (Tpsig)—Continued

PST101m2-Continued

\begin{tabular}{|c|c|c|c|c|c|c|c|c|c|c|c|c|c|c|c|}
\hline S32PU14C2 & 66.34 & 18.97 & 0.18 & 0.01 & 0.48 & 0.05 & 0.03 & 5.38 & 8.99 & 100.42 & 46.54 & 2.29 & 51.17 & 0.05 & 0.13 \\
\hline S3E & 66.59 & 18.77 & 0.21 & 0.00 & 0.45 & 0.07 & 0.00 & 5.39 & 9.02 & 100.50 & 46.57 & 2.15 & 51.28 & 0.00 & 0.18 \\
\hline S3I & 66.95 & 18.84 & 0.21 & 0.00 & 0.38 & 0.11 & 0.00 & 5.30 & 9.19 & 100.99 & 45.86 & 1.82 & 52.32 & 0.00 & 0.28 \\
\hline S4E & 66.89 & 18.89 & 0.20 & 0.00 & 0.42 & 0.06 & 0.08 & 5.15 & 8.59 & 100.28 & 46.67 & 2.10 & 51.22 & 0.15 & 0.16 \\
\hline S4I & 66.61 & 18.96 & 0.17 & 0.00 & 0.44 & 0.02 & 0.08 & 5.10 & 8.55 & 99.94 & 46.50 & 2.22 & 51.29 & 0.15 & 0.05 \\
\hline S5I & 67.39 & 18.79 & 0.18 & 0.00 & 0.34 & 0.05 & 0.03 & 5.29 & 8.60 & 100.69 & 47.50 & 1.69 & 50.81 & 0.05 & 0.13 \\
\hline S5I2 & 66.76 & 18.83 & 0.23 & 0.00 & 0.43 & 0.04 & 0.04 & 5.44 & 8.50 & 100.36 & 48.27 & 2.11 & 49.62 & 0.07 & 0.11 \\
\hline S5MR & 67.51 & 18.69 & 0.17 & 0.00 & 0.36 & 0.03 & 0.05 & 5.26 & 8.89 & 100.96 & 46.52 & 1.76 & 51.72 & 0.09 & 0.08 \\
\hline S5R & 66.91 & 18.76 & 0.20 & 0.00 & 0.37 & 0.06 & 0.07 & 5.06 & 8.83 & 100.27 & 45.69 & 1.85 & 52.46 & 0.13 & 0.16 \\
\hline S6E & 66.76 & 18.72 & 0.19 & 0.02 & 0.43 & 0.07 & 0.05 & 5.20 & 8.83 & 100.27 & 46.23 & 2.11 & 51.65 & 0.09 & 0.19 \\
\hline S6I & 67.43 & 18.97 & 0.16 & 0.00 & 0.41 & 0.06 & 0.08 & 5.08 & 8.86 & 101.04 & 45.62 & 2.03 & 52.35 & 0.15 & 0.16 \\
\hline S7GL6I & 67.39 & 18.72 & 0.17 & 0.01 & 0.41 & 0.06 & 0.04 & 5.16 & 8.81 & 100.76 & 46.14 & 2.03 & 51.83 & 0.07 & 0.16 \\
\hline S7GL6I2 & 67.50 & 18.72 & 0.16 & 0.01 & 0.37 & 0.05 & 0.02 & 5.21 & 8.85 & 100.89 & 46.36 & 1.82 & 51.82 & 0.04 & 0.13 \\
\hline S7GL6MR & 66.74 & 18.80 & 0.18 & 0.00 & 0.39 & 0.07 & 0.01 & 5.04 & 8.98 & 100.21 & 45.15 & 1.93 & 52.92 & 0.02 & 0.19 \\
\hline S7GL6R & 67.44 & 18.78 & 0.17 & 0.00 & 0.36 & 0.04 & 0.03 & 5.03 & 9.24 & 101.09 & 44.48 & 1.76 & 53.76 & 0.05 & 0.11 \\
\hline S7GL6R2 & 66.28 & 18.71 & 0.18 & 0.00 & 0.42 & 0.06 & 0.08 & 5.25 & 8.90 & 99.88 & 46.31 & 2.05 & 51.65 & 0.14 & 0.16 \\
\hline S9C & 66.72 & 19.04 & 0.19 & 0.02 & 0.43 & 0.06 & 0.05 & 5.37 & 8.93 & 100.81 & 46.76 & 2.07 & 51.17 & 0.09 & 0.16 \\
\hline S9MC & 66.71 & 19.03 & 0.21 & 0.00 & 0.44 & 0.08 & 0.08 & 5.32 & 8.90 & 100.79 & 46.59 & 2.13 & 51.28 & 0.14 & 0.21 \\
\hline \$9MC2 & 66.69 & 18.75 & 0.20 & 0.00 & 0.40 & 0.09 & 0.03 & 5.47 & 9.12 & 100.76 & 46.79 & 1.89 & 51.32 & 0.05 & 0.23 \\
\hline S9MR & 66.97 & 18.90 & 0.18 & 0.00 & 0.40 & 0.05 & 0.06 & 5.12 & 8.90 & 100.58 & 45.73 & 1.97 & 52.30 & 0.11 & 0.13 \\
\hline S9MR2 & 66.81 & 18.96 & 0.15 & 0.02 & 0.43 & 0.03 & 0.00 & 5.07 & 9.36 & 100.82 & 44.22 & 2.07 & 53.71 & 0.00 & 0.08 \\
\hline S9MR3 & 66.19 & 18.83 & 0.18 & 0.00 & 0.41 & 0.06 & 0.03 & 5.09 & 9.27 & 100.06 & 44.59 & 1.98 & 53.43 & 0.05 & 0.16 \\
\hline S9R & 67.04 & 19.02 & 0.18 & 0.01 & 0.43 & 0.04 & 0.09 & 5.18 & 9.00 & 100.98 & 45.68 & 2.10 & 52.22 & 0.16 & 0.11 \\
\hline
\end{tabular}

PST101m10

\begin{tabular}{|c|c|c|c|c|c|c|c|c|c|c|c|c|c|c|c|}
\hline S10GL7I2 & 66.32 & 18.68 & 0.13 & 0.02 & 0.35 & 0.03 & 0.03 & 5.15 & 9.25 & 99.95 & 45.06 & 1.69 & 53.25 & 0.05 & 0.08 \\
\hline S10GL7MI & 65.39 & 18.66 & 0.16 & 0.02 & 0.43 & 0.01 & 0.05 & 5.04 & 9.14 & 98.88 & 44.64 & 2.10 & 53.26 & 0.09 & 0.03 \\
\hline S10GL7MR & 67.14 & 18.76 & 0.19 & 0.02 & 0.34 & 0.03 & 0.09 & 4.85 & 9.59 & 101.02 & 42.74 & 1.66 & 55.60 & 0.16 & 0.08 \\
\hline S10GL7MR2 & 66.04 & 18.23 & 0.17 & 0.02 & 0.35 & 0.06 & 0.04 & 4.85 & 9.53 & 99.30 & 42.87 & 1.71 & 55.42 & 0.07 & 0.16 \\
\hline S10GL7MR3 & 66.47 & 18.62 & 0.14 & 0.03 & 0.43 & 0.01 & 0.06 & 4.87 & 9.44 & 100.07 & 43.03 & 2.10 & 54.87 & 0.11 & 0.03 \\
\hline S10GL7MR4 & 66.87 & 18.64 & 0.15 & 0.02 & 0.34 & 0.07 & 0.04 & 5.00 & 9.41 & 100.54 & 43.94 & 1.65 & 54.41 & 0.07 & 0.18 \\
\hline S10GL7R & 66.54 & 18.56 & 0.16 & 0.01 & 0.36 & 0.01 & 0.05 & 5.45 & 8.75 & 99.88 & 47.78 & 1.74 & 50.47 & 0.09 & 0.03 \\
\hline S10GL7R2 & 66.47 & 18.55 & 0.15 & 0.02 & 0.35 & 0.05 & 0.05 & 5.12 & 9.25 & 100.02 & 44.92 & 1.70 & 53.39 & 0.09 & 0.13 \\
\hline S10GL7R3 & 66.03 & 18.42 & 0.14 & 0.03 & 0.36 & 0.04 & 0.08 & 5.18 & 9.01 & 99.28 & 45.81 & 1.76 & 52.43 & 0.14 & 0.11 \\
\hline S11GL9I & 66.09 & 19.01 & 0.14 & 0.00 & 0.37 & 0.11 & 0.03 & 5.09 & 9.35 & 100.19 & 44.47 & 1.79 & 53.74 & 0.05 & 0.29 \\
\hline S11GL9R & 66.33 & 19.03 & 0.16 & 0.00 & 0.41 & 0.11 & 0.07 & 5.24 & 9.14 & 100.49 & 45.64 & 1.97 & 52.38 & 0.12 & 0.29 \\
\hline S12GL10I & 66.34 & 18.89 & 0.19 & 0.00 & 0.36 & 0.04 & 0.00 & 5.06 & 9.46 & 100.34 & 44.07 & 1.73 & 54.20 & 0.00 & 0.10 \\
\hline S12GL10MR & 66.51 & 19.00 & 0.14 & 0.00 & 0.34 & 0.03 & 0.00 & 4.93 & 9.44 & 100.40 & 43.52 & 1.66 & 54.82 & 0.00 & 0.08 \\
\hline S12GL10MR2 & 65.57 & 19.00 & 0.13 & 0.01 & 0.37 & 0.00 & 0.01 & 5.01 & 9.36 & 99.45 & 44.05 & 1.80 & 54.15 & 0.02 & 0.00 \\
\hline S12GL10MR4 & 66.75 & 18.83 & 0.18 & 0.00 & 0.35 & 0.03 & 0.08 & 4.98 & 9.30 & 100.50 & 44.10 & 1.71 & 54.19 & 0.14 & 0.08 \\
\hline S12GL10R & 65.98 & 19.03 & 0.18 & 0.00 & 0.35 & 0.01 & 0.00 & 5.66 & 8.54 & 99.75 & 49.34 & 1.69 & 48.98 & 0.00 & 0.03 \\
\hline S12GL10R2 & 66.47 & 19.09 & 0.14 & 0.01 & 0.36 & 0.02 & 0.00 & 4.99 & 9.35 & 100.43 & 44.00 & 1.75 & 54.24 & 0.00 & 0.05 \\
\hline S12GL10R3 & 66.62 & 18.92 & 0.13 & 0.00 & 0.38 & 0.02 & 0.00 & 5.13 & 9.08 & 100.27 & 45.34 & 1.86 & 52.80 & 0.00 & 0.05 \\
\hline S12GL10R4 & 66.21 & 19.04 & 0.18 & 0.00 & 0.38 & 0.11 & 0.04 & 5.13 & 9.24 & 100.33 & 44.92 & 1.84 & 53.24 & 0.07 & 0.29 \\
\hline S12GL10MR3 & 66.59 & 18.54 & 0.14 & 0.01 & 0.36 & 0.01 & 0.06 & 4.66 & 9.56 & 99.92 & 41.80 & 1.78 & 56.42 & 0.11 & 0.03 \\
\hline S18E & 66.30 & 18.51 & 0.15 & 0.01 & 0.33 & 0.04 & 0.01 & 5.13 & 9.13 & 99.62 & 45.32 & 1.61 & 53.07 & 0.02 & 0.11 \\
\hline S19E & 65.52 & 18.66 & 0.16 & 0.03 & 0.37 & 0.05 & 0.03 & 4.95 & 9.26 & 99.02 & 44.01 & 1.82 & 54.17 & 0.05 & 0.13 \\
\hline S1GL1C & 65.66 & 19.15 & 0.17 & 0.00 & 0.41 & 0.04 & 0.00 & 5.36 & 9.04 & 99.82 & 46.47 & 1.96 & 51.57 & 0.00 & 0.10 \\
\hline S1GLIMC & 66.15 & 19.08 & 0.18 & 0.00 & 0.40 & 0.04 & 0.01 & 5.01 & 9.38 & 100.25 & 43.94 & 1.94 & 54.12 & 0.02 & 0.10 \\
\hline S1GL1MC2 & 66.23 & 18.98 & 0.13 & 0.00 & 0.36 & 0.03 & 0.00 & 5.03 & 9.24 & 100.01 & 44.48 & 1.76 & 53.76 & 0.00 & 0.08 \\
\hline S1GL1MR & 67.01 & 18.93 & 0.16 & 0.00 & 0.38 & 0.04 & 0.00 & 5.03 & 9.49 & 101.04 & 43.80 & 1.83 & 54.37 & 0.00 & 0.10 \\
\hline S1GL1MR2 & 66.50 & 18.84 & 0.16 & 0.01 & 0.39 & 0.02 & 0.00 & 4.99 & 9.36 & 100.28 & 43.91 & 1.90 & 54.19 & 0.00 & 0.05 \\
\hline
\end{tabular}


Appendix 1. Sanidine compositions-Continued.

\begin{tabular}{|c|c|c|c|c|c|c|c|c|c|c|c|c|c|c|c|}
\hline $\begin{array}{l}\text { Oxide wi pct or } \\
\text { feldspar mol pct }\end{array}$ & $\mathrm{SiO}_{2}$ & $\mathrm{~A}_{2} \mathrm{O}_{2}$ & $\mathrm{Fe}_{2} \mathrm{O}_{3}$ & $\mathrm{MgO}$ & $\mathrm{CaO}$ & Sro & $\mathrm{BaO}$ & $\mathrm{Na}_{2} \mathrm{O}$ & $\mathrm{K}_{2} \mathrm{O}$ & Total & $\mathbf{A b}$ & An & Or & Celsian & Sr-Feldspar \\
\hline \multicolumn{16}{|c|}{ PST101m10—Continued } \\
\hline S1GLIR & 67.02 & 19.21 & 0.16 & 0.00 & 0.36 & 0.03 & 0.05 & 5.13 & 8.91 & 100.86 & 45.84 & 1.78 & 52.38 & 0.09 & 0.08 \\
\hline S10GL7I & 66.11 & 18.50 & 0.18 & 0.02 & 0.38 & 0.06 & 0.06 & 5.09 & 9.33 & 99.72 & 44.50 & 1.84 & 53.67 & 0.11 & 0.16 \\
\hline S20GL23C & 66.85 & 18.87 & 0.16 & 0.00 & 0.40 & 0.00 & 0.06 & 5.13 & 9.29 & 100.75 & 44.75 & 1.93 & 53.32 & 0.11 & 0.00 \\
\hline S20GL23R & 66.81 & 18.75 & 0.17 & 0.00 & 0.37 & 0.00 & 0.08 & 5.29 & 8.81 & 100.29 & 46.85 & 1.81 & 51.34 & 0.14 & 0.00 \\
\hline S21MP1E & 66.55 & 18.53 & 0.20 & 0.00 & 0.40 & 0.04 & 0.10 & 5.33 & 9.14 & 100.31 & 46.09 & 1.91 & 52.00 & 0.17 & 0.10 \\
\hline S21MP1I & 65.64 & 18.58 & 0.15 & 0.01 & 0.44 & 0.08 & 0.11 & 4.97 & 9.18 & 99.17 & 44.17 & 2.16 & 53.67 & 0.20 & 0.21 \\
\hline S21MP1ME & 65.86 & 18.52 & 0.19 & 0.01 & 0.38 & 0.05 & 0.04 & 5.07 & 9.23 & 99.35 & 44.66 & 1.85 & 53.49 & 0.07 & 0.13 \\
\hline S21MPIME2 & 66.49 & 18.66 & 0.16 & 0.01 & 0.38 & 0.07 & 0.04 & 5.17 & 9.13 & 100.12 & 45.40 & 1.84 & 52.75 & 0.07 & 0.18 \\
\hline S21MP1MI & 65.91 & 18.70 & 0.15 & 0.01 & 0.38 & 0.06 & 0.14 & 4.92 & 9.21 & 99.48 & 43.97 & 1.88 & 54.15 & 0.25 & 0.16 \\
\hline S22GL25C & 66.39 & 18.97 & 0.19 & 0.00 & 0.40 & 0.10 & 0.04 & 4.96 & 9.25 & 100.30 & 44.02 & 1.96 & 54.02 & 0.07 & 0.27 \\
\hline S22GL25MC & 66.30 & 19.00 & 0.17 & 0.00 & 0.42 & 0.09 & 0.04 & 5.07 & 9.34 & 100.42 & 44.29 & 2.03 & 53.68 & 0.07 & 0.24 \\
\hline S22GL25MC2 & 66.10 & 18.84 & 0.16 & 0.00 & 0.38 & 0.12 & 0.05 & 5.13 & 9.47 & 100.24 & 44.34 & 1.81 & 53.85 & 0.09 & 0.31 \\
\hline S22GL25MR & 66.82 & 19.18 & 0.17 & 0.00 & 0.37 & 0.13 & 0.00 & 4.94 & 9.23 & 100.83 & 44.04 & 3.82 & 54.14 & 0.00 & 0.35 \\
\hline S22GL25MR2 & 66.13 & 19.06 & 0.16 & 0.00 & 0.39 & 0.11 & 0.07 & 5.21 & 9.28 & 100.41 & 45.18 & 1.87 & 52.95 & 0.12 & 0.29 \\
\hline S22GL25MR3 & 65.97 & 18.90 & 0.15 & 0.00 & 0.42 & 0.09 & 0.09 & 5.03 & 9.40 & 100.05 & 43.94 & 2.03 & 54.03 & 0.16 & 0.24 \\
\hline S22GL25MR4 & 66.53 & 18.92 & 0.17 & 0.00 & 0.37 & 0.10 & 0.03 & 4.97 & 9.47 & 100.54 & 43.58 & 1.79 & 54.63 & 0.05 & 0.26 \\
\hline S22GL25MR5 & 66.54 & 19.11 & 0.16 & 0.00 & 0.43 & 0.10 & 0.06 & 5.18 & 9.24 & 100.82 & 45.06 & 2.07 & 52.88 & 0.11 & 0.26 \\
\hline S22GL25R & 66.61 & 19.11 & 0.14 & 0.00 & 0.36 & 0.07 & 0.06 & 5.13 & 9.50 & 100.98 & 44.30 & 1.72 & 53.98 & 0.10 & 0.18 \\
\hline S22GL25R2 & 66.70 & 19.07 & 0.17 & 0.00 & 0.36 & 0.11 & 0.04 & 4.87 & 9.51 & 100.84 & 43.00 & 1.76 & 55.24 & 0.07 & 0.29 \\
\hline S23PU6I & 66.39 & 18.81 & 0.15 & 0.00 & 0.34 & 0.03 & 0.05 & 5.23 & 8.81 & 99.80 & 46.64 & 1.68 & 51.69 & 0.09 & 0.08 \\
\hline S23PU6MR & 67.22 & 19.02 & 0.20 & 0.00 & 0.34 & 0.07 & 0.03 & 5.13 & 8.99 & 101.00 & 45.67 & 1.67 & 52.66 & 0.05 & 0.19 \\
\hline S23PU6R & 66.58 & 18.97 & 0.15 & 0.00 & 0.30 & 0.07 & 0.02 & 5.09 & 9.29 & 100.48 & 44.77 & 1.46 & 53.77 & 0.04 & 0.18 \\
\hline S30MR & 66.47 & 18.35 & 0.16 & 0.02 & 0.35 & 0.06 & 0.08 & 5.29 & 9.04 & 99.82 & 46.28 & 1.69 & 52.03 & 0.14 & 0.16 \\
\hline S30R & 65.73 & 18.56 & 0.16 & 0.00 & 0.37 & 0.00 & 0.02 & 5.56 & 8.78 & 99.18 & 48.18 & 1.77 & 50.05 & 0.04 & 0.00 \\
\hline S33PU7I & 66.62 & 18.97 & 0.18 & 0.00 & 0.36 & 0.08 & 0.07 & 5.20 & 9.25 & 100.72 & 45.28 & 1.73 & 52.99 & 0.12 & 0.21 \\
\hline S33PU7R & 67.32 & 18.80 & 0.16 & 0.01 & 0.37 & 0.06 & 0.08 & 5.04 & 9.08 & 100.92 & 44.93 & 1.82 & 53.25 & 0.14 & 0.16 \\
\hline S34R & 66.62 & 18.83 & 0.19 & 0.00 & 0.36 & 0.07 & 0.09 & 4.93 & 9.45 & 100.55 & 43.45 & 1.75 & 54.80 & 0.16 & 0.18 \\
\hline S40PU4R & 67.43 & 19.51 & 0.18 & 0.00 & 0.49 & 0.07 & 0.07 & 7.55 & 4.85 & 100.16 & 68.56 & 2.46 & 28.98 & 0.13 & 0.19 \\
\hline S40PU4R2 & 67.45 & 19.06 & 0.19 & 0.00 & 0.53 & 0.05 & 0.04 & 8.39 & 4.20 & 99.90 & 73.30 & 2.56 & 24.14 & 0.07 & 0.13 \\
\hline S6E & 65.75 & 18.74 & 0.18 & 0.01 & 0.44 & 0.04 & 0.01 & 5.27 & 8.75 & 99.20 & 46.76 & 2.16 & 51.08 & 0.02 & 0.11 \\
\hline S8GL28I & 67.17 & 18.77 & 0.18 & 0.00 & 0.35 & 0.05 & 0.03 & 4.88 & 9.40 & 100.84 & 43.35 & 1.72 & 54.94 & 0.05 & 0.13 \\
\hline S8GL28MI & 66.98 & 18.86 & 0.16 & 0.01 & 0.33 & 0.02 & 0.06 & 4.74 & 9.46 & 100.61 & 42.52 & 1.64 & 55.84 & 0.11 & 0.05 \\
\hline S8GL28MR & 66.43 & 18.78 & 0.15 & 0.00 & 0.34 & 0.03 & 0.06 & 5.10 & 9.35 & 100.23 & 44.58 & 1.64 & 53.78 & 0.11 & 0.08 \\
\hline S8GL28R & 67.17 & 18.88 & 0.15 & 0.00 & 0.31 & 0.05 & 0.03 & 5.22 & 9.05 & 100.87 & 46.01 & 1.51 & 52.48 & 0.05 & 0.13 \\
\hline S9GL29E & 66.96 & 18.81 & 0.16 & 0.00 & 0.34 & 0.02 & 0.08 & 5.12 & 9.15 & 100.64 & 45.20 & 1.66 & 53.14 & 0.14 & 0.05 \\
\hline S9GL29I & 66.65 & 18.83 & 0.19 & 0.00 & 0.36 & 0.05 & 0.06 & 5.03 & 9.34 & 100.52 & 44.22 & 1.75 & 54.03 & 0.11 & 0.13 \\
\hline S9GL29MI & 66.74 & 18.76 & 0.19 & 0.01 & 0.34 & 0.11 & 0.08 & 5.17 & 9.31 & 100.72 & 45.02 & 1.64 & 53.34 & 0.14 & 0.29 \\
\hline S9GL29MR & 66.32 & 18.59 & 0.20 & 0.00 & 0.38 & 0.04 & 0.02 & 4.98 & 9.30 & 99.83 & 44.04 & 1.86 & 54.11 & 0.04 & 0.11 \\
\hline S9GL29R & 66.85 & 18.77 & 0.14 & 0.01 & 0.35 & 0.01 & 0.10 & 5.48 & 8.26 & 99.97 & 49.33 & 1.74 & 48.92 & 0.18 & 0.03 \\
\hline S9GL29R2 & 66.07 & 18.40 & 0.18 & 0.02 & 0.36 & 0.03 & 0.03 & 5.81 & 8.43 & 99.32 & 50.28 & 1.72 & 48.00 & 0.05 & 0.08 \\
\hline \multicolumn{16}{|l|}{ PST101m64 } \\
\hline S10MS1C & 67.03 & 19.17 & 0.12 & 0.00 & 0.41 & 0.06 & 0.02 & 4.64 & 8.87 & 100.33 & 43.35 & 2.12 & 54.53 & 0.04 & 0.17 \\
\hline S10MS1C2 & 67.95 & 19.14 & 0.11 & 0.00 & 0.37 & 0.07 & 0.01 & 4.64 & 9.23 & 101.52 & 42.50 & 1.87 & 55.63 & 0.02 & 0.19 \\
\hline S10MS1R & 67.12 & 18.87 & 0.14 & 0.00 & 0.35 & 0.08 & 0.03 & 4.73 & 9.14 & 100.46 & 43.25 & 1.77 & 54.98 & 0.06 & 0.22 \\
\hline Sic & 67.15 & 18.78 & 0.11 & 0.00 & 0.35 & 0.10 & 0.03 & 4.66 & 9.35 & 100.53 & 42.34 & 1.76 & 55.90 & 0.06 & 0.27 \\
\hline S2C & 67.20 & 18.68 & 0.12 & 0.00 & 0.36 & 0.10 & 0.14 & 4.52 & 9.28 & 100.40 & 41.76 & 1.84 & 56.41 & 0.26 & 0.28 \\
\hline $\mathrm{s} 3 \mathrm{C}$ & 66.84 & 18.70 & 0.20 & 0.00 & 0.40 & 0.07 & 0.06 & 5.26 & 9.20 & 100.75 & 45.60 & 1.92 & 52.48 & 0.11 & 0.18 \\
\hline S3R & 67.22 & 18.93 & 0.19 & 0.00 & 0.38 & 0.07 & 0.06 & 5.45 & 8.79 & 101.08 & 47.63 & 1.84 & 50.54 & 0.11 & 0.18 \\
\hline S4C & 67.38 & 18.53 & 0.20 & 0.00 & 0.38 & 0.08 & 0.07 & 5.15 & 9.54 & 101.33 & 44.26 & 1.80 & 53.94 & 0.12 & 0.21 \\
\hline S4R & 67.15 & 18.75 & 0.17 & 0.00 & 0.39 & 0.06 & 0.13 & 5.14 & 9.27 & 101.07 & 44.87 & 1.88 & 53.25 & 0.23 & 0.16 \\
\hline S5R & 66.93 & 18.81 & 0.21 & 0.00 & 0.43 & 0.04 & 0.06 & 5.40 & 9.19 & 101.08 & 46.22 & 2.03 & 51.75 & 0.10 & 0.10 \\
\hline S6R & 67.13 & 19.11 & 0.20 & 0.00 & 0.40 & 0.08 & 0.00 & 5.45 & 9.05 & 101.42 & 46.88 & 1.90 & 51.22 & 0.00 & 0.21 \\
\hline
\end{tabular}


Appendix 1. Sanidine compositions-Continued.

\begin{tabular}{|c|c|c|c|c|c|c|c|c|c|c|c|c|c|c|c|}
\hline $\begin{array}{l}\text { Oxide wi pet or } \\
\text { feldspar mol pct }\end{array}$ & $\mathrm{SiO}_{2}$ & $\mathrm{~A}_{2} \mathrm{O}_{2}$ & $\mathrm{Fe}_{2} \mathrm{O}_{3}$ & $\mathrm{MgO}$ & $\mathrm{CaO}$ & SrO & $\mathrm{BaO}$ & $\mathrm{Na}_{2} \mathrm{O}$ & $\mathrm{K}_{2} \mathrm{O}$ & Total & $\mathbf{A b}$ & An & Or & Celsian & Sr-Feldspar \\
\hline \multicolumn{16}{|c|}{ PST101m64—Continued } \\
\hline S7C & 66.92 & 19.39 & 0.18 & 0.00 & 0.41 & 0.08 & 0.04 & 5.36 & 8.89 & 101.27 & 46.87 & 1.98 & 51.15 & 0.07 & 0.21 \\
\hline$S 7 R$ & 67.70 & 18.90 & 0.18 & 0.00 & 0.38 & 0.06 & 0.08 & 5.29 & 9.29 & 101.88 & 45.56 & 1.81 & 52.64 & 0.14 & 0.15 \\
\hline S8R & 66.74 & 18.74 & 0.20 & 0.00 & 0.42 & 0.05 & 0.05 & 5.31 & 9.21 & 100.73 & 45.77 & 2.00 & 52.23 & 0.09 & 0.13 \\
\hline S9C & 66.89 & 18.74 & 0.21 & 0.00 & 0.42 & 0.07 & 0.00 & 5.52 & 8.69 & 100.54 & 48.13 & 2.02 & 49.85 & 0.00 & 0.18 \\
\hline S9R & 67.44 & 19.06 & 0.16 & 0.01 & 0.42 & 0.07 & 0.10 & 5.48 & 8.99 & 101.73 & 47.13 & 2.00 & 50.87 & 0.17 & 0.18 \\
\hline
\end{tabular}

Cook Canyon tuff-Basal fallout deposits (Tccb)

PST008m2

\begin{tabular}{|c|c|c|c|c|c|c|c|c|c|c|c|c|c|c|c|}
\hline S1MP1PU4I & 63.90 & 19.65 & 0.26 & 0.00 & 0.65 & 0.26 & 2.02 & 4.23 & 9.35 & 100.32 & 39.38 & 3.34 & 57.27 & 3.80 & 0.72 \\
\hline SIMP1PU412 & 64.97 & 19.96 & 0.24 & 0.00 & 0.69 & 0.24 & 1.97 & 4.29 & 9.48 & 101.84 & 39.33 & 3.50 & 57.18 & 3.65 & 0.66 \\
\hline S1MP1PU4MI & 64.63 & 19.71 & 0.26 & 0.00 & 0.71 & 0.25 & 2.04 & 4.29 & 9.27 & 101.17 & 39.79 & 3.64 & 56.57 & 3.82 & 0.69 \\
\hline SIMPIPU4R & 64.36 & 19.73 & 0.24 & 0.00 & 0.66 & 0.24 & 2.05 & 4.22 & 9.38 & 100.88 & 39.23 & 3.39 & 57.38 & 3.85 & 0.67 \\
\hline S1MP1PU4R2 & 64.52 & 19.84 & 0.29 & 0.00 & 0.71 & 0.23 & 1.91 & 4.24 & 9.35 & 101.08 & 39.32 & 3.64 & 57.04 & 3.58 & 0.64 \\
\hline S2MP2PU4I & 63.92 & 19.92 & 0.30 & 0.00 & 0.81 & 0.28 & 2.43 & 4.40 & 8.98 & 101.03 & 40.91 & 4.16 & 54.93 & 4.57 & 0.78 \\
\hline S2MP2PU4I & 64.58 & 19.80 & 0.25 & 0.00 & 0.75 & 0.27 & 2.40 & 4.30 & 9.11 & 101.46 & 40.16 & 3.87 & 55.97 & 4.53 & 0.75 \\
\hline S2MP2PU4MI & 64.00 & 19.74 & 0.32 & 0.00 & 0.62 & 0.34 & 2.28 & 4.41 & 9.34 & 101.05 & 40.47 & 3.14 & 56.39 & 4.23 & 0.93 \\
\hline S2MP2PU4R & 64.91 & 19.42 & 0.25 & 0.00 & 0.49 & 0.22 & 1.34 & 4.27 & 9.80 & 100.70 & 38.86 & 2.46 & 58.68 & 2.46 & 0.60 \\
\hline
\end{tabular}

Cook Canyon tuff-Ignimbrite? (ig?)

PST102m2 (CCT?)

\begin{tabular}{|c|c|c|c|c|c|c|c|c|c|c|c|c|c|c|}
\hline S1GL1R & 64.28 & 19.70 & 0.24 & 0.0 & 0.6 & 0.24 & 2.01 & 4.21 & 9.36 & 100.68 & 39.24 & 3.39 & 57.37 & 3.80 \\
\hline
\end{tabular}

Tuff unit A of Fort Rock Creek rhyodacite unit

PST005

\begin{tabular}{|c|c|c|c|c|c|c|c|c|c|c|c|c|c|c|c|}
\hline S10PU24C & 64.71 & 19.38 & 0.11 & 0.00 & 0.27 & 0.23 & 0.98 & 3.18 & 11.75 & 100.60 & 28.75 & 1.35 & 69.90 & 1.79 & 0.62 \\
\hline S10PU24R & 63.37 & 19.30 & 0.12 & 0.00 & 0.20 & 0.29 & 1.99 & 3.15 & 11.47 & 99.89 & 29.15 & 1.02 & 69.83 & 3.72 & 0.80 \\
\hline S12GL19I & 63.94 & 19.58 & 0.13 & 0.00 & 0.15 & 0.35 & 2.51 & 3.10 & 11.26 & 101.01 & 29.27 & 0.78 & 69.95 & 4.79 & 0.99 \\
\hline S12GL19R & 64.61 & 19.28 & 0.11 & 0.00 & 0.18 & 0.36 & 1.64 & 3.04 & 11.65 & 100.87 & 28.14 & 0.92 & 70.94 & 3.07 & 1.00 \\
\hline$S 13 C$ & 63.38 & 19.45 & 0.10 & 0.00 & 0.28 & 0.26 & 1.63 & 3.22 & 11.62 & 99.93 & 29.22 & 1.40 & 69.38 & 2.99 & 0.71 \\
\hline S13R & 63.53 & 19.22 & 0.10 & 0.00 & 0.22 & 0.30 & 1.89 & 3.20 & 11.53 & 99.99 & 29.34 & 1.11 & 69.55 & 3.50 & 0.82 \\
\hline S1GL3E & 63.00 & 19.29 & 0.11 & 0.00 & 0.19 & 0.30 & 1.91 & 3.07 & 11.76 & 99.62 & 28.13 & 0.96 & 70.90 & 3.54 & 0.82 \\
\hline SIGL3I & 63.80 & 19.39 & 0.10 & 0.01 & 0.22 & 0.26 & 1.28 & 3.21 & 11.77 & 100.06 & 28.98 & 1.10 & 69.92 & 2.34 & 0.70 \\
\hline S2GL5C & 63.97 & 19.42 & 0.11 & 0.01 & 0.26 & 0.28 & 1.66 & 3.20 & 11.61 & 100.54 & 29.14 & 1,31 & 69.55 & 3.05 & 0.76 \\
\hline S2GL5R & 64.41 & 18.98 & 0.13 & 0.00 & 0.16 & 0.20 & 0.31 & 3.30 & 12.19 & 99.69 & 28.93 & 0.77 & 70.30 & 0.55 & 0.52 \\
\hline S3I & 63.77 & 19.21 & 0.10 & 0.00 & 0.20 & 0.31 & 1.92 & 3.03 & 11.49 & 100.02 & 28.32 & 1.03 & 70.65 & 3.63 & 0.87 \\
\hline S4GL15I & 65.94 & 18.73 & 0.09 & 0.00 & 0.13 & 0.14 & 0.31 & 3.24 & 12.26 & 100.86 & 28.48 & 0.63 & 70.89 & 0.55 & 0.37 \\
\hline S4GL15R & 64.81 & 18.99 & 0.08 & 0.00 & 0.20 & 0.21 & 0.75 & 3.23 & 12.22 & 100.50 & 28.38 & 0.97 & 70.65 & 1.33 & 0.55 \\
\hline S5E & 64.16 & 19.15 & 0.15 & 0.00 & 0.29 & 0.30 & 1.52 & 3.44 & 11.15 & 100.17 & 31.46 & 1.47 & 67.08 & 2.81 & 0.82 \\
\hline S5I & 64.40 & 19.18 & 0.10 & 0.00 & 0.21 & 0.28 & 1.14 & 3.28 & 11.90 & 100.48 & 29.22 & 1.03 & 69.75 & 2.05 & 0.75 \\
\hline S6GL16I & 63.45 & 19.34 & 0.11 & 0.00 & 0.22 & 0.32 & 2.02 & 3.00 & 11.42 & 99.89 & 28.21 & 1.14 & 70.65 & 3.84 & 0.90 \\
\hline S6GL16R & 64.21 & 19.39 & 0.12 & 0.00 & 0.21 & 0.29 & 1.83 & 3.22 & 11.56 & 100.83 & 29.43 & 1.06 & 69.51 & 3.38 & 0.79 \\
\hline S7GL17E & 65.00 & 19.14 & 0.12 & 0.00 & 0.22 & 0.24 & 0.89 & 3.18 & 11.77 & 100.57 & 28.79 & 1.10 & 70.11 & 1.63 & 0.65 \\
\hline S7GL17I & 63.39 & 19.60 & 0.12 & 0.00 & 0.26 & 0.27 & 2.53 & 3.13 & 11.29 & 100.59 & 29.25 & 1.34 & 69.41 & 4.78 & 0.75 \\
\hline S8GL18E & 65.14 & 19.26 & 0.11 & 0.00 & 0.20 & 0.28 & 0.78 & 3.35 & 11.90 & 101.02 & 29.67 & 0.98 & 69.35 & 1.40 & 0.74 \\
\hline S8GL18I & 64.83 & 18.98 & 0.14 & 0.00 & 0.24 & 0.27 & 0.90 & 3.18 & 11.84 & 100.38 & 28.64 & 1.19 & 70.16 & 1.64 & 0.73 \\
\hline S9PU23I & 63.81 & 19.50 & 0.12 & 0.00 & 0.26 & 0.31 & 1.59 & 3.28 & 11.59 & 100.46 & 29.69 & 1.30 & 69.01 & 2.91 & 0.84 \\
\hline
\end{tabular}

Fallout tuff deposits $\left(\mathrm{ft}_{\mathbf{2}}\right)$

PST025

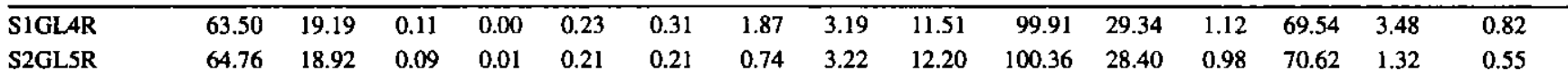


Appendix 1. Sanidine compositions-Continued.

\begin{tabular}{|c|c|c|c|c|c|c|c|c|c|c|c|c|c|c|c|}
\hline $\begin{array}{l}\text { Oxide wt pct or } \\
\text { feldspar mol pct }\end{array}$ & $\mathrm{SiO}_{2}$ & $\mathrm{~A}_{2} \mathrm{O}_{2}$ & $\mathrm{Fe}_{2} \mathrm{O}_{3}$ & $\mathrm{MgO}$ & $\mathrm{CsO}$ & SrO & $\mathrm{BaO}$ & $\mathrm{Na}_{2} \mathrm{O}$ & $\mathrm{K}_{2} \mathrm{O}$ & Total & $\mathbf{A b}$ & An & Or & Celsian & Sr-Feldspar \\
\hline \multicolumn{16}{|c|}{ Wild Horse Mesa Tuff (Twhm) } \\
\hline \multicolumn{16}{|l|}{ Lower member } \\
\hline$S(L M) l$ & 66.47 & 19.06 & 0.17 & nd & 0.30 & nd & nd & 7.19 & 6.44 & 99.63 & 61.96 & 1.43 & 36.61 & nd & nd \\
\hline $\mathrm{S}(\mathbf{L M}) \mathrm{m}$ & 66.86 & 19.15 & 0.14 & nd & 0.30 & nd & nd & 6.83 & 6.97 & 100.25 & 58.91 & 1.43 & 39.66 & nd & nd \\
\hline \multicolumn{16}{|l|}{ Middle member } \\
\hline S(MM)l & 66.79 & 19.06 & 0.18 & nd & 0.22 & nd & nd & 6.98 & 6.74 & 100.07 & 60.45 & 1.05 & 38.50 & nd & nd \\
\hline $\mathbf{S}(\mathbf{M M}) \mathbf{m}$ & 66.52 & 19.03 & 0.20 & nd & 0.27 & nd & nd & 6.63 & 7.27 & 99.92 & 57.38 & 1.29 & 41.33 & nd & nd \\
\hline $\mathrm{S}(\mathrm{MM}) \mathrm{u}$ & 66.50 & 19.14 & 0.17 & nd & 0.25 & nd & nd & 6.61 & 7.43 & 100.01 & 57.03 & 1.19 & 41.77 & nd & nd \\
\hline \multicolumn{16}{|l|}{ Upper member } \\
\hline S(UM)f & 67.09 & 19.08 & 0.40 & nd & 0.26 & nd & nd & 7.37 & 6.32 & 100.52 & 63.09 & 1.23 & 35.68 & nd & nd \\
\hline S(UM)l & 66.61 & 19.19 & 0.36 & nd & 0.26 & nd & nd & 7.29 & 6.34 & 100.14 & 62.76 & 1.24 & 36.00 & nd & nd \\
\hline$S(U M) u$ & 67.34 & 18.65 & 0.32 & nd & 0.18 & nd & nd & 6.65 & 6.43 & 99.57 & 60.51 & 0.90 & 38.59 & nd & nd \\
\hline S(UM)t & 65.71 & 20.10 & 0.30 & nd & 1.09 & nd & nd & 6.27 & 7.52 & 101.01 & 52.99 & 5.10 & 41.92 & nd & nd \\
\hline
\end{tabular}


Appendix 2. Plagioclase compositions.

\begin{tabular}{lllllllllllllllllllll}
\hline $\begin{array}{l}\text { Oxide wt pct or } \\
\text { feldspar mol pct }\end{array}$ & $\mathrm{SiO}_{2}$ & $\mathrm{Al}_{2} \mathrm{O}_{3}$ & $\mathrm{Fe}_{2} \mathrm{O}_{3}$ & $\mathrm{MgO}$ & $\mathrm{CaO}$ & $\mathrm{SrO}$ & $\mathrm{BaO}$ & $\mathrm{Na}_{2} \mathrm{O}$ & $\mathrm{K}_{2} \mathrm{O}$ & Total & Ab & An & Or & $\mathrm{Celsian}$ & $\mathrm{Sr}-\mathrm{Feldspar}$
\end{tabular}

Peach Springs Tuff-Layer 1 (Tpsl $)$

PST045cm5

\begin{tabular}{|c|c|c|c|c|c|c|c|c|c|c|c|c|c|c|c|}
\hline P11GL13I & 64.39 & 21.81 & 0.23 & 0.01 & 3.54 & 0.04 & 0.05 & 8.92 & 1.51 & 100.50 & 75.15 & 16.48 & 8.37 & 0.09 & 0.10 \\
\hline P11GL13R & 65.26 & 21.67 & 0.22 & 0.00 & 3.10 & 0.02 & 0.03 & 8.79 & 1.83 & 100.93 & 75.08 & 14.63 & 10.28 & 0.05 & 0.05 \\
\hline P12CC1GL52E & 63.89 & 21.74 & 0.28 & 0.00 & 3.39 & 0.00 & 0.00 & 8.61 & 1.42 & 99.33 & 75.41 & 16.41 & 8.18 & 0.00 & 0.00 \\
\hline P12CC1GL52E2 & 64.38 & 21.95 & 0.28 & 0.00 & 3.41 & 0.00 & 0.00 & 8.86 & 1.50 & 100.38 & 75.52 & 16.06 & 8.41 & 0.00 & 0.00 \\
\hline P12CC1GL52I & 64.60 & 22.06 & 0.29 & 0.00 & 3.80 & 0.00 & 0.00 & 8.70 & 1.38 & 100.83 & 74.31 & 17.94 & 7.76 & 0.00 & 0.00 \\
\hline P13GL17I & 65.23 & 21.76 & 0.26 & 0.00 & 3.33 & 0.00 & 0.00 & 8.86 & 1.53 & 100.98 & 75.68 & 15.72 & 8.60 & 0.00 & 0.00 \\
\hline P13GL17MI & 64.94 & 21.61 & 0.27 & 0.00 & 3.13 & 0.03 & 0.00 & 8.93 & 1.68 & 100.59 & 75.90 & 14.70 & 9.40 & 0.00 & 0.08 \\
\hline P13GL17R & 65.62 & 21.07 & 0.27 & 0.00 & 2.70 & 0.00 & 0.00 & 8.74 & 1.85 & 100.24 & 76.34 & 13.03 & 10.63 & 0.00 & 0.00 \\
\hline P14E & 60.02 & 24.66 & 0.51 & 0.00 & 7.46 & 0.23 & 0.13 & 6.30 & 1.68 & 100.99 & 54.65 & 35.76 & 9.59 & 0.23 & 0.60 \\
\hline P14I & 59.67 & 24.74 & 0.64 & 0.01 & 7.23 & 0.25 & 0.15 & 6.41 & 1.43 & 100.53 & 56.49 & 35.21 & 8.29 & 0.27 & 0.66 \\
\hline P15GL21I & 63.58 & 22.56 & 0.30 & 0.00 & 4.38 & 0.00 & 0.00 & 8.76 & 1.28 & 100.86 & 72.86 & 20.13 & 7.00 & 0.00 & 0.00 \\
\hline P15GL21R & 65.10 & 21.51 & 0.25 & 0.00 & 3.12 & 0.00 & 0.00 & 8.86 & 1.69 & 100.53 & 75.75 & 14.74 & 9.51 & 0.00 & 0.00 \\
\hline P16GL23I & 64.96 & 22.04 & 0.27 & 0.00 & 3.38 & 0.00 & 0.00 & 8.69 & 1.44 & 100.79 & 75.53 & 16.23 & 8.23 & 0.00 & 0.00 \\
\hline P16GL23I2 & 64.57 & 21.53 & 0.26 & 0.00 & 3.29 & 0.04 & 0.01 & 8.71 & 1.49 & 99.90 & 75.68 & 15.80 & 8.52 & 0.02 & 0.10 \\
\hline P16GL23I3 & 65.27 & 21.86 & 0.24 & 0.03 & 3.34 & 0.06 & 0.04 & 8.77 & 1.43 & 101.04 & 75.89 & 15.97 & 8.14 & 0.07 & 0.16 \\
\hline P16GL23R & 65.93 & 21.22 & 0.26 & 0.00 & 2.52 & 0.00 & 0.00 & 8.94 & 1.91 & 100.78 & 77.14 & 12.02 & 10.84 & 0.00 & 0.00 \\
\hline P17PU12E & 61.36 & 23.91 & 0.52 & 0.01 & 6.73 & 0.11 & 0.03 & 7.26 & 0.91 & 100.85 & 62.71 & 32.12 & 5.17 & 0.05 & 0.28 \\
\hline P17PU12I & 61.64 & 22.98 & 0.45 & 0.11 & 5.61 & 0.11 & 0.13 & 6.86 & 1.56 & 99.45 & 62.44 & 28.22 & 9.34 & 0.24 & 0.30 \\
\hline $\mathrm{P} 19 \mathrm{C}$ & 56.09 & 26.95 & 0.62 & 0.06 & 9.72 & 0.13 & 0.10 & 5.44 & 0.99 & 100.10 & 47.46 & 46.86 & 5.68 & 0.18 & 0.34 \\
\hline P19R & 57.78 & 25.67 & 0.64 & 0.07 & 8.22 & 0.20 & 0.09 & 5.97 & 1.47 & 100.11 & 52.01 & 39.57 & 8.43 & 0.16 & 0.52 \\
\hline P1E & 63.48 & 21.90 & 0.30 & 0.00 & 3.76 & 0.00 & 0.00 & 8.58 & 1.25 & 99.27 & 74.74 & 18.10 & 7.16 & 0.00 & 0.00 \\
\hline P1I & 64.06 & 22.03 & 0.31 & 0.00 & 3.83 & 0.01 & 0.01 & 8.66 & 1.29 & 100.19 & 74.49 & 18.21 & 7.30 & 0.02 & 0.03 \\
\hline P20GL34I & 65.59 & 21.28 & 0.25 & 0.00 & 2.72 & 0.00 & 0.03 & 8.67 & 2.00 & 100.54 & 75.46 & 13.08 & 11.45 & 0.05 & 0.00 \\
\hline P20GL34R & 65.35 & 21.06 & 0.25 & 0.00 & 3.00 & 0.01 & 0.00 & 8.75 & 1.90 & 100.32 & 75.06 & 14.22 & 10.72 & 0.00 & 0.03 \\
\hline P21PU14E & 64.51 & 21.46 & 0.24 & 0.00 & 3.07 & 0.04 & 0.01 & 8.66 & 1.62 & 99.62 & 75.82 & 14.85 & 9.33 & 0.02 & 0.10 \\
\hline P2JPU14I & 64.96 & 21.66 & 0.29 & 0.00 & 3.32 & 0.01 & 0.01 & 8.87 & 1.69 & 100.81 & 75.06 & 15.53 & 9.41 & 0.02 & .0 .03 \\
\hline P22CC2PU15C & 58.92 & 24.47 & 0.65 & 0.02 & 6.75 & 0.65 & 0.31 & 6.58 & 1.42 & 99.78 & 58.52 & 33.17 & 8.31 & 0.56 & 1.73 \\
\hline P22CC2PU15R & 59.06 & 24.13 & 0.61 & 0.02 & 6.38 & 0.56 & 0.27 & 6.56 & 1.66 & 99.25 & 58.69 & 31.54 & 9.77 & 0.49 & 1.50 \\
\hline P23CC2PU15R & 62.38 & 22.37 & 0.45 & 0.00 & 4.03 & 0.39 & 0.74 & 7.46 & 2.53 & 100.36 & 65.72 & 19.62 & 14.66 & 1.32 & 1.03 \\
\hline P26PU19C & 57.94 & 25.37 & 0.47 & 0.03 & 7.95 & 0.33 & 0.29 & 6.16 & 1.37 & 99.90 & 53.78 & 38.35 & 7.87 & 0.51 & 0.86 \\
\hline P26PU19MC & 58.06 & 25.34 & 0.47 & 0.02 & 7.94 & 0.36 & 0.28 & 6.10 & 1.36 & 99.94 & 53.59 & 38.55 & 7.86 & 0.50 & 0.95 \\
\hline P26PU19MC2 & 57.59 & 26.61 & 0.54 & 0.02 & 8.68 & 0.32 & 0.21 & 5.73 & 1.13 & 100.83 & 50.84 & 42.56 & 6.60 & 0.38 & 0.85 \\
\hline P26PU19MC3 & 58.10 & 25.84 & 0.53 & 0.03 & 8.59 & 0.30 & 0.20 & 6.04 & 1.27 & 100.89 & 51.97 & 40.84 & 7.19 & 0.35 & 0.77 \\
\hline P26PU19MC4 & 57.78 & 25.62 & 0.47 & 0.02 & 8.25 & 0.26 & 0.25 & 6.10 & 1.16 & 99.91 & 53.40 & 39.91 & 6.68 & 0.44 & 0.68 \\
\hline P26PU19MR & 58.88 & 24.69 & 0.48 & 0.01 & 6.93 & 0.25 & 0.25 & 6.31 & 1.78 & 99.58 & 55.79 & 33.86 & 10.35 & 0.45 & 0.66 \\
\hline P26PU19MR2 & 59.24 & 24.91 & 0.42 & 0.01 & 7.19 & 0.26 & 0.31 & 6.27 & 1.58 & 100.18 & 55.57 & 35.21 & 9.21 & 0.56 & 0.69 \\
\hline P26PU19R & 58.60 & 25.26 & 0.40 & 0.02 & 7.32 & 0.24 & 0.38 & 6.34 & 1.55 & 100.13 & 55.59 & 35.47 & 8.94 & 0.67 & 0.63 \\
\hline P26PU19R2 & 64.54 & 20.35 & 0.33 & 0.00 & 2.30 & 0.16 & 0.54 & 6.30 & 5.19 & 99.70 & 57.35 & 11.57 & 31.08 & 0.99 & 0.44 \\
\hline P26PU19R3 & 64.17 & 20.31 & 0.32 & 0.00 & 2.01 & 0.14 & 0.65 & 6.50 & 5.54 & 99.64 & 57.75 & 9.87 & 32.38 & 1.17 & 0.37 \\
\hline P26PU19R4 & 58.59 & 24.77 & 0.46 & 0.03 & 7.02 & 0.32 & 0.26 & 6.31 & 1.58 & 99.35 & 56.19 & 34.55 & 9.26 & 0.47 & 0.85 \\
\hline P27PU14I & 65.02 & 21.47 & 0.28 & 0.00 & 3.16 & 0.02 & 0.00 & 8.93 & 1.69 & 100.56 & 75.75 & 14.81 & 9.43 & 0.00 & 0.05 \\
\hline P27PU14MR & 65.18 & 21.16 & 0.22 & 0.00 & 2.76 & 0.00 & 0.00 & 8.92 & 1.82 & 100.06 & 76.62 & 13.10 & 10.28 & 0.00 & 0.00 \\
\hline P27PU14R & 65.36 & 21.20 & 0.24 & 0.00 & 2.90 & 0.01 & 0.00 & 8.95 & 1.90 & 100.56 & 75.83 & 13.58 & 10.59 & 0.00 & 0.03 \\
\hline P29GL30I & 64.72 & 21.87 & 0.26 & 0.00 & 3.54 & 0.00 & 0.00 & 9.02 & 1.44 & 100.86 & 75.65 & 16.41 & 7.95 & 0.00 & 0.00 \\
\hline P29GL30R & 65.50 & 21.10 & 0.25 & 0.00 & 3.03 & 0.00 & 0.00 & 8.61 & 1.72 & 100.21 & 75.42 & 14.67 & 9.91 & 0.00 & 0.00 \\
\hline P30CC JG52E & 64.81 & 21.75 & 0.29 & 0.00 & 3.57 & 0.00 & 0.00 & 8.73 & 1.48 & 100.64 & 74.77 & 16.90 & 8.34 & 0.00 & 0.00 \\
\hline P30CC1GL52] & 65.02 & 21.78 & 0.28 & 0.00 & 3.21 & 0.00 & 0.00 & 8.82 & 1.54 & 100.65 & 75.99 & 15.28 & 8.73 & 0.00 & 0.00 \\
\hline P32GL5E & 65.47 & 21.70 & 0.49 & 0.00 & 3.38 & 0.00 & 0.00 & 8.42 & 1.77 & 101.23 & 73.52 & 16.31 & 10.17 & 0.00 & 0.00 \\
\hline P34PU1R & 64.87 & 21.59 & 0.24 & 0.00 & 3.32 & 0.02 & 0.00 & 8.67 & 1.58 & 100.29 & 75.10 & 15.89 & 9.00 & 0.00 & 0.05 \\
\hline P4E & 64.19 & 21.38 & 0.26 & 0.00 & 3.14 & 0.04 & 0.06 & 8.53 & 1.74 & 99.35 & 74.76 & 15.21 & 10.03 & 0.11 & 0.10 \\
\hline
\end{tabular}


Appendix 2. Plagioclase compositions-Continued.

$\begin{array}{lllllllllllllllll}\begin{array}{l}\text { Oxide wt pet or } \\ \text { feldspar mol pet }\end{array} & \mathrm{SiO}_{2} & \mathrm{Al}_{2} \mathrm{O}_{3} & \mathrm{Fe}_{2} \mathrm{O}_{3} & \mathrm{MgO} & \mathrm{CaO} & \mathrm{SrO} & \mathrm{BaO} & \mathrm{Na}_{2} \mathrm{O} & \mathrm{K}_{2} \mathrm{O} & \text { Total } & \text { Ab } & \text { An } & \text { Or } & \mathrm{Cel} \text { sian } & \mathrm{Sr} \cdot \mathrm{Feldspar}\end{array}$

Peach Springs Tuff-Layer $1\left(\right.$ Tpsl $\left._{1}\right)$-Continued

PST045cm5-Continued

\begin{tabular}{|c|c|c|c|c|c|c|c|c|c|c|c|c|c|c|c|}
\hline P4I & 61.28 & 23.62 & 0.33 & 0.00 & 5.22 & 0.18 & 0.22 & 8.20 & 0.86 & 99.90 & 70.38 & 24.76 & 4.86 & 0.38 & 0.46 \\
\hline P5E & 64.59 & 21.29 & 0.30 & 0.00 & 2.94 & 0.04 & 0.00 & 8.91 & 1.74 & 99.81 & 76.29 & 13.91 & 9.80 & 0.00 & 0.10 \\
\hline P5I & 64.50 & 21.79 & 0.23 & 0.00 & 3.63 & 0.05 & 0.02 & 8.77 & 1.50 & 100.48 & 74.56 & 17.05 & 8.39 & 0.03 & 0.13 \\
\hline P7E & 62.34 & 23.36 & 0.27 & 0.00 & 5.34 & 0.11 & 0.14 & 8.34 & 0.91 & 100.80 & 70.15 & 24.82 & 5.04 & 0.24 & 0.28 \\
\hline P8E & 59.89 & 24.55 & 0.49 & 0.01 & 7.08 & 0.21 & 0.10 & 6.90 & 1.20 & 100.44 & 59.47 & 33.72 & 6.81 & 0.17 & 0.54 \\
\hline P8I & 58.79 & 25.34 & 0.41 & 0.00 & 7.66 & 0.21 & 0.19 & 6.57 & 1.17 & 100.35 & 56.77 & 36.58 & 6.65 & 0.33 & 0.54 \\
\hline P8ME & 59.23 & 24.93 & 0.43 & 0.02 & 7.45 & 0.30 & 0.14 & 6.82 & 1.22 & 100.54 & 58.09 & 35.07 & 6.84 & 0.24 & 0.76 \\
\hline P8MI & 59.04 & 24.96 & 0.39 & 0.03 & 7.29 & 0.30 & 0.15 & 6.66 & 1.24 & 100.05 & 57.89 & 35.02 & 7.09 & 0.26 & 0.78 \\
\hline \multicolumn{16}{|l|}{ PST045cm45 } \\
\hline P13E & 62.19 & 23.30 & 0.18 & 0.00 & 5.01 & 0.09 & 0.09 & 8.39 & 1.03 & 100.27 & 70.88 & 23.39 & 5.73 & 0.15 & 0.23 \\
\hline P13I & 61.07 & 23.81 & 0.15 & 0.00 & 5.91 & 0.13 & 0.12 & 7.56 & 0.93 & 99.67 & 66.10 & 28.55 & 5.35 & 0.21 & 0.34 \\
\hline P14GL16I & 64.76 & 21.78 & 0.08 & 0.00 & 3.52 & 0.02 & 0.00 & 8.78 & 1.31 & 100.25 & 75.77 & 16.79 & 7.44 & 0.00 & 0.05 \\
\hline P14GL16R & 64.74 & 21.47 & 0.05 & 0.00 & 2.94 & 0.00 & 0.07 & 8.76 & 1.64 & 99.69 & 76.42 & 14.17 & 9.41 & 0.12 & 0.00 \\
\hline P15E & 64.52 & 21.73 & 0.12 & 0.00 & 2.94 & 0.00 & 0.04 & 9.04 & 1.65 & 100.03 & 76.93 & 13.83 & 9.24 & 0.07 & 0.00 \\
\hline Pl5I & 64.94 & 21.62 & 0.11 & 0.00 & 3.12 & 0.03 & 0.06 & 8.91 & 1.48 & 100.27 & 76.76 & 14.85 & 8.39 & 0.10 & 0.08 \\
\hline P16GL20E & 64.91 & 21.19 & 0.09 & 0.00 & 2.74 & 0.00 & 0.00 & 9.47 & 1.76 & 100.16 & 77.99 & 12.47 & 9.54 & 0.00 & 0.00 \\
\hline P16GL20I & 63.64 & 22.19 & 0.12 & 0.00 & 3.95 & 0.01 & 0.02 & 8.62 & 1.23 & 99.78 & 74.23 & 18.80 & 6.97 & 0.03 & 0.03 \\
\hline P16GL20ME & 64.88 & 21.37 & 0.08 & 0.00 & 2.96 & 0.02 & 0.02 & 9.00 & 1.62 & 99.95 & 76.91 & 13.98 & 9.11 & 0.03 & 0.05 \\
\hline P17GL20E & 64.54 & 21.58 & 0.09 & 0.00 & 2.96 & 0.01 & 0.03 & 8.75 & 1.73 & 99.70 & 75.93 & 14.19 & 9.88 & 0.05 & 0.03 \\
\hline P17GL20I & 62.59 & 22.75 & 0.11 & 0.00 & 4.33 & 0.02 & 0.03 & 8.30 & 0.95 & 99.09 & 73.34 & 21.14 & 5.52 & 0.05 & 0.05 \\
\hline P1PU1E & 64.36 & 21.62 & 0.11 & 0.00 & 3.25 & 0.04 & 0.00 & 9.00 & 1.52 & 99.89 & 76.30 & 15.23 & 8.48 & 0.00 & 0.10 \\
\hline P1PU1I & 65.11 & 21.95 & 0.07 & 0.00 & 3.21 & 0.02 & 0.03 & 9.12 & 1.54 & 101.04 & 76.59 & 14.90 & 8.51 & 0.05 & 0.05 \\
\hline P1PU112 & 64.78 & 21.86 & 0.27 & 0.00 & 3.31 & 0.06 & 0.00 & 9.00 & 1.56 & 100.84 & 75.91 & 15.43 & 8.66 & 0.00 & 0.15 \\
\hline PIPUIMI & 64.82 & 21.90 & 0.10 & 0.00 & 3.11 & 0.01 & 0.03 & 8.85 & 1.53 & 100.35 & 76.46 & 14.85 & 8.70 & 0.05 & 0.03 \\
\hline P20GL30I & 63.82 & 21.69 & 0.09 & 0.00 & 3.30 & 0.06 & 0.06 & 9.09 & 1.41 & 99.53 & 76.77 & 15.40 & 7.83 & 0.10 & 0.15 \\
\hline P20GL30MR & 64.14 & 21.54 & 0.07 & 0.00 & 3.01 & 0.00 & 0.00 & 8.90 & 1.62 & 99.28 & 76.53 & 14.30 & 9.17 & 0.00 & 0.00 \\
\hline P20GL30R & 64.27 & 21.08 & 0.09 & 0.00 & 2.68 & 0.01 & 0.04 & 8.96 & 1.87 & 98.99 & 76.77 & 12.69 & 10.54 & 0.07 & 0.03 \\
\hline P23I & 62.34 & 23.45 & 0.28 & 0.01 & 5.08 & 0.04 & 0.02 & 8.48 & 0.92 & 100.61 & 71.31 & 23.60 & 5.09 & 0.03 & 0.10 \\
\hline P27GL38I & 63.83 & 21.99 & 0.13 & 0.00 & 3.41 & 0.00 & 0.01 & 8.95 & 1.30 & 99.61 & 76.56 & 16.12 & 7.32 & 0.02 & 0.00 \\
\hline P27GL38MI & 64.71 & 21.69 & 0.11 & 0.00 & 3.30 & 0.02 & 0.01 & 8.83 & 1.29 & 99.97 & 76.77 & 15.85 & 7.38 & 0.02 & 0.05 \\
\hline P27GL38MR & 64.70 & 21.34 & 0.12 & 0.00 & 2.92 & 0.02 & 0.03 & 8.81 & 1.69 & 99.64 & 76.37 & 13.99 & 9.64 & 0.05 & 0.05 \\
\hline P27GL38R & 65.32 & 21.17 & 0.14 & 0.00 & 2.81 & 0.03 & 0.07 & 9.04 & 1.79 & 100.39 & 76.80 & 13.19 & 10.01 & 0.12 & 0.08 \\
\hline Р29СC3E & 64.14 & 22.12 & 0.12 & 0.00 & 3.76 & 0.00 & 0.06 & 8.70 & 1.21 & 100.10 & 75.17 & 17.95 & 6.88 & 0.10 & 0.00 \\
\hline P29CC3I & 64.21 & 22.43 & 0.10 & 0.00 & 3.76 & 0.03 & 0.05 & 8.70 & 1.28 & 100.56 & 74.87 & 17.88 & 7.25 & 0.09 & 0.08 \\
\hline P2E & 64.45 & 21.58 & 0.09 & 0.00 & 3.06 & 0.01 & 0.01 & 8.97 & 1.54 & 99.71 & 76.84 & 14.48 & 8.68 & 0.02 & 0.03 \\
\hline P2E2 & 65.13 & 21.43 & 0.09 & 0.00 & 2.87 & 0.03 & 0.06 & 9.14 & 1.71 & 100.45 & 77.12 & 13.38 & 9.49 & 0.10 & 0.08 \\
\hline P32E & 63.59 & 22.74 & 0.15 & 0.00 & 4.07 & 0.00 & 0.03 & 8.71 & 1.09 & 100.38 & 74.60 & 19.26 & 6.14 & 0.05 & 0.00 \\
\hline P32I & 64.06 & 22.12 & 0.08 & 0.00 & 3.60 & 0.00 & 0.07 & 9.12 & 1.22 & 100.28 & 76.56 & 16.70 & 6.74 & 0.12 & 0.00 \\
\hline P4E & 62.69 & 22.84 & 0.14 & 0.00 & 4.45 & 0.05 & 0.06 & 8.44 & 1.07 & 99.74 & 72.74 & 21.19 & 6.07 & 0.10 & 0.13 \\
\hline P4E2 & 64.77 & 22.13 & 0.13 & 0.00 & 3.36 & 0.04 & 0.07 & 8.91 & 1.45 & 100.86 & 76.02 & 15.84 & 8.14 & 0.12 & 0.10 \\
\hline P4I & 62.78 & 22.82 & 0.12 & 0.00 & 4.37 & 0.04 & 0.04 & 8.63 & 1.05 & 99.84 & 73.54 & 20.58 & 5.89 & 0.07 & 0.10 \\
\hline P5E & 58.52 & 25.60 & 0.46 & 0.00 & 7.91 & 0.21 & 0.19 & 6.54 & 1.36 & 100.80 & 55.40 & 37.02 & 7.58 & 0.33 & 0.53 \\
\hline P5I & 56.95 & 26.19 & 0.45 & 0.03 & 8.76 & 0.27 & 0.10 & 6.02 & 1.10 & 99.88 & 51.97 & 41.79 & 6.25 & 0.17 & 0.70 \\
\hline P5MI & 58.27 & 25.99 & 0.45 & 0.01 & 8.52 & 0.23 & 0.13 & 6.05 & 1.09 & 100.74 & 52.72 & 41.03 & 6.25 & 0.23 & 0.60 \\
\hline P7E & 64.07 & 21.77 & 0.11 & 0.00 & 3.25 & 0.01 & 0.01 & 8.96 & 1.48 & 99.66 & 76.39 & 15.31 & 8.30 & 0.02 & 0.03 \\
\hline P7I & 63.53 & 22.05 & 0.09 & 0.00 & 4.01 & 0.01 & 0.03 & 8.69 & 1.11 & 99.53 & 74.68 & 19.04 & 6.28 & 0.05 & 0.03 \\
\hline P8CCIE & 64.42 & 21.99 & 0.12 & 0.00 & 3.41 & 0.00 & 0.07 & 8.97 & 1.29 & 100.27 & 76.65 & 16.10 & 7.25 & 0.12 & 0.00 \\
\hline P8CC1I & 63.13 & 22.76 & 0.11 & 0.00 & 4.28 & 0.05 & 0.05 & 8.75 & 1.01 & 100.14 & 74.28 & 20.08 & 5.64 & 0.09 & 0.13 \\
\hline P9CCIE & 64.86 & 21.47 & 0.09 & 0.00 & 2.99 & 0.03 & 0.01 & 8.80 & 1.71 & 99.94 & 76.01 & 14.27 & 9.72 & 0.02 & 0.08 \\
\hline P9CC1I & 64.06 & 21.83 & 0.11 & 0.00 & 3.41 & 0.01 & 0.00 & 9.02 & 1.46 & 99.90 & 76.02 & 15.88 & 8.10 & 0.00 & 0.03 \\
\hline
\end{tabular}


Appendix 2. Plagioclase compositions-Continued.

\begin{tabular}{|c|c|c|c|c|c|c|c|c|c|c|c|c|c|c|c|}
\hline $\begin{array}{l}\text { Oxide wt pet or } \\
\text { feldspar mol pet }\end{array}$ & $\mathrm{SiO}_{2}$ & $\mathrm{Al}_{2} \mathrm{O}_{3}$ & $\mathrm{Fe}_{2} \mathrm{O}_{3}$ & $\mathrm{MgO}$ & $\mathrm{CaO}$ & Sno & $\mathrm{BaO}$ & $\mathrm{Na}_{2} \mathrm{O}$ & $\mathrm{K}_{2} \mathrm{O}$ & Total & $A b$ & $A_{n}$ & Or & Celsian & Sr-Feldspar \\
\hline \multicolumn{16}{|c|}{ PST045cm45-Continued } \\
\hline P9CCIME & 64.75 & 21.38 & 0.08 & 0.00 & 2.81 & 0.00 & 0.01 & 8.84 & 1.68 & 99.54 & 76.88 & 13.50 & 9.61 & 0.02 & 0.00 \\
\hline P9CC1MI & 64.34 & 21.72 & 0.12 & 0.00 & 3.35 & 0.01 & 0.02 & 9.10 & 1.42 & 100.06 & 76.56 & 15.58 & 7.86 & 0.03 & 0.03 \\
\hline P9CC1MI2 & 64.72 & 21.64 & 0.11 & 0.00 & 3.14 & 0.00 & 0.02 & 9.18 & 1.49 & 100.30 & 77.17 & 14.59 & 8.24 & 0.03 & 0.00 \\
\hline
\end{tabular}

Peach Springs Tuff-Ignimbrite (Tpsig)

PST101m2

\begin{tabular}{|c|c|c|c|c|c|c|c|c|c|c|c|c|c|c|c|}
\hline P10E & 55.26 & 27.30 & 0.52 & 0.05 & 9.79 & 0.33 & 0.17 & 5.55 & 0.80 & 99.77 & 48.32 & 47.10 & 4.58 & 0.30 & 0.86 \\
\hline PlIGLIC & 61.99 & 23.23 & 0.28 & 0.00 & 4.97 & 0.07 & 0.07 & 8.26 & 0.95 & 99.84 & 71.01 & 23.61 & 5.37 & 0.12 & 0.18 \\
\hline PJ1GL1MC & 62.98 & 22.98 & 0.26 & 0.02 & 4.67 & 0.04 & 0.08 & 8.32 & 1.07 & 100.42 & 71.70 & 22.24 & 6.07 & 0.14 & 0.10 \\
\hline P11GL1MR & 63.84 & 22.03 & 0.27 & 0.01 & 3.44 & 0.03 & 0.04 & 8.72 & 1.44 & 99.82 & 75.38 & 16.43 & 8.19 & 0.07 & 0.08 \\
\hline PlIGLIR & 65.15 & 21.18 & 0.17 & 0.00 & 2.62 & 0.00 & 0.04 & 8.95 & 1.95 & 100.07 & 76.62 & 12.39 & 10.98 & 0.07 & 0.00 \\
\hline P12GL2E & 64.55 & 21.31 & 0.19 & 0.00 & 2.97 & 0.00 & 0.05 & 8.71 & 1.79 & 99.57 & 75.55 & 14.24 & 10.22 & 0.09 & 0.00 \\
\hline P12GL2I & 63.84 & 22.48 & 0.21 & 0.00 & 3.97 & 0.02 & 0.03 & 8.77 & 1.21 & 100.52 & 74.58 & 18.66 & 6.77 & 0.05 & 0.05 \\
\hline P12GL2MI & 63.74 & 22.22 & 0.26 & 0.00 & 3.87 & 0.00 & 0.05 & 8.58 & 1.28 & 99.98 & 74.22 & 18.50 & 7.28 & 0.09 & 0.00 \\
\hline P12GL2MI2 & 64.11 & 21.82 & 0.20 & 0.00 & 3.36 & 0.02 & 0.02 & 8.71 & 1.50 & 99.75 & 75.39 & 16.07 & 8.54 & 0.03 & 0.05 \\
\hline P12GL2R & 64.52 & 21.55 & 0.18 & 0.00 & 3.01 & 0.00 & 0.00 & 8.85 & 1.76 & 99.88 & 75.83 & 14.25 & 9.92 & 0.00 & 0.00 \\
\hline P14GL8C & 63.74 & 22.07 & 0.24 & 0.01 & 3.56 & 0.03 & 0.02 & 8.83 & 1.33 & 99.82 & 75.65 & 16.85 & 7.50 & 0.03 & 0.08 \\
\hline P14GL8R & 65.82 & 21.09 & 0.17 & 0.01 & 2.40 & 0.02 & 0.07 & 8.97 & 2.08 & 100.63 & 76.90 & 11.37 & 11.73 & 0.12 & 0.05 \\
\hline P18CC1GL29I & 62.24 & 23.04 & 0.20 & 0.00 & 4.92 & 0.02 & 0.07 & 8.23 & 0.98 & 99.70 & 70.99 & 23.45 & 5.56 & 0.12 & 0.05 \\
\hline P18CC1GL29MI & 63.31 & 22.43 & 0.24 & 0.01 & 4.17 & 0.00 & 0.08 & 8.68 & 1.15 & 100.06 & 73.93 & 19.63 & 6.44 & 0.14 & 0.00 \\
\hline P18CC1GL29MR & 65.02 & 21.59 & 0.17 & 0.02 & 3.10 & 0.00 & 0.03 & 8.67 & 1.68 & 100.27 & 75.47 & 14.91 & 9.62 & 0.05 & 0.00 \\
\hline P18CC1GL29R & 64.51 & 21.26 & 0.25 & 0.03 & 2.83 & 0.00 & 0.03 & 8.82 & 1.86 & 99.59 & 75.98 & 13.47 & 10.54 & 0.05 & 0.00 \\
\hline P19GL27E & 64.34 & 21.12 & 0.20 & 0.00 & 2.91 & 0.01 & 0.03 & 8.96 & 1.70 & 99.26 & 76.67 & 13.76 & 9.57 & 0.05 & 0.03 \\
\hline P19GL27I & 58.51 & 25.40 & 0.26 & 0.01 & 7.60 & 0.12 & 0.13 & 7.05 & 0.57 & 99.66 & 60.65 & 36.13 & 3.23 & 0.23 & 0.31 \\
\hline P19GL27MI & 60.19 & 24.21 & 0.27 & 0.01 & 6.26 & 0.12 & 0.09 & 7.77 & 0.74 & 99.65 & 66.32 & 29.53 & 4.16 & 0.16 & 0.31 \\
\hline P19GL27MR & 64.53 & 21.99 & 0.24 & 0.02 & 3.46 & 0.02 & 0.07 & 8.80 & 1.48 & 100.61 & 75.31 & 16.36 & 8.33 & 0.12 & 0.05 \\
\hline P19GL27MR2 & 63.31 & 22.93 & 0.28 & 0.03 & 4.50 & 0.04 & 0.05 & 8.51 & 1.14 & 100.78 & 72.45 & 21.17 & 6.39 & 0.09 & 0.10 \\
\hline P20GL34C & 61.62 & 23.36 & 0.27 & 0.02 & 4.99 & 0.10 & 0.16 & 8.67 & 0.97 & 100.17 & 71.86 & 22.85 & 5.29 & 0.27 & 0.25 \\
\hline P20GL34MC & 62.14 & 23.38 & 0.28 & 0.03 & 4.90 & 0.08 & 0.13 & 8.29 & 0.99 & 100.22 & 71.16 & 23.24 & 5.59 & 0.23 & 0.21 \\
\hline P20GL34MC2 & 62.62 & 22.91 & 0.27 & 0.00 & 4.40 & 0.03 & 0.07 & 8.58 & 1.16 & 100.05 & 72.87 & 20.65 & 6.48 & 0.12 & 0.08 \\
\hline P20GL34MC3 & 62.98 & 22.47 & 0.25 & 0.04 & 4.30 & 0.01 & 0.07 & 8.58 & 1.20 & 99.89 & 73.05 & 20.23 & 6.72 & 0.12 & 0.03 \\
\hline P20GL34MR & 63.88 & 22.17 & 0.26 & 0.01 & 3.61 & 0.02 & 0.08 & 8.85 & 1.46 & 100.35 & 74.97 & 16.90 & 8.14 & 0.14 & 0.05 \\
\hline P20GL34MR2 & 63.28 & 22.27 & 0.26 & 0.01 & 3.90 & 0.02 & 0.04 & 8.85 & 1.30 & 99.92 & 74.62 & 18.17 & 7.21 & 0.07 & 0.05 \\
\hline P20GL34R & 64.75 & 21.31 & 0.21 & 0.01 & 2.94 & 0.06 & 0.09 & 8.69 & 1.75 & 99.81 & 75.79 & 14.17 & 10.04 & 0.16 & 0.16 \\
\hline P20GL34R2 & 61.88 & 24.07 & 0.24 & 0.01 & 5.57 & 0.19 & 0.23 & 7.92 & 0.81 & 100.91 & 68.68 & 26.69 & 4.62 & 0.40 & 0.49 \\
\hline P21GL39I & 59.24 & 25.04 & 0.32 & 0.02 & 7.25 & 0.10 & 0.09 & 7.29 & 0.58 & 99.93 & 62.43 & 34.31 & 3.27 & 0.16 & 0.26 \\
\hline P21GL39MI & 59.57 & 25.20 & 0.28 & 0.00 & 7.07 & 0.11 & 0.11 & 7.35 & 0.64 & 100.33 & 62.94 & 33.46 & 3.61 & 0.19 & 0.28 \\
\hline P21GL39MI2 & 61.29 & 23.37 & 0.31 & 0.05 & 5.06 & 0.01 & 0.04 & 8.18 & 0.92 & 99.23 & 70.63 & 24.14 & 5.23 & 0.07 & 0.03 \\
\hline P21GL39MR & 64.98 & 21.62 & 0.20 & 0.03 & 3.07 & 0.00 & 0.01 & 8.92 & 1.57 & 100.39 & 76.57 & 14.56 & 8.87 & 0.02 & 0.00 \\
\hline P21GL39R & 64.90 & 21.49 & 0.18 & 0.00 & 2.95 & 0.02 & 0.04 & 8.64 & 1.79 & 100.01 & 75.47 & 14.24 & 10.29 & 0.07 & 0.05 \\
\hline P22MP1PU13E & 66.47 & 20.00 & 0.18 & 0.00 & 1.61 & 0.01 & 0.00 & 7.70 & 4.94 & 100.90 & 65.03 & 7.51 & 27.45 & 0.00 & 0.03 \\
\hline P22MP1PU13E2 & 65.65 & 20.89 & 0.21 & 0.01 & 2.30 & 0.01 & 0.00 & 8.51 & 2.85 & 100.43 & 73.01 & 10.90 & 16.09 & 0.00 & 0.03 \\
\hline P22MP1PU13I & 65.77 & 20.95 & 0.22 & 0.02 & 2.55 & 0.01 & 0.00 & 8.89 & 2.19 & 100.60 & 75.72 & 12.00 & 12.27 & 0.00 & 0.03 \\
\hline P8GLAE & 65.46 & 21.11 & 0.15 & 0.01 & 2.70 & 0.00 & 0.03 & 8.69 & 1.96 & 100.09 & 75.75 & 13.01 & 11.24 & 0.05 & 0.00 \\
\hline P8GLAI & 65.24 & 21.78 & 0.16 & 0.04 & 3.08 & 0.03 & 0.04 & 8.73 & 1.67 & 100.77 & 75.71 & 14.76 & 9.53 & 0.07 & 0.08 \\
\hline P8GL4MI & 64.21 & 22.17 & 0.23 & 0.02 & 3.50 & 0.00 & 0.07 & 8.90 & 1.44 & 100.54 & 75.54 & 16.42 & 8.04 & 0.12 & 0.00 \\
\hline P8GL4MI2 & 64.18 & 21.98 & 0.28 & 0.01 & 3.49 & 0.01 & 0.02 & 8.71 & 1.36 & 100.04 & 75.52 & 16.72 & 7.76 & 0.04 & 0.03 \\
\hline P8GL4R & 64.05 & 22.26 & 0.16 & 0.00 & 3.90 & 0.00 & 0.03 & 8.54 & 1.33 & 100.27 & 73.81 & 18.63 & 7.56 & 0.05 & 0.00 \\
\hline P9CC1R & 63.74 & 21.67 & 0.23 & 0.02 & 3.31 & 0.03 & 0.07 & 8.77 & 1.53 & 99.36 & 75.57 & 15.76 & 8.67 & 0.12 & 0.08 \\
\hline \multicolumn{16}{|l|}{ PST101m10 } \\
\hline P14PU1I & 63.91 & 21.94 & 0.27 & 0.00 & 3.55 & 0.00 & 0.01 & 8.92 & 1.30 & 99.90 & 76.00 & 16.71 & 7.29 & 0.02 & 0.00 \\
\hline P14PU1MI & 64.12 & 21.77 & 0.25 & 0.00 & 3.37 & 0.00 & 0.00 & 8.79 & 1.41 & 99.70 & 75.91 & 16.08 & 8.01 & 0.00 & 0.00 \\
\hline
\end{tabular}


Appendix 2. Plagioclase compositions-Continued.

\begin{tabular}{|c|c|c|c|c|c|c|c|c|c|c|c|c|c|c|c|}
\hline $\begin{array}{l}\text { Oxide wt pet or } \\
\text { feldspar mol pct }\end{array}$ & $\mathrm{SiO}_{2}$ & $\mathrm{Al}_{2} \mathrm{O}_{3}$ & $\mathrm{Fe}_{2} \mathrm{O}_{3}$ & $\mathrm{MgO}$ & $\mathrm{CaO}$ & Sro & $\mathrm{BaO}$ & $\mathrm{Na}_{2} \mathrm{O}$ & $\mathrm{K}_{2} \mathrm{O}$ & Total & $A b$ & An & Or & Celsian & Sr-Feldspar \\
\hline \multicolumn{16}{|c|}{ PST101m10-Continued } \\
\hline P14PU1MI2 & 64.15 & 21.78 & 0.27 & 0.00 & 3.26 & 0.00 & 0.01 & 8.88 & 1.49 & 99.83 & 76.15 & 15.45 & 8.41 & 0.02 & 0.00 \\
\hline P14PU1MR & 64.42 & 21.72 & 0.25 & 0.00 & 2.82 & 0.02 & 0.02 & 8.68 & 1.89 & 99.82 & 75.60 & 13.57 & 10.83 & 0.04 & 0.05 \\
\hline P14PUIMR2 & 65.15 & 21.07 & 0.23 & 0.00 & 2.71 & 0.00 & 0.04 & 8.87 & 1.98 & 100.05 & 76.01 & 12.83 & 11.16 & 0.07 & 0.00 \\
\hline P14PU1MR3 & 65.37 & 21.30 & 0.24 & 0.00 & 2.83 & 0.00 & 0.00 & 8.72 & 1.83 & 100.29 & 75.91 & 13.61 & 10.48 & 0.00 & 0.00 \\
\hline P14PU1R & 64.79 & 20.97 & 0.24 & 0.00 & 2.52 & 0.00 & 0.04 & 9.04 & 1.64 & 99.23 & 78.53 & 12.10 & 9.37 & 0.07 & 0.00 \\
\hline P16I & 64.20 & 22.13 & 0.28 & 0.00 & 3.56 & 0.00 & 0.04 & 8.87 & 1.39 & 100.48 & 75.48 & 16.74 & 7.78 & 0.07 & 0.00 \\
\hline P16R & 65.10 & 21.70 & 0.21 & 0.00 & 3.12 & 0.00 & 0.02 & 9.17 & 1.56 & 100.88 & 76.93 & 14.46 & 8.61 & 0.03 & 0.00 \\
\hline P22GL16E & 65.63 & 21.59 & 0.25 & 0.00 & 2.84 & 0.00 & 0.00 & 8.88 & 1.73 & 100.91 & 76.63 & 13.54 & 9.82 & 0.00 & 0.00 \\
\hline P22GL16I & 64.00 & 22.25 & 0.25 & 0.00 & 3.74 & 0.00 & 0.04 & 8.66 & 1.37 & 100.31 & 74.47 & 17.77 & 7.75 & 0.07 & 0.00 \\
\hline P25E & 65.11 & 21.81 & 0.29 & 0.00 & 2.93 & 0.00 & 0.00 & 9.01 & 1.68 & 100.83 & 76.78 & 13.80 & 9.42 & 0.00 & 0.00 \\
\hline P25I & 64.99 & 21.90 & 0.23 & 0.00 & 3.28 & 0.01 & 0.04 & 8.94 & 1.48 & 100.86 & 76.24 & 15.46 & 8.30 & 0.07 & 0.03 \\
\hline P26E & 55.52 & 27.63 & 0.56 & 0.06 & 10.18 & 0.34 & 0.10 & 5.39 & 0.70 & 100.48 & 46.97 & 49.02 & 4.01 & 0.18 & 0.89 \\
\hline P26I & 55.92 & 27.59 & 0.56 & 0.05 & 10.30 & 0.33 & 0.07 & 5.66 & 0.58 & 101.06 & 48.24 & 48.51 & 3.25 & 0.12 & 0.84 \\
\hline P29E & 64.88 & 21.28 & 0.23 & 0.00 & 2.87 & 0.00 & 0.04 & 8.95 & 1.88 & 100.13 & 76.02 & 13.47 & 10.51 & 0.07 & 0.00 \\
\hline P29I & 64.56 & 21.75 & 0.29 & 0.00 & 3.27 & 0.03 & 0.07 & 8.76 & 1.57 & 100.28 & 75.52 & 15.58 & 8.90 & 0.12 & 0.08 \\
\hline P31I & 63.56 & 21.92 & 0.25 & 0.00 & 3.41 & 0.00 & 0.00 & 8.81 & 1.29 & 99.23 & 76.32 & 16.32 & 7.35 & 0.00 & 0.00 \\
\hline P31R & 65.48 & 21.42 & 0.25 & 0.02 & 2.81 & 0.03 & 0.01 & 8.99 & 1.57 & 100.58 & 77.66 & 13.41 & 8.92 & 0.02 & 0.08 \\
\hline P32E & 57.20 & 26.50 & 0.47 & 0.06 & 8.79 & 0.28 & 0.07 & 6.30 & 0.55 & 100.21 & 54.69 & 42.17 & 3.14 & 0.12 & 0.73 \\
\hline P32I & 56.63 & 26.62 & 0.41 & 0.04 & 9.08 & 0.33 & 0.10 & 6.08 & 0.71 & 100.00 & 52.57 & 43.39 & 4.04 & 0.17 & 0.85 \\
\hline P33GL22E & 65.17 & 21.61 & 0.24 & 0.01 & 2.80 & 0.00 & 0.00 & 8.93 & 1.78 & 100.53 & 76.66 & 13.28 & 10.05 & 0.00 & 0.00 \\
\hline P33GL22E2 & 64.34 & 21.87 & 0.25 & 0.01 & 3.21 & 0.00 & 0.01 & 9.16 & 1.59 & 100.44 & 76.46 & 14.81 & 8.73 & 0.02 & 0.00 \\
\hline P33GL22I & 65.26 & 21.67 & 0.25 & 0.01 & 2.87 & 0.00 & 0.00 & 8.91 & 1.86 & 100.84 & 76.03 & 13.53 & 10.44 & 0.00 & 0.00 \\
\hline P33GL22I2 & 64.97 & 21.52 & 0.23 & 0.00 & 2.80 & 0.00 & 0.02 & 9.00 & 1.79 & 100.33 & 76.76 & 13.20 & 10.04 & 0.03 & 0.00 \\
\hline P34CC3E & 64.72 & 21.34 & 0.26 & 0.00 & 2.83 & 0.00 & 0.00 & 8.66 & 1.81 & 99.63 & 75.87 & 13.70 & 10.43 & 0.00 & 0.00 \\
\hline P34CC3I & 62.62 & 23.09 & 0.27 & 0.01 & 4.60 & 0.00 & 0.05 & 8.65 & 0.97 & 100.25 & 73.12 & 21.49 & 5.39 & 0.09 & 0.00 \\
\hline P37MP1E & 64.89 & 21.61 & 0.25 & 0.00 & 2.90 & 0.04 & 0.04 & 8.87 & 1.80 & 100.41 & 76.09 & 13.75 & 10.16 & 0.07 & 0.10 \\
\hline P37MP1I & 64.67 & 21.55 & 0.20 & 0.00 & 2.96 & 0.01 & 0.08 & 9.17 & 1.61 & 100.26 & 77.29 & 13.79 & 8.93 & 0.14 & 0.03 \\
\hline P41E & 56.50 & 26.10 & 0.59 & 0.19 & 8.93 & 0.27 & 0.14 & 6.15 & 0.67 & 99.53 & 53.36 & 42.82 & 3.82 & 0.25 & 0.70 \\
\hline P41I & 56.25 & 26.78 & 0.52 & 0.03 & 8.98 & 0.18 & 0.11 & 5.80 & 1.03 & 99.69 & 50.70 & 43.38 & 5.92 & 0.19 & 0.47 \\
\hline P43I & 65.07 & 21.72 & 0.23 & 0.00 & 2.92 & 0.00 & 0.06 & 9.14 & 1.71 & 100.87 & 76.94 & 13.58 & 9.47 & 0.10 & 0.00 \\
\hline P43MI & 64.21 & 21.69 & 0.21 & 0.00 & 3.16 & 0.01 & 0.02 & 8.97 & 1.58 & 99.85 & 76.30 & 14.85 & 8.84 & 0.03 & 0.03 \\
\hline P43R & 65.15 & 21.61 & 0.22 & 0.00 & 2.64 & 0.02 & 0.01 & 8.97 & 1.84 & 100.46 & 77.07 & 12.53 & 10.40 & 0.02 & 0.05 \\
\hline P44PU5C2 & 63.50 & 22.46 & 0.25 & 0.00 & 3.71 & 0.03 & 0.05 & 8.73 & 1.27 & 100.00 & 75.16 & 17.65 & 7.19 & 0.09 & 0.08 \\
\hline P44PU5MC & 64.80 & 22.16 & 0.23 & 0.00 & 3.24 & 0.00 & 0.00 & 9.10 & 1.54 & 101.06 & 76.45 & 15.04 & 8.51 & 0.00 & 0.00 \\
\hline P44PU5R & 64.85 & 21.51 & 0.23 & 0.01 & 2.66 & 0.00 & 0.00 & 9.24 & 1.91 & 100.40 & 77.22 & 12.28 & 10.50 & 0.00 & 0.00 \\
\hline P44PU5R & 64.85 & 21.51 & 0.23 & 0.01 & 2.66 & 0.00 & 0.00 & 9.24 & 1.91 & 100.40 & 77.22 & 12.28 & 10.50 & 0.00 & 0.00 \\
\hline P50E2 & 65.60 & 21.50 & 0.25 & 0.00 & 2.68 & 0.03 & 0.00 & 8.79 & 1.82 & 100.67 & 76.65 & 12.91 & 10.44 & 0.00 & 0.08 \\
\hline P50I & 64.44 & 21.73 & 0.22 & 0.00 & 3.31 & 0.02 & 0.01 & 8.89 & 1.49 & 100.12 & 75.99 & 15.63 & 8.38 & 0.02 & 0.05 \\
\hline P50ME2 & 65.53 & 21.17 & 0.21 & 0.00 & 2.66 & 0.04 & 0.06 & 8.85 & 1.91 & 100.44 & 76.45 & 12.70 & 10.86 & 0.10 & 0.10 \\
\hline P50MI & 65.34 & 21.77 & 0.22 & 0.00 & 2.98 & 0.04 & 0.00 & 8.70 & 1.69 & 100.74 & 75.93 & 14.37 & 9.70 & 0.00 & 0.10 \\
\hline P5CC2E & 63.73 & 21.48 & 0.23 & 0.00 & 3.14 & 0.00 & 0.04 & 9.00 & 1.59 & 99.21 & 76.39 & 14.73 & 8.88 & 0.07 & 0.00 \\
\hline P5CC2I & 64.51 & 21.70 & 0.22 & 0.00 & 3.18 & 0.00 & 0.08 & 8.93 & 1.60 & 100.23 & 76.06 & 14.97 & 8.97 & 0.14 & 0.00 \\
\hline P5CC2MI & 64.90 & 21.49 & 0.21 & 0.00 & 2.89 & 0.00 & 0.03 & 9.15 & 1.76 & 100.43 & 76.86 & 13.41 & 9.73 & 0.05 & 0.00 \\
\hline $\mathrm{P} 8 \mathrm{CC} 4 \mathrm{C}$ & 61.17 & 23.56 & 0.30 & 0.00 & 5.18 & 0.03 & 0.01 & 8.16 & 0.83 & 99.23 & 70.54 & 24.74 & 4.72 & 0.02 & 0.08 \\
\hline P8CC4MC & 62.99 & 23.33 & 0.28 & 0.00 & 4.82 & 0.03 & 0.06 & 8.56 & 0.99 & 101.06 & 72.08 & 22.43 & 5.49 & 0.10 & 0.08 \\
\hline $\mathrm{P} 8 \mathrm{CC} 4 \mathrm{MC} 2$ & 61.98 & 23.72 & 0.32 & 0.00 & 5.34 & 0.04 & 0.10 & 8.27 & 0.82 & 100.58 & 70.32 & 25.09 & 4.59 & 0.17 & 0.10 \\
\hline P8CC4MR & 65.03 & 21.69 & 0.23 & 0.00 & 3.01 & 0.01 & 0.01 & 8.95 & 1.68 & 100.60 & 76.37 & 14.19 & 9.43 & 0.02 & 0.03 \\
\hline P8CC4MR2 & 63.34 & 22.99 & 0.26 & 0.00 & 4.48 & 0.00 & 0.05 & 8.59 & 1.01 & 100.73 & 73.23 & 21.11 & 5.66 & 0.09 & 0.00 \\
\hline P8CC4R & 65.04 & 21.59 & 0.23 & 0.00 & 2.80 & 0.02 & 0.00 & 9.22 & 1.66 & 100.55 & 77.74 & 13.05 & 9.21 & 0.00 & 0.05 \\
\hline \multicolumn{16}{|l|}{ PST101m64 } \\
\hline $\mathrm{P} 11 \mathrm{CC} 2 \mathrm{C}$ & 62.75 & 23.62 & 0.27 & 0.00 & 5.45 & 0.00 & 0.00 & 8.31 & 0.82 & 101.22 & 70.06 & 25.39 & 4.55 & 0.00 & 0.00 \\
\hline $\mathrm{P} 11 \mathrm{CC} 2 \mathrm{R}$ & 66.17 & 21.39 & 0.24 & 0.00 & 2.63 & 0.00 & 0.00 & 9.32 & 1.56 & 101.31 & 78.98 & 12.32 & 8.70 & 0.00 & 0.00 \\
\hline
\end{tabular}


Appendix 2. Plagioclase compositions--Continued.

\begin{tabular}{|c|c|c|c|c|c|c|c|c|c|c|c|c|c|c|c|}
\hline $\begin{array}{l}\text { Oxide wl pcl or } \\
\text { feldspar mol pcl }\end{array}$ & $\mathrm{SiO}_{2}$ & $\mathrm{Al}_{2} \mathrm{O}_{3}$ & $\mathrm{Fe}_{2} \mathrm{O}_{3}$ & $\mathrm{MgO}$ & $\mathrm{CaO}$ & SrO & $\mathrm{BaO}$ & $\mathrm{Na}_{2} \mathrm{O}$ & $\mathrm{K}_{2} \mathrm{O}$ & Total & $\mathbf{A b}$ & An & Or & Celsian & Sr-Feldspar \\
\hline \multicolumn{16}{|c|}{ PST101m64-Continued } \\
\hline P12CClC & 61.54 & 24.22 & 0.29 & 0.00 & 5.95 & 0.10 & 0.16 & 7.07 & 0.65 & 99.98 & 65.55 & 30.48 & 3.97 & 0.30 & 0.28 \\
\hline $\mathrm{P} 12 \mathrm{CC} 1 \mathrm{C} 2$ & 60.64 & 24.66 & 0.26 & 0.00 & 6.55 & 0.12 & 0.20 & 6.81 & 0.54 & 99.79 & 63.14 & 33.56 & 3.29 & 0.37 & 0.33 \\
\hline P12CC1R & 66.17 & 21.02 & 0.17 & 0.00 & 2.46 & 0.01 & 0.09 & 8.13 & 1.98 & 100.03 & 75.33 & 12.60 & 12.07 & 0.17 & 0.03 \\
\hline P12CC1R & 65.71 & 21.09 & 0.16 & 0.00 & 2.77 & 0.03 & 0.01 & 8.25 & 1.52 & 99.51 & 76.53 & 14.20 & 9.28 & 0.02 & 0.08 \\
\hline P12CC1R2 & 66.63 & 21.26 & 0.20 & 0.00 & 3.01 & 0.00 & 0.07 & 8.17 & 1.39 & 100.72 & 76.02 & 15.48 & 8.51 & 0.13 & 0.00 \\
\hline P12CC1R2B & 65.81 & 21.35 & 0.20 & 0.00 & 2.87 & 0.01 & 0.04 & 7.97 & 1.57 & 99.83 & 75.27 & 14.98 & 9.76 & 0.08 & 0.03 \\
\hline P13CClC & 64.03 & 22.24 & 0.21 & 0.00 & 4.12 & 0.01 & 0.00 & 7.70 & 1.04 & 99.34 & 72.23 & 21.36 & 6.42 & 0.00 & 0.03 \\
\hline P13CC1R & 65.55 & 21.70 & 0.20 & 0.00 & 2.98 & 0.04 & 0.00 & 7.90 & 1.68 & 100.05 & 74.16 & 15.46 & 10.38 & 0.00 & 0.11 \\
\hline PIC & 65.89 & 21.19 & 0.18 & 0.00 & 2.69 & 0.05 & 0.07 & 7.93 & 1.87 & 99.87 & 74.48 & 13.96 & 11.56 & 0.13 & 0.14 \\
\hline P1R & 65.72 & 21.03 & 0.18 & 0.00 & 2.79 & 0.00 & 0.04 & 7.96 & 1.65 & 99.37 & 75.18 & 14.56 & 10.25 & 0.08 & 0.00 \\
\hline $\mathrm{P} 2 \mathrm{Cl}$ & 64.79 & 21.62 & 0.19 & 0.00 & 3.16 & 0.02 & 0.04 & 7.91 & 1.38 & 99.13 & 74.88 & 16.53 & 8.59 & 0.08 & 0.06 \\
\hline $\mathrm{P} 2 \mathrm{C} 2$ & 65.17 & 21.88 & 0.22 & 0.00 & 3.51 & 0.03 & 0.08 & 8.25 & 1.30 & 100.44 & 74.69 & 17.56 & 7.74 & 0.15 & 0.08 \\
\hline P2R & 66.48 & 21.52 & 0.19 & 0.00 & 2.71 & 0.02 & 0.01 & 8.35 & 1.44 & 100.71 & 77.35 & 13.87 & 8.78 & 0.02 & 0.06 \\
\hline P3R & 58.45 & 26.05 & 0.47 & 0.00 & 8.38 & 0.17 & 0.19 & 5.57 & 0.83 & 100.13 & 51.83 & 43.09 & 5.08 & 0.36 & 0.47 \\
\hline P4R & 60.50 & 24.78 & 0.46 & 0.00 & 7.12 & 0.23 & 0.15 & 6.25 & 0.59 & 100.11 & 59.11 & 37.21 & 3.67 & 0.29 & 0.65 \\
\hline P5C & 64.64 & 22.87 & 0.23 & 0.00 & 4.25 & 0.03 & 0.03 & 7.82 & 1.03 & 100.90 & 72.10 & 21.65 & 6.25 & 0.06 & 0.08 \\
\hline P5R & 66.32 & 21.90 & 0.22 & 0.00 & 2.91 & 0.05 & 0.06 & 8.34 & 1.49 & 101.28 & 76.31 & 14.71 & 8.97 & 0.11 & 0.14 \\
\hline P6C & 55.12 & 28.60 & 0.33 & 0.00 & 10.56 & 0.21 & 0.03 & 5.54 & 0.39 & 100.80 & 47.63 & 50.17 & 2.21 & 0.05 & 0.54 \\
\hline P6R & 59.57 & 25.87 & 0.31 & 0.02 & 8.04 & 0.29 & 0.10 & 6.82 & 0.54 & 101.56 & 58.70 & 38.24 & 3.06 & 0.17 & 0.75 \\
\hline P7C & 65.31 & 21.49 & 0.25 & 0.00 & 3.30 & 0.00 & 0.02 & 8.95 & 1.26 & 100.58 & 77.14 & 15.72 & 7.14 & 0.03 & 0.00 \\
\hline P7R & 66.06 & 20.95 & 0.22 & 0.00 & 2.41 & 0.00 & 0.05 & 9.30 & 1.69 & 100.67 & 79.19 & 11.34 & 9.47 & 0.09 & 0.00 \\
\hline
\end{tabular}

Cook Canyon tuff-Basal fallout deposits (Tccb)

\section{PST008m2}

\begin{tabular}{|c|c|c|c|c|c|c|c|c|c|c|c|c|c|c|c|}
\hline P11PU5C & 56.96 & 26.41 & 0.46 & 0.01 & 8.89 & 0.30 & 0.07 & 6.06 & 0.74 & 99.91 & 52.88 & 42.87 & 4.25 & 0.12 & 0.78 \\
\hline P11PU5R & 58.21 & 24.96 & 0.49 & 0.04 & 7.42 & 0.33 & 0.15 & 6.76 & 0.99 & 99.34 & 58.72 & 35.62 & 5.66 & 0.26 & 0.86 \\
\hline P12PUSI & 54.89 & 27.36 & 0.54 & 0.03 & 10.19 & 0.36 & 0.09 & 5.30 & 0.55 & 99.31 & 46.93 & 49.86 & 3.20 & 0.16 & 0.95 \\
\hline P12PU5R & 58.50 & 25.10 & 0.49 & 0.01 & 7.41 & 0.31 & 0.06 & 6.64 & 1.03 & 99.55 & 58.18 & 35.88 & 5.94 & 0.11 & 0.81 \\
\hline P13GL5C & 58.14 & 26.09 & 0.50 & 0.02 & 8.40 & 0.39 & 0.18 & 6.26 & 0.83 & 100.79 & 54.68 & 40.55 & 4.77 & 0.32 & 1.02 \\
\hline P13GL5MC & 59.70 & 25.20 & 0.43 & 0.02 & 7.43 & 0.41 & 0.15 & 6.75 & 1.03 & 101.14 & 58.53 & 35.60 & 5.88 & 0.26 & 1.06 \\
\hline P13GL5MC2 & 59.76 & 25.25 & 0.36 & 0.01 & 7.37 & 0.32 & 0.14 & 6.79 & 1.01 & 101.02 & 58.90 & 35.33 & 5.76 & 0.25 & 0.83 \\
\hline P13GL5MR & 59.58 & 25.12 & 0.45 & 0.02 & 7.19 & 0.39 & 0.14 & 6.49 & 1.02 & 100.40 & 58.29 & 35.68 & 6.03 & 0.25 & 1.05 \\
\hline P13GL5MR2 & 58.30 & 24.94 & 0.45 & 0.03 & 7.32 & 0.36 & 0.14 & 6.73 & 0.94 & 99.21 & 59.07 & 35.50 & 5.43 & 0.25 & 0.94 \\
\hline PI3GL5R & 59.15 & 25.59 & 0.41 & 0.02 & 7.65 & 0.40 & 0.10 & 6.64 & 0.94 & 100.89 & 57.81 & 36.81 & 5.38 & 0.18 & 1.04 \\
\hline P14PU6C & 58.49 & 26.10 & 0.33 & 0.00 & 8.19 & 0.27 & 0.06 & 6.37 & 0.85 & 100.64 & 55.61 & 39.51 & 4.88 & 0.11 & 0.70 \\
\hline P14PU6MC & 58.78 & 25.66 & 0.40 & 0.00 & 8.03 & 0.31 & 0.07 & 6.31 & 0.83 & 100.39 & 55.87 & 39.29 & 4.84 & 0.13 & 0.82 \\
\hline P14PU6MC2 & 59.02 & 25.24 & 0.36 & 0.01 & 7.50 & 0.38 & 0.10 & 6.75 & 0.99 & 100.36 & 58.46 & 35.90 & 5.64 & 0.18 & 0.98 \\
\hline P14PU6MC3 & 57.60 & 26.52 & 0.40 & 0.00 & 8.59 & 0.38 & 0.12 & 6.14 & 0.73 & 100.48 & 54.02 & 41.76 & 4.23 & 0.21 & 1.00 \\
\hline P14PU6MC4 & 58.39 & 25.91 & 0.65 & 0.01 & 8.23 & 0.36 & 0.07 & 6.33 & 0.84 & 100.77 & 55.38 & 39.79 & 4.83 & 0.12 & 0.94 \\
\hline P14PU6MR & 56.64 & 25.94 & 0.46 & 0.01 & 8.21 & 0.33 & 0.10 & 6.31 & 0.82 & 98.81 & 55.42 & 39.84 & 4.74 & 0.18 & 0.87 \\
\hline P14PU6MR2 & 58.01 & 25.54 & 0.40 & 0.00 & 8.03 & 0.34 & 0.11 & 6.53 & 0.86 & 99.83 & 56.62 & 38.47 & 4.91 & 0.19 & 0.88 \\
\hline P14PU6MR3 & 56.89 & 26.61 & 0.43 & 0.03 & 8.87 & 0.33 & 0.12 & 6.05 & 0.70 & 100.03 & 53.01 & 42.95 & 4.04 & 0.21 & 0.86 \\
\hline P14PU6MR4 & 58.32 & 25.57 & 0.38 & 0.00 & 7.86 & 0.37 & 0.14 & 6.41 & 0.85 & 99.88 & 56.66 & 38.39 & 4.94 & 0.25 & 0.98 \\
\hline P14PU6R & 56.03 & 26.56 & 0.38 & 0.03 & 8.85 & 0.30 & 0.10 & 6.12 & 0.70 & 99.08 & 53.35 & 42.63 & 4.01 & 0.18 & 0.78 \\
\hline P14PU6R2 & 57.12 & 26.46 & 0.39 & 0.03 & 9.06 & 0.31 & 0.07 & 6.01 & 0.66 & 100.10 & 52.49 & 43.72 & 3.79 & 0.12 & 0.81 \\
\hline P16GL8C & 57.29 & 26.64 & 0.40 & 0.00 & 8.94 & 0.34 & 0.07 & 6.08 & 0.71 & 100.47 & 52.93 & 43.01 & 4.07 & 0.12 & 0.89 \\
\hline P16GL8R & 60.18 & 24.82 & 0.36 & 0.00 & 6.66 & 0.33 & 0.14 & 7.01 & 1.13 & 100.62 & 61.31 & 32.19 & 6.50 & 0.25 & 0.86 \\
\hline P17GL9C & 55.53 & 27.23 & 0.42 & 0.03 & 9.51 & 0.40 & 0.09 & 5.78 & 0.59 & 99.57 & 50.60 & 46.00 & 3.40 & 0.16 & 1.05 \\
\hline P17GL9MC & 56.89 & 26.38 & 0.46 & 0.02 & 8.83 & 0.39 & 0.13 & 6.03 & 0.70 & 99.84 & 53.03 & 42.92 & 4.05 & 0.23 & 1.03 \\
\hline P17GL9MC2 & 56.31 & 27.05 & 0.42 & 0.01 & 9.36 & 0.39 & 0.15 & 6.01 & 0.63 & 100.34 & 51.82 & 44.60 & 3.57 & 0.26 & 1.01 \\
\hline P17GL9MR & 58.98 & 25.50 & 0.39 & 0.02 & 7.67 & 0.31 & 0.12 & 6.71 & 0.93 & 100.64 & 58.04 & 36.66 & 5.29 & 0.21 & 0.80 \\
\hline P17GL9R & 58.18 & 25.80 & 0.49 & 0.01 & 7.91 & 0.34 & 0.10 & 6.42 & 0.86 & 100.11 & 56.53 & 38.49 & 4.98 & 0.18 & 0.90 \\
\hline P18PU9R & 59.42 & 25.11 & 0.38 & 0.02 & 7.33 & 0.37 & 0.16 & 6.70 & 0.97 & 100.45 & 58.83 & 35.57 & 5.60 & 0.28 & 0.97 \\
\hline
\end{tabular}


Appendix 2. Plagioclase compositions-Continued.

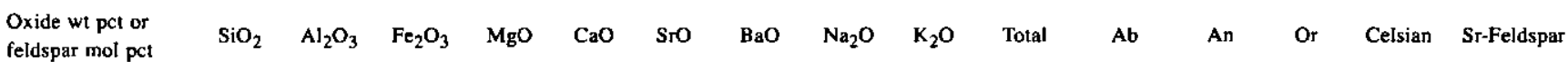

Cook Canyon tuff-Basal fallout deposits (Tccb)

PST008m2—Continued

\begin{tabular}{|c|c|c|c|c|c|c|c|c|c|c|c|c|c|c|c|}
\hline P19GL11E & 57.38 & 26.41 & 0.46 & 0.02 & 9.07 & 0.36 & 0.14 & 6.01 & 0.66 & 100.51 & 52.46 & 43.75 & 3.79 & 0.25 & 0.94 \\
\hline P19GL11I & 56.02 & 27.49 & 0.51 & 0.04 & 9.98 & 0.36 & 0.06 & 5.34 & 0.53 & 100.33 & 47.66 & 49.22 & 3.11 & 0.11 & 0.96 \\
\hline P5GL1C & 58.12 & 25.86 & 0.43 & 0.01 & 8.04 & 0.33 & 0.15 & 6.44 & 0.83 & 100.22 & 56.35 & 38.87 & 4.78 & 0.27 & 0.86 \\
\hline P5GL1R & 59.47 & 24.35 & 0.35 & 0.02 & 6.92 & 0.35 & 0.10 & 6.69 & 1.07 & 99.32 & 59.64 & 34.09 & 6.28 & 0.18 & 0.93 \\
\hline P6GL2C & 58.41 & 25.92 & 0.45 & 0.01 & 8.11 & 0.37 & 0.16 & 6.38 & 0.75 & 100.57 & 56.19 & 39.47 & 4.35 & 0.28 & 0.97 \\
\hline P6GL2MC & 55.76 & 27.59 & 0.42 & 0.02 & 10.17 & 0.34 & 0.06 & 5.43 & 0.54 & 100.33 & 47.61 & 49.28 & 3.12 & 0.11 & 0.89 \\
\hline P6GL2MR & 54.79 & 28.85 & 0.43 & 0.04 & 11.06 & 0.40 & 0.09 & 4.95 & 0.47 & 101.09 & 43.53 & 53.75 & 2.72 & 0.16 & 1.05 \\
\hline P6GL2MR2 & 56.08 & 28.21 & 0.45 & 0.02 & 10.48 & 0.39 & 0.10 & 5.36 & 0.56 & 101.65 & 46.53 & 50.27 & 3.20 & 0.18 & 1.01 \\
\hline P6GL2R & 58.38 & 25.46 & 0.45 & 0.00 & 7.73 & 0.38 & 0.09 & 6.71 & 0.94 & 100.13 & 57.84 & 36.82 & 5.33 & 0.16 & 0.98 \\
\hline P7MP1PU4I & 62.24 & 23.18 & 0.42 & 0.00 & 5.06 & 0.22 & 0.18 & 7.01 & 1.99 & 100.30 & 63.07 & 25.16 & 11.78 & 0.33 & 0.59 \\
\hline P8MP2PU4E & 62.59 & 22.62 & 0.39 & 0.00 & 4.00 & 0.38 & 0.55 & 6.79 & 3.28 & 100.59 & 60.85 & 19.81 & 19.34 & 1.00 & 1.02 \\
\hline P8MP2PU4I & 62.24 & 23.10 & 0.38 & 0.00 & 4.66 & 0.31 & 0.18 & 7.65 & 1.91 & 100.43 & 66.63 & 22.43 & 10.94 & 0.32 & 0.81 \\
\hline P9PU4C & 60.63 & 24.03 & 0.42 & 0.00 & 5.89 & 0.31 & 0.11 & 7.26 & 1.38 & 100.04 & 63.56 & 28.49 & 7.95 & 0.19 & 0.81 \\
\hline P9PU4R & 61.83 & 23.06 & 0.43 & 0.00 & 4.98 & 0.37 & 0.41 & 7.38 & 1.83 & 100.30 & 65.10 & 24.28 & 10.62 & 0.73 & 0.98 \\
\hline
\end{tabular}

Cook Canyon tuff-Ignimbrite (ig)

PST025m13

\begin{tabular}{|c|c|c|c|c|c|c|c|c|c|c|c|c|c|c|c|}
\hline P11PU3C & 57.03 & 26.59 & 0.43 & 0.01 & 8.39 & 0.36 & 0.15 & 6.40 & 0.79 & 100.14 & 55.38 & 40.12 & 4.50 & 0.26 & 0.93 \\
\hline P11PU3R & 59.21 & 25.16 & 0.36 & 0.00 & 7.07 & 0.36 & 0.14 & 6.79 & 1.02 & 100.11 & 59.73 & 34.37 & 5.90 & 0.25 & 0.95 \\
\hline P12PU3I & 58.42 & 24.83 & 0.39 & 0.02 & 6.96 & 0.32 & 0.15 & 7.03 & 1.17 & 99.29 & 60.36 & 33.03 & 6.61 & 0.26 & 0.82 \\
\hline P12PU3R & 59.08 & 24.74 & 0.35 & 0.00 & 6.65 & 0.32 & 0.20 & 6.97 & 1.19 & 99.48 & 60.99 & 32.16 & 6.85 & 0.35 & 0.84 \\
\hline P15PU5C & 56.49 & 26.51 & 0.44 & 0.01 & 8.99 & 0.34 & 0.15 & 5.81 & 0.62 & 99.36 & 51.94 & 44.41 & 3.65 & 0.27 & 0.91 \\
\hline Pl5PU5R & 59.44 & 24.38 & 0.37 & 0.00 & 6.50 & 0.31 & 0.20 & 7.04 & 1.14 & 99.37 & 61.85 & 31.56 & 6.59 & 0.36 & 0.81 \\
\hline P16PU7C & 60.97 & 24.39 & 0.33 & 0.00 & 6.01 & 0.31 & 0.26 & 7.32 & 1.27 & 100.85 & 63.78 & 28.94 & 7.28 & 0.46 & 0.81 \\
\hline P16PU7MC & 59.58 & 25.02 & 0.35 & 0.01 & 6.42 & 0.34 & 0.23 & 7.06 & 1.16 & 100.17 & 62.09 & 31.20 & 6.71 & 0.41 & 0.89 \\
\hline P16PU7MC2 & 60.35 & 24.78 & 0.37 & 0.00 & 6.43 & 0.33 & 0.16 & 7.13 & 1.23 & 100.78 & 62.04 & 30.92 & 7.04 & 0.28 & 0.86 \\
\hline P16PU7MR & 59.83 & 24.68 & 0.38 & 0.01 & 6.52 & 0.29 & 0.23 & 7.08 & 1.18 & 100.20 & 61.78 & 31.44 & 6.77 & 0.41 & 0.76 \\
\hline P16PU7R & 59.24 & 25.15 & 0.40 & 0.00 & 7.04 & 0.35 & 0.16 & 6.77 & 1.03 & 100.15 & 59.71 & 34.31 & 5.98 & 0.29 & 0.92 \\
\hline P17PU7C & 58.04 & 25.21 & 0.37 & 0.00 & 7.55 & 0.29 & 0.19 & 6.62 & 0.94 & 99.22 & 58.02 & 36.56 & 5.42 & 0.34 & 0.76 \\
\hline P17PU7R & 58.15 & 25.31 & 0.43 & 0.00 & 7.35 & 0.36 & 0.14 & 6.51 & 0.94 & 99.19 & 58.18 & 36.30 & 5.53 & 0.25 & 0.96 \\
\hline PlPU1C & 58.69 & 25.13 & 0.40 & 0.00 & 7.15 & 0.29 & 0.13 & 6.78 & 0.95 & 99.52 & 59.70 & 34.79 & 5.50 & 0.23 & 0.76 \\
\hline P1PU1MR & 60.71 & 24.10 & 0.37 & 0.00 & 5.63 & 0.28 & 0.24 & 7.46 & 1.40 & 100.19 & 64.91 & 27.07 & 8.02 & 0.42 & 0.73 \\
\hline PJPU1R & 61.13 & 23.44 & 0.39 & 0.00 & 5.00 & 0.27 & 0.29 & 7.41 & 1.69 & 99.63 & 65.66 & 24.48 & 9.85 & 0.52 & 0.72 \\
\hline P2GL3R & 58.92 & 24.77 & 0.44 & 0.01 & 6.73 & 0.32 & 0.17 & 6.94 & 1.11 & 99.41 & 60.93 & 32.65 & 6.41 & 0.30 & 0.84 \\
\hline P5GL5E & 56.74 & 26.33 & 0.42 & 0.01 & 8.82 & 0.34 & 0.09 & 5.92 & 0.76 & 99.43 & 52.42 & 43.16 & 4.43 & 0.16 & 0.90 \\
\hline P5GL5I & 58.07 & 25.38 & 0.38 & 0.00 & 7.54 & 0.35 & 0.13 & 6.51 & 0.97 & 99.32 & 57.54 & 36.82 & 5.64 & 0.23 & 0.93 \\
\hline P5GL5ME & 57.46 & 25.84 & 0.42 & 0.00 & 7.98 & 0.31 & 0.10 & 6.49 & 0.80 & 99.40 & 56.80 & 38.59 & 4.61 & 0.18 & 0.81 \\
\hline P5GL5MI & 57.53 & 26.04 & 0.36 & 0.01 & 8.32 & 0.30 & 0.15 & 6.35 & 0.78 & 99.83 & 55.41 & 40.12 & 4.48 & 0.26 & 0.78 \\
\hline P6CC1GL6E & 56.50 & 26.18 & 0.53 & 0.00 & 8.39 & 0.29 & 0.12 & 6.18 & 0.74 & 98.94 & 54,67 & 41.02 & 4.31 & 0.21 & 0.77 \\
\hline P7CCJGL6E & 56.34 & 26.20 & 0.42 & 0.01 & 8.36 & 0.33 & 0.15 & 6.37 & 0.74 & 98.92 & 55.50 & 40.25 & 4.24 & 0.26 & 0.86 \\
\hline P8E & 59.73 & 24.73 & 0.39 & 0.00 & 6.66 & 0.32 & 0.18 & 6.70 & 1.18 & 99.90 & 60.05 & 32.99 & 6.96 & 0.33 & 0.86 \\
\hline P8I & 55.82 & 27.67 & 0.49 & 0.02 & 10.10 & 0.36 & 0.18 & 5.38 & 0.51 & 100.53 & 47.62 & 49.41 & 2.97 & 0.32 & 0.95 \\
\hline P8ME & 58.18 & 25.79 & 0.37 & 0.00 & 7.90 & 0.35 & 0.07 & 6.44 & 0.82 & 99.94 & 56.76 & 38.48 & 4.76 & 0.12 & 0.92 \\
\hline P8MI & 55.83 & 26.93 & 0.49 & 0.01 & 9.37 & 0.40 & 0.13 & 5.87 & 0.60 & 99.62 & 51.30 & 45.25 & 3.45 & 0.23 & 1.05 \\
\hline P9GL7C & 60.37 & 23.58 & 0.37 & 0.00 & 5.56 & 0.29 & 0.25 & 7.57 & 1.56 & 99.55 & 64.87 & 26.33 & 8.80 & 0.43 & 0.74 \\
\hline P9GL7R & 60.35 & 23.88 & 0.36 & 0.00 & 5.74 & 0.26 & 0.21 & 7.48 & 1.38 & 99.66 & 64.71 & 27.44 & 7.85 & 0.37 & 0.67 \\
\hline \multicolumn{16}{|c|}{ PST102m2 (ig?) } \\
\hline P1PU1R & 59.03 & 24.83 & 0.43 & 0.01 & 6.75 & 0.33 & 0.16 & 6.95 & 1.13 & 99.62 & 60.92 & 32.66 & 6.42 & 0.30 & 0.83 \\
\hline P2GL2R & 56.42 & 26.24 & 0.44 & 0.00 & 8.38 & 0.34 & 0.15 & 6.39 & 0.75 & 99.11 & 55.49 & 40.26 & 4.23 & 0.26 & 0.87 \\
\hline P3GL3R & 58.17 & 25.30 & 0.42 & 0.00 & 7.40 & 0.38 & 0.16 & 6.54 & 0.96 & 99.33 & 58.12 & 36.40 & 5.48 & 0.27 & 0.97 \\
\hline
\end{tabular}


Appendix 2. Plagioclase compositions--Continued.

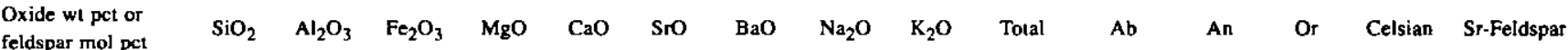

PST136m1 (ig?)

\begin{tabular}{|c|c|c|c|c|c|c|c|c|c|c|c|c|c|c|c|}
\hline PJGL1R & 58.21 & 25.38 & 0.45 & 0.01 & 7.37 & 0.36 & 0.15 & 6.53 & 0.95 & 99.41 & 58.18 & 36.30 & 5.53 & 0.25 & 0.96 \\
\hline P2PU1R & 60.74 & 24.09 & 0.34 & 0.00 & 5.65 & 0.28 & 0.23 & 7.45 & 1.38 & 100.16 & 64.91 & 27.08 & 8.02 & 0.42 & 0.72 \\
\hline P3PU2R & 59.78 & 24.64 & 0.39 & 0.01 & 6.50 & 0.30 & 0.24 & 7.10 & 1.19 & 100.15 & 61.80 & 31.40 & 6.79 & 0.42 & 0.77 \\
\hline
\end{tabular}

Tuff unit A of Fort Rock Creek rhyodacite unit

PST005

\begin{tabular}{|c|c|c|c|c|c|c|c|c|c|c|c|c|c|c|c|}
\hline P13PU14C & 56.87 & 26.97 & 0.23 & 0.00 & 8.84 & 0.45 & 0.00 & 6.15 & 0.48 & 99.98 & 54.18 & 43.04 & 2.78 & 0.00 & 1.19 \\
\hline P13PU14R & 60.39 & 25.14 & 0.21 & 0.00 & 6.90 & 0.40 & 0.01 & 7.11 & 0.68 & 100.84 & 62.53 & 33.53 & 3.93 & 0.02 & 1.05 \\
\hline P14PU16I & 61.89 & 23.98 & 0.18 & 0.01 & 5.14 & 0.23 & 0.09 & 8.46 & 1.03 & 101.00 & 70.63 & 23.71 & 5.66 & 0.15 & 0.57 \\
\hline P14PU16R & 61.54 & 24.00 & 0.19 & 0.00 & 5.05 & 0.32 & 0.11 & 8.13 & 0.97 & 100.29 & 70.34 & 24.14 & 5.52 & 0.19 & 0.83 \\
\hline P15GL8I & 62.61 & 23.07 & 0.21 & 0.00 & 4.56 & 0.20 & 0.11 & 8.57 & 1.08 & 100.40 & 72.62 & 21.35 & 6.02 & 0.19 & 0.51 \\
\hline P15GL8R & 62.17 & 23.59 & 0.21 & 0.00 & 4.88 & 0.33 & 0.15 & 8.60 & 1.05 & 100.99 & 71.74 & 22.50 & 5.76 & 0.25 & 0.82 \\
\hline P16PU18C & 61.70 & 23.71 & 0.21 & 0.00 & 5.14 & 0.38 & 0.11 & 8.05 & 0.95 & 100.24 & 69.91 & 24.67 & 5.43 & 0.19 & 0.99 \\
\hline P16PU18R & 62.27 & 23.18 & 0.18 & 0.00 & 4.64 & 0.28 & 0.04 & 8.07 & 1.05 & 99.73 & 71.26 & 22.64 & 6.10 & 0.07 & 0.74 \\
\hline P17GL12R & 62.06 & 23.22 & 0.17 & 0.00 & 4.81 & 0.25 & 0.03 & 8.22 & 1.10 & 99.87 & 70.85 & 22.91 & 6.24 & 0.05 & 0.64 \\
\hline P18PU21E & 62.03 & 23.18 & 0.18 & 0.01 & 4.61 & 0.33 & 0.13 & 8.61 & 1.12 & 100.19 & 72.39 & 21.42 & 6.20 & 0.22 & 0.83 \\
\hline P19PU21C & 58.15 & 26.74 & 0.22 & 0.02 & 8.44 & 0.32 & 0.11 & 6.22 & 0.65 & 100.87 & 54.99 & 41.23 & 3.78 & 0.20 & 0.85 \\
\hline P19PU21C2 & 57.13 & 26.26 & 0.27 & 0.00 & 7.56 & 0.47 & 0.09 & 6.94 & 0.56 & 99.29 & 60.42 & 36.37 & 3.21 & 0.16 & 1.22 \\
\hline P19PU21MC & 60.65 & 24.07 & 0.20 & 0.00 & 5.44 & 0.34 & 0.11 & 8.02 & 0.89 & 99.73 & 69.07 & 25.89 & 5.04 & 0.19 & 0.88 \\
\hline P19PU21R & 59.76 & 24.91 & 0.20 & 0.00 & 6.36 & 0.34 & 0.13 & 7.82 & 0.78 & 100.30 & 66.00 & 29.66 & 4.33 & 0.22 & 0.86 \\
\hline P20PU21C & 59.58 & 25.06 & 0.19 & 0.00 & 6.41 & 0.38 & 0.16 & 7.63 & 0.77 & 100.17 & 65.33 & 30.33 & 4.34 & 0.28 & 0.97 \\
\hline P20PU21MC & 59.90 & 24.54 & 0.18 & 0.01 & 5.73 & 0.37 & 0.10 & 7.97 & 0.84 & 99.65 & 68.18 & 27.09 & 4.73 & 0.17 & 0.95 \\
\hline P20PU21MC2 & 62.30 & 23.15 & 0.20 & 0.00 & 4.65 & 0.22 & 0.10 & 8.58 & 1.20 & 100.40 & 71.86 & 21.52 & 6.61 & 0.17 & 0.55 \\
\hline P20PU21MR & 62.03 & 23.83 & 0.18 & 0.00 & 5.07 & 0.34 & 0.05 & 8.17 & 1.02 & 100.69 & 70.17 & 24.06 & 5.76 & 0.09 & 0.87 \\
\hline P20PU21R & 62.13 & 23.46 & 0.19 & 0.00 & 4.81 & 0.36 & 0.09 & 8.51 & 1.06 & 100.61 & 71.72 & 22.40 & 5.88 & 0.15 & 0.91 \\
\hline $\mathrm{P} 21 \mathrm{C}$ & 64.27 & 22.48 & 0.16 & 0.00 & 3.67 & 0.14 & 0.06 & 9.13 & 1.17 & 101.08 & 76.54 & 17.00 & 6.45 & 0.10 & 0.35 \\
\hline P21MC & 64.38 & 22.19 & 0.16 & 0.00 & 3.40 & 0.12 & 0.04 & 9.37 & 1.29 & 100.95 & 77.45 & 15.53 & 7.02 & 0.07 & 0.30 \\
\hline P21MC2 & 64.41 & 22.04 & 0.17 & 0.00 & 3.25 & 0.10 & 0.09 & 9.13 & 1.42 & 100.61 & 76.98 & 15.14 & 7.88 & 0.15 & 0.25 \\
\hline P21MR & 63.25 & 23.11 & 0.20 & 0.00 & 4.29 & 0.25 & 0.07 & 8.51 & 1.16 & 100.84 & 73.09 & 20.36 & 6.55 & 0.12 & 0.64 \\
\hline P21R & 62.55 & 23.17 & 0.20 & 0.00 & 4.43 & 0.28 & 0.10 & 8.63 & 1.17 & 100.53 & 72.84 & 20.66 & 6.50 & 0.17 & 0.71 \\
\hline P24PU23E & 62.37 & 23.37 & 0.17 & 0.01 & 4.69 & 0.43 & 0.21 & 8.27 & 1.15 & 100.67 & 71.18 & 22.31 & 6.51 & 0.37 & 1.11 \\
\hline P24PU23I & 62.34 & 23.64 & 0.23 & 0.00 & 4.83 & 0.25 & 0.16 & 8.33 & 1.04 & 100.82 & 71.30 & 22.85 & 5.86 & 0.28 & 0.64 \\
\hline P25PU24E & 62.71 & 23.08 & 0.17 & 0.00 & 4.35 & 0.20 & 0.10 & 8.86 & 1.24 & 100.70 & 73.35 & 19.90 & 6.75 & 0.17 & 0.50 \\
\hline P25PU24I & 61.89 & 22.86 & 0.20 & 0.00 & 4.10 & 0.38 & 0.13 & 8.56 & 1.18 & 99.30 & 73.78 & 19.53 & 6.69 & 0.23 & 0.98 \\
\hline P25PU24ME & 63.76 & 22.38 & 0.16 & 0.00 & 3.51 & 0.35 & 0.13 & 8.34 & 1.48 & 100.11 & 74.11 & 17.24 & 8.65 & 0.23 & 0.93 \\
\hline P26PU23E & 62.70 & 23.15 & 0.21 & 0.00 & 4.49 & 0.19 & 0.08 & 8.48 & 1.12 & 100.42 & 72.49 & 21.21 & 6.30 & 0.14 & 0.49 \\
\hline P2PU3E & 61.66 & 24.00 & 0.17 & 0.00 & 5.22 & 0.25 & 0.10 & 8.39 & 0.92 & 100.71 & 70.62 & 24.28 & 5.10 & 0.17 & 0.63 \\
\hline P2PU3I & 61.84 & 23.67 & 0.18 & 0.00 & 4.68 & 0.29 & 0.07 & 8.43 & 1.00 & 100.16 & 72.21 & 22.15 & 5.64 & 0.12 & 0.74 \\
\hline P3GLAI & 57.88 & 26.15 & 0.22 & 0.00 & 7.77 & 0.40 & 0.10 & 7.12 & 0.54 & 100.18 & 60.50 & 36.48 & 3.02 & 0.17 & 1.02 \\
\hline P3GL4R & 60.82 & 23.73 & 0.21 & 0.00 & 4.97 & 0.37 & 0.16 & 8.33 & 0.96 & 99.57 & 71.15 & 23.46 & 5.39 & 0.28 & 0.95 \\
\hline P7PU7C & 58.64 & 26.23 & 0.20 & 0.00 & 7.59 & 0.46 & 0.04 & 7.20 & 0.54 & 100.89 & 61.28 & 35.70 & 3.02 & 0.07 & 1.17 \\
\hline P7PU7R & 61.41 & 23.55 & 0.18 & 0.00 & 4.95 & 0.31 & 0.16 & 8.54 & 0.94 & 100.06 & 71.80 & 23.00 & 5.20 & 0.27 & 0.78 \\
\hline
\end{tabular}

Fallout tuff deposits $\left(\mathrm{ft}_{2}\right)$

PST025

\begin{tabular}{|c|c|c|c|c|c|c|c|c|c|c|c|c|c|c|c|}
\hline PlGL1R & 62.33 & 23.21 & 0.18 & 0.00 & 4.64 & 0.28 & 0.03 & 8.07 & 1.05 & 99.79 & 71.26 & 22.64 & 6.10 & 0.07 & 0.74 \\
\hline P2GL2R & 59.68 & 24.89 & 0.21 & 0.00 & 6.36 & 0.34 & 0.13 & 7.81 & 0.78 & 100.20 & 66.00 & 29.66 & 4.33 & 0.22 & 0.86 \\
\hline \multicolumn{16}{|c|}{ Wild Horse Mesa Tuff (Twhm) } \\
\hline$P(L M) m$ & 65.93 & 20.68 & 0.12 & nd & 1.72 & nd & nd & 9.84 & 1.57 & 99.86 & 83.20 & 8.05 & 8.75 & nd & nd \\
\hline $\mathbf{P}(\mathbf{M M}) \mathrm{t}$ & 52.91 & 28.84 & 0.55 & nd & 11.62 & nd & nd & 4.71 & 0.34 & 98.42 & 41.27 & 56.26 & 2.48 & nd & nd \\
\hline
\end{tabular}





\title{
Introduction to the Area South of I-40 and North of I-10, Calif. and Ariz.
}

\author{
By Jane E. Nielson ${ }^{1}$, Keith A. Howard ${ }^{1}$, and Allen F. Glazner ${ }^{2}$
}

The stratigraphic columns in the area between Interstate Highways 10 and 40 are from localities in an east-trending belt from the central part of southeastem California near Barstow to west-central Arizona. The area encompasses parts of the southern Basin and Range physiographic province, including the southeastern Mojave Desert and Colorado River valley in California, and the Transition Zone to the Colorado Plateau in Arizona (fig. 1; also see Duebendorfer and others, this volume, fig. 1). Tertiary rocks in the region are characterized by marked lithologic heterogeneity and stratigraphic and structural complexity. Interpretations of the regional Tertiary stratigraphy in parts of the area are in Bassett and Kupfer (1964), Eberly and Stanley (1978), and Carr (1991). Field guides to Tertiary rocks in the area include ones by Frost and Martin (1982), Hazlett (1986), Nielson and Glazner (1986), Howard and others (1987), and Dokka and others (1988).

Highly extended terranes of Miocene age underlie the western and central parts of this area. These terranes are part of a belt of "core complexes" of the North American Cordillera, which trend from southern Canada to northern Mexico (Coney, 1980). The western extensional terrane has been called the Central Mojave extensional complex (Dokka, 1986), Mojave Rift (Dokka and others, 1988), or Mojave extensional belt (Dokka, 1989). The eastern extensional terrane has been called the Colorado River extensional corridor (Howard and John, 1987). Less-extended areas lie between the two terranes, and to the east of the Colorado River valley.

Late Cretaceous thrust faulting, metamorphism, and plutonism in the area were followed by a time of relative tectonic quiescence during most of the Paleogene, which lacks a depositional record. Oligocene(?) and lower Miocene nonmarine strata rest nonconformably on Proterozoic and Mesozoic gneiss and granite and local outcrops of $\mathrm{Pa}$ leozoic strata. These lowest Tertiary deposits are largely terrigenous sedimentary and volcanic rocks deposited during extensional tectonism. Upper parts of the Tertiary sections are related to younger strike-slip faulting and

\footnotetext{
${ }^{1}$ U.S. Geological Survey, Menlo Park, CA 94025

${ }^{2}$ University of North Carolina, Chapel Hill, NC 27514
}

compression, local alluvial deposition, estuarine flooding, and establishment of the throughgoing Colorado River.

\section{STRUCTURAL SETTING}

Principal Tertiary extensional structures of the region are west- or southwest-tilted fault blocks that are underlain by mostly east- to northeast-dipping, undulating detachment fault systems (for example, Carr and Dickey, 1980; Carr and others, 1980; Dickey and others, 1980; Davis and others, 1980; Howard, Goodge, and John, 1982; Howard, Stone, and others, 1982; Dokka, 1986; 1989; Howard and John, 1987; Glazner and others, 1989). The tilt of the fault blocks is opposite to the largely northeast direction of upper-plate transport on the detachment faults. Transfer faults that trend parallel to the direction of extension have segmented the extended terranes (Dokka, 1986; Hileman and others, 1990; Nielson and Beratan, 1990; Simpson and others, 1991). Aggregate fault displacements of about 40 $\mathrm{km}$ in the central Mojave Desert and more than $50 \mathrm{~km}$ in the Colorado River valley suggest extension on the order of 100 percent (Reynolds and Spencer, 1985; Howard and John, 1987; Glazner and others, 1989; Spencer and Reynolds, 1989a).

The Mojave extensional belt exposes a detachment fault north of Barstow, Calif., in the Waterman Hills (Glazner and others, 1989). Tilted faulted blocks above the projection of this fault can be traced downdip as far east as the Ship Mountains, Calif. They are cut by younger northwest-striking strike-slip faults (Dokka, 1986; Dokka and others, 1988; Glazner and others, 1989). The detailed stratigraphy of Miocene volcanic and sedimentary rocks in these ranges is known from the Cady Mountains (Glazner, 1988), Newberry Mountains, and several ranges near Barstow, Calif. (Dibblee, 1968; Burke and others, 1982; Woodburne and others, 1990). Most tilting and extension in this terrane occurred between 23 and 18.5 Ma (Dokka, 1986; Glazner, 1988; Hileman and others, 1990; Walker and others, 1990), before eruption of the Peach Springs Tuff of Young and Brennan (1974).

The detachment faults of the Colorado River extensional corridor lie between the Old Woman Mountains of 


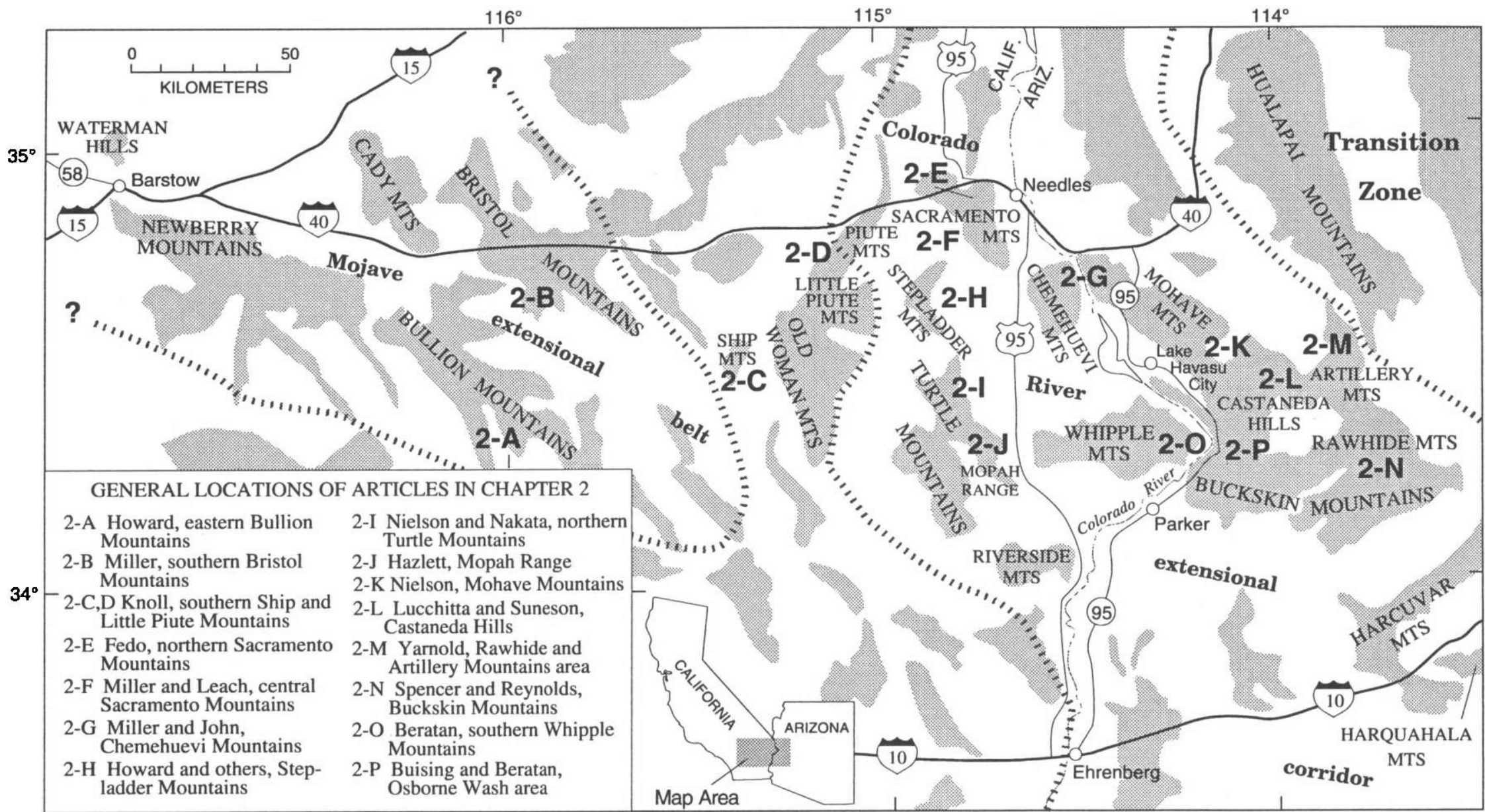

Figure 1. Locations and mountain ranges of the region covered by chapter 2; broken lines depict approximate boundaries of the extensional terranes. Distribution of the Bouse Formation shown in topical paper by Buising (this vol.). 
California and the Hualapai Mountains in the Transition Zone of Arizona. The faults are exposed in the uplifted cores of several mountain ranges--from north to southeast, these are: the Sacramento (McClelland, 1982; Spencer and Tumer, 1983), Chemehuevi (John, 1987), Whipple (Davis and others, 1980), and Riverside Mountains in California (Carr and Dickey, 1980), and the Rawhide, Buckskin, Harcuvar, and Harquahala Mountains of Arizona (Reynolds and Spencer, 1985; Spencer and Reynolds, 1989a, b; DeWitt and others, 1988; Richard, this volume; Spencer and Reynolds, this volume). Extension-related tilting of the Tertiary sections in these ranges occurred between 20 and $14 \mathrm{Ma}$ (Eberly and Stanley, 1978; Suneson and Lucchitta, 1983; Davis and others, 1980; Howard, Stone, and others, 1982; Nielson and Beratan, 1990; Nakata and others, 1990), and rapid cooling from uplift in the range cores had a similar age span (Davis, 1988; Davis and Lister, 1988; Foster and others, 1990; Richard and others, 1990; Bryant and others, 1991).

\section{STRATIGRAPHY}

Large lateral variations of Miocene sedimentary and volcanic sections are observed between and even within mountain ranges, and tilted sections range in age from Oligocene(?) to middle Miocene, with volcanic rocks locally predominant (Hazlett, 1990; Howard and others, this volume). The reconstructed thicknesses of overlying lower and middle Miocene sections commonly are between 1 and 3 $\mathrm{km}$ but may be thicker locally. The bulk of the stratigraphic sequences consist of locally derived nonmarine epiclastic, volcanic, and evaporite rocks. The lower Miocene Peach Springs Tuff is widespread across the entire region and is found in most of these sections (Glazner and others, 1986; Gusa and others, 1987; Wells and Hillhouse, 1989). Except for this marker unit, the sections exhibit large lateral variations in facies and in the proportion of sedimentary to volcanic rocks. These variations reflect deposition in small basins or subbasins (Suneson and Lucchitta, 1983; Dunn, 1986; Knoll and others, 1986; Hileman and others, 1990; Nielson and Beratan, 1990; Carr, 1991).

Upper Miocene to Quaternary lacustrine, estuarine, fluvial, and alluvial fan deposits are slightly tilted to untilted. Many of these materials were deposited in closed basins, but particularly in the Colorado River valley, the younger rocks record a transition to the throughgoing drainage system of the present day (Suneson and Lucchitta, 1983; Buising and Beratan, this volume; Nielson, this volume).

\section{SEDIMENTARY ROCKS}

The lowermost Tertiary deposits commonly are Oligocene or Miocene arkosic conglomerate and grus that nonconformably overlie deeply weathered pre-Tertiary metamorphic and plutonic rocks. Lower and middle Miocene strata above the basal arkose consist predominantly of nonmarine fluvial and alluvial arkosic to tuffaceous sandstone, siltstone, conglomerate, and lesser lacustrine carbonate units (Beratan, this volume; Buising and Beratan this volume; Buising, this volume; Fedo, this volume; Lucchitta and Suneson, this volume; Miller and Leach, this volume). Landslide or avalanche breccia and megabreccia deposits are nearly ubiquitous in the sections (Suneson and Lucchitta, 1983; Dunn, 1986; Howard and others, 1987; Miller and John, 1988; Sherrod, 1988; Fedo, this volume). The younger Bouse Formation comprises fine-grained clastic and evaporite rocks (gypsum, carbonate rocks) ascribed to an estuarine environment (Metzger and Loeltz, 1973; Buising, 1990, this volume).

\section{IGNEOUS ROCKS}

Lower and middle Miocene volcanic rocks are predominantly of intermediate compositions, including basaltic andesite, andesite, dacite, and latite. Basalt and rhyolite also are present locally. Lava and pyroclastic materials were erupted from central volcanic complexes in the Mojave extensional belt (Dibblee, 1964; 1966; 1967a, b; Glazner, 1988; Howard, this volume), and from linear dikes and small aligned volcanic edifices that are preserved as plugs in and near the Colorado River extensional corridor (Suneson and Lucchitta, 1983; Lukk, 1982; Hazlett, 1990; Nielson and Nakata, chap. 2, this volume). The source of the voluminous Peach Springs Tuff has not yet been identified, but probably was located near or north of Needles, Calif. (Hillhouse and Wells, 1991).

Exposures of deeper crustal levels reveal early Miocene dike swarms and local plutons of Oligocene to early Miocene age in many ranges (Dibblee, 1966; Dibblee and Bassett, 1966a, b; Davis and others, 1982; John, 1982; Nakata, 1982; Howard and John, 1984; Spencer, 1985; Dokka, 1986; Wright and others, 1986; Howard and others, 1987; Bryant and Wooden, 1989; Anderson and Cullers, 1990; Foster and others, 1990; Richard and others, 1990; Nakata and others, 1990; Howard, this volume). The dike swarms account for as much as 16 percent by volume or $2 \mathrm{~km}$ in thickness in some ranges (Nakata, 1982).

Late Miocene and younger volcanic rocks are less abundant than the earlier ones and consist largely of basalt and locally rhyolite. In the Castaneda Hills, rhyolite flows and intrusions are dated between 15 and $10 \mathrm{Ma}$, and basalt flows are as young as $8 \mathrm{Ma}$ (Suneson and Lucchitta, 1979, 1983). Basalt flows were erupted intermittently in the area throughout the Neogene and into Holocene time (Miller, 1989). 


\section{RELATIONSHIP OF SEDIMENTARY AND VOLCANIC ROCKS TO TERTIARY EXTENSION}

The Tertiary sections of the central Mojave and Colorado River extensional corridor comprise unconformitybounded sequences of sedimentary and volcanic rocks. At least two (synextension and postextension) sequences are identifiable throughout the region (Eberly and Stanley, 1978; Suneson and Lucchitta, 1983; Glazner, 1988; Sherrod, 1988; Hileman and others, 1990; Walker and others, 1990). Lower to middle Miocene strata record episodes of sedimentation and volcanism that probably occurred contemporaneously with movement along major detachment and transfer faults (Nielson and Beratan, 1990; Simpson and others, 1991). Within the synextensional sequences, local angular unconformities define two stages of deposition in the east part of the central Mojave and west part of the Colorado River extensional terranes (Howard, Stone, and others, 1982; Hileman and others, 1990; Hazlett, 1990, this volume). Three synextensional Miocene sequences are distinguished locally in the central part of the Colorado River extensional corridor (Nielson and Beratan, 1990; Beratan, this volume; Lucchitta and Suneson, this volume; Miller and John, this volume).

The lower Miocene sedimentary and volcanic rocks represent the fillings of depositional basins, many bounded by high-angle faults, that formed during movement on underlying detachment faults. These basins received coarse clastic detritus and eruptive rocks (Suneson and Lucchitta, 1983; Knoll and others, 1986; Sherrod, 1988; Nielson and Beratan, 1990; Knoll, this volume; Lucchitta and Suneson, this volume; D. Miller, this volume; Yarnold, this volume). Flows of lava and pyroclastic ejecta dammed and modified the local depositional systems in some localities (Hazlett, 1990; Nielson and Beratan, 1990). High-level intrusions engulfed older sedimentary deposits in areas of abundant volcanism (Nielson and Beratan, 1990).

Abundant clastic sedimentation followed the major early Miocene volcanism in both the Mojave and Colorado River extensional terranes (Suneson and Lucchitta, 1983; Miller and John, 1988; Fedo, this volume). Landslide breccia, immature locally derived sharpstone conglomerate, and lacustrine and playa facies commonly are present in Tertiary stratigraphic sections of the Colorado River extensional corridor. Rocks of these depositional environments suggest a landscape of basins bounded by fault scarps of substantial local relief.

Many of the lower and middle Miocene sections show systematic decreases in stratal tilt upsection, suggesting deposition in active growth-fault basins. Waning and ending of tectonic extension is recorded by younger Miocene strata that are relatively undeformed and that overlie the tilted Miocene rocks.

\section{REFERENCES CITED}

Anderson, J.L., and Cullers, R.L., 1990, Middle to upper crustal plutonic construction of a magmatic arc; an example from the Whipple Mountains metamorphic core complex, in Anderson, J.L., ed., The nature and origin of Cordilleran magmatism: Geological Society of America Memoir 174, p. 47-69.

Bassett, A.M, and Kupfer, D.H., 1964, A geologic reconnaissance in the southeastern Mojave Desert, California: California Division of Mines and Geology Special Report 83, 43 p.

Bryant, Bruce, Naeser, C.W., and Fryxell, J.E., 1991, Implications of low-temperature cooling history on a transect across the Colorado Plateau-Basin and Range boundary, west-central Arizona: Journal of Geophysical Research, v. 96, no. B7, p. $12,375-12,388$.

Bryant, Bruce, and Wooden, J.L., 1989, Lower-plate rocks of the Buckskin Mountains, Arizona; a progress report, in Spencer, J.E., and Reynolds, S.J., eds., Geology and mineral resources of the Buckskin and Rawhide Mountains, westcentral Arizona: Arizona Geological Survey Bulletin 198, p. $47-50$.

Buising, A.V., 1990, The Bouse Formation and bracketing units, southeastem California and Arizona: implications for the evolution of the proto-Gulf of California and the lower Colorado River: Journal of Geophysical Research, v. 95, no. B12, p. $20,111-20,132$.

Burke, D.B., Hillhouse, J.W., McKee, E.H., Miller, S.T., and Morton, J.L., 1982, Cenozoic rocks in the Barstow basin area of southern California-Stratigraphic relations, radiometric ages, and paleomagnetism: U.S. Geological Survey Bulletin 1529-E, 16 p.

Carr, W.J., 1991, Tectonic history of the Vidal-Parker region, California and Arizona: U.S. Geological Survey Professional Paper 1430, $40 \mathrm{p}$.

Carr, W.J., and Dickey, D.D., 1980, Geologic map of the Vidal, Califomia, and Parker SW, Califomia-Arizona quadrangles: U.S. Geological Survey Miscellaneous Investigations Map I1125 , scale $1: 24,000$.

Carr, W.J., Dickey, D.D., and Quinlivan, W.D., 1980, Geologic map of the Vidal NW, Vidal Junction, and parts of the Savahia Peak SW and Savahia Peak quadrangles, San Bernardino County, California: U.S. Geological Survey Miscellaneous Investigations Map I-1126, scale 1:24,000.

Coney, P.F., 1980, Cordilleran metamorphic core complexes: An overview, in Crittenden, M.D., Jr., Coney, P.F., and Davis, G.H., eds., 1980, Cordilleran metamorphic core complexes: Geological Society of America Memoir 153, p. 7-31.

Davis, G.A., 1988, Rapid upward transport of mid-crustal mylonitic gneisses in the footwall of a Miocene detachment fault, Whipple Mountains, southeastern California: Geologische Rundschau, v. 77, no. 1, p. 191-209.

Davis, G.A., Anderson, J.L., Frost, E.G., and Shackelford, T.J., 1980, Mylonitization and detachment faulting in the Whipple-Buckskin-Rawhide Mountains terrane, southeastern California and western Arizona, in Crittenden, M.D., Jr., Coney, P.J., and Davis, G.H., eds., Cordilleran metamorphic core complexes: Geological Society of America Memoir 153, p. 79-129. 
Davis, G.A., Anderson, J.L., Martin, D.L., Krummenacher, Daniel, Frost, E.G., and Armstrong, R.L., 1982, Geologic and geochronologic relations in the lower plate of the Whipple detachment fault, Whipple Mountains, southeastern California; a progress report, in Frost, E.G., and Martin, D.L., eds., Mesozoic-Cenozoic tectonic evolution of the Colorado River region, California, Arizona, and Nevada (AndersonHamilton Volume): San Diego, Calif., Cordilleran Publishers, p. 408-432.

Davis, G.A., and Lister, G.S., 1988, Detachment faulting in continental extension: perspectives from the southwestern U.S. Cordillera, in Clark, S.P., Jr., Burchfiel, B.C., and Suppe, J., eds., Processes in continental lithospheric deformation: Geological Society of America Special Paper 218, p. 133-159.

DeWitt, Edward, Richard, S.M., Hassemer, J.R., Hanna, W.F., and Thompson, J.R., 1988, Mineral resources of the Harquahala Mountains Wilderness Study Area, La Paz and Maricopa Counties, Arizona: U.S. Geological Survey Bulletin 1701-C, $27 \mathrm{p}$.

Dibblee, T.W., Jr., 1964, Geologic map of the Rodman Mountains quadrangle, San Bernardino County, California: U.S. Geological Survey Miscellaneous Investigations Map I-430, scale $1: 62,500$.

-1966 , Geologic map of the Lavic quadrangle, San Bernardino County, California: U.S. Geological Survey Miscellaneous Investigations Map I-472, scale 1:62,500.

-1967 a, Geologic map of the Ludlow quadrangle, San Bernardino County, California: U.S. Geological Survey Miscellaneous Investigations Map I-477, scale 1:62,500.

1967b, Geologic map of the Broadwell Lake quadrangle, San Bernardino County, California: U.S. Geological Survey Miscellaneous Investigations Map I-478, scale 1:62,500.

-1968 , Geology of the Fremont Peak and Opal Mountain quadrangles, California: California Division of Mines and Geology Bulletin, no. 188, 64 p.

Dibblee, T.W., Jr., and Bassett, A.M., 1966a, Geologic map of the Cady Mountains quadrangle, San Bernardino County, Califomia: U.S. Geological Survey Miscellaneous Investigations Map I-467, scale 1:62,500.

1966b, Geologic map of the Newberry quadrangle, San Bernardino County, California: U.S. Geological Survey Miscellaneous Investigations Map I-461, scale 1:62,500.

Dickey, D.D., Carr, W.J., and Bull, W.B., 1980, Geologic map of the Parker NW, Parker, and parts of the Whipple Mountains SW and Whipple Wash quadrangles, California and Arizona: U.S. Geological Survey Miscellaneous Investigations Map I1124, scale 1:24,000.

Dokka, R.K., 1986, Patterns and modes of early Miocene crustal extension, central Mojave Desert, California, in Mayer, Larry, ed., Extensional tectonics of the southwestern United States: a perspective on processes and kinematics: Geological Society of America Special Paper 208, p. 75-95.

1989, The Mojave extensional belt of southern California: Tectonics, v. 8, no. 2, p. 363-390.

Dokka, R.K., McCurry, Michael, Woodburne, M.O., Frost, E.G., and Okaya, D.A., 1988, A field guide to the Cenozoic crustal structure of the Mojave Desert, in Weide, D.L., and Faber, M.L., eds., This extended land: geological journeys in the southem Basin and Range: Las Vegas, University of Nevada Department of Geosciences Special Publication 2: Geologi- cal Society of America, Cordilleran Section, Las Vegas, Nev., March 1988 Field Trip Guidebook, p. 21-44.

Dunn, J. F., 1986, The structural geology of northeastern Whipple Mountains detachment terrane: Los Angeles, University of Southem Catifornia, M.S. thesis, 113 p.

Eberly, L.D. and Stanley, T.B., Jr., 1978, Cenozoic stratigraphy and geologic history of southwestern Arizona: Geological Society of America Bulletin, v. 89, no. 6, p. 921-940.

Foster, D.A., Harrison, T.M., Miller, C.F., and Howard, K.A., 1990 , The ${ }^{40} \mathrm{Ar} /{ }^{39} \mathrm{Ar}$ thermochronology of the eastern Mojave Desert, California, and adjacent western Arizona with implications for the evolution of metamorphic core complexes: Journal of Geophysical Research, v. 95, no. B12, p. $20,005-20,024$.

Frost, E.G., and Martin, D.L., 1982, Comparison of Mesozoic compressional tectonics with mid-Tertiary detachment faulting in the Colorado River area, California, Arizona, and Nevada, in Cooper, J.D., compiler, Geologic excursions in the California desert: Geological Society of America, Cordilleran Section, 78th, Anaheim, Calif., April 1982, Volume and Guidebook, Field Trip nos. 2, 7, and 13, p. 113-159.

Glazner, A.F., 1988, Stratigraphy, structure, and potassic alteration of Miocene volcanic rocks in the Sleeping Beauty area, central Mojave Desert, California: Geological Society of America Bulletin, v. 100, no. 3, p. 424-435.

Glazner, A.F., Bartley, J.M., and Walker, J.D., 1989, Magnitude and significance of Miocene crustal extension in the central Mojave desert, California: Geology, v. 17, no. 1, p. 50-53.

Glazner, A.F., Nielson, J.E., Howard, K.A., and Miller, D.M., 1986, Correlation of the Peach Springs Tuff, a large-volume Miocene ignimbrite sheet in California and Arizona: Geology, v. 14 , no. 10 , p. $840-843$.

Gusa, Sharon, Nielson, J.E., and Howard, K.A., 1987, Heavy mineral suites confirm the wide extent of the Peach Springs Tuff in California and Arizona, U.S.A.: Journal of Volcanology and Geothermal Research, v. 33, no. 4, p. 343-347.

Hazlett, R.W., 1986, Geology of the central Mopah Range; a guide for excursions in the Mopah Spring area: in Cenozoic stratigraphy, structure and mineralization in the Mojave Desert: Geological Society of America, Cordilleran Section, 82d, Los Angeles, Calif., March 1986, Guidebook and Volume, Field Trips 5 and 6, p. 33-42.

1990, Extension-related Miocene volcanism in the Mopah Range volcanic field, southeastern California, in Anderson, J.L., ed., The nature and origin of Cordilleran magmatism: Geological Society of America Memoir 174, p. 133-145.

Hileman, G.E., Miller, C.F., and Knoll, M.A., 1990, Mid-Tertiary structural evolution of the Old Woman Mountains region: implications for crustal extension across southeastern California: Journal of Geophysical Research, v. 95, no. B1, p. 581-597.

Hillhouse, J.W., and Wells, R.E., 1991, Magnetic fabric, flow directions, and source area of the lower Miocene Peach Springs Tuff in Arizona, California, and Nevada: Journal of Geophysical Research, v. 96, no. B7, p. 12,443-12,460.

Howard, K.A., Goodge, J.W., and John, B.E., 1982, Detached crystalline rocks of the Mohave, Buck, and Bill Williams Mountains, western Arizona, in Frost, E.G., and Martin, D.L., eds., Mesozoic-Cenozoic tectonic evolution of the Colorado River region, California, Arizona, and Nevada 
(Anderson-Hamilton Volume): San Diego, Calif., Cordilleran Publishers, p. 377-390.

Howard, K.A., and John, B.E., 1984, Geologic map of the Sheep Hole-Cadiz Wilderness Study Area (CDCA-305), San Bernardino County, California: U.S. Geological Survey Miscellaneous Field Studies Map MF-1615-A, scale 1:62,500.

-1987, Crustal extension along a rooted system of imbricate low-angle faults, Colorado River extensional corridor, California and Arizona, in Coward, M.P., Dewey, J.F., and Hancock, P.L., eds., Continental extensional tectonics: Geological Society of London Special Publication 28, p. 299311.

Howard, K.A., John, B.E., and Miller, C.F., 1987, Metamorphic core complexes, Mesozoic ductile thrusts, and Cenozoic detachments: Old Woman Mountains-Chemehuevi Mountains transect, California and Arizona: Arizona Bureau of Geology and Mineral Technology Special Paper 5, p. 365-382.

Howard, K.A., Stone, Paul, Pernokas, M.A., and Marvin, R.F., 1982, Geologic and geochronologic reconnaissance of the Turtle Mountains area, California: west border of the Whipple Mountains detachment terrane, in Frost, E.G., and Martin, D.L., eds., Mesozoic-Cenozoic tectonic evolution of the Colorado River region, California, Arizona, and Nevada (Anderson-Hamilton Volume): San Diego, Calif., Cordilleran Publishers, p. 341-354.

John, B.E., 1982, Geologic framework of the Chemehuevi Mountains, southeastern California, in Frost, E.G., and Martin, D.L., eds., Mesozoic-Cenozoic tectonic evolution of the Colorado River region, Califomia, Arizona, and Nevada (Anderson-Hamilton Volume): San Diego, Calif., Cordilleran Publishers, p. 317-325.

- 1987, Geometry and evolution of a mid-crustal extensional fault system: Chemehuevi Mountains, southeastern California, in Coward, M.P., Dewey, J.F. and Hancock, P.L., eds., Continental extensional tectonics: Geological Society of London Special Publication 28, p. 312-333.

Knoll, M.A., Miller, C. F., and James, W.C., 1986, Mid-Tertiary stratigraphic and structural evolution of the Piute Mountains basin and adjacent areas of the Old Woman Mountains region, southeastem California, in Cenozoic stratigraphy, structure and mineralization in the Mojave Desert: Geological Society of America, Cordilleran Section, 82d, Los Angeles, Calif., March 1986, Guidebook and Volume, Field Trips 5 and 6, p. 43-49.

Lukk, M.E., 1982, The geology and geochemistry of the Tertiary volcanic rocks of the northeastern half of the Clipper Mountains, eastern Mojave Desert, California: Riverside, University of California, M.S. thesis, $120 \mathrm{p}$.

McClelland, W.C., 1982, Structural geology of the central Sacramento Mountains, San Bernardino County, in Frost, E.G., and Martin, D.L., eds., Mesozoic-Cenozoic tectonic evolution of the Colorado River region, California, Arizona, and Nevada (Anderson-Hamilton Volume): San Diego, Calif., Cordilleran Publishers, p. 401-407.

Metzger, D.G., and Loeltz, O.J., 1973, Geohydrology of the Needles area, Arizona, California, and Nevada: U.S. Geological Survey Professional Paper 486-J, 54 p.

Miller, C.D., 1989, Potential hazards from future volcanic eruptions in California: U.S. Geological Survey Bulletin 1847 , $17 \mathrm{p}$.
Miller, J.M.G., and John, B.E., 1988, Detached strata in a Tertiary low-angle normal fault terrane, southeastern California: a sedimentary record of unroofing, breaching, and continued slip: Geology, v. 16, no. 7, p. 645-648.

Nakata, J.K., 1982, Preliminary report on diking events in the Mohave Mountains, Arizona, in Frost, E.G., and Martin, D.L., eds., Mesozoic-Cenozoic tectonic evolution of the Colorado River region, California, Arizona, and Nevada (Anderson-Hamilton Volume): San Diego, Calif., Cordilleran Publishers, p. 85-90.

Nakata, J.K, Pernokas, M.A., Howard, K.A., Nielson, J.E., and Shannon, J.R., 1990, K-Ar and fission-track ages (dates) of volcanic, intrusive, altered, and metamorphic rocks in the Mohave Mountains area, west-central Arizona: Isochron/ West, no. 56 , p. $8-20$.

Nielson, J.E., and Beratan, K.K., 1990, Tertiary basin development and tectonic implications, Whipple detachment system, Colorado River extensional corridor, California and Arizona: Journal of Geophysical Research, v. 95, no. B1, p. 599-614.

Nielson, J.E., and Glazner, A.F., 1986, Miocene stratigraphy and structure: Colorado Plateau to the central Mojave Desert: Introduction and Road Log, in Cenozoic stratigraphy, structure and mineralization in the Mojave Desert: Geological Society of America, Cordilleran Section, 82d, Los Angeles, Calif., March 1986, Guidebook and Volume, Field Trips 5 and 6, p. 1-6.

Reynolds, S.J., and Spencer, J.E., 1985, Evidence for large-scale transport on the Bullard detachment fault, west-central Arizona: Geology, v. 13 , no. 5 , p. 353-356.

Sherrod, D.R., 1988, Preliminary geologic map of the Monkeys Head quadrangle, Mohave and La Paz Counties, Arizona: U.S. Geological Survey Open-File Report 88-597, scale $1: 24,000$.

Simpson, Carol, Schweitzer, Janet, and Howard, K.A., 1991, A reinterpretation of the timing, position, and significance of the Sacramento Mountains detachment fault, SE Califomia: Geological Society of America Bulletin, v. 103, no. 6, p. 751-761.

Spencer, J.E., 1985, Miocene low-angle nomal faulting and dike emplacement, Homer Mountain and surrounding areas, southeastem California and southernmost Nevada: Geological Society of America Bulletin, v. 96, no. 9, p. 1,140-1,155.

Spencer, J.E., and Reynolds, S.J., 1989a, Tertiary structure, stratigraphy, and tectonics of the Buckskin Mountains, in Spencer, J.E., and Reynolds, S.J., eds., Geology and mineral resources of the Buckskin and Rawhide Mountains, west-central Arizona: Arizona Geological Survey Bulletin 198, p. 103-167.

Spencer, J.E., and Reynolds, S.J., 1989b, Middle Tertiary tectonics of Arizona and adjacent areas, in Jenney, J.P., and Reynolds, S.J., eds., Geologic evolution of Arizona: Arizona Geological Society Digest 17, p. 539-574.

Spencer, J.E., and Tumer, R.D., 1983, Geologic map of part of the northwestern Sacramento Mountains, southeastem California: U.S. Geological Survey Open-File Report 83-614, scale, 1:24,000.

Suneson, Neil, and Lucchitta, Ivo, 1979, K/Ar ages of Cenozoic volcanic rocks, west-central Arizona: Isochron/West, no. 24, p. 25-29.

1983, Origin of bimodal volcanism, southern Basin and Range province, west-central Arizona: Geological Society of America Bulletin, v. 94, no. 8, p. 1,005-1,019. 
Walker, J.D., Bartley, J.M., and Glazner, A.F., 1990, Large-magnitude Miocene extension in the central Mojave Desert; implications for Paleozoic to Tertiary paleogeography and tectonics: Journal of Geophysical Research, v. 95, no. B1, p. 557-569.

Wells, R.E., and Hillhouse, J.W., 1989, Paleomagnetism and tectonic rotation of the lower Miocene Peach Springs Tuff: Colorado Plateau, Arizona, to Barstow, California: Geological Society of America Bulletin, v. 101, no. 6, p. 846-863.

Woodburne, M.O, Tedford, R.H., and Swisher, C.C., 1990, Lithostratigraphy, biostratigraphy, and geochronology of the Barstow Formation, Mojave Desert, southern California:
Geological Society of America Bulletin, v. 102, no. 4, p. $459-477$

Wright, J.E., Anderson, J.L., and Davis, G.A., 1986, Timing of plutonism, mylonitization, and decompression in a metamorphic core complex, Whipple Mountains, California [abs.]: Geological Society of America Abstracts with Programs, v. 18 , no. 2 , p. 201 .

Young, R.A., and Brennan, W.J., 1974, Peach Springs Tuff: its bearing on structural evolution of the Colorado Plateau and development of Cenozoic drainage in Mohave County, Arizona: Geological Society of America Bulletin, v. 85, no. 1, p. 83-90. 



\title{
Cenozoic Stratigraphy of the Lead Mountain and Valley Mountain Areas, Eastern Bullion Mountains, Southeastern Calif.
}

\author{
By Keith A. Howard ${ }^{1}$
}

\section{INTRODUCTION}

Tertiary rocks are rare in the south-central Mojave Desert. Consequently the Tertiary record is known from widely separated and fragmentary sections. Early Cenozoic erosion in the region was followed by early Miocene tectonic extension. Faulting continued into Quaternary time along northwest-striking right-slip faults and eaststriking left-slip faults (Dibblee, 1967; Dokka, 1986; Dokka and Travis, 1990). This report describes Cenozoic stratigraphy in the adjoining Lead Mountain and Valley Mountain 15-minute quadrangles, an area between Amboy and Twentynine Palms, Calif. (fig. 1). Mesozoic granitoids underlie much of the eastern Bullion Mountains, which are centrally located in this area, and locally derived Quaternary alluvium and windblown sand occupy the floors of intervening valleys. Fragmentary sections of Tertiary rocks, which crop out at Lead Mountain in the north and at Valley Mountain in the south, likely represent separate depocenters.

\section{LOWER MIOCENE ROCKS}

The oldest Tertiary rocks known in the area are of early Miocene age (col. 2-A, pl. 2). A basanite flow (43 percent $\mathrm{SiO}_{2}$ ) overlies and intrudes Jurassic granite at Valley Mountain; the basalt has a $\mathrm{K}-\mathrm{Ar}$ age of $22.7 \pm 0.7 \mathrm{Ma}$ (whole rock) (J.K. Nakata, written commun., 1986). At Lead Mountain, amygdaioidal basalt (which proved undateable) and unstudied clastic sedimentary rocks range from steeply dipping to overturned and are the lowest Tertiary units exposed; they nonconformably overlie Jurassic quartz monzonite. Clasts of the basalt occur in locally exposed arkosic sharpstone conglomerate that is intruded by an irregular dacite stock.

The stock occupies the core of a volcanic complex, more than $5 \mathrm{~km}$ across, of dacite to rhyodacite dikes,

\footnotetext{
'U.S. Geological Survey, 345 Middlefield Road, Menlo Park, CA 94025
}

glassy flows, breccia, and tuff, and local dacite-clast conglomerate. The complex is several hundred meters thick in aggregate; it underlies most of Lead Mountain and is interpreted as the remnants of a volcano. The layered rocks dip from $10^{\circ}$ to $60^{\circ}$ and are more faulted than the intrusive rocks in the complex. The intrusive and layered rocks contain abundant phenocrysts of plagioclase, less abundant biotite, and local hornblende or quartz. Two analyzed

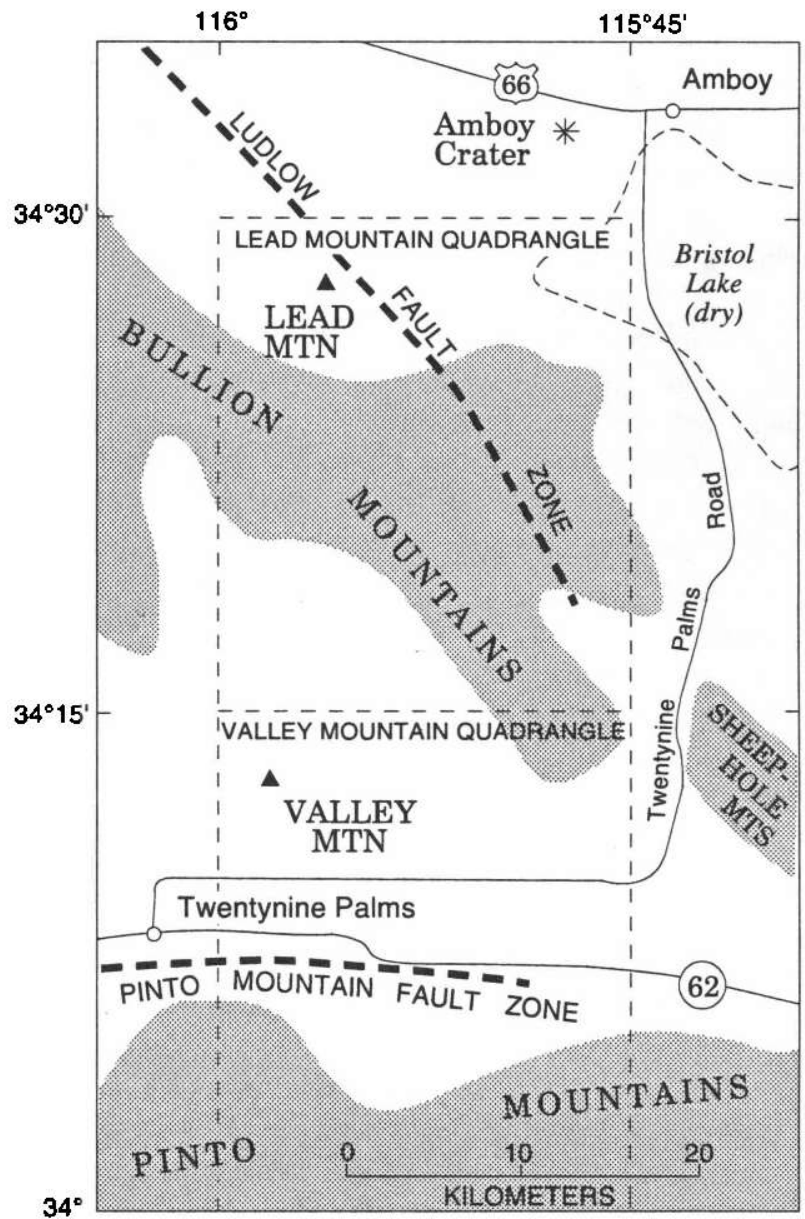

Figure 1. Map showing geographic and geologic features discussed in text. 
dacite flows and a rhyolite flow contained from 67 to 73 percent $\mathrm{SiO}_{2}$. J.K. Nakata (written commun., 1985) obtained $\mathrm{K}$-Ar ages of $20.8 \pm 0.5 \mathrm{Ma}$ from homblende in one flow and 20.1 $\pm 1.0 \mathrm{Ma}$ from biotite in another. The volcanic center may be related to a swarm of lithologically and chemically similar plagioclase-phyric dikes $(68$ percent $\mathrm{SiO}_{2}$ ) that intrudes pre-Tertiary rocks now in the easternmost Bullion Mountains, 10 to $25 \mathrm{~km}$ southwest of Lead Mountain (Miller and others, 1982; Howard and John, 1984).

\section{UPPER TERTIARY AND QUATERNARY DEPOSITS}

Three deposits of conglomerate and gravel are assigned to the upper Neogene. The most prominent is a sequence about $500 \mathrm{~m}$ thick of boulder and cobble conglomerate and interbedded sandstone on the southeast flank of Lead Mountain. The conglomerate unit dips from $10^{\circ}$ to $30^{\circ}$ and rests on an irregular surface eroded on deformed dacite of the Lead Mountain volcano. A clast assemblage of dacite, quartz monzonite, muscovite granite, and rarer wollastonite marble suggests a source in the easternmost Bullion Mountains, 5 to $20 \mathrm{~km}$ to the southeast. Restoration of several kilometers of right slip along the northwest-trending Ludlow fault zone (Bishop, 1963) would place the conglomerate and this inferred eastern source in closer proximity. Such a restoration would also bring the dacite dike swarm and the Lead Mountain volcano closer together.

Clasts from now-isolated sources also characterize the other two upper Neogene conglomerate units, both of which are preserved as high-level perched gravel beds on bedrock hills in the Valley Mountain quadrangle. Gravel that caps a flat summit in the Pinto Mountains $7 \mathrm{~km}$ southeast of Twentynine Palms rests on Proterozoic gneiss and consists of angular clasts of the gneiss and also of white quartzite for which the nearest source is $15 \mathrm{~km}$ distant. The other gravel forms a faulted patch that rests on Jurassic metavolcanic rocks $12 \mathrm{~km}$ east of Valley Mountain. It consists of angular to subrounded boulders of likely Miocene flow-banded rhyolite, spherulitic rhyolite, crystal-rich dacite, and friable quartz sandstone. The source for the clasts is unknown.

Deformed Pleistocene sedimentary rocks crop out along young fault zones in the southern Bullion Mountains and also in the east-trending Twentynine Palms valley between the Bullion and Pinto Mountains. The deposits in the Bullion Mountains consist of arkosic sandstone and locally derived gravel. The deposits near Twentynine Palms were described and subdivided by Bacheller (1978; see also Moyle, 1961; Bassett and Kupfer, 1964; Dibblee, 1968). The sedimentary rocks of Campbell Hill contain a Rancholabrean fauna and are more than $370 \mathrm{~m}$ thick. They consist of sand, bedded clast-supported gravel, and lacustrine silt, marl, and clay. Clasts derived from the San Bernardino Mountains indicate eastward transport of sediment along the modern valley. The Campbell Hill unit interfingers abruptly southward with fanglomerate, breccia, and arkosic sandstone adjacent to the Pinto Mountains, where lenses of brown and green sandstone are present. Bacheller (1978) suggested that an ash bed found within a section of green sandstone low in the sequence correlates with the $\sim 0.7$ Ma Bishop Tuff, based on petrographic and chemical similarities. He found that clast assemblages of Jurassic quartz monzonite and Proterozoic gneiss in the fanglomerate align with bedrock sources if several kilometers of Quaternary left slip are restored along the east-trending Pinto Mountain fault zone.

Basalt cinder cones and flows near Lead Mountain range from Pliocene(?) to late Quaternary in age. The older cones, west of Lead Mountain, are dissected by erosion. An 8-km-long flow of basalt (49 percent $\mathrm{SiO}_{2}$ ) derived from a cone on the south flank of Lead Mountain has a KAr age of $0.36 \pm 0.04 \mathrm{Ma}$ (whole rock) (J.K. Nakata, written commun., 1985). Holocene(?) basalt at Amboy Crater northeast of Lead Mountain overlies playa deposits of Bristol dry lake, according to Bassett and Kupfer (1964).

\section{REFERENCES CITED}

Bacheller, John, 1978, Quatemary geology of the Mojave Desert-eastern Transverse Ranges boundary in the vicinity of Twentynine Palms, California: Los Angeles, University of Califomia, M.S. thesis, 157 p.

Bassett, A.M., and Kupfer, D.H., 1964, A geologic reconnaissance in the southeastern Mojave Desert, California: California Division of Mines and Geology Special Report 83, 43 p.

Bishop, C.C., compiler, 1963, Needles sheet, Geologic atlas of California: California Division of Mines and Geology, scale $1: 250,000$.

Dibblee, T.W., Jr., 1967, Evidence of major lateral displacement on the Pinto Mountain fault, southeastern California [abs.]: Geological Society of America Special Paper 115, Abstracts for 1967 , p. 322.

1968, Geologic map of the Twentynine Palms quadrangle, San Bernardino and Riverside Counties, Califomia: U.S. Geological Survey Miscellaneous Investigations Map I-561, scale 1:62,500.

Dokka, R.K., 1986, Patterns and modes of early Miocene crustal extension of the central Mojave Desert, California, in Mayer, Larry, ed., Extensional tectonics of the southwestern United States: a perspective on processes and kinematics: Geological Society of America Special Paper 208, p. 75-95.

Dokka, R.K. and Travis, C.J., 1990, Late Cenozoic strike-slip faulting in the Mojave Desert, California: Tectonics, v. 9, no. 2, p. 311-340. 
Howard, K.A. and John, B.E., 1984, Geologic map of the Sheep Hole-Cadiz Wilderness Study Area (CDCA-305), San Bernardino County, California: U.S. Geological Survey Miscellaneous Field Studies Map MF-1615-A, scale $1: 62,500$.

Miller, D.M., Howard, K.A., and John, B.E., 1982, Preliminary geology of the Bristol Lake region, Mojave Desert, Califor- nia, in Cooper, J.D., compiler, Geologic excursions in the California desert, Geological Society of America, Cordilleran Section, 78th, Anaheim, Calif., April 1982, Volume and Guidebook, Field Trips 2, 7, and 13, p. 91-100.

Moyle, W.R., 1961, Data on water wells in the Dale Valley area, San Bernardino and Riverside Counties, California: California Department of Water Resources Bulletin 91-5, 55 p. 



\title{
Cenozoic Deposits in the Lava Hills and Southern Bristol Mountains, Southeastern Calif.
}

\author{
By David M. Miller ${ }^{1}$
}

\section{INTRODUCTION}

Cenozoic strata are widespread in the southern Bristol Mountains and Lava Hills of the east-central Mojave Desert (fig. 1). Described here are deposits in the Bagdad and western part of the Cadiz 15-minute quadrangles, where a sequence of continental sedimentary and volcanic rocks rests nonconformably on Mesozoic granitoids. Most

'U.S. Geological Survey, Mail Stop 975, 345 Middlefield Road, Menlo Park, CA 94025
Cenozoic deposits lie in or near the Lava Hills, so I will refer to the study area as the Lava Hills region.

Previous studies of Cenozoic deposits in the Lava Hills region are few in number. Bassett and Kupfer (1964) described many rock types from their reconnaissance in the central Mojave Desert, and Dibblee (1980) provided a regional synthesis of the Cenozoic deposits in the Mojave Desert. More detailed studies of Cenozoic rocks nearby (Marble Mountains-Glazner and Bartley, 1990; northern Bristol Mountains-Brady, this volume; Cady Mountains-Glazner, 1988; Van Winkle Mountain-Miller and others, 1985; Bullion Mountains-Howard, this volume) established an early Miocene age for thick deposits of

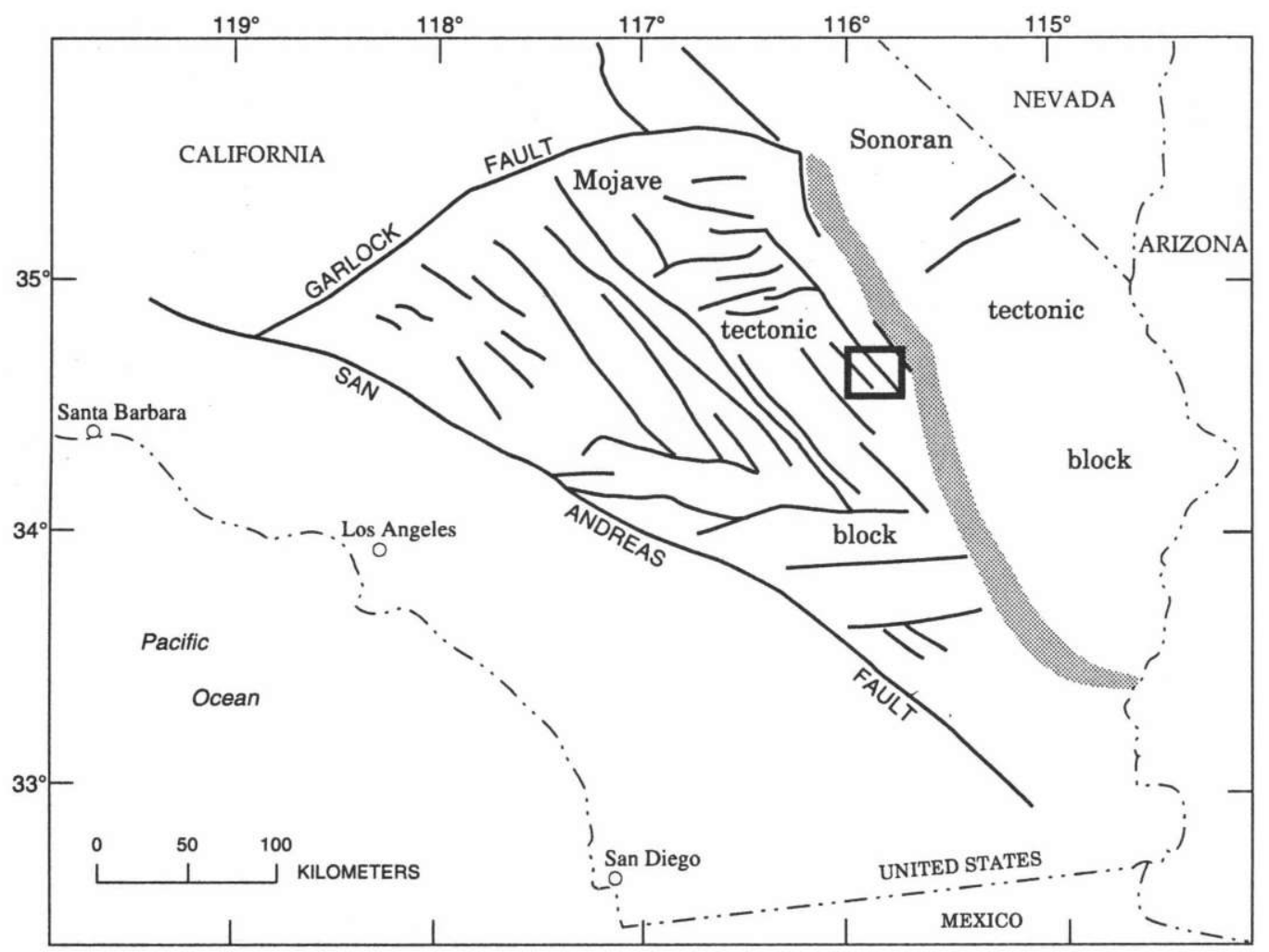

Figure 1. Neotectonic map of southeastern California, from Jennings (1975). Mojave tectonic block lies between Garlock and San Andreas faults and is made up of many fault blocks. Sonoran tectonic block lies to east. Dark shading shows transition zone between the two tectonic blocks. Lava Hills and southern Bristol Mountains area enclosed by box. 


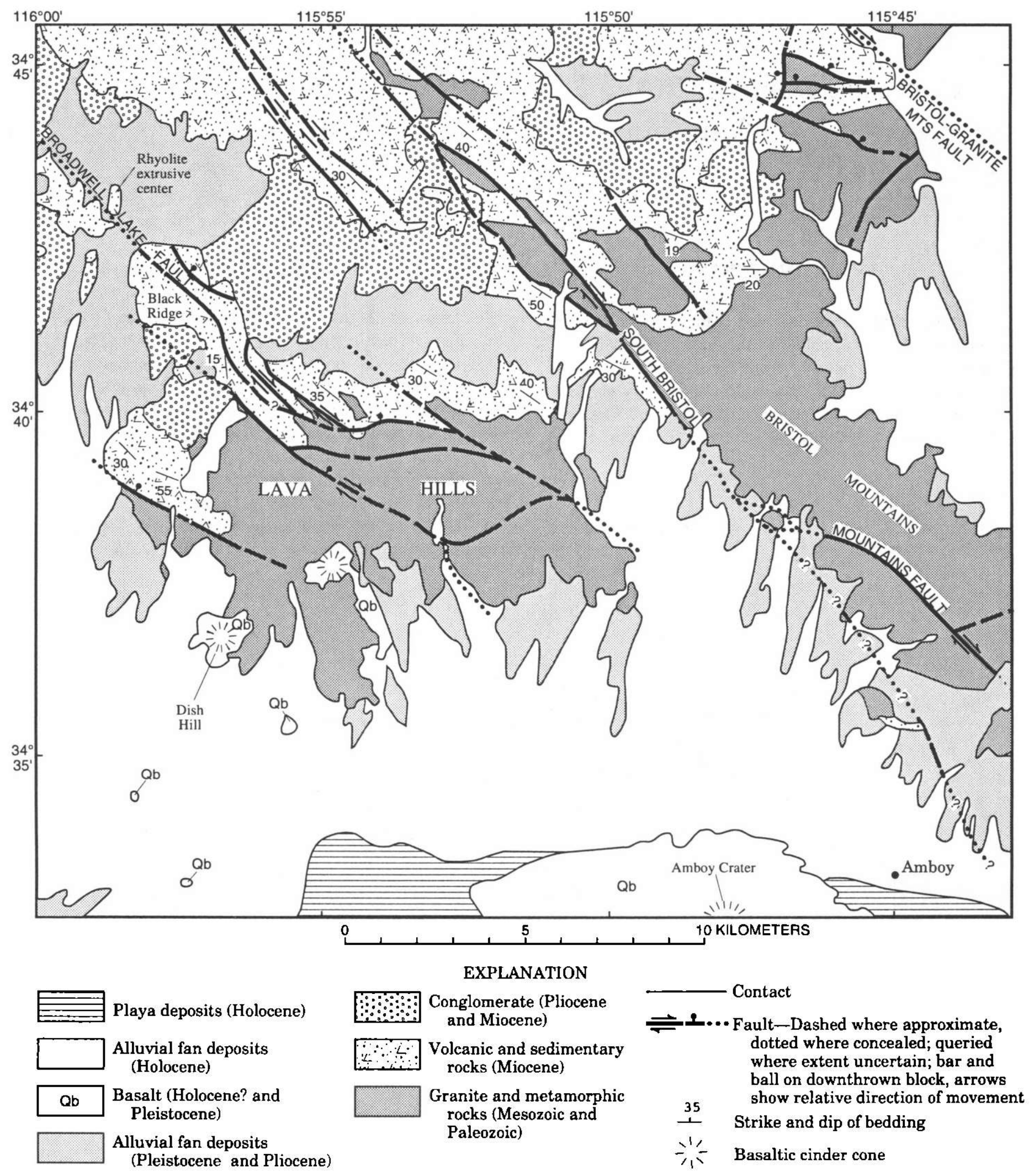

Figure 2. Generalized geologic map showing Cenozoic deposits of the Lava Hills and southern Bristol Mountains. Based on unpublished mapping by D.M. Miller, 1981 . 
continental sedimentary and volcanic rocks, many of which lie in complex structural basins. Miller and others (1982) briefly described the Cenozoic sequences of the Lava Hills and adjacent mountains, and they suggested that a distinctive tuff containing conspicuous blue sanidine in that area correlates with the Peach Springs Tuff of Young and Brennan (1974), a correlation since proven by chemical and stratigraphic (Glazner and others, 1986), mineralogic (Gusa and others, 1987), and paleomagnetic (Wells and Hillhouse, 1989) studies. Wilshire and NielsonPike (1986) described late Tertiary (upper Pliocene) to Pleistocene alkali basalts in the southern Lava Hills.

Miocene deposits (col. 2-B, pl. 2) include lacustrine limestone and siltstone; fuvial sandstone, sedimentary breccia, and conglomerate; and volcanic lava flows, tuff, tuff breccia, and ignimbrite. Volcanogenic rocks are more voluminous than sedimentary rocks and range from older than $22 \mathrm{Ma}$ to about $18 \mathrm{Ma}$. Volcanic rocks range from basaltic andesite to rhyolite in composition. Basaltic andesite and dacite are present throughout the section of rocks, whereas rhyolite is restricted to the upper part of the section.

\section{STRUCTURAL FRAMEWORK}

The Mojave Desert is bounded on the north by the Garlock fault and on the southwest by the San Andreas fault (fig. 1). The western Mojave Desert contains northwest-trending ranges, many of which are bounded by youthful dextral-slip faults (the Mojave tectonic block of Fuis, 1981). In contrast, the eastern Mojave Desert contains irregular ranges of generally north trend and only sparse late Cenozoic faults (Sonoran tectonic block). The transition zone between these tectonic blocks lies east of the Lava Hills region but may include the Bristol Mountains.

Much of the westem Mojave Desert underwent crustal extension in the early Miocene, as shown by tilted lower Miocene strata and abundant normal faults (Dokka, 1986, 1989; Glazner and others, 1989). Thick deposits of coarse clastic sediment appear to be spatially and temporally related to the region of crustal extension, as does volcanism. Extension apparently ceased prior to eruption of the 18.5Ma Peach Springs Tuff, and deformation of the unit records middle Miocene to Holocene dextral motion on faults related to the San Andreas fault system (Wells and Hillhouse, 1989; Dokka and Travis, 1990).

Two main sets of faults cut Cenozoic deposits in the Lava Hills region (Miller, 1988). Orientations of the fault sets overlap, making them difficult to distinguish in many cases, but unambiguous examples of each set exist. The older set consists of northwest-striking normal faults con- temporaneous with or slightly postdating deposition of early Miocene strata. The younger set consists of northwest-striking dextral slip faults of late Miocene, Pliocene, and early Pleistocene age.

Normal faults crop out in the Lava Hills and in a few places in the Bristol Mountains (fig. 1). They are a northwest- to west-striking, moderately dipping set with consistent down-to-the-north separation. A thick section of Miocene strata in the Lava Hills dips from $30^{\circ}$ to $55^{\circ}$ southwest into these normal faults. In the Bristol Mountains, strata at the top of the Miocene section are generally flat lying, except near dextral faults, but lower strata have dips as much as $30^{\circ}$.

Well-exposed angular unconformities within several Miocene sections indicate tilting during deposition. Available evidence indicates that normal faulting accompanied deposition of strata in the Lava Hills and of the lower section in the Bristol Mountains; these rocks range in age from older than $22 \mathrm{Ma}$ to about $19 \mathrm{Ma}$, as described below. I interpret the normal faults as part of the central Mojave Desert Miocene extensional terrane. In the Bristol Mountains, as well as at Van Winkle Mountain (Miller and others, 1985) and in the Marble Mountains (Glazner and Bartley, 1990) to the east, minor normal faulting took place in a corridor along the margin of a more highly extended terrane to the west and south.

Strike-slip faults in the Lava Hills region strike northwest, and some are parallel to normal faults. Throughout the Mojave tectonic block, similarly oriented faults consistently show dextral separation and appear to be late Miocene to Holocene (Dibblee, 1961; Garfunkel, 1974; Dokka and Travis, 1990). In the Lava Hills region, fault splays suggest dextral separation (fig. 2). The faults postdate the Peach Springs Tuff and cut sediments as young as middle or late Pleistocene but do not cut Holocene deposits. Restoring offset along the south Bristol Mountains fault (fig. 2) using several lithologic types, principally Mesozoic granitoids, yields about $6.5 \mathrm{~km}$ of slip.

Separations on other strike-slip faults in figure 2 cannot be constrained fully by local geologic relations. Using satellite imagery, Ford and others (1990) described a prominent lineament in the Lava Hills that they named the Broadwell Lake fault; their field checks suggested strikeslip movement. My mapping showed that several parallel northwest-striking faults are joined by others with easterly strikes. I conclude that the Broadwell Lake fault is one of a system of faults. Offset on the system is poorly constrained because dip-slip movement would distort apparent strike offset of moderately dipping features such as volcanic strata and their basal nonconformity. Map relations (fig. 2) indicate about $6 \mathrm{~km}$ of right separation if the faults are of strike-slip origin; however, some or all of these faults may be strictly normal faults. Throughout the Lava 
Hills region, Miocene strata commonly are tilted and rotated near strike-slip faults, suggesting local accommodation during faulting (Wells and Hillhouse, 1989).

\section{MIOCENE STRATA}

Miocene sedimentary and volcanic rocks form thick sequences with few widely distributed markers for distinguishing internal subdivisions; the sequences were deposited on Mesozoic granitoids. Thick-bedded to virtually unbedded tuff breccia and volcanogenic sedimentary rocks make up much of the sections; these strata are interbedded with basaltic andesite to dacite lavas. One section is capped by a distinctive felsic volcanic sequence of rhyolite and rhyodacite lava and pyroclastic rocks.

\section{LAVA HILLS}

The thickness of lower Miocene strata exposed in the Lava Hills is more than $1.5 \mathrm{~km}$. The thickest section is conveniently divided into upper and lower parts by a marker interval of distinctive dacite lavas. In an area where the dacite flows are missing, a group of basaltic andesite lava flows provides a convenient marker at about the same stratigraphic position. The lower section is about $700 \mathrm{~m}$ thick, and approximately $500 \mathrm{~m}$ of strata lie above the dacite flows. The top of the upper section is truncated by faults.

Above the basal nonconformity, the lower section in most places consists of tuff breccia, although lacustrine marl is present locally. Upsection, thin-bedded fluvial sandstone and conglomerate, and thick limestone beds, are interbedded with mainly tuffaceous rocks. The tuffaceous rocks are generally thick bedded, complex, and of various origins. Pumiceous (lapilli and bomb) tuff breccia is most common; tuffaceous sandstone and siltstone of lacustrine origin also are common. Possible air-fall tuff is uncommon. Some breccia beds are probably of sedimentary origin, but tuffaceous components are ubiquitous, making genetic interpretations difficult. Breccia beds contain clasts as large as $2 \mathrm{~m}$ in mainly matrix-supported deposits. Tuff breccia units commonly have mixed-clast assemblages of dacite and basaltic andesite.

The marker interval between the lower and upper sections comprises dacite and basaltic andesite lava flows. The composite thickness of dacite flows is 225 to $335 \mathrm{~m}$. Two widespread dacite flows are nearly aphyric and display a pronounced jointing parallel to bedding. A plagioclase porphyry nearby contains plagioclase, hornblende, and biotite. The aphyric flow was fed from a system of probable dikes in the Lava Hills. The basaltic andesite of Black Ridge (col. 2-B, pl. 2) contains olivine and plagioclase in a black aphanitic matrix and is about $140 \mathrm{~m}$ maxi- mum thickness. Abundant dikes of similar composition in the Black Ridge area mark an extrusive center. The dacite and basaltic andesite yield $\mathrm{K}$-Ar ages about $22 \mathrm{Ma}$ (table 1). The age of $22.4 \pm 0.3 \mathrm{Ma}$ for M82BR-27 was obtained from the freshest materials, and I consider it the best age for this part of the section. Ages for adjacent units, of 22.1 $\pm 0.6 \mathrm{Ma}$ for the dacite (M84LH-106) and $22.1 \pm 1.3 \mathrm{Ma}$ for the basaltic andesite (M81LH-58), are in close agreement.

The upper section consists of dacite tuff breccia and tuffaceous sediment. Breccia deposits are more common and lacustrine and fluvial sediments are rare, compared to the lower section.

Strata in the Lava Hills are tilted almost uniformly. No internal unconformities were observed, and systematic changes in dips upward in the section are evident in only one fault block, in which dips change from $-50^{\circ}$ at the base to $-30^{\circ}$ near the top. This block is apparently undisturbed by strike-slip faults, suggesting that tilting occurred both during and following deposition of the sequence.

\section{BRISTOL MOUNTAINS}

Sections of Miocene strata in the Bristol Mountains have slightly tilted lower parts and nearly horizontal upper parts. Several minor angular unconformities are present in the upper part of the tilted section. Near the south Bristol Mountains fault, even the younger strata are tilted, probably by deformation associated with strike-slip movement. Structurally and stratigraphically similar sections are found to the east at Van Winkle Mountain and the Marble Mountains (Miller and others, 1985; Glazner and Bartley, 1990). The Miocene sections in the Bristol Mountains are thinner compared to ones in the Lava Hills (about $350 \mathrm{~m}$ total compared to $1,500 \mathrm{~m}$ ).

The lower section of tilted strata in the Bristol Mountains is about $250 \mathrm{~m}$ thick. In many places basal beds are lacustrine marl, which is draped over a few meters of relief in the underlying granitoid rocks. Successively overlying tuff breccia, tuffaceous sandstone, conglomerate of fluvial and lacustrine origin, and mudflow and debris-flow deposits are similar to those in the Lava Hills. Dacite lava flows within this section also are similar to those in the Lava Hills in that they contain homblende, biotite, and plagioclase phenocrysts. Pumice clasts in many tuff breccias contain the same phenocryst assemblage as the dacite lava, suggesting a similar source. Toward the top of this tuffaceous sequence the beds angularly overlie older beds, creating a decreasing dip upward, to nearly horizontal in many places.

The upper, nearly horizontal part of the sequence is about $100 \mathrm{~m}$ thick and consists of several distinctive lava and ash flows, most of them rhyolitic. The lowest unit is prominently flow-banded siliceous rhyolite, about $30 \mathrm{~m}$ 
Table 1. K-Ar ages of volcanic rocks in Lava Hills and Bristol Mountains.

\begin{tabular}{|c|c|c|c|c|c|c|c|c|c|}
\hline Sample No. ${ }^{1}$ & $\begin{array}{l}\text { Latitude } \\
\text { (N.) }\end{array}$ & $\begin{array}{l}\text { Longitude } \\
\text { (W.) }\end{array}$ & Rock type & Material dated & $\begin{array}{c}\mathrm{K}_{2} \mathrm{O} \\
\text { (wt pc1) }\end{array}$ & $\begin{array}{c}{ }^{40} \mathrm{Ar}_{\text {rad }} \\
10^{-11} \mathrm{~mol} / \mathrm{g}\end{array}$ & $\begin{array}{l}\text { Percent } \\
{ }^{40} \mathrm{Ar}_{\mathrm{rad}}\end{array}$ & $\begin{array}{l}\text { Calculated age } \\
(\mathrm{Ma})^{2}\end{array}$ & $\begin{array}{l}\text { Assigned age } \\
(\mathrm{Ma})^{3}\end{array}$ \\
\hline \multicolumn{10}{|c|}{ Lava Hills } \\
\hline M81LH-58 & $34^{\circ} 40^{\prime} 27^{\prime \prime}$ & $115^{\circ} 56^{\prime} 36^{\prime \prime}$ & Basaltic andesite & Whole rock & 1.57 & $\begin{array}{l}4.60 \\
5.45\end{array}$ & $\begin{array}{l}53.8 \\
62.8\end{array}$ & $\begin{array}{l}20.2 \pm 2.6 \\
23.9 \pm 2.6\end{array}$ & $22.1 \pm 1.3$ \\
\hline M82BR-27 & $34^{\circ} 39^{\prime} 31^{\prime \prime}$ & $115^{\circ} 55^{\prime} 34^{\prime \prime}$ & Dacite & Biotite & 8.38 & $\begin{array}{l}0.276 \\
0.267\end{array}$ & $\begin{array}{l}79.5 \\
63.1\end{array}$ & $\begin{array}{l}22.7 \pm 0.6 \\
22.0 \pm 0.6\end{array}$ & $22.4 \pm 0.3$ \\
\hline M84LH-106 & $34^{\circ} 38^{\prime} 38^{\prime \prime}$ & $115^{\circ} 57^{\prime} 35^{\prime \prime}$ & do & Biotite & 8.38 & 0.268 & 67.7 & & $22.1 \pm 0.6$ \\
\hline \multicolumn{10}{|c|}{ Bristol Mounsains } \\
\hline M82BR-103 & $34^{\circ} 41^{\prime} 19^{\prime \prime}$ & $115^{\circ} 48^{\prime} 30^{\prime \prime}$ & Dacite & Whole rock & 1.60 & $\begin{array}{l}4.03 \\
3.81\end{array}$ & $\begin{array}{l}46.4 \\
32.5\end{array}$ & $\begin{array}{l}17.4 \pm 1.3 \\
16.5 \pm 1.3\end{array}$ & $17.0 \pm 0.7$ \\
\hline M82BR-34 & $34^{\circ} 44^{\prime} 03^{\prime \prime}$ & $115^{\circ} 55^{\circ} 42^{\prime \prime}$ & $\begin{array}{c}\text { Flow-banded } \\
\text { rhyolite }\end{array}$ & Plagioclase & 1.50 & 5.47 & 5.22 & & $25.1 \pm 8.4$ \\
\hline BH82BR-28 & $34^{\circ} 43^{\prime} 37^{\prime \prime}$ & $115^{\circ} 50^{\circ} 49^{\prime \prime}$ & Rhyodacite flow & Plagioclase & 0.55 & $\begin{array}{l}1.24 \\
1.33\end{array}$ & $\begin{array}{l}9.94 \\
14.3\end{array}$ & $\begin{array}{l}15.5 \pm 4.5 \\
16.8 \pm 3.4\end{array}$ & $16.2 \pm 1.9$ \\
\hline M82BR-21 & $34^{\circ} 42^{\prime} 58^{\prime \prime}$ & $115^{\circ} 55^{\prime} 34^{\prime \prime}$ & Basaltic andesite & Whole rock & 2.13 & $\begin{array}{l}5.71 \\
4.98\end{array}$ & $\begin{array}{l}54.5 \\
54.7\end{array}$ & $\begin{array}{l}18.6 \pm 1.5 \\
16.2 \pm 1.5\end{array}$ & $17.4 \pm 0.8$ \\
\hline M81BR-41 & $34^{\circ} 45^{\prime} 38^{\prime \prime}$ & $115^{\circ} 49^{\prime} 59^{\prime \prime}$ & $\begin{array}{c}\text { Peach Springs } \\
\text { Tuff }\end{array}$ & Feldspar & 3.50 & 9.11 & 82.3 & & $18.0 \pm 0.5$ \\
\hline M80BR-85 & $34^{\circ} 35^{\prime} 29^{\prime \prime}$ & $115^{\circ} 44^{\prime} 58^{\prime \prime}$ & do & Sanidine & 9.07 & $\begin{array}{l}0.258 \\
0.257\end{array}$ & $\begin{array}{l}78.5 \\
69.7\end{array}$ & $\begin{array}{l}19.6 \pm 0.6 \\
19.5 \pm 0.5\end{array}$ & $19.6 \pm 0.3$ \\
\hline M80BR-85 & $34^{\circ} 35^{\prime} 29^{\prime \prime}$ & $115^{\circ} 44^{\prime} 58^{\prime \prime}$ & do & Biotite & 8.66 & 0.251 & 57.0 & $20.1 \pm 0.5$ & $20.1 \pm 0.5$ \\
\hline BH82BR-39 & $34^{\circ} 44^{\prime} 55^{\prime \prime}$ & $115^{\circ} 57^{\prime} 39^{\prime \prime}$ & do & Sanidine & 9.16 & $\begin{array}{l}0.223 \\
0.221 \\
0.218\end{array}$ & $\begin{array}{l}67.8 \\
49.9 \\
79.5\end{array}$ & $\begin{array}{l}16.9 \pm 0.4 \\
16.7 \pm 0.4 \\
16.5 \pm 0.4\end{array}$ & $16.7 \pm 0.1$ \\
\hline
\end{tabular}

'Sample preparation and analytical work were done at U.S. Geological Survey; Martha A. Pernokas and John K. Nakata, analysts. $\mathrm{K}_{2} \mathrm{O}$ analyses by $\mathrm{P}$. Klock, $\mathrm{S}$. Neil, and $\mathrm{D}$. Vivit.

${ }^{2} \mathrm{~K}$ - $\mathrm{Ar}$ ages were calculated using the constants for the radioactive decay and abundance of ${ }^{40} \mathrm{~K}$ recommended by the International Union of Geological Sciences Subcommission on Geochronology (Steiger and Jäger, 1977). These constants are: $\lambda_{\varepsilon}=0.580 \times$ $10^{-10} \mathrm{yr}^{-1}, \lambda_{\beta}=4.962 \times 10^{-10} \mathrm{yr}^{-1}$, and ${ }^{40} \mathrm{~K} / \mathrm{K}_{\text {total }}=1.167 \times 10^{-4} \mathrm{~mol} / \mathrm{mol}$.

${ }^{3}$ Assigned ages are means weighted by inverse of the variance; errors are standard errors of the mean.

thick, that is exposed across much of the central Bristol Mountains and continues east to Van Winkle Mountain. The rhyolite contains sparse, generally altered sanidine and biotite phenocrysts and is marked by a prominent black basal vitrophyre. It is overlain by a phenocryst-rich rhyodacite lava flow that contains feldspar, biotite, and homblende, all typically altered. The rhyodacite flow is about $20 \mathrm{~m}$ thick and crops out mainly in the area traversed by Interstate 40 . Overlying the rhyodacite flow is well-bedded rhyolite to rhyodacite air-fall tuff and a locally exposed ash-flow unit, which ranges from tuff to lapilli tuff. The air-fall tuff is white and yellow, typically has graded beds, and locally is cross-bedded. It varies greatly in thickness, filling in lowlying areas to depths of $20 \mathrm{~m}$ in many places and locally up to $100 \mathrm{~m}$. Phenocrysts of hornblende, biotite, and sanidine in this unit indicate that it may be related compositionally to the underlying rhyodacite.

The uppermost flow in the upper sequence is the Peach Springs Tuff. It is typically 30 to $50 \mathrm{~m}$ thick, densely weld- ed, and distinguished by blue sanidine and minor biotite, hornblende, and sphene. Locally, olivine basalt flows lie above and below the Peach Springs Tuff (col. 2-B, pl. 2). Near Amboy, unwelded tuff that contains identical phenocrysts overlies the welded Peach Springs, making a total thickness of about $90 \mathrm{~m}$.

Lava flows in the upper sequence of the Bristol Mountains probably had local sources. The flow-banded rhyolite probably issued from an area of several domes with similar composition and fabric. These domes lie between 1 and $3 \mathrm{~km}$ west-northwest of Black Ridge, near Interstate 40 (fig. 2). Thicknesses of rhyodacite lava and related overlying air-fall tuff increase toward the structurally complex central Bristol Mountains (Casey, 1981), indicating a source in that direction. In contrast, the source area for Peach Springs Tuff was probably east of the Bristol Mountains, near the California-Arizona State line (Nielson and others, 1990; Hillhouse and Wells, 1991). 
Isotopic ages determined on lava fiows in the Bristol Mountains are difficult to interpret because only altered minerals were available from many units. Lavas closely underlying the 18.5 \pm 0.2 Ma-Peach Springs Tuff (Nielson and others, 1990) yielded $\mathrm{K}$ - Ar ages of $25.1 \pm 8.4$, $17.4 \pm 0.8$, and $16.2 \pm 1.9 \mathrm{Ma}$ (table 1). On the basis of field relations, $I$ interpret these data as the emplacement ages of lavas of the upper section-probably from 20 or $19 \mathrm{Ma}$ shortly before eruption of the Peach Springs Tuff at 18.5 Ma. Dacite breccia, associated with dacite flows lower in the section, has a K-Ar age of $17.0 \pm 0.7 \mathrm{Ma}$ (whole rock); this age is incompatible with its stratigraphic position. The unit is lithologically similar to 22.4-Ma dacite in the Lava Hills, and 20.2-Ma dacite in the Marble Mountains (Glazner and Bartley, 1990). The widely varying ages for the Peach Springs Tuff (table 1) probably are due to contamination from lithic material (M80BR-85), complicated by incomplete release of radiogenic Ar from sanidine in analysis (Nielson and others, 1990).

\section{COMPOSITION OF VOLCANIC ROCKS}

Phenocrysts and limited geochemical analyses show that the volcanic rocks range from basaltic to rhyolite compositions, with $\mathrm{SiO}_{2}$ contents varying from 55 to 76 percent $\mathrm{SiO}_{2}$ (all analyses reported as volatile-free). Olivine-bearing rocks are basaltic andesite and mafic andesite (fig. 3; table 2). Homblende-biotite-plagioclase rocks are 63 to 66 percent $\mathrm{SiO}_{2}$ dacite. Sanidine-quartz rocks are 72 to 76 percent $\mathrm{SiO}_{2}$. Most dacite and rhyolite samples have high $\mathrm{K}_{2} \mathrm{O}$ content, making them high- $\mathrm{K}$ dacite and high- $\mathrm{K}$ rhyolite in the classification of Ewart (1979). Rhyolites show $\mathrm{K}_{2} \mathrm{O}$ much greater than $\mathrm{Na}_{2} \mathrm{O}$, whereas $\mathrm{Na}_{2} \mathrm{O}$ is greater than $\mathrm{K}_{2} \mathrm{O}$ for dacite and basaltic andesite. No evidence of ultrapotassic metasomatism, such as described by Glazner (1988) in the Cady Mountains, is known from the Bristol Mountains. However, several rocks exhibit unusual oxide abundances, most probably due to alteration that introduced clays and calcite. Initial ${ }^{87} \mathrm{Sr} /{ }^{86} \mathrm{Sr}$ isotopic compositions of three volcanic rocks from the Lava Hills region were reported by Glazner and O'Neill (1989): two basaltic andesite samples have ratios of 0.7065 and 0.7068 , and dacite is 0.7081 . These values reflect contamination of the magmas by radiogenic crustal rocks.

\section{DEPOSITIONAL ENVIRONMENT}

Miocene deposits record tectonic sedimentary basins near the edge of the Mojave extensional terrane. Deposits in the lower section of the several structural blocks in the Lava Hills indicate initial lacustrine and fluvial conditions, suggesting that early basins were broad and had fairly uniform depositional environments. Several volcanic eruptions produced breccia and tuff breccia, most probably from a dacitic extrusive center in the Bullion Mountains to the south (Howard, this volume). Dacite lavas erupted across wide areas at the same time. Although some faulting was probably concurrent with volcanism, the region was broken by numerous faults and tilted as small tectonic blocks, only after the presently exposed rocks were deposited.

Units of the lower sequence in the Bristol Mountains also indicate early deposition in shallow lakes. Lacustrine environments were succeeded by rapid subaerial deposition of coarse volcaniclastic rocks, probably in tectonically subsiding basins. Strata in the upper Miocene sequence of

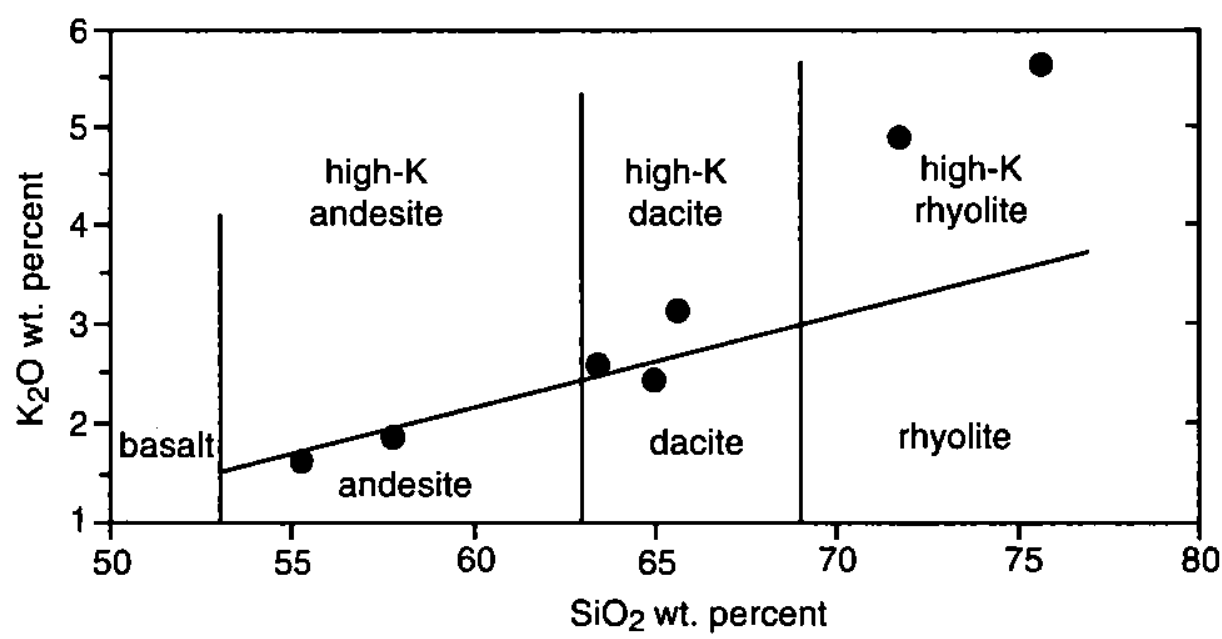

Figure 3. Geochemistry and classification scheme for representative volcanic rocks of the Lava Hills and Bristol Mountains, calculated on anhydrous basis. Classification modified from Ewart (1979). 
Table 2. Chemical analyses, in weight percent, of lower Miocene volcanic rocks.

[Sample preparation and analytical work were done at U.S. Geological Survey. T. Frost, P. Klock, A.J. Barte], K. Syewart, and J. Taggart, analysis. $\mathrm{Rb}, \mathrm{Sr}, \mathrm{Nb}, \mathrm{Zr}$, and $\mathrm{Y}$ analyses in parts per million]

\begin{tabular}{|c|c|c|c|c|c|c|c|}
\hline $\begin{array}{l}\text { Sample No. } \\
\text { Rock unit }\end{array}$ & $\begin{array}{c}\text { M84BR-109 } \\
\text { Basaltic andesite }\end{array}$ & $\begin{array}{l}\text { M84BR-110 } \\
\text { Rhyolite tuff }\end{array}$ & $\begin{array}{c}\text { M84BR-114 } \\
\text { Rhyodacite flow }\end{array}$ & $\begin{array}{c}\text { M83BR-135 } \\
\text { Flow-banded } \\
\text { rhyolite }\end{array}$ & $\begin{array}{c}\text { M84LH-106 } \\
\text { Porphyritic dacite }\end{array}$ & $\begin{array}{c}\text { M84LH-107 } \\
\text { Aphyric dacite }\end{array}$ & $\begin{array}{c}\text { M84LH- } 108 \\
\text { Basaltic andesite }\end{array}$ \\
\hline $\mathrm{SiO}_{2}$ & 56.6 & 65.3 & 63.3 & 70.8 & 63.8 & 61.3 & 54.7 \\
\hline $\mathrm{TiO}_{2}$ & 1.31 & 0.17 & 0.62 & 0.13 & 0.72 & 1.09 & 1.45 \\
\hline $\mathrm{Al}_{2} \mathrm{O}_{3}$ & 16.5 & 11.8 & 15.9 & 12.8 & 16.2 & 17.2 & 16.3 \\
\hline $\mathrm{Fe}_{2} \mathrm{O}_{3}$ & 1.89 & 0.75 & 1.78 & 0.57 & 2.74 & 4.31 & 2.00 \\
\hline $\mathrm{FeO}$ & 4.55 & 0.35 & 1.78 & 0.33 & 1.10 & 0.49 & 5.84 \\
\hline $\mathrm{MnO}$ & 0.09 & 0.04 & 0.05 & 0.04 & 0.05 & 0.04 & 0.12 \\
\hline $\mathrm{MgO}$ & 4.14 & 0.40 & 2.14 & 0.21 & 2.40 & 1.25 & 5.56 \\
\hline $\mathrm{CaO}$ & 6.90 & 5.37 & 4.18 & 0.92 & 4.50 & 4.28 & 7.34 \\
\hline $\mathrm{Na}_{2} \mathrm{O}$ & 3.76 & 2.27 & 3.49 & 2.44 & 4.01 & 3.87 & 3.61 \\
\hline $\mathrm{K}_{2} \mathrm{O}$ & 1.81 & 4.44 & 3.02 & 5.26 & 2.38 & 2.49 & 1.63 \\
\hline $\mathrm{P}_{2} \mathrm{O}_{5}$ & 0.29 & 0.06 & 0.16 & 0.04 & 0.17 & 0.22 & 0.30 \\
\hline LOI & 1.16 & 8.68 & 2.93 & 5.46 & 1.30 & 2.55 & 0.81 \\
\hline TOTAL & 99.00 & 99.63 & 99.35 & 99.00 & 99.37 & 99.09 & 99.66 \\
\hline $\mathrm{H}_{2} \mathrm{O}^{+}$ & 0.45 & 4.28 & 2.10 & 4.38 & 0.76 & 1.01 & 0.61 \\
\hline $\mathrm{H}_{2} \mathrm{O}^{-}$ & 0.52 & 0.99 & 0.61 & 0.90 & 0.47 & 1.46 & 0.28 \\
\hline $\mathrm{CO}_{2}$ & 0.27 & 3.30 & 0.12 & 0.06 & 0.09 & 0.06 & 0.16 \\
\hline $\mathbf{R b}$ & & & 72 & & 66 & & 44 \\
\hline $\mathrm{Sr}$ & & & 735 & & 720 & & 590 \\
\hline $\mathrm{Nb}$ & & & 13 & & 13 & & 22 \\
\hline $\mathbf{Z r}$ & & & 156 & & 182 & & 195 \\
\hline $\mathbf{Y}$ & & & 14 & & 15 & & 22 \\
\hline
\end{tabular}

the Bristol Mountains were tilted during deposition, indjcating the tectonic origin of the basin. Sparse paleocurrent information indicates west- and southeast-directed fluvial currents.

The wide distribution of lava and ash flows in the upper part of the Bristol Mountains sequence indicates low physiographic relief following extensional tectonism. The flow-banded rhyolite probably issued from west of Black Ridge and flowed north and east as far as Van Winkle Mountain. This suggests that the Lava Hills region, which was the site of a subsiding basin during extension and deposition of the lower part of the sequence, had been elevated relative to areas farther east before the upper part was deposited.

\section{UPPER MIOCENE TO QUATERNARY DEPOSITS}

A section, greater than $20 \mathrm{~m}$ thick, of bouldery conglomerate that I interpret as alluvial fan deposits, lies discordantly across tilted Miocene strata in the Lava Hills and Bristol Mountains. In most places, the bouldery conglomerate unit carries abundant rounded flow-banded rhyolite clasts in a sand-sized matrix. Most of the deposit is clast supported; clast provenance points to south and southeast-directed current flow. Bedding in the conglomerate deposits is crudely defined by grain-size variations and is close to horizontal in the Bristol Mountains but dips as much as $15^{\circ}$ southwest in exposures between the Bristol Mountains and Lava Hills. Locally near the Lava Hills, bedding dips northeast. This tilting, plus the location of exposures adjacent to late Miocene and Pliocene strike-slip faults, suggests that the conglomerate formed in shallow basins caused by faulting. From all these relations 1 infer a late Miocene and Pliocene age for the conglomerate.

The conglomerate deposits are overlain by upper Pliocene and Quaternary alluvial fan deposits. These alluvial fan units are (1) highly dissected, oxidized alluvium (probably of uppermost Pliocene to early Pleistocene age); (2) moderately dissected deposits with abundant pedogenic calcite and well-developed desert pavement surfaces (middie to late Pleistocene); and (3) active fans (Holocene). 
Alkali basaltic cinder cones and lava flows near Dish Hill and at Amboy Crater are interbedded with alluvium of units 1 and 2 . Dish Hill volcanic rocks are dated at $1.9 \pm 0.2$ and $2.1 \pm 0.2 \mathrm{Ma}$ (Wilshire and Nielson-Pike, 1986). Fine-grained deposits of Bristol Lake (playa deposits of fig. 2) lap onto the flows that emanated from these cinder cones.

\section{ACKNOWLEDGMENTS}

Special thanks are due Martha Pernokas for field assistance and to Pernokas and John Nakata, both of whom contributed substantially by $\mathrm{K}$-Ar dating of rocks. I have benefited from collaboration with several colleagues, notably Keith A. Howard, Jane E. Nielson, and Allen F. Glazner, who discussed, both in the field and office, Cenozoic strata and tectonics.

\section{REFERENCES CITED}

Bassett, A.M., and Kupfer, D.H., 1964, A geologic reconnaissance in the southeastern Mojave Desert, California: California Division of Mines and Geology Special Report 83, 43 p.

Casey, B.J., 1981, The geology of a portion of the northwestern Bristol Mountains, Mojave Desert, Califomia: Riverside, University of Califomia, M.S. thesis, 128 p.

Dibblee, T.W., Jr., 1961, Evidence of strike-slip faulting along northwest-trending faults in the Mojave Desert: U.S. Geological Survey Professional Paper 424-B, p. 197-199.

1980, Cenozoic rock units of the Mojave Desert, in Fife, D.L., and Brown, A.R., eds., Geology and mineral wealth of the California desert: Santa Ana, Calif., South Coast Geological Society, p. 41-68.

Dokka, R.K., 1986, Patterns and modes of early Miocene crustal extension of the central Mojave Desert, Califomia, in Mayer, Larry, ed., Extensional tectonics of the southwestern United States: a perspective on processes and kinematics: Geological Society of America Special Paper 208, p. 75-95.

1989, The Mojave extensional belt of southern California: Tectonics, v. 8, no. 2, p. 363-390.

Dokka, R.K., and Travis, C.J., 1990, Late Cenozoic strike-slip faulting in the Mojave Desert, California: Tectonics, v. 9, no. 2, p. 311-340.

Ewart, A., 1979, A review of the mineralogy and chemistry of Tertiary-Recent dacitic, latitic, rhyolitic, and related salic volcanic rocks, in Barker, F., ed., Trondhjemites, dacites, and related rocks: Elsevier, New York, p. 13-121.

Ford, J.P., Dokka, R.K., Crippen, R.E., and Blom, R.G., 1990 , Faults in the Mojave Desert, California, as revealed on enhanced Landsat images: Science, v. 248, p. 1,000-1,003.

Fuis, G.S., 1981, Crustal structure of the Mojave Desert, in Howard, K.A., Carr, M.D., and Miller D.M., eds., Tectonic framework of the Mojave and Sonoran Deserts, Califomia and Arizona: U.S. Geological Survey Open-File Report 81503, p. 36-38.

Garfunkel, Zvi, 1974, Model for the late Cenozoic tectonic history of the Mojave Desert, California, and its relation to adjacent regions: Geological Society of America Bulletin, v. 85 , no. 12 , p. 1,931-1,944.

Glazner, A.F., 1988, Stratigraphy, structure, and potassic alteration of Miocene volcanic rocks in the Sleeping Beauty area, central Mojave Desert, California: Geological Society of America Bulletin, v. 100, no. 3, p. 424-435.

Glazner, A.F., and Bartley, J.M., 1990, Early Miocene dome emplacement, diking, and limited tectonism in the northern Marble Mountains, eastern Mojave Desert, California, in Foster, J.H., and Lewis, L.L., eds., Lower Colorado River extensional terrane and Whipple Mountains: Santa Ana, Calif., South Coast Geological Society, (Annual Field Trip Guide No. 18), p. 89-97.

Glazner, A.F., Bartley, J.M., and Walker, J.D., 1989, Magnitude and significance of Miocene crustal extension in the central Mojave Desert, California: Geology, v. 17, no. 1, p. 50-53.

Glazner, A.F., Nielson, J.E., Howard, K.A., and Miller, D.M., 1986, Correlation of the Peach Springs Tuff, a large-volume Miocene ignimbrite sheet in California and Arizona: Geology, v. 14 , no. 10, p. $840-843$.

Glazner, A.F., and O'Neil, J.R., 1989, Crustal structure of the Mojave Desert, California: Inferences from $\mathrm{Sr}$ and $\mathrm{O}$ isotope studies of Miocene volcanic rocks: Joumal of Geophysical Research, v. 94, no. B6, p. 7,861-7,870.

Gusa, Sharon, Nielson, J.E., and Howard, K.A., 1987, Heavymineral suites confirm the wide extent of the Peach Springs Tuff in California and Arizona, U.S.A.: Journal of Volcanology and Geothermal Research, v. 33, no. 4, p. 343-347.

Hillhouse, J.W., and Wells, R.E., 1991, Magnetic fabric, flow directions, and source area of the lower Miocene Peach Springs Tuff in Arizona, California, and Nevada: Journal of Geophysical Research, v. 96, no. B7, p. 12,443-12,460.

Jennings, C.W., 1975, Fault map of California, with locations of volcanoes, thermal springs, and thermal wells: California $\mathrm{Di}-$ vision of Mines and Geology Map 1, scale 1:750,000.

Miller, D.M., 1988, Stratigraphy and structure of Miocene rocks in the Lava Hills and southem Bristol Mountains, California [abs.]: Geological Society of America Abstracts with Programs, v. 20 , no. 3 , p. 215.

Miller, D.M., Glick, L.L., Goldfarb, Richard, Simpson, R.W., Hoover, D.B., Detra, D.E., Dohrenwend, J.C., and Munts, S.R., 1985, Mineral resources and resource potential map of the South Providence Mountains Wilderness Study Area, San Bernardino County, California: U.S. Geological Survey Miscellaneous Field Studies Map MF-1780-A, scale 1:62,500.

Miller, D.M., Howard, K.A., and John, B.E., 1982, Preliminary geology of the Bristol Lake region, Mojave Desert, California, in Cooper, J.D., compiler, Geologic excursions in the California Desert: Geological Society of America, Cordilleran Section, 78th, Anaheim, Calif., April 1982, Volume and Guidebook, Field Trips 2, 7, and 13, p. 91-100.

Nielson, J.E., Lux, D.R., Dalrymple, G.B., and Glazner, A.F., 1990, Age of the Peach Springs Tuff, southeastern California and western Arizona: Journal of Geophysical Research, v. 95, no. B1, p. 571-580.

Steiger, R.H., and Jäger, E., 1977, Subcommission on geochronology: Convention on the use of decay constants in geo- and cosmochronology: Earth and Planetary Science Letters, v. 36, no. 3, p. 359-362.

Wells, R.E., and Hillhouse, J.W., 1989, Paleomagnetism and tectonic rotation of the lower Miocene Peach Springs 
Tuff: Colorado Plateau, Arizona to Barstow, California: Geological Society of America Bulletin, v. 101, no. 6, p. 846-863.

Wilshire, H.G., and Nielson-Pike, J.E., 1986, Upper-mantle xenoliths in alkaline basalt, Dish Hill, California, in Mojave Desert xenolith suites, Malapais Hill and Dish Hill: Geological Society of America, Cordilleran Section, 82d, Los Ange- les, Calif., March, 1986, Volume and Guidebook, Field Trips 9,11 , and 15 , p. $9-11$.

Young, R.A., and Brennan, W.J., 1974, Peach Springs Tuff: its bearing on structural evolution of the Colorado Plateau and development of Cenozoic drainage in Mojave County, Arizona: Geological Society of America Bulletin, v. 85, no. 1 , p. 83-90. 



\title{
Stratigraphy of the Southern Ship Mountains and Little Piute Mountains, Southeastern Calif.
}

\author{
By Martin A. Knoll ${ }^{1}$
}

Tertiary strata consisting of both siliciclastic and volcanic rocks are found within the southern Ship and Little Piute Mountains, which lie on either side of the Old Woman Mountains horst (fig. 1). Siliciclastic rocks are predominantly conglomerate and sandstone, with minor siltstone and local breccia units. Basaltic andesite is the most common of the volcanic rocks, which range from rhyolite to basalt in composition (Miller and others, 1987; Miller, 1989). Among the volcanic strata of both ranges is the Peach Springs Tuff of Young and Brennan (1974), a felsic

\footnotetext{
'Department of Forestry and Geology, University of the South, Sewanee, TN 37383-4003
}

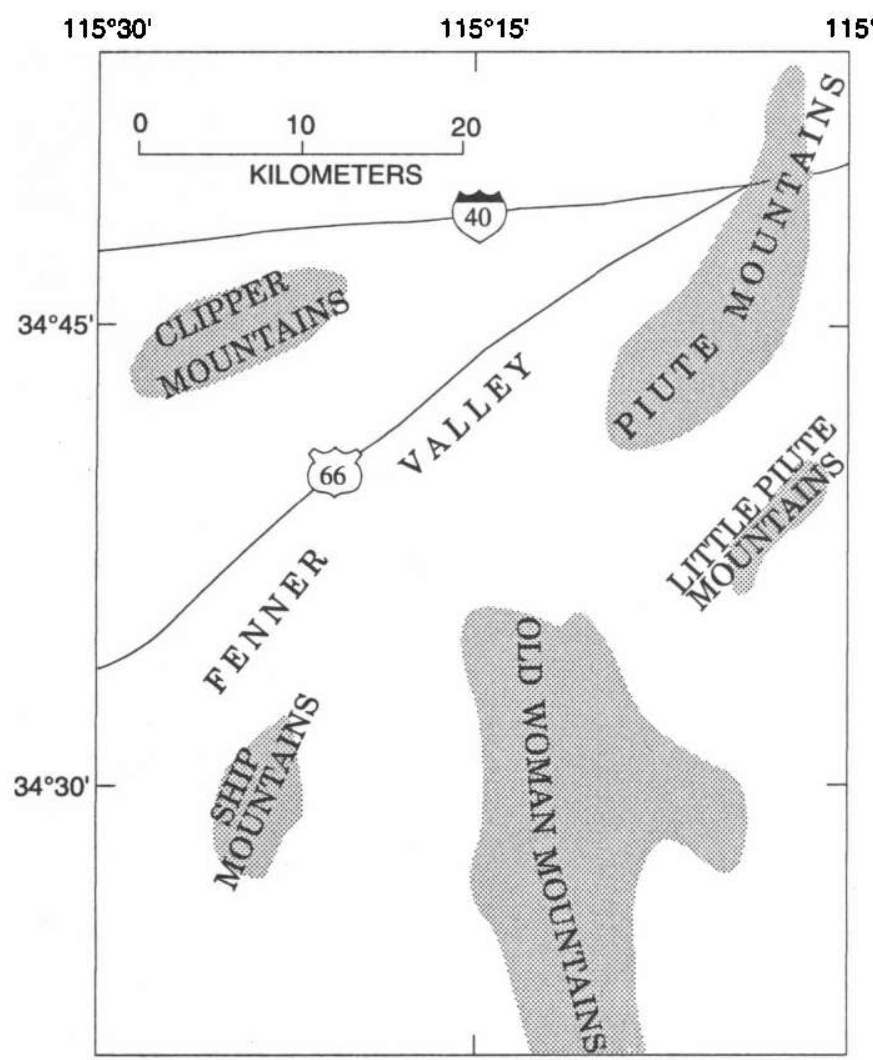

Figure 1. Map showing location of geographic features discussed in text. ignimbrite emplaced about $18.5 \pm 0.2 \mathrm{Ma}$ (Nielson and others, 1990).

Tertiary stratigraphic sequences in both mountain ranges are characterized by an overall pattern, from oldest to youngest, of (1) conglomerate and sandstone, (2) mafic to intermediate volcanic rocks, (3) Peach Springs Tuff, and (4) conglomerate and sandstone (cols. 2-C and 2-D, pl. 2; see also Knoll and others, 1986; Knoll, 1988). Although the sequences are similar in both the Ship and Little Piute Mountains, the Peach Springs Tuff is the only stratigraphic unit that can be correlated with certainty between the two ranges. A K-Ar age of 19.4 $\pm 0.5 \mathrm{Ma}$ (bjotite) (J.K. Nakata, written commun., 1985) from a dacite clast in the basal conglomerate of the Piute Mountains, located approximately $10 \mathrm{~km}$ northwest of the Little Piute Mountains (fig. 1), is the only other meaningful age from middle Tertiary rocks in the immediate vicinity. The conglomerate cannot be reliably correlated between the Piute and Little Piute Mountains, but the Peach Springs Tuff caps both sections.

Rock fragments within the Tertiary sedimentary units are of local provenance and were derived primarily from metamorphic and igneous rocks of the adjacent Old Woman and Piute Mountains (fig. 1) as they were uplifted and denuded. Provenance and paleocurrent directions indicate that sediment was shed east and west from the uplifted source into basins of the Little Piute and Ship Mountains, respectively. This sediment was deposited mainly on coalescing alluvial fans and braid plains that emanated from the Old Woman-Piute Mountains highland.

A moderate angular unconformity is found within the Tertiary sequence of the Ship Mountains (col. 2-C, pl. 2). The unconformity is marked by a landslide breccia and represents about $15^{\circ}$ of rotation, thus indicating a major episode of faulting before eruption of the Peach Springs Tuff. No pre-Peach Springs faulting is recorded in the Little Piute Mountains.

\section{ACKNOWLEDGMENTS}

This research was funded in part by a grant from Winthrop University, Rock Hill, South Carolina. 


\section{REFERENCES CITED}

Knoll, M.A., 1988, Tertiary basin evolution, eastern Mojave Desert: El Paso, University of Texas, Ph.D. dissertation, $189 \mathrm{p}$.

Knoll, M.A., Miller, C.F., and James, W.C., 1986, Mid-Tertiary stratigraphic and structural evolution of the Piute Mountains basin and adjacent areas of the Old Woman Mountains region, southeastern California, in Cenozoic stratigraphy, structure and mineralization in the Mojave Desert: Geological Society of America, Cordilleran Section, 82d, Los Angeles, Calif., March 1986, Guidebook and Volume, Field Trips 5 and 6, p. 43-49.

Miller, J.S., 1989, Mid-Tertiary volcanism in the Old Woman Mountains region, southeastern Mojave Desert, California:
Nashville, Tenn., Vanderbilt University, M.S. thesis, 160 p.

Miller, J.S., Hazlett, R.W., Knoll, M.A., and Miller, C.F., 1987, Petrology and geochemistry of Tertiary volcanic rocks in the Old Woman Mountains region, southeastern Mojave Desert, California [abs.]: Geological Society of America Abstracts with Programs, v. 19, no. 6, p. 433.

Nielson, J.E., Lux, D.R., Dalrymple, G.B., and Glazner, A.F., 1990, Age of the Peach Springs Tuff, southeastern California and western Arizona: Journal of Geophysical Research, v. 95, no. B1, p. 571-580.

Young, R.A., and Brennan, W.J., 1974, Peach Springs Tuff: its bearing on structural evolution of the Colorado Plateau and development of Cenozoic drainage in Mohave County, Arizona: Geological Society of America Bulletin, v. 85, no. 1 , p. 83-90. 


\title{
Geologic Framework of Middle Tertiary Strata, Northern Sacramento Mountains, Southeastern Calif.
}

\author{
By Christopher M. Fedo ${ }^{1}$
}

\section{GEOLOGIC SETTING}

The Sacramento Mountains, which lie approximately $10 \mathrm{~km}$ west of Needles, California (fig. 1), form a roughly north-northwest-trending range situated in the Colorado River extensional corridor (Howard and John, 1987). Characteristics typical of metamorphic core complexes (Coney, 1980) are well developed here. The northern core of the range is underlain by a complex of Precambrian through Mesozoic(?) plutonic and metamorphic rocks, which is unexamined in detail. A prominent, middle Tertiary, east-striking dike swarm intruded the older rocks about 19 Ma (Spencer, 1985). A thick sequence of predominantly felsic pyroclastic flows and sedimentary rocks is locally found in fault contact on the plutonic and metamorphic complex (col 2-E, pl. 2). Exposures of a basal contact between Tertiary sections and older rocks are not presently known in the Sacramento Mountains.

The Sacramento Mountains detachment fault system is the dominant structural feature in the area (Spencer and Turner, 1983; Spencer, 1985). Two strands of the system

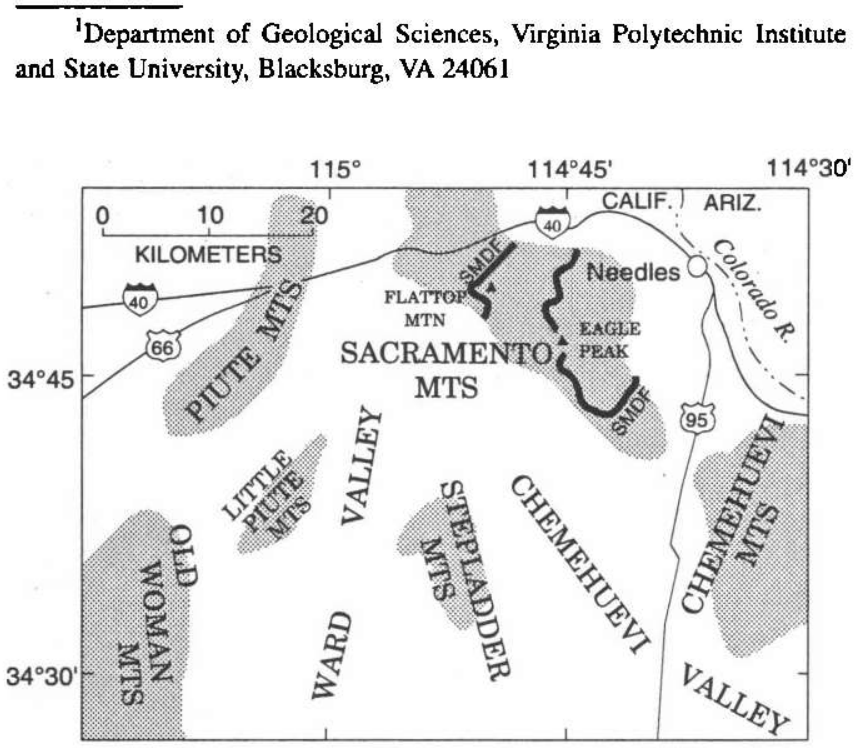

Figure 1. Map showing geographic features discussed in text. SMDF, Sacramento Mountains detachment fault, generalized from Spencer (1985). define three plates in the Sacramento Mountains: a lower plate consisting of the Precambrian through Mesozoic rocks, a middle plate consisting of Tertiary pyroclastic flows and less abundant volcaniclastic, carbonate, and siliciclastic sedimentary rocks, and an upper plate consisting of tilted Tertiary boulder breccia and conglomerate, sandstone, and mudstone capped by flat-lying lava flows (nomenclature of Spencer, 1985). Strata of the middle and upper plates are variably tilted against the detachment faults, relations that indicate episodes of postdepositional rotation. However, the position of these structures on the stratigraphic column has no temporal significance (col. 2-E, pl. 2).

\section{TERTIARY STRATA}

\section{MIDDLE PLATE}

Middle-plate rocks in the northem Sacramento Mountains have not been well studied. Spencer and Turner (1983) provide the most detail about these rocks and the following is a summary of their findings. Eight mappable units, totaling about $300 \mathrm{~m}$ in stratigraphic thickness, form the middle plate. Pyroclastic flows comprise the major lithotype of the plate.

Lowermost strata consist of tuffaceous sandstone and conglomerate locally interbedded with limestone, chert, siltstone, and tuff. These lower units are overlain by a thick section of felsic tuff. One welded tuff that contains phenocrysts of adularescent sanidine and sphene characteristic of the widespread Peach Springs Tuff of Young and Brennan (1974) yielded a K-Ar age of $18.5 \pm 0.2 \mathrm{Ma}$ (biotite) (Spencer, 1985). The Peach Springs Tuff has an accepted age of $18.5 \pm 0.2 \mathrm{Ma}$ (Nielson and others, 1990). A sequence of interbedded volcaniclastic sedimentary rocks and volcanic-lithic tuff completes the middle-plate section.

\section{UPPER PLATE}

\section{FACIES ASSOCIATIONS}

Upper-plate rocks crop out over an area of $50 \mathrm{~km}^{2}$ as discontinuous, highly faulted sections that expose a thick 
(approximately $1 \mathrm{~km}$ ) predominantly sedimentary rock sequence. Deposits related to a single basin lie in structural juxtaposition against middle- and upper-plate rocks. No basal contact is exposed in the area. The rocks are divisible into three distinct facies associations: (1) fluvial-dominated alluvial fan, (2) lacustrine, and (3) gravity- dominated alluvial fan.

The fluvial-dominated alluvial fan association is characterized by crudely stratified sandy conglomerate (facies Gm of Miall, 1977), gravely sandstone, and less abundant matrix-rich conglomerate. The clast assemblage is heterogenous but is dominated by debris that resembles nearby Precambrian plutonic and metamorphic rocks. Scattered clasts of muscovite and two-mica granite resemble Cretaceous plutons that crop out in the nearby Old Woman Mountains (Miller and Bradfish, 1980). The clast assemblage also contains locally abundant sandstone and limestone that were probably derived intrabasinally. Sedimentary characteristics are consistent with origin in an expansive mid-alluvial fan setting.

The lacustrine association consists of two variants: one dominated by a mixture of green claystone, mudstone, and siltstone with less abundant green graded sandstone and matrix-rich conglomerate and carbonate, and the other dominated by grayish-orange and maroon, plane-bedded, disorganized and crossbedded sandstone and siltstone. The fine-grained green strata record deposition of clastic detritus under quiet-water conditions, with the coarser grained interbeds representing turbidity and debris flows that traversed the lake. The grayish-orange and maroon sandstone and siltstone have characteristics of lacustrine-margin sand flats, an environment where sheet floods on distal alluvial fans flow into the lake along its margin (Hardie and others, 1978; Hubert and Hyde, 1982).

The gravity-dominated alluvial fan association is dominated by poly- and monolithologic, cobble to boulder, matrix- and framework-supported conglomerate and breccia. Clasts are exclusively Precambrian granitoid and gneiss. Locally, layers of monolithologic breccia display crackle and jigsaw brecciation, indicating that they moved as coherent masses. Such features are typical of large rock-avalanche deposits (Yarnold and Lombard, 1989) and debris-flow deposits that are expected to form near the margins of a tectonically active basin (for example, Nielson and Beratan, 1990).

\section{BASIN EVOLUTION}

Basin-formation events in the northern Sacramento Mountains are poorly constrained, although inferences based on facies distribution patterns are possible. Lacustrine associations intimately mixed with basin-margin associations at the southwest end of the basin permit the interpretation that the basin opened as an asymmetric half graben (Morley, 1989). Such a configuration is consistent with regional trends that show northeast-directed extension along northeast-dipping detachment faults (Wust, 1986). Upper-plate rocks are younger than the 18.5-Ma Peach Springs(?) Tuff of the middle plate. Sedimentation began prior to $14.6 \pm 0.9 \mathrm{Ma}$ (K-Ar whole rock, Spencer, 1985), the age of an interbedded lava flow near the middle(?) of the section.

Most strata in the upper plate form a homocline that dips west-southwest. Stratal tilts vary slightly and there are neither obvious faults nor evidence for unconformities in the west-southwest-tilted deposits, suggesting that the basin filled during a phase of relative tectonic quiescence, followed by an episode of block faulting. A pronounced angular unconformity is exposed at high elevations in the area, where gently dipping conglomerate (less than $50 \mathrm{~m}$ thick) overlies tilted strata of the basin. These perched rocks represent paleovalley filling following block faulting of the main body of strata. The entire sequence is capped by nearly flat-lying lava flows, one of which has a $\mathrm{K}$-Ar age of 14.6 $\pm 0.2 \mathrm{Ma}$ (whole rock) (Spencer, 1985). The nearly synchronous age of dipping and flat-lying strata indicates that a significant amount of sedimentation and tilting can occur quickly during crustal extension.

\section{ACKNOWLEDGMENTS}

My research in the Sacramento Mountains was supported by grants from the Geological Society of America, American Association of Petroleum Geologists, Sigma Xi, and the Department of Geology at Vanderbilt University. Julia M.G. Miller provided partial support from an American Chemical Society-Petroleum Research Fund grant.

\section{REFERENCES CITED}

Coney, P.F., 1980, Cordilleran metamorphic core complexes: An overview, in Crittenden, M.D., Jr., Coney, P.F., and Davis, G.H., eds., 1980, Cordilleran metamorphic core complexes: Geological Society of America Memoir 153, p. 7-31.

Hardie, L.A., Smoot, J.P., and Eugster, H.P., 1978, Saline lakes and their deposits: a sedimentologic approach, in Matter, Albert, and Tucker, M.E., eds., Modern and ancient lake sediments: Oxford, England, Blackwell Scientific Publications, International Association of Sedimentologists Special Publication 2, p. 7-41.

Howard, K.A., and John, B.E., 1987, Crustal extension along a rooted system of imbricate low-angle faults: Colorado River extensional corridor, California and Arizona, in Coward, M.P., Dewey, J.F., and Hancock, P.L., eds., Continental extensional tectonics: Geological Society of London Special Publication 28, p. 299-311.

Hubert, J.F., and Hyde, M.G., 1982, Sheet-flow deposits of graded beds and mudstones on an alluvial sandflat-playa system: 
Upper Triassic Blomidon redbeds, St. Mary's Bay, Nova Scotia: Sedimentology, v. 29, no. 4, p. 457-474.

Miall, A.D., 1977, A review of the braided-river depositional environment: Earth-Science Reviews, v. 13, no. 1, p. 1-62.

Miller, C.F., and Bradfish, L.J., 1980, An inner Cordilleran belt of muscovite-bearing plutons: Geology, v. 8, no. 9, p. 412416.

Morley, C.K., 1989, Extension, detachments, and sedimentation in continental rifts (with particular reference to East Africa): Tectonics, v. 8, no. 6, p. 1,175-1,192.

Nielson, J.E., and Beratan, K.K., 1990, Tertiary basin development and tectonic implications, Whipple detachment system, Colorado River extensional corridor, California and Arizona: Journal of Geophysical Research, v. 95, no. B1, p. 599-614.

Nielson, J.E., Lux, D.R., Dalrymple, G.B., and Glazner, A.F., 1990, Age of the Peach Springs Tuff, southeastern California and western Arizona: Journal of Geophysical Research, v. 95 , no. B1, p. 571-580.

Spencer, J.E., 1985, Miocene low-angle normal faulting and dike emplacement, Homer Mountain and surrounding areas, south- eastern California and southernmost Nevada: Geological Society of America Bulletin, v. 96, no. 9, p. 1,140-1,155.

Spencer, J.E., and Turner, R.D., 1983, Geologic map of part of the northwestern Sacramento Mountains, southeastern California: U.S. Geological Survey Open-File Report 83-614, scale $1: 24,000$.

Wust, S.L., 1986, Regional correlation of extension directions in Cordilleran metamorphic core complexes: Geology, v. 14, no. 10 , p. $828-830$.

Yarnold, J.C., and Lombard, J.P., 1989, A facies model for large rock-avalanche deposits formed in dry climates, in Colburn, I.P., Abbot, P.L., and Minch, John, eds., Conglomerates in basin analysis: a symposium dedicated to A.O. Woodford: Los Angeles, Calif., Pacific Section, Society of Economic Paleontologists and Mineralogists, v. 62, p. 9-31.

Young, R.A., and Brennan, W.J., 1974, Peach Springs Tuff: its bearing on structural evolution of the Colorado Plateau and development of Cenozoic drainage in Mohave County, Arizona: Geological Society of America Bulletin, v. 85, no. 1 , p. 83-90. 



\title{
Tertiary Stratigraphy of the Central Sacramento Mountains, Southeastern Calif.
}

\author{
By Julia M.G. Miller ${ }^{1}$ and Brad R. Leach ${ }^{2}$
}

\section{INTRODUCTION}

The Sacramento Mountains lie on the west side of the Colorado River, west and southwest of Needles (fig. 1). This report describes Tertiary rocks exposed west and southwest of Eagle Peak in the central part of the range, approximately $17 \mathrm{~km}$ southwest of Needles, Calif. Geologic studies in this area have been done by Collier (1960), McClelland (1982, 1984) and Leach (1985). Spencer and Turner (1983), Spencer (1985), and Fedo (this volume) describe correlative rocks in an adjacent area to the north.

The Sacramento Mountains are situated within the Colorado River extensional corridor (Howard and John, 1987), a zone of extreme continental extension. They comprise a metamorphic core complex (Coney, 1980) in which Proterozoic to Mesozoic piutonic and metamorphic rocks constitute the autochthonous rocks (Schweitzer and Simpson, 1989). Three stacked and undulating low-angle normal or detachment faults displace the overlying allochthonous units. The structurally lowest Sacramento Moun37235

'Department of Geology, Vanderbilt University, Nashville, TN

${ }^{2}$ Newmont Exploration Ltd., P.O. Box 669, Carlin, NV 89822

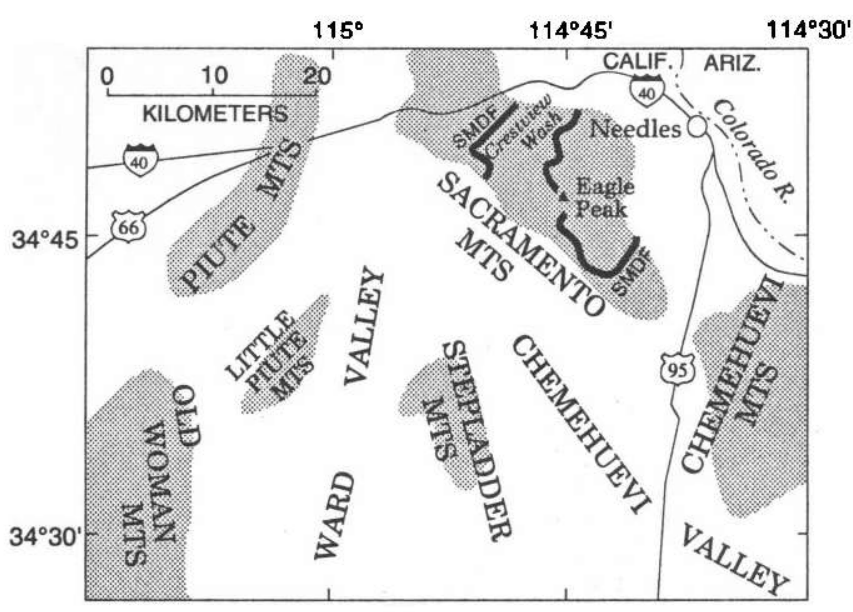

Figure 1. Map showing location of geographic features discussed in text. SMDF, Sacramento Mountains detachment fault, generalized from Spencer (1985). tains detachment fault moved last (McClelland, 1982). Tertiary strata are exposed in the upper two allochthonous plates. The lower volcanic and sedimentary sequence lies between the lower or middle and the upper detachment faults, and the upper sedimentary sequence is bounded at its base by the upper detachment fault (McClelland, 1982, 1984; Leach, 1985).

\section{LOWER VOLCANIC AND SEDIMENTARY SEQUENCE}

Mafic and silicic flows and tuff are interbedded with carbonate and volcaniclastic sedimentary rocks and locally lie nonconformably on Proterozoic and Mesozoic crystalline rocks (col. 2-F, pl. 2). Elsewhere the Tertiary rocks are bounded at their base by a detachment fault. These strata total about $400 \mathrm{~m}$ thick. An angular unconformity separates the sequence into two parts. Average dips below the unconformity are $52^{\circ}$, whereas dips above it average $31^{\circ}$ (Leach, 1985).

The lowest $72 \mathrm{~m}$ of section below the unconformity is composed of plagioclase-rich, porphyritic andesite with minor interbeds of volcaniclastic sedimentary rocks overlain by locally vesicular basalt. Medium-bedded, chert-rich limestone caps the basalt. Although the thickness varies, the limestone is about $14 \mathrm{~m}$ thick and contains rare ostracodes, peloidal structures, ooids, algal structures, and clastic debris. Above it is very thin to thin-bedded dolomitic limestone containing ostracodes. This unit is probably about $15 \mathrm{~m}$ thick but is profoundly deformed, most likely due to both soft-sediment and tectonic deformation. It is locally rich in magnesite and includes a small magnesite deposit that was once commercially operated (Vitaliano, 1950).

Tuffaceous sandstone 50 to $60 \mathrm{~m}$ thick overlies the unconformity. It is well bedded in western exposures but poorly bedded in eastern areas, and it locally contains conglomerate 6 to $9 \mathrm{~m}$ thick. A K-Ar age of $18.2 \pm 0.5 \mathrm{Ma}$ (biotite) was obtained for a lithic-rich tuff within this sandstone unit (Simpson and others, 1991). Dolomitic limestone $33 \mathrm{~m}$ thick overlies and interfingers with the tuffaceous sandstone. It is cherty and fossiliferous, containing 
ostracodes, peloids, gastropods, charophyte algae, some petrified wood, and some concentrically laminated algal structures; it also shows soft-sediment deformation.

Tuff breccia and lithic tuff overlie the carbonate rocks and thin eastward from about 35 to $9 \mathrm{~m}$. Locally the unit includes large $(1-3 \mathrm{~m})$ deformed slivers of limestone that commonly are aligned along a northwest-southeast trend. In western exposures calcareous sandstone, about $18 \mathrm{~m}$ thick and containing some conglomeratic and tuffaceous layers, overlies the tuff; in eastern outcrops a porphyritic basalt 20 to $30 \mathrm{~m}$ thick is found at the same stratigraphic level. Capping the sequence in all locations is a resistant pinkish to orange-weathering crystal-lithic tuff. This tuff contains adularescent sanidine and sphene and is probably equivalent to the Peach Springs Tuff of Young and Brennan (1974). About $15 \mathrm{~m}$ of tuff is exposed but the top of the unit is truncated by the upper detachment fault.

\section{UPPER SEDIMENTARY SEQUENCE}

Monolithologic breccia at the exposed base of the upper sedimentary sequence is composed of gneiss clasts most likely derived from the Fenner Gneiss of Hazzard and Dosch (1937), a Proterozoic augen gneiss exposed extensively in the Old Woman and Piute Mountains, about $25 \mathrm{~km}$ farther west. The breccia is generally structureless and probably 50 to $100 \mathrm{~m}$ thick. It is overlain by conglomerate containing abundant granite clasts as well as clasts of gneiss, basalt, and limestone. Clast imbrication in the conglomerate shows paleocurrent transport toward the north or northeast. A large debris flow, $10 \mathrm{~m}$ thick and filling a channel, is exposed in one spectacular outcrop. The granitic debris is derived from a pluton in the Stepladder Mountains, which now is exposed $8 \mathrm{~km}$ southwest of these conglomerate outcrops. Gypsiferous shale and silty limestone more than $20 \mathrm{~m}$ thick overlie the conglomerate.

A sandstone unit at least $46 \mathrm{~m}$ thick is exposed on the west flank of Eagle Peak. It is composed of siltstone to sandstone with minor shale and conglomerate. Sedimentary structures include ripple marks, load structures, and sole marks near the base of the unit; channels, rip-up clasts, parallel lamination and some cross lamination are found nearer the top. Zones of dense plant roots in some upper beds suggest some paleosol development. The stratigraphic position of this unit is uncertain because all its contacts are faults. We assign the sandstone unit to the upper sedimentary sequence on the basis of the general similarity of depositional setting and topographic level between it and the breccia and conglomerate that elsewhere form the upper sedimentary sequence.

The upper sedimentary sequence most likely correlates with similar breccia, conglomerate, and sandstone exposed in the Crestview Wash area about $8 \mathrm{~km}$ to the north. The age of units in Crestview Wash is constrained by an inter- bedded basalt, which is $14.6 \pm 0.9 \mathrm{Ma}(\mathrm{K}-\mathrm{Ar}$, whole rock) (Spencer, 1985; Fedo, this volume). The upper sedimentary sequence is unconformably overlain by Quaternary gravel deposits or locally faulted against the rhyolite of Eagle Peak.

\section{RHYOLITE OF EAGLE PEAK}

Extrusive and intrusive phases of rhyolite are present at Eagle Peak. McClelland (1984) described the relations as intrusive; however, at the spectacular exposure in Eagle Pass, Simpson and others (1991) have established that the rhyolite was extruded over the exhumed surface of the Sacramento Mountains detachment fault. The rhyolite is $14.3 \pm 0.4 \mathrm{Ma}$ on the basis of $\mathrm{K}$-Ar ages from sanidine and biotite (Simpson and others, 1991). The top contact of the rhyolite is unexposed but must represent an unconformity.

\section{GEOLOGIC HISTORY AND DEPOSITIONAL ENVIRONMENTS}

Carbonate rocks in the lower volcanic and sedimentary sequence record marginal lacustrine deposition in an intermontane basin. Both charophyte algae and ostracodes are good indicators of fresh water conditions. Dolomitization in the lower volcanic and sedimentary sequence was probably penecontemporaneous with deposition, associated with seasonal fluctuations of lake level (Leach, 1985). Lacustrine deposition initially developed on a surface mantled by basalt and andesite lava flows, then increasing volcanic activity nearby led to deposition of pyroclastic debris, which was reworked in the lake. Later the basin was dominated by subaerial pyroclastic deposition that culminated when the Peach Springs(?) Tuff blanketed the area.

Breccia and conglomerate in the upper sedimentary sequence record very proximal alluvial fan deposition with some crude fining upward. Gypsiferous siltstone could record playa lake deposition between channels areas. The presence of large Stepladder Mountain-derived granite clasts suggests 4 to $7 \mathrm{~km}$ of tectonic transport of these rocks, allowing for 1 to $3 \mathrm{~km}$ of sedimentary transport down the alluvial fan (Leach, 1985). The fault-bounded sandstone records distal alluvial fan or fluvial deposition.

Emplacement of the rhyolite of Eagle Peak about 14.3 Ma was the last Tertiary magmatic event in the region and followed the last movements on the detachment faults.

\section{REFERENCES CITED}

Collier, J.T., 1960, Geology and mineral resources of Township 8 North, Ranges 21 and 22 East, San Bernardino base line and 
Meridian, San Bernardino County: Albuquerque, N.M., Santa Fe Mining Inc., Southern Pacific Land Company report, scale $1: 24,000$.

Coney, P.F., 1980, Cordilleran metamorphic core complexes: An overview, in Crittenden, M.D., Jr., Coney, P.F., and Davis, G.H., eds., Cordilleran metamorphic core complexes: Geological Society of America Memoir 153, p. 7-31.

Hazzard, J.C., and Dosch, E.F., 1937, Archean rocks in the Piute and Old Woman Mountains, San Bernardino County, California [abs.]: Geological Society of America Proceedings for 1936, 35th Annual Meeting, p. 308-309.

Howard, K.A., and John, B.E., 1987, Crustal extension along a rooted system of imbricate low-angle faults: Colorado River extensional corridor, California and Arizona, in Coward, M.P., Dewey, J.F., and Hancock, P.L., eds., Continental extensional tectonics: Geological Society of London Special Publication 28 , p. $299-311$

Leach, B.R., 1985, Petrology and depositional history of Miocene nonmarine sedimentary rocks, central Sacramento Mountains, San Bernardino County, Califomia: Nashville, Tenn., Vanderbilt University, M.S. thesis, $161 \mathrm{p}$.

McClelland, W.C., 1982, Structural geology of the central Sacramento Mountains, San Bernardino County, California, in Frost, E.G., and Martin, D.L., eds., Mesozoic-Cenozoic tectonic evolution of the Colorado River region, California, Arizona, and Nevada (Anderson-Hamilton Volume): San Diego, Calif., Cordilleran Publishers, p. 401-407.
1984, Low-angle Cenozoic faulting in the central Sacramento Mountains, San Bemardino County, California: Los Angeles, University of Southern California, M.S. thesis, 94 p.

Schweitzer, Janet, and Simpson, Carol, 1989, On the absence of a simple mylonite front in the Sacramento Mts., S.E. California [abs.]: Geological Society of America Abstracts with Programs, v. 21, no. 5, p. 141.

Simpson, Carol, Schweitzer, Janet, and Howard, K.A., 1991, A reinterpretation of the timing, position, and significance of the Sacramento Mountains detachment fault, SE California: Geological Society of America Bulletin, v. 103, no. 6, p. 751-761.

Spencer, J.E., 1985, Miocene low-angle normal faulting and dike emplacement, Homer Mountain and surrounding areas, southeastem California and southernmost Nevada: Geological Society of America Bulletin, v. 96, no. 9, p. 1,140-1,155.

Spencer, J.E., and Turner, R.D., 1983, Geologic map of part of the northwestern Sacramento Mountains, southeastern California: U.S. Geological Survey Open-File Report 83-614, scale 1:24,000.

Vitaliano, C.J., 1950, Needles magnesite deposit, San Bernardino County, California: California Journal of Mines and Geology, v. 46 , no. 3, p. $357-372$.

Young, R.A., and Brennan, W.J., 1974, Peach Springs Tuff: its bearing on structural evolution of the Colorado Plateau and development of Cenozoic drainage in Mohave County, Arizona: Geological Society of America Bulletin, v. 85, no. 1, p. 83-90. 



\title{
Tertiary Stratigraphy of the Chemehuevi Mountains, Southeastern Calif. and Western Ariz.
}

\author{
By Julia M.G. Miller ${ }^{1}$ and Barbara E. John ${ }^{2}$
}

\section{INTRODUCTION}

The Chemehuevi Mountains straddle the Colorado River in southeastern Califomia and western Arizona (fig. 1). Disrupted exposures of Tertiary stratified rocks encircle the range. Those on the northern and eastern flanks are described here; others occur in the Sawtooth Range (Howard and others, this volume) and the southern Chemehuevi Mountains. Previous geologic mapping and description of these deposits may be found in Coonrad

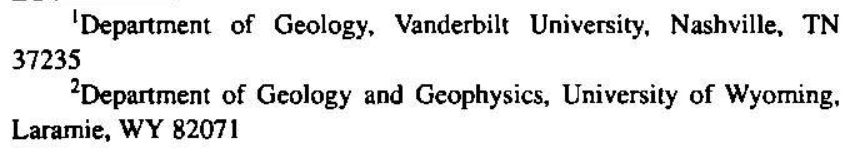
37235

'Department of Geology, Vanderbilt University, Nashville, TN

${ }^{2}$ Department of Geology and Geophysics, University of Wyoming, Laramie, WY 82071

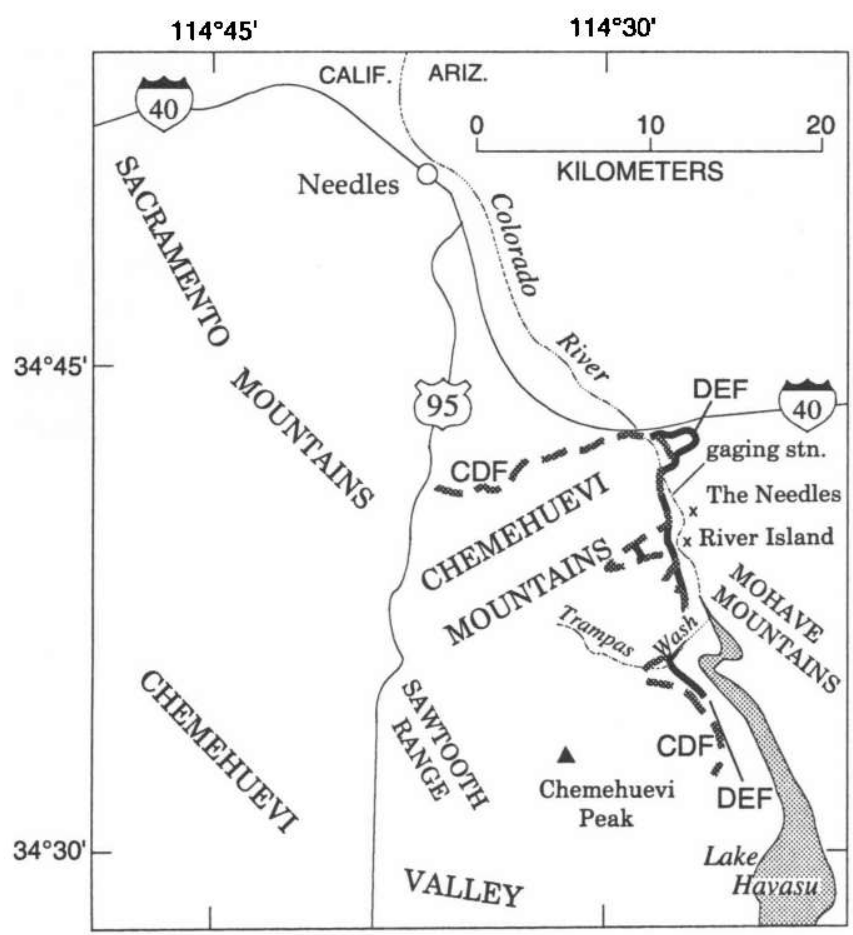

Figure 1. Map showing location of Chemehuevi Mountains and other features named in text. CDF, Chemehuevi detachment fault (dashed line); DEF, Devils Elbow fault (heavy line), from John (1987b).
(1960), Coonrad and Collier (1960), John (1987b), and Miller and John (1988).

The Chemehuevi Mountains lie within the Colorado River extensional corridor, a region of extreme crustal extension (Howard and John, 1987). The area is characterized by moderately to steeply tilted fault blocks that lie above regionally developed low-angle normal or detachment faults (Davis and others, 1980). Tertiary volcanic and sedimentary rocks lie both nonconformably and in fault contact above Proterozoic gneisses and granites in the hanging walls of two detachments faults, the Chemehuevi and Devils Elbow faults (fig. 1) (John, 1987a, b). The Tertiary rocks are divided into four sequences, from oldest to youngest (col. 2-G, pl. 2): (1) deformed lower Miocene mafic and intermediate lava and interstratified sedimentary rocks, (2) the Peach Springs Tuff of Young and Brennan (1974), (3) a deformed thick middle Miocene alluvial fan sequence of conglomerate, breccia, and sandstone with thin interbedded mafic and silicic flows and tuffs, and (4) undeformed sedimentary deposits of late Miocene to Pliocene age. The Miocene section is estimated to be at least 2 to $3 \mathrm{~km}$ thick. The lower three of these sequences probably correlate directly to those of Nielson and Beratan (1990), in the adjacent Mohave Mountains of Arizona.

\section{LOWER VOLCANIC AND SEDIMENTARY SECTION}

The lowest Tertiary rocks consist of an undated sequence about $500 \mathrm{~m}$ thick assigned to the early Miocene. The section consists of mafic and intermediate flows, breccia, and laharic deposits, with interstratified conglomeratic sedimentary strata. The rocks crop out in numerous faultbounded blocks along the Colorado River and are best exposed in the area around The Needles and River Island in Arizona. Volcanic units are lithologically variable but commonly include andesitic to dacitic laharic deposits low in the section, basalt and plagioclase-phyric ("jackstraw") andesitic or latitic flows at intermediate levels, and finegrained mafic flows high in the section. Locally, volcanic agglomerate composed of andesitic to dacitic clasts and ranging in thickness from a few meters to over $100 \mathrm{~m}$ is 
found at the base. Sedimentary interbeds include arkosic sandstone, shale, and pebble conglomerate a few meters thick near the base of the volcanic section. High in the section the interbeds include volcanic-clast tuffaceous conglomerate that contains clasts of volcanic and gneissic rocks and are as thick as $140 \mathrm{~m}$.

\section{PEACH SPRINGS TUFF}

The Peach Springs Tuff of Young and Brennan (1974) lies concordantly or in slight discordance above the basal volcanic and sedimentary sequence. The tuff fills a channel; its thickness ranges from less than $2 \mathrm{~m}$ over topographic highs to greater than $160 \mathrm{~m}$ at The Needles. Over a paleohigh near the Colorado River gaging station, a thin section of tuff rests directly on basal agglomerate of the underlying sequence. The upper part of the tuff is commonly cut by massive travertine veins (as wide as $40 \mathrm{~cm}$ ), and in places the upper surface shows 2 to $3 \mathrm{~m}$ of sharp local relief or is capped by caliche-supported conglomerate. These relations suggest a period of hot-spring activity, weathering, and erosion prior to deposition of the overlying sediment.

Outcrops of the Peach Springs Tuff in the Chemehuevi Mountains are correlated with other parts of the regionally extensive unit on the basis of petrography, geochronology, and magnetization. A sample from the westernmost Chemehuevi Mountains yielded a $\mathrm{K}$-Ar age of $18.1 \pm 0.6 \mathrm{Ma}$ (sanidine) (Howard and others, 1982), thus overlapping the more precisely determined age of $18.5 \pm 0.2 \mathrm{Ma}$ (Nielson and others, 1990).

\section{UPPER SEDIMENTARY SEQUENCE}

The Peach Springs Tuff is overlain by a sequence of monolithologic breccia, conglomerate, sandstone, rare shale, and intercalated silicic tuff and basaltic flows. Locally, bedded conglomerate lies with angular discordance (as great as $35^{\circ}$ ) on the underlying tuff; elsewhere the sedimentary section is disconformable or slightly discordant to the tuff.

The sedimentary sequence typically is 1 to $2 \mathrm{~km}$ thick. It is best exposed in three geographically distinct areas that contain similar stratigraphic sections. Massive to poorly bedded matrix-rich pebble and cobble breccia is predominant at the base of each section and contains mostly volcanic and gneissic clasts; monolithologic landslide megabreccia deposits composed of Proterozoic gneiss and granite or of Miocene volcanic rocks are present locally. In some sections monolithologic breccia at the base is overlain by progressively more polylithologic and better bedded breccia and conglomerate.
Pebble and cobble conglomerate with crude horizontal stratification is interbedded with the matrix-rich breccia and conglomerate and becomes more abundant upsection. This conglomerate is the most abundant sedimentary facies in the sequence; it contains rare channels and sandstone lenses. The conglomerate locally contains finingand coarsening-upward sequences from 0.5 to $20 \mathrm{~m}$ thick. Monolithologic breccia lenses composed of volcanic, gneissic, or granitic debris are also found locally. Sandstone interbeds contain planar bedding, ripple marks, desiccation cracks, camel tracks, graded bedding, and poorly sorted, matrix-rich sandy beds. Siltstone interbeds with clay partings are rarely present.

Clasts within the conglomerate show an inverted stratigraphy: older conglomerate contains debris derived from the hanging wall of the Chemehuevi fault, such as Proterozoic and Miocene rocks including the Peach Springs Tuff. Younger conglomerate is dominated by Mesozoic granitoid rocks derived from the footwall. In the Trampas Wash area the conglomerate can be subdivided into (from oldest to youngest) volcanic-clast, gneiss-clast, and granite-clast conglomerate on the basis of the predominant clast types.

Interstratified basalt flows and rhyolite tuff exist locally in the section. The basalt flows contain phenocrysts of olivine, plagioclase, and pyroxene, are locally amygdaloidal, and generally are about $5 \mathrm{~m}$ thick but locally tens of meters thick. Thin (less than $3 \mathrm{~m}$ thick), partly reworked, lithic- and biotite-rich rhyolitic tuff beds are found throughout the stratigraphic sequence. Work is in progress to date some beds of rhyolitic tuff and the thick basalt. This basalt texturally resembles a basalt exposed $1.5 \mathrm{~km}$ southwest of the Chemehuevi Mountains that has a $\mathrm{K}-\mathrm{Ar}$ age of 14.5 $\pm 1.0 \mathrm{Ma}$ (whole rock) (Howard and others, this volume).

In the central Chemehuevi Mountains, basalt plugs

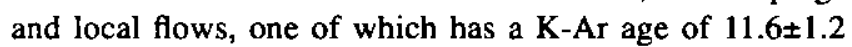
Ma (whole rock) (J.K. Nakata, oral commun., 1984; see John, 1987a), intrude or overlie and fuse cataclasite in the Chemehuevi detachment fault zone, indicating that movement had ceased on the Chemehuevi fault by late Miocene time.

\section{UNDEFORMED PIEDMONT GRAVELS AND BOUSE AND CHEMEHUEVI FORMATIONS}

Undeformed sediment lies with angular discordance on the section just described. The lowest sediment is locally derived, matrix-supported conglomerate that underlies the Bouse Formation (Metzger and Loeltz, 1973). The Bouse Formation, assigned to the upper Miocene and Pliocene, has been described in the area by Metzger and Loeltz (1973) and Buising (this volume). It consists of ba- 
sal marl 0.2 to $8 \mathrm{~m}$ thick and an overlying unit as much as $15 \mathrm{~m}$ thick of interbedded clay and silt with fewer interbeds of sand.

Overlying the Bouse are locally derived piedmont gravels and Pliocene(?) and Pleistocene alluvial deposits of the Colorado River. The piedmont gravels are lithologically similar to pre-Bouse conglomerate. Some upper Pleistocene, mostly fine-grained alluvial deposits were considered by Metzger and others (1973) to be equivalent to the Chemehuevi Formation as defined by Longwell (1936).

\section{GEOLOGIC HISTORY}

The distribution of rock types within the Tertiary section exposed in the northern and eastern Chemehuevi Mountains implies that at least moderate relief existed throughout the time of deposition. The basal section lies unconformably above deformed and metamorphosed Proterozoic gneiss and granite. Stratigraphic relationships below the Peach Springs Tuff imply local relief of bundreds of meters with little tilting. Eruption of the Peach Springs Tuff coincided with (1) initiation of major block tilting related to crustal extension in the region, (2) development of numerous unconformities and syndepositional fault scarps, and (3) generation of a huge volume of detritus shed into small basins.

The upper sedimentary sequence records alluvial fan deposition interrupted by a period of lacustrine conditions. The overall crude upward fining from very proximal fan facies to proximal and mid-fan facies is consistent with accumulation during retreat of a mountain front or lowering of source area relief. Interbedded landslide megabreccia and 10- to 20-m-thick coarsening-upward sequences suggest some syndepositional faulting.

Clast assemblages in the alluvial fan sequence record progressive unroofing of both the hanging wall and footwall to the Chemehuevi detachment fault system. Conglomerate in the lower Trampas Wash area clearly records breaching of the Chemehuevi detachment fault, and distinctive clasts within the youngest conglomerate beds displaced by the Chemehuevi fault constrain later movement on the fault to less than $5 \mathrm{~km}$ (Miller and John, 1988).

\section{REFERENCES CITED}

Coonrad, W.L., 1960, Geology and mineral resources of Township 6 North, Range 24 East, San Bernardino base line and Meridian, San Bernardino County: Albuquerque, N.M., Santa Fe Mining Inc., Southern Pacific Land Company report, scale $1: 24,000$.

Coonrad, W.J., and Collier, J.P., 1960, Areal economic geology, Township 5 North, Ranges 23-24 East, and Township 7
North, Ranges 23-24 East, San Bernardino base line and Meridian, San Bernardino County: Albuquerque, N.M., Santa Fe Mining Inc., Southem Pacific Land Company report, scale 1:24,000.

Davis, G.A., Anderson, J.L., Frost, E.G., and Shackelford, T.J., 1980, Mylonitization and detachment faulting in the Whipple-Buckskin-Rawhide Mountains terrane, southeastern California and western Arizona, in Crittenden, M.D., Coney, P.J., and Davis, G.H., eds., Cordilleran metamorphic core complexes: Geological Society of America Memoir 153, p. 79129.

Howard, K.A., and John, B.E., 1987, Crustal extension along a rooted system of imbricate low-angle faults: Colorado River extensional corridor, California and Arizona, in Coward, M.P., Dewey, J.F., and Hancock, P.L., eds., Continental extensional tectonics: Geological Society of London Special Publication 28, p. 299-311.

Howard, K.A., Stone, Paul, Pemokas, M.A., and Marvin, R.F., 1982, Geologic and geochronologic reconnaissance of the Turtle Mountains area, California: west border of the Whipple Mountains detachment terrane, in Frost, E.G., and Martin, D.L., eds., Mesozoic-Cenozoic tectonic evolution of the Colorado River region, California, Arizona, and Nevada (Anderson-Hamilton Volume): San Diego, Calif., Cordilleran Publishers, p. 341-354.

John, B.E., 1987a, Geometry and evolution of a mid-crustal extensional fault system: Chemehuevi Mountains southeastern California, in Coward, M.P., Dewey, J.F., and Hancock, P.L., eds., Continental extensional tectonics: Geological Society of London Special Publication 28, p. 312-333.

1987b, Geologic map of the Chemehuevi Mountains area, San Bemardino County, California, and Mohave County, Arizona: U.S. Geological Survey Open-File Report 87-666, scale $1: 24,000$.

Longwell, C.R., 1936, Geology of the Boulder Reservoir floor, Arizona-Nevada: Geological Society of America Bulletin, v. 47 , no. 9, p. 1,393-1,476.

Metzger, D.G., and Loeltz, O.J., 1973, Geohydrology of the Needles area, Arizona, California, and Nevada: U.S. Geological Survey Professional Paper 486-J, 54 p.

Metzger, D.G., Loeltz, O.J., and Irelan, Burdge, 1973, Geohydrology of the Parker-Blythe-Cibola area, Arizona and California: U.S. Geological Survey Professional Paper 486-G, 130 p.

Miller, J.M.G., and John, B.E., 1988, Detached strata in a Tertiary low-angle normal fault terrane, southeastern California: a sedimentary record of unroofing, breaching, and continued slip: Geology, v. 16, no. 7, p. 645-648.

Nielson, J.E., and Beratan, K.K., 1990, Tertiary basin development and tectonic implications, Whipple detachment system, Colorado River extensional corridor, California and Arizona: Journal of Geophysical Research, v. 95, no. B1, p. 571-580.

Nielson, J.E., Lux, D.R., Dalrymple, G.B., and Glazner, A.F., 1990, Age of the Peach Springs Tuff, southeastem California and western Arizona: Journal of Geophysical Research, v. 95 , no. B1, p. 571-580.

Young, R.A., and Brennan, W.J., 1974, Peach Springs Tuff: its bearing on structural evolution of the Colorado Plateau and development of Cenozoic drainage in Mohave County, Arizona: Geological Society of America Bulletin, v. 85, no. 1, p. 83-90. 



\title{
Cenozoic Stratigraphy of Northern Chemehuevi Valley and Flanking Stepladder Mountains and Sawtooth Range, Southeastern Calif.
}

\author{
By Keith A. Howard ${ }^{1}$, Peter P. Christiansen ${ }^{2}$, and Barbara E. John ${ }^{3}$
}

INTRODUCTION

Northem Chemehuevi Valley and its flanking ranges expose Neogene stratigraphic sections in which unconformities and synorogenic clastic sedimentary rocks are related to tectonic extension. The area lies within the Colorado River extensional corridor, which is characterized by fault blocks tilted southwestward in the Miocene above regional detachment faults (Howard and John, 1987). The originally east-dipping detachments faults were domed to the surface on the east side of Chemehuevi Valley in the Chemehuevi metamorphic core complex (Frost and Okaya, 1986; John, 1987a).

The Stepladder Mountains on the west side of northern Chemehuevi Valley and the Sawtooth Range on the east side (fig. 1) expose fragmentary sections of Miocene lava flows and pyroclastic and epiclastic deposits (Cooksley, 1960; Coonrad, 1960a, b; Bishop, 1963; Christiansen, 1987; Howard and others, 1982; Howard 1991; John, 1982, 1987b).

Cenozoic rocks in the area can be divided into three sequences bounded by angular unconformities: a lower volcanic sequence of early Miocene age, a middle sequence of Miocene sedimentary rocks and basalt fiows, and an upper, postorogenic sequence of surficial deposits of late Miocene(?) to Holocene age (col. 2-H, pl. 2). The lower volcanic sequence rests nonconformably on Proterozoic gneiss, dips southwesterly at moderate to high angles, and predates most extension-related tilting. The middle sequence exhibits moderate southwesterly dips indicating deposition during tilting, whereas the upper sequence is undeformed.

\section{LOWER VOLCANIC SEQUENCE}

The lower volcanic sequence consists largely of andesitic and dacitic flows, tuff, and breccia and is capped in

\footnotetext{
${ }^{2}$ Department of Geology, Stanford University, Stanford, CA 94305

${ }^{3}$ Department of Geology and Geophysics, University of Wyoming, Laramie, WY 82071
} 94025

'U.S. Geological Survey, 345 Middlefield Road, Menlo Park, CA most places by the Peach Springs Tuff of Young and Brennan (1974). In the Stepladder Mountains, the section is faulted and is several hundred meters thick; the Peach Springs Tuff is absent. A basal flow of basanite (rock classification of Le Bas and others, 1986) in the northern Stepladder Mountains with a K-Ar age of $21.7 \pm 0.5 \mathrm{Ma}$ (whole rock) (M.A. Pernokas and J.K. Nakata, written commun., 1984) rests in probable nonconformity on weathered Proterozoic gneiss. Dacitic tuff breccia that overlies the basalt contains pumice from which J.K. Nakata (written commun., 1984) obtained K-Ar ages of $20.9 \pm 0.5 \mathrm{Ma}$ (biotite) and $19.9 \pm 0.5 \mathrm{Ma}$ (plagioclase). Abundant plagioclase phenocrysts characterize several hundred meters of overlying cream, tan, or pink porphyritic dacitic flows, flow breccia, tuff breccia, and debris

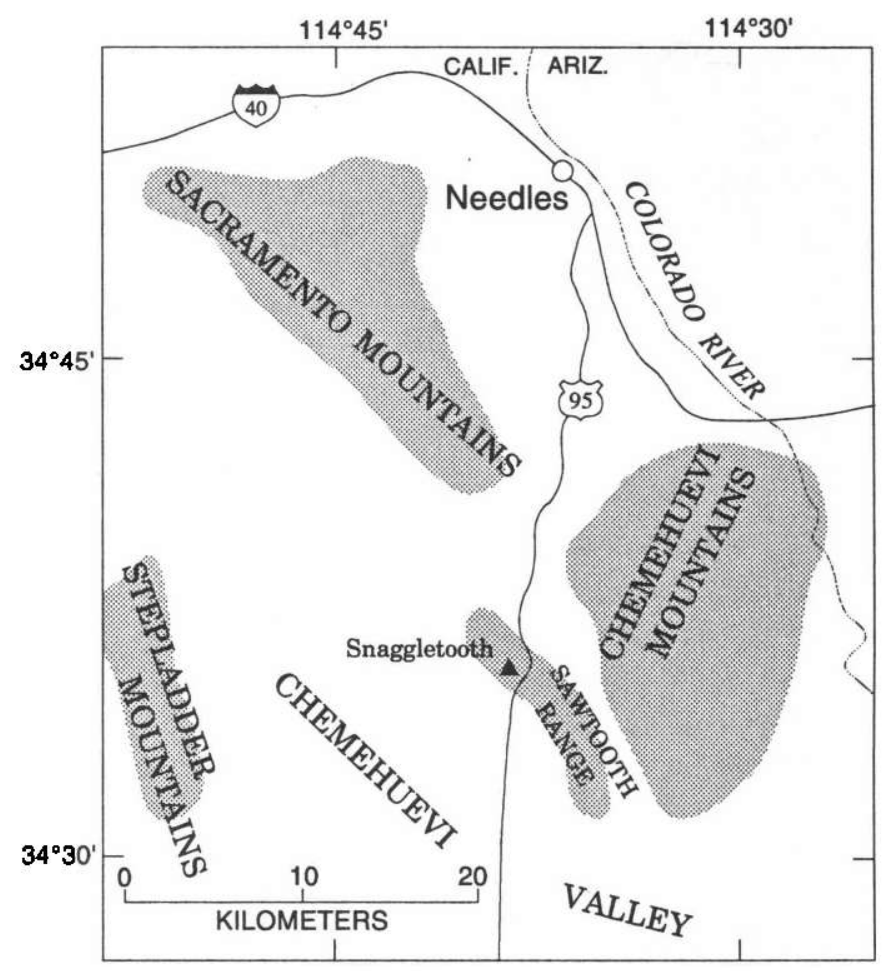

Figure 1. Map showing location of geographic features discussed in text. 
flows. Dark vesicular andesite overlies and interfingers with the dacite. It is overlain in turn by 50 to $100 \mathrm{~m}$ of poorly bedded matrix-supported lahar diamictite, conglomerate, and thin tuff interbeds that together form the uppermost part of the sequence.

In the southem Stepladder Mountains, the lower several hundred meters of exposed section is dominated by a series of flows, flow breccia, and debris flows of compositions that include pyroxene andesite, hornblende andesite, and dacite. An east-striking andesite dike cuts nearby basement rocks. Some of the andesite contains orthopyroxene as well as clinopyroxene. Interfingering with the andesitic rocks are poorly sorted andesitic debris-flow deposits, representing lahars, that are about 200 meters in total thickness. These lahars are associated with local channel lenses of sandy conglomerate with wavy bed forms. The foregoing units are overlain by dacitic to rhyolite porphyry flows with brecciated margins, which merge into discordant shallow intrusive bodies and a swarm of east-striking feeder dikes. Abundant plagioclase and biotite phenocrysts characterize the porphyry, and minor hornblende or pyroxene occur less commonly.

The Sawtooth Range exposes a conformable section about $700 \mathrm{~m}$ thick of dacitic and andesitic flows, flow breccias, tuffs, and agglomerate, all capped by the Peach Springs Tuff. These rocks rest on Proterozoic gneiss and granite. Dips range from $40^{\circ}$ to $90^{\circ}$, depending on local structure.

The base of the section in the Sawtooth Range is varied and locally includes (1) welded andesitic ash-flow tuff units a few meters thick that contain plagioclase and homblende, (2) bedded dacitic tuff a few meters thick that contain plagioclase, biotite, and sanidine, and (3) pyroxene andesite flows. As much as $500-600 \mathrm{~m}$ of boldly outcropping porphyritic dacitic flows dominate the overlying section, including massive rocks at Snaggletooth that were earlier mapped as intrusive (Coonrad, 1960a; Bishop, 1963). This dacitic unit weathers light tan, pale violet, or cream colored. Abundant 2- to 3-mm plagioclase phenocrysts and phenocryst clusters characterize the unit, and varied amounts of phenocrysts as long as 3 to $8 \mathrm{~mm}$ of biotite, homblende, and sparser clinopyroxene phenocrysts are present. Interfingered with these lower units are pinkish dacitic tuff breccia as thick as $330 \mathrm{~m}$ and an overlying 500 -m-thick lens of gray volcanic breccia containing a mix of clasts. The tuff breccia is biotite and plagioclase phyric. The mixed-clast breccia includes glassy breadcrust andesite blocks.

Up to $250 \mathrm{~m}$ of dark, commonly platy andesite and trachyandesite flows overlie and interfinger with the porphyritic dacitic unit. These flows are aphyric to poorly phyric with homblende, pyroxene, and biotite. Thin (1-2 m) andesitic breccia containing a mix of clasts locally forms the uppermost part of the section below the Peach Springs Tuff.
A section $110 \mathrm{~m}$ thick of the Peach Springs Tuff overlies the andesitic rocks concordantly or with small angular discordance. The tuff is crystal-rich rhyolite consisting here of a lower pink-weathering welded part and an upper part of white, unwelded lithic tuff. Flattened pumice lapilli are recrystallized and replaced by cristobalite and chalcedony. The Peach Springs Tuff in the Sawtooth Range yielded a $\mathrm{K}$-Ar age of $18.1 \pm 0.6 \mathrm{Ma}$ (sanidine) (Howard and others, 1982) and is correlated with the regionally extensive ash-flow tuff dated as $18.5 \pm 0.2 \mathrm{Ma}$ (Nielson and others, 1990). Paleomagnetic results from the Sawtooth Range confirm this correlation (Wells and Hillhouse, 1989).

The interfingering porphyritic dacitic rocks in the Sawtooth Range and andesitic rocks in the Stepladder Mountains are similar, and they are also similar to rocks in the Turtle Mountains and Mopah Range south of the Stepladder Mountains (Carr and others, 1980; Howard and others, 1982; Hazlett, 1986, 1990, this volume; Nielson and Turner, 1986; Nielson and Nakata, this volume). The similarities suggest that the pre-Peach Springs sections are part of a shared volcanic field, fed in part by the east-striking dikes in the southern Stepladder Mountains and by dikes and necks exposed in the Turtle and Mopah Ranges (see Hazlett, this volume; Nielson and Nakata, this volume). The sections in the Sawtooth Range and Stepladder Mountains are $20 \mathrm{~km}$ apart and are inferred to have been closer before being dismembered and tilted along east-dipping normal faults. The K-Ar ages determined for the Stepladder Mountains rocks and the age of the Peach Springs Tuff suggest that the lower volcanic sequence in the Sawtooth Range and Stepladder Mountains ranges in age from about 22 to $18.5 \mathrm{Ma}$.

\section{MIDDLE SEQUENCE OF SEDIMENTARY ROCKS AND BASALT}

A ridge-capping sequence more than 50 to $100 \mathrm{~m}$ thick of gently dipping olivine basalt to andesite flows and interleaved tuff and tuffaceous sandstone overlies the more highly faulted lower volcanic sequence in the Stepladder Mountains, on an angular unconformity of $20^{\circ}$ to $30^{\circ}$. To the north the capping basalt unit laps across the lower sequence to rest directly on Cretaceous granodiorite and Proterozoic gneiss. The capping basalt unit therefore postdates some but not all of the Miocene tilting and faulting. Where the unit overlies gneiss in an inselberg in the western Stepladder Mountains, a basaltic trachyandesite yielded a K-Ar age of $18.1 \pm 0.6 \mathrm{Ma}$ (whole rock) (Howard and others, 1982). Similar capping basalts to the south in the Turtle Mountains and western Whipple Mountains have yielded $\mathrm{K}-\mathrm{Ar}$ whole-rock ages of $14.9 \pm 0.3$ and $17.0 \pm 0.4$ $\mathrm{Ma}$, respectively (Carr and others, 1980; Nielson and $\mathrm{Na}-$ kata, this volume). 
Two isolated exposures of rocks considered to be similar in age to the capping basalt crop out near the Sawtooth Range. Shale at least 5 to $8 \mathrm{~m}$ thick and holocrystalline olivine basalt overlying it occur $5 \mathrm{~km}$ south of Snaggletooth. The shale is cherty to dolomitic and contains distorted laminae and possible silicified wood. The unconformably(?) overlying basalt dips about $10^{\circ}$ and has a K-Ar age of $14.5 \pm 1.0 \mathrm{Ma}$ (whole rock) (M.A. Pernokas, written commun., 1982). Westerly dips suggest that these rocks were involved in late tilting related to the Miocene extension.

The second exposure consists of folded sedimentary rocks that dip $20^{\circ}$ to $30^{\circ}$ westerly and rest nonconformably or in fault contact on Proterozoic gneiss and granite at a site $5 \mathrm{~km}$ north-northwest of Snaggletooth. A basal breccia of Tertiary dacitic clasts is overlain by about 100 $\mathrm{m}$ of volcanic-clast conglomerate, which is in turn overlain by a similar thickness of landslide megabreccia containing large boulders of Tertiary volcanic rocks and Proterozoic gneiss and granite. The sedimentary rocks are inferred to correlate with conglomerate and breccia in McClelland's (1982) fault plate "C" in the Sacramento Mountains $15 \mathrm{~km}$ to the north. The section in the Sacramento Mountains was also described by Leach (1985), by Miller and Leach (this volume), and by Spencer and Turner (1983), who found it to be interstratified with tilted basalt and unconformably overlain by flat-lying basalt. The older basalt has a $\mathrm{K}-\mathrm{Ar}$ age of $14.6 \pm 0.9 \mathrm{Ma}$ (whole rock) and the younger has a K-Ar age of $14.6 \pm 0.2 \mathrm{Ma}$ (whole rock) (Spencer, 1985).

\section{POSTOROGENIC DEPOSITS}

Locally derived piedmont gravel forms the floors of northern Chemehuevi Valley. The deposit probably ranges in age from late Miocene(?) to modern. The oldest exposed postorogenic deposit is dissected gravel in the southern Stepladder Mountains; it contains boulders of plutonic and metamorphic rocks, although it rests on the lower volcanic section. Estuarine deposits of the upper Miocene and Pliocene Bouse Formation, which is exposed nearby in southern Chemehuevi Valley (Noble, 1931; Metzger and Loeltz, 1973), probably lies at shallow depth interbedded with piedmont gravels in northern Chemehuevi Valley. This relation is suggested by the presence of shallow horizontal seismic reflectors (Frost and Okaya, 1986).

\section{GEOLOGIC HISTORY}

The stratigraphic sections in and around northern Chemehuevi Valley suggest an early Miocene history, be- ginning about $22 \mathrm{Ma}$, in which local volcanic venting in and south of the Stepladder Mountains resulted in accumulation of several hundred meters of intermediate lavas, breccias, tuffs, lahars, and rarer epiclastic sediments. Deposition of the regional Peach Springs Tuff about 18.5 Ma coincided with the end of this episode and the beginning of fault-block tilting of the sections. Normal faulting along east-dipping faults was accompanied by westward tilting of fault blocks above regional detachment faults. Basaltic magmatism in the south and west accompanied the tilting, while synorogenic conglomerate, landslide breccia, and lacustrine shale were deposited in the north and east. Tilting and faulting ceased at about $14 \mathrm{Ma}$ after the uplift and exposure of the Chemehuevi metamorphic core complex on the east. Postorogenic piedmont gravel began to accumulate in late Miocene time prior to deposition of the Bouse Formation and has continued through latest Cenozoic time.

\section{REFERENCES CITED}

Bishop, C.C., compiler, 1963, Needles sheet, Geologic atlas of California: California Division of Mines and Geology, scale $1: 250,000$.

Carr, W.J., Dickey, D.D., and Quinlivan, W.D., 1980, Geologic map of the Vidal NW, Vidal Junction, and parts of the Savahia Peak SW and Savahia Peak quadrangles, San Bernardino County, California: U.S. Geological Survey Miscellaneous Investigations Map I-1126, scale 1:24,000.

Christiansen, P.P., 1987, Miocene geology of the Stepladder Mountains, San Bemardino County, California: Claremont, Calif., Pomona College, senior thesis, 35 p.

Cooksley, J.W., 1960, Geology and mineral resources of Township 6 North, Ranges 19 and 20 East, San Bernardino base line and Meridian, San Bernardino County, California: Albuquerque, N.M., Santa Fe Mining Inc., Southem Pacific Land Company report, scale $1: 24,000$.

Coonrad, W.L., 1960a, Geology and mineral resources of Township 6 North, Ranges 21 and 22 East, San Bernardino base line and Meridian, San Bernardino County, California: Albuquerque, N.M., Santa Fe Mining Inc., Southern Pacific Land Company report, scale 1:24,000.

1960b, Geology and mineral resources of Township 5 North, Ranges 21 and 22 East, San Bernardino base line and Meridian, San Bernardino County, California: Albuquerque, N.M., Santa Fe Mining Inc., Southern Pacific Land Company report, scale $1: 24,000$.

Frost, E.G., and Okaya, D.A., 1986, Application of seismic reflection profiles to tectonic analysis in mineral exploration: Arizona Geological Society Digest, v. 16, p. 137-152.

Hazlett, R.W., 1986, Geology of the central Mopah Range; a guide for excursions in the Mopah Spring area, in Cenozoic stratigraphy, structure and mineralization in the Mojave Desert: Geological Society of America, Cordilleran Section, 82d, Los Angeles, Calif., March 1986, Guidebook and Volume, Field Trips 5 and 6, p. 33-42. 
1990, Extension-related Miocene volcanism in the Mopah Range volcanic field, southeastern Califomia, in Anderson, J.L., ed., The nature and origin of Cordilleran magmatism: Geological Society of America Memoir 174, p. 133-145.

Howard, K.A., 1991, Intrusion of horizontal dikes: Tectonic significance of Middle Proterozoic diabase sheets widespread in the upper crust of the southwestern United States: Journal of Geophysical Research, v. 96, no. B7, p. 12,46112,478 .

Howard, K.A., and John, B.E., 1987, Crustal extension along a rooted system of imbricate low-angle faults: Colorado River extensional corridor, Califomia and Arizona, in Coward, M.P., Dewey, J.F., and Hancock, P.L., eds., Continental extensional tectonics: Geological Society of London Special Publication 28, p. 299-311.

Howard, K.A., Stone, Paul, Pernokas, M.A., and Marvin, R.F., 1982, Geologic and geochronologic reconnaissance of the Turtle Mountains area, California: west border of the Whipple Mountains detachment terrane, in Frost, E.G., and Martin, D.L., eds., Mesozoic-Cenozoic tectonic evolution of the Colorado River region, California, Arizona, and Nevada (Anderson-Hamilton Volume): San Diego, Calif., Cordilleran Publishers, p. 341-354.

John, B.E., 1982, Geologic framework of the Chemehuevi Mountains, southeastern California, in Frost, E.G., and Martin, D.L., eds., Mesozoic-Cenozoic tectonic evolution of the Colorado River region, California, Arizona, and Nevada (Anderson-Hamilton Volume): San Diego, Calif., Cordilleran Publishers, p. 317-325.

John, B.E., 1987a, Geometry and evolution of a mid-crustal extensional fault system: Chemehuevi Mountains, southeastern California, in Coward, M.P., Dewey, J.F., and Hancock, P.L., eds., Continental extensional tectonics: Geological Society of London Special Publication 28, p. 312-333.

1987b, Geologic map of the Chemehuevi Mountains area, San Bernardino County, California, and Mohave County, Arizona: U.S. Geological Survey Open-File Report 87-666, scale 1:24,000.

Leach, B.R., 1985, Petrology and depositional history of Miocene nonmarine sedimentary rocks, central Sacramento Mountains, San Bernardino County, California: Nashville, Tenn., Vanderbilt University, M.S. thesis, 161 p.
Le Bas, M.J., Le Maitre, R.W., Streckeisen, A., and Sanettin, B., 1986, A chemical classification of volcanic rocks based on the total alkali-silica diagram: Journal of Petrology, v. 27, part 3, p. 745-750.

McClelland, W.C., 1982, Structural geology of the central Sacramento Mountains, San Bernardino County, California, in Frost, E.G., and Martin, D.L., eds., Mesozoic-Cenozoic tectonic evolution of the Colorado River region, California, Arizona, and Nevada (Anderson-Hamilton Volume): San Diego, Calif., Cordilleran Publishers, p. 401-407.

Metzger, D.G., and Loeltz, O.J., 1973, Geohydrology of the Needles area, Arizona, California, and Nevada: U.S. Geological Survey Professional Paper 486-J, 54 p.

Nielson, J.E., Lux, D.R., Dalrymple, G.B., and Glazner, A.F., 1990, Age of the Peach Springs Tuff, southeastern California and western Arizona: Journal of Geophysical Research, v. 95 , no. B1, p. 571-580.

Nielson, J.E., and Tumer, R.D., 1986, Miocene rocks of the northern Turtle Mountains, San Bernardino County, California, in Cenozoic stratigraphy, structure and mineralization in the Mojave Desert: Geological Society of America, Cordilleran Section, 82d, Los Angeles, Calif., March 1986, Guidebook and Volume, Field Trips 5 and 6, p. 25-32.

Noble, L.F., 1931, Nitrate deposits in southeastern California: U.S. Geological Survey Bulletin 820, 108 p.

Spencer, J.E., 1985, Miocene low-angle normal faulting and dike emplacement, Homer Mountain and surrounding areas, southeastern California and southernmost Nevada: Geological Society of America Bulletin, v. 96, no. 9, p. 1,140-1,155.

Spencer, J.E. and R.D. Tumer, 1983, Geologic map of part of the northwestern Sacramento Mountains, southeastern California: U.S. Geological Survey Open-File Report 83-614, scale $1: 24,000$.

Wells, R.E. and Hillhouse, J.W., 1989, Paleomagnetism and tectonic rotation of the lower Miocene Peach Springs Tuff: Colorado Plateau, Arizona, to Barstow, California: Geological Society America Bulletin, v. 101, no. 6, p. 846-863.

Young, R.A., and Brennan, W.J., 1974, Peach Springs Tuff: its bearing on structural evolution of the Colorado Plateau and development of Cenozoic drainage in Mohave County, Arizona: Geological Society of America Bulletin, v. 85, no. 1, p. 83-90. 


\title{
Tertiary Stratigraphy and Structure of the Northern Turtle Mountains, Calif.
}

\author{
By Jane E. Nielson ${ }^{1}$ and John K. Nakata ${ }^{1}$
}

\section{SETTING}

The Turtle Mountains, Stepladder Mountains, and Mopah Range are components of two parallel ranges with north to northwest trends in the western part of the Colorado River extensional corridor, southeastem California (fig. 1). They lie west of the Whipple, southwest of the Chemehuevi, and southeast of the Old Woman Mountains; the last forms the western margin of the extensional corridor (Howard and others, 1982; Knoll and others, 1986; Hileman and others, 1990). The sections of Tertiary volcanic and sedimentary rocks described here are located east of the main mass of the Turtle Mountains and between the Mopah Range to the south and the Stepladder

'U.S. Geological Survey, Mail Stop 975, 345 Middlefield Road, Menlo Park, CA 94025

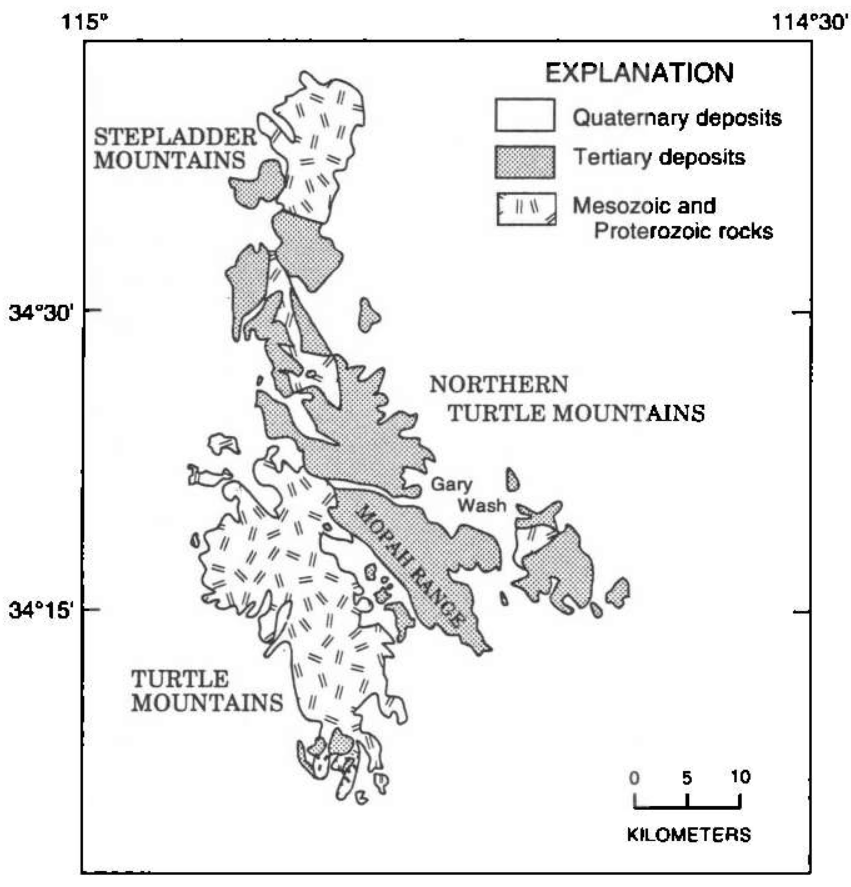

Figure 1. Map showing locations and generalized geology of the Turtle Mountains, Mopah Range, and Stepladder Mountains, southeastern California.
Mountains to the north (see also Hazlett, this volume) The main part of the Turtle Mountains is composed predominantly of mixed Proterozoic gneiss intruded by Proterozoic diorite and granite plutons, and diabase dikes. These rocks are intruded by Cretaceous granodiorite and diorite plutons, and quartz rhyolite porphyry dikes (Howard and others, 1982).

Thin volcanic sections overlie the metamorphicplutonic complex in the south part of the main Turtle Mountains (fig. 1). A section of Tertiary rocks as much as $1 \mathrm{~km}$ thick nonconformably overlies the complex of older rocks in the northern Turtle Mountains (Nielson and Turner, 1986). This section is continuous with that of the Mopah Range (Hazlett, 1986; 1990; this volume), which lies south of Gary Wash, a major east-trending drainage (fig. 1). There is no exposure of either the older rocks or the basal contact between pre-Tertiary and Tertiary rocks in the Mopah Range.

\section{STRATIGRAPHY}

The section of Tertiary rocks in both the northem Turtle Mountains and Mopah Range comprises a locally exposed basal arkose of Tertiary (Miocene or older) age and two units of Miocene volcanic rocks that are separated by an angular unconformity (col 2-I, pl. 2). The volcanic rocks are overlain locally by Tertiary estuarine and broadly by Tertiary to Quatemary alluvial fan deposits. The basal arkose is clast-supported and oxidized boulder to cobble conglomerate, with interbeds of sandstone and matrix-supported conglomerate. Above the basal arkose, rocks of the lower unit are of early Miocene age; these include volcanic flows, breccia, air-fall, and ash-flow tuff, with local thin interbeds of lacustrine shale, sandstone, and limestone. The volcanic rocks in this section are mostly andesitic and rhyolitic in composition, although basalt flows occur locally. The sedimentary units are mostly derived from volcanic rocks. The upper unit is predominantly basalt flows and cinders of middle Miocene age, with thin air-fall tuff horizons and thick interbeds of finegrained sandstone. These sandstones are of mixed volcanic and arkosic derivation and locally contain beds of arkosic conglomerate and breccia. 
Table 1. K-Ar ages of Turtle Mountains and Mopah Range rocks.

\begin{tabular}{|c|c|c|c|c|c|c|c|c|c|}
\hline Sample No.' & $\begin{array}{l}\text { Latitude } \\
\text { (N.) }\end{array}$ & $\begin{array}{l}\text { Longitude } \\
\text { (W.) }\end{array}$ & Rock type & Material dated & $\begin{array}{c}\mathrm{K}_{2} \mathrm{O} \\
(w t p c t)\end{array}$ & $\begin{array}{c}{ }^{40} \mathrm{Ar}_{\mathrm{rad}} \\
10^{-11} \mathrm{~mol} / \mathrm{g}\end{array}$ & $\begin{array}{l}\text { Percent } \\
{ }^{40} \mathrm{Ar}_{\mathrm{rad}}\end{array}$ & $\begin{array}{l}\text { Calculated age } \\
(\mathbf{M a})^{2}\end{array}$ & Assigned age $(\mathrm{Ma})^{2}$ \\
\hline JP83TM-127 & $34^{\circ} 24^{\prime} 30^{\prime \prime}$ & $114^{\circ} 50^{\prime} 45^{\prime \prime}$ & Andesite breccia & Plagioclase & 0.78 & $\begin{array}{l}1.81 \\
1.86\end{array}$ & $\begin{array}{l}56.9 \\
59.7\end{array}$ & $\begin{array}{c}15.97 \\
16.4\end{array}$ & $16.0 \pm 0.4$ \\
\hline BH82TM-86b & $34^{\circ} 26^{\prime} 40^{\prime \prime}$ & $114^{\circ} 48^{\prime} 30^{\prime \prime}$ & Basalt flow & Whole rock & 1.32 & $\begin{array}{l}3.22 \\
3.22\end{array}$ & $\begin{array}{l}50.2 \\
62.7\end{array}$ & $\begin{array}{l}16.96 \\
16.98\end{array}$ & $17.0 \pm 0.4$ \\
\hline JP82TM-128 & $34^{\circ} 23^{\prime} 45^{\prime \prime}$ & $114^{\circ} 47^{\prime} 21^{\prime \prime}$ & Rhyolite (dike) & $\begin{array}{l}\text { Biotite } \\
\text { Homblende }\end{array}$ & $\begin{array}{l}8.42 \\
0.74\end{array}$ & $\begin{array}{l}2.38 \\
2.40 \\
2.11 \\
2.02\end{array}$ & $\begin{array}{l}55.3 \\
49.7 \\
20.8 \\
16.1\end{array}$ & $\begin{array}{l}19.55 \\
19.68 \\
19.74 \\
18.90\end{array}$ & $19.5 \pm 0.5$ \\
\hline RT83TM-100 & $34^{\circ} 23^{\prime} 33^{\prime \prime}$ & $114^{\circ} 47^{\prime} 26^{\prime \prime}$ & Rhyolite (dike) & $\begin{array}{l}\text { Biotite } \\
\text { Homblende }\end{array}$ & $\begin{array}{l}8.47 \\
0.76\end{array}$ & $\begin{array}{l}2.41 \\
2.33\end{array}$ & $\begin{array}{l}33.0 \\
12.0\end{array}$ & $\begin{array}{l}19.69 \\
21.2\end{array}$ & $19.7 \pm 0.5$ \\
\hline JP82TM-94c & $34^{\circ} 25^{\prime} 03^{\prime \prime}$ & $114^{\circ} 49^{\prime} 21^{\prime \prime}$ & $\begin{array}{c}\text { Homblende } \\
\text { andesite flow }\end{array}$ & Homblende & 0.88 & $\begin{array}{l}2.54 \\
2.55\end{array}$ & $\begin{array}{l}25.8 \\
11.7\end{array}$ & $\begin{array}{l}19.96 \\
19.98\end{array}$ & $20.0 \pm 0.5$ \\
\hline $\begin{array}{l}\text { RT83TM-99 } \\
\text { N. Mopah Pk }\end{array}$ & $34^{\circ} 18^{\prime} 33^{\prime \prime}$ & $114^{\circ} 45^{\prime} 37^{\prime \prime}$ & Rhyolite (plug) & $\begin{array}{l}\text { Biotite } \\
\text { Homblende }\end{array}$ & $\begin{array}{l}8.65 \\
0.82\end{array}$ & $\begin{array}{l}2.50 \\
2.17\end{array}$ & $\begin{array}{l}61.1 \\
35.5\end{array}$ & $\begin{array}{l}19.99 \\
18.32\end{array}$ & $20.0 \pm 0.5$ \\
\hline
\end{tabular}

\footnotetext{
${ }^{1}$ Sample preparation and analytical work were done at U.S. Geological Survey, $\mathrm{K}_{2} \mathrm{O}$ analyses by M. Dyslin, L. Espos, P. Klock, S. Macpherson, S. Pribble, and D. Vivit.

${ }^{2} \mathrm{~K}$-Ar ages were calculated using the constants for the radioactive decay and abundance of ${ }^{40} \mathrm{~K}$ recommended by the Intemational Union of Geological Sciences Subcommission on Geochronology (Steiger and Jäger, 1977). These constants are: $\lambda_{\mathrm{e}}=0.580 \times 10^{-10} \mathrm{yr}^{-1}, \lambda_{\beta}=4.962 \times 10^{-10} \mathrm{yr}^{-1}$, and ${ }^{40} \mathrm{~K} / \mathrm{K}_{\text {tolal }}=1.167 \times 10^{-4} \mathrm{~mol} / \mathrm{mol}$.
}

\section{MIDDLE MIOCENE AND OLDER ROCKS}

Volcanic rock types in the basal part of the lower unit are lahar and mudflow deposits, andesite lava flows, and both monolithologic andesite flow and collapse breccia. The strata are intruded by dikes, abundant small plugs, and local large plugs of identical rock types; the predominant kind of deposit and the lithology of the units vary from south to north. Above the andesitic units are interbedded rhyolite and basalt to basaltic andesite deposits. These units include repetitive sequences of tuff (locally ash-flow or surge deposits, bedded air-fall tuff, and coarse pumice breccia) overlain by rhyolite flows with vitrophyric bases, flow-banded stony cores, and rubbly tops. The flows were fed by local dikes and plugs that abound in the section immediately north of Gary Wash. The mafic rocks are massive to brecciated lava flows and volcaniciastic breccia. Basaltic feeder dikes also are common in the section.

Potassium-argon ages on rocks of the lower unit range from 20 to $16 \mathrm{Ma}$. Ages from two tuffs are $20.2 \pm 1.0$ and $20.0 \pm 0.7 \mathrm{Ma}$ (biotite; Howard and others, 1982), and an andesite flow in this unit has an age of $20.0 \pm 0.5 \mathrm{Ma}$ (hornblende: table 1). Two rhyolite feeder dikes in the predominantly rhyolite-basalt part of the lower unit produced $\mathrm{K}$-Ar ages from biotite of $19.5 \pm 0.5$ $\mathrm{Ma}$ and $19.7 \pm 0.5 \mathrm{Ma}$ (table 1 ). These ages are very close to one of $20.0 \pm 0.5 \mathrm{Ma}$ determined on biotite from the north Mopah Peak in the Mopah Range (Hazlett, this volume). One brecciated flow produced an age of $16.0 \pm 0.4 \mathrm{Ma}$.

Volcanic rocks of the upper unit include basalts that are solely pyroxene-phyric, and some that contain modal olivine. In general, the pyroxene-bearing basalts occur near the base of the unit and are overlain by volumetrically dominant olivine basalt. A whole-rock $\mathrm{K}$-Ar age on olivine basalt from the northern Turtle Mountains is $17.0 \pm 0.4 \mathrm{Ma}$ (table 1 ).

The overlap of ages between the upper and lower volcanic units create an interpretive problem, which is dealt with differently in the columns for the northern Turtle Mountains (col 2-I, pl. 2) and the Mopah Range (col 2-J, pl. 2, Hazlett, this volume). Hazlett resolved the problem by showing concurrent deposition of the youngest flows in the lower unit and the earliest flows in the upper unit. Because there is a distinct angular discordance and erosional surface between lower and upper units in the northern Turtle Mountains, we question the validity of the young $\mathrm{K}$-Ar age on a flow breccia that clearly is in the tilted lower unit and have discarded it. Therefore, column 2-I (pl. 2) shows a hiatus between eruption of the lower and upper units.

The Peach Springs Tuff of Young and Brennan (1974) crops out in the northern Turtle Mountains within a fault-bounded exposure of conglomerate and mafic flows. The presence of the tuff could help resolve the 
conflict between stratigraphic interpretations; however, none of the associated deposits are distinctive enough to indicate a lower- or an upper-unit context. We have shown the Peach Springs Tuff within the upper part of the lower unit (col. 2-I, pl. 2), based on relations in nearby areas (Carr and others, 1980; Howard and others, this volume).

\section{LATE MIOCENE(?) AND YOUNGER DEPOSITS}

Ubiquitous deposits that overlie the middle Miocene and older rocks are alluvial plain and fan gravels and sandstone. Locally these are interbedded with and overlie finely bedded clastic and evaporite facies of the estuarine Bouse Formation (Howard and others, 1982; Buising, this volume). The alluvial deposits that interfinger with the basal Bouse strata presumably range in age from late Miocene(?) to Pliocene, and the overlying gravel is likely Quaternary in age (Carr and others, 1980).

\section{STRUCTURE}

Miocene rocks of the northern Turtle Mountains and Mopah Range generally strike north and northwest and dip west and southwest. Strata in the lower unit are tilted between $25^{\circ}$ and $40^{\circ}$, although andesite breccias in the lower part of the unit have dips as great as $65^{\circ}$. Nielson and Turner (1986) suggested that these units formed on the slopes of local volcanoes and that as much as $30^{\circ}$ of their tilts are due to original dips. If this is correct, similar beds that dip in directions other than west or southwest are not preserved. Tilts on strata of the upper unit range up to $10^{\circ}$ west or southwest.

The Miocene rocks are tilted by myriad faults with north to northwest strikes and east to northeast dips. Exposed fault planes have dip-slip slickenside striae (Nielson and Turner, 1986). Most of these faults have offsets on the order of meters to tens of meters. However, several northwest-striking faults have considerable stratigraphic throw and in places juxtapose the upper unit of the Miocene section against Proterozoic rocks.

Faults with west-northwest strikes are the youngest structures in the northern Turtle Mountains. These offset faults with more northerly trends and may have a strikeslip component.

\section{REFERENCES CITED}

Carr, W.J., Dickey, D.D., and Quinlivan, W.D., 1980, Geologic map of the Vidal NW, Vidal Junction, and parts of the Savahia Peak SW and Savahia Peak quadrangles, San Bernardino County, California: U.S. Geological Survey Miscellaneous Investigations Map I-1126, scale 1:24,000.

Hazlett, R.W., 1986, Geology of a Tertiary volcanic center, Mopah Range, San Bernardino County, California: Los Angeles, University of Southern California, Ph.D. dissertation, $303 \mathrm{p}$.

1990, Extension-related Miocene volcanism in the Mopah Range volcanic field, southeastern California, in Anderson, J.L., ed., The nature and origin of cordilleran magmatism: Geological Society of America Memoir 174, p. 133-145.

Hileman, G.E., Miller, C.F., and Knoll, M.A., 1990, Mid-Tertiary structural evolution of the Old Woman Mountains region: Implications for crustal extension across southeastern California: Journal of Geophysical Research, v. 95, no. B1, p 581-597.

Howard, K.A., Stone Paul, Pernokas, M.A., and Marvin, R.F., 1982, Geologic and geochronologic reconnaissance of the Turtle Mountains area California: west border of the Whipple Mountains detachment terrane, in Frost, E.G., and Martin, D.L., eds., Mesozoic-Cenozoic tectonic evolution of the Colorado River region, California, Arizona, and Nevada (Anderson-Hamilton Volume): San Diego, Calif., Cordilleran Publishers, p. 341-354.

Knoll, M.A., Miller, C. F., and James, W.C., 1986, Mid-Tertiary stratigraphic and structural evolution of the Piute Mountains basin and adjacent areas of the Old Woman Mountains region, southeastem California, in Cenozoic stratigraphy, structure and mineralization in the Mojave Desert: Geological Society of America, Cordilleran Section, 82d, Los Angeles, Calif., March 1986, Guidebook and Volume, Field Trips 5 and 6, p. 43-49.

Nielson, J.E., and Turner, R.D., 1986, Miocene rocks of the northem Turtle Mountains, San Bernardino County, California, in Cenozoic stratigraphy, structure and mineralization in the Mojave Desert: Geological Society of America, Cordilleran Section, 82d, Los Angeles, Calif., March 1986, Guidebook and Volume, Field Trips 5 and 6, Field Trip nos. 5 and 6, p. 25-32.

Steiger, R.H., and Jäger, E., 1977, Subcommission on geochronology: Convention on the use of decay constants in geoand cosmochronology: Earth and Planetary Science Letters, v. 36, no. 3, p. 359-362.

Young, R.A., and Brennan, W.J., 1974, Peach Springs Tuff: its bearing on structural evolution of the Colorado Plateau and development of Cenozoic drainage in Mohave County, Arizona: Geological Society of America Bulletin, v. 85, no. 1, p. 83-90. 



\title{
Stratigraphic Section of the Central Mopah Range, Calif.
}

\author{
By Richard W. Hazlett ${ }^{1}$
}

The Mopah Range is an eastern spur of the Turtle Mountains, in southeastern San Bernardino County, California (fig. 1). This area is shown on the Savahia Peak 7.5-minute and Turtle Mountains 15-minute topographic quadrangle maps. The main body of the Turtle Mountains consists of Precambrian and Mesozoic crystalline rocks (Howard and others, 1982), whereas the Mopah Range consists of diverse volcanic and sedimentary rocks of Tertiary age. To the west, strata of the Mopah Range dip into the crystalline rocks along both low- and high-angle faults. Presumably the Tertiary rocks overlie the older rocks nonconformably at depth, as suggested by exposure of a basal nonconformity at the northern end of the range (Nielson and Turner, 1986; Nielson and Nakata, this volume). All rocks are intensely faulted, especially along the eastern flank of the range. These faults are related to the same late Tertiary extensional event that produced the nearby Whipple detachment fault (Howard and others, 1982). The

\footnotetext{
'Department of Geology, Pomona College, Claremont, CA 91711
}

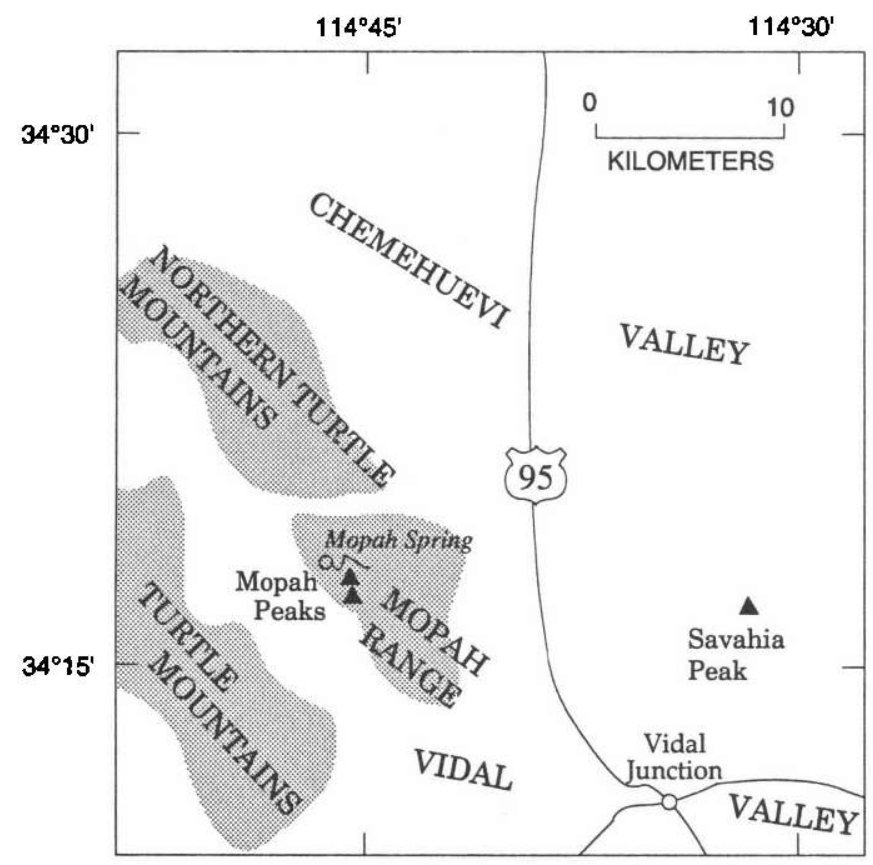

Figure 1. Map showing location of geographic features discussed in text. mean north-northwest strike of faults is subparallel to that of dikes that intrude the Tertiary section.

The stratigraphic section in the central Mopah Range is at least $1 \mathrm{~km}$ thick, but the base of the section is unexposed (col. 2-J, pl. 2). The most complete exposure is in the drainage basin of Mopah Spring (fig. 1) (Hazlett, 1986). The most abundant rocks in the lower section are subalkaline clinopyroxene-plagioclase-phyric andesite and minor alkali-olivine basalt, which form flow stacks up to several hundred meters in thickness. These flows are overIain by pumiceous crystal-lithic dacite tuff and pyroclastic flow breccia, locally as much as $100 \mathrm{~m}$ thick. Dacite, and minor rhyolite lava flows, individually several tens of meters thick, overlie the tuff, forming the steepest topography in the field. Dacite plugs and a north-northwest-striking swarm of dacitic and basaltic dikes intrude the section.

The intermediate and silicic flows and breccia are overlain unconformably by alkalic to subalkalic olivineclinopyroxene-plagioclase-phyric basalt, in flow stacks up to $200 \mathrm{~m}$ in thickness. Locally interbedded with these basalt units in the western Mopah Range are arkosic sandstone and crystalline-clast conglomerate of westward provenance, presumably derived from the main body of the Turtle Mountains.

Only a few isotopic ages are available from the central Mopah Range. A sample of andesite collected by me at Mopah Spring yielded a $\mathrm{K}-\mathrm{Ar}$ age of $20.4 \pm 0.4 \mathrm{Ma}$ (whole rock) (J.K. Nakata, oral commun., 1986). This is the oldest reasonable age obtained for the section. Mineralogically similar andesite dated by Dickey and others (1980) at the southern end of the Turtle Mountains yielded nearly identical ages $(20.4 \pm 0.5,20.4 \pm 1.2$, and $20.8 \pm 0.8$ Ma). A sample collected by R.D. Turner from a rhyolite dike in felsic flows near Craik Mine, north of the Mopah Range, gave a K-Ar age of $19.7 \pm 0.5$ Ma (biotite) (see Nielson and Nakata, this volume, North Turtle Mountains col. 2-I). A hornblende age from the same site is $21.2 \pm 1.1$ $\mathrm{Ma}$ (Nielson and Nakata, this volume). Biotite and hornblende separates from a sample collected by R.D. Tumer atop the northern Mopah Peak plug gave $\mathrm{K}$-Ar ages of $20.0 \pm 0.5$ and $18.3 \pm 0.8 \mathrm{Ma}$, respectively (Nielson and $\mathrm{Na}-$ kata, this volume). Finally, one of the capping basalt flows in the central Mopah Range has a $\mathrm{K}$-Ar age of $17.0 \pm 0.4$ (whole rock), and an age of $16.0 \pm 0.4 \mathrm{Ma}$ was determined from an andesite flow breccia underlying the 
capping basalt unconformity (Nielson and Nakata, this volume). Though tenuous, this evidence suggests that the unconformity developed diachronously. Ages have also been obtained from lava flows sampled at the southern and northern end of the Mopah Range and in nearby, possibly related volcanic terranes (Carr and others, 1980; Dickey and others, 1980; Howard and others, 1982; Nielson and Turner, 1986). These isotopic ages suggest that nearly all the volcanic and sedimentary strata in the Mopah Range were deposited between 21 and $16 \mathrm{Ma}$. Given the small number of ages listed above, the chronological representation of the Mopah Range section included with this article should be regarded as only roughly constrained.

\section{REFERENCES CITED}

Carr, W.J., Dickey, D.D., and Quinlivan, W.D., 1980, Geologic map of the Vidal NW, Vidal Junction, and parts of the Savahia Peak SW and Savahia Peak quadrangles, San Bernardino County, California: U.S. Geological Survey Miscellaneous Investigations Map I-1126, scale 1:24,000.
Dickey, D.D., Carr, W.J., and Bull, W.B., 1980, Geologic map of the Parker NW, Parker, and parts of the Whipple Mountains SW and Whipple Wash quadrangles, California and Arizona: U.S. Geological Survey Miscellaneous Investigations Map I1124 , scale 1:24,000.

Hazlett, R.W., 1986, Geology of the central Mopah Range; a guide for excursions in the Mopah Spring area, in Cenozoic stratigraphy, structure and mineralization in the Mojave Desert: Geological Society of America, Cordilleran Section, 82d, Los Angeles, Calif., March 1986, Guidebook and Volume, Field Trips 5 and 6, p. 33-42.

Howard, K.A., Stone, Paul, Pernokas, M.A., and Marvin, R.F., 1982, Geologic and geochronologic reconnaissance of the Turtle Mountains area, California: west border of the Whipple Mountains detachment terrane, in Frost, E.G., and Martin, D.L., eds., Mesozoic-Cenozoic tectonic evolution of the Colorado River region, California, Arizona, and Nevada (Anderson-Hamilton Volume): San Diego, Calif., Cordilleran Publishers, p. 341-354.

Nielson, J.E., and Turner, R.D., 1986, Miocene rocks of the northern Turtle Mountains, San Bernardino County, California, in Cenozoic stratigraphy, structure and mineralization in the Mojave Desert: Geological Society of America, Cordilleran Section, 82d, Los Angeles, Calif., March 1986, Guidebook and Volume, Field Trips 5 and 6, p. 25-32. 


\title{
Stratigraphic and Structural Correlation of Tertiary Strata of the Mohave Mountains and Aubrey Hills, Ariz.
}

\author{
By Jane E. Nielson ${ }^{1}$
}

\section{SETTING}

The Mohave Mountains and Aubrey Hills of Arizona are located in the Colorado River extensional corridor (Howard and John, 1987), east of the Whipple and Chemehuevi Mountains and west of the faulted margin of the Colorado Plateau. The geology of the Aubrey Hills is continuous with that of the southern Mohave Mountains. Northeast-striking faults divide the Mohave Mountains and Aubrey Hills into three structural areas (fig. 1, from north to south): the Yucca Mine area, the Crossman Peak area, and the Aubrey Hills-Standard Wash area (Nielson, 1986; Nielson and Beratan, 1990).

Rocks in all three structural areas consist of slightly deformed to undeformed Proterozoic and Mesozoic plutonic rocks that are intruded by Proterozoic diabase sills, and are nonconformably overlain by Tertiary sedimentary and volcanic deposits. Swarms of Tertiary dikes, which locally form as much as 30 percent of exposures, intrude gneiss and granite in the central part of the range (Howard and others, 1982; Nakata, 1982). Tilted, predominantly Miocene, sedimentary and volcanic rocks occur along the west, north, and south margins (Pike and Hansen, 1982).

\section{STRATIGRAPHY}

The stratigraphy of the three structural areas of the Mohave Mountains is shown as two columns (cols. 2$\mathrm{Ka}, \mathrm{b}$, pl. 2). Stratigraphic correlation between the areas is shown in figure 2.

Miocene deposits in the Mohave Mountains comprise four unconformity-bounded sequences, on the basis of stratigraphic and structural relations (Nielson, 1986; Nielson and Beratan, 1990) (fig. 2). The sequences, numbered I to IV from oldest to youngest, are composed of locally derived epiclastic and volcanic rocks and the Peach Springs Tuff of Young and Brennan (1974); detailed characterizations of the sequences are in Nielson and Beratan

'U.S. Geological Survey, Mail Stop 975, 345 Middlefield Road, Menlo Park, CA 94025
(1990). Sequences I to III of the Mohave Mountains correspond directly to the lower Miocene sequences distinguished in the Chemehuevi Mountains by Miller and John (this volume). Between the fault-bounded areas the rocks in each sequence are generally similar but have distinctive differences in both lithology and the character of intervening unconformities (Nielson and Beratan, 1990).

In all the areas the basal strata of sequence I are locally exposed arkosic conglomerate and sandstone of probable pre-Miocene (Oligocene?) to earliest Miocene age, deposited on deeply weathered pre-Tertiary rocks. Conglomerate clast types reflect variations of the underlying complex of older rocks. The basal arkose is overiain by sedimentary rocks of mixed arkosic and volcanic derivation, tuff and tuff breccia, local monolithologic megabreccia, and variable volumes of lava flows and sills. Mafic flows and sills of the lowermost part of sequence $I$ are distinctive porphyries characterized by clinopyroxene and flow-aligned ("jackstraw" or "turkey-track") plagioclase phenocrysts. In all areas, sequence I is capped by a unit of white silicic air-fall tuff that is locally interbedded with or intruded by basalt.

Proportions of epiclastic to volcaniclastic sedimentary rocks and volcanogenic units in sequence $I$ vary from mostly volcanic in the Yucca Mine and northern Crossman Peak areas to about equal abundances of volcanic and sedimentary units in the Aubrey Hills-Standard Wash area (fig. 2). Dikes are ubiquitous in the sections, and some can be traced into the flows that they feed. Where sills are abundant, they commonly invaded, dismembered, and partly to wholly incorporated sedimentary strata. Units correlative with sequence $I$ in the Aubrey Hills-Standard Wash area also occur west of the study area, in Whipple Wash (Frost, 1983; Beratan, 1990).

Sequence II is composed mostly of intermediate to silicic flows, flow breccia, and welded tuff, principally the Peach Springs Tuff. Sequence III consists of sedimentary units that locally are interbedded with sparse fragmental volcanic rocks or basalt flows; megabreccia and large landslide deposits occur locally. The sequence is dominated by arkosic-volcaniclastic conglomerate, sandstone, and subordinate finer grained clastic rocks and limestone. Sparse lava flows, lahar, and tuff are interbedded locally 
with the sedimentary strata. Clasts derived from the Peach Springs Tuff commonly occur in sequence III conglomerate. Sequence IV includes rhyolite and basalt lava flows intercalated with sandstone and conglomerate, and it is equivalent in age and stratigraphic position to the fanglomerate of Osbome Wash of Carr and Dickey (1980).

Sequence IV is overlain conformably by younger (upper Miocene and Pliocene) deposits of the Colorado River valley, which include estuarine-lacustrine epiclastic and evaporite strata (Bouse Formation) and river gravels.

\section{UNCONFORMITIES}

Unconformities form the upper and lower boundaries of all the sequences identified in the study area. The character of the unconformity between sequences I and II var- ies significantly between the Crossman Peak area and other parts of the Mohave Mountains. An angular unconformity of at least $40^{\circ}$ separates sequences $I$ and II in the Crossman Peak area (col. 2-Ka, pl. 2). The unconformity is developed on the eroded surface of sequence I strata and intrusions; on the basis of $\mathrm{K}-\mathrm{Ar}$ ages, Nielson and Bératan $(1988 ; 1990)$ estimated the age between 21.5 and 19.9 Ma. In the Yucca Mine and Aubrey Hills-Standard Wash areas, sequences I and II are separated by an angular discordance of only about $10^{\circ}$, which developed before deposition of the Peach Springs Tuff. At most sites this unconformity is not obvious, but at one locality in the Yucca Mine area it can be observed directly. Where contacts between sequences II and III are exposed, there is always a marked angular unconformity. An angular unconformity also occurs between sequence IV and older rocks wherever contacts are exposed.

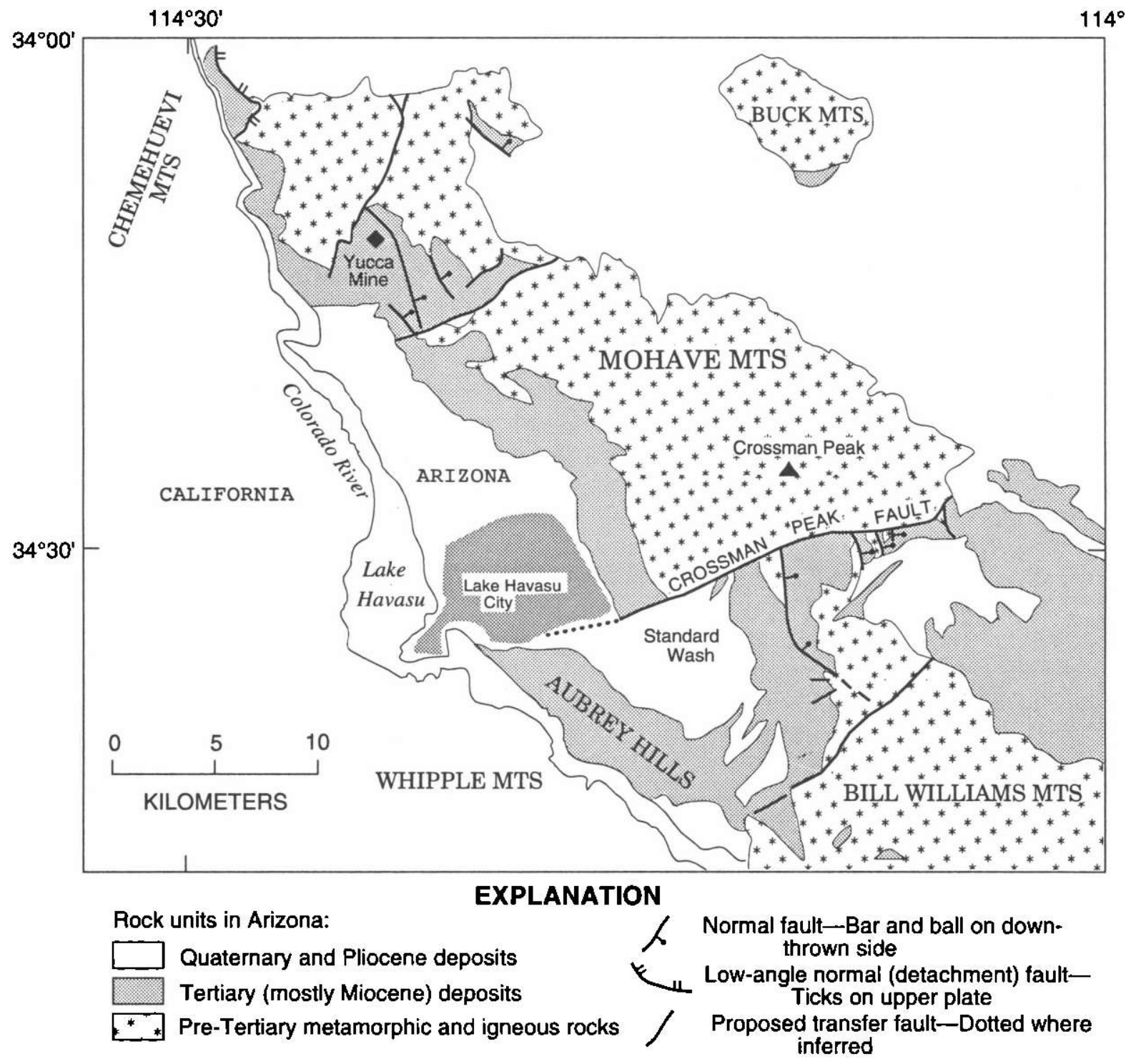

Figure 1. Locations and generalized geology of the Mohave Mountains and Aubrey Hills, Arizona. 


\section{STRATIGRAPHY OF THE YUCCA MINE AND AUBREY HILLS-STANDARD WASH AREAS}

Tertiary sections of the Yucca Mine and Aubrey HillsStandard Wash areas are highly similar in stratigraphy, as well as in their unconformable relations (col. 2-Kb, pl. 2). Sequence $I$ in both areas includes rare rhyolite flows and bedded tuff in addition to mafic and intermediate lava flows. Most lava flows and sills in the middle and upper units of sequence I are sparsely phyric, microphyric, or aphyric and probably were mafic (basalt?) compositions that are altered to quartz latite (Nielson and Beratan, 1990). Rare thyolite flows with perlitic bases interfinger with the mafic flows. These silicic rocks are relatively unaltered, compared to the mafic lavas (Pike, 1983).

In the Aubrey Hills-Standard Wash area, two volcanic tuff and breccia units are interbedded with "jack- straw" porphyry flows. Breccia in the lower tuff unit yielded an age of $23 \pm 2.4 \mathrm{Ma}$ (Beratan, 1990) by fissiontrack dating of zircon. This is the oldest age determined on any unit in the Mohave Mountains area. The distinctive upper tuff breccia is thick and strongly welded in the Aubrey Hills but becomes thinner and is only slightly welded to unwelded to the north and east in Standard Wash. Ages on biotite in fresh-appearing rhyolite flows in sequence $I$ of both Standard Wash and the Yucca Mine area range from $20.5 \pm 1.6$ to $19.2 \pm 0.5$ Ma (Nakata and others, 1990). A whole-rock age from a mafic flow in the Yucca Mine area is $19.8 \pm 0.6 \mathrm{Ma}$ (Nakata and others, 1990).

A boulder-bearing sandstone in the upper part of sequence $I$ in the Aubrey Hills-Standard Wash area contains clasts of undeformed porphyritic granite as much as $3 \mathrm{~m}$ in diameter in a matrix of fine quartz sand and silicic

NW

SE

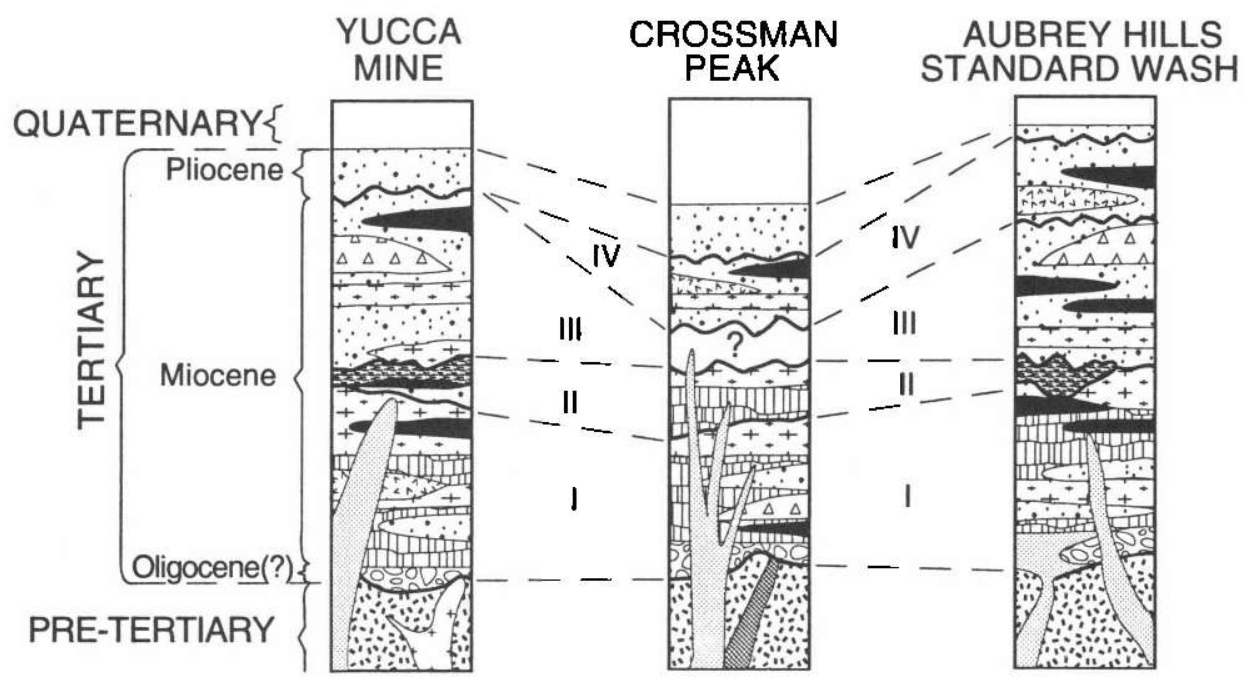

EXPLANATION

Quaternary rocks:

Alluvial deposits

Tertiary rocks:

Dikes and sills

Tuff and tuff breccia

Peach Springs Tuff of Young and Brennan (1974)

Basalt flows and sills

$\triangle \Delta$ Megabreccia and

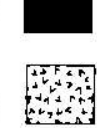

Rhyolite flows

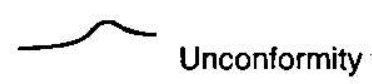

Pre-Tertiary rocks:

++ Cretaceous(?)

$[+]$ plutonic rocks

Proterozoic sills

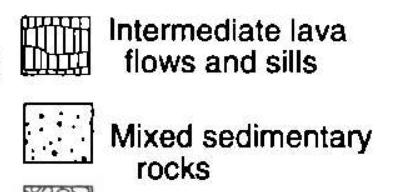

Arkosic conglomerate

Figure 2. Correlation of Tertiary sequences I through IV between parts of the Mohave Mountains and Aubrey Hills. See text for discussion. 
volcanic ash. Clast sizes decrease from the general vicinity of the Crossman Peak fault (fig. 1) south toward the Aubrey Hills. Underlying conglomerate units are finer grained; thus, large boulders were not previously shed from this source. In the northwest part of the Aubrey Hills, sequence $I$ is capped by a rhyolitic unit, which includes biotite-rich rhyolite flows and blocky rhyolite monolithologic breccia deposits that probably were derived from collapse of volcanic domes or spires. The unit pinches out both to the south and northeast.

Sequence II deposits in both the Yucca Mine and Aubrey Hills-Standard Wash areas consist predominantly or entirely of the Peach Springs Tuff, which is precisely dated at $18.5 \pm 0.5 \mathrm{Ma}$ by two ${ }^{40} \mathrm{Ar} /{ }^{39} \mathrm{Ar}$ techniques (Nielson and others, 1990). Conventional K-Ar ages on Peach Springs Tuff samples from the Yucca Mine and Standard Wash areas range from $17.6 \pm 0.4$ to $18.7 \pm 0.7 \mathrm{Ma}$ (Nakata and others, 1990). In the Yucca Mine area, sequence II also includes fluvial tuffaceous conglomeratic sandstone interbedded with a vesicular basalt flow; these units conformably underlie a very thick section of the Peach Springs Tuff. A 60-m-thick section of the Peach Springs Tuff in the Aubrey Hills marks the location of a paleochannel. Two small outcrops of the Peach Springs Tuff are preserved in Standard Wash.

Sequence III in the Yucca Mine and Aubrey HillsStandard Wash areas comprises lacustrine sandstone and interbedded air-fall tuff. In the Aubrey Hills-Standard Wash area these units include lenses of limestone. Southwestward, they grade into conglomerate and sandstone that probably were deposited on alluvial fans (Beratan, 1990). Basalt flows are interbedded with the lacustrine deposits-one yielded an age of $14.1 \pm 0.3 \mathrm{Ma}$ (whole rock; Nakata and others, 1990). A northeast-trending series of plugs that intruded tilted sequence I strata in the Yucca Mine area produced an age of $15.1 \pm 0.4 \mathrm{Ma}$ (plagioclase; Nakata and others, 1990) and may be coeval with sequence III deposits.

Lenses of megabreccia that may be more than $200 \mathrm{~m}$ thick locally are interbedded within the upper part of the lacustrine rocks. The megabreccia is interpreted as a rockfall avalanche deposit (Beratan, 1990). Megabreccia in the Aubrey Hills contains mylonitic adamellite intruded by a nonmylonitic quartz diorite-gabbro complex (Beratan, 1990). In the Yucca Mine area a large block of the Peach Springs Tuff is interbedded with sandstone and air-fall tuff in the lower part of sequence III.

Sequence IV in the Aubrey Hills-Standard Wash area consists of a thick bimodal suite including rhyolitic ashflow tuff, volcaniclastic breccia, lava flows, and plugs (Suneson, 1980), which are capped by basalt flows. These rocks range in age from $8.6 \pm 0.3 \mathrm{Ma}$ (whole rock) of capping basalt flows (Suneson and Lucchitta, 1979, 1983) to $12.7 \pm 0.6 \mathrm{Ma}$ (sanidine) on an underlying rhyolitic ashflow tuff (Nakata and others, 1990).

\section{STRATIGRAPHY OF THE CROSSMAN PEAK AREA}

In the Crossman Peak area, (col. 2-Ka, pl. 2) sequence $\mathrm{I}$ is predominantly volcanic, with interbedded conglomerate and sandstone beds that are composed mostly of intermediate and mafic volcanic clasts. The lower part of sequence I contains distinctive monolithologic cobble and boulder breccia lenses that are interpreted as rock-fall avalanche deposits. A K-Ar whole rock age on a mafic flow in sequence $I$ of the northern Crossman Peak area is $21.5 \mathrm{Ma}$ (W.A. Rehrig, oral commun., 1982). A young age of $17.9 \pm 0.7 \mathrm{Ma}$ was derived from fresh basalt near the base of the section, in the south part of the area (Nakata and others, 1990). This unit may be a sill emplaced in sequence I strata during later magmatism. A rhyolitic unit that thickens from south to north caps sequence I in the Crossman Peak area.

The largest and most abundant intrusions occur at the north end of the Crossman Peak area (Pike and Hansen, 1982). In this area, a mass of dark-colored dikes and pluglike intrusions, roughly $100 \mathrm{~m}$ across in aggregate, invaded interbedded lava flows and sedimentary strata. The complex of strata and mafic intrusions is intruded in tum by thin silicic dikes.

Sequence II in the Crossman Peak area comprises a stack of altered flows and flow breccia, of quartz trachyte (formerly andesite? and latite?) to rhyolite compositions. This massive flow stack occurs only near the site of the most abundant intrusions in sequence I strata. The flows in sequence II are of local origin and the Peach Springs Tuff has not been found. The lowermost unit at the northwest end of the Crossman Peak area yielded a conventional $\mathrm{K}$ Ar age of $19.9 \pm 0.5 \mathrm{Ma}$ on fresh-appearing biotite (Nakata and others, 1990). An ${ }^{40} \mathrm{Ar} /{ }^{39} \mathrm{Ar}$ sequential release age of $20.5 \pm 0.5 \mathrm{Ma}$ was determined on hornblende from the same sample (J.K. Nakata, written commun., 1992). Capping the unit are silicic tuff and a plagioclase-rich welded ash-flow tuff, which yielded a $\mathrm{K}$-Ar age of $17.9 \pm 0.5 \mathrm{Ma}$ (plagioclase; Nakata and others, 1990). High precision ${ }^{40} \mathrm{Ar} /{ }^{39} \mathrm{Ar}$ dating of other samples from the Crossman Peak area confirm that the age of sequence II deposits is between about 19.7 and $18 \mathrm{Ma}$ (P.B. Gans, oral commun., 1991).

Thick sections of rocks with ages younger than late early Miocene are not known in the Crossman Peak area. Sequences III and IV are found as isolated remnants of sedimentary deposits and (or) bimodal volcanic rocks. Sequence III units north of Lake Havasu City include gently tilted sandstone and conglomerate and slightly tilted or untilted rhyolite and silicic tuff, interbedded with basaltic cinder deposits. A block of vesicular basalt from a cinder cone that underlies untilted rhyolite tuff produced a $\mathrm{K}-\mathrm{Ar}$ age of $15.8 \pm 0.4 \mathrm{Ma}$ (whole rock; J.K. Nakata, written commun., 1992). A rhyolite flow overlying gently tilted air-fall tuff yielded an age of 10.9 Ma (plagioclase; W.A. 
Rehrig, oral commun., 1982), equivalent to ages of sequence IV units in Standard Wash.

\section{STRUCTURE}

\section{ORIENTATION OF STRATA}

Dips on upright strata in all sequences are to the southwest. In all the areas, sequence I basal strata are steeply tilted to overturned and overlying beds are less steeply tilted. For example, sequence I strata in the Yucca Mine area have dips that range from $80^{\circ}$ southwest to overturned in the lower part, and the uppermost units dip $40^{\circ}$ to $60^{\circ}$. In the Aubrey Hills-Standard Wash area, the dips of units in the lower part of sequence I tend to be steep locally near faults. Tilted sedimentary units of the magmatic center have local dips and strikes that are highly variable and the strikes commonly are discordant to the regional structural trends.

Large variations in dip are typical of units in sequence II, both within and between structural areas. For example, dips of the Peach Springs Tuff in the Yucca Mine area range from $55^{\circ}$ to $65^{\circ}$, but locally the beds are vertical or overtumed. In contrast, in the Aubrey Hills-Standard Wash area the unit dips between $25^{\circ}$ and $35^{\circ}$. Individual units of sequence Il in the Crossman Peak area show gentle to moderate dips in all directions, but uppermost units dip between $25^{\circ}$ and $35^{\circ}$ south-southwest. These variable tilts probably are due to original dips of locally derived flows deposited on uneven topography.

Local exposures of sequence III rocks show upsection lessening of dips, from moderate to gentle. However, measured dips on some units vary between $12^{\circ}$ and $40^{\circ}$ with no evident relation either to faults or stratigraphic position. Again, this large variability is partly due to tilting and partly to original dips. Sequence IV units in all areas have dips up to $5^{\circ}$ or are horizontal.

\section{FAULTS}

The major faults in the Mohave Mountains have variably sinuous to linear, north-northeast to east-northeast strikes and moderately low dips $\left(35^{\circ}\right.$ to $\left.45^{\circ}\right)$ to either northwest or southeast (fig. 1). A pair of these faults form the north and south boundaries of the Yucca Mine area; a third, the Crossman Peak fault (Howard and others, 1982; Nielson and Beratan, 1990), forms the southeast boundary of the Crossman Peak area, and a fourth separates the Aubrey Hills-Standard Wash area from areas farther to the south (fig. 1) (Howard and others, 1982).

In both the Yucca Mine and Aubrey Hills-Standard Wash areas, the Miocene rocks are exposed repeatedly in four or more tilted blocks with down-to-the-east sense. The blocks are presumed to be bounded by normal faults with north to northwest strike and steep east to northeast dips. These faults are poorly exposed and for the most part are inferred from stratigraphy. The distance between faults averages $1 \mathrm{~km}$ in the Yucca Mine area and ranges from 1 to $2 \mathrm{~km}$ in the Aubrey Hills-Standard Wash area.

\section{FOLDS}

Strata of sequences $I$ and II in the Yucca Mine area have a greater variation of dip than do these units in the other areas. These rocks are folded into one anticline of small wavelength and four asymmetric open synclines. The folds are cut by high-angle normal faults with northwest strikes, which generally are parallel to strikes of both strata and fold axes. The variable dips of beds appear related to asymmetry of the fold limbs and proximity to the faults. The aggregate thicknesses of strata in sequences I through III are greater in the west-dipping limb of each syncline than in the east-dipping limb. Sequences are thinnest in the vicinity of the faulted anticlinal axis (Nielson and Beratan, 1990).

\section{REFERENCES CITED}

Beratan, K.K., 1990, Basin development during Miocene detachment faulting, Whipple Mountains, southeastern California: Los Angeles, University of Southern California, Ph.D. dissertation, $267 \mathrm{p}$.

Carr, W.J., and Dickey, D.D., 1980, Geologic map of the Vidal, California, and Parker SW, California-Arizona quadrangles: U.S. Geological Survey Miscellaneous Investigations Map I1125 , scale $1: 24,000$.

Frost, E.G., 1983, Structural geology of a portion of the Whipple-Buckskin detachment terrane, southeastern California and western Arizona: Los Angeles, University of Southern California, Ph.D. dissertation, 291 p.

Howard, K.A., and John, B.E., 1987, Crustal extension along a rooted system of imbricate low-angle faults: Colorado River extensional corridor, California and Arizona, in Coward, M.P., Dewey, J.F. and Hancock, P.L., eds., Continental extensional tectonics: Geological Society of London Special Publication 28, p. 299-311.

Howard, K.A., Goodge, J.W., and John, B.E., 1982, Detached crystalline rocks of the Mohave, Buck, and Bill Williams Mountains, western Arizona, in Frost, E.G., and Martin, D.L., eds., Mesozoic-Cenozoic tectonic evolution of the Colorado River region, California, Arizona, and Nevada (Anderson-Hamilton Volume): San Diego, Calif., Cordilleran Publishers, p. 377-390.

Nakata, J.K., 1982, Preliminary report on diking events in the Mohave Mountains, Arizona, in Frost, E.G., and Martin, D.L., eds., Mesozoic-Cenozoic tectonic evolution of the Colorado River region, California, Arizona, and Nevada (Anderson-Hamilton Volume): San Diego, Calif., Cordilleran Publishers, p. 85-90. 
Nakata, J.K, Pernokas, M.A., Howard, K.A., Nielson, J.E., and Shannon, J.R., 1990, K-Ar and fission-track ages (dates) of volcanic, intrusive, altered, and metamorphic rocks in the Mohave Mountains area, west-central Arizona: Isochron/ West, no. 56, p. 8-20.

Nielson, J.E., 1986, Miocene stratigraphy of the Mohave Mountains, Arizona, and correlation with adjacent ranges, in Cenozoic stratigraphy, structure and mineralization in the Mojave Desert: Geological Society of America, Cordilleran Section, 82d, Los Angeles, Calif., March 1986, Guidebook and Volume, Field Trips 5 and 6, p. 15-24.

Nielson, J.E., and Beratan, K.K., 1988, Time of detachment faulting from Miocene sequences, Colorado River extended terrane [abs.]: Geological Society of America Abstracts with Programs, v. 20, no. 7, p. A393.

1990, Tertiary basin development and tectonic implications, Whipple detachment system, Colorado River extensional corridor, California and Arizona: Journal of Geophysical Research, v. 95, no. B1, p. 599-614.

Nielson, J.E., Lux, D.R., Dalrymple, G.B., and Glazner, A.F., 1990, Age of the Peach Springs Tuff, southeastern California and western Arizona: Journal of Geophysical Research, v. 95 , no. B1, p. 571-580.
Pike, J.E., 1983, Composition of Tertiary volcanic rocks, Mohave Mountains, Arizona [abs.]: Geological Society of America Abstracts with Programs, v. 15, no. 5, p. 304.

Pike, J.E., and Hansen, V.L., 1982, Complex Tertiary stratigraphy and structure, Mohave Mountains, Arizona: A preliminary report, in Frost, E.G., and Martin, D.L., eds., Mesozoic-Cenozoic tectonic evolution of the Colorado River region, California, Arizona, and Nevada (Anderson-Hamilton Volume): San Diego, Calif., Cordilleran Publishers, p. 91-96.

Suneson, N.H., 1980, The origin of bimodal volcanism, westcentral Arizona: Santa Barbara, University of California, Ph.D. dissertation, 293 p.

Suneson, Neil, and Lucchitta, Ivo, 1979, K/Ar ages of Cenozoic volcanic rocks, west-central Arizona: Isochron/West, no. 24, p. 25-29.

1983, Origin of bimodal volcanism, southern Basin and Range province, west-central Arizona: Geological Society of America Bulletin, v. 94 , no. 8, p. 1,005-1,019.

Young, R.A., and Brennan, W.J., 1974, Peach Springs Tuff: its bearing on structural evolution of the Colorado Plateau and development of Cenozoic drainage in Mohave County, Arizona: Geological Society of America Bulletin, v. 85, no. 1, p. 83-90. 


\title{
Stratigraphic Section of the Castaneda Hills-Signal Area, Arizona
}

\author{
By Ivo Lucchitta ${ }^{1}$ and Neil H. Suneson ${ }^{2}$
}

\section{GEOGRAPHIC AND GEOLOGIC DESCRIPTION}

This report discusses a region of west-central Arizona near the Bill Williams River that is most conveniently referred to as the Castaneda Hills-Signal area. The area extends northward from the Bill Williams River to Dutch Flat, and from the Castaneda Hills at the west margin to the abandoned mining camp of Signal, on the Big Sandy River, at the east margin (fig. 1). The area is in the southern Basin and Range province between the lower Colorado River and the Colorado Plateau-Transition Zone.

The stratigraphic information presented in this report (col 2-L, pl. 2) is derived from detailed mapping at a scale of 1:24,000 of the entire Castaneda Hills 15-minute quadrangle and the northwest quarter of the Artillery Peak 15-minute quadrangle (Lucchitta and Suneson, 1988a, b, 1990, 1991, and in press, a-d).

Intricately dissected hills are typical of the area and locally are separated by broad alluviated plains and pediments. Many of the hills (Castaneda Hills, Aubrey Peak, Eagle Point) are impressively sharp because they consist of clusters of silicic volcanoes. At the north end of the area, the intricate hills give way to linear, north-trending ranges separated by wide valleys that are typical of classic basin-range topography. The two domains are separated by the Aubrey lineament (Suneson and Lucchitta, 1979), an important northwest-trending topographic and geologic boundary.

The Castaneda Hills-Signal area lies near the intersection of three distinct geologic terranes. To the south and west are the metamorphic core complexes of the Rawhide, Buckskin, and Whipple Mountains. To the north are ranges (McCracken and Hualapai Mountains) and basins (Dutch Flat, Big Sandy Valley) typical of the Basin and Range province. To the east and northeast are the Colorado Plateau and the Transition Zone. It is this 86001

'U.S. Geological Survey, 2255 N. Gemini Drive, Flagstaff, AZ

${ }^{2}$ Oklahoma Geological Survey, 100 E. Boyd Street, Nomnan, OK 73019 location amidst contrasting terranes that makes the area particularly interesting and useful in attempting to understand the highly extended terranes and their relation to the neighboring, little-deformed Colorado Plateau.

All three structural elements that form metamorphic core complexes are exposed in the southern part of the area. The Rawhide Mountains contain a lower plate composed of lineated, mylonitic, amphibolite-grade quartzfeldspar gneiss formed by ductile deformation (Rawhide metamorphic core complex) and an upper plate that has undergone brittle deformation along closely spaced northwest-striking faults, which sole in the underlying Rawhide detachment fault. This fault separates the two plates; the fault is planar and gently dipping regionally but undulating in detail.

Rocks and structures of the upper plate crop out over most of the area and extend to the nearby Colorado Plateau, showing that the upper plate is physically continuous with the plateau. Faults in the upper plate are closely spaced and dip mostly northeast; the intervening structural blocks show pronounced rotation, mostly to the southwest; structural relief is modest. To the northeast, fault spacing progressively increases and the amount of rotation of structural blocks decreases.

Upper-plate faults formed basins of relatively small extent and depth in which upper Oligocene through Miocene basalt, rhyolite, and fluviolacustrine sedimentary strata accumulated. Deposition was synchronous with movement on the faults. Widely spaced younger basinrange faults with minor rotation of blocks and considerable structural relief crop out along the north edge of the area. Movement on these faults formed high ranges separated by major basins in which hundreds to thousands of meters of interior-basin deposits accumulated during the middle and late Miocene. Tectonic activity ended after the Miocene and integrated drainage networks formed. Cessation of tectonic activity at the end of the Miocene allowed establishment of the Colorado River drainage network, which caused widespread incisement of streams, the formation of pediments and alluvial fans in piedmont areas, and local deposition of alluvium along drainages during the Pliocene and Quaternary. 


\section{METAMORPHIC ROCKS IN THE LOWER PLATE OF RAWHIDE DETACHMENT FAULT}

Metamorphic rocks underlying the Rawhide detachment fault are fine- to medium-grained, foliated and lineated mylonitic quartz-feldspar gneiss. The gneiss is locally chloritic, hematitic, and silicified, with thin bands of ultramylonite. Near the Rawhide detachment fault the unit includes thin bands of chloritic breccia and microbreccia. Even though the attitude of foliation planes is variable, the lineations mostly plunge approximately southwest. Regional studies to the south and southeast suggest that the protolith consists largely of Precambrian, Mesozoic, and (or) Tertiary granitic rocks, and Paleozoic(?) clastic and carbonate rocks (Bryant and Wooden, 1989; Shackelford, 1989).

\section{PRE-TERTIARY ROCKS IN UPPER PLATE OF RAWHIDE DETACHMENT FAULT}

Pre-Tertiary rocks above the Rawhide detachment fault consist of Mesozoic(?) metavolcanic and metasedimentary rocks, Precambrian(?) gneiss, and the Middle Pro- terozoic Signal Granite. The metavolcanic rocks include phyllitic, generally well-foliated porphyritic metadacite(?) and metatuff(?). The metasedimentary rocks are mostly quartzite and quartz-sandstone and, more rarely, limestone. Similar metavolcanic and metasedimentary rocks south of the Bill Williams River are included within the Buckskin Formation (Triassic) and Planet Volcanics (Jurassic) of Reynolds and Spencer (1989). The gneiss consists mostly of banded quartz-feldspar gneiss, unfoliated to weakly foliated amphibolite or diorite, fine-grained metatuff(?), and rare pegmatite. The Signal Granite (Lucchitta and Suneson, 1982) is an unfoliated to weakly foliated, medium- to coarse-grained porphyritic biotite granite or monzogranite. Phenocrysts typically are 2- to 3-cm-long twinned potassium feldspar. The unit is intruded by aplite, pegmatite, leucogranite, metarhyolite porphyry, and diabase dikes.

\section{SEDIMENTARY AND VOLCANIC ROCKS DEPOSITED IN BASINS NOT RELATED TO PRESENT TOPOGRAPHY}

A widespread arkose is preserved at the base of the Tertiary sequence in many parts of the area. The arkose consists of poorly sorted, poorly stratified, medium- to

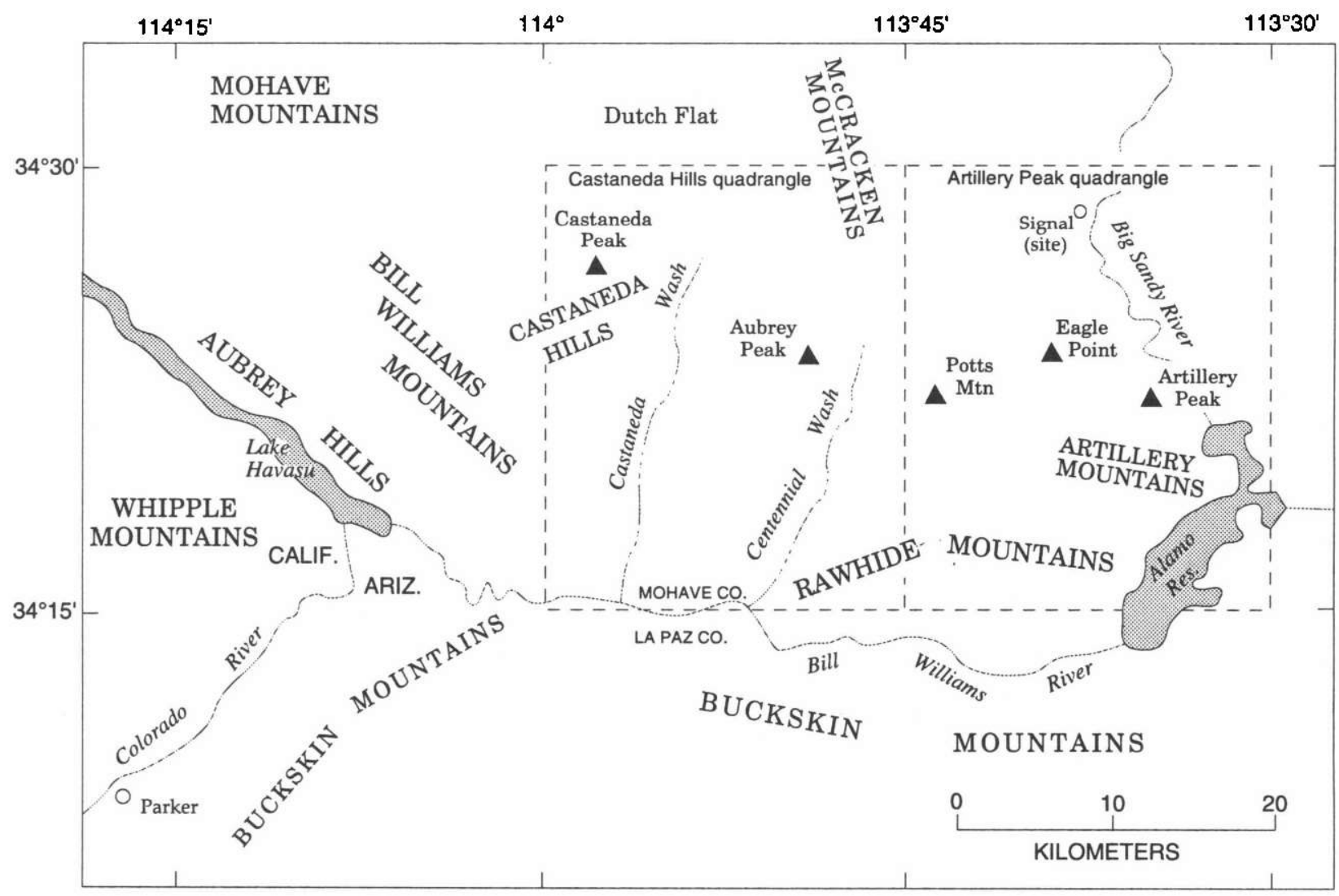

Figure 1. Map showing location of geographic features discussed in text. 
coarse-grained, moderately indurated arkosic sandstone and pebble- and boulder- conglomerate. Clasts are angular to rounded, typically less than $10 \mathrm{~cm}$ in diameter but locally as much as $1 \mathrm{~m}$ in diameter, and consist of Precambrian rock types, of which porphyritic granite is the most common. In places the unit is highly contorted, sheared, fractured, altered, silicified, cemented by carbonate, and mineralized with copper carbonates. The base grades into deeply weathered granite and the top interfingers with the lower basin beds. The basal arkose probably is in part a regolith developed on Precambrian crystalline rocks, notably the Signal Granite.

Overlying the basal arkose are sedimentary rocks which we have informally referred to as the lower basin beds (Lucchitta and Suneson, 1988a, 1991, and in press, a-d). The lower basin beds are well- to poorly consolidated, generally well-stratified, locally contorted to brecciated arkosic sandstone, pebbly sandstone, granule conglomerate, limy sandstone, siltstone, fissile shale, cherty limestone, tuff, and tuffaceous sandstone. The unit forms conspicuous hogbacks where limestone and limy sandstone predominate. In the Artillery Peak area, the unit can be separated into an upper limy facies containing Miocene palynomorphs (R.F. Hevly, written commun., 1979) and a lower clastic facies containing an air-fall tuff that has yielded ${ }^{40} \mathrm{Ar} /{ }^{39} \mathrm{Ar}$ ages (laser fusion) of $26.28 \pm 0.01 \mathrm{Ma}$ (sanidine) and $26.57 \pm 0.15 \mathrm{Ma}$ (biotite) (table 1). Tilts are steep and the contact with the basal arkose is gradational to sharp.

A widespread, unstratified breccia overlies the lower basin beds. The breccia is moderately to poorly indurated and consists of unsorted, predominantly angulas fragments a few centimeters to several meters in diameter. Dominant clast types are weakly foliated metavolcanic rocks (porphyritic dacite?) and metasedimentary rocks (quartzite). The breccia is clast supported and the clast-to-matrix ratio is variable but generally high. Banding and carbonate veins are probably related to internal shear planes. The breccia is a regional marker bed throughout the area and is everywhere present in the same stratigraphic position. In places the breccia is difficult to distinguish from brecciated metavolcanic and metasedimentary rocks in the upper plate of the Rawhide detachment fault, which are the same composition as the breccia clasts.

A local, lithologically distinctive facies of the breccia is interbedded with the overlying upper basin beds. This facies is composed predominantly of angular clasts of foliated, coarse-grained porphyroblastic granite; it is unstratified, chaotic, poorly indurated, and unsorted and contains clasts as much as $2 \mathrm{~m}$ in diameter.

Locally, an alluvial facies of the breccia unit separates and is interbedded with the underlying breccia and overlying upper basin beds. It consists of poorly stratified coarse sandstone, pebble- to boulder-conglomerate, and wellstratified medium-grained sandstone and siltstone. The subangular to well-rounded clasts in the conglomerate are dominantly metavolcanic and metasedimentary rocks lithologically similar to those in the breccia.

The upper basin beds include a variety of sedimentary rocks that conformably overlie or locally are interbedded with the breccia. The beds include well-stratified to platy limestone with thin chert and gypsum layers, sandstone, cobble- and pebble-conglomerate, coarse- to mediumgrained sandstone, tuffaceous and locally pumiceous sandstone, and fissile siltstone and claystone. Disharmonic folds are common where limestone and gypsum are abundant. The coarser grained beds include clasts of many rock types.

Basaltic lava, the Peach Springs Tuff of Young and Brennan (1974), and a sedimentary unit known as the arkose of Keenan Camp (Lucchitta and Suneson, 1988a, 1990,1991 , and in press, a-d) overlie the upper basin beds. The basalt consists of altered, mostly equigranular, fine-grained lava flows and probable dikes and plugs. It is generally vesicular to amygdaloidal and locally shattered. Copper carbonate mineralization is present locally. In places the unit contains flows with about 20 percent plagioclase phenocrysts as much as $13 \mathrm{~mm}$ long; this type of basalt is identified elsewhere as "turkey-track andesite" or "jackstraw porphyry" (Nielson and Beratan, 1990). In the Artillery Peak area the unit includes porphyritic plagioclase and olivine basalt. Potassium-argon ages are $18.7 \pm 0.3$ and $16.5 \pm 0.2 \mathrm{Ma}$ (whole rock) (Suneson and Lucchitta, 1979, 1983). The basalt, which is steeply tilted and highly faulted, mostly underlies but locally is interbedded with the arkose of Keenan Camp (discussed below).

The Peach Springs Tuff is present only in the northwestern part of the area near Castaneda Peak, where it overlies the basalt, is interbedded with the lower part of the arkose of Keenan Camp, and is moderately tilted.

The arkose of Keenan Camp consists of well-indurated to unconsolidated, interbedded boulder- and cobble-conglomerate, granule-conglomerate, sandstone, and siltstone that is mostly arkosic in composition. The arkose is well stratified to unstratified and chaotic with no internal sedimentary structures; crossbedding, ripple marks, and channels are rare. Boulders and cobbles typically are supported in a matrix of coarse sand. The subrounded to rounded clasts range widely in lithology and are as much as $2.5 \mathrm{~m}$ in diameter, though typically 1 to $10 \mathrm{~cm}$. Even though many rock types are represented in the clasts of this unit, individual beds may be monolithologic. Manganese stain is common. Tuff and (or) tuffaceous sandstone beds and rare limestone beds are locally present. The upper part of the unit locally resembles overlying basin-fill strata, from which it is separated by a disconformable to gradational contact; in most places, however, the units are separated by an angular unconformity. The basal part of the arkose locally interfingers with and grades into the upper basin 
Table $1 .{ }^{40} \mathrm{Ar} /{ }^{39} \mathrm{Ar}$ ages of air-fall tuff in "lower basin beds."

\begin{tabular}{|c|c|c|c|c|c|c|c|}
\hline Sample No. ${ }^{1}$ & Material dated & ${ }^{37} \mathrm{Ar} /{ }^{39} \mathrm{Ar}$ & ${ }^{36} \mathrm{Ar} /{ }^{39} \mathrm{Ar}$ & ${ }^{40} \mathrm{Ar} /{ }^{39} \mathrm{Ar}$ & $\begin{array}{l}\text { Percent } \\
{ }^{40} \mathrm{Ar}_{\mathrm{rad}}\end{array}$ & Calculated age (Ma) & Assigned age $(\mathrm{Ma})^{2}$ \\
\hline \multirow[t]{7}{*}{ AZ10-24-89 } & Biotite & 0.036554 & 0.052958 & 10.4481 & 40.0 & $26.44 \pm 0.32$ & \\
\hline & do. & 0.036077 & 0.077776 & 10.5556 & 31.5 & $26.71 \pm 0.45$ & \\
\hline & do. & 0.075416 & 0.055150 & 10.5285 & 39.3 & $26.64 \pm 0.36$ & \\
\hline & do. & 0.040338 & 0.084563 & 10.5490 & 29.7 & $26.69 \pm 0.61$ & \\
\hline & do. & 0.024405 & 0.059254 & 10.4243 & 37.3 & $26.38 \pm 0.37$ & $26.57 \pm 0.15$ \\
\hline & do. & 0.009559 & 0.000136 & 10.3812 & 99.6 & $26.27 \pm 0.23$ & \\
\hline & do. & 0.008549 & 0.000231 & 10.3852 & 99.3 & $26.28 \pm 0.23$ & $26.28 \pm 0.01$ \\
\hline
\end{tabular}

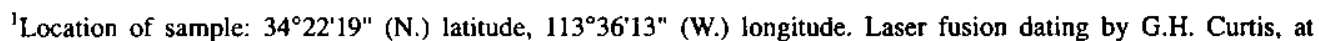
University of Califomia, Berkeley, Calif. Sanidine age is preferred because of its higher percentage of radiogenic argon. Biotite ages are likely to be less accurate because of high calcium content of plagioclase in sample.

${ }^{2} \mathrm{Age}$ assigned to multiple determinations is weighted mean average of individual determinations.
}

beds. The arkose is moderately to steeply tilted, highly faulted, and also present in gravity-glide blocks.

In the southern part of the area, a facies of the arkose of Keenan Camp is composed predominantly of subangular Mesozoic(?) metavolcanic clasts derived from the upper plate of the Rawhide detachment fault. The basal contact of this facies locally resembles the low-grade metamorphic rocks.

Gravity-glide blocks of Precambrian(?) plutonic rocks and foliated biotite augen gneiss and fractured cherty Paleozoic(?) limestone and fractured porcellaneous quartzite are interbedded with the arkose of Keenan Camp near its base. Where the two types of rock are juxtaposed, the blocks composed of Precambrian(?) rocks overlie blocks composed of Paleozoic(?) rocks. In addition, the arkose of Keenan Camp is included in some gravity glide blocks.

The syntectonic rocks were emplaced during the main pulse of extension in the area. The youngest unit assigned to this tectonic event consists of silicic volcanic and volcaniclastic rocks that include flows, domes, plugs, tuffaceous sandstone and conglomerate, and vitric-lithic tuff. The flows and domes range from aphyric to coarsely porphyritic; they are commonly devitrified, more rarely glassy, and have a flow-banded matrix. Xenoliths of granite and basalt are common. The pyroclastic and epiclastic rocks are well stratified to unstratified and commonly contain pumice lapilli and xenoliths of rhyolite and granite. Rock types include tuffaceous sandstone and conglomerate and vitriclithic ash-flow and air-fall tuff. The lava flows and domes include high-silica (76 percent $\mathrm{SiO}_{2}$ ) and high-potassium (8 percent $\mathrm{K}_{2} \mathrm{O}$ ) varieties. Potassium-argon ages (sanidine, except where noted) of the silicic volcanic rocks are $15.1 \pm 0.1, \quad 13.7 \pm 0.2, \quad 13.1 \pm 0.1, \quad 12.7 \pm 0.1, \quad 12.6 \pm 0.1$, $12.4 \pm 0.1,12.4 \pm 0.2,11.7 \pm 0.2$ (biotite), and $10.3 \pm 0.1 \mathrm{Ma}$ (Suneson and Lucchitta, 1979, 1983). The youngest silicic volcanic rocks are from the Bill Williams Mountains, where they overlie mesa-forming basalt and are associated with intrusive megacryst-bearing basalt; samples with older ages are from the Castaneda Hills and Aubrey Peak areas. Reworked tuff is locally interbedded with the arkose of Keenan Camp. Domes and dikes are intruded preferentially along faults or at fault intersections; in the Castaneda Hills, most dikes strike northwest. The silicic volcanic rocks are moderately tilted.

\section{UNITS DEPOSITED IN PRESENT BASINS MOSTLY UNDER CONDITIONS OF INTERIOR DRAINAGE}

Basin-fill deposits are a heterogeneous assemblage of locally derived, poorly sorted, moderately stratified to chaotic, moderately consolidated, pebble to boulder fanglomerate, sandstone, and rarely siltstone. Clasts are typically angular, 0.5 to $50 \mathrm{~cm}$ in diameter, consist of granite, metamorphic rocks, rhyolite, basalt, and arkose, and are supported in a sandstone matrix. In places, the deposits are monolithologic. The unit locally contains tuffaceous fanglomerate and sandstone beds with abundant rhyolite clasts and pumice lapilli and very rare air-fall tuff beds. The basin-fill deposits may be equivalent to the Muddy Creek Formation, the fanglomerate of Metzger and others (1973), the fanglomerate of Osborne Wash of Dickey and others (1980), and the Big Sandy Formation (Sheppard and Gude, 1972). The upper part of the unit contains megacryst-bearing basalt and includes pediment gravel that is lithologically indistinguishable from the basin-fill deposits. These relations indicate a transition from interior- to through-flowing drainage. The unit typically overlies older strata in angular unconformity; locally however, the upper part of the arkose of Keenan Camp is lithologically indistinguishable from the basin fill. The basin-fill deposits are mostly undeformed and only locally have been faulted, tilted, or folded. 
Mesa-forming mafic lava flows include basalt and basaltic andesite that crop out as subhorizontal to gently tilted erosional remnants forming areally equidimensional mesas. The tilt results from offsetting of the units along high-angle normal faults. The flows are medium gray, fresh, slightly vesicular to massive, diktytaxitic, blocky to spheroidally weathering, and porphyritic to glomeroporphyritic. Cinders are present in vent areas. Each mesa consists of many flows that are petrographically similar to each other but different from flows of other mesas. The $\mathrm{K}$ $\mathrm{Ar}$ ages of the mesa-forming basalt flows are $9.2 \pm 0.2$, $9.2 \pm 0.3,11.3 \pm 0.7,13.0 \pm 0.5$, and 13.1 $\pm 0.2 \mathrm{Ma}$ (whole rock) (Suneson and Lucchitta, 1979, 1983) and thus overlap ages of some of the silicic volcanic rocks discussed above. However, the mesa-forming basalt in the Bill Williams Mountains predates the silicic volcanic rocks of that area.

Several thin flows of quartz-bearing basalt form isolated exposures. The quartz-bearing basalt is slightly porphyritic and contains rounded and embayed quartz. The basalt is generally similar to the mesa-forming basalt but is areally less extensive, and it does not form mesas. Potassiumargon ages are $13.7 \pm 0.3$ and $12.4 \pm 0.1 \mathrm{Ma}$ (whole rock) (Suneson and Lucchitta, 1979), which overlap those of the mesa-forming basalts. These flows are moderately tilted.

\section{DEPOSITS INDICATING THROUGH- FLOWING DRAINAGE}

Megacryst-bearing basalt forms thin flows, cinder deposits, dikes, and irregularly shaped intrusive masses characterized by conspicuous, typically rounded megacrysts whose amount is variable within and between flows. The basalt is dark to medium gray, generally unaltered, and vesicular to dense. Columnar joints are rare. Megacrysts as large as $7 \mathrm{~cm}$ of plagioclase, clinopyroxene, olivine, spinel, and magnetite are common; nodules of mafic and ultramafic plutonic rocks as large as $10 \mathrm{~cm}$ are rare. Vent areas are characterized by accumulations of cinders; flow direction is down the present drainages. Dikes are vertical and strike north-northeast. Potassium-argon ages are $7.7 \pm 0.5,7.5 \pm 0.2,6.8 \pm 0.2 \mathrm{Ma}$ (whole rock) (Suneson and Lucchitta, 1979) and 5.4 $\pm 0.6 \mathrm{Ma}$ (plagioclase) (Suneson and Lucchitta, 1983). Slightly older megacryst-bearing basalt $(8.6 \pm 0.3 \mathrm{Ma}$, whole rock) (Suneson and Lucchitta, 1983) flowed oblique to present topography. Pre-8-Ma basalt flows are little faulted and gently folded locally, whereas older flows are offset by high-angle faults with tens of meters of displacement. In the Bill Williams Mountains, megacryst-bearing basalt dikes intrude and are intruded by silicic volcanic rocks, one of which has a KAr age of 10.3 $\pm 0.1 \mathrm{Ma}$ (sanidine) (Suneson and Lucchitta, 1979).
Surficial deposits are generally 1 to $20 \mathrm{~m}$ thick and unfaulted. The unit includes piedmont-slope deposits, alluvium deposited by the Bill Williams and Big Sandy Rivers, and colluvium, talus, and landslide deposits.

Piedmont-slope deposits consist of locally derived pediment gravels and channel fill of arroyos that dissect the pediments. The deposits are composed of poorly sorted, angular to subangular silt, sand, and gravel with varying degrees of cementation and dissection. They include, in order of increasing age and elevation above present drainages, alluvium of active channels, alluvium of inactive channels, pediment gravels with desert varnish, and a calcrete unit. Locally, terrace gravels associated with major arroyos are found tens of meters above present drainages. The alluvium of the Bill Williams and Big Sandy Rivers consists of nonlocal rock types and includes moderately well-sorted, unconsolidated sand and gravel of the present channel and lower, intermediate, and upper terrace gravels.

\section{REFERENCES CITED}

Bryant, Bruce, and Wooden, J.L., 1989, Lower-plate rocks of the Buckskin Mountains: A progress report, in Spencer, J.E., and Reynolds, S.J., ed., Geology and mineral resources of the Buckskin and Rawhide Mountains, west-central Arizona: Arizona Geological Survey Bulletin 198, p. 47-50.

Dickey, D.D., Carr, W.J., and Bull, W.B., 1980, Geologic map of the Parker NW, Parker, and parts of the Whipple Mountains SW and Whipple Wash quadrangles, California and Arizona: U.S. Geological Survey Miscellaneous Investigations Map I1124, scale $1: 24,000$.

Lucchitta, Ivo, and Suneson, N.H., 1982, Signal Granite (Precambrian), west-central Arizona: U.S. Geological Survey Bulletin 1529-H, p. H87-H90.

1988a, Geologic map of the Artillery Peak NW quadrangle, Mohave County, Arizona: U.S. Geological Survey Open-File Report 85-277, scale 1:24,000.

1988b, Geologic map of the Planet $2 \mathrm{SW}$ quadrangle, Mohave County, Arizona: U.S. Geological Survey Open-File Report 88-547, scale 1:24,000.

1990, Geologic map of the Planet 2 NW quadrarigle, Mohave County, Arizona: U.S. Geological Survey Open-File Report 89-673, scale 1:24,000.

1991, Geologic map of the Planet 2 SE quadrangle, Mohave and La Paz Counties, Arizona: U.S. Geological Survey Open-File Report 91-354, scale 1:24,000.

- in press, a, Geologic map of the Signal quadrangle, Mohave County, Arizona: U.S. Geological Survey Geologic Quadrangle Map 1709, scale 1:24,000.

in press, b, Geologic map of the Centennial Wash quadrangle, Mohave and La Paz Counties, Arizona: U.S. Geological Survey Geologic Quadrangle Map 1718, scale 1:24,000.

in press, c, Geologic map of the Castaneda Hills SW quadrangle, Mohave and La Paz Counties, Arizona: U.S. Geological Survey Geologic Quadrangle Map 1719, scale 1:24,000. 
in press, d, Geologic map of the Castaneda Hills quadrangle, Mohave County, Arizona: U.S. Geological Survey Geologic Quadrangle Map 1720, scale 1:24,000.

Metzger, D.G., Loeltz, O.J., and Irelan, Burdge, 1973, Geohydrology of the Parker-Blythe-Cibola area, Arizona and California: U.S. Geological Survey Professional Paper 486-G, $130 \mathrm{p}$.

Nielson, J.E., and Beratan, K.K., 1990, Tertiary basin development and tectonic implications, Whipple detachment system, Colorado River extensional corridor, California and Arizona: Journal of Geophysical Research, v. 95, no. B1, p. 599-614.

Reynolds, S.J., and Spencer, J.E., 1989, Pre-Tertiary rocks and structures in the upper plate of the Buckskin detachment fault, west-central Arizona, in Spencer, J.E., and Reynolds, S.J., ed., Geology and mineral resources of the Buckskin and Rawhide Mountains, west-central Arizona: Arizona Geological Survey Bulletin 198, p. 67-102.

Shackelford, T.J., 1989, Structural geology of the Rawhide
Mountains, Mojave County, Arizona, in Spencer, J.E., and Reynolds, S.J., eds., Geology and mineral resources of the Buckskin and Rawhide Mountains, west-central Arizona: Arizona Geological Survey Bulletin 198, p. 15-46.

Sheppard, R.A., and Gude, A.J., III, 1972, Big Sandy Formation near Wikieup, Mohave County, Arizona: U.S. Geological Survey Bulletin 1354-C, 10 p.

Suneson, Neil, and Lucchitta, Ivo, 1979, K/Ar ages of Cenozoic volcanic rocks, west-central Arizona: Isochron/West, no. 24, p. $25-29$.

-1983, Origin of bimodal volcanism, southern Basin and Range province, west-central Arizona: Geological Society of America Bulletin, v. 94, no. 8, p. 1,005-1,019.

Young, R.A., and Brennan, W.J., 1974, Peach Springs Tuff: its bearing on structural evolution of the Colorado Plateau and development of Cenozoic drainage in Mohave County, Arizona: Geological Society of America Bulletin, v. 85, no. 1 , p. 83-90. 


\title{
Middle Tertiary Stratigraphy of the Northern Rawhide Mountains and Artillery Mountains, Ariz.
}

\author{
By John C. Yarnold ${ }^{1}$
}

\begin{abstract}
Along its northern flank, the upper plate of the Harcuvar metamorphic core complex in the Artillery Mountains and along the northwestern edge of the Rawhide Mountains (fig. 1 ) is structurally separated into several individual tilt blocks (A-D, fig. 2). These tilt blocks are bounded by northeast-dipping normal faults (present horizontal spacing is on the order of about 2 to $4 \mathrm{~km}$ ). The tilt blocks contain Tertiary sedimentary and volcanic rocks overlying primarily Proterozoic crystalline basement. Correlations of Tertiary stratigraphic units in different blocks have been made on the basis of lithologic similarity, stratal position,
\end{abstract}

\footnotetext{
'Department of Geosciences, University of Arizona, Tucson, AZ
}

and sparse geochronologic constraints. The following discussion will concentrate on stratigraphic and sedimentologic aspects of the Tertiary sections; discussion of tilting history and the tectonic significance of units is deferred pending completion of current investigations.

The stratigraphic column (col. 2-M, pl. 2) is a schematic composite of sedimentary sequences exposed within parts of the four tilt blocks. Unit numbers assigned to intervals of the stratigraphic column are for reference purposes only and are not intended as formal names or designations. It is important to point out that compilation of this composite section required the assumption of some lithologic correlations and the assignment of many age ranges which have yet to be fully substantiated by

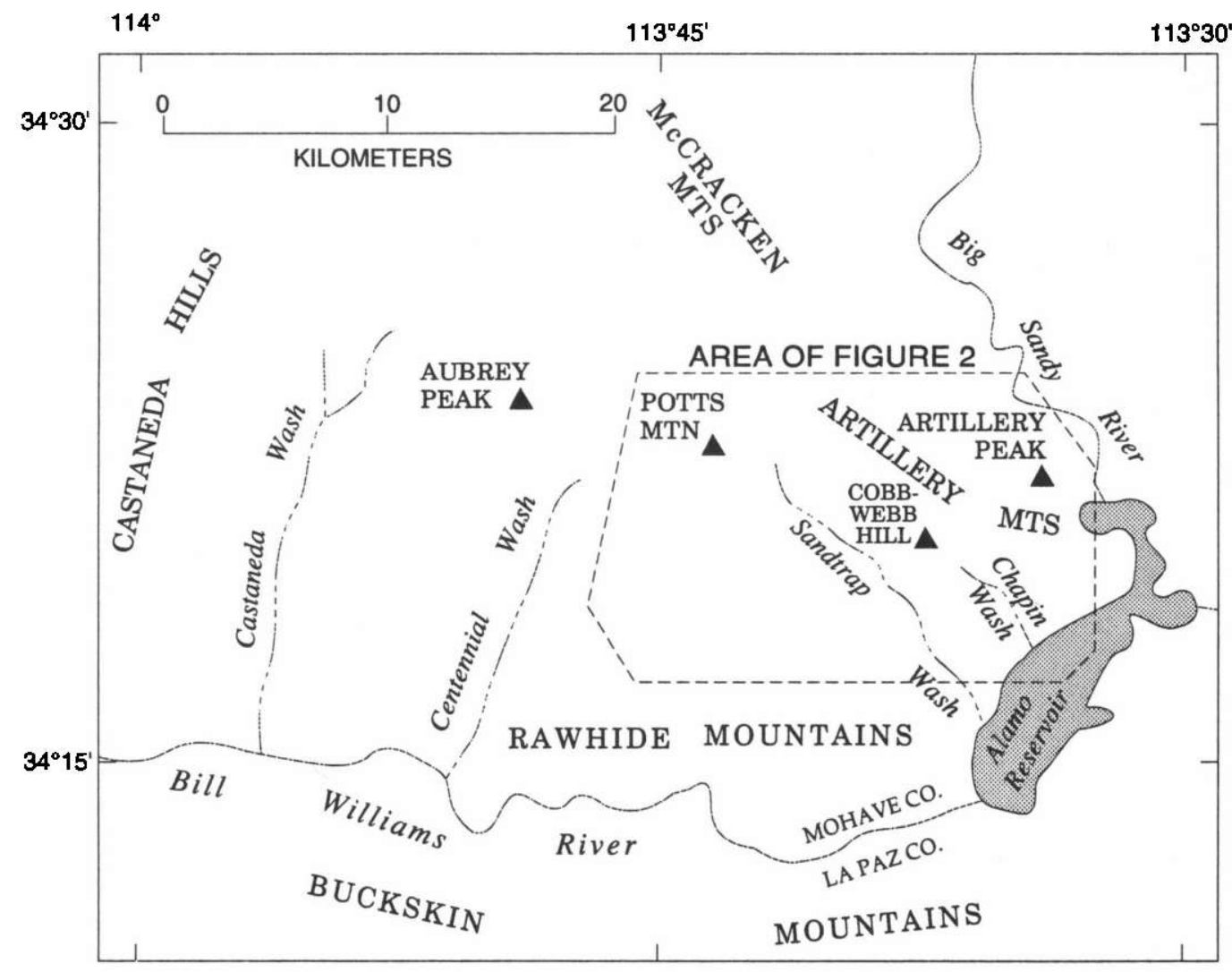

Figure 1. Map showing location of geographic features named in text. 
geochronologic data. In particular, correlations between blocks $\mathrm{A}, \mathrm{B}$, and $\mathrm{C}$ are more reliable at present than between these blocks and block $\mathrm{D}$, where the section is much thicker overall and displays some unique characteristics.

Unit 1 consists of a red to orange, fluvial conglomeratic sandstone derived predominantly from Proterozoic crystalline rocks. It depositionally overlies Proterozoic granite and gneiss across most of the study area. The unit coarsens laterally to a cobble-to-boulder conglomerate facies in the southeastern part of block $\mathrm{A}$, where it contains clasts of granite, gneiss, Mesozoic metamorphic rocks, white to red quartzite, and silicic volcanic rocks of probable Mesozoic age. Similar coarse lithofacies are also present as laterally restricted lag deposits near the base of the unit in blocks B and D. Although previous investigators have inferred that the source area for unit 1 was to the northeast (for example, Spencer and others, 1989; Lucchitta, 1990), this coarsening trend indicates that at least a second source of detritus existed to the south or east of block A.
Unit 2 consists of fluviolacustrine sedimentary rocks in which tuffaceous detritus is common. The basal contact of the unit varies from gradational to interfingering. In blocks $A$ and $B$, unit 2 is chiefly sandstone and siltstone near the base but contains an increasing amount of limestone toward the top. The limestone commoniy displays distinctive silicified rootlets. Unit 2 may be represented in block $C$ by a 55-m-thick sequence of pebbly sandstone, limestone, and siltstone exposed on the east side of Potts Mountain. In block D, the lower half of unit 2 consists mainly of lacustrine thin-bedded marlstone and siltstone, whereas the upper half is chiefly fluvial pebbly sandstone. Samples from tuff interbeds in unit 2 in the Artillery Peak area have yielded a K-Ar age of $23.0 \mathrm{Ma}$ (biotite) (R.J. Miller, in Spencer and others, 1989 ) and ${ }^{40} \mathrm{Ar} /{ }^{39} \mathrm{Ar}$ ages of $26.57 \pm 0.15 \mathrm{Ma}$ (biotite) and 26.28 $\pm 0.01 \mathrm{Ma}$ (sanidine) (G.H. Curtis, in Lucchitta and Suneson, this volume). Unit 2 is approximately 60 to $70 \mathrm{~m}$ thick in blocks A and B and about 350 $\mathrm{m}$ thick in the Artillery Peak area of block D, which was probably nearer to the depocenter at the time of deposition. Unit 2 locally displays a turbidite-rich lithofacies in block

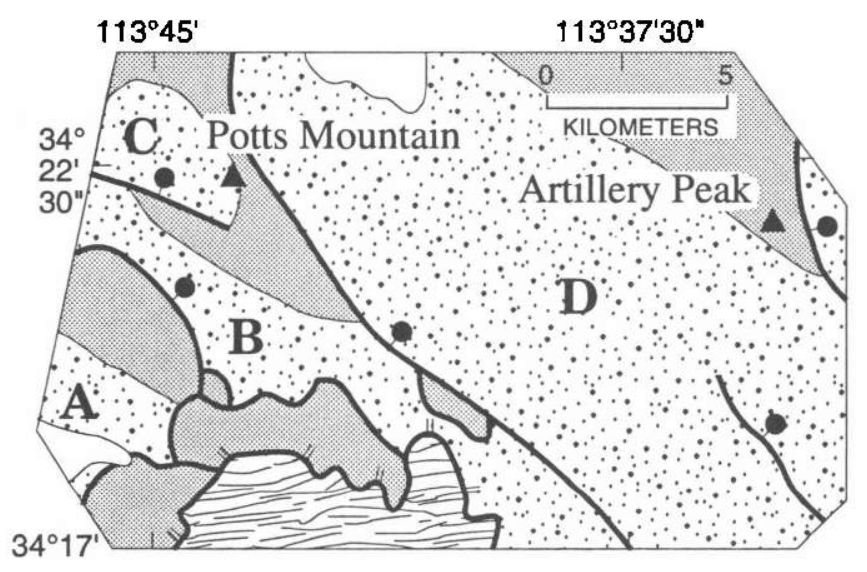

\section{EXPLANATION}

Upper Cenozoic surficial deposits

$\because \quad$ Tertiary sedimentary and volcanic rocks-In upper plate of Rawhide detachment fault

Pre-Tertiary rocks - In upper plate of Rawhide detachment fault

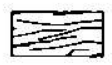

Crystalline rocks-Bearing Tertiary mylonitic fabric. In lower plate of Rawhide detachment fault

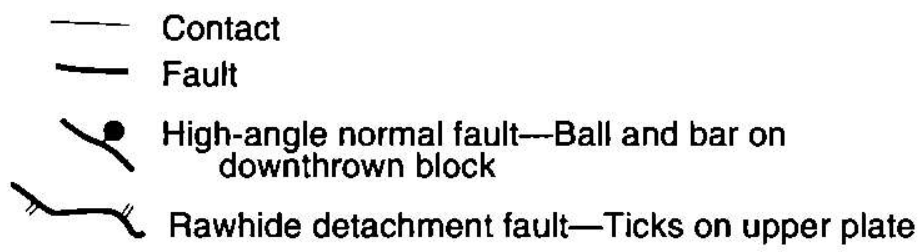

Figure 2. Generalized geologic map showing upper-plate tilt blocks (A, B, C, D) referred to in text. Modified from Spencer and Reynolds (1989). 
B and a southeastward transition toward sandstone-dominated lithofacies in the same part of block A (southeastem) that displays a coarsening trend within unit 1.

Unit 3 is composed of pebbly arkosic sandstone and rounded pebble conglomerate with abundant well-imbricated ellipsoidal clasts. Dominant clast types are Mesozoic metamorphic rocks and white quartzite of unknown age, although silicic volcanic clasts of probable Mesozoic age and limestone blocks of probable Tertiary age also occur in the unit in the southeastern part of block $A$. The unit is recognized only in blocks $A$ and $B$, where it separates unit 2 strata from stratigraphically overlying deposits.

Unit 4 consists of a thick sequence of marginal lacustrine deposits, which is observed only in blocks B (where its thickness is about $270 \mathrm{~m}$ ) and D (thickness about $175 \mathrm{~m}$ southwest of Artillery Peak). In block B, lacustrine lithofacies within unit 4 interfinger southeastward with sandy conglomerate and breccias that form unit 5 . In block D, unit 4 consists of a sequence of carbonate rocks that locally displays turbidite-rich lithofacies and algal features.

In blocks A, B, and C, unit 5 is composed of a laterally extensive series of sedimentary breccia that interfingers laterally and vertically with fluvial sandy conglomerate. Dominant clast types are Mesozoic greenschist-grade metavolcanic rocks; other minor clast types include quartzite, Mesozoic metasedimentary rocks, Paleozoic marble, and Precambrian granitic rocks (Lucchitta, 1990). Paleocurrent investigations of conglomeratic facies indicate dominantly northerly and westerly dispersal directions. The breccia in unit 5 includes rock-avalanche and debris-flow deposits, with the former locally displaying features characteristic of large rock-avalanche deposits as described by Yamold and Lombard (1989). In block $\mathrm{D}$, unit 5 is represented by a series of fluviolacustrine sedimentary rocks that contain breccia bodies of variable size that are texturally and compositionally similar to breccias described in blocks $\mathrm{A}, \mathrm{B}$, and $C$ (Yarnold, 1991). The fluviolacustrine deposits display marginal lacustrine lithofacies south of Artillery Peak and coarsen northwestward to fluvial facies with local debris-flow interbeds (Spencer and others, 1989).

Unit 6 occurs locally within all four blocks as fluviolacustrine sedimentary rocks that overlie unit 5. Lacustrine and marginal lacustrine facies dominate unit 6 exposures in blocks $A$ and $C$, whereas in block $B$ the lacustrine facies interfinger southeastward with fluvial sandy conglomerate similar to and continuous with the conglomerate deposits described from unit 5. In detail, the conglomerate is separated from lacustrine facies by a sequence of fluvial pebbly sandstone. Gypsiferous interbeds are locally associated with the lacustrine facies of unit 6 in blocks $B$ and $C$. In block D, sedimentary rocks assigned to unit 6 are locally similar to underlying fluviolacustrine facies of unit 5 . These sedimentary rocks display a facies transition from a lacustrine-dominated section south of Artillery Peak to a fluvial-dominated section farther to the northwest (Spencer and others, 1989) and may also grade southeastward into fluvial conglomerate toward Santa Maria Peak (Lasky and Webber, 1949). In addition, basalt flows are common in this interval within block $\mathrm{D}$; one flow has a $\mathrm{K}$-Ar age of 16.2 $\pm 0.4 \mathrm{Ma}$ (whole rock) (Shackelford, 1980, 1989). Although laterally variable, the thickness of unit 6 is about $160 \mathrm{~m}$ in block $\mathrm{B}$ and $100 \mathrm{~m}$ in block $\mathrm{C}$; the unit is only partially exposed in block $A$.

Unit 7 is the informally named Artillery megabreccia of Spencer and others (1989). (The Artillery megabreccia forms most of the upper member of the Artillery Formation as redefined by Spencer and others, 1989). The megabreccia is recognized within block $D$ and comprises sedimentary breccia dominated by granitoids of probable Proterozoic age. The local occurrence of breccia derived from Paleozoic and Mesozoic rocks within this unit indicates that it was shed from a source to the west or south (Spencer and others, 1989). Preliminary investigations suggest that the Artillery megabreccia southwest of Artillery Peak comprises one or more large rock-avalanche deposits. A texturally and compositionally similar breccia deposit is present within eastern block B and may correlate with unit 7 in the Artillery Peak area. Although poorly exposed, the breccia appears to be stratigraphically bracketed between unit 5 conglomerate and unit 10 .

Unit 8 is represented in block D by red silty sandstone of the Chapin Wash Formation (Lasky and Webber, 1949) and an underlying, variably thick sequence of similar red arkosic sandstone and subordinate siltstone and conglomerate, which was mapped as the upper part of the Artillery Formation by Lasky and Webber (1949) and grouped with the Chapin Wash Formation by Shackelford (1976). Strong lithologic similarity between unit 8 sediment and a fluvial sequence of conglomerate and arkosic sandstone over 300 $m$ thick in block $C$ (arkose of Keenan Camp of Lucchitta and Suneson, 1988) suggests that the two may be correlative. Conglomeratic facies within the fluvial sequence exposed in block $\mathrm{C}$ contain a variety of clasts, including Proterozoic gneiss and granite, equigranular granodiorite, vesicular basalt, Mesozoic metavolcanic and metasedimentary rocks, Tertiary volcanic rocks, and local limestone and red arkosic sandstone of probable Tertiary age. Similar clast assemblages were observed in coarse interbeds within the Chapin Wash Formation. In addition, mylonitic clasts resembling those from footwall exposures of the Rawhide Mountains were reported in the Chapin Wash Formation at Cobbwebb Hill (Spencer and others, 1989). Alternatively, the fluvial conglomerate exposed in block $\mathrm{C}$ may correlate with coarse lithofacies of unit 6 exposed locally within block $\mathrm{D}$.

Basalt underlying the arkose of Keenan Camp (Lucchitta and Suneson, 1988) in the Castaneda Hills area is as young as $16.5 \pm 0.2 \mathrm{Ma}$ (K-Ar, whole rock) (Suneson and Lucchitta, 1979), and silicic volcanic rocks overlying the arkose are as old as $15.1 \pm 0.1 \mathrm{Ma}$ (K-Ar, sanidine) (Suneson 
and Lucchitta, 1979). Near Castaneda Peak, the Peach Springs Tuff of Young and Brennan (1974) is interbedded with the lower part of unit 8 (Lucchitta and Suneson, this volume). Unit 8 appears to be represented in block $B$ by red fluvial sandstone that occurs at the top of the exposed section. The sandstone interfingers along its base with deposits of unit 6, as well as with conglomerates identical to those described in unit 5 . It remains uncertain whether a lithostratigraphic equivalent of unit 8 exists in block $A$.

At Potts Mountain, a rhyolite plug intrudes unit 8 . The plug has a $\mathrm{K}-\mathrm{Ar}$ age of 12.6 $\pm 0.1 \mathrm{Ma}$ (sanidine) (Suneson and Lucchitta, 1979). Detritus from the plug is present in local exposures of unit 10 .

Unit 9 is the Cobwebb ${ }^{1}$ Basalt (Lasky and Webber, 1949), a discontinuous sequence of aphanitic lava flows. A sample from one flow has a $\mathrm{K}$ - $\mathrm{Ar}$ age of $13.3 \pm 2.1 \mathrm{Ma}$ (whole rock) (Eberly and Stanley, 1978; recalculated using modern decay constants by Reynolds and others, 1986). The Cobwebb Basalt is found only in block D, where it locally separates unit 10 strata from those of unit 8 .

Unit 10 (Sandtrap Conglomerate as defined by Lasky and Webber, 1949) is composed predominantly of fluvial conglomeratic and silty sandstone. Most exposures are thin to medium bedded and moderately well stratified. Crude clast imbrications suggest a northeasterly dispersal direction. Clast compositions are highly varied and include Proterozoic granite and gneiss, chloritic metamorphic rocks, Mesozoic volcanic and sedimentary rocks, equigranular granodiorite, and mylonites similar to those present in footwall exposures within the Rawhide Mountains. Flat-lying to gently dipping mesa-forming basalt lava flows are interbedded in unit 10 and have $\mathrm{K}$-Ar ages ranging from 13.7 to $9.2 \mathrm{Ma}$ (whole rock) (Suneson and Lucchitta, 1979). The thickness of unit 10 in block D was estimated by Lasky and Webber (1949) to be approximately 500 to $700 \mathrm{~m}$.

\section{REFERENCES CITED}

Eberly, L.D., and Stanley, T.B., Jr., 1978, Cenozoic stratigraphy and geologic history of southwestern Arizona: Geological Society of America Bulletin, v. 89, no. 6, p. 921-940.

Lasky, S.G., and Webber, B.N., 1949, Manganese resources of the Artillery Mountains region, Mohave County, Arizona: U.S. Geological Survey Bulletin 961, 86 p.

\footnotetext{
${ }^{1}$ Spelling differs between modern topographic maps and the original name of the unit [eds.]
}

Lucchitta, Ivo, 1990, Role of heat and detachment in continental extension as viewed from the eastern Basin and Range province in Arizona: Tectonophysics, v. 174, nos. 1-2, p. 77-114.

Lucchitta, Ivo, and Suneson, N.H., 1988, Geologic map of the Planet 2 SW quadrangle, Mohave County, Arizona: U.S. Geological Survey Open-File Report 88-547, scale $1: 24,000$.

Reynolds, S.J., Florence, F.P., Welty, J.W., Roddy, M.S., Currier, D.A., Anderson, A.V., and Keith, S.B., 1986, Compilation of radiometric age determinations in Arizona: Arizona Bureau of Geology and Mineral Technology Bulletin 197, $258 \mathrm{p}$.

Shackelford, T.J., 1976, Structural geology of the Rawhide Mountains, Mojave County, Arizona: Los Angeles, University of Southem California, Ph.D. dissertation, 175 p.

1980, Tertiary tectonic denudation of a Mesozoic-early Tertiary(?) gneiss complex, Rawhide Mountains, western Arizona: Geology, v. 8, no. 4, p. 190-194.

1989, Structural geology of the Rawhide Mountains, Mojave County, Arizona, in Spencer, J.E., and Reynolds, S.J., eds., Geology and mineral resources of the Buckskin and Rawhide Mountains, west-central Arizona: Arizona Geological Survey Bulletin 198, p. 15-46.

Spencer, J.E., Grubensky, M.J., Duncan, J.T., Shenk, J.D., Yarnold, J.C., and Lombard, J.P., 1989, Geology and mineral deposits of the central Artillery Mountains, in Spencer, J.E., and Reynolds, S.J., eds., Geology and mineral resources of the Buckskin and Rawhide Mountains, west-central Arizona: Arizona Geological Survey Bulletin 198, p. 168-183.

Spencer, J.E., and Reynolds, S.J., 1989, Tertiary structure, stratigraphy, and tectonics of the Buckskin Mountains, in Spencer, J.E., and Reynolds, S.J., ed., Geology and mineral resources of the Buckskin and Rawhide Mountains, westcentral Arizona: Arizona Geological Survey Bulletin 198, p. 103-167.

Suneson, Neil, and Lucchitta, Ivo, 1979, K/Ar ages of Cenozoic volcanic rocks, west-central Arizona: Isochron/West, no. 24, p. 25-29.

Yarnold, J.C., 1991, The depositional origin of sedimentary breccias and megabreccias in the Artillery Mountains area, westcentral Arizona [abs.]: Geological Society of America Abstracts with Programs, v. 23, no. 2, p. A111.

Yarnold, J.C., and Lombard, J.P., 1989, A facies model for large rock-avalanche deposits formed in dry climates, in Colburn, I.P., Abbott, P.L., and Minch, John, eds., Conglomerates in basin analysis: a symposium dedicated to A.O. Woodford: Los Angeles, Calif., Pacific Section, Society of Economic Paleontologists and Mineralogists, v. 62, p. 9-31.

Young, R.A., and Brennan, W.J., 1974, Peach Springs Tuff: its bearing on structural evolution of the Colorado Plateau and development of Cenozoic drainage in Mohave County, Arizona: Geological Society of America Bulletin, v. 85, no. 1 , p. 83-90. 


\title{
Stratigraphy of Middle Tertiary Rocks in the Central and Eastern Buckskin Mountains, West-Central Ariz.
}

\author{
By Jon E. Spencer ${ }^{1}$ and Stephen J. Reynolds ${ }^{1}$
}

The Buckskin Mountains are within the Harcuvar metamorphic core complex of west-central Arizona (fig. 1) (Rehrig and Reynolds, 1980). Within this complex, as within almost all Cordilleran metamorphic core complexes, middle Tertiary sedimentary and volcanic rocks are preserved in fault blocks above a large-displacement, lowangle normal fault known as a detachment fault. Displacement on the detachment fault has juxtaposed upper-crustal rocks, including synextensional sedimentary and volcanic rocks, against middle-crustal rocks that were mylonitized within a ductile shear zone that was downdip from the initial detachment fault (for example, Wemicke, 1981; Davis and others, 1986). Normal faulting and basin formation occurred above the detachment fault and reflect detachment-fault displacement and extensional dismemberment of the upper plate.

Thick sequences of upper-plate Tertiary sedimentary and volcanic strata are well preserved and exposed in the Swansea and Lincoln Ranch areas of the central and eastern Buckskin Mountains (fig. 1) (Spencer and Reynolds, 1989). Both sequences are displaced by the underlying

\footnotetext{
'Arizona Geological Survey, 845 N. Park Avenue, Tucson, AZ 85719
}

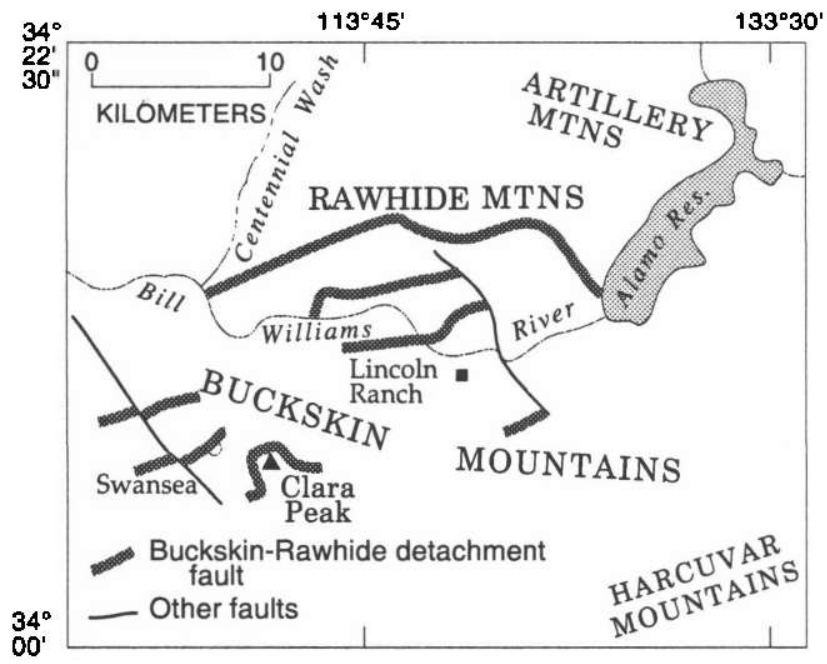

Figure 1. Map showing location of geographic features discussed in text.
Buckskin-Rawhide detachment fault and are internally faulted. The single section presented here is a composite of these two areas (col. 2-N, pl. 2). The lower part of the section is from the Swansea area in the central Buckskin Mountains. In this area basal arkosic sandstone and local conglomerate rest depositionally on Mesozoic and older metamorphic and igneous rocks and grade upward into limestone and interbedded welded tuff and sedimentary breccia. The breccia units represent catastrophic debrisavalanche deposits of the type described by Shreve (1968). A tuff in this sequence yielded $\mathrm{K}-\mathrm{Ar}$ ages of $21.8 \pm 0.5 \mathrm{Ma}$ (biotite) (Spencer and others, 1989) and 23.2 $\pm 0.5 \mathrm{Ma}$ (biotite; Robert Miller, written commun., 1991) and another sample from this tuff or a slightly lower tuff yielded a $\mathrm{K}$-Ar age of $27.3 \pm 1.1 \mathrm{Ma}$ (biotite) (Wilkins and Heidrick, 1982). The origin of the discrepancy between these dates is not known.

The sequence of limestone, tuff, and breccia is overlain by mafic volcanic flows that are similar to basalt flows in the Lincoln Ranch area of the eastern Buckskin Mountains (fig. 1). The basalt flows in the Lincoln Ranch area, included within the intermediate volcanic unit of Spencer and Reynolds (1989), overlie a thin unit of interbedded arkosic sandstone, limestone, tuff, and sedimentary breccia. A feldspar concentrate from the basalt in the Lincoln Ranch area yielded a $\mathrm{K}-\mathrm{Ar}$ age of $20.2 \pm 0.9 \mathrm{Ma}$ (Spencer and others, 1989; date is a weighted average of two dates calculated by the method of Long and Rippeteau, 1974). The basalt is overlain by a sequence of sandstone, siltstone, and calcareous siltstone that is in tum overlain by a coarse, poorly bedded to massive cobble conglomerate. This conglomerate is correlative with the Sandtrap Conglomerate (Lasky and Webber, 1949), which is exposed in the nearby Artillery and eastern Rawhide Mountains (see Yamold, this volume). In the Lincoln Ranch area, 30 to 40 percent of the clasts in this conglomerate consist of mylonitic crystalline rocks that were derived from below the detachment fault. These clasts record subaerial exposure of the lower plate as it was uncovered by detachment faulting (Spencer and Reynolds, 1989).

Flat-lying to gently dipping, postdetachment basalt and locally underlying conglomerate are exposed in the northwestern Buckskin Mountains and along the northern flank of the adjacent Rawhide Mountains (Suneson and 
Lucchitta, 1983; Spencer, 1989). Most of the basalts have yielded whole-rock K-Ar ages ranging from 12 to $9 \mathrm{Ma}$ (Armstrong and others, 1976; Suneson and Lucchitta, 1979; Reynolds and others, 1986; Spencer and others, 1989, see Lucchitta and Suneson, this vol., col. 2-L, pl. 2).

\section{REFERENCES CITED}

Armstrong, R.L., Speed, R.C., Graustein, W.C., and Young, A.Y., 1976, K-Ar dates from Arizona, Montana, Nevada, Utah, and Wyoming: Isochron/West, no. 16, p. 1-6.

Davis, G.A., Lister, G.S., and Reynolds, S.J., 1986, Structural evolution of the Whipple and South Mountains shear zones, southwestern United States: Geology, v. 14, no. 1, p. 7-10.

Lasky, S.G., and Webber, B.N., 1949, Manganese resources of the Artillery Mountains region, Mohave County, Arizona: U.S. Geological Survey Bulletin 961, 86 p.

Long, Austin, and Rippeteau, Bruce, 1974, Testing contemporaneity and averaging radiocarbon dates: American Antiquity, v. 39, no. 2, p. 205-215.

Rehrig, W.A., and Reynolds, S.J., 1980, Geologic and geochronologic reconnaissance of a northwest-trending zone of metamorphic core complexes in southern and western Arizona, in Crittenden, M.D., Jr., Coney, P.J., and Davis, G.H., Cordilleran metamorphic core complexes: Geological Society of America Memoir 153, p. 131-157.

Reynolds, S.J., Florence, F.P., Welty, J.W., Roddy, M.S., Currier, D.A., Anderson, A.V., and Keith, S.B., 1986, Compilation of radiometric age determinations in Arizona: Arizona Bureau of Geology and Mineral Technology Bulletin 197, 258 p.

Shreve, R.L., 1968, The Blackhawk landslide: Geological Society of America Special Paper 108, 47 p.
Spencer, J.E., 1989, Compilation geologic map of the Buckskin and Rawhide Mountains, west-central Arizona, in Spencer, J.E., and Reynolds, S.J., eds., Geology and mineral resources of the Buckskin and Rawhide Mountains, west-central Arizona: Arizona Geological Survey Bulletin 198, plate 3, scale $1: 100,000$.

Spencer, J.E., and Reynolds, S.J., 1989, Tertiary structure, stratigraphy, and tectonics of the Buckskin Mountains, in Spencer, J.E., and Reynolds, S.J., ed., Geology and mineral resources of the Buckskin and Rawhide Mountains, westcentral Arizona: Arizona Geological Survey Bulletin 198, p. 103-167.

Spencer, J.E., Shafiqullah, M., Miller, R.J., and Pickthorn, L.G., 1989, K-Ar geochronology of Miocene extension, volcanism, and potassium metasomatism in the Buckskin and Rawhide Mountains, in Spencer, J.E., and Reynolds, S.J., eds., Geology and mineral resources of the Buckskin and Rawhide Mountains, west-central Arizona: Arizona Geological Survey Bulletin 198, p. 184-189.

Suneson, Neil, and Lucchitta, Ivo, 1979, K/Ar ages of Cenozoic volcanic rocks, west-central Arizona: Isochron/West, no. 24, p. $25-29$.

1983, Origin of bimodal volcanism, southern Basin and Range Province, west-central Arizona: Geological Society of America Bulletin, v. 94, no. 8, p. 1,005-1,019.

Wernicke, Brian, 1981, Low-angle normal faults in the Basin and Range Province: Nappe tectonics in an extending orogen: Nature, v. 291, no. 5817, p. 645-648.

Wilkins, Joe, Jr., and Heidrick, T.L., 1982, Base and precious metal mineralization related to low-angle tectonic features in the Whipple Mountains, California and Buckskin Mountains, Arizona, in Frost, E.G., and Martin, D.L., eds., MesozoicCenozoic tectonic evolution of the Colorado River region California, Arizona, and Nevada (Anderson-Hamilton Volume): San Diego, Calif., Cordilleran Publishers, p. 182-203. 


\title{
Tertiary Stratigraphy of the Southern Whipple Mountains, Southeastern Calif.
}

\author{
By Kathi K. Beratan ${ }^{1}$
}

\section{INTRODUCTION}

The Whipple Mountains of southeastern California (fig. 1) are part of the Colorado River extensional corridor (Howard and John, 1987). This area contains extensive exposures of lower to middle Miocene sedimentary and volcanic strata deposited during extension along the underlying Whipple detachment fault. On a regional scale this

\footnotetext{
'Department of Geological and Planetary Science, 321 Old Engineering Hall, University of Pittsburgh, Pittsburgh, PA 15260
}

low-angle normal fault dips to the northeast; the direction of regional tectonic transport for the lower plate is to the southwest (Davis and others, 1980).

Strata deposited within a single Tertiary sedimentary basin are now exposed in the southern and eastern Whipple Mountains, in an area approximately $28 \mathrm{~km}$ long (northeast-southwest) by $17 \mathrm{~km}$ wide (northwest-southeast). The basin has been extended to the northeast and southwest an unknown amount by syndetachment westtilting of upper-crustal fault blocks. The maximum cumulative thickness of Tertiary deposits is about $1,500 \mathrm{~m}$; stratal thickness at most localities is about $1,000 \mathrm{~m}$.

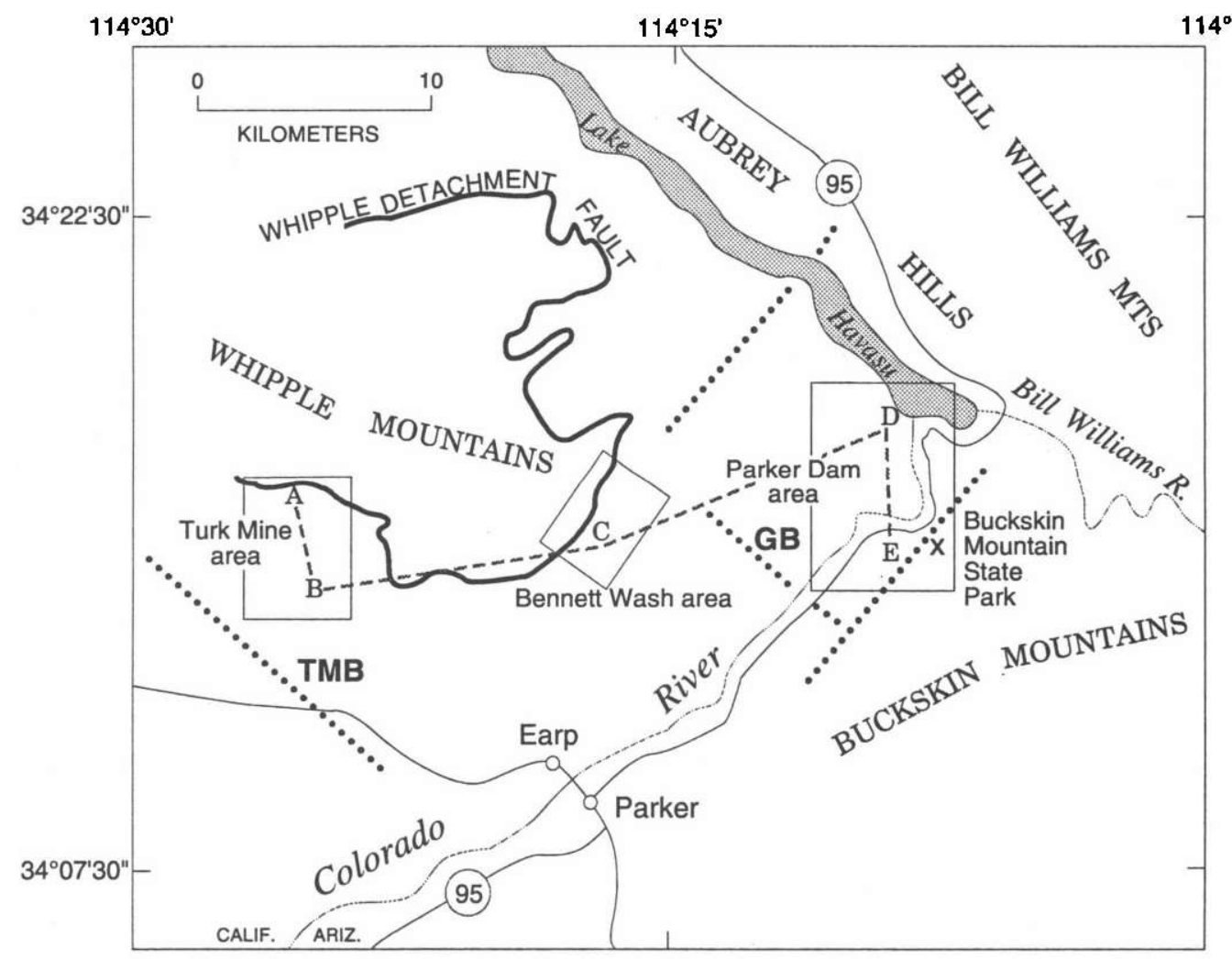

Figure 1. Map showing location of some geologic and geographic features discussed in text. Whipple detachment fault from Davis and others (1980). Heavy dotted lines indicate approximate position of basin boundaries (GB, inferred high-angle normal fault bounding Gene basin; TMB, inferred high-angle normal fault bounding Turk Mine Basin). Stratigraphic sections on traverse A-E (dashed line) are shown in figure 2 . 
Braided stream and sheetflood deposits characterize the Tertiary sedimentary rocks on the southern and eastern flanks of the Whipple Mountains. In the eastern part of the study area, these rocks are associated with monolithologic breccia beds deposited by rock avalanches and mass flows; locally present are interbeds of limestone and lacustrine sandstone and siltstone. Lacustrine limestone forms an extensive unit in the western part of the study area. Volcanic flows and pyroclastic deposits are scarce.

Syndetachment strata deposited within the study area can be divided into two distinct sequences. The sequences are separated in the eastern part of the area by an angular unconformity. Elsewhere, they are distinguished by differences in outcrop extent and location, facies distribution, and clast composition. The sequences are interpreted as being the deposits of two different subbasins, separated in time but overlapping in space, both related to motion on the underlying Whipple detachment fault. For clarity in the following descriptions and discussion, the older subbasin will be referred to as the Gene basin and the younger one as the Turk Mine basin (fig. 1). The two sequences are unconformably overlain by nearly flatlying sedimentary and volcanic strata of the Osborne Wash Formation of Davis and others (1980).

A more complete description of the stratigraphic units and the basin development history is given in Bera$\tan$ (1991).

\section{STRATIGRAPHIC NOMENCLATURE}

Davis and others (1980) (see also Ransome, 1931, 1933) defined the older Gene Canyon Formation and the younger Copper Basin Formation on the basis of a prominent angular unconformity within exposures near Parker Dam (fig. 1). Beratan (1991) redefined these formations on the basis of (1) stratigraphic position relative to the Peach Springs Tuff of Young and Brennan (1974), (2) presence or absence of Peach Springs Tuff clasts in conglomerate beds where outcrops of the tuff are lacking, (3) presence or absence of lava flows and intrusive rocks, (4) stratigraphic position relative to angular unconformities, (5) dominance of limestone compared to siliclastic rocks, and (6) paleocurrent directions relative to basin depocenters.

Using the above criteria, Beratan (1991) also introduced two new units, the Turk Mine and Twin Lode Mine Formations, which are equivalent to parts of the Gene Canyon Formation. An informally named "basal conglomerate" of uncertain age also was described. The defining characteristics of these stratigraphic units are summarized in table 1 .

\section{STRATIGRAPHY}

The basal unit in the eastern part of the study area (Gene basin) will be described first, followed by the three lowermost units in the western part of the area (Turk Mine basin). The remaining units are found throughout the study area. Section names refer to the generalized stratigraphic columns presented in figure 2 . A composite time-stratigraphic column is shown on plate 2 (col. 2-O). The stratigraphic units, particularly in the eastern half of the basin, correspond to the three synextensional Miocene sequences mentioned in the introduction to this chapter (Nielson and others, this volume).

\section{GENE CANYON FORMATION}

The Gene Canyon Formation of Beratan (1991) is found only in the eastern part of the study area, near Parker Dam. This unit is subdivided into three members, which from oldest to youngest are the Giers Wash Member, the Desilt Wash Member, and the Gene Wash Member.

The Giers Wash Member is characterized by dramatic lateral and vertical facies changes, lack of volcanic rocks either as primary deposits or as clasts, and by the presence of monolithologic breccia beds that have been interpreted as rock avalanche deposits. In the Parker Dam section (fig. 2), the unit is dominated by coarse-grained sandstone and pebbly sandstone interpreted as streamflood deposits with subordinate matrix-supported mass-flow deposits and small lenses of limestone. Cobble- to small-boulder-bearing, sand matrix-supported strata, interpreted as mass-flow breccias, dominate in the Buckskin Mountain State Park section (fig. 2), with subordinate stratified sandstones and conglomerates interpreted as streamflood deposits. Clast types include those derived from Proterozoic(?) and Cretaceous(?) granitoids and gneisses, and metasedimentary rocks including quartzite, phyllite, and white marble.

The Desilt Wash Member displays considerably less facies variation than does the Giers Wash Member. In the Parker Dam section, the unit comprises medium-reddishbrown, moderately well-indurated, fine pebble-bearing coarse-grained sandstone, with subordinate interbedded medium and mixéd .medium-grained to very coarse grained sandstone and pebble to cobble conglomerate. These strata are interpreted as streamflood deposits. In contrast, laterally persistent beds of thinly bedded finegrained sandstone and siltstone, interpreted as playa deposits, and interbedded streamflood deposits dominate in the Buckskin Mountain State Park section (fig. 2). Clasts within the Desilt Wash Member were derived primarily from Proterozoic(?) and Cretaceous(?) granitoid and gneiss and also include rare clasts of Tertiary mafic to in- 
Table 1. Summary of the defining characteristics of stratigraphic units used in this study.

\begin{tabular}{|c|c|c|c|}
\hline Unit name & Reference sections & Distinguishing characteristics & Boundary definition \\
\hline Copper Basin Formation & $\begin{array}{l}\text { Parker Dam, Turk } \\
\text { Mine, Bennett Wash }\end{array}$ & $\begin{array}{l}\text { Clastic sediment deposited after emplacement of the Peach Springs } \\
\text { Tuff; heterogeneous clast assemblage, including those derived from } \\
\text { Peach Springs Tuff. } \\
\text { Lacks interbedded volcanic flows }\end{array}$ & \multirow{5}{*}{$\begin{array}{l}\text { Angular unconformity } \\
\text { Angular unconformity or } \\
\text { first clasts of Peach } \\
\text { Springs Tuff } \\
\text { First volcanic } \\
\text { flow } \\
\text { Color change, } \\
\text { facies change } \\
\\
\text { Nonconformity on older } \\
\text { granitic suite }\end{array}$} \\
\hline Gene Canyon Formation & $\begin{array}{l}\text { Parker Dam, Buckskin } \\
\text { Mtn. State Park }\end{array}$ & $\begin{array}{l}\text { Deposited before and during emplacement of the Peach Springs Tuff; } \\
\text { deposits include a well-defined basin center and basin margin }\end{array}$ & \\
\hline \multicolumn{2}{|l|}{ Gene Wash Member } & Volcanic flows and tuff with interbedded sandstone and conglomerate & \\
\hline \multicolumn{2}{|l|}{ Desilt Wash Member } & $\begin{array}{l}\text { Lack of volcanic flows; presence of minor quantities of Tertiary vol- } \\
\text { canic rock clasts; lack of monolithologic breccia }\end{array}$ & \\
\hline \multicolumn{2}{|l|}{ Giers Wash Member } & $\begin{array}{l}\text { Lack of volcanic rocks either as flows or clasts; presence of mono- } \\
\text { lithologic breccia; lateral and vertical variability in texture and grain } \\
\text { size }\end{array}$ & \\
\hline $\begin{array}{l}\text { Twin Lode Mine } \\
\text { Formation }\end{array}$ & $\begin{array}{c}\text { Turk Mine, North Turk } \\
\text { Mine }\end{array}$ & Lacustrine limestone; lack of volcanic flows & $\begin{array}{l}\text { Change from limestone } \\
\text { to clastic deposits }\end{array}$ \\
\hline Turk Mine Formation & $\begin{array}{c}\text { Turk Mine, North Turk } \\
\text { Mine }\end{array}$ & $\begin{array}{l}\text { Dominated by volcanic flows of mafic to intermediate composition; } \\
\text { sedimentary interbeds lack clasts of Peach Springs Tuff }\end{array}$ & $\begin{array}{l}\text { Base of first limestone } \\
\text { bed }\end{array}$ \\
\hline Basal conglomerate & Turk Mine & $\begin{array}{l}\text { Coarse-grained clastic deposits derived from nearby sources; lacks } \\
\text { clasts of Peach Springs Tuff or limestone; deposits lack a recogniz- } \\
\text { able basin margin or basin center }\end{array}$ & $\begin{array}{l}\text { Nonconformity on older } \\
\text { granitic suite }\end{array}$ \\
\hline
\end{tabular}

termediate volcanic rocks. Metasedimentary clasts are less common in this unit than in the Giers Wash Member.

The Gene Wash Member is distinguished from underlying units by the presence of thin, strongly altered, mafic to intermediate lava flows with interbedded coarse-grained sedimentary strata. A conformable rhyolitic ash-flow tuff that tentatively has been identified as the Peach Springs Tuff caps the unit (Beratan, 1991). The lava flows are sparsely porphyritic, containing about 3 to 5 percent small (1 $\mathrm{mm}$ ) oxidized pyroxene(?) phenocrysts; plagioclase phenocrysts are rare to absent. Interbedded sedimentary strata consist of conglomerate and medium- and coarsegrained sandstone, similar to the underlying Desilt Wash Member with additional prominent boulder and cobble conglomerate beds. The sedimentary strata are generally coarser grained in the Parker Dam section than in the Buckskin Mountain State Park section.

\section{BASAL CONGLOMERATE}

Strata that form the base of the Turk Mine, North Turk Mine, and Bennett Wash sections in the western half of the study area (fig. 2) are texturally variable and include poorly sorted, unorganized, clast- and matrix-supported breccia (rock avalanches) and very coarse grained pebbly sandstone, interpreted as mass-flow deposits, and moderately sorted, coarse-grained sandstone and clast-supported conglomerate, interpreted as streamflood deposits. The clasts in any given exposure commonly are limited in vari- ety and similar in composition to local basement rocks. The basal conglomerate varies in thickness, indicating topographic relief on the original depositional surface.

\section{TURK MINE FORMATION}

The Turk Mine Formation of Beratan (1991) is found in the Bennett Wash and Turk Mine areas, in the western part of the study area (fig. 2). It conformably overlies the basal conglomerate and consists of medium-gray lava flows of mafic to intermediate composition which are strongly potassium metasomatized. The formation varies from about 100 to $500 \mathrm{~m}$ thick, and sedimentary interbeds are uncommon. The lava flows commonly contain 1 to 3 percent small (about $1 \mathrm{~mm}$ long) plagioclase phenocrysts, 1 percent small $(1-1.5 \mathrm{~mm}$ ) altered clinopyroxene(?) phenocrysts, and rare iddingsitized olivine. Individual flows are difficult to distinguish but generally appear to be less than $5 \mathrm{~m}$ thick.

\section{TWIN LODE MINE FORMATION}

The volcanic flows of the Turk Mine Formation of Beratan (1991) are overlain conformably by as much as 200 m of lacustrine limestone (fig. 2) predominantly composed of calcitic micrite, which contains abundant algal material. The siliciclastic content of the limestone is variable but generally high. Rare conglomerate interbeds are dominated 


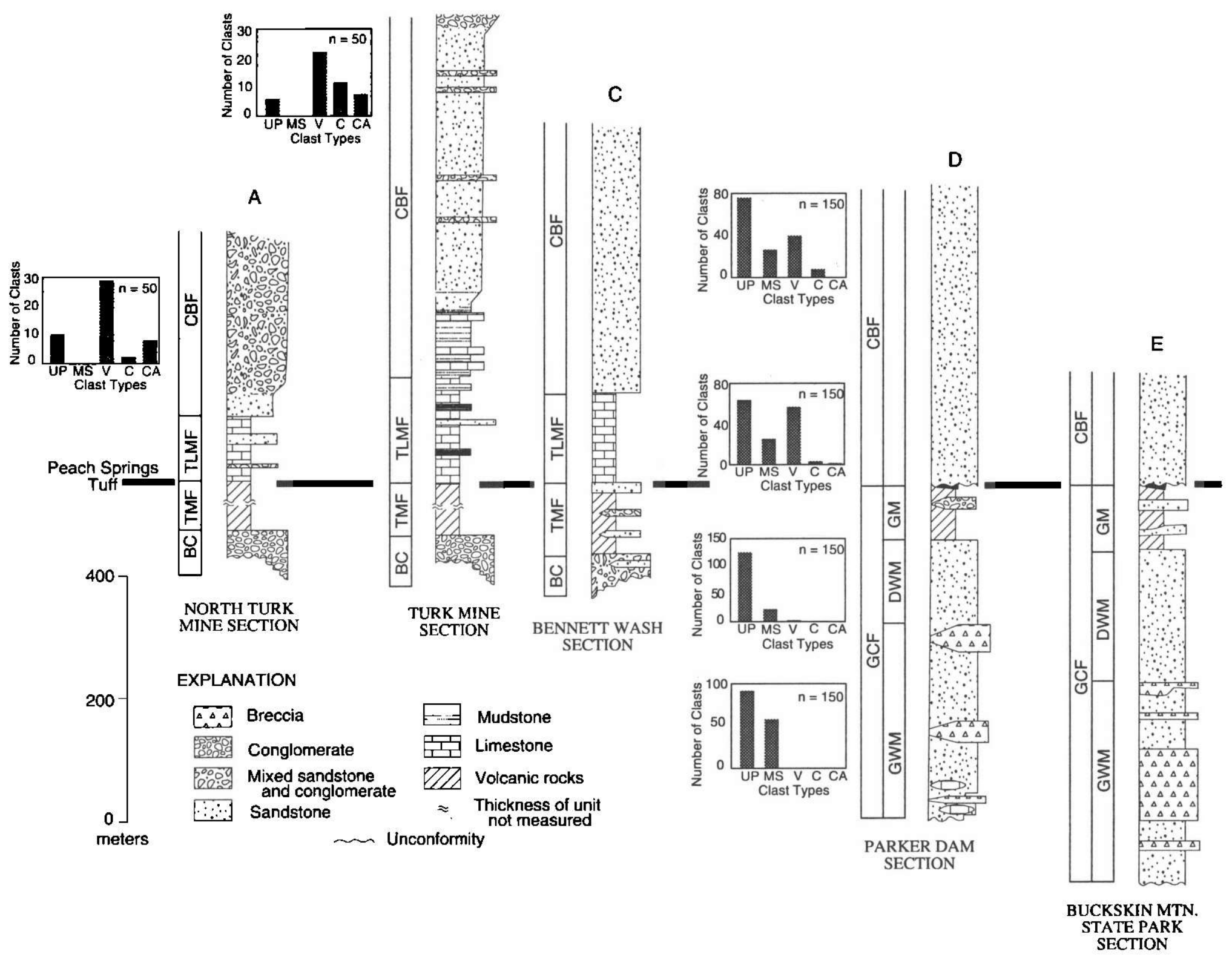

Figure 2. Generalized stratigraphic columns and clast-count data. Key to stratigraphic units: CBF, Copper Basin Formation; GCF, Gene Canyon Formation; GM, Gene Wash Member; DWM, Desilt Wash Member; GWM, Giers Wash Member; TLMF, Twin Load Mine Formation; TMF, Turk Mine
Formation; BC, basal conglomerate. Key to clast types: UP, upper plate Proterozoic rocks; MS, Paleozoic and Mesozoic metasedimentary rocks; V, Tertiary volcanic rocks; $C$, Tertiary siliciclastic rocks; CA, Tertiary carbonate rocks. See figure 1 for locations of sections A-E. 
by pebble-sized mudstone and carbonate intraclasts. One clast of rhyolitic tuff, similar to the Peach Springs Tuff, but not positively identified, was found in the limestone. Secondary silica is a common and characteristic component of the Twin Lode Mine Formation, varying from incipient replacement of calcite by microcrystalline quartz and chalcedony to nodules and massive layers of chert.

\section{COPPER BASIN FORMATION}

The Copper Basin Formation of Beratan (1991) is found throughout the study area. In the Parker Dam area, the Copper Basin Formation unconformably overlies the Gene Canyon Formation with $15^{\circ}$ to $20^{\circ}$ of angular discordance. The unit is dominated by moderately sorted, medium-grained to very coarse grained sandstone. The beds are laterally discontinuous; crude stratification and largescale, low-angle crossbedding are the most common sedimentary structures. These sandstone and conglomerate beds are interpreted as streamflood deposits. A large variety of clast types (fig. 2) is present, including granitic gneiss and coarsely crystalline granite derived from the upper plate of the Whipple detachment fault, Tertiary volcanic rocks including the Peach Springs Tuff, Tertiary limestone, and quartzite. Tertiary volcanic rocks are the most abundant clast type near the base of the Copper Basin Formation, with clasts from the upper-plate crystalline assemblage becoming more abundant higher in the unit.

In the western half of the basin, the Copper Basin Formation conformably overlies the Twin Lode Mine Formation. The unit is dominated by sandstone, with several different recognizable facies. One facies consists of fine-grained sandstone and siltstone with well-developed bedding surfaces that are laterally persistent at outcrop scale. Partial Bouma sequences can be recognized, primarily $\mathrm{B}-\mathrm{D}(\mathrm{E}$ ?) with some poorly developed $\mathrm{C}$ zones; zone $A$ is rare. These strata are interpreted as interbedded turbidite and traction deposits ("resedimented deposits" in terminology of Walker and Mutti, 1973). A ripple-marked sandstone facies consists of well-indurated thin- to medium-bedded, well-sorted medium-grained sandstone beds 5 to $8 \mathrm{~cm}$ thick that are separated by recessive, finer grained layers of about the same thickness. The lower surfaces of the sandstone beds are flat and the upper surfaces are typically covered by symmetric ripple bedforms, which have mostly straight to sinuous crests and some bifurcations. These ripples probably were formed in very shallow water by wind-driven waves.

Within the western half of the study area, interbedded sandstones and conglomerates interpreted as streamfiood deposits overlie the Twin Lode Mine Formation locally. Tertiary volcanic rocks of mafic to intermediate composition are the most common clast type in the conglomerate (fig. 2). Clasts of granite and gneiss also are common, as are limestone and chert clasts derived from the underlying Turk Mine Formation. Sandstone intraclasts also occur, as do rare clasts of rhyolitic tuff and the Peach Springs Tuff.

\section{OSBORNE WASH FORMATION}

Along the eastern edge of the study area, the postdetachment Osborne Wash Formation of Davis and others (1980) consists of interbedded alkali-olivine basalt flows, agglomerate, tuff, trachyte, and other volcanic rocks with interbedded coarse-grained clastic sedimentary rocks. Within the remainder of the study area, relatively unstudied alluvial fan and streamflood deposits form a depositional apron around the flanks of the Whipple Mountains and generally have been assigned to the Osborne Wash Formation. Further work is needed to verify this stratigraphic designation.

\section{BOUSE FORMATION}

The Bouse Formation, which marks the northernmost well-documented extent of the proto-Gulf of California (Buising, 1988, this volume), is composed of a basal white limestone overlain by an olive-gray claystone. Minor amounts of silt, sand, and gravel occur throughout the unit; the percentage of silt and sand increases upsection. The most distinctive lithologic units are the bright-white basal limestone and a similarly bright white tufa (Metzger, 1968; Smith, 1970). This unit forms much of the lowlands near Earp, California, and Parker, Arizona.

\section{TIME OF DEPOSITION}

Ages of strata within the study area are poorly constrained due to the scarcity of dateable material within the basin. A fission-track age of $23 \pm 2.4 \mathrm{Ma}$ (zircon) was obtained from a lacustrine tuff located near the base of the Tertiary section in the Aubrey Hills (Beratan, 1991; Nielson, this volume); this is the best estimate of the age of basin inception in the Whipple detachment system. Volcanic rocks that overlie sedimentary rocks in the western part of the study area are strongly altered and cannot be dated. Some constraints on the timing of volcanism are provided by ages from nearby basins; for example, mafic flows within the lower part of the Tertiary section in the Buckskin Mountains were erupted between approximately 21 and 18 Ma (Spencer and others, 1989), and volcanic rocks of the lower sequence in the Mopah Range were deposited between approximately 21 and $17 \mathrm{Ma}$ (Hazlett, 1986; this volume). Therefore, the age of basal volcanic flows in the Turk Mine Formation, which may be related to volcanism in the Mopah Range, probably is also about $21 \mathrm{Ma}$. 
The Peach Springs Tuff provides an upper age limit for the Gene Canyon Formation and a lower age limit for the Copper Basin Formation. The accepted age of this widespread ignimbrite is $18.5 \pm 0.2 \mathrm{Ma}$, as determined by ${ }^{40} \mathrm{Ar} /{ }^{39} \mathrm{Ar}$ methods on sanidine from pumice lapilli (Nielson and others, 1990).

A sequence of basalt lava fows within strata in the Aubrey Hills that are thought to be slightly younger than the Copper Basin Formation has yielded a preliminary $\mathrm{K}$ Ar age of $14.1 \pm 0.3 \mathrm{Ma}$ (whole rock) (Nakata and others, 1990).

The oldest rocks of the Osborne Wash Formation in the southwestern Buckskin Mountains are probably 16 to 14 Ma (Grubensky, 1989). Flat-lying ("postdetachment") basaltic to locally rhyolitic volcanic strata in the western Buckskin, southeastern Bill Williams, and northem Rawhide Mountains were deposited between about 12 and $9 \mathrm{Ma}$ (Spencer and others, 1989). Published ages on the base of the Bouse Formation suggest that it is perhaps as old as 8.1 Ma and probably no younger than about 5.5 Ma (Buising, this volume).

\section{SUMMARY OF INFERRED BASIN HISTORY}

The geographic coincidence between facies changes in basin deposits and mappable faults indicates that boundaries of the sedimentary basins in the eastern and southern Whipple Mountains were fault controlled. High-angle normal faults formed the southwestern and northeastern margins, and transfer faults formed the southeastem, and perhaps also the northwestern margins (Nielson and Beratan, 1990). Shifts in the position of the basin depocenter reflect fault motions and depositional evolution. Prior to Copper Basin time, a major shift of depocenter southwest, parallel to the direction of regional tectonic transport on the lower plate, may have been due to a change in the location of the active high-angle normal fault, and a shift perpendicular to transport direction probably was caused by overtopping of a topographic barrier within the rotated fault block (Beratan, 1991).

Fault activity was episodic. The period of most active faulting probably occurred early in the history of the basin, followed by a time of relative quiescence and a final episode of block rotation. Uplift of the core of the Whipple Mountains, probably as a result of isostatic readjustment in response to tectonic denudation, raised the edge of the basin during this quiescent period, thus allowing older synextensional strata to be eroded. These units subsequently supplied clasts to the upper part of the Copper Basin Formation.

\section{ACKNOWLEDGMENTS}

This work has grown out of a Ph.D. dissertation done at the University of Southern California. Thanks to my advisor, Dr. Robert Osborne. Thanks to Dr. Gregory A. Davis for suggesting the project, and also to Lawford Anderson for providing assistance and support. Special thanks to Dr. Jane Nielson for her continuing role as collaborator and friend.

\section{REFERENCES CITED}

Beratan, K.K., 1991, Miocene synextension sedimentation patterns, Whipple Mountains, southeastern California: Implications for the geometry of the Whipple detachment system: Journal of Geophysical Research, v. 96, no. B7, p. 12,42512,442 .

Buising, A.V., 1988, Contrasting subsidence histories, northem and southem proto-Gulf of California: implications for proto-Gulf tectonic models [abs.]: Geological Society of America Abstracts with Programs, v. 20, no. 3, p. 346-147.

Davis, G.A., Anderson, J.L., Frost, E.G., and Shackelford, T.J., 1980, Mylonitization and detachment faulting in the Whipple-Buckskin-Rawhide Mountains terrane, southeastern California and western Arizona, in Crittenden, M.D., Jr., Coney, P.J., and Davis, G.H., eds., Cordilleran metamorphic core complexes: Geological Society of America Memoir 153, p. 79-129.

Grubensky, M.J., 1989, Geology of postdetachment, Miocene volcanic rocks in the southwestern Buckskin Mountains, in Spencer, J.E., and Reynolds, S.J., eds., Geology and mineral resources of the Buckskin and Rawhide Mountains, west-central Arizona: Arizona Geological Survey Bulletin 198, p. 255262.

Hazlett, R.W., 1986, Geology of the central Mopah Range; a guide for excursions in the Mopah Spring area, in Cenozoic stratigraphy, structure and mineralization in the Mojave Desert: Geological Society of America, Cordilleran Section, 82d, Los Angeles, Calif., March 1986, Guidebook and Volume, Field Trips 5 and 6, p. 33-42.

Howard, K.A., and John, B.E., 1987, Crustal extension along a rooted system of imbricate low-angle normal faults, Colorado River extensional corridor, California and Arizona, in Coward, M.P., Dewey, J.F. and Hancock, P.L., eds., Continental extensional tectonics: Geological Society of London Special Publication 28, p. 299-311.

Metzger, D.G., 1968, The Bouse Formation (Pliocene) of the Parker-Blythe-Cibola area, Arizona and California: U.S. Geological Survey Professional Paper 600-D, p. D126-D136.

Nakata, J.K, Pernokas, M.A., Howard, K.A., Nielson, J.E., and Shannon, J.R., 1990, K-Ar and fission-track ages (dates) of volcanic, intrusive, altered, and metamorphic rocks in the Mohave Mountains area, west-central Arizona: Isochron/ West, no. 56, p. 8-20. 
Nielson, J.E., and Beratan, K.K., 1990, Tertiary basin development and tectonic implications, Whipple detachment system, Colorado River extensional corridor, California and Arizona: Journal of Geophysical Research, v. 95, no. B1, p. 599-614.

Nielson, J.E., Lux, D.R., Dalrymple, G.B., and Glazner, A.F., 1990, Age of the Peach Springs Tuff, southeastern California and western Arizona: Journal of Geophysical Research, v. 95 , no. B1, p. 571-580.

Ransome, F.L., 1931, Geological reconnaissance of the revised Parker route through the Whipple Mountains: Los Angeles, Calif., Metropolitan Water District consulting report, 23 p.

1933, Final report on the geology of the Whipple Mountain tunnels: Los Angeles, Calif., Metropolitan Water District consulting report, $23 \mathrm{p}$.

Smith, P.B., 1970, New evidence for Pliocene marine embayment along the lower Colorado River area, California and Arizona: Geological Society of America Bulletin, v. 81 , no. 5 , p. $1,411-1,420$.
Spencer, J.E., Shafiqullah, M., Miller, R.J., and Pickthom, L.G., 1989, K-As geochronology of Miocene extension, volcanism, and potassium metasomatism in the Buckskin and Rawhide Mountains, in Spencer, J.E., and Reynolds, S.J., eds., Geology and mineral resources of the Buckskin and Rawhide Mountains, west-central Arizona: Arizona Geological Survey Bulletin 198, p. 184-189.

Walker, R.G. and Mutti, Emiliano, 1973, Turbidite facies and facies associations, in Middleton, G.V., and Bouma, A.H., eds., Turbidites and deep-water sedimentation: Los Angeles, Calif., Pacific Section, Society of Economic Paleontologist and Mineralogists Pacific Section Short Course, Anaheim, Calif., p. 119-157.

Young, R.A., and Brennan, W.J., 1974, Peach Springs Tuff: its bearing on structural evolution of the Colorado Plateau and development of Cenozoic drainage in Mohave County, Arizona: Geological Society of America Bulletin, v. 85, no. 1 , p. 83-90. 



\title{
Preliminary Stratigraphic Reevaluation of Upper Tertiary Units, Osborne Wash Area, La Paz County, Ariz.
}

\author{
By Anna V. B!ıising ${ }^{1}$ and Kathi K. Beratan ${ }^{2}$
}

\section{INTRODUCTION}

Gently tilted to flat-lying upper Tertiary alluvial and volcanic strata in western Arizona and adjacent parts of southeastern California have been assigned either to the Osborne Wash Formation by Davis and others (1980) or to the fanglomerate of Osborne Wash (see Carr and Dickey, 1980; Carr and others, 1980; Dickey and others, 1980). These rocks unconformably overlie more highly tilted lower to middle Tertiary strata that record basin formation during the main pulses of detachment faulting in the region. The Osborne Wash Formation has thus been interpreted as recording the end of detachment faulting. However, despite its tectonic significance, the Osbome Wash Formation remains essentially unstudied.

The goal of our current research is to isolate regionally applicable stratigraphic and paleogeomorphic criteria that will permit more accurate recognition and correlation of late-detachment rocks in the lower Colorado River area. Greater attention to details of the stratigraphy and structure of these units should provide a better understanding of the waning stages of detachment faulting. In addition, because the uppermost strata of the Osbome Wash Formation interfinger with the overlying Bouse Formation, we expect to shed further light on the subsidence that allowed waters of the proto-Gulf of California to inundate much of what is now the lower Colorado River trough during latest Miocene and Pliocene time.

This paper represents a progress report on work in the Osbome Wash-Black Peak area east of Parker, Ariz. (fig. 1), which was chosen for study because of excellent exposures of at least two sequences of late-detachment to post-detachment clastic and volcanic units, including the best-known exposures of the Osborne Wash Formation of Davis and others (1980). Work to date has included mapping and section measuring in the area east of the Colorado Rjver Indian Reservation boundary (fig. 1).

\footnotetext{
'Department of Geological Sciences, California State University, Hayward, CA 94542

${ }^{2}$ Department of Geological and Planetary Science, 321 Old Engineering Hall, University of Pittsburgh, Pittsburgh, PA 15260
}

\section{STRATIGRAPHY}

\section{OVERVIEW AND CONTACT RELATIONSHIPS}

An informal nomenclature will be used in this report, pending completion of the study. We recognize four mappable late- and postdetachment units in the study area (col. 2-P, pl. 2). These are, from oldest to youngest, the lower clastic unit, the lower volcanic unit, the upper volcanic unit, and the upper clastic unit. Some uncertainty about stratigraphic relations remains at this time.

The lower clastic unit consists of interbedded conglomerate and sandstone and is conformably overlain by mafic lava flows of the lower volcanic unit. A gentle angular discordance separates the lower and upper volcanic units. The lower clastic and lower volcanic units are overlain in a buttressing, unconformable contact by conglomerate and sandstone of the upper clastic unit, which in turn is conformably overlain by, and locally interfingers with, the basal white carbonate strata of the Bouse Formation basin-fill association (Buising, this volume).

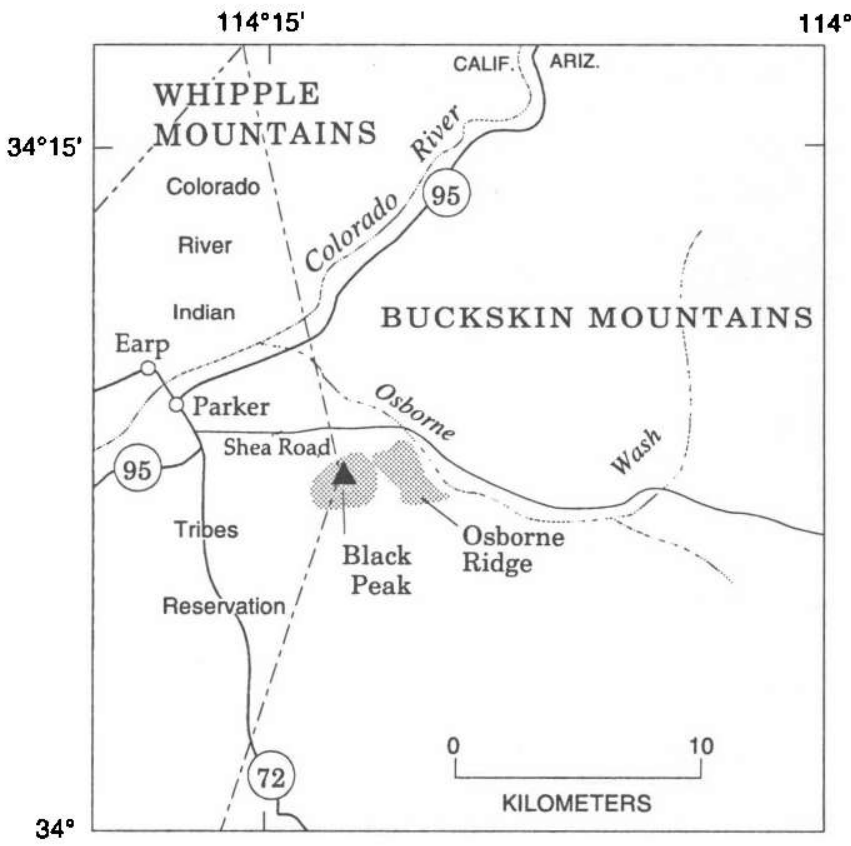

Figure 1. Map showing location of Osbome Wash area, Ariz. 
Contact relationships on Osborne Ridge (fig. 1) suggest that the lower volcanic unit conformably overlies sandstone and conglomerate of the lower clastic unit. However, an angular discordance separates volcanic strata from underlying clastic rocks at Black Peak. We hypothesize that these volcanic rocks belong to the upper volcanic unit; further mapping will allow us to test this interpretation.

The upper clastic unit is not exposed in direct contact with the upper volcanic unit in the study area. Thus, it is clear that the upper clastic unit and the Bouse Formation both postdate the lower clastic unit, and probably the conformably superposed lower volcanic unit as well, but the relationship between the upper clastic unit and the upper volcanic unit is somewhat less clear. Because the upper volcanic unit is part of the Black Peak-Osborne Ridge erosional remnant and because the erosional event(s) which produced the modern topography in this area predate(s) deposition of the upper clastic unit, we postulate that the upper clastic unit and the Bouse Formation postdate the upper volcanic unit and are separated from it by an angular unconformity (fig. 2).

\section{LOWER CLASTIC UNIT}

The lower clastic unit consists of at least $145 \mathrm{~m}$ of interbedded sandstone and conglomerate (col. 2-P, pl. 2); the base of this unit is not exposed in the Osborne Wash area. The unit displays an overall thickening and coarsening upward trend; sandstone:conglomerate ratios vary from $3: 1$ near the base of the exposed section to as much as 1:4 or 1:5 near the top of the section. Bed thicknesses are predominantly of decimeter scale; beds thicker than $1 \mathrm{~m}$ are rare and restricted to the upper one-third to one-half of the exposed section. Beds commonly are lenticular on outcrop scale. Color is predominantly grayish orange pink ( 5 YR 7/2), light brown (5 YR 6/4), or grayish orange (10 YR 7/4). In a section measured at the northeast end of

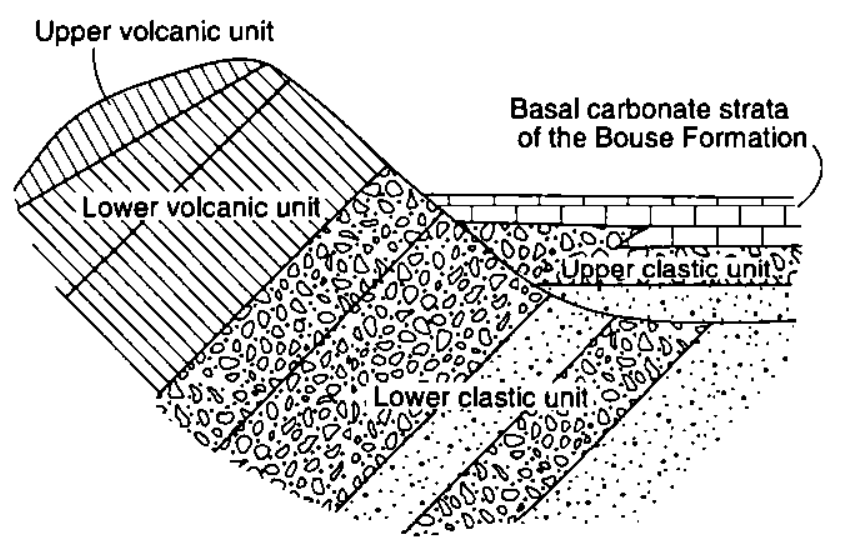

Figure 2. Sketch of geologic relations exposed in Osborne Wash area.
Osbome Ridge (fig. 1), the lower $72 \mathrm{~m}$ of section are considerably darker (moderate reddish orange, $10 \mathrm{R} 6 / 6$, and pale reddish brown, $10 \mathrm{R} \mathrm{5/4);} \mathrm{the} \mathrm{color} \mathrm{lightens} \mathrm{upward,}$ grading over about $6 \mathrm{~m}$ of section into $5 \mathrm{YR} 7 / 2$. The significance, if any, of this color change is not known. Both sandstone and conglomerate are commonly calcite cemented. Paleocurrent indicators in the lower clastic unit (primarily imbrication, with sparse data from trough cross-beds and scour and channel axes) suggest predominantly northeasterly transport, with subordinate directions to the northwest and southeast.

Sandstone units range from fine grained to very coarse grained; sand is typically angular, very poorly sorted, and lithic rich. Sandstone beds locally have erosional bases. Sedimentary structures include parallel lamination, scour and fill, and medium- to large-scale trough cross-bedding. Sandstone beds locally contain small, hemicylindrical, unwalled burrows with horizontal, branching shapes and large, near-vertical, unbranched walled burrows.

Coarse-grained clastic units range from granule and pebbly sandstone to boulder conglomerate. Both maximum and average clast sizes increase from the base of the exposed section to the top of the unit. Conglomerate units are primarily matrix supported to matrix rich. Well-washed clast-supported beds are less abundant and appear to be restricted to the upper part of the section. Sorting ranges from very poor to moderate, and the degree of sorting generally increases with decreasing matrix content. Clasts vary from angular to subrounded and include a variety of foliated high-grade metamorphic rock types (gneiss, schist, mylonite), quartzite and quartz-rich metamorphic rocks, miscellaneous granitoids (including a distinctive garnet leucogranite, several kinds of Proterozoic granite porphyry, and possibly the Fenner Gneiss of Hazzard and Dosch, 1937), Tertiary mafic to intermediate volcanic rocks, Tertiary silicic volcanic rocks (including the Peach Springs Tuff of Young and Brennan, 1974), metavolcanic rocks (Planet Volcanics of Reynolds and Spencer, 1989), and reworked red and yellow sandstone. Conglomerate units are locally structureless but commonly show well-developed imbrication and (or) reverse, reverseto-normal, or normal (commonly coarsetail) grading. They have scoured or channelized bases in a number of sites and are locally amalgamated. Trough cross-bedding occurs in at least one locality; troughs are approximately 0.5 to $1.0 \mathrm{~m}$ deep, and 5 to $6 \mathrm{~m}$ wide. Cobble and boulder trains are common throughout the unit; boulder trains increase in abundance upsection.

\section{LOWER AND UPPER VOLCANIC UNITS}

The lower and upper volcanic units both consist of mafic lava flows that are very similar in texture and composition and therefore will be described together. We distinguish two different textural types in both units, which 
will be identified as flow types 1 and 2 . The lower volcanic unit consists predominantly of type 1 with subordinate type 2 flows, whereas the upper volcanic unit is dominated by type 2 flows. Both types are similar in texture and composition to flows described by Grubensky (1989) from the southern Buckskin Mountains (fig. 1) and were probably derived from the same source. The phenocryst assemblage of both types consists of plagioclase (probably andesine or calcic labradorite), iddingsitized olivine, clinopyroxene, and oxidized opaque minerals.

Type 1 flows are medium-gray coarse-grained and trachytic-textured olivine basalt with a coarsely crystalline groundmass and abundant plagioclase, pyroxene, and olivine phenocrysts. Where flow surfaces can be distinguished, flows average about 2 to $3 \mathrm{~m}$ in thickness, and individual flows have massive cores with agglomeratic upper and lower margins. Type 2 flows are medium-gray to black fine-grained olivine basalt. The groundmass contains abundant fine-grained plagioclase laths and locally approaches a felted texture. Phenocrysts are generally rare ( $<5$ percent). Where surfaces of type 2 flows can be distinguished, the flows average about $2 \mathrm{~m}$ thick and the surfaces are fairly smooth and undulating to somewhat blocky.

Several lines of evidence, including (1) lack of truncation of lower clastic unit sedimentary beds and (2) similar attitudes of lower volcanic unit flow surfaces and bedding orientation in the lower clastic unit suggest that lava flows of the lower volcanic unit are conformable on underlying sedimentary strata. The basal few centimeters of the lower volcanic unit are strongly oxidized, due to deposition of the lowermost lava flow on a damp substrate, postdepositional movement of groundwater along the contact, or both.

\section{UPPER CLASTIC UNIT}

The upper clastic unit comprises grayish-orange-pink and light-brown (5 YR 6/4, 5 YR 7/2) conglomerate and sandy conglomerate, with less abundant sandstone interbeds. Conglomerate intervals range from massive to well bedded; bedding is generally better defined in the more clast-rich beds. Conglomerate beds are typically matrix supported; they range from clast poor to clast rich. Less abundant clast-supported beds also are present. Conglomerate beds are commonly lenticular, with lenses from $7 \mathrm{~cm}$ thick by $0.3 \mathrm{~m}$ wide to more than $0.3 \mathrm{~m}$ thick and as much as 3 to $7 \mathrm{~m}$ wide. Clasts range from gravel to boulder size and are predominantly angular to subangular but locally include subrounded material. The clast assemblage is overwhelmingly dominated by locally derived volcanic rocks; subordinate clast types include granitoids and high-grade metamorphic rocks lithologically similar to the assemblage of the lower clastic unit. The matrix contains abundant fine-grained volcanic detritus. Sedimentary structures include low-angle and curviplanar, festoon-like cross-bedding, as well as reverse and reverse-to-normal grading in conglomerate beds. Conglomerate of the upper clastic unit is locally interbedded with as much as several meters of light-colored lithic tuff.

The upper clastic unit is commonly capped by 1 to 2 $m$ of medium- to coarse-grained yellow sandstone with local conglomerate lenses. Ostracodes and centimeter-scale gastropods are common in this interval. The yellow sandstone shows medium- to large-scale trough cross-bedding and channelization. Conglomerate lenses are as much as $13 \mathrm{~cm}$ thick by $1 \mathrm{~m}$ wide with clasts from granule to boulder size. This unit commonly interfingers with the overlying basal carbonate strata of the Bouse Formation.

\section{BOUSE FORMATION}

Detailed descriptions of facies of the Bouse Formation are given by Buising (1988, this volume). Facies of the Bouse Formation exposed in the Osborne Wash area include basin-margin tufa, and basin-fill carbonate strata and mudstone. Most conspicuous are the well-bedded basalcarbonate strata of the basin-fill association, which crop out as a bright white, neariy flat-lying, 1- to 2-m-thick band that follows modern topographic contours. The carbonate strata are in buttress unconformity with tilted strata of the lower clastic unit and lower volcanic unit; they are overlain by as much as 5 to $10 \mathrm{~m}$ of poorly exposed finegrained terrigenous-clastic strata. Flat-lying, or very gently dipping strata of the basin-fill association have conformable buttress relations against basin-margin tufa, which locally forms a rind on outcrops of the lower clastic and lower volcanic units.

\section{AGE OF UNITS}

Potassium-argon ages of $20.5 \pm 3.1,16.1 \pm 0.8$, and $14.1 \pm 0.7 \mathrm{Ma}$ (whole rock) have been reported for three lava flows at Black Peak, which have been assigned to the Osborne Wash Formation (Eberly and Stanley, 1978; Shafiqullah and others, 1980; Fugro, Inc., 1975); for a summary of data, see Grubensky (1989) or Reynolds and others (1986). The age of $20.5 \mathrm{Ma}$ is probably too old, because conglomerate of the lower clastic unit contains clasts of the Peach Springs Tuff $(18.5 \pm 0.2 \mathrm{Ma}$; Nielson and others, 1990). Other workers have treated this age with caution because of its large uncertainty (for example, Grubensky, 1989).

The locations of the two samples with reported ages of 16.1 and $14.1 \mathrm{Ma}$ are outside the area mapped to date and cannot be assigned with certainty to a particular volcanic unit. Three possible interpretations of the three ages 
are suggested here; further mapping and additional dating should resolve this uncertainty.

(1) The dated samples may all be from the lower volcanic unit. In this case, the age of the lower volcanic unit is probably about 16 to $14 \mathrm{Ma}$, and the Peach Springs Tuff-bearing lower clastic unit thus was deposited between 18.5 and $16 \mathrm{Ma}$.

(2) The samples may all be from the upper volcanic unit. In this case, the age of the upper volcanic unit is 16 to $14 \mathrm{Ma}$, and the lower clastic and lower volcanic units were deposited between 18.5 and $16 \mathrm{Ma}$.

(3) The samples were collected from both the upper and lower volcanic units. In this case, the volcanic units in the Osborne Wash are between 16 and $14 \mathrm{Ma}$, and the lower clastic unit was deposited between 18.5 and $16 \mathrm{Ma}$.

The age of the upper clastic unit and the overlying Bouse Formation remain problematic. Published ages on the basal part of the Bouse Formation suggest that it may be as old as $8.1 \mathrm{Ma}$ and certainly is no younger than about $5.5 \mathrm{Ma}$ (Buising, this volume).

\section{ENVIRONMENTAL AND PALEOGEO- GRAPHIC INTERPRETATIONS}

We interpret the lower and upper clastic units as alluvial fan deposits. Paleocurrent directions suggest that the detritus in the lower clastic unit was derived from a southerly to southwesterly source (present orientation), and clast compositions require a source including exposures of both supracrustal and deep-crustal rock types. Deposition of the lower clastic unit clearly predated the development of modern topography in the western Buckskin Mountains. By contrast, the buttressing relationship between nearly flat-lying beds of the upper clastic unit and hills of the present landscape suggests that this unit was deposited on essentially modern landforms (see fig. 2). Further, although transport indicators are sparse in the upper clastic unit, its clast assemblage suggests derivation from local volcanic units and the lower clastic unit, subsequent to tilting and erosional dissection. The capping yellow sandstone of the upper clastic unit records a transition in dominant deposition mechanism from sediment gravity flow (primarily debris flow) to dilute flow. This transition probably marks the initial transgression by the proto-Gulf of California. The overlying and interfingering basal carbonate strata of the Bouse Formation are interpreted as recording the development of stable marine-estuarine carbonate deposition in the proto-Gulf.

\section{ACKNOWLEDGMENT}

Buising gratefully acknowledges the Small Grants Program at California State University, Hayward, which provided funds for radiometric dating.

\section{REFERENCES CITED}

Buising, A.V., 1988, Depositional and tectonic evolution of the northem proto-Gulf of Califomia and lower Colorado River, as documented in the Mio-Pliocene Bouse Formation and bracketing units, southeastern California and westem Arizona: Santa Barbara, University of California, Ph.D. dissertation, $196 \mathrm{p}$.

Carr, W.J., and Dickey, D.D., 1980, Geologic map of the Vidal, California, and Parker SW, California-Arizona quadrangles: U.S. Geological Survey Miscellaneous Investigations Map I-1125, scale 1:24,000.

Carr, W.J., Dickey, D.D., and Quinlivan, W.D., 1980, Geologic map of the Vidal NW, Vidal Junction, and parts of the Savahia Peak SW and Savahia Peak quadrangles, San Bernardino County, California: U.S. Geological Survey Miscellaneous Investigations Map I-1126, scale 1:24,000.

Davis, G.A., Anderson, J.L., Frost, E.G., and Shackelford, T.J., 1980, Mylonitization and detachment faulting in the Whipple-Buckskin-Rawhide Mountains terrane, southeastern California and western Arizona, in Crittenden, M.D., Jr., Coney, P.J., and Davis, G.H., eds., Cordilleran metamorphic core complexes: Geological Society of America Memoir 153 , p. $79-129$.

Dickey, D.D., Carr, W.J., and Bull, W.B., 1980, Geologic map of the Parker NW, Parker, and parts of the Whipple Mountains SW and Whipple Wash quadrangles, Califomia and Arizona: U.S. Geological Survey Miscellaneous Investigations Map I-1124, scale 1:24,000.

Eberly, L.D., and Stanley, T.B., Jr., 1978, Cenozoic stratigraphy and geologic history of southwestern Arizona: Geological Society of America Bulletin, v. 89, no. 6, p. 921-940.

Fugro, Inc., 1975, Geotechnical investigations, Parker Valley alternate site, Sun Desert Nuclear Project: San Diego, Calif., San Diego Gas and Electric Company, Section 2.5, p. 5363.

Grubensky, M.J., 1989, Geology of postdetachment, Miocene volcanic rocks in the southwestern Buckskin Mountains, in Spencer, J.E., and Reynolds, S.J., eds., Geology and mineral resources of the Buckskin and Rawhide Mountains, westcentral Arizona: Arizona Geological Survey Bulletin 198, p. $255-262$.

Hazzard, J.C., and Dosch, E.F., 1937, Archean rocks in the Piute and Old Woman Mountains, San Bernardino County, California [abs.]: Geological Society of America Proceedings for 1936, 35th Annual Meeting, p. 308-309.

Nielson, J.E., Lux, D.R., Dalrymple, G.B., and Glazner, A.F., 1990, Age of the Peach Springs Tuff, southeastern California and western Arizona: Joumal of Geophysical Research, v. 95 , no. B1, p. $571-580$.

Reynolds, S.J., Florence, F.P., Welty, J.W., Roddy, M.S., Currier, D.A., Anderson, A.V., and Keith, S.B., 1986, Compilation of radiometric age determinations in Arizona: Arizona Bureau of Geology and Mineral Technology Bulletin 197. $258 \mathrm{p}$.

Reynolds, S.J., and Spencer, J.E., 1989, Pre-Tertiary rocks and structures in the upper plate of the Buckskin detachment fault, west-central Arizona, in Spencer, J.E., and Reynolds, S.J., ed., Geology and mineral resources of the Buckskin and Rawhide Mountains, west-central Arizona: Arizona Geological Survey Bulletin 198, p. 67-102. 
Shafiqullah, M., Damon, P.E., Lynch, D.J., Reynolds, S.J., Rehrig, W.A., Raymond, R.H., 1980, K-Ar geochronology and geologic history of southwestern Arizona and adjacent areas, in Jenney, J.P., and Stone, Claudia, eds., Studies in western Arizona: Arizona Geological Society Digest, v. 12, p. 201-260.
Young, R.A., and Brennan, W.J., 1974, Peach Springs Tuff: its bearing on structural evolution of the Colorado Plateau and development of Cenozoic drainage in Mohave County, Arizona: Geological Society of America Bulletin, v. 85, no. 1, p. $83-90$.

[Note added in proof]

Two new K-Ar ages were obtained recently (table 1). A basalt flow exposed near the base of the lower volcanic unit at the north end of Osborne Ridge yielded an age of $16.8 \pm 0.6 \mathrm{Ma}$. A pumiceous lapilli tuff bed from the upper clastic unit near the south end of Osborne Ridge yielded an age of $9.2 \pm 0.3 \mathrm{Ma}$.

On the basis of these ages, the Peach Springs Tuff-bearing lower clastic unit, which underlies the dated basalt, was deposited between 18.5 and about 16.8 Ma. The upper clastic unit is at least as old as about $9.2 \mathrm{Ma}$ and no younger than about $5.5 \mathrm{Ma}$, which is the probable maximum age of the overlying Bouse Formation (Buising, this volume).

Table 1. New K-Ar ages from Osborne Ridge area.

\begin{tabular}{llcccc}
\hline \multicolumn{1}{c}{ Sample No.' } & Material dated & $\begin{array}{c}\mathrm{K}_{2} \mathrm{O} \\
(\mathrm{wt} \mathrm{pct})^{2}\end{array}$ & $\begin{array}{c}{ }^{40} \mathrm{Ar}_{\mathrm{rad}} \\
\left(10^{-11} \mathrm{~mol} / \mathrm{g}\right)^{2}\end{array}$ & $\begin{array}{c}\text { Percent } \\
40\end{array}$ & $\begin{array}{c}\text { Calculated age } \\
(\mathrm{Ma})^{3}\end{array}$ \\
\hline OWBP-ML30-11/91 & Sanidine & $(6.943)$ & $(9.2125)$ & & $9.2 \pm 0.3$ \\
& (tuff bed) & 6.937 & 9.2925 & 69.4 & \\
& & 6.949 & 9.1325 & 69.8 & \\
OWBP-LD-LVU-11/91 & Whole rock & & & \\
& & $(1.344)$ & $(3.2600)$ & & \\
& (basalt) & 1.356 & 3.2075 & 50.0 & \\
& & 1.332 & 3.3100 & 50.7 & \\
\hline
\end{tabular}

'Dating by Geochron Laboratories, Cambridge, Mass. Both samples were crushed to $-80 /+200$ mesh and treated with dilute $\mathrm{HF}$ and $\mathrm{HNO}_{3}$.

${ }^{2}$ Value in parentheses is arithmetic mean used in age calculation.

${ }^{3} \mathrm{~K}$-Ar ages were calculated using these constants for the radioactive decay and abundance of ${ }^{40} \mathrm{~K}$ : $\lambda_{\alpha}=0.581 \times 10^{-10} \mathrm{yr}^{-1}, \lambda_{\beta}=4.962 \times 10^{-10} \mathrm{yr}^{-1}$, and ${ }^{40} \mathrm{~K} / \mathrm{K}_{\text {total }}=1.193 \times 10^{-4} \mathrm{~g} / \mathrm{g}$.

${ }^{4}$ For basalt sample, a plagioclase concentrate (nonmagnetic fraction of whole rock) yielded an impossibly old age. The age reported here was obtained using residuum from the plagioclase separation (magnetically susceptible material, chiefly glass and ferromagnesian minerals). This material was reportedly 90 to 98 percent plagioclase free. 



\title{
Stratigraphic Overview of the Bouse Formation and Gravels of the Colorado River, Riverside Mountains, Eastern Vidal Valley, and Mesquite Mountain Areas, Calif. and Ariz.
}

\author{
By Anna V. Buising ${ }^{1}$

\section{INTRODUCTION}

\section{BOUSE FORMATION}

Strata of the Bouse Formation (Miocene and Pliocene) record inundation of much of what is now the lower Colorado River region by waters of the proto-Gulf of California and subsequent progradation of the ancestral Colorado River delta into the northern end of the proto-Gulf embayment. The Bouse Formation is exposed in discontinuous erosional remnants over an area of several thousand square kilometers along the Colorado River trough and in neighboring valleys (fig. 1). Among the best exposures are those at Mesquite Mountain (fig. 1), which preserve as much as 60 to $70 \mathrm{~m}$ of deltaic section as well as extensive shoreline complexes. Excellent exposures also occur west of the Colorado Rjver on the northeast flank of the Riverside Mountains. Stratigraphic data in this paper are drawn primarily from study of the Riverside Mountains, eastern Vidal Valley, and Mesquite Mountain exposures, supplemented by information from Trigo Mountains exposures of the basal carbonate strata of the Bouse Formation.

In this paper, I preserve Metzger's (1968) definition of the Bouse Formation but use a revised internal stratigraphy subdividing the Bouse into two coeval, interfingering facies associations, the basin-margin and basin-fill associations (fig. 2). This breakdown is evident in most exposures, as little-deformed strata of the Bouse largely preserve original depositional geometries and facies relationships.

Outcrop relationships between units of the basin-margin and basin-fill associations reflect irregular basin topography during Bouse deposition. Basin margin strata commonly dip from $5^{\circ}$ to $30^{\circ}$ basinward. Their attitude is controlled by the shape of uneven pre-Bouse topography; beds wrap around the curved flanks of topographic highs or dip into pre-Bouse drainages from both sides. As a result, flat-lying basin-fill beds locally buttress against contemporaneous, basinward-dipping basin-margin strata.

\footnotetext{
'Department of Geological Sciences, California State University, Hayward, CA 94542
}

\section{BASIN-MARGIN ASSOCIATION}

The basin-margin association includes a light-gray shoreline tufa interbedded with a variety of carbonate- and terrigenous-clastic lithofacies. The tufa commonly occurs as a hard, porous rind coating basement rocks. Several horizons of tufa can be distinguished at most localities; individual layers are generally less than $0.5 \mathrm{~m}$ thick. Stratal attitudes vary from nearly horizontal on gently dipping surfaces to vertical on cliff faces, reflecting the topography of underlying basement exposures. Outcrops of tufa commonly extend over as much as $100 \mathrm{~m}$ of elevation. The continuity of tufa exposures in many locations (for example, Mesquite Mountain) suggests that this represents original deposition, rather than an outcrop pattern produced by later faulting. In many places the depositional base of the tufa is marked by a sedimentary breccia consisting of highly angular, very poorly sorted granule- to boulder-grade clasts of the local basement in a matrix of gray limestone. Similar breccia locally occurs interbedded with the tufa. The tufa locally shows branching tubular structures in outcrop and microtubules and millimeter-scale laminae in thin section.

The tufa intercalates with both carbonate-clastic and terrigenous-clastic strata. Clastic carbonate strata are white to gray, are moderately to well bedded on a scale of 1 to $4 \mathrm{~cm}$, and include clastic limestone and barnacle coquina, which is dominated by the delicate plates of Balanus canabus (new species; Zullo and Buising, 1989). Clastic limestone locally grades into calcareous lithic sandstone containing abundant locally derived granule- to pebblegrade clasts. Sedimentary structures in clastic limestones include medium- to large-scale trough cross-bedding, medium-scale low-angle wedge-set planar and gently curviplanar cross-bedding, roughly domical cross-bedding reminiscent of hummocky cross-stratification, and symmetrical ripples. Terrigenous-clastic interbeds include conglomerate and medium- to coarse-grained, locally parallel-laminated yellow sandstone. Conglomerate varies from crudely to well bedded (beds $2 \mathrm{~cm}$ to $1 \mathrm{~m}$ thick) and 
from matrix to clast supported. Sedimentary structures include large-scale trough cross-bedding and low-angle cross-bedding; unbedded zones show reverse and reverseto-normal grading. Terrigenous-clastic units are pervasive along strike of the Bouse shoreline, although they are locally discontinuous due to erosion and (or) coastline irregularity. Their basinward extent is limited in most cases to less than 50 to $100 \mathrm{~m}$.

The basin-margin association of the Bouse Formation records deposition at and near the Bouse shoreline (Buising, 1988). I agree with Metzger (1968) in interpreting the tufa as representing the Bouse shoreline per se. It seems unlikely that the entire vertical extent of modern outcrop was active shoreline at one time; the present outcrop pattern may record either the slow rise and fall of sea level or minor sea level fluctuations during the lifetime of the northern proto-Gulf. The presence of biogenic structures such as algal laminae and microscopic and macroscopic tubules suggests that carbonate precipitation was at least locally biologically controlled. Where such structures are absent, tufa precipitation may have been inorganic.

Clastic limestone records shoreline reworking of estuarine carbonate material; large- and medium-scale crossbedding attest to the activity of strong currents, which may have been either tidal or wave generated. Wedge-set and hummock-like cross-bedding as well as the gentle basinward dip of these beds are consistent with deposition by wave currents. Barnacle beds are interpreted as resulting from nearshore reworking of intrabasinal barnacle detritus. Local admixture of terrigenous clasts indicates intermittent or localized terrigenous-clastic input to the shoreline carbonate environment. Terrigenous-clastic strata reflect higher-volume input of detritus from immediately adjacent highlands. This resulted in basinward progradation of small alluvial fans and (or) fan deltas, where debris-flow processes (matrix-supported conglomerate and reverse-

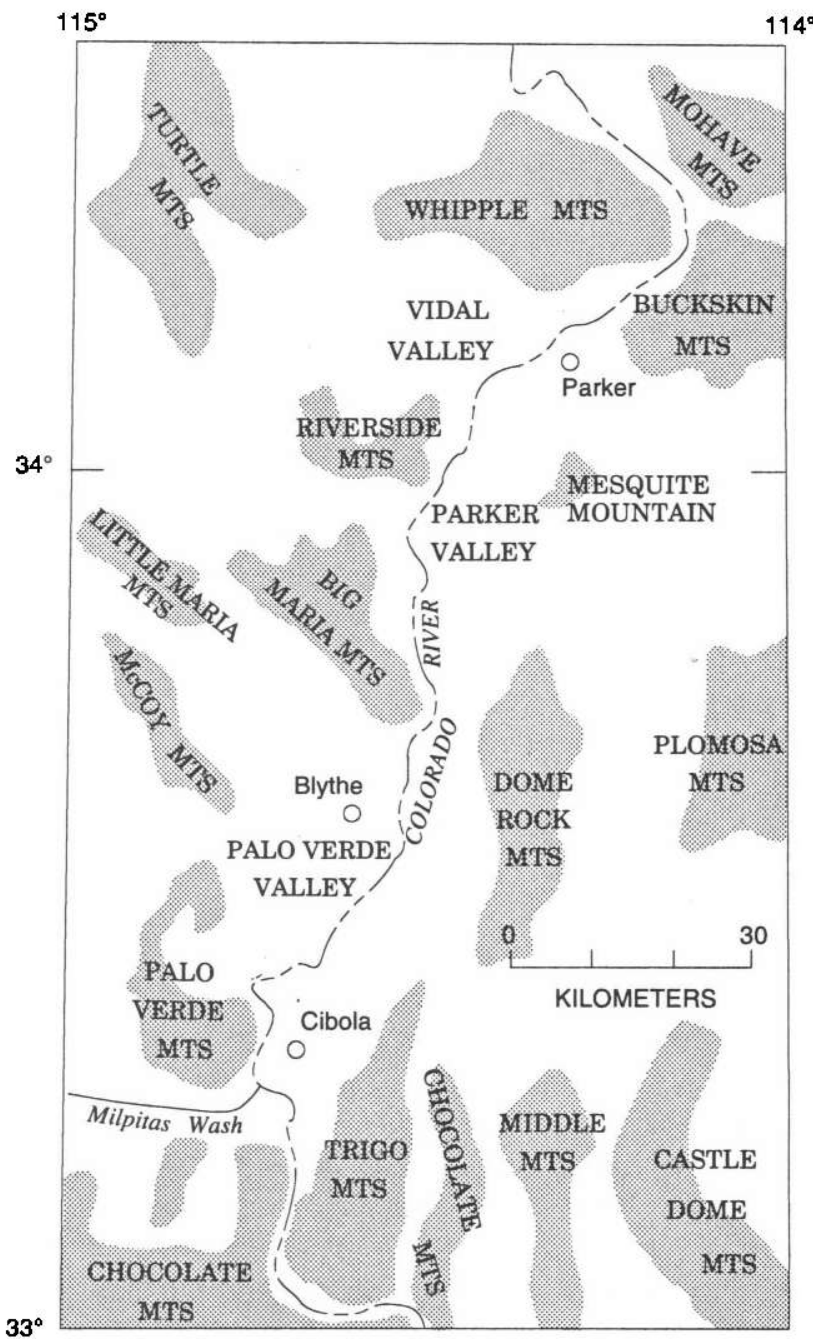

Figure 1. Left, Known extent of exposed and unexposed Bouse Formation deposits (dark stipple; southern limit is uncertain, as shown by queries) and discontinuous exposure of related stratigraphic units and structural trends of the proto-Gulf of California (light stipple) (modified from Buising, 1988). Right, Locations of geographic features named in text. 
and reverse-to-normal graded conglomerate) alternated with high-energy dilute flow deposition (trough cross-bedded and low-angle cross-bedded units).

\section{BASIN-FILL ASSOCIATION}

The basin-fill association of the Bouse Formation comprises a lower, carbonate sequence and an upper, terrigenous-clastic-dominated sequence (fig. 2). Exposed thicknesses vary greatly. The basal carbonate unit ranges from $\sim 1$ to $6 \mathrm{~m}$ thick in outcrops, and the maximum exposed thickness of the terrigeneous-clastic sequence is 60 to $70 \mathrm{~m}$.

The carbonate sequence is equivalent to the basal limestone of Metzger (1968) and to the basal marl of Winterer (1975). It consists of bedded clastic limestone (including at its base about $9 \mathrm{~cm}$ of locally derived carbonate-matrix pebble to cobble breccia) with interbeds of barnacle coqui- na. The carbonate sequence is characteristically bright white and well bedded, with beds from 1 to $5 \mathrm{~cm}$ thick, locally showing millimeter-scale internal lamination.

Sedimentary structures in the carbonate sequence include trough cross-bedding (set height ranges from ripple scale to greater than $1 \mathrm{~m}$ ), sigmoidal cross-bedding (set height $9-15 \mathrm{~cm}$ ), normal and possible reverse-to-normal grading, local draping over barnacle-encrusted boulders, and probable bioturbation. Winterer (1975) has reported greater than 50 percent terrigenous-clastic material in samples of the basal marl; by contrast, samples I have studied contain less than 20 percent terrigenous clasts, primarily quartz, feldspar (plagioclase, microcline, untwinned K-feldspar), locally derived metamorphic rock fragments, biotite, and epidote. Sparse, angular granules of local basement rocks are also locally present. Barnacle coquina interbeds range from 1 to $5 \mathrm{~cm}$ thick and in many cases are lenticular on a scale of 1 to $10 \mathrm{~m}$, with detritus locally fining basinward.

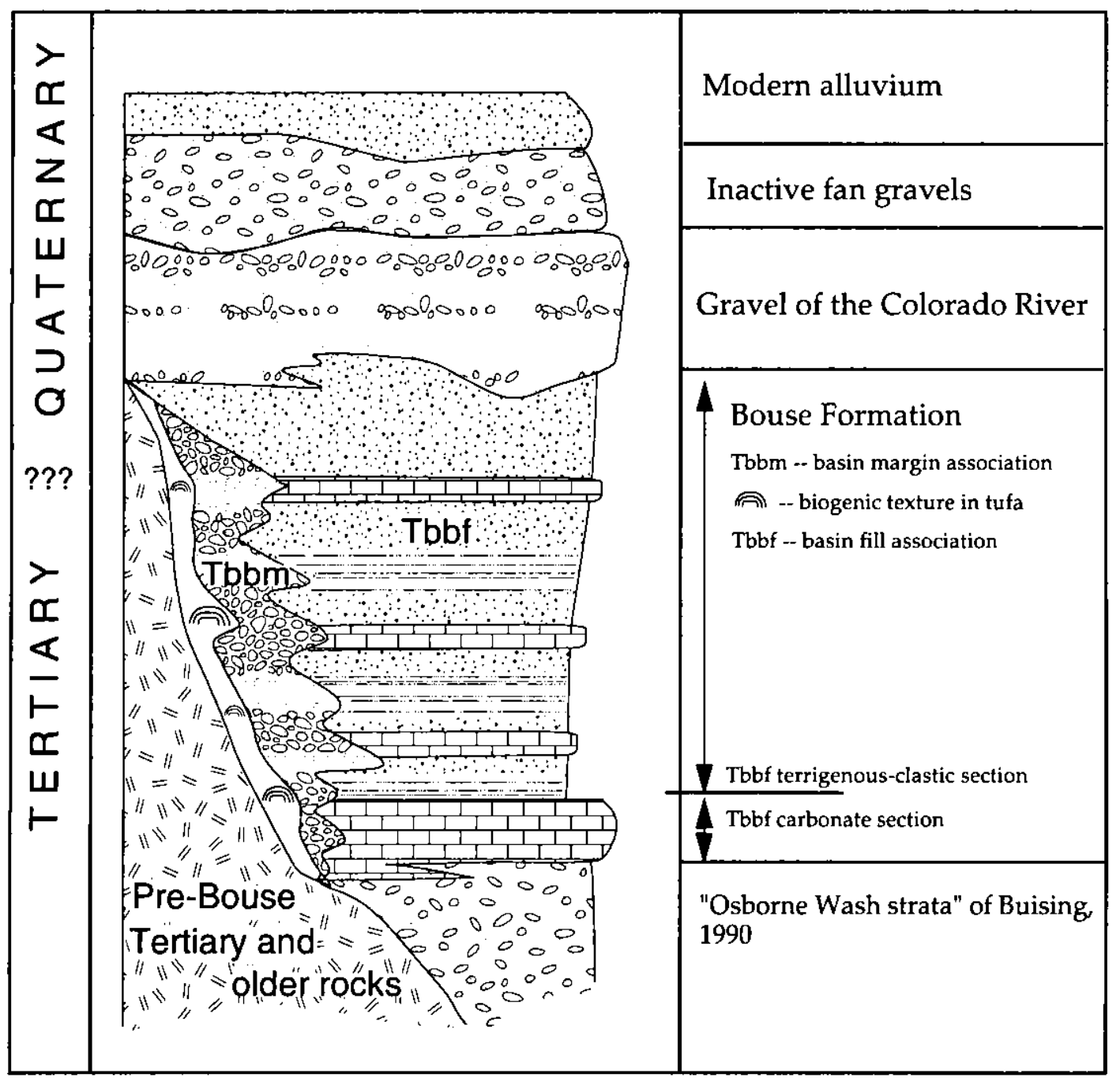

Figure 2. Generalized stratigraphy of Bouse Formation and underlying and overlying units, lower Colorado River area. No vertical scale; exposed thicknesses vary along strike. See text for detailed descriptions. 
The upper, terrigenous-clastic sequence of the basinfill association shows a coarsening-upward trend. The lower part is dominated by interbedded red, green, and yellow mudstone with pink siltstone and white limestone interbeds; siltstone and fine-grained sandstone become more abundant upsection, and the upper 10 to $15 \mathrm{~m}$ consist entirely of pink siltstone and sandstone with minor pebbly sandstone and lenses of locally derived cobble to boulder breccia.

Mudstone in the terrigenous-clastic sequence is generally well bedded, with bed thickness ranging from 2.5 to $7 \mathrm{~cm}$. Bed thickness varies on outcrop scale; beds are commonly lenticular or discontinuous. Sedimentary structures include parallel lamination, ripple cross-lamination (primarily migrating ripples with wavelength less than 2 $\mathrm{cm}$, amplitude less than $1 \mathrm{~cm}$ ), shrinkage cracks (probably including both mudcracks and subaqueous syneresis cracks), and soft-sediment deformation, including convolute bedding, load casts, and flame structures. Centimeterscale sand-silt bedding couplets resembling tidal bedding as defined by Klein (1977) occur locally. Some localities show clusters of calcareous blebs and nodules that are believed to represent poorly developed caliche horizons.

Siltstone beds in the terrigenous clastic sequence range in thickness from less than $1 \mathrm{~cm}$ to more than $1 \mathrm{~m}$, with average bed thickness increasing upsection. Beds are locally erosive based or channelized. The principal sedimentary structures of siltstones and sandstones include trough cross-bedding, parallel lamination, current lineations, and ripple cross-lamination (in- and out-of-phase climbing ripples, migrating ripples). Herringbone trough cross-bedding is locally present. Trough cross-beds and parallel laminations commonly pass laterally or upsection into rippled horizons. Scale of trough cross-bedding and channelization correlate directly with bed thickness. Subsidiary sedimentary structures of siltstones and sandstones include soft-sediment deformation (millimeter-scale to horizons several meters thick) and basal load casting. Abandoned channels are commonly filled with green or red mud, which locally contains abundant barnacle fragments. Paleocurrent orientations suggest southwesterly to southeasterly transport, with a strong northerly inland component and extreme complexity near the paleoshoreline (Buising, 1990).

Rocks of the basin-fill association are commonly fossiliferous. Mudstone and claystone locally contain land plant fragments, barnacles, foraminifers, and ostracodes. Limestone interbeds include barnacles and centimeter-scale high-spired gastropods. Siltstone and sandstone locally contain barnacles, rootlets, and in one locality, calcareous rhizoliths.

I interpret the basal carbonate strata of the basin-fill association as marine-estuarine deposits of the proto-Gulf of California (Buising, 1988). The basal breccia probably records the transition from dilute-flow terrigenous-clastic deposition during the initial phases of transgressionrecorded in a 1- to 2-m-thick yellow sandstone that caps the underlying fanglomerate sequence (Osborne Wash Formation of Davis and others, 1980; approximately equivalent to the upper clastic unit of Buising and Beratan, this volume) - to carbonate deposition in a stable estuarine environment, recorded in overlying limestone. The presence of varying amounts of siliciclastic material in the limestone indicates continued terrigenous input to the basin, although this sediment was never sufficiently abundant to interfere with carbonate precipitation. Although Winterer (1975) suggested that carbonate fixation might have been due to algal activity, abundant traction structures indicate clastic reworking of carbonate detritus, regardless of its ultimate source. Large-scale trough cross-bedding indicates at least intermittent strong currents; sigmoidal cross-beds suggest that these currents may have been tidal in origin. Normal and reverse-to-normal graded beds may record sediment gravity flow deposition. Bioturbation and fossil content suggest a thriving biologic community.

The upper, terrigenous-clastic part of the basin-fill association records progradation of a regionally extensive deltaic complex into the northern end of the proto-Gulf (Lucchitta, 1972, 1979; Buising, 1988). Disregarding nearshore complexities, paleocurrent directions suggest derivation from a source to the north or northeast; northwarddirected paleocurrents probably reflect a tidal influence. Sedimentary structures and bedding geometry of basin-fill association mudstone and claystone reflect depositional processes on interdistributary flats of this low-gradient, tidally influenced delta system. Siltstone and sandstone of the basin-fill association are interpreted as distributary channel deposits where channelized or scoured, and as overbank deposits where their bases are not erosive. Lenses and interbeds of locally derived coarse-clastic material in the sandstone and siltstone of the upper part of the basin-fill association reflect intermittent increases in local energy conditions, such that coarse detritus supplied to the basin was periodically transported downchannel along deltaic distributaries instead of remaining restricted to small marginal alluvial fans, as was the case for locally derived coarse-clastic material lower in the section. This change can be linked to the southward progradation of the deltaic complex and concomitant increase in average local energy.

Soft-sediment deformation in terrigenous-clastic basinfill association sediments may have resulted from several causes. Load casting and flame structures suggest rapid deposition of water-rich sediment. Small-scale convolute bedding may reflect slumping on oversteepened slopes, perhaps on channel margins or levees. Larger scale occurrences of disturbed bedding are most common on the flanks of basement highs; they are locally associated with the development of an intraformational erosional surface, as in the vicinity of Cibola (fig. 1). These cases may reflect wholesale slumping of oversteepened beds deposited 
on an inclined substrate. Alternatively, large-scale slumping may be due to periodic tectonic activity, possibly associated with continued subsidence, or to compaction-related settling.

\section{GRAVELS OF THE COLORADO RIVER}

The Bouse Formation is overlain by a section of cobble conglomerate and associated finer grained clastic material herein referred to informally as the gravels of the Colorado River (hereinafter referred to as the Colorado River gravels for the sake of brevity) (see also Metzger and others, 1973; Metzger and Loeltz, 1973). Although the base of the Colorado River gravels-defined as the stratigraphically lowest occurrence of trough cross-bedded, far-traveled conglomerate-is typically erosional, the conglomerate interfingers with trough cross-bedded sandstone and siltstone of the underlying Bouse Formation. Minor angular discordance exists locally.

The characteristic lithofacies of the Colorado River gravels is gray, trough cross-bedded cobble conglomerate, with trough sets up to slightly greater than $1.6 \mathrm{~m}$ in height. Trough orientations indicate predominantly southwesterly to southeasterly transport, with rare outcrops indicating northeasterly transport. Conglomerates include both matrix-poor and matrix-rich deposits. Clast types include red, yellow, and white metaquartzite, red and yellow jasper, intermediate volcanic porphyry, various granitoids, gray fossiliferous limestone, and locally derived metamorphic rocks. The metaquartzite clasts are without exception very well rounded; other metamorphic clasts are highly angular. Other clast types display a range of intermediate degrees of rounding.

The Colorado River gravels also contain lenses and interbeds of pink to reddish sand and silt and red mud. These horizons are distinguished from interfingering tongues of the uppermost part of the Bouse Formation by their stratigraphic position entirely within the gravels and by their redder color. Sand and silt beds range from 1 to $12 \mathrm{~cm}$ in thickness; sedimentary structures include millimeter-scale parallel lamination, small-scale and ripple trough cross-bedding, in- and out-of-phase stacked symmetrical ripples (wavelength from 5 to $9 \mathrm{~cm}$, amplitude from 0.5 to $0.7 \mathrm{~cm}$ ), and starved ripples capped by mud fallout. Minor interbeds of white, highly calcareous clay and lenses (to $0.5 \mathrm{~cm}$ thick, $2 \mathrm{~m}$ long) and interbeds (to $5 \mathrm{~cm}$ thick) of crystalline gypsum are locally present.

Abundant trough cross-bedding, scour, and channelization suggest that the conglomerates of the Colorado River gravels represent channel deposits recording the arrival of the throughgoing Colorado fluvial system in the Gulf province (Lucchitta, 1972, 1979; Buising, 1988). The dominance of coarse-grained sediment and the large scale of bedforms indicate a high-energy system. Clast types re- flect both distant and local sources. Many metamorphic clasts are clearly derived from fairly local basement exposures; however, well-rounded clasts of quartzite, jasper, and fossiliferous limestone are believed to have been derived from Paleozoic and Mesozoic source rocks exposed on the Colorado Plateau. Fine-grained clastic material interbedded with Colorado fluvial conglomerates may represent overbank or interchannel deposits. Reddish color and the presence of local gypsum lenses indicate periods of subaerial exposure and a warm, fairly dry climate.

\section{AGE OF THE BOUSE FORMATION AND GRAVELS OF THE COLORADO RIVER}

Several K-Ar ages have been published for a tuffaceous interbed in Milpitas Wash exposures of the Bouse basin-fill carbonate association sequence: $8.1 \pm 0.5 \mathrm{Ma}$ (P.E. Damon, in Metzger and others, 1973), 5.47 $\pm 0.20 \mathrm{Ma}$ (Damon and others, 1978; Shafiquallah and others, 1980), and $3.02 \pm 1.15 \mathrm{Ma}$ (glass in partially devitrifed sample; P.E. Damon, in Metzger and others, 1973). The 3.02-Ma age can be regarded as a minimum due to the potential disturbance of $\mathrm{K}$-Ar ratios during devitrification. However, both regional stratigraphic patterns and imprecise age estimates based on paleontology (Smith, 1960, 1970; Winterer, 1975) appear to permit either the 5.47-Ma or the 8.1Ma age (Buising, 1990).

Since the Bouse Formation interfingers with underlying fanglomerate, it should be possible to use the age of the fanglomerate to further constrain age estimates on the basal part of the Bouse Formation. Unfortunately, however, the age of the upper part of the fanglomerate (upper clastic unit of Buising and Beratan, this volume, which is for the most part equivalent to the Osborne Wash Formation of Davis and others, 1980) remains uncertain.

Regional correlation provides a tentative age constraint for the upper terrigenous-clastic part of the basinfill association. Magnetostratigraphic work of Johnson and others (1983) indicates an age of 4.3 Ma for the marine basal part of the Imperial Formation in the western Salton Trough. This led Winker (1987) to suggest an age of $4 \mathrm{Ma}$ for the stratigraphically lowest occurrence of far-traveled Colorado River detritus in the Imperial Formation. This horizon of the Imperial Formation probably corresponds roughly to the base of the deltaic section in the Bouse Formation. The delta presumably reached the Parker area sometime before its arrival in the Salton Trough to the southwest (fig. 1). Thus, the basal part of the deltaic clastic section in the Parker area is probably older than $4 \mathrm{Ma}$.

Basalt flows overlying Colorado River fluvial gravels in the Lake Mead area have $\mathrm{K}$-Ar ages of $3.79 \pm 0.46 \mathrm{Ma}$ and $3.80 \pm 0.11 \mathrm{Ma}$ (whole-rock; Shafiqullah and others, 1980), suggesting that the gravels themselves are older than about 3.5 to $4 \mathrm{Ma}$. Since the fluviodeltaic system 
prograded southward, Colorado River gravels in the Parker area could be somewhat younger than their Lake Mead counterparts.

\section{SUMMARY}

The Bouse Formation and overlying Colorado River gravels document four stages in the evolution of the lower Colorado River region. Initial transgression of this area by waters of the proto-Gulf of California is believed to be recorded in an ostracode- and gastropod-bearing sandstone that caps the underlying fanglomerate sequence (see Buising and Beratan, this volume). Stabilization of a marineestuarine carbonate environment is recorded in the basal carbonate strata of the Bouse Formation. This probably occurred no earlier than about $8.1 \mathrm{Ma}$ and no later than about 5.5 Ma. Fine-grained terrigenous-clastic material of the Bouse basin-fill association upper member records progradation of the ancestral Colorado River delta into the northern end of the proto-Gulf embayment slightly before 4.3 Ma; the Colorado River gravels themselves document arrival of the fluvial channel proper atop its own deltaic deposits prior to 3.5 to $4 \mathrm{Ma}$.

\section{REFERENCES CITED}

Buising, A.V., 1988, Depositional and tectonic evolution of the northern proto-Gulf of California and lower Colorado River, as documented in the Mio-Pliocene Bouse Formation and bracketing units, southeastern California and western Arizona: Santa Barbara, University of California, Ph.D. dissertation, $196 \mathrm{p}$.

1990, The Bouse Formation and bracketing units, southeastern California and western Arizona: implications for the evolution of the proto-Gulf of California and the lower Colorado River: Joumal of Geophysical Research, v. 95, no. B12, p. 20,111-20,132.

Damon, P.E., Shafiqullah, M., and Scarborough, R.B., 1978, Revised chronology for critical stages in the evolution of the lower Colorado River [abs.]: Geological Society of America Abstracts with Programs, v. 10, no. 3, p. 101-102.

Davis, G.A., Anderson, J.L., Frost, E.G., and Shackelford, T.J., 1980, Mylonitization and detachment faulting in the Whipple-Buckskin-Rawhide Mountains terrane, southeastern California and western Arizona, in Crittenden, M.D., Jr., Coney, P.J., and Davis, G.H., eds., Cordilleran metamorphic core complexes: Geological Society of America Memoir 153, p. 79-129.
Fugro, Inc., 1975, Geotechnical investigations, Parker Valley alternate site, Sun Desert Nuclear Project: San Diego, Calif., San Diego Gas and Electric Company consulting report, section 2.5, p. 53-63.

Johnson, N.M., Officer, C.B., Opdyke, N.D., Woodard, G.D., Zeitler, P.K., and Lindsay, E.H., 1983, Rates of late Cenozoic tectonism in the Vallecito-Fish Creek basin, western Imperial Valley, California: Geology, v. 11, no. 11, p. 664-667.

Klein, G.D., 1977, Clastic tidal facies: Champaign, Ill., Continuing Education Publication Company (CEPCO), 149 p.

Lucchitta, Ivo, 1972, Early history of the Colorado River in the Basin and Range province: Geological Society of America Bulletin, v. 83, no. 7, p. 1,933-1,948.

1979, Late Cenozoic uplift of the southwestern Colorado Plateau and adjacent lower Colorado River region: Tectonophysics, v. 61, nos. 1-3, p. 63-95.

Metzger, D.G., 1968, The Bouse Formation (Pliocene) of the Parker-Blythe-Cibola area, Arizona and Califomia: U.S. Geological Survey Professional Paper 600-D, p. D126D136.

Metzger, D.G., and Loeltz, O.J., 1973, Geohydrology of the Needles area, Arizona, California, and Nevada: U.S. Geological Survey Professional Paper 486-J, 54 p.

Metzger, D.G., Loeltz, O.J., and Irelan, Burdge, 1973, Geohydrology of the Parker-Blythe-Cibola area, Arizona and California: U.S. Geological Survey Professional Paper 486-G, $130 \mathrm{p}$.

Shafiqullah, M., Damon, P.E., Lynch, D.J., Reynolds, S.J., Rehrig, W.A., and Raymond, R.H., 1980, K-Ar geochronology and geologic history of southwestern Arizona and adjacent areas, in Jenney, J.P., and Stone, Claudia, eds., Studies in western Arizona: Arizona Geological Society Digest, v. 12, p. 201-260.

Smith, P.B., 1960, Fossil Foraminifera from the southeastern California deserts: U.S. Geological Survey Professional Paper 400-B, p. B278-B279.

1970, New evidence for Pliocene marine embayment along the lower Colorado River area, Califomia and Arizona: Geological Society of America Bulletin, v. 81, no. 5, p. 1,411-1,420.

Winker, C.D., 1987, Neogene stratigraphy of the Fish Creek-Vallecito section, southem California: implications for early history of the northern Gulf of California and Colorado delta: Tucson, University of Arizona, Ph.D. dissertation, 494 p.

Winterer, J.I., 1975, Biostratigraphy of the Bouse Formation: A Pliocene Gulf of California deposit in California, Arizona, and Nevada: Long Beach, California State University, M.S. thesis, $230 \mathrm{p}$.

Zullo, V.A., and Buising, A.V., 1989, An unusual species of the Balanus amphitrite Darwin complex (Cirripedia, Balanidae) from the ancestral Colorado River delta in western Arizona and southeastern California: Proceedings of the Biological Society of Washington, v. 102, no. 4, p. 924-932. 


\title{
Introduction to Tertiary Stratigraphy of the Area South of I-10, Ariz. and Calif.
}

\author{
By Stephen M. Richard ${ }^{1}$ and David R. Sherrod ${ }^{2}$
}

Reports in this chapter describe stratigraphic relations of Tertiary rocks in southeast California and southwest Arizona north of the Gila River (fig. 1). Tertiary rocks occupy a northeast-trending belt between the edge of the Transition Zone physiographic province in Arizona (Spencer and Reynolds, 1989b) and the Salton Trough in California.

A three- or four-part stratigraphic sequence characterizes the Tertiary rocks, although the age relations between the parts vary across the region. Many mountain ranges expose (1) a prevolcanic, arkosic sedimentary unit, (2) a middle, mostly volcanic unit, and (3) an upper sedimentary unit with interbedded basalt and rhyolite lava flows (see Eberly and Stanley, 1978; Scarborough, 1989). The fourth part of the sequence, youngest sedimentary rocks, are mainly limited to the basins between mountain ranges, but their depositional relationship to underlying units is commonly exposed along the range fronts.

Prevolcanic sedimentary sequences are generally thin except in the trough along the Gila River (Olmsted and others, 1973; Spencer and Reynolds, 1989b; Lombard, this volume). The age of the oldest of these rocks is poorly known but presumably is not older than late Eocene. A younger age limit is bracketed by overlying volcanic rocks: early Oligocene in the lower Colorado River region (for example, Sherrod and Hughes, this volume) and progressively younger-late Oligocene to early Miocene-toward the northeast (Richard, this volume, Big Horn Mountains area; Sherrod, this volume). In most areas, onset of volcanism abruptly terminated the deposition of arkosic strata. However, in the Gila trough, a structural basin that parallels the modern Gila River from Muggins Mountains to Sentinel Plain (fig. 1), thick deposits of breccia, debris flows, conglomerate, and sandstone continued to accumulate along with minor volcanic rocks that have K-Ar ages between 27 and $23 \mathrm{Ma}$ (Olmsted and others, 1973; Scarborough and Wilt, 1979; Pridmore, 1983; Lombard, this volume).

The rocks of the volcanic unit vary from basalt to rhyolite and are alkali-calcic to calc-alkaline in character (Annis and Keith, 1986; Spencer and Reynolds, 1989b). Volcanic

\footnotetext{
${ }^{1}$ Arizona Geological Survey, 845 N. Park Ave., Tucson, AZ 85719

${ }^{2}$ U.S. Geological Survey, 5400 MacArthur Blvd., Vancouver, WA 98661
}

rocks discussed in this section form a nearly continuous outcrop belt from southeastern California east and northeast into central Arizona (fig. 1). Volcanism began in the lower Colorado River region about $32 \mathrm{Ma}$ with the eruption of the Quechan volcanic rocks of Crowe (1978), a sequence of mainly andesitic to dacitic lava flows and fewer volcaniclastic rocks (Mayo, this volume; Richard, this volume, Ferguson Wash area; Sherrod and Hughes, this volume). In general, the initiation of volcanism becomes progressively younger to the northeast along this belt to as young as about $22 \mathrm{Ma}$ (compare columns 3-G and 3-E, southwest, with 3-C, 3-B, and 3-A, northeast). Volcanic sequences in the southwestern part of the region are characterized by silicic ash-flow tuffs, whereas northeastern sections are characterized by silicic domes and lava flows with very local pyroclastic deposits. Basalt to dacite lava flows typically underlie and are interbedded with the silicic rocks throughout the belt. Eruption of major pyroclastic flows began about 27-25 $\mathrm{Ma}$ in the lower Colorado River region (Crowe, 1978; Crowe and others, 1979); silicic lavas are as old as $21 \mathrm{Ma}$ in the northeast (Capps and others, 1985; data summarized in table 1 of Richard, this volume, Big Horn Mountains area).

Widespread sedimentation that formed the upper, mainly postvolcanic sedimentary unit followed a major pulse of early Miocene extensional deformation, which occurred after $22 \mathrm{Ma}$ in most of the area discussed here. The sedimentary rocks are chiefiy sandstone, conglomerate, and sedimentary breccia; one such unit is the conglomerate of Bear Canyon (Crowe, 1978; Hughes, this volume). The conglomerate of Bear Canyon is syntectonic; its older parts typically dip more steeply than younger parts, and minor intraformation unconformities are widespread. Basalt and rhyolite interbedded in the clastic units range in age from about $17 \mathrm{Ma}$ in the northeast to as young as $13 \mathrm{Ma}$ in the southwest, but the eruptive sites are too spotty and poorly dated to define a pattern. Between 15 and $12 \mathrm{Ma}$ the chemistry of the volcanic rocks changed as sedimentation continued; after this time mostly alkaline basalt was erupted (Spencer and Reynolds, 1989b), with sparse associated rhyolite

Upper Miocene and Pliocene sedimentary rocks, the fourth and youngest part of the stratigraphic sequence, were deposited in the present physiographic and structural 
basins. In most places they consist of subaerial conglomerate, sandstone, and siltstone; lacustrine mudstone and evaporite are found locally. Marine and estuarine lime- stone, siltstone, and sandstone of the upper Miocene and Pliocene Bouse Formation (for example, Buising, this volume) record a complex setting of estuaries and deltas

\section{EXPLANATION}

Sedimentary rocks and deposits (Holocene to Miocene)-Includes middle Miocene fanglomerate deposited during extensional deformation. Also includes minor upper Miocene and Pliocene basalt flows

Volcanic rocks (Miocene and Oligocene)-Mainly 32-15 Ma. Include minor Tertiary granite

Len Sedimentary and volcanic rocks (Miocene and Oligocene)-Mainly in Laguna, Muggins, and Gila Bend Mountains

Orocopia Schist (Mesozoic) - Includes some large granitic intrusive masses of Mesozoic and Tertiary age in westem Chocolate Mountains

Meta-igneous and metasedimentary rocks (pre-Tertiary)

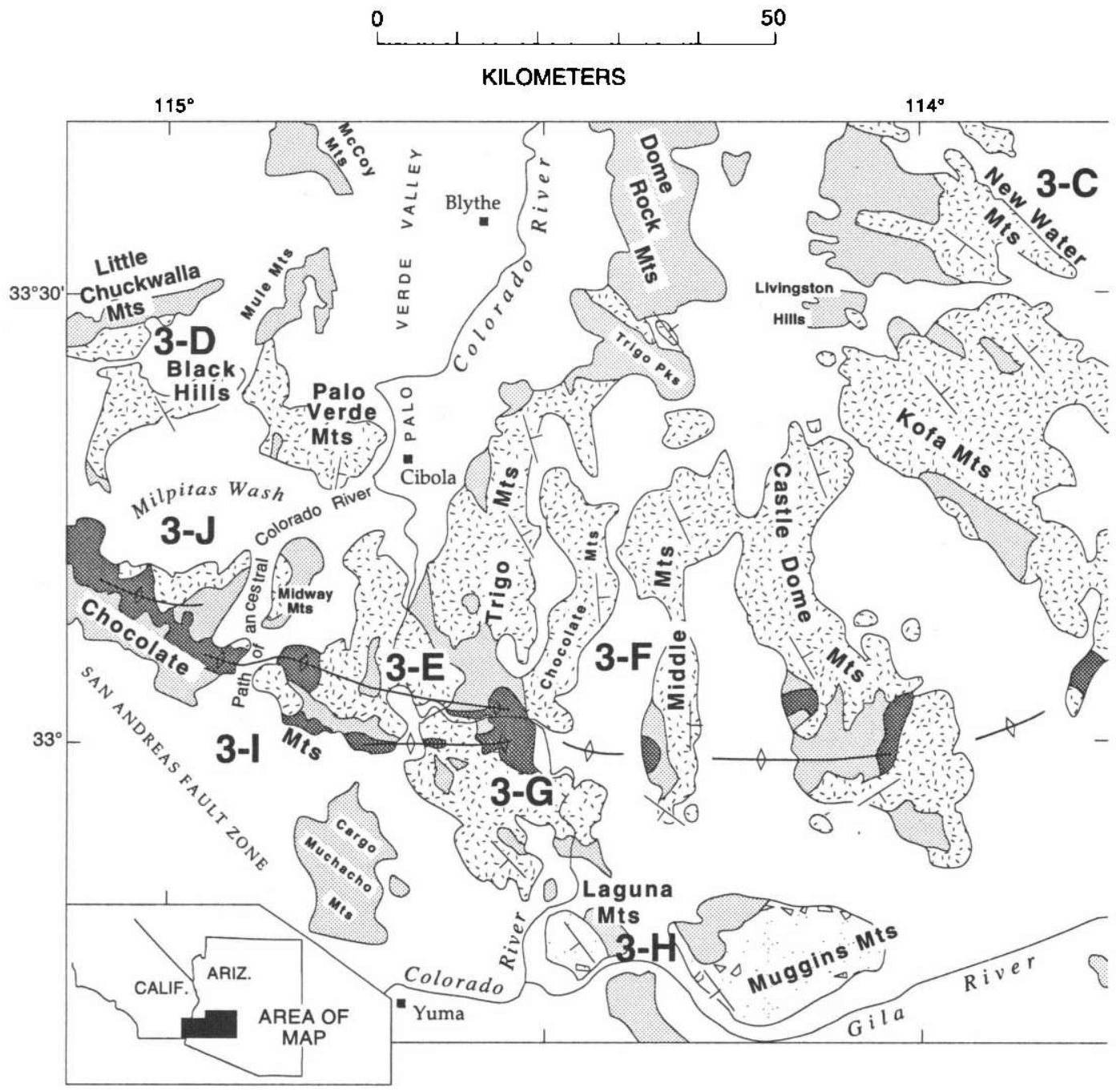

Figure 1. Map showing generalized geology and location of geographic names discussed in text. Modified from Sherrod and Tosdal (1991) and Reynolds (1988). See text discussions and plate 3 for stratigraphic columns (sections) 3-A,B through 3-H; see text discussions for topical papers 3-I and 3-J. 
along the Colorado and Gila River valleys. Contact relations between the youngest sedimentary rocks and older units vary from major angular unconformities, especially at the mountain fronts (Scarborough, 1989), to concordant and gradational sequences toward the centers of the larger physiographic basins. This youngest unit is present mostly

(Explanation, continued)

A Chocolate Mountains anticlinorium (from Haxel and others, 1985)

- Generalized orientation of bedding in volcanic and sedimentary rocks

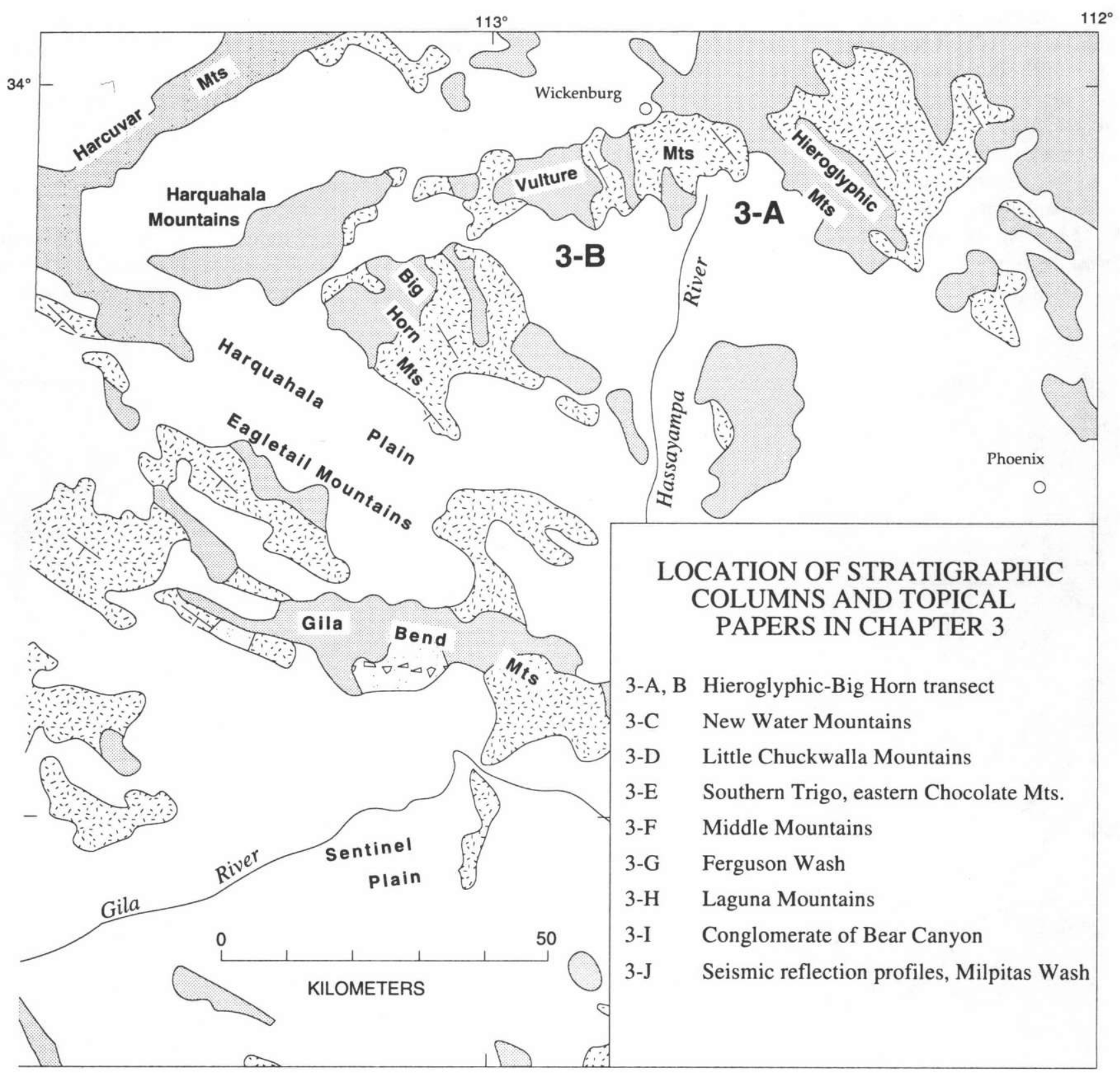


in the subsurface and thus has received little consideration in most geologic studies.

\section{PRE-TERTIARY GEOLOGIC SETTING}

Southwestern Arizona and southeastern Califomia encompass several pre-Tertiary bedrock domains (fig. 2). In the northeast, Tertiary strata are deposited on Proterozoic igneous and metamorphic rocks intruded by sparse, mesozonal to epizonal Cretaceous plutons, all of which lie above the regional Whipple-Buckskin-Bullard detachment fault system (Davis and others, 1980; Spencer and Reynolds, 1989a) and are continuous with rocks underlying the Colorado Plateau. To the southwest, in the footwall of this major detachment system, Tertiary strata are deposited on highly deformed, slightly metamorphosed Paleozoic and Mesozoic strata in the Maria fold and thrust belt (Reynolds and others, 1986). Farther southwest, the Tertiary rocks overlap the southern boundary of the Maria fold and thrust belt and are deposited on Triassic(?) and Jurassic crystalline rocks in the hanging wall of the Mule Moun- tains thrust (Tosdal, 1988, 1990). Tertiary strata overlie Jurassic or Cretaceous supracrustal rocks in the vicinity of the Chocolate Mountains anticlinorium (Dillon, 1975; Haxel and others, 1985; Grubensky and Bagby, 1990). At the southwestern end of the belt, Tertiary strata are deposited on Proterozoic igneous and metamorphic rocks that have been correlated with the San Gabriel terrane of Powell $(1981,1982)$.

\section{MIDDLE TERTIARY TECTONIC SETTING}

Tertiary rocks throughout the region have been affected by a major period of crustal extension and associated normal faulting that occurred after about $22 \mathrm{Ma}$ (Sherrod and others, 1987; Spencer and Reynolds, 1989b). Movement on normal faults has tilted the Tertiary strata mainly to the northeast or southwest; dips range from very gentle to steeply overtumed.

Faults younger than about $12 \mathrm{Ma}$ (the late Miocene block-faulting episode of Eberly and Stanley, 1978) cut low-angle normal faults throughout the region and have

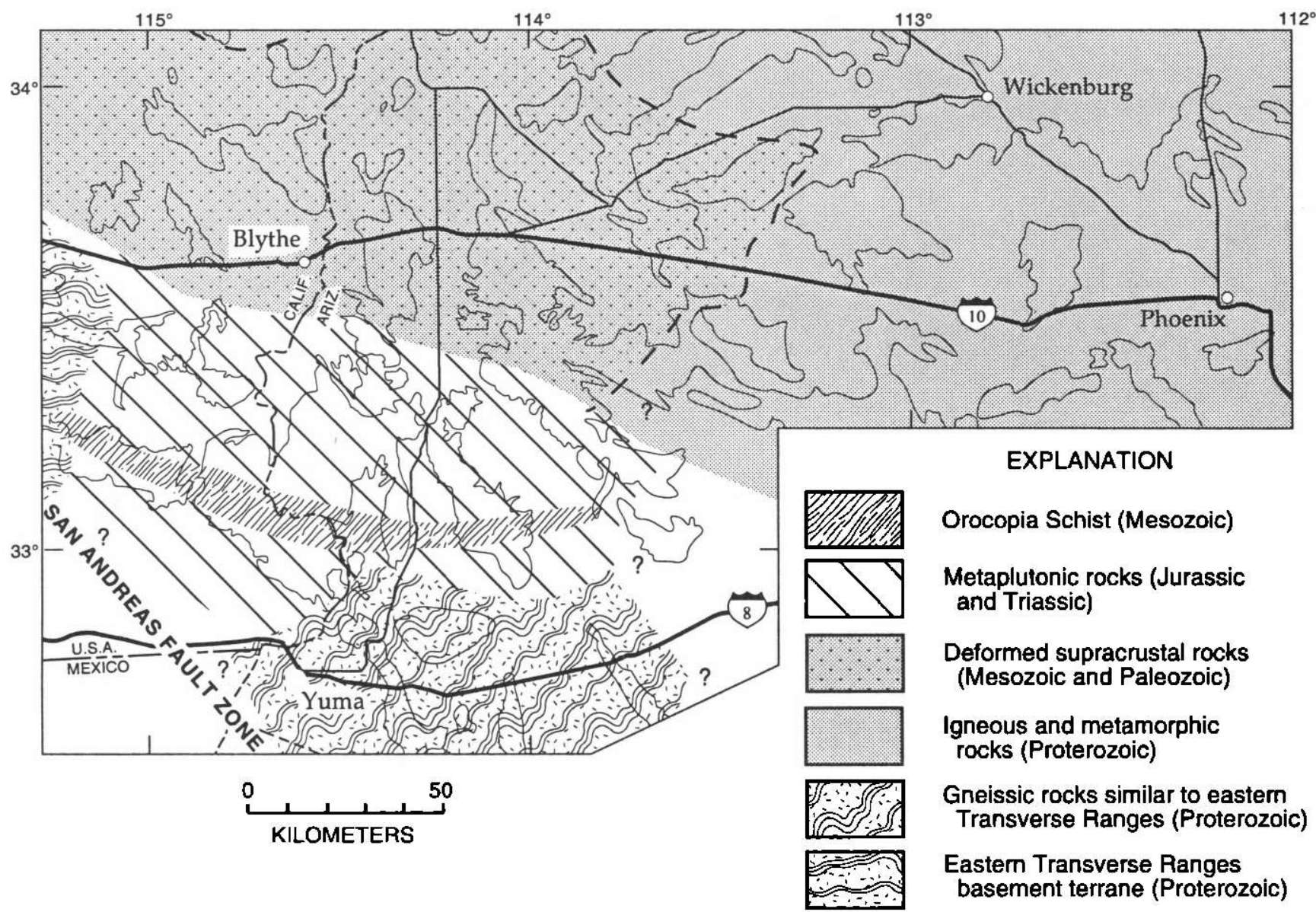

Figure 2. Map showing major pre-Tertiary lithotectonic domains in southwestern Arizona and southeastern California. Domains shown queried where of uncertain extent. Outline of mountain ranges shown by fine lines; compare with figure 1 for range names. 
determined the present physiography. In the northeast these are mostly northwest-striking high-angle oblique-slip faults with components of right slip, generally down on the southwest. In the southwestern part of the region, these younger faults form a complex array and bound smaller, irregular, north-trending basins.

\section{CONTROLS ON PALEOGEOGRAPHY}

Thick prevolcanic clastic strata in the Gila trough southeast of the western Arizona volcanic belt were deposited in a northeast-trending graben (Eberly and Stanley, 1978; Spencer and Reynolds, 1989b). Dates from tuff overlying and interbedded with sedimentary rocks in the southwestern part of the trough indicate that tectonism was underway in that region in Oligocene time (Olmsted and others, 1973; Lombard, this volume). The tectonic setting of the Gila trough is uncertain; its northeast trend is difficult to reconcile with the uniform northeasterly extension direction associated with early Miocene extension in the region. Oligocene deformation this close to the continental margin may be related to the transition from a convergent to transform plate margin in Oligocene time (Severinghaus and Atwater, 1990).

The paleogeographic setting of the flow- and domedominated volcanic fields northeast of the Kofa and Middle Mountains was probably dominated by volcanic construction and cannot be directly correlated with tectonic features. Also, the distribution of the 32- to 26-Ma Quechan volcanic rocks and temporally equivalent units, which are widespread in the western and southwestern parts of the area but absent eastward from the Kofa Mountains, most likely reflects the distribution of volcanic centers.

Other subsidence zones are probably volcano-tectonic features. The distribution of lower Miocene ash-flow tuffs, which are laterally discontinuous and terminate abruptly over short distances between the Kofa Mountains and Picacho State Park area (near location 3-E, fig. 1), is interpreted to reflect the location of several such zones. However, the youngest tuff, the 22-Ma tuff of Felipe Pass (Sherrod and others, 1990), blankets a large area in the Trigo, Middle, and Kofa Mountains (Sherrod and Tosdal, 1991). The tuff of Felipe Pass is absent within a large silicic eruptive center in the northern Castle Dome and Middle Mountains, which must have been a positive feature not buried by the tuff.

Some stratigraphic cut-outs may be structurally controlled, however. Volcanism southwest of the Chocolate Mountains anticlinorium in western Arizona may have started as early as $32 \mathrm{Ma}$, and the major period of volcanism was over by $26 \mathrm{Ma}$ (Crowe, 1978). Northeast of the anticlinorium, volcanic rocks range in age from 24 to about $16 \mathrm{Ma}$ (Bagby and others, 1987) and include several pyroclastic-flow deposits; these rocks are conspicuously absent south of the anticlinorium. Their fairly abrupt cutout across the Chocolate Mountains anticlinorium suggests that it was a positive feature by early Miocene time (Richard, 1989; Grubensky and Bagby, 1990).

Overall, the volcanic belt was probably a positive paleogeographic feature, as indicated by the paucity of epiclastic sedimentary rocks interbedded with the extrusive volcanic rocks. The pattern of syndepositional volcanotectonic subsidence and subsequent normal faulting has determined where these rocks are preserved. It is thus unlikely that a sedimentary basin was present in the central part of the western Arizona-southeastern California volcanic belt.

Clastic strata that generally overlie the calc-alkaline volcanic sequences were deposited in grabens produced by Miocene normal faulting. The abundance of coarsegrained deposits in this part of the stratigraphic sequence indicates significant local relief. Some of these deposits grade upsection into the alluvium that fills the present topographic basins, implying that some of these grabens were continuously subsiding through Miocene time. In other places, the middle Miocene graben-filling sediment is now deeply dissected and exposed in mountain ranges. Normal faults that defined the early to middle Miocene grabens were more closely spaced (10 to $15 \mathrm{~km}$ ) than the younger faults that define the present basin-and-range physiography $(20$ to $30 \mathrm{~km})$.

\section{ACKNOWLEDGMENTS}

We wish to thank Michael J. Grubensky for reviewing an early version of this manuscript.

\section{REFERENCES CITED}

Annis, D.R., and Keith, S.B., 1986, Petrochemical variation in post-Laramide igneous rocks in Arizona and adjacent regions: Geotectonic and metallogenic implications, in Beatty, Barbara, and Wilkinson, P.A.K., eds., Frontiers in the geology and ore deposits of Arizona and the Southwest: Arizona Geological Society Digest, v. 16, p. 448-458.

Bagby, W.C., Haxel, G.B., Smith, D.B., Koch, R.D., Grubensky, M.J., Sherrod, D.R., and Pickthorn, L.G., 1987, Mineral resource assessment of the Kofa National Wildlife Refuge, Arizona: U.S. Geological Survey Open-File Report 87-609, $72 \mathrm{p}$.

Capps, R.C., Reynolds, S.J., Kortemeier, C.P., Stimac, J.A., Scott, E.A., and Allen, G.B., 1985, Preliminary geologic maps of the eastern Big Horn and Belmont Mountains, westcentral Arizona: Arizona Bureau of Geology and Minera! Technology Open-File Report 85-14, scale 1:24,000.

Crowe, B.M., 1978, Cenozoic volcanic geology and probable age of inception of basin-range faulting in the southeasternmost 
Chocolate Mountains, California: Geological Society of America Bulletin, v. 89, no. 2, p. 251-264.

Crowe, B.M., Crowell, J.C., and Krummenacher, Daniel, 1979, Regional stratigraphy, K-Ar ages, and tectonic implications of Cenozoic volcanic rocks, southeastem California: American Journal of Science, v. 279, no. 2, p. 186-216.

Davis, G.A., Anderson, J.L., Frost, E.G., and Shackelford, T.J., 1980, Mylonitization and detachment faulting in the Whipple-Buckskin-Rawhide Mountains terrane, southeastern California and western Arizona, in Crittenden, M.D., Jr., Coney, P.J., and Davis, G.H., eds., Cordilleran metamorphic core complexes: Geological Society of America Memoir 153, p. 79-129.

Dillon, J.T., 1975, Geology of the Chocolate and Cargo Muchacho Mountains, southeasternmost California: Santa Barbara, University of California, Ph.D. dissertation, $405 \mathrm{p}$.

Eberly, L.D., and Stanley, T.B., Jr., 1978, Cenozoic stratigraphy and geologic history of southwestem Arizona: Geological Society of America Bulletin, v. 89, no. 6, p. 921-940.

Grubensky, M.J., and Bagby, W.C., 1990, Miocene calc-alkaline magmatism, calderas, and crustal extension in the Kofa and Castle Dome Mountains, southwestern Arizona: Journal of Geophysical Research, v. 95, no. B12, p. 19,989-20,003.

Haxel, G.B., Tosdal, R.M., and Dillon, J.T., 1985, Tectonic setting and lithology of the Winterhaven Formation, a new Mesozoic stratigraphic unit in southeasternmost Califomia and southwestern Arizona: U.S. Geological Survey Bulletin $1599,19 \mathrm{p}$.

Olmsted, F.H., Loeltz, O.J., and Irelan, Burdge, 1973, Geohydrology of the Yuma area, Arizona and California: U.S. Geological Survey Professional Paper 486-H, $227 \mathrm{p}$.

Powell, R.E., 1981, Geology of the crystalline basement complex, eastem Transverse Ranges, Califomia: constraints on regional tectonic interpretation: Pasadena, California Institute of Technology, Ph.D. dissertation, $441 \mathrm{p}$.

1982, Crystalline basement terranes in the southern eastern Transverse Ranges, California, in Cooper, J.D., compiler, Geologic excursion in the Transverse Ranges, southem California: Geological Society of America, Cordilleran section, 78th, Anaheim, Calif., April 1982, Volume and Guidebook, Field Trip nos. 5, 6, and 11, p. 109-151.

Pridmore, C.L., 1983, The genetic association of mid-Tertiary sedimentation, detachment-fault deformation, and antiformal uplift in the Baker Peaks-Copper Mountains area of Southwestern Arizona: San Diego, Calif., San Diego State University, M.S. thesis, $127 \mathrm{p}$.

Reynolds, S.J., 1988, Geologic map of Arizona: Arizona Geological Survey Map 26, scale 1:1,000,000.

Reynolds, S.J., Spencer, J.E., Richard, S.M., and Laubach, S.E., 1986, Mesozoic structures in west-central Arizona, in Beatty, Barbara, and Wilkinson, P.A.K., eds., Frontiers in geology and ore deposits of Arizona and the Southwest: Arizona Geological Society Digest, v. 16, p. 35-51.

Richard, S.M., 1989, The Chocolate Mountains anticlinorium in the Middle Mountains, SW Arizona [abs.]: Geological Society of America Abstracts with Programs, v. 21, no. 6, p. A64.

Scarborough, Robert, 1989, Cenozoic erosion and sedimentation in Arizona, in Jenney, J.P., and Reynolds, S.J., eds., Geologic evolution of Arizona: Tucson, Arizona Geological Society Digest 17, p. 515-537.

Scarborough, R., and Wilt, J.C., 1979, A study of uranium favorability of Cenozoic sedimentary rocks, Basin and Range Province, Arizona; Part I, General geology and chronology of pre-late Miocene Cenozoic sedimentary rocks: Arizona Bureau of Geology and Mineral Technology Open-File Report 79-1, $101 \mathrm{p}$.

Severinghaus, Jeff, and Atwater, Tanya, 1990, Cenozoic geometry and thermal state of the subducting slabs beneath western North America, in Wernicke, B.P., ed., Basin and Range extensional tectonics near the latitude of Las Vegas, Nevada: Geological Society of America Memoir 176, p. 1-22.

Sherrod, D.R., Koch, R.D., and Grubensky, M.J., 1990, Geologic map of the Vicksburg quadrangle, La Paz County, Arizona: U.S. Geological Survey Geologic Quadrangle Map GQ1684 , scale $1: 62,500$.

Sherrod, D.R., Pickthorn, L.B.G., Tosdal, R.M., Grubensky, M.J., and Koch, R.D., 1987, Major early Miocene extensional deformation in southwestern Arizona and southeastern California [abs.]: Geological Society of America Abstracts with Programs, v. 19, no. 7, p. 841.

Sherrod, D.R., and Tosdal, R.M., 1991, Geologic setting and Tertiary structural evolution of southwestem Arizona and southeastern Califomia: Journal of Geophysical Research, v. 96, no. B7, p. 12,407-12,423.

Spencer, J.E., and Reynolds, S.J., 1989a, Tertiary structure, stratigraphy, and tectonics of the Buckskin Mountains, in Spencer, J.E., and Reynolds, S.J., eds., Geology and mineral resources of the Buckskin and Rawhide Mountains, westcentral Arizona: Arizona Geological Survey Bulletin 198, p. 103-167.

1989b, Middle Tertiary tectonics of Arizona and adjacent areas, in Jenney, J.P., and Reynolds, S.J., eds., Geologic evolution of Arizona: Tucson, Arizona Geological Society Digest 17, p. $539-574$.

Tosdal, R.M., 1988, Mesozoic rock units along the Late Cretaceous Mule Mountains thrust system, southeastern California and southwestern Arizona: Santa Barbara, University of California, Ph.D. dissertation, 365 p.

-1990 , Constraints on the tectonics of the Mule Mountains thrust system, southeast California and southwest Arizona: Journal of Geophysical Research, v. 95, no. B12, p. 20,02520,048 . 


\title{
Tertiary Stratigraphy of a Transect from the Hieroglyphic to the Big Horn Mountains, West-Central Ariz.
}

\author{
By Stephen M. Richard ${ }^{1}$
}

\section{INTRODUCTION}

This article summarizes the stratigraphy of Tertiary rocks exposed in a transect from the Transition Zone physiographic province in central Arizona southwest to the Harquahala Plain in the Basin and Range province (fig. 1). Lithologic description of rocks in the Big Horn Mountains is based on the work of Capps and others (1985), description of rocks in the Vulture Mountains is compiled from Grubensky (1989) and Grubensky and others (1987), and description of rocks from the Wickenburg and Hieroglyphic Mountains is based on the work of Capps and others (1986) and Stimac and others (1987) -all recent reports

\footnotetext{
'Arizona Geological Survey, 845 N. Park Ave., Tucson, AZ 85719
}

published by the Arizona Geological Survey. Stratigraphic relationships described here are based on interpretation of the geologic maps included in those reports.

Volcanic and sedimentary rocks as much as 1 to $2 \mathrm{~km}$ thick blanket pre-Tertiary metamorphic and igneous rocks along this transect (cols. 3-A and 3-B, pl. 3). The prevolcanic surface, reconstructed from cross sections drawn along the transect, locally had significant topographic features, especially in the northeast (for example, Stimac and others, 1987). As much as $30 \mathrm{~m}$ of arkosic sandstone and conglomerate is present at the base of the Tertiary section. The overlying volcanic rocks include interbedded basaltic to rhyolitic lava flows and, locally, silicic dome complexes. Widespread ash-flow tuff sheets are absent, but welded and nonwelded tuff and tuffaceous sedimentary rocks are typically associated with the silicic lavas. Basalt lavas that

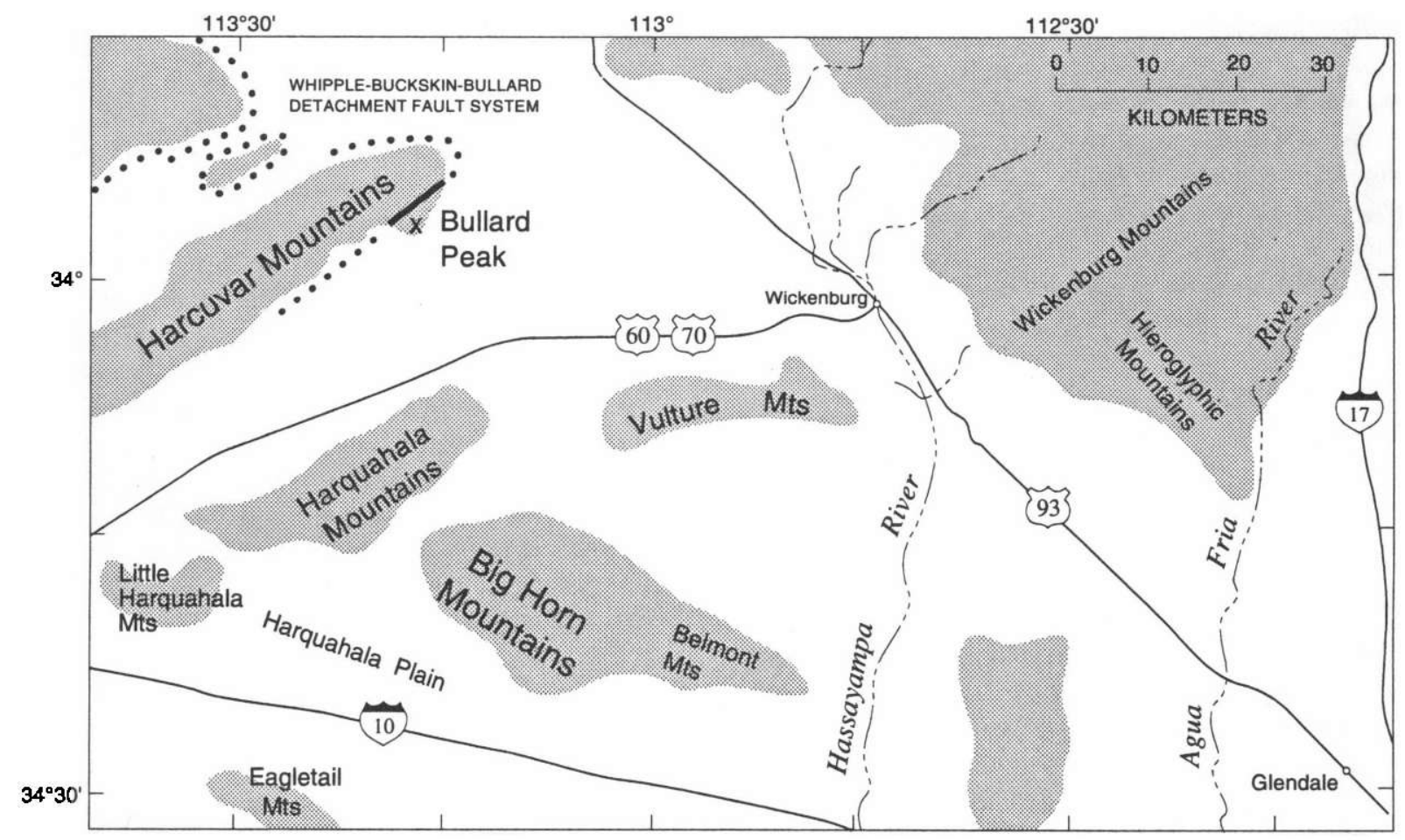

Figure 1. Map showing geographic features discussed in text. Detachment fault system, dotted where buried, shown in area of Harcuvar Mountains. 
cap the volcanic sequences are interbedded with or overlain by sedimentary breccia and conglomerate, which form a grossly fining-upward sequence.

Few of the volcanic units in this region have been reliably dated, owing to extensive potassium metasomatism. Dated volcanic rocks range in age from about 21 to $15 \mathrm{Ma}$ (table 1). If andesite lava in the Bullard Peak area of the Harcuvar Mountains correlates with some part of the section in the Big Horn Mountains, volcanism had commenced by $24 \mathrm{Ma}$ (Roddy and others, 1988).

Volcanism began before normal faulting throughout the transect. Angular unconformities and growth fault relationships characterize the middle and upper part of the stratigraphic successions, indicating that normal faulting was ongoing before volcanism had ceased. Coarse-grained clastic rocks overlie the volcanic-rock assemblages along large angular unconformities and are confined to asymmetric grabens. Normal faulting clearly continued after the cessation of volcanic activity.

The stratigraphy of Tertiary rocks along the Hieroglyphic-Big Horn transect contrasts sharply with that of Tertiary rocks in the hanging wall of the Whipple detachment system to the northeast. Sections to the northeast are dominated by fluvial and lacustrine strata with interbedded sedimentary breccia (Lasky and Weber, 1949; Yarnold, this volume; Spencer and Reynolds, this volume). Fluvial deposits interbedded with basalt lava in the western Big Horn Mountains (Capps and others, 1985) may represent the southeastern edge of the fluviolacustrine system that lay to the northeast. Cobbles in conglomerate in these deposits are unlike basement rocks exposed in the adjacent ranges. The rounded granitic cobbles, presence of far-traveled clasts, and successions of 5- to 10-m-thick, upward-fining sequences all suggest that these strata were deposited in a regionally integrated drainage system. Along the transect described here the stratigraphic section is dominated by volcanic rocks, and epiclastic sedimentary rocks are largely absent except in the basal and uppermost parts of the section. Volcanic construction apparently outpaced subsidence, and a sedimentary basin may never have developed along the Hieroglyphic-Big Horn transect. In the hanging wall of the Whipple-Buckskin-Bullard detachment fault system (fig. 1) to the northeast, subsidence apparently preceded and accompanied extension, and volcanic rocks are not as abundant there.

Tertiary volcanic rocks crop out over a wide area along the Hieroglyphic-Big Horn transect because regional extension was accommodated by numerous normal faults with relatively small slip (Richard and others, 1988, 1990). Large-magnitude normal slip on the Whipple-Buckskin-Bullard detachment fault system has denuded Tertiary rocks from a large area to the northeast, forming the Harcuvar metamorphic core complex (Rehrig and Reynolds, 1980; Spencer and Reynolds, in press). The contrasting sedimentation history between these domains of contrast- ing extensional style suggests a genetic relationship between the evolution of the preextension and synextension stratigraphy and the style of extension.

\section{STRATIGRAPHY}

The following stratigraphic framework attempts to encompass the myriad stratigraphic names applied to volcanic units mapped in the mountain ranges of the transect. Additional names are listed in table 1 in order that dated samples remain connected to particular stratigraphic units, thereby avoiding confusion.

\section{HIEROGLYPHIC AND WICKENBURG MOUNTAINS}

Arkosic sandstone and conglomerate are overlain by basalt, basaltic andesite, and minor interbedded andesite lava flows with a maximum combined thickness of $400 \mathrm{~m}$ (col. 3-A, pl. 3). Rhyolite lava flows with minor interbedded tuff conformably overlie the mafic lava flows. These rhyolitic rocks are known informally as the San Domingo volcanics unit in the Wickenburg and northwestern Hieroglyphic Mountains (Stimac and others, 1987), and they are broadly correlative with rocks known as the Morgan City rhyolite unit and overlying Spring Valley rhyolite unit in the northeastern Hieroglyphic Mountains (Capps and others, 1986). The San Domingo volcanics unit thins northeastward from a maximum of $1,100 \mathrm{~m}$ in the Vulture Mountains to about $400 \mathrm{~m}$ in thickness in the central Wickenburg Mountains; the correlative Morgan City rhyolite unit in the Hieroglyphic Mountains is as thick as $240 \mathrm{~m}$.

The San Domingo volcanics unit is overlain by rhyodacite to dacite lava flows and associated tuff and debrisflow deposits called the Hells Gate volcanics unit by Stimac and others (1987) (Hells Gate latite unit of Capps and others, 1986). The Hells Gate volcanics unit is exposed over a large area in the northern Wickenburg and Hieroglyphic Mountains and underlies almost all of the adjacent Buckhorn Mountains. Strata as young as the upper part of the Hells Gate volcanics unit were deposited on the pre-Tertiary basement, which indicates long-lived erosional relief on the basal nonconformity. The sustained relief probably resulted from some combination of preexisting relief, synvolcanic faulting, and erosion (fig. 2).

The Hells Gate volcanics unit is interbedded in its upper part with and overlain by debris-flow deposits and sedimentary breccia derived mostly from the Hells Gate volcanics unit (col 3-A, pl. 3). Clasts and breccia derived from pre-Tertiary crystalline rocks that underlie the Tertiary section are also present. Lenses of shattered and unshattered dacite from the Hells Gate volcanics unit were probably derived from fault scarps during the inception of 
Table 1. Potassium-argon ages from Big Horn, Vulture, and Hieroglyphic Mountains, west-central Arizona.

\begin{tabular}{|c|c|c|c|c|c|}
\hline Sample No. & $\begin{array}{l}\text { General geographic locale } \\
\text { or stratigraphic unit }\end{array}$ & Rock type & $\begin{array}{l}\text { Material } \\
\text { dated }\end{array}$ & Age (Ma) & Reference \\
\hline \multicolumn{6}{|c|}{ Hot Rock basalt unit of Capps and others (1985) and upper basalt of Grubensky (1987) } \\
\hline UAKA $73-10$ & Hot Rock Mountain & basalt & whole rock & $15.01 \pm 0.42$ & Shafiqullah and others (1980) \\
\hline RLE-20-68 & Black Butte & basalt & whole rock & $15.62 \pm 0.35$ & Scarborough and Wilt (1979) \\
\hline \multicolumn{6}{|c|}{ Big Horn volcanics unit of Capps and others (1985) (atso source of the following unit names) } \\
\hline$\cdots$ & Beer Bottle rhyolite unit & - & feldspar & $16.4 \pm 0.2$ & Capps and others (1985) \\
\hline-- & Upper aphyric basalt unit & -- & whole rock & $16.1 \pm 0.2$ & Do. \\
\hline--- & Blue Hope rhyolite unit & $\cdots$ & biotite & $21.4 \pm 0.3$ & Do. \\
\hline--- & Hummingbird rhyolite unit & --- & biotite & $20.3 \pm 0.2$ & Do. \\
\hline & Old Camp volcanic unit & --- & biotite & $19.6 \pm 0.2$ & Do. \\
\hline \multicolumn{6}{|c|}{ Hells Gate volcanics unit of Stimac and others (1986) } \\
\hline $3-2-1$ & Latite of Mitchell Springs & latite lava & biotite & $20.3 \pm 0.8$ & Kortemeier and others (1986) \\
\hline $3-3-4$ & Latite of Hells Gate & latite lava & biotite & $16.1 \pm 0.5$ & Kortemeier and others (1986) \\
\hline UAKA-72-71 & $\begin{array}{l}\text { Hells Gate latite unit of } \\
\text { Capps and others (1986) }\end{array}$ & latite porphyry & biotite & $17.98 \pm 0.43$ & Shafiqullah and others (1980) \\
\hline
\end{tabular}

\begin{tabular}{lccccc}
\hline \multicolumn{5}{c}{ Spring Valley rhyolite unit of Capps and others (1986) } \\
\hline 3-3-3 & Rhyolite of Garfias Wash & vitrophyre & obsidian & $18.7 \pm 0.6$ & Kortemeier and others (1986) \\
\hline \multicolumn{7}{c}{ Basal mafic lava flows } \\
\hline UAKA-78-40 & West side of Lake Pleasant & basaltic andesite & whole rock & $16.63 \pm 0.35$ & Scarborough and Wilt (1979) \\
\hline
\end{tabular}

normal faulting and from slope failure on volcanic edifices. The unit of debris-flow deposits and sedimentary breccia, which contains interbedded basalt flows at its base, fines upward into sandstone, siltstone, and conglomerate that were deposited in grabens resulting from early to middle Miocene normal faulting. Dips generally decrease upsection, indicating syntectonic deposition.

\section{VULTURE MOUNTAINS}

Different Tertiary stratigraphic sequences are exposed in the southwestern and northeastem Vulture Mountains (fig. 2). In the southwest, the volcanic sequence consists of a lower basalt unit as thick as $300 \mathrm{~m}$ that is overlain by an upper basalt unit with interbedded rhyolite lava and tuff, mostly in its lower part. Sandstone and conglomerate overlie the volcanic rocks. An angular unconformity separates the lower and upper units. In the northeastem Vulture Mountains, a thin lower basalt unit overlies and is interbedded with arkosic clastic rocks (arkose not shown on fig. 2). The volcanic sequence is dominated by a complex of rhyolitic extrusive rocks and associated volcaniclastic rocks as much as $1,100 \mathrm{~m}$ thick that were mapped as the San Domingo volcanics unit by Stimac and others (1987). An overlying sequence of basalt (upper basalt of Grubensky, 1989) overlies the San Domingo volcanics unit along an angular unconformity. The upper basalt is interbedded with sandstone and conglomerate in the vicinity of the Hassayampa River.

\section{BIG HORN MOUNTAINS}

The basal sedimentary rocks consist of reddish-brown to greenish-gray coarse sandstone, conglomerate, and laharic breccia (col 3-B, pl. 3). Clasts are Precambrian metamorphic and intrusive rocks, Cretaceous intrusive rocks, and rare basalt; sandstone is quartzofeldspathic. The unit is generally less than $10 \mathrm{~m}$ thick but locally thickens to $30 \mathrm{~m}$.

Overlying the basal sedimentary rocks is the Big Horn volcanics unit of Capps and others (1985), which comprises a series of interbedded basalt, andesite, and rhyolite lavas, with lesser volcaniclastic sedimentary rocks. The lower part of the unit consists of basalt with several intercalated rhyolite lava flows. Rhyolite lavas typically are underlain by poorly welded lithic tuff. The upper part of the unit consists of andesite and basalt lava flows that are locally capped by rhyolite lava flows.

The volcanic rocks are overlain by coarse clastic deposits that include shattered blocks derived from underlying volcanic rocks and basement rocks of the Big Horn Mountains; the blocks form lenses as much $100 \mathrm{~m}$ thick and several kilometers long. These deposits probably originated as landslide breccia or glide blocks. Stratigraphic relations between volcanic units are preserved within some 


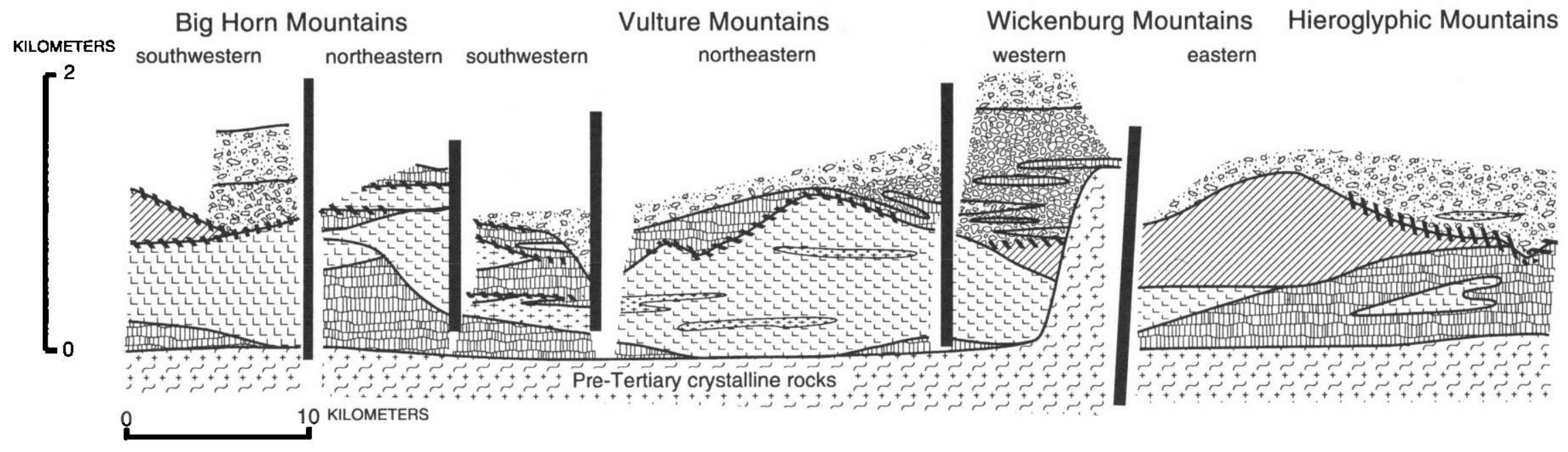

- Angular unconformities within Tertiary volcanic and sedimentary sequences

Major normal fault

Figure 2. Stratigraphic sections from Hieroglyphic, Wickenburg, Vulture, and Big Hom Mountains. Sections are generalized according to major fault blocks; width of blocks shown in present (postextension) configuration. Scales are schematic. Lithologic symbols explained on plate 3. 
of the blocks. In some areas, breccia derived from the volcanic deposits is interbedded with breccia derived from crystalline rocks. Monolithologic and polymict sedimentary breccia and boulder conglomerate are locally associated with the landslide breccia units. The sequence fines upward to sandstone and conglomerate beds, which have progressively decreasing dips.

The youngest volcanic rocks in the area are nearly flat-lying basalt flows called the Hot Rock basalt unit by Capps and others (1985). These middle Miocene lavas (table 1) are correlative with the upper basalt in the Big Horn Mountains.

\section{ACKNOWLEDGMENTS}

I thank Mike Grubensky for reviewing an early version of this manuscript.

\section{REFERENCES CITED}

Capps, R.C., Reynolds, S.J., Kortemeier, C.P., and Scott, E.A., 1986, Geologic map of the northeastern Hieroglyphic Mountains, central Arizona: Arizona Bureau of Geology and Mineral Technology Open-File Report 86-10, scale 1:24,000.

Capps, R.C., Reynolds, S.J., Kortemeier, C.P., Stimac, J.A., Scott, E.A., and Allen, G.B., 1985, Preliminary geologic maps of the eastern Big Horn and Belmont Mountains, westcentral Arizona: Arizona Bureau of Geology and Mineral Technology Open-File Report 85-14, scale 1:24,000.

Grubensky, M.J., 1989, Geologic map of the Vulture Mountains, west-central Arizona: Arizona Geological Survey Map 27, scale $1: 24,000$.

Grubensky, M.J., Stimac, J.A., Reynolds, S.J., and Richard, S.M., 1987, Geologic map of the northeastem Vulture Mountains and vicinity, central Arizona: Arizona Bureau of Geology and Mineral Technology Open-File Report 87-10, scale $1: 24,000$

Kortemeier, C.P., Jorgensen, M., and Sheridan, M.F., 1986, Volcanic geology of the Castle Hot Springs area, in Beatty, Barbara, and Wilkinson, P.A.K., eds., Frontiers in geology and ore deposits of Arizona and the Southwest: Arizona Geological Society Digest, v. 16, p. 473-477.

Lasky, S.G., and Weber, B.N., 1949, Manganese resources of the Artillery Mountains region, Mohave County, Arizona: U.S. Geological Survey Bulletin 961, 86 p.

Rehrig, W.A., and Reynolds, S.J., 1980, Geologic and geochronologic reconnaissance of a northwest-trending zone of metamorphic core complexes in southern and western Arizona, in Crittenden, M.D., Jr., Coney, P.J., and Davis, G.H., eds., Cordilleran metamorphic core complexes: Geological Society of America Memoir 153, p. 131-157.

Richard, S.M., Fryxell, J.E., Reynolds, S.J., and Grubensky, M.J., 1988, SE termination of the Buckskin-Bullard detachment fault, west-central Arizona: one versus many normal faults [abs.]: Geological Society of America Abstracts with Programs, v. 20, no. 7, p. 382.

Richard, S.M., Fryxell, J.E., and Sutter, J.F., 1990, Tertiary structure and thermal history of the Harquahala and Buckskin Mountains, west-central Arizona: implications for denudation by a major detachment fault system: Journal of Geophysical Research, v. 95, no. B12, p. 19,973-19,987.

Roddy, M.S., Reynolds, S.J., Smith, B.M., and Ruiz, Joaquin, 1988, K-metasomatism and detachment-related mineralization, Harcuvar Mountains, Arizona: Geological Society of America Bulletin, v. 100, no. 10, p. 1,627-1,639.

Scarborough, R., and Wilt, J.C., 1979, A study of uranium favorability of Cenozoic sedimentary rocks, Basin and Range province, Arizona; Part I, General geology and chronology of pre-late Miocene Cenozoic sedimentary rocks: Arizona Bureau of Geology and Mineral Technology Open-File Report 79-1, $101 \mathrm{p}$.

Shafiqullah, M., Damon, P.E., Lynch, D.J., Reynolds, S.J., Rehrig, W.A., and Raymond, R.H., 1980, K-Ar geochronology and geologic history of southwestern Arizona and adjacent areas, in Jenney, J.P., and Stone, Claudia., eds., Studies in western Arizona: Arizona Geological Society Digest, v. 12, p. 201260.

Spencer, J.E., and Reynolds, S.J., in press, Tectonics of mid-Tertiary extension along a transect through west-central Arizona: Geological Society of America Bulletin.

Stimac, J.A., Fryxell, J.E., Reynolds, S.J., Richard, S.M., Grubensky, M.J., and Scott, E.A., 1987, Geologic map of the Wickenburg, southern Buckhorn, and northwestern Hieroglyphic Mountains, central Arizona: Arizona Bureau of Geology and Mineral Technology Open-File Report 87-9, scale 1:24,000. 



\title{
Tertiary Stratigraphy of the New Water Mountains, Ariz.
}

\author{
By David R. Sherrod ${ }^{1}$
}

The New Water Mountains (fig. 1) are a late Tertiary horst composed of Proterozoic to Tertiary igneous and sedimentary rocks. Tertiary volcanism commenced in the Oligocene or early Miocene; Tertiary sedimentary rocks that predate volcanism are exposed only locally. The following description of Tertiary stratigraphic units and geologic history is based on work done as part of a mineral resource assessment in the New Water Mountains and the Kofa National Wildlife Refuge (Bagby and others, 1987; Sherrod and others, 1989; Sherrod and others, 1990).

Proterozoic quartz monzonite is the oldest rock unit exposed in the area (Miller, 1970). It is nonconformably overlain by Cambrian sedimentary rocks, which form the base of a northeast-striking, southeast-dipping homocline of sedimentary and volcanic strata that are Paleozoic and Mesozoic in age (Miller, 1970; Sherrod and others, 1990). The youngest of these rocks are part of the McCoy Mountains Formation of Harding and Coney (1985). The preTertiary rocks were folded, faulted, and metamorphosed to lower greenschist facies during Late Cretaceous thrusting (Harding and Coney, 1985; Reynolds and others, 1986; Sherrod and Koch, 1987), then beveled during Late Cretaceous and early Tertiary erosion.

The oldest Tertiary unit in the New Water Mountains is a coarse sedimentary breccia (col 3-C, pl. 3). The unit probably was deposited during an Oligocene or early Miocene episode of faulting, as interpreted from the poorly developed bedding of the breccia, the large clast size in the beds, and the abrupt termination of the breccia against older crystalline rocks. The upper part of the sedimentary breccia is interbedded with overlying silicic volcaniclastic rocks.

The silicic volcaniclastic rocks are moderately sorted and moderately to well-bedded tuff and tuffaceous sandstone. They probably formed mostly as medial and distal epiclastic deposits shed from rhyolitic volcanoes (domes) that are exposed in the New Water Mountains; some tuff may record distant volcanism in the Kofa Mountains, about $10 \mathrm{~km}$ to the south. The tuffaceous rocks interfinger near their top with the basalt of New Water Mountains (Sherrod and others, 1990).

The basalt of New Water Mountains comprises lava flows of slightly porphyritic to aphyric olivine basalt. Rhy-

\footnotetext{
'U.S. Geological Survey, 5400 MacArthur Blvd., Vancouver, WA 98661
}

olite lava flows and one ash-flow tuff are interbedded with the basalt. A K-Ar age of $19.8 \pm 0.4 \mathrm{Ma}$ (biotite) was obtained from a sample of thyolite near the top of the basalt of New Water Mountains (L.G. Pickthorn, in Bagby and others, 1987).

Lower Miocene fanglomerate overlies all older rocks at the margins of the New Water Mountains and consists of poorly to moderately sorted, moderately to well-consolidated sand and gravel. Generally the lowermost part of the fanglomerate contains clasts only from the Tertiary volcanic sequence, whereas higher parts also contain clasts of pre-Tertiary rocks. Evidently the pre-Tertiary rocks were unroofed by erosion and incorporated into the enlarging alluvial fans. The fanglomerate forms moderately dissected hills in much of the area, but it is overlain by the basalt of Black Mesa at the summit of the New Water Mountains. The fanglomerate, which was at least $250 \mathrm{~m}$ thick prior to post-early Miocene uplift(?) and erosion, probably originally covered much of the low-lying terrain on the flanks of the New Water Mountains.

The basalt of Black Mesa, the youngest volcanic rock in the New Water Mountains, was erupted $17.23 \pm 0.43 \mathrm{Ma}$

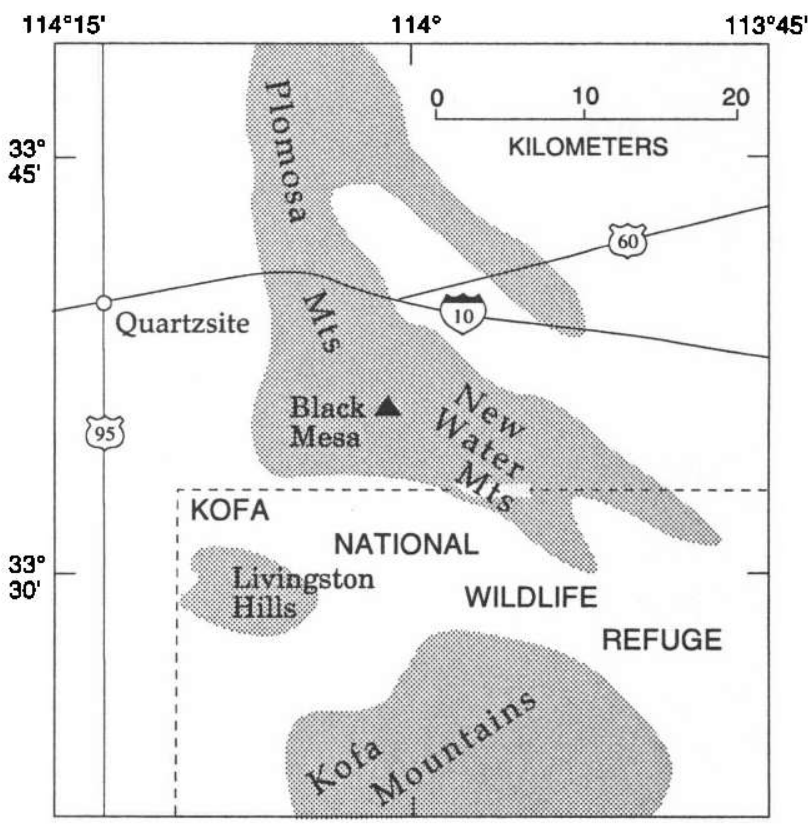

Figure 1. Map showing location of geographic features discussed in text. 
(K-Ar, whole rock) (Shafiqullah and others, 1980), following deposition of the widespread, lower Miocene fanglomerate. The region is now being eroded and dissected by ephemeral streams that connect with the Colorado River, 50 to $60 \mathrm{~km}$ west of the study area. Upper Pliocene and Quaternary alluvial deposits in basins flanking the New Water Mountains are probably thin, masking a pediment cut into the lower Miocene fanglomerate.

Northwest-striking, steep to vertical normal faults bound the northeast margin of the New Water Mountains; most have down-to-the-northeast displacements. As a result of the faulting, the Tertiary units dip $6^{\circ}$ to $30^{\circ}$ southwest. The range of dip values results from differentially deforming blocks and does not necessarily indicate decreasing deformation during early Miocene time. The range-bounding faults probably formed as part of basinand-range extensional tectonism that affected much of southwestem Arizona (for example, Eberly and Stanley, 1978; Spencer and Reynolds, 1986).

\section{REFERENCES CITED}

Bagby, W.C., Haxel, G.B., Smith, D.B., Koch, R.D., Grubensky, M.J., Sherrod, D.R., and Pickthorn, L.G., 1987, Mineral resource assessment of the Kofa National Wildlife Refuge, Arizona: U.S. Geological Survey Open-File Report 87-609, $72 \mathrm{p}$.

Eberly, L.D., and Stanley, T.B., Jr., 1978, Cenozoic stratigraphy and geologic history of southwestern Arizona: Geological Society of America Bulletin, v. 89, no. 6, p. 921-940.

Harding, L.E., and Coney, P.J., 1985. The geology of the McCoy Mountains Formation, southeastern California and south- western Arizona: Geological Society of America Bulletin, v. 96 , no. 6 , p. $755-769$.

Miller, F.K., 1970, Geologic map of the Quartzsite quadrangle, Yuma County, Arizona: U.S. Geological Survey Geologic Quadrangle Map GQ-841, scale 1:62,500.

Reynolds, S.J., Spencer, J.E., Richard, S.M., and Laubach, S.E., 1986, Mesozoic structures in west-central Arizona, in Beatty, Barbara, and Wilkinson, P.A.K., eds., Frontiers in geology and ore deposits of Arizona and the Southwest: Arizona Geological Society Digest, v. 16, p. 35-51.

Shafiqullah, M., Damon, P.E., Lynch, D.J., Reynolds, S.J., Rehrig, W.A., and Raymond, R.H., 1980, K-Ar geochronology and geologic history of southwestern Arizona and adjacent areas, in Jenney, J.P., and Stone, Claudia, eds., Studies in western Arizona: Arizona Geological Society Digest, v. 12, p. 201-260.

Sherrod, D.R., and Koch, R.D., 1987, Structure and stratigraphy of Mesozoic sedimentary and volcanic rocks in the New Water Mountains, southwestern Arizona, in Dickinson, W.R., and Klute, M.A., eds., Mesozoic Rocks of southem Arizona and adjacent areas: Arizona Geological Society Digest, v. 18 , p. $81-90$.

Sherrod, D.R., Koch, R.D., and Grubensky, M.J., 1990, Geologic map of the Vicksburg quadrangle, La Paz County, Arizona: U.S. Geological Survey Geologic Quadrangle Map GQ1684 , scale $1: 62,500$.

Sherrod, D.R., Smith, D.B., Koch, R.D., Hanna, W.F., Pitkin, J.A., and Lane, M.E., 1989, Mineral resources of the New Water Mountains Wilderness Study Area, La Paz County, Arizona: U.S. Geological Survey Bulletin 1702-B, 18 p.

Spencer, J.E., and Reynolds, S.J., 1986, Some aspects of the middle Tertiary tectonics of Arizona and southeastern California, in Beatty, Barbara, and Wilkinson, P.A.K., eds., Frontiers in the geology and ore deposits of Arizona and the Southwest: Arizona Geological Society Digest, v. 16, p. 102-107. 


\title{
Tertiary Stratigraphy of the Little Chuckwalla Mountains, Southeastern Calif.
}

\author{
By David P. Mayo ${ }^{1}$
}

\section{INTRODUCTION}

The Little Chuckwalla Mountains are located in the northem Colorado Desert of southeastern California, about $50 \mathrm{~km}$ east-northeast of the San Andreas fault zone (fig. 1), $40 \mathrm{~km}$ west of the Colorado River, and $90 \mathrm{~km}$ north of the Mexican border. The mountain range is an elongate, northeast-trending ridge about 25 long by $5 \mathrm{~km}$ wide; its maximum elevation is less than $640 \mathrm{~m}$. Tertiary rocks exposed on the southeastern flank of the Little Chuckwalla Mountains lie along the northwestern edge of a belt of Oligocene to early Miocene volcanic, intrusive, and sedimentary rocks that extends to the west to the Chocolate Mountains and east beyond the Palo Verde Mountains into southwestern Arizona.

Crowe and others (1979) first described and compared the isolated Tertiary exposures of southeastern California. A detailed geochemical and petrologic study of Tertiary volcanic rocks from the Little Chuckwalla Mountains recently was completed by Mayo (1990).

\section{STRATIGRAPHY}

Basement rocks in the Little Chuckwalla Mountains consist of pre-Mesozoic metamorphic and plutonic rocks intruded by Mesozoic plutons. The youngest of these, a hornblende-biotite-sphene granodiorite pluton exposed in Graham Pass between the Little Chuckwalla and Chuckwalla Mountains (Powell, 1981), has K-Ar cooling ages (biotite and hornblende) of about $71 \mathrm{Ma}$ (Armstrong and Suppe, 1973).

The Tertiary rocks consist of a thick, southeastwardtilted succession of upper Oligocene to lowermost $\mathrm{Mi}$ ocene(?) volcanic and sedimentary strata cut by coeval hypabyssal dikes and overlain unconformably by relatively thin, subhorizontal Miocene(?) fanglomerate. The tilted volcanic and sedimentary rocks are informally referred to as the Little Chuckwalla Mountains volcanic sequence.

'Department of Geological Sciences, University of Southern Califormia, Los Angeles, CA 90007
The Little Chuckwalla Mountains volcanic sequence rests nonconformably on pre-Tertiary crystalline rocks at some locations and is faulted against them elsewhere. The total exposed thickness of the sequence is about $1.5 \mathrm{~km}$ (col 3-D, pl. 3). Strata in the sequence are largely conformable, although discordant contacts are abundant.

Locally derived arkosic fanglomerate and breccia, deposited as alluvial fans and talus, are discontinuously exposed along the basal nonconformity and locally interbedded with the oldest lava flows. The fanglomerate typically is less than $10 \mathrm{~m}$ thick and becomes finer grained upsection. Volcanic clasts are absent or extremely rare.

Andesite and basaltic andesite lava flows and associated breccia volumetrically dominate the lower half of the Little Chuckwalla Mountains volcanic sequence. Pyroclastic rocks and tephra are very rare, and vents are absent or unexposed. A two-pyroxene andesite lava flow from this part of the sequence has a $\mathrm{K}-\mathrm{Ar}$ age of $26.2 \pm 0.2 \mathrm{Ma}$

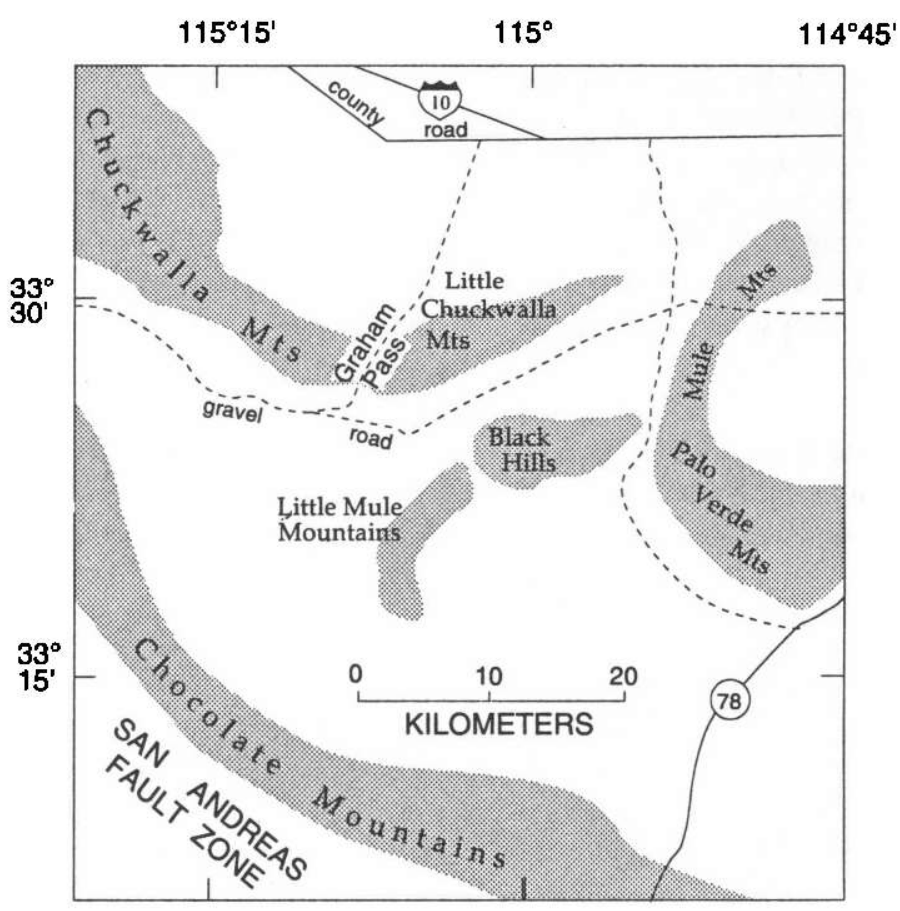

Figure 1. Map showing some geographic and geologic features discussed in text. 
(plagioclase) (Crowe and others, 1979; age recalculated using constants in Dalrymple, 1979).

The upper half of the Little Chuckwalla Mountains volcanic sequence is dominated by dacitic domes, locally erupted dacitic lava flows, and locally derived volcaniclastic rocks, but it also includes minor basaltic andesite to rhyolite lava flows. A tilted stack of resistant two-pyroxene andesite lava flows near the top of the volcanic section forms the highest peaks underlain by Tertiary volcanic rocks in the mountain range. Plagjoclase from one of these flows has a $\mathrm{K}-\mathrm{Ar}$ age of $26.3 \pm 4.2 \mathrm{Ma}$ (Crowe and others, 1979; recalculated using constants in Dalrymple, 1979).

Andesite, dacite, and rhyolite dikes cut pre-Tertiary basement rocks and the Little Chuckwalla Mountains volcanic sequence. Hypabyssal intrusion of the dacite and rhyolite dikes is indicated by abundant miarolitic cavities, extensive hydrothermal alteration of country rocks, and the intrusion of one of the dacite dikes into its own extrusive equivalents. Crosscutting and contact relations discussed by Mayo (1990) indicate that the composition of the dikes, like the volcanic section, became more silicic with time. This correlation of relative ages and compositions between eruptive rocks and intrusions suggests that the volcanic strata were largely dike fed. Exposed dike-fed vents are limited, however, to a single occurrence in the upper half of the section where the largest dacite dike, as much as $50 \mathrm{~m}$ thick and exposed for about $2 \mathrm{~km}$ along strike, merges with tifted lava flows and pyroclastic equivalents.

The stratigraphic and compositional boundary between the andesitic (lower) and dacitic (upper) halves of the Little Chuckwalla Mountains volcanic sequence is a key feature relating the section to Tertiary strata elsewhere in southeastern California. A broadly correlative regional boundary separates the "basal" and "silicic" volcanic sequences of Crowe and others (1979). The resistant andesitic lava flows near the top of the Little Chuckwalla Mountains volcanic sequence represent the older part of their regionally defined "capping volcanic sequence" (Crowe and others, 1979). Subhorizontal basaltic lava flows, with K-Ar ages ranging from 19 to $13 \mathrm{Ma}$, are the youngest volcanic rocks in several sections of southeastern California (Crowe, 1978; Crowe and others, 1979) but have no equivalents in the Little Chuckwalla Mountains.

\section{STRUCTURE}

The Little Chuckwalla Mountains volcanic sequence is a faulted homocline that strikes about N. $30^{\circ} \mathrm{E}$. and $\operatorname{dips} 10^{\circ}$ to $45^{\circ}$ southeast. Normal faults that cut the section have strikes between north and N. $60^{\circ} \mathrm{E}$. and west to northwest dips between $45^{\circ}$ and $60^{\circ}$. Dip separation across faults is difficult to estimate because of the lithologic monotony of parts of the volcanic section; the few reliable determinations are typically a few meters or less. The only significant known exception is a normal fault with a dip separation of about $300 \mathrm{~m}$ where it cuts wellexposed peak-capping andesite lava flows near the top of the section.

Most of the hypabyssal dikes strike within several degrees of $\mathrm{N} .35^{\circ} \mathrm{W}$. and have near-vertical dips. Exceptions to the $\mathrm{N} .35^{\circ} \mathrm{W}$. strike occur where the dikes locally intrude older, north-striking fault zones in the preTertiary basement rocks.

\section{SUMMARY OF VOLCANIC AND STRUCTURAL HISTORY}

The volcanic and structural history of Tertiary rocks in the Little Chuckwalla Mountains consists of four partly overlapping episodes. (1) Subaerial eruptions from vents of largely unknown location during late Oligocene time produced a thick proximal-facies sequence of andesitic to basaltic rocks (lower half of volcanic section). Deposition of alluvium rich in basement clasts was interrupted early in the episode, and the thickening volcanic section eventually buried the local pre-Tertiary basement rocks. (2) Numerous hypabyssal dikes with northwest strikes fed eruptions of viscous dacitic to rhyolitic lavas and nearvent pyroclastic deposits (upper half of volcanic section). Elongate dacite domes, flanked by lava flows and pyroclastic rocks, were extruded from feeder dikes, increasing local relief and forming small interdomal basins that trapped abundant, locally derived volcaniclastic debris, some juvenile pumice and ash, and volumetrically minor andesitic lava flows. (3) Southeastward tilting and downto-the-northwest normal faulting occurred after about 26 Ma. The youngest faults bound parts of the Little Chuckwalla Mountains volcanic sequence. (4) Thick, locally derived fanglomerate accumulated over the next several million years during the denudation of the uplifted edges of tilted fault blocks.

\section{ACKNOWLEDGMENTS}

This summary is taken largely from my M.S. thesis completed at California State University, Los Angeles. The work was partially funded by the Stone Fellowship and by grants from the Office of Graduate Studies and Research there. I wish to thank Dave Sherrod (U.S. Geological Survey), Robert Stull (California State University, Los Angeles), and Rick Hazlett (Pomona College) for their time in the field as well as instructive discussions about the geology of southeastern California and southwestern Arizona. 


\section{REFERENCES CITED}

Amstrong, R.L., and Suppe, John, 1973, Potassium-argon geochronometry of Mesozoic igneous rocks in Nevada, Utah, and southern California: Geological Society of America Bulletin, v. 84, no. 4, p. 1,375-1,392.

Crowe, B.M., 1978, Cenozoic volcanic geology and probable age of inception of basin-range faulting in the southeasternmost Chocolate Mountains, California: Geological Society of America Bulletin, v. 89, no. 2, p. 251-264.

Crowe, B.M., Crowell, J.C., and Krummenacher, Daniel, 1979, Regional stratigraphy, K-Ar ages, and tectonic implications of Cenozoic volcanic rocks, southeastern California: American Journal of Science, v. 279, no. 2, p. 186-216.

Dalrymple, G.B., 1979, Critical tables for conversion of K-Ar ages from old to new constants: Geology, v. 7, no. 11, p. 558-560.

Mayo, D.P., 1990, Geology and geochemistry of Tertiary volcanic rocks in the Little Chuckwalla Mountains, southeastern California: Los Angeles, California State University, M.S. thesis, $131 \mathrm{p}$.

Powell, R.E., 1981, Geology of the crystalline basement complex, eastern Transverse Ranges, southern California: constraints on regional tectonic interpretation: Pasadena, Califomia Institute of Technology, Ph.D. dissertation, 441 p. 



\title{
Tertiary Stratigraphy of the Southern Trigo Mountains, Ariz., and Eastern Chocolate Mountains, Calif.: Picacho State Park Area
}

\author{
By David R. Sherrod ${ }^{1}$ and Kathleen M. Hughes ${ }^{2}$
}

\begin{abstract}
SUMMARY
The Picacho State Park area lies along the Colorado River, which forms the border between Arizona and California. It lies in the area where southwest-trending Trigo Mountains meet the southeast-trending Chocolate Mountains (fig. 1). These rocky desert mountain ranges have relief as great as $750 \mathrm{~m}$. They are underlain by Proterozoic gneiss, Mesozoic intrusive rocks, and Tertiary volcanic rocks that underwent a major episode of extensional deformation beginning after $22 \mathrm{Ma}$. Sedimentary basins that bound the two ranges were formed during this time and subsequently filled by coalescing alluvial fans. About $5 \mathrm{Ma}$ an arm of the proto-Gulf of California briefly inundated low-lying areas, resulting in deposition of sandstone, siltstone, and limestone of the Bouse Formation in some basins south, west, and northwest of Picacho State Park. Faulting since that time enabled the Colorado River to establish its modern course in a trough along the west margin of the Trigo Mountains and through the southeastern Chocolate Mountains.
\end{abstract}

\section{STRATIGRAPHY}

Pre-Tertiary rocks in the Picacho State Park area include plutonic and metaplutonic rocks of Proterozoic and Mesozoic age and Jurassic metasedimentary and metavolcanic rocks (Haxel and others, 1985) (col. 3-E, pl. 3). These rocks, which form the upper plates of Late Cretaceous thrust faults (Chocolate Mountains thrust in study area), structurally overlie the Orocopia Schist, a metamorphosed assemblage of oceanic and sedimentary volcanic rocks of tentative Jurassic (protolith) age (Haxel and others, 1985, 1987). Eocene(?) to lower Miocene sedimentary and volcanic strata were deposited on the upper-plate meta-igneous and metasedimentary rocks. Lower and mid98661

${ }^{1}$ U.S. Geological Survey, 5400 MacArthur Blvd., Vancouver, WA

${ }^{2}$ Woodward-Clyde Consultants, 2020 E. First Street, Suite 400 , Santa Ana, CA 92705 dle Tertiary units are nowhere preserved in depositional contact with the Orocopia Schist, and we surmise that the Chocolate Mountains thrust remained unbreached by erosion and faulting until middle Miocene time.

Arkosic sedimentary rocks as thick as $34 \mathrm{~m}$ are commonly found mantling the pre-Tertiary unconformity. The

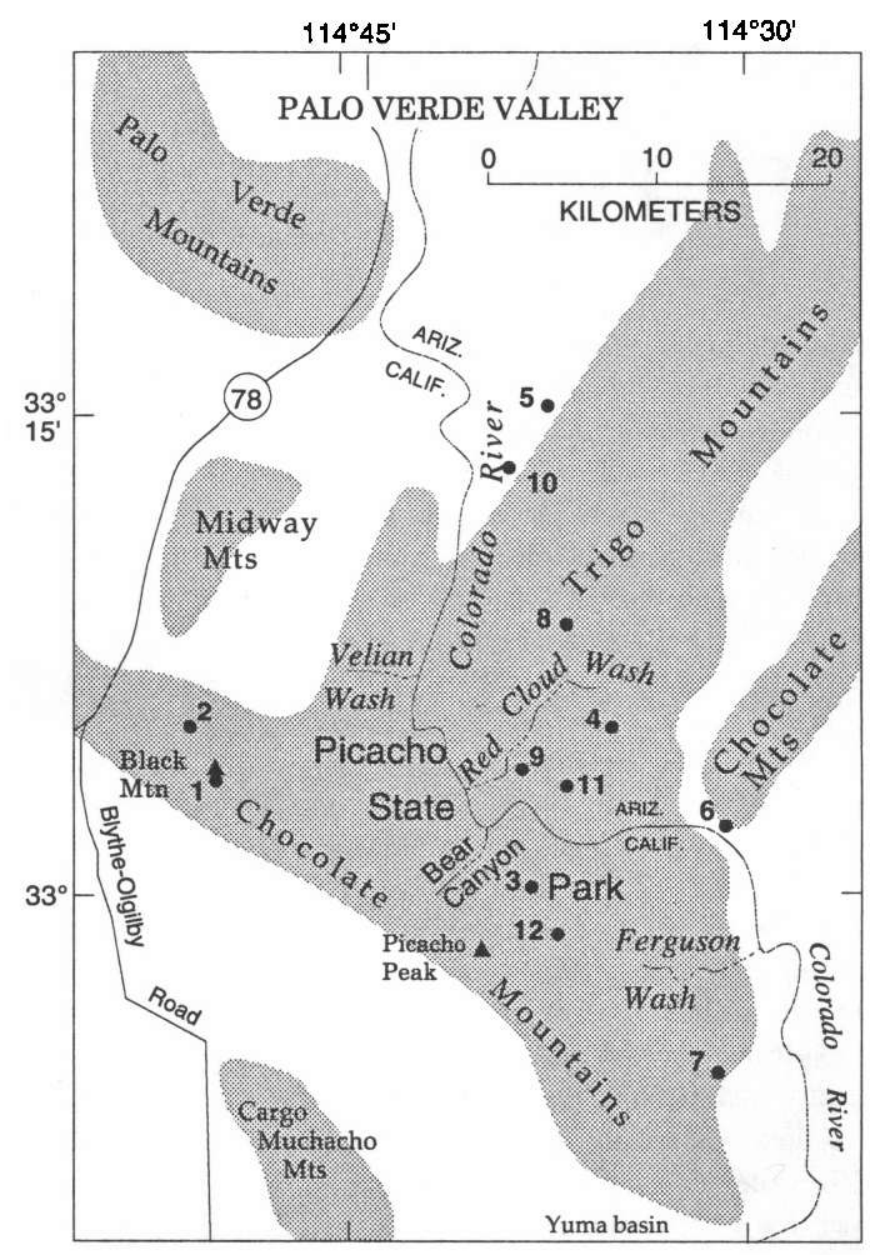

Figure 1. Map showing location of geographic features and dated samples discussed in text; numbers refer to table 1. In this paper, "Chocolate Mountains" refers to California Chocolate Mountains, not to northeast-trending Arizona Chocolate Mountains. 
Table 1. Potassium-argon ages of Tertiary volcanic rocks discussed in text

[Ages in boldface are stratigraphically consistent; other ages are spurious or of uncertain interpretation. All ages have been recalculated using modem isotopic decay consiants.]

\begin{tabular}{|c|c|c|c|c|c|}
\hline $\begin{array}{l}\text { Map No. } \\
\text { (see fig. 1) }\end{array}$ & Rock unit & Age & $\begin{array}{c}\text { Material } \\
\text { dated }\end{array}$ & $\begin{array}{c}\text { Sample } \\
\text { No. }\end{array}$ & Reference \\
\hline \multicolumn{6}{|c|}{ Isolated lava flows } \\
\hline 1 & Basalt of Black Mountain & $9.6 \pm 1.8$ & Whole rock & 121 & Eberly and Stanley (1978) \\
\hline 2 & do & ${ }^{2} 13.4 \pm 2.6$ & Plagioclase & PP-100 & Crowe (1978) \\
\hline \multicolumn{6}{|c|}{ Silicic tuff sequence and associated lava flows } \\
\hline--1 & Tuff of Felipe Pass & $22.2 \pm 0.6$ & Plagioclase & KRK165A & Bagby and others (1987) \\
\hline 3 & Rhyodacite & ${ }^{2} 23.3 \pm 6.1$ & Plagioclase & $3-26$ & Crowe (1978) \\
\hline 4 & Basalt (in sequence) & $28.9 \pm 3.5$ & Plagioclase & Qb-1 & Weaver $(1982)$ \\
\hline 5 & Unnamed tuff & $26.0 \pm 1.7$ & Whole rock & 120 & Eberly and Stanley (1978) \\
\hline 6 & Ignimbrite of Ferguson Wash & $24.9 \pm 1.5$ & Biotite & $T-42$ & Weaver (1982) \\
\hline 7 & do & ${ }^{2} 26.9 \pm 1.6$ & Sanidine & COL 2-35:1a & Olmsted and others (1973) \\
\hline--1 & do & $227.0 \pm 1.0$ & Biotite & PED 4-65 & Do. \\
\hline \multicolumn{6}{|c|}{ Quechan volcanic rocks and correlative rocks } \\
\hline 8 & Andesite & $25.2 \pm 2.5$ & Plagioclase & UP-21 & Weaver (1982) \\
\hline 9 & Rhyolite & $27.0 \pm 3.2$ & do & T.37 & Do. \\
\hline 10 & Andesite & $27.7 \pm 6.8$ & do & UP-20 & Do. \\
\hline 11 & Dacite & $29.1 \pm 3.5$ & do & $\mathrm{T}-40$ & Do. \\
\hline 12 & Dacite & ${ }^{2} 32.6 \pm 3.3$ & Plagioclase & $5-86$ & Crowe (1978) \\
\hline
\end{tabular}

${ }^{1}$ Not on fig. 1.

${ }^{2}$ Original published data incomplete. Age recalculated using critical table (Dalrymple, 1979).

sedimentary unit, comprising fine- to coarse-grained sandstone and sedimentary breccia, becomes finer grained upsection and northward; also it thins northward. Though undated, the arkosic sedimentary strata were probably deposited during Eocene(?) to early Oligocene time because they are locally interbedded with tuffaceous sandstone that correlates with the basal part of an overlying volcanic sequence as old as about $33 \mathrm{Ma}$ (table 1, No. 12). We show the arkosic sedimentary rocks as old as $37 \mathrm{Ma}$ (col. 3-E, pl. 3), but no maximum age constraint is available.

Well-bedded, flaggy tuffaceous sandstone, tuff, and lapilli tuff conformably overlie the arkosic sedimentary rocks at many localities. The tuffaceous sequence generally is about 10 to $20 \mathrm{~m}$ thick but locally thickens to nearly $70 \mathrm{~m}$. For example, it contains $40 \mathrm{~m}$ of thin-bedded, flaggy limestone, sandy limestone, and siltstone overlain by $30 \mathrm{~m}$ of tuffaceous sandstone at Velian Wash.

Volcanic rocks as thick as $\mathbf{3 0 0} \mathrm{m}$ conformably overlie Tertiary sedimentary rocks throughout the Picacho State Park area. Called the Quechan volcanic rocks by Crowe (1978), they consist of locally erupted mafic to silicic lava flows and fewer volcaniclastic strata. Ash-flow tuffs are of limited extent; most are unwelded or only partially welded, moderately pumiceous, and lithic rich. Potassium-argon ages from the Quechan volcanic rocks range from about $33 \mathrm{Ma}$ to $27 \mathrm{Ma}$ in the area of Picacho State Park (table 1, Nos. 8-12); ages are recalculated using modern decay constants where necessary.

A widespread sequence of silicic tuff, mainly pyroclastic flows and volcaniclastic rocks that originated as rhyodacite and rhyolite pyroclastic flows, conformably overlies the Quechan volcanic rocks. The silicic tuff sequence is about $300 \mathrm{~m}$ thick and contains several mappable pyroclastic-flow units, a few silicic lava flows, and minor basalt and andesite lava. The ignimbrite of Ferguson Wash (Crowe, 1978) is the most widespread of the ashflow tuffs in the Picacho State Park area and was probably erupted about 27-25 Ma (table 1, Nos. 6 and 7) from a caldera $30 \mathrm{~km}$ to the south or southeast (Richard, this volume). It is distributed over $500 \mathrm{~km}^{2}$ in the southern part of the lower Colorado River region. The tuff of Felipe Pass (Sherrod and Tosdal, 1991), which was erupted about 22 Ma (table 1) and is the youngest part of the silicic tuff sequence, is found at one locale along Red Cloud Wash east of the Colorado River and is increasingly widespread to the north and northeast.

Lava flows of intermediate and silicic composition conformably or perhaps disconformably overlie the silicic tuff at a few scattered localities. Their thickness is generally less than $50 \mathrm{~m}$. 
Widespread extensional deformation affected rocks in nearly all mountain ranges of the region surrounding Picacho State Park. The deformation, which occurred after deposition of the 22-Ma tuff of Felipe Pass (Sherrod and others, 1987), resulted in erosional debris being shed into several basins throughout the area. These sedimentary rocks, known from the Picacho State Park area as the conglomerate of Bear Canyon (Crowe, 1978; see also Hughes, this volume), lie conformably to unconformably above the volcanic rocks and consist of sandstone, and locally coarse sedimentary breccia that accumulated as large alluvial fans in grabens and half grabens.

Deposition of the conglomerate of Bear Canyon and extension of the region were simultaneous at first, leading to numerous internal unconformities in the lower part of the unit; also, dips decrease to nearly subhorizontal across a short stratigraphic thickness, commonly less than a few tens of meters. The unit commonly grades upsection from entirely volcanic clasts to mixtures of Tertiary volcanic and pre-Tertiary crystalline clasts, in response to increasingly widespread exposure of crystalline rocks along moderately dipping faults. Aggradation in the Picacho State Park area had largely ceased before eruption of basalt lava at Black Mountain in middle or late Miocene time; the two K-Ar whole-rock ages from basalt at Black Mountain-13.4 $2.6 \mathrm{Ma}$ and $9.6 \pm 1.8 \mathrm{Ma}$ (table 1 , Nos. 1 and 2) -have large analytical error, and the entire sequence of lava flows exposed at Black Mountain was probably emplaced in a short period of time. Other sites had a more protracted depositional history, especially some of the large areas that coincide with present basins such as Palo Verde Valley, Milpitas Wash, and the Yuma basin. The Bouse Formation and overlying alluvium were deposited in these areas in late Miocene and Pliocene time. The Yuma basin and perhaps Palo Verde Valley were depocenters for locally derived alluvium and Colorado River detritus during the early Quaternary as well.

The Picacho State Park area has been undergoing mainly erosion since Black Mountain time (beginning sometime between about 13 and $9 \mathrm{Ma}$ ). Alluvium deposited as terraces and small alluvial fans may be as thick as $50 \mathrm{~m}$, however. These units thicken away from the mountains and into surrounding basins. The Colorado River established its present course between Blythe and Yuma in late Pliocene or early Pleistocene time. Nested terraces in- dicate downcutting of the Colorado River in late Pleistocene and Holocene time.

\section{REFERENCES CITED}

Bagby, W.C., Haxel, G.B., Smith, D.B., Koch, R.D., Grubensky, M.J., Sherrod, D.R., and Pickthom, L.B.G., 1987, Mineral resource assessment of the Kofa National Wildlife Refuge, Arizona: U.S. Geological Survey Open-File Report 87-609, 72 p.

Crowe, B.M., 1978, Cenozoic volcanic geology and probable age of inception of basin-range faulting in the southeasternmost Chocolate Mountains, California: Geological Society of America Bulletin, v. 89, no. 2, p. 251-264.

Dalrymple, G.B., 1979, Critical tables for conversion of $\mathrm{K}-\mathrm{Ar}$ ages from old to new constants: Geology, v. 7, no. 11, p. 558560.

Eberly, L.D., and Stanley, T.B., Jr., 1978, Cenozoic stratigraphy and geologic history of southwestern Arizona: Geological Society of America Bulletin, v. 89, no. 6, p. 921-940.

Haxel, G.B., Budahn, J.R., Fries, T.L., King, B.W., White, L.D., and Aruscavage, P.J., 1987, Geochemistry of the Orocopia Schist, southeastern California: Summary, in Dickinson, W.R., and Klute, M.A., eds., Mesozoic rocks of southern Arizona and adjacent areas: Arizona Geological Society Digest, v. 18, p. $49-64$.

Haxel, G.B., Tosdal, R.M., and Dillon, J.T., 1985, Tectonic setting and lithology of the Winterhaven Formation: A new Mesozoic stratigraphic unit in southeasternmost California and southwestern Arizona: U.S. Geological Survey Bulletin $1599,19 \mathrm{p}$.

Olmsted, F.H., Loeltz, O.J., and Irelan, Burdge, 1973, Geohydrology of the Yuma area, Arizona and California: U.S. Geological Survey Professional Paper 486-H, 227 p.

Sherrod, D.R., Pickthom, L.B.G., Tosdal, R.M., Grubensky, M.J., and Koch, R.D., 1987, Major early Miocene extensional deformation in southwestern Arizona and southeastern California [abs.]: Geological Society of America Abstracts with Programs, v. 19, no. 7, p. 841.

Sherrod, D.R., and Tosdal, R.M., 1991, Geologic setting and Tertiary structural evolution of southwestem Arizona and southeastern Califomia: Joumal of Geophysical Research, v. 96, no. B7, p. 12,407-12,423.

Weaver, B.F., 1982, Reconnaissance geology and K-Ar geochronology of the Trigo Mountains detachment terrane, Yuma County, Arizona: San Diego, Calif., San Diego State University, M.S. thesis, 119 p. 



\title{
Tertiary Stratigraphy of the Middle and Chocolate Mountains of Southwestern Ariz.
}

\author{
By Stephen M. Richard ${ }^{1}$
}

\section{INTRODUCTION}

The region north of the Chocolate Mountains anticlinorium in the Middle and Chocolate Mountains of southwestern Arizona is blanketed by a 1- to 2-km-thick section of Oligocene and Miocene volcanic rocks that include mostly intermediate-composition lava flows in the lower part and silicic ash-flow tuffs in the upper part. The following section briefly describes the Tertiary rocks in this area; the stratigraphic column (col 3-F, pl. 3) is a composite because the units are nowhere present in a continuous section. Throughout this paper, "Chocolate Mountains" refers to the Chocolate Mountains in Arizona (fig. 1), which are separated by the Colorado River from the better known Chocolate Mountains of southeastern California.

\section{STRATIGRAPHY}

\section{BASAL SEDIMENTARY ROCKS}

Tertiary sedimentary strata with highly variable thickness nonconformably overlie the Jurassic(?) Winterhaven Formation (Haxel and others, 1985) and Jurassic(?) granitoid rocks along the northern side of the Chocolate Mountains anticlinorium. The basal sedimentary section generally consists of thin- to medium-bedded brown lithic sandstone with shale partings, commonly interbedded with conglomerate that contains angular clasts derived from underlying pre-Tertiary rocks. The conglomerate is typically heterolithic and matrix rich; monolithologic, matrix-poor conglomerate is locally abundant. The lithic sandstone and conglomerate are commonly overlain by thin-bedded, white tuffaceous sandstone. The thickness of the basal sedimentary unit is generally less than 100 meters, but stratigraphic details near the nonconformity are commonly obscured by structural disruption, which is concentrated by the differential competence of pre-Tertiary and Tertiary rocks near the nonconformity.

\footnotetext{
${ }^{1}$ Arizona Geological Survey, 845 N. Park Ave., Tucson, AZ 85719
}

The basal sedimentary unit is younger than early Tertiary and older than late Oligocene in age. It overlies crystalline rocks lithologically similar to and correlated with rocks in the Trigo Mountains (Weaver, 1982) that have Late Cretaceous or early Tertiary biotite $\mathrm{K}-\mathrm{Ar}$ cooling ages. The basal sedimentary unit is overlain by intermediate-composition volcanic rocks, which are identified here as the lower(?) and upper Oligocene Quechan volcanic rocks of Crowe (1978).

\section{ANDESITE, DACITE, AND BASALT LAVA}

This heterogeneous unit includes brown dacite or andesite with phenocrysts of plagioclase, hornblende(?), and rare quartz; dark-gray basalt with olivine, pyroxene, and plagioclase phenocrysts; and andesite containing about 5 percent of 1- to 2-mm-long plagioclase phenocrysts and sparse altered ferromagnesian phenocrysts. Large volumes of homogeneous, massive, intrusive(?) andesite are present in the Chocolate Mountains. The ferromagnesian phenocrysts are typically altered to hematite and clay, making identification difficult. Flow contacts in the basaltic rocks form red-stained, highly vesicular or fragmental zones, but flow margins in the andesitic to dacitic rocks tend to be cryptic; shallow intrusive rocks are very difficult to distinguish from extrusive rocks.

The unit of andesite, dacite, and basalt lava is equivalent to lithologically similar rocks in nearby southeastern California that were called the Quechan volcanic rocks by Crowe (1978). The Quechan volcanic rocks may be as old as $32 \mathrm{Ma}$ (Crowe, 1978).

\section{LITHIC RHYOLITE TUFF}

Buff to $\tan$ lithic lapilli-to-block tuff with 2 to 4 percent quartz, sanidine, biotite, plagioclase, and hornblende phenocrysts forms a compound cooling unit. The unit thickens dramatically northwest of Trip Mountain by addition and thickening of individual pyroclastic-flow deposits. Vitrophyre zones separate several of the cooling units present in this area. Lithic fragments of red-brown, 
feldspar-phyric felsite are abundant in beds of the lower part, whereas fragments of medium-grained equigranular granodiorite and subordinate quartz-feldspar gneiss and homblende schist are more abundant in the upper part of the unit. A distinctive tuff that contains abundant clasts of argillite derived from the Winterhaven(?) Formation is present near the top of the unit. A thin deposit of the tuff of Ten Ewe Mountain (Grubensky and others, in press) is interbedded in the sequence of lithic tuffs just below the Winterhaven(?) clast-bearing tuff.

The lithic rhyolite tuff is probably partly equivalent to the tuff of Crazy Woman Wash, which is widespread in the northern Trigo Mountains (D.R. Sherrod and R.M. Tosdal, unpublished data, 1989). Because the lithic rhyolite tuff represents a series of eruptions, possibly derived from more than one source (for example, tuff of Ten Ewe Mountain), the stratigraphic relationship between it and the tuff of Crazy Woman Wash is uncertain. At the north edge of the Red Hill quadrangle in the northern Chocolate Mountains, lithic tuff beds overlie and appear to interfin- ger northward with dacitic lava, tuff, and fragmental rocks that underlie Mohave Peak. To the south they overlie andesite or basalt flows lithologically similar to the Quechan volcanic rocks (Crowe, 1978). The unit of lithic tuff is overlain by and interfingers locally with basalt or andesite flows that separate it from the tuff of Felipe Pass (fig. 2). The lithic tuff unit thins rapidly to the south in the Chocolate Mountains as the tuff of Ten Ewe Mountain thickens; a thin stratigraphic section of tuff, including the Winterhaven(?)-clast tuff, is present in the northern Middle Mountains.

\section{TUFF OF TEN EWE MOUNTAIN}

A tan, hornblende-biotite crystal tuff that contains 4 to 7 percent crystais of homblende, biotite, and plagioclase forms a thick emplacement unit in the central part of the Chocolate and Middle Mountains. Quartz and sanidine are abundant toward the base of the unit north of Los Angeles

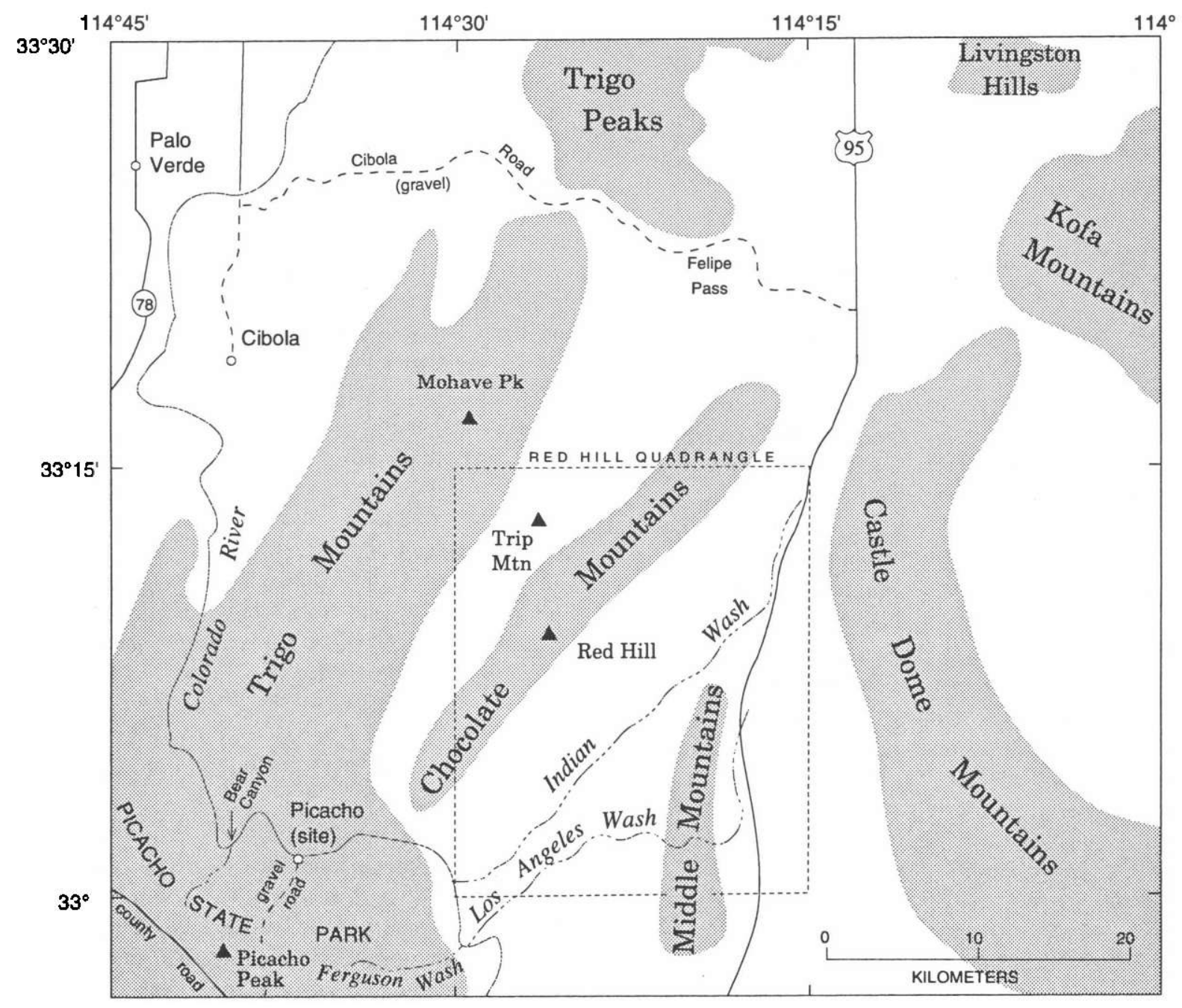

Figure 1. Map showing location of geographic features discussed in text. 
Wash in the Middle Mountains, where a black basal vitrophyre is also present. The tuff contains 10 to 20 percent lithic fragments of hornblende- and plagioclase-phyric andesite, and sparse but ubiquitous fragments of equigranular, medium-grained hornblende-biotite granodiorite. This tuff is identified here as the tuff of Ten Ewe Mountain on the basis of its lithologic similarity to exposures of the Ten Ewe Mountain mapped east of Stone Cabin on U.S. Highway 95 by Grubensky and others (in press). In the Kofa Mountains, the tuff of Ten Ewe Mountain has a K-Ar age of 22.1 $\pm 0.3 \mathrm{Ma}$ (biotite; L.G. Pickthorn, in Bagby and others, 1987).

Tuff breccia containing blocks of underlying units is present near the abrupt southern boundary of the tuff, which suggests that this boundary was an escarpment, possibly a volcano-tectonic collapse structure. The tuff thins to the north and pinches out in the lithic rhyolite tuff unit.

\section{ANDESITE AND BASALT}

A sequence of 10- to 70-m-thick andesite to basalt lava flows overlies the lithic rhyolite tuff or the tuff of Ten Ewe Mountain. Flow contacts are locally visible as redstained, highly vesicular zones. South of Indian Wash in the Middle Mountains, the flows interfinger with andesitic tuffaceous sedimentary rocks and breccia. In the Middle Mountains the unit consists mostly of reddish-brown to dark-gray, highly fractured, vesicular to massive andesite(?) with 1 to 3 percent augite(?) phenocrysts as much as $3 \mathrm{~mm}$ across in a very fine grained, microlitic groundmass. Ferromagnesian phenocrysts typically are unidentifiable because they are altered to hematite and clay. The source of the flows was probably in the central Chocolate Mountains, where lithologically similar andesitic dikes and sills intrude the underlying tuff of Ten Ewe Mountain. Some dikes are continuous with overlying flows.

\section{TUFF OF FELIPE PASS}

The tuff of Felipe Pass (Sherrod and others, 1990; Sherrod and Tosdal, 1991) is a pink-brown, generally strongly welded rhyodacite or rhyolite crystal tuff. It contains 1 to 2 percent phenocrysts of biotite and blocky plagioclase; accessory augite is diagnostic. Sparse plagioclase-phyric felsite lithic fragments are present. Thick sections in the northern Middle Mountains and northern Chocolate Mountains comprise several 5- to 15-m-thick cooling units, each with basal vitrophyres; the vitrophyres are overlain by massive, densely welded, lithophysal tuff, within which welding decreases upsection. The section is capped by a crystal-poor, stony rhyolite tuff that contains about 1 percent sanidine and quartz crystals and a trace of biotite; commonly the base of this unit is strongly welded and forms a break in slope. The tuff grades to massive dacite (very densely welded tuff?) and tuff breccia in the Los Angeles Wash area of the central Middle Mountains. The tuff of Felipe Pass has a $\mathrm{K}$-Ar age of $22.2 \pm 0.6 \mathrm{Ma}$ (plagioclase) (L.G. Pickthorn, in Bagby and others, 1987).

\section{VOLCANIC ROCKS IN THE STONE CABIN AREA}

Rhyolite or rhyodacite lava flows underlie a large area of the northeastern Chocolate Mountains and the northern Castle Dome Mountains (Bagby and others, 1987). These lavas vary from crystal-rich to aphyric and are massive to flow-laminated. Crystals generally include plagioclase, biotite, and variable amounts of quartz, sanidine, and hornblende. Flows typically have a glassy base, variably devitrified central core, devitrified upper zone, and capping tuff. Tuffaceous sedimentary rocks separate flows.

Individual flows are as thick as $200 \mathrm{~m}$ in the northeasternmost Chocolate Mountains. They thin and decrease

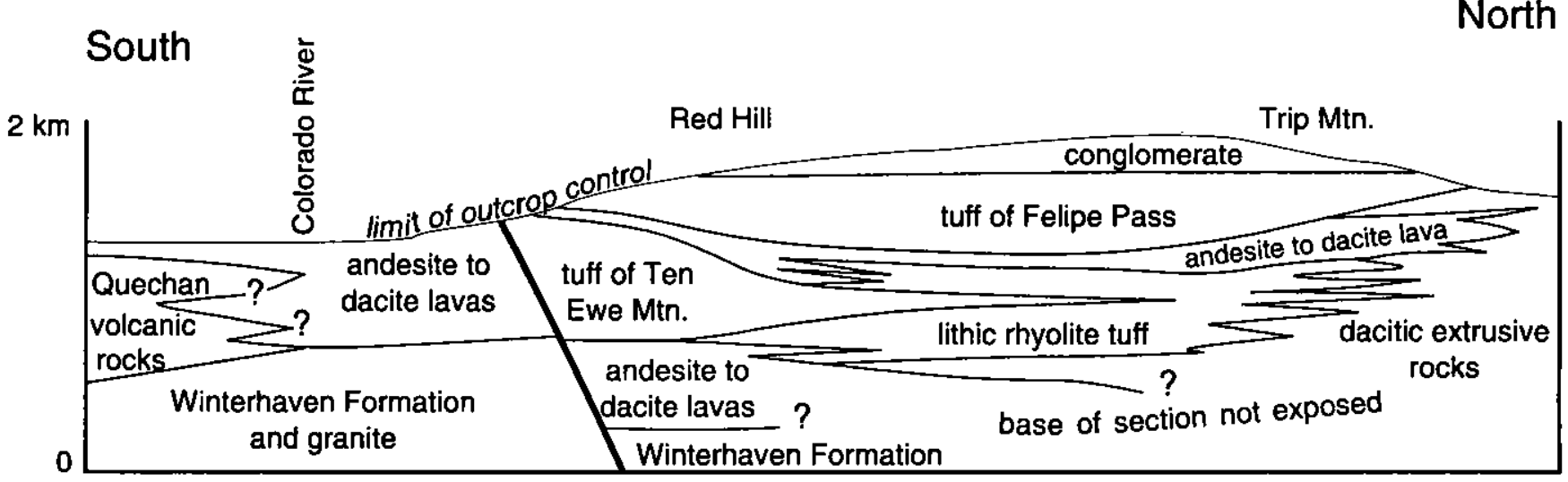

Vertical scale approximate. No horizontal scale

Figure 2. Schematic stratigraphic cross section summarizing relationships exposed in several different fault blocks, Arizona Chocolate Mountains. All units Tertiary in age except Jurassic Winterhaven Formation and associated granite. Contacts queried where uncertain. 
in number to the south, where the unit is formed mostly of tuff and tuffaceous sedimentary rocks.

Rhyolite flows included in this unit interfinger with the tuff of Felipe Pass and the andesite and basalt unit in the northem Middle Mountains. Lithic rhyolite tuff in the northern Chocolate Mountains may correlate with this unit; a similar relation is seen by the interfingering of correlative rhyolite flows with the tuff of Ten Ewe Mountain in the northern Castle Dome Mountains (Grubensky and others, in press). Dacite flows and fragmental rocks become abundant in this stratigraphic interval in the northern Chocolate Mountains, but relationships are unclear due to sparse outcrops, lack of marker units, and very limited access to key localities on the U.S. Army's Yuma Proving Ground. Gutmann (1981) reported a K-Ar age of 22.2 \pm 0.5 Ma (biotite) from a sample of rhyolite collected south of Stone Cabin.

\section{CONGLOMERATE}

Tan-weathering, volcanic-lithic sandstone and pebble to boulder conglomerate overlies all the volcanic rocks on an angular unconformity of considerable relief. Clasts in the conglomerate are derived from all volcanic rocks in the area. This conglomerate probably is similar in age and tectonic setting to the conglomerate of Bear Canyon of Crowe (1978), which was described from the area of Picacho State Park, Calif (Hughes, this vol.; Sherrod and Hughes, this vol.). Contacts between this Tertiary conglomerate and lithologically similar alluvium of late Tertiary and early Quatemary age are difficult to locate precisely; however, the conglomerate generally has better developed bedding.

\section{UPPER TERTIARY AND LOWER QUATERNARY ALLUVIUM}

This unit includes massive to poorly bedded, poorly indurated, cobble to boulder conglomerate. The heterogeneous clast population includes pre-Tertiary rocks from the Castle Dome Mountains as well as locally derived volcanic rocks. The upper Tertiary and lower Quaternary alluvium overlies volcanic-clast conglomerate in angular unconformity on a surface with 5 to $50 \mathrm{~m}$ of relief.

\section{PALEOGEOGRAPHY}

Stratigraphic relationships in the Middle and Chocolate Mountains suggest that a composite volcano-tectonic trough lay parallel to and north of the Chocolate Mountains anticlinorium. This trough is defined by thick accumulations of the tuff of Ten Ewe Mountain, which pinches out abruptly to the south and thins more gradually to the north. The depositional asymmetry suggests both that the southern trough boundary may be a volcanic-subsidence feature and that subsidence was concentrated on the south side of the trough.

The tuff of Felipe Pass thins gradually to the north and south in the northern Middle Mountains, possibly filling a paleovalley between volcanic edifices that were sources of the volcanic rocks in the Stone Cabin area and of intermediate-composition lava along the location of the Chocolate Mountains anticlinorium. Although the section in the central Middle Mountains is not as thick as those in the northem part of the range, its association with tuff breccia suggests proximity to vents. A northeast-striking, flow-banded rhyodacite dike with a crystal assemblage similar to the tuff of Felipe Pass is exposed in the central Middle Mountains and may be one of the vents for this tuff.

The tuff of Felipe Pass thins and apparently pinches out against the thick accumulations of volcanic rocks in the Stone Cabin area but is relatively thick in the type area, $7 \mathrm{~km}$ north of Felipe Pass. The volcanic rocks of Stone Cabin thus probably formed a volcanic edifice that controlled the distribution and thickness of the tuff of Felipe Pass.

\section{ACKNOWLEDGMENTS}

I wish to thank Mike Grubensky for reviewing an early version of this manuscript.

\section{REFERENCES CITED}

Bagby, W.C., Haxel, G.B., Smith, D.B., Koch, R.D., Grubensky, M.J., Sherrod, D.R., and Pickthorn, L.G., 1987, Mineral resource assessment of the Kofa National Wildlife Refuge, Arizona: U.S. Geological Survey Open-File Report 87-609, 72 p.

Crowe, B.M., 1978, Cenozoic volcanic geology and probable age of inception of basin-range faulting in southeasternmost Chocolate Mountains, California: Geological Society of America Bulletin, v. 89, no. 2, p. 251-264.

Grubensky, M.J., Haxel, G.B., and Koch, R.D., in press, Geologic map of the Castle Dome Mountains: U.S. Geological Survey Miscellaneous Investigations Map I-2138, scale $1: 62,500$.

Gutmann, J.T., 1981, Geologic framework and hot dry rock geothermal potential of the Castle Dome area, Yuma County, Arizona: Los Alamos Scientific Laboratory Report LA-8723HDR, UC-66b, $23 \mathrm{p}$.

Haxel, G.B., Tosdal, R.M., and Dillon, J.T., 1985, Tectonic setting and lithology of the Winterhaven Formation, a new Mesozoic stratigraphic unit in southeasternmost California and southwestern Arizona: U.S. Geological Survey Bulletin $1599,19 \mathrm{p}$. 
Sherrod, D.R., Koch, R.D., and Grubensky, M.J., 1990, Geologic map of the Vicksburg quadrangle, La Paz County, Arizona: U.S. Geological Survey Geologic Quadrangle Map GQ1684 , scale $1: 62,500$.

Sherrod, D.R., and Tosdal, R.M., 1991, Geologic setting and Tertiary structural evolution of southwestern Arizona and south- eastern California: Journal of Geophysical Research, v. 96, no. B7, p. $12,407-12,423$.

Weaver, B.F., 1982, Reconnaissance geology and K-Ar geochronology of the Trigo Mountains detachment terrane, Yuma County, Arizona: San Diego, Calif., San Diego State University, M.S. thesis, 119 p. 



\title{
Stratigraphy of the Ferguson Wash Area, Southeastern Calif., and Adjacent Parts of Southwestern Ariz.
}

\author{
By Stephen M. Richard ${ }^{1}$
}

Pre-Tertiary rocks along the Chocolate Mountains anticlinorium are overlain by 1 to $2 \mathrm{~km}$ of Oligocene and Miocene volcanic rocks. This report describes the stratigraphy of volcanic rocks south of the anticlinorium between Ferguson Wash and Laguna Dam in California and correlative sections in Arizona as far east as the southern Middle Mountains (fig. 1).

Along the southwest edge of outcrops in the Laguna Dam area, the oldest Tertiary unit is a thick sequence of sedimentary breccia (col. 3-G, pl. 3) (Olmsted and others, 1973; Olmsted, 1972; Lombard, 1990, this volume). The breccia thins to the north and is overlain by widespread volcanic rocks (Crowe, 1978). The volcanic rocks typically include abundant basalt or andesite lava flows that are overlain by ash-flow tuff. The volcanic section is capped by sandstone, conglomerate, and locally interbedded basalt flows (Crowe and others 1979; Crowe, 1978).

'Arizona Geological Survey, 845 N. Park Ave., Tucson, AZ 85719

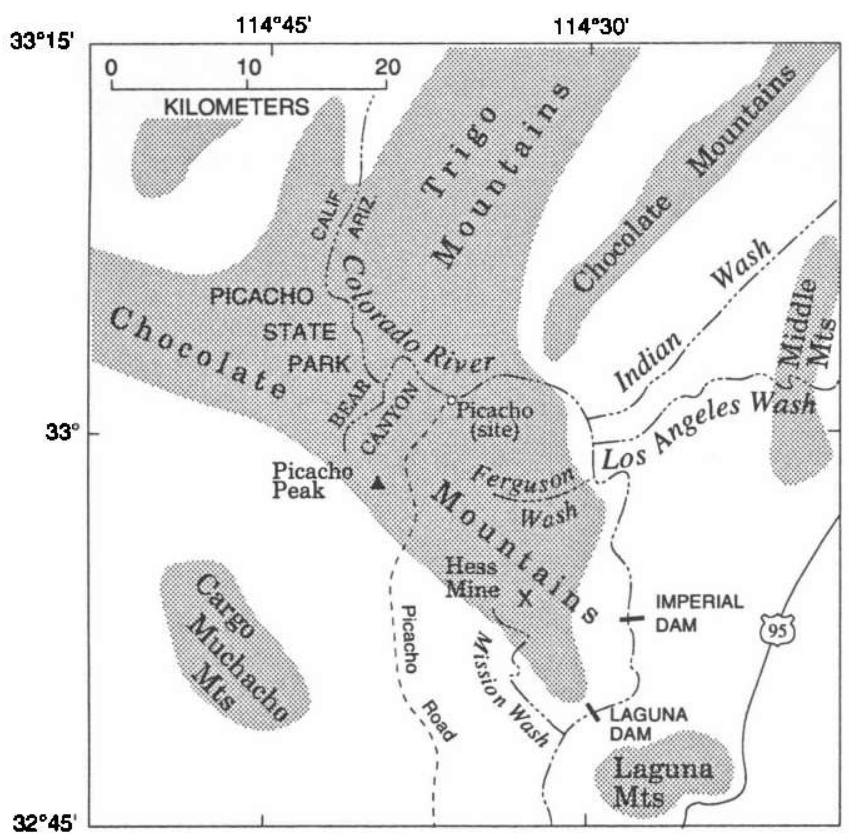

Figure 1. Map showing location of selected geographic features discussed in text.

\section{STRATIGRAPHY}

\section{PRE-TERTIARY ROCKS}

Along the southern side of the Chocolate Mountains anticlinorium, pre-Tertiary rocks include the Jurassic(?) Winterhaven Formation (Haxel and others, 1985), rocks closely resembling the Jurassic(?) and Cretaceous McCoy Mountains Formation of Harding and Coney (1985), and Jurassic plutonic and volcanic rocks. In the southernmost outcrops along the Colorado River near Laguna Dam, preTertiary rocks are heterogeneous quartzofeldspathic gneiss that lithologically resembles rocks of the San Gabriel terrane (Powell, 1981a, b) and coarse-grained monzogranite, both of presumed Proterozoic age. Contacts between the diverse pre-Tertiary units are concealed by the overlying Tertiary strata.

\section{TERTIARY SEDIMENTARY BRECCIA AND CONGLOMERATE}

The oldest Tertiary rocks in the region form a thick section of sedimentary breccia found in the vicinity of Laguna Dam (Olmsted, 1972; Lombard, 1990). The breccia is poorly indurated and forms rounded hills. It consists of cobbles to boulders (as large as $20 \mathrm{~m}$ in diameter) in a matrix of poorly sorted sand and pebbles. Bedding is rarely visible as an alignment of elongate boulders or in lenses of planar-laminated or cross-bedded sandstone. Several facies of the breccia that are recognized by clast composition are discussed here.

Breccia units east of the Colorado River were derived mostly from Proterozoic(?) crystalline rocks lithologically similar to those exposed in the Laguna Mountains (Olmsted and others, 1973; Lombard, 1990, this volume). In contrast, the southwest-dipping section west of the Colorado River near Laguna Dam (unit Tbh, fig. 2) contains abundant clasts of Mesozoic sedimentary rocks. Clasts in the lower part of the unit are mostly brown feldspathic-lithic sandstone and conglomerate that are lithologically similar to the Mesozoic conglomerate exposed west of Imperial Dam (McCoy Mountains? 
Formation). Clasts of Jurassic volcanic and granitic rocks increase in abundance upsection. The uppermost part of the unit is conglomeratic and characterized by subround- ed clasts and more readily discernible bedding. This breccia unit, which is at least $1,100 \mathrm{~m}$ thick, unconformably overlies coarse-grained Proterozoic monzogranite
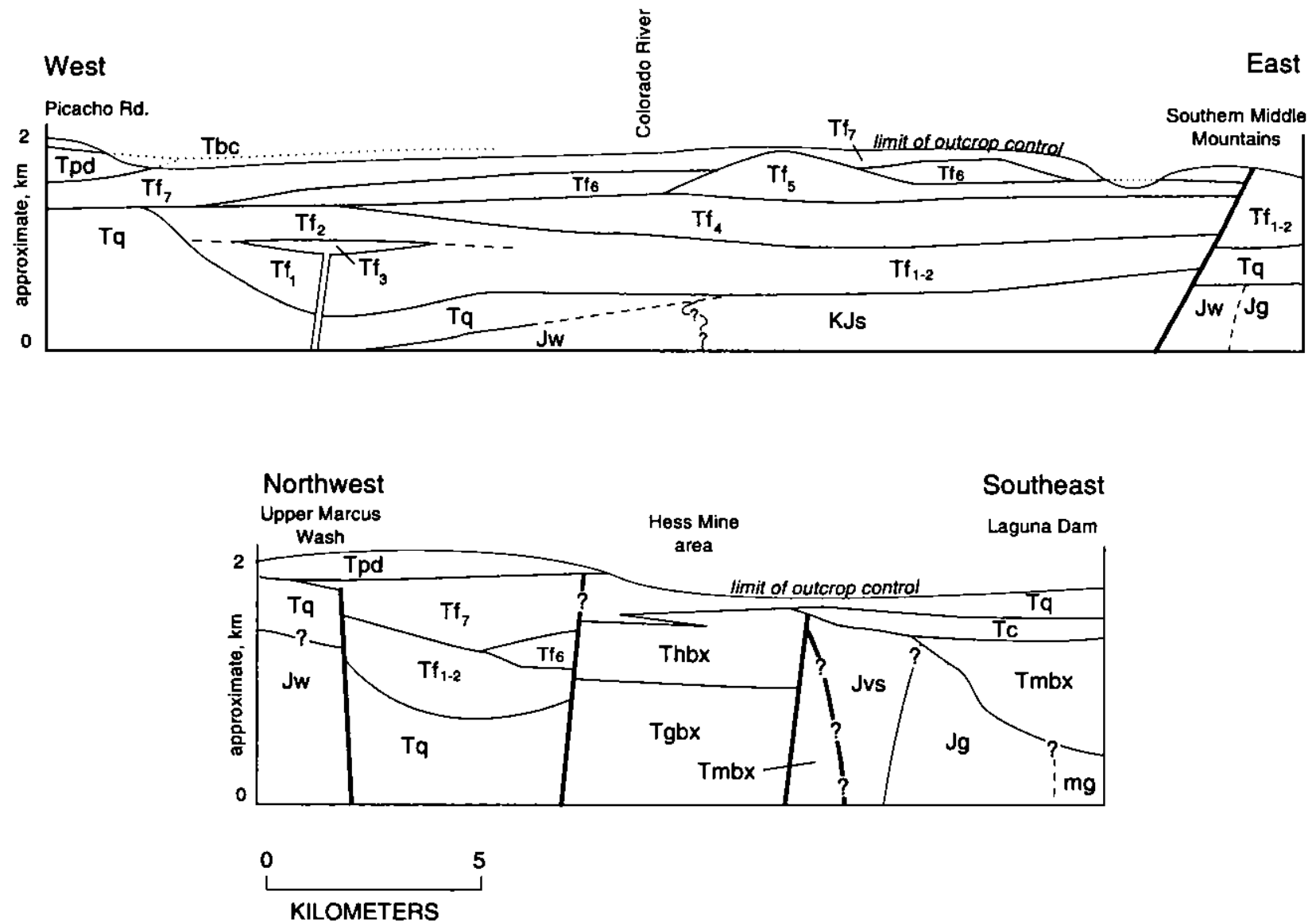

\section{EXPLANATION}

Tbc Conglomerate of Bear Canyon of Crowe (1978) (Miocene)

Tpd Dacite of Picacho Peak of Crowe (1978) (Miocene)

$\mathrm{Tf}_{1-7}$ Ignimbrite of Ferguson Wash of Crowe (1978) (Oligocene)-Divided into seven units, from oldest $\left(\mathrm{Tf}_{1}\right)$ to youngest $\left(\mathrm{Tf}_{7}\right)$; see figure 3 . Units 1 and $2\left(\operatorname{Tf}_{1-2}\right)$ locally shown undivided

Tq Quechan volcanic rocks of Crowe (1978) (Oligocene)

Tc Conglomerate (Oligocene)

Thbx Heterogeneous breccia (Oligocene)
Tgbx Granodiorite-clast breccia (Oligocene)

Tmbx Mesozoic supracrustal rocks-clast breccia (Oligocene)-Contains clasts of from units Jvs and KJs

KJs Sedimentary rocks (Cretaceous and Jurassic)

Jvs Volcanic and sedimentary rocks (Jurassic)

Jw Winterhaven Formation (Jurassic?)

Jg Granitoids (Jurassic)

mg Monzogranite (Proterozoic)

Contact-Dashed or queried where inferred

Fault-Dashed or queried where inferred

Figure 2. Schematic stratigraphic cross sections of Ferguson Wash caldera. Thicknesses are not to scale, and horizontal scale is approximate. Unit symbols correspond to those used in text. 
(unit mg, fig. 2; see also Olmsted, 1972). The contact between the breccia and Jurassic granitoids to the north is highly discordant to bedding, indicating either a fault or buttress unconformity.

Megabreccia and sedimentary breccia north of Hess mine contain angular clasts of crystalline rocks lithologically resembling those exposed in the Cargo Muchacho Mountains (fig. 1) (R.M. Tosdal, oral commun., 1990). The breccia is generally monolithologic; where heterolithologic, the clast assemblages are similar to the rocks in the source area. A lower unit of foliated biotite and hornblende-biotite granodiorite-clast breccia (unit Tgbx, fig. 2) is overlain by heterogeneous breccia containing clasts of quartzofeldspathic gneiss, schist, leucogranite, and pegmatite (unit Thbx, fig. 2). Both units consist largely of shattered, matrix-poor rock bodies, but layers of definite sedimentary origin are present throughout, indicating that the shattered lithosomes are not outcrops of pre-Tertiary bedrock. The base of the crystalline-clast breccia unit is not exposed; it is faulted against heterogeneous breccia (unit Tmbx, fig. 2) to the east. The crystalline rocks-clast breccia is Iocally interbedded with and overlain by basalt lava flows and basalt-clast breccia.

A white to light-gray, well-bedded pebble to boulder conglomerate (unit Tc, fig. 2) overlies the sedimentary breccias with slight angular unconformity. Clasts are subrounded to subangular and consist mostly of crystalline rocks lithologically similar to those in the crystalline rocks-clast breccia unit that crops out north of Hess mine, but rare vesicular basalt clasts are also present. The conglomerate is well bedded, with low-angle cross-beds and planar-laminated sandstone beds. In one location a lens of algal limestone is present in the middle part of the unit.

\section{QUECHAN VOLCANIC ROCKS}

The Quechan volcanic rocks of Crowe (1973, 1978) include basalt, andesite, and dacite flows and hypabyssal intrusive rocks where first described from the Picacho State Park area (Calif.). I have included in this unit the vesicular, crystal-rich basalt or andesite lava flows exposed near Hess mine and Mission Wash. Interbedded(?) crystalline rocks-clast conglomerate and sedimentary breccia are present at the base of the lava flows in the area north of Hess mine and at their top east of Picacho State Park road.

The lava flows near Hess Mine and Mission Wash areas were interpreted by Crowe (1978) as part of a younger, pyroxene andesite unit, probably because these lavas are not as altered or as extensively faulted as the typical Quechan volcanic rocks. However, they underlie the ignimbrite of Ferguson Wash (described next) and are therefore correlative with some part of the Quechan volcanic rocks, as interpreted from their stratigraphic position and lithology.

Hypabyssal intrusive rocks are abundant in the Chocolate Mountains anticlinorium (Crowe, 1973; Richard, unpub. mapping), which suggests that the source of these volcanic rocks lay in this area. Five K-Ar ages from the Quechan volcanic rocks in the Picacho State Park area range from 32 to $26 \mathrm{Ma}$ (plagioclase) (Crowe, 1978; Olmsted and others, 1973). A K-Ar age from the correlative, less-altered volcanic unit near Laguna Dam is $25.1 \mathrm{Ma}$ (whole rock) (Olmsted and others, 1973), which is younger than $\mathrm{K}$-Ar ages from overlying units. Because many of these samples from the Quechan volcanic rocks are altered, an unambiguous age has not been determined.

\section{IGNIMBRITE OF FERGUSON WASH}

Crowe (1978) assigned widespread exposures of ashflow tuff in the Picacho State Park area to the ignimbrite of Ferguson Wash. I have divided the ignimbrite of Ferguson Wash into seven mappable units-five tuffs (units $\mathrm{Tf}_{1}, \mathrm{Tf}_{3}, \mathrm{Tf}_{4}, \mathrm{Tf}_{6}$, and $\mathrm{Tf}_{7}$ ) and two andesite lava flows (units $\mathrm{Tf}_{2}$ and $T f_{5}$ ); see figure 3 for descriptions. The areas of thickest accumulation of the various units do not coincide (fig. 2), but thick composite sections of the ignimbrite of Ferguson Wash are confined to a narrow, east-west-trending trough between the southern Middle Mountains in Arizona and the area just south of Picacho Peak in California, referred to here as the Ferguson Wash caldera.

Three K-Ar ages previously determined by Olmsted and others (1973; recalculated for modern decay constants using method of Dalrymple, 1979) can be assigned to specific units of the ignimbrite of Ferguson Wash. These ages, mineral phases dated, and respective units are: $26.6 \pm 0.9 \mathrm{Ma}$, biotite, from rhyodacite crystal tuff $\left(\mathrm{Tf}_{1}\right) ; 25.4 \pm 2.1 \mathrm{Ma}$, hornblende, from hornblende trachyandesite $\left(\mathrm{Tf}_{2}\right)$; and $26.9 \pm 1.6 \mathrm{Ma}$, sanidine, from welded tuff with prominent light-tan fiamme $\left(\mathrm{Tf}_{7}\right)$.

\section{DACITE OF PICACHO PEAK}

The dacite of Picacho Peak (unit Tpd, fig. 2) was defined and described by Crowe (1978); it consists of crystal-poor dacite with 2 to 3 percent of $1-\mathrm{mm}$ pyroxene and sparse 2- to 4-mm pyroxene(?) phenocrysts; microlitic plagioclase is abundant in the groundmass. Flow breccia is present at the base of the unit near Picacho State Park road and is overlain by a thick lava flow with a massive, platy-jointed core. 


\section{CONGLOMERATE OF BEAR CANYON}

Poorly indurated cobble to boulder conglomerate and tan, fine-grained sandstone (unit Tbc, fig. 2) (Dillon, 1975; Hughes, 1990, this volume) unconformably overlie all older units and overlap normal faults. The conglomerate generally dips less than $20^{\circ}$, and underlying units have been tilted as much as $55^{\circ}$. Fine-grained sandstone becomes more abundant to the west. Clasts in the conglomerate are locally derived. This unit is equivalent, in part, to the conglomerate of the Chocolate Mountains
(Olmsted and others, 1973) and the conglomerate of Bear Canyon (Crowe, 1978).

\section{PALEOGEOGRAPHY}

The northern margin of the Ferguson Wash caldera lies parallel to and just south of outcrops of the Orocopia Schist that define the Chocolate Mountains anticlinorium. Tuffs north and south of the anticlinorium are similar, but existing geochronologic data indicate that the tuffs north of the

Maximum thickness

(m)

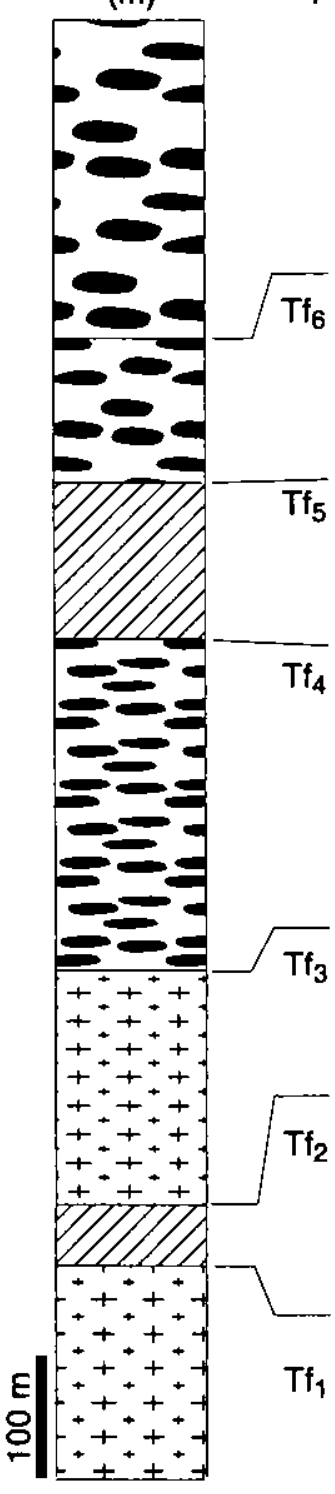

$\mathrm{Tf}_{7}$ Unit 7-Light-gray, buff, and light-brown welded tuff with prominent light-tan fiamme and about 1 to 2 percent phenocrysts. Phenocrysts less than $1 \mathrm{~mm}$ across and include biotite, hornblende, quartz, plagioclase, and sanidine; biotite commonly copper colored. Sparse volcanic clasts are present. Strongly welded parts of this tuff east of Hess Mine are very similar to the dacite tuff $\left(\mathrm{Tf}_{4}\right)$. Absence of strongly welded, ridge-forming parts of unit north of Ferguson Wash and south of Senator Wash is interpreted to indicate location of caldera margins. K-Ar age is $26.9 \pm 1.6 \mathrm{Ma}$ (sanidine; Olmsted and others, 1973). Maximum thickness, $258 \mathrm{~m}$

Unit 6-Light-gray, crystal-poor rhyolite tuff. Includes 2 to 3 percent phenocrysts, $1 \mathrm{~mm}$ across, of sanidine, quartz, and sparse biotite. Pinches out rapidly to northwest and southeast; correlated with unwelded sanidine-biotite tuff along southwest margin of caldera. Maximum thickness, $117 \mathrm{~m}$

Unit 5-Andesite flows and intrusive rocks. Dark-gray, crystal-poor, massive to vesicular andesite(?). Present between Squaw Lake and southern Middle Mountains. Eruptive center suggested by thick hypabyssal intrusive rocks and breccia in hills south of Martinez Lake. Maximum thickness, $125 \mathrm{~m}$

Unit 4-Dacite(?) tuff. Reddish-brown and lithophysal where strongly welded. Contains 3 to 5 percent phenocrysts of plagioclase and minor quartz, biotite, or hornblende; also strongly altered pyroxene locally present. Plagioclase crystals blocky and 1 to $2 \mathrm{~mm}$ in diameter; other crystals less than $1 \mathrm{~mm}$. Few lithic fragments. Lithologically resembles the tuff of Felipe Pass (Sherrod and Tosdal, 1991). Commonly lithophysal, especially in thick, densely welded sections east of Colorado River and in southern Middle Mountains. Fiamme are similar in color to matrix, thus very hard to see. Maximum thickness, $270 \mathrm{~m}$

Unit 3-Lithic rhyodacite(?) tuff. Phenocrysts 3 to 4 percent, with biotite and hornblende predominant; other phenocrysts are plagioclase, quartz, and sanidine. Contains notable amounts of clasts from pre-Tertiary crystalline rocks, Winterhaven Formation, and unit $\mathrm{Tf}_{2}$. Maximum thickness, $190 \mathrm{~m}$

Unit 2-Hornblende trachyandesite. Contains 5 to 7 percent phenocrysts of homblende 2 to $5 \mathrm{~mm}$ long in a medium-gray, very fine grained groundmass. Single thick flow separates units $\mathrm{Tt}_{1}$ and $\mathrm{Tf}_{3}$ in Ferguson Wash area. Pinches out to north near caldera margin and thins southeast, grading into lenses of hornblende trachyandesitic tuff breccia. K-Ar age is $25.4 \pm 2.1 \mathrm{Ma}$ (homblende; Olmsted and others, 1973). Maximum thickness, $50 \mathrm{~m}$

$\mathrm{Tf}_{1}$ Unit 1-Rhyodacite crystal tuff. Generally white or buff, poorly welded tuff. Contains 3 to 5 percent phenocrysts of biotite, homblende, plagioclase, sanidine, and quartz. Abundant biotite and homblende give outcrops a sparkling, speckled look. Contact with unit $\mathrm{Tf}_{3}$ difficult to discem where intervening hornblende trachyandesite $\left(\mathrm{Tf}_{2}\right)$ is absent. $\mathrm{K}$-Ar age is $26.6 \pm 0.9 \mathrm{Ma}$ (biotite; Olmsted and others, 1973). Maximum thickness, $170 \mathrm{~m}$

Figure 3. Lithologic column for ignimbrite of Ferguson Wash of Crowe (1978). Thicknesses shown are for thickest recognized section. Rock names and estimates of crystal content are based on field observations, except for unit $\mathrm{Tf}_{2}$, for which Crowe (1973) reports a chemical analysis. 
Chocolate Mountains anticlinorium (Richard, this volume) are entirely younger than those to the south. This stratigraphic difference, if real, suggests topographically high areas lay between the sources for the different tuffs and prevented them from interfingering or overlapping. The topographic highs may have resulted from fault-bounded uplift or, alternatively, an andesitic volcanic edifice.

\section{REFERENCES CITED}

Crowe, B.M., 1973, Cenozoic volcanic geology of the southeastern Chocolate Mountains, California: Santa Barbara, University of California, Ph.D. dissertation, $117 \mathrm{p}$.

1978, Cenozoic volcanic geology and probabie age of inception of basin-range faulting in southeasternmost Chocolate Mountains, California: Geological Society of America Bulletin, v. 89, no. 2, p. 251-264.

Crowe, B.M., Crowell, J.C., and Krummenacher, Daniel, 1979, Regional stratigraphy, K/Ar ages, and tectonic implications of Cenozoic volcanic rocks, southeastern California: American Journal of Science, v. 279, no. 2, p. 186-216.

Dalrymple, G.B., 1979, Critical tables for conversion of K-Ar ages from old to new constants: Geology, v. 7, no. 11, p. 558-560.

Dillon, J.T., 1975, Geology of the Chocolate and Cargo Muchacho Mountains, southeasternmost California: Santa Barbara, University of California, Ph.D. dissertation, $405 \mathrm{p}$.

Harding, L.E., and Coney, P.J., 1985, The geology of the McCoy Mountains Formation, southeastern California and southwestern Arizona: Geological Society of America Bulletin, v. 96, no. 6 , p. $755-769$.
Haxel, G.B., Tosdal, R.M., and Dillon, J.T., 1985, Tectonic setting and lithology of the Winterhaven Formation, a new Mesozoic stratigraphic unit in southeasternmost California and southwestern Arizona: U.S. Geological Survey Bulletin $1599,19 \mathrm{p}$.

Hughes, K.M., 1990, The Bear Canyon conglomerate as a record of tectonics and sedimentation during initiation of the Salton Trough: San Diego, Calif., San Diego State University, M.S. thesis, $104 \mathrm{p}$.

Lombard, J.P., 1990, Middle Tertiary stratigraphy of the Laguna Mountains, Yuma County, southwestern Arizona [abs.]: Geological Society of America Abstracts with Programs, v. 22, no. 3 , p. 37.

Olmsted, F.H., 1972, Geologic map of the Laguna Dam 7.5 minute quadrangle, Arizona and California: U.S. Geological Survey Geologic Quadrangle Map GQ-1014, scale 1:24,000.

Olmsted, F.H., Loeltz, O.J., and Irelan, Burdge, 1973, Geohydrology of the Yuma area, Arizona and California: U.S. Geological Survey Professional Paper 486-H, 227 p.

Powell, R.E., 1981a, Geology of the crystalline basement complex, eastern Transverse Ranges, southem California: constraints on regional tectonic interpretation, in Howard, K.A., Carr, M.D., and Miller D.M., eds., Tectonic framework of the Mojave and Sonoran Deserts, California and Arizona: U.S. Geological Survey Open-File Report 81-503, p. 87-89.

$1981 \mathrm{~b}$, Geology of the crystalline basement complex, eastern Transverse Ranges, California: constraints on regional tectonic interpretation: Pasadena, California Institute of Technology, Ph.D. dissertation, 441 p.

Sherrod, D.R., and Tosdal, R.M., 1991, Geologic setting and Tertiary structural evolution of southwestern Arizona and southeastern California: Journal of Geophysical Research, v. 96, no. B7, p. $12,407-12,423$. 



\title{
Tertiary Stratigraphy of the Laguna Mountains, Yuma County, Ariz.
}

\author{
By James P. Lombard ${ }^{1}$
}

\section{SUMMARY}

Measured sections and measurements from geologic maps indicate that the composite thickness of discontinuously exposed middle Tertiary strata in the Laguna Mountains of southwestern Arizona exceeds 2,870 m. The basal upper Eocene(?) and lower Oligocene strata consist of conglomerate, sandstone, and mudstone deposited on Proterozoic granite and gneiss in the Laguna Mountains. These strata grade upward into sedimentary breccia and conglomerate derived from Proterozoic granite and from Mesozoic rocks lithologically similar to those exposed in the Chocolate Mountains to the northwest. The upper Eocene(?) and lower Oligocene strata dip an average of $20^{\circ}$ to $40^{\circ}$ southwest and are unconformably overlain by a $26.9 \pm 1.0-\mathrm{Ma}$ ash-flow tuff that also dips southwest; they are unconformably overlain by the upper Oligocene(?) and lower Miocene Kinter Formation. The Kinter Formation is tilted $3^{\circ}$ to $23^{\circ}$ southwest or northwest and is overlain by the upper Miocene and Pliocene Bouse Formation in a borehole west of the Laguna Mountains. The Bouse Formation is overlain by Pliocene and Quaternary gravel of the Colorado River and locally derived alluvium.

\section{GEOLOGIC SETTING}

Middle Tertiary tectonism in southwestern Arizona and southeastern California began in late Eocene(?) or early Oligocene time and was characterized by deposition of sedimentary breccia and conglomerate, tilting of Tertiary strata, extensional faulting, and volcanism. In some areas, such as in the Laguna Mountains, tectonism began before widespread volcanism. Tilting of Tertiary strata was completed in southwestern Arizona by early Miocene time but continued in other areas through the early Miocene after the main pulse of volcanism (Spencer and Reynolds, 1989).

Middle Tertiary strata in the Laguna Mountains are predominantly sedimentary with minor volcanic rocks. Po-

'Errol L. Montgomery \& Associates, Inc., 1075 East Fort Lowell Road, Suite B, Tucson, AZ 85719 tassium-argon ages from volcanic rocks in the sequence indicate that deposition began in the late Eocene(?) and early Oligocene prior to $27 \mathrm{Ma}$ and continued into the early Miocene (Spencer and Reynolds, 1989). Sedimentary sequences that are probably time-correlative with strata in the Laguna Mountains also occur in the Muggins Mountains to the east and in the southern Chocolate Mountains to the northwest (fig. 1; Olmsted and others, 1973; Crowe, 1978; Smith and others, 1989; Richard, this volume). Potassium-argon ages from volcanic units in the Muggins and southern Chocolate Mountains range from 32 to $22 \mathrm{Ma}$ (Crowe, 1978; Shafiqullah and others, 1980; Olmsted and others, 1973). Deposition of prevolcanic sedimentary rocks in the southern Chocolate Mountains probably began in the late Eocene(?) or early Oligocene (Sherrod and Tosdal, 1991). Lithologically correlative sedimentary strata also crop out in the northern Gila Mountains and in Yuma, where they dip to the west or southwest (Olmsted and others, 1973). Although not exposed, thick middle Tertiary strata occupy the Gila trough, a structural trough that parallels the Gila River for $200 \mathrm{~km}$ from the Muggins Mountains northeast to the vicinity of Hyder, Arizona. Rocks in the Gila trough may be time correlative with the strata in Yuma and in the Laguna, Muggins, Gila, and southem Chocolate Mountains (Eberly and Stanley, 1978). The Laguna Mountains strata are east of known splays of the San Andreas fault zone (Crowell and Sylvester, 1979) and are presumably close to their middle Tertiary latitude.

\section{STRATIGRAPHY}

A composite stratigraphic column (col. 3-H, pl. 3) was constructed from exposures at several localities within the Laguna Mountains. The lower $770 \mathrm{~m}$ of section were measured by me, and the upper $2,100 \mathrm{~m}$ of section were estimated from geologic maps and well logs (Olmsted, 1972; Olmsted and others, 1973). Coarse-grained monzogranite, fine-grained mafic dikes, and heterogeneous quartzofeldspathic gneiss underlie the Tertiary strata in the Laguna Mountains (Olmsted, 1972) and are thought to be of Proterozoic age because they resemble rocks of the San Gabriel Mountains, southeastern California (Richard, this volume). 


\section{EOCENE(?) AND OLIGOCENE RED BEDS AND LACUSTRINE STRATA}

Arkosic red beds are the oldest Tertiary strata exposed in the Laguna Mountains (Olmsted and others, 1973; this paper). The red beds have been divided here into six mappable units (from oldest to youngest, units $T r_{1}, T r_{2}, T r_{3}, T r_{4}, T r_{5}$, and $\left.T r_{6}\right)$. Figure 2 shows the geology of an area in the southern Laguna Mountains where the red beds are best exposed.

The basal strata (unit $\mathrm{Tr}_{1}$ on fig. 2) are $75 \mathrm{~m}$ thick and consist of sandstone and conglomerate that were derived from locally exposed bedrock. The strata are reddish-brown and form resistant outcrops. Unit $\mathrm{Tr}_{1}$ was deposited nonconformably against Proterozoic bedrock; angles between bedding and paleosurfaces are as great as $35^{\circ}$. The sandstone is very coarse to medium grained, poorly sorted, angular to subrounded, and quartzofeldspathic in composition. Cobbles and gravel clasts are subangular to subrounded and composed of quartzofeldspathic gneiss and granitic rocks. Bedding is usually thick, with some beds as thick as $1.5 \mathrm{~m}$. Some beds fine upward, with conglomeratic sandstone near their bases and coarse sandstone at their tops. Beds commonly have cobbly-gravel lag deposits overlying erosional lower contacts with underlying beds. Sedimentary structures are indistinct, but where structures were observed, planar low-angle cross-stratification predominates. Rare intervals of structureless silty and clayey sandstone were observed, generally overlying fining-upward conglomeratic sandstone beds. Root casts filled with fine sand, silt, and clay are locally present in the silty and clayey sandstone. These strata were probably deposited subaerially in wide, low-gradient, bedload-dominated streams and alluvial fans.

Unit $\mathrm{Tr}_{1}$ grades upward into a thinly bedded mudstone and claystone unit (unit $T r_{2}$, fig. 2) that is $12 \mathrm{~m}$ thick. These friable slope-forming strata are green, red, yellow, orange, and buff. Thin bedding and parallel laminae characterize the sedimentary structures in this unit. Thin beds of fine-grained sandstone and gypsum were also observed in these strata.

Unit $\mathrm{Tr}_{2}$ grades upward into a mudstone, evaporite, and sandstone unit (unit $\mathrm{Tr}_{3}, \mathrm{fig} .2$ ) that is $48 \mathrm{~m}$ thick. The unit is identified by laminated green siltstone and claystone with thin fine-grained sandstone interbeds. A 3-m-thick bed of light-gray silt with a strong salty taste and numerous halite-filled fractures occurs in this unit.

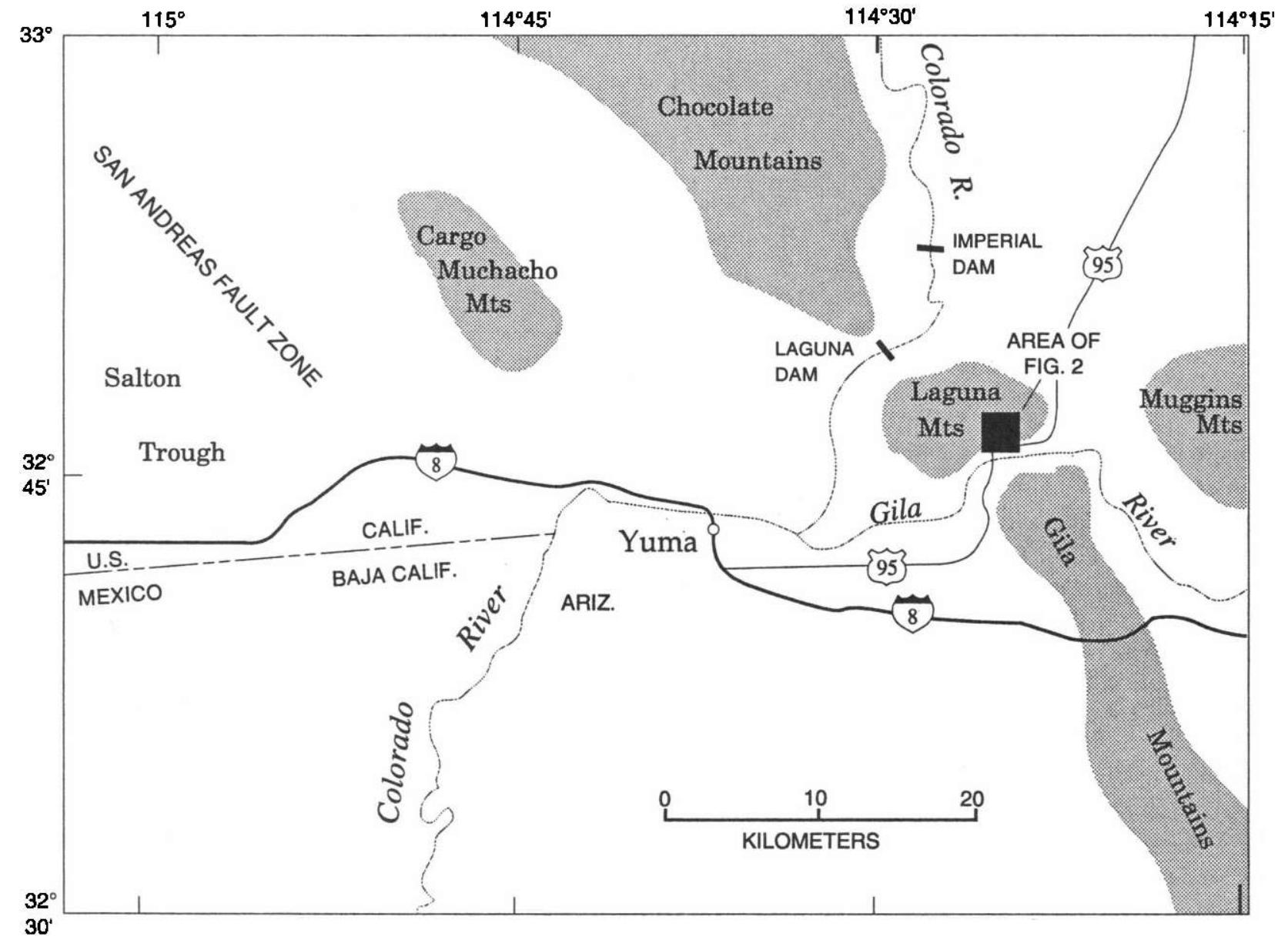

Figure 1. Map showing location of geographic features discussed in text. 


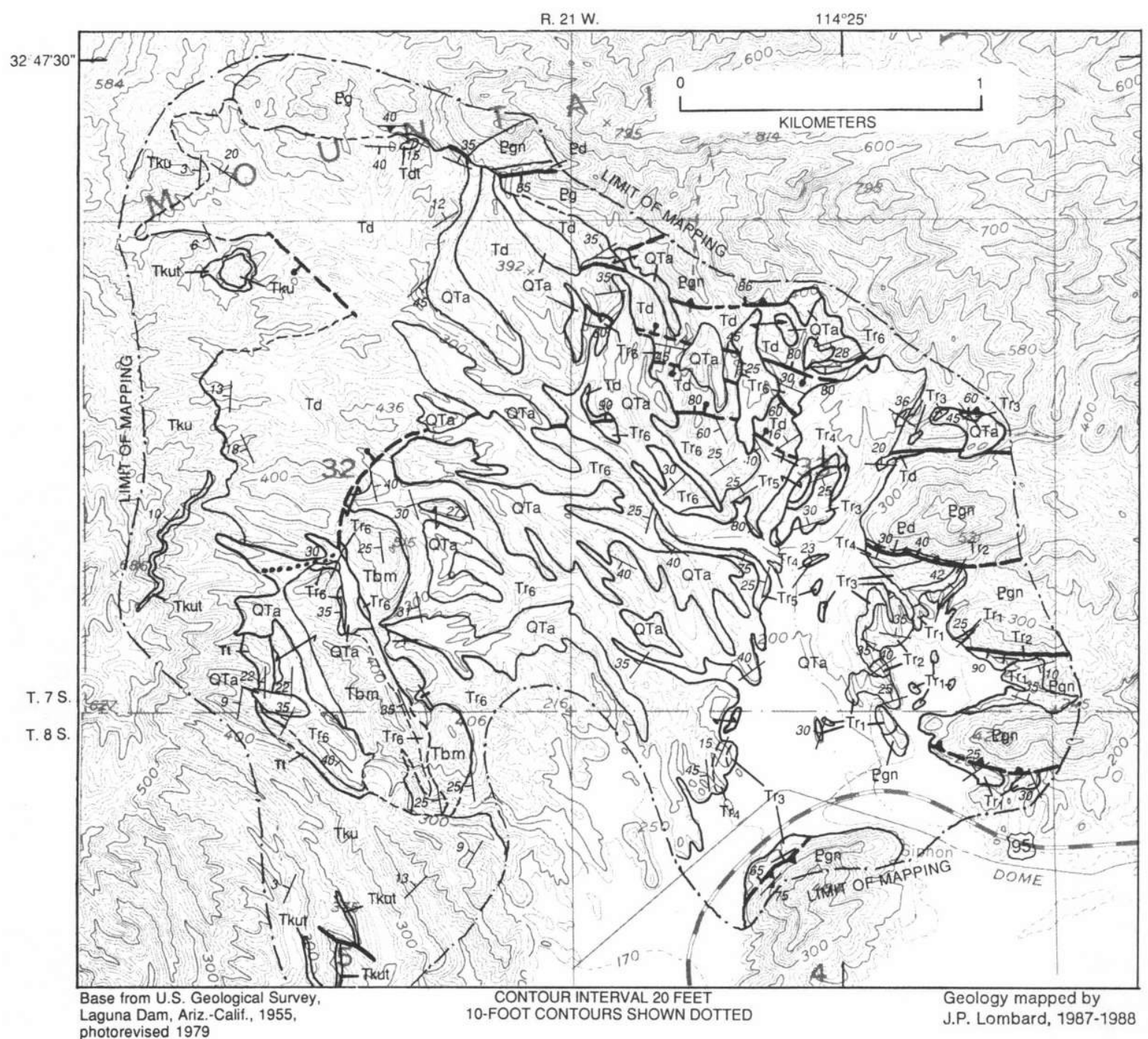

EXPLANATION

(see text for additional lithologic information)

OTa Alluvium and terrace deposits (Quaternary and Pliocene) Kinter Formation (Miocene and Oligocene?)-Consists of: Upper member-Locally includes:

Tku

Tkut

$\mathbf{T t}$

$\mathrm{Tbm}$

Td

Tdt

$\mathrm{Tr}_{6}$

$\mathrm{Tr}_{5}$

$\mathrm{Tr}_{4}$

$\mathrm{Tr}_{3}$

$\mathrm{Tr}_{2}$

$\mathrm{Tr}_{1}$

Ed
Tuff-Bentonitic weakly lithified ash. K-Ar age is 24.2 $11.2 \mathrm{Ma}$

Tuff (Oligocene)-Tan rhyolitic ash-flow tuff. K-Ar age is $26.9 \pm 1.0 \mathrm{Ma}$

Monolithologic breccia (Oligocene and Eocene?) - Gray sedimentary breccia

Diamictite and sedimentary breccia (Oligocene and Eocene?)-Red and gray chaotically deformed unit Locally, divided into:

Tuff-Reworked tan rhyolitic tuff interbed

Red-bed deposits (Oligocene and Eocene?)-Consist of:

Red fluvial sandstone and conglomeratic sandstone

Brown fluvial sandstone and conglomeratic sandstone

Yellow and brown fluviolacustrine sandstone

Green lacustrine mudstone, evaporite, and sandstone

Multicolored lacustrine mudstone and claystone

Reddish-brown fluvial sandstone and conglomerate

Mafic dike (Proterozoic) - Green altered mafic intrusion
Pg Monzogranite (Proterozoic)—Pink and gray monzogranite

Pgn Gneiss (Proterozoic) Gray gneiss; quartzofeldspathic in composition

Contact-Dashed where approximately located

Faults - Dashed where approximately located; dotted where concealed or inferred; queried where extent uncertain

Reverse or thrust - Showing dip. Teeth on upper plate

Normal-Showing dip. Ball and bar on downthrown side

High-angle-Showing dip. Sense of displacement unknown

Strike and dip of bedding

$\stackrel{27}{\perp}$ Inclined

Vertical

Strike and dip of mylonitic foliation

Leader-Connecting areas of same rock unit

Figure 2. Geologic map of part of southern Laguna Mountains north of McPhaul Bridge, showing area where red beds are best exposed. 
Thinner beds of gypsum and laminated calcium carbonate are common in some intervals. A lacustrine origin for units $\mathrm{Tr}_{2}$ and $\mathrm{Tr}_{3}$ is indicated by sedimentary structures such as laterally continuous bedding, ripple crossbedding in the sandstone, laminated calcium carbonate beds, and thin gypsum beds interbedded with mudstone.

Unit $\mathrm{Tr}_{3}$ grades upward into a sandstone unit (unit $\mathrm{Tr}_{4}$, fig. 2) that is $30 \mathrm{~m}$ thick. The contact between the units is marked by an interval with 1- to 2-cm-thick gypsum layers interbedded with fine- to medium-grained sandstone. Unit $\mathrm{Tr}_{4}$ is yellow, light brown, and reddish brown and is fine to medium grained. The sandstone is moderately sorted, subangular to subrounded, and quartzofeldspathic in composition. The sandstone is identified by its color and by numerous thin $(3-20 \mathrm{~cm}$ thick) sandstone beds with ripple cross-bedding and heavy mineral concentrations. Thin red mudstone interbeds are common between the ripple cross-bedded sandstone beds. Several thick beds of sandstone that fine upward from medium- to fine-grained sandstone also were observed in this unit. Unit $\mathrm{Tr}_{4}$ probably was deposited in a transitional environment intermediate between the lacustrine setting of units $\mathrm{Tr}_{2}$ and $\mathrm{Tr}_{3}$ and the fluvial environment of units $\mathrm{Tr}_{5}$ and $\mathrm{Tr}_{6}$.

Unit $\mathrm{Tr}_{4}$ grades upward into a well-bedded, moderately sorted fluvial sandstone and conglomerate interval that is $600 \mathrm{~m}$ thick. The lower part of the interval (unit $\mathrm{Tr}_{5}$ on fig. 2) is brown and the upper part of the interval (unit $\mathrm{Tr}_{6}$ on fig. 2) is red; otherwise units $\mathrm{Tr}_{5}$ and $\mathrm{Tr}_{6}$ are lithologically similar. The sandstone is coarse to fine grained and poorly to moderately well sorted; grains are angular to subrounded and quartzofeldspathic in composition. Cobbles and gravel clasts are subrounded to very well rounded. Sources of the conglomerate clasts were mainly granitic rocks and gneissic rocks, but clasts of lavender metatuff, brown and tan quartzite, and darkgray micritic limestone indicate other sources (quartzite and limestone are not presently found in the Laguna Mountains area). Sedimentary structures in units $\operatorname{Tr}_{5}$ and $\mathrm{Tr}_{6}$ are commonly planar low-angle cross-beds, planar horizontal beds, and low-angle trough cross-beds. Where measurable, trough cross-bedding indicates southwesterly paleocurrents. Conglomeratic sandstone and conglomerate beds are common and occupy paleochannels with scoured bases that are as much as $1.5 \mathrm{~m}$ deep. Finingupward sequences as much as $4 \mathrm{~m}$ thick, with conglomeratic sandstone grading upward to sandstone and siltstone, were observed. Several beds of structureless calcium carbonate as much as $0.5 \mathrm{~m}$ thick extend for more than $100 \mathrm{~m}$ along strike in this unit. The sedimentary structures, sorting, and gravel clast composition indicate that units $\operatorname{Tr}_{5}$ and $T r_{6}$ were deposited by a wide, bedload-dominated stream system that drained a large, well-integrated watershed.

\section{EOCENE(?) AND OLIGOCENE BRECCIA AND CONGLOMERATE}

Coarse sedimentary breccia, megabreccia, and conglomerate (units Tbm and Tbh of Olmsted, 1972) that are more than $1,200 \mathrm{~m}$ thick overlie the red beds (units $\mathrm{Tr}_{1}$ $\mathrm{Tr}_{6}$ ). This estimated thickness is based on Olmsted's (1972) geologic map of the Laguna Mountains quadrangle and from my reconnaissance mapping. However, poor exposure could conceal faults that repeat parts of the section, in which case the estimate is too great.

Monolithologic sedimentary breccia and megabreccia beds that were derived from coarsely porphyritic granite, quartz monzonite, and associated dike rocks (unit Tbm, fig. 2; also Olmsted's, 1972, unit Tbm) interfinger with fluvial sandstones of unit $\operatorname{Tr}_{6}$. Individual breccia beds are as much as $100 \mathrm{~m}$ thick and form very resistant gray ridges with cavernous weathering. Monolithologic breccia in the area shown on figure 2 consists of domains of very angular fragments that range from sand to boulder size, with variable matrix content. Both clasts and matrix of the sedimentary breccia are clearly derived from the same rock type, and the matrix appears to consist of crushed fragments of the rock in the deposits. The breccia beds in unit Tbm in figure 2 are interpreted as long-runout rockavalanche deposits (Yarnold and Lombard, 1989). Folded red beds beneath the monolithologic breccia and striations at the base of the lowermost breccia bed indicate a westerly or easterly transport direction.

Above the basal breccia beds of unit Tbm, poorly exposed slope-forming boulder conglomerate from the same source rocks as the breccia and megabreccia is interbedded with breccia. The conglomerate is not shown on figure 2 but was mapped along the southern edge of the Laguna Mountains by Olmsted (1972). Bedding is thick or very thick, and where exposed, sedimentary structures such as sorting and grading indicate sedimentary deposition.

Monolithologic breccia ( $\mathrm{Tbm}$ ) grades upward into heterogeneous sedimentary breccia and conglomerate (unit Tbh of Olmsted, 1972). Poorly exposed, slope-forming outcrops contain mainly metasedimentary and metavolcanic clasts including pink and gray quartzite, muscovite schist, propylitized plagioclase porphyry dacite, and densely welded gray tuff, as well as granite and gneiss. Heterogeneous conglomerate (unit Tbh of Olmsted, 1972) and monolithologic conglomerate (unit Tbm of Olmsted, 1972) clearly interfinger in the southern Laguna Mountains (Olmsted, 1972). In the southwestern Laguna Mountains, outcrops of matrix-poor monolithologic megabreccia were mapped as quartz monzonite bedrock by Olmsted (1972). I have reinterpreted these outcrops as sedimentary deposits of monolithologic megabreccia (Tbm) that are interbedded with heterogeneous breccia and conglomerate (Tbh). 
Monolithologic breccia (unit Tbm of Olmsted, 1972) is also exposed in the city of Yuma (Olmsted and others, 1973). Borehole and geophysical data indicate that about $300 \mathrm{~m}$ of the unit occupy a $6-\mathrm{km}$-wide subsurface basin between Yuma and the southeastern Cargo Muchacho Mountains (Mattick and others, 1973). Areas of shallow bedrock in the vicinity of Yuma, such as the Yuma basement high of Mattick and others (1973), consist of coarsely porphyritic quartz monzonite and granite. These rocks are considered to be likely sources for monolithologic breccia in both the Yuma area and in the Laguna Mountains (Olmsted and others, 1973). Another possible source for monolithologic breccia is the coarse monzogranite exposed in the northern Laguna Mountains (unit qmo of Olmsted, 1972).

\section{EOCENE(?) AND OLIGOCENE DIAMICTITE AND BRECCIA}

A chaotically deformed deposit of diamictite and breccia (unit Td, fig. 2) was mapped by Olmsted as the lower member of the Kinter Formation (Olmsted, 1972). However, the strata mapped by Olmsted as the upper member of the Kinter Formation (unit Tku of Olmsted, 1972) overlie the diamictite and breccia unit with angular unconformity (fig. 2). Therefore, the diamictite and breccia unit is considered by me to be an older unit and probably correlative with the sedimentary breccia and conglomerate units (units Tbm and Tbh of Olmsted, 1972) for the reasons outlined below. The exact stratigraphic position of the diamictite and breccia (Td) is unclear, owing to poorly exposed, commonly faulted contacts with underlying and overlying units.

The diamictite and breccia (Td) consists of extremely poorly sorted breccia, conglomerate, sandstone, and mudstone. Bedding is rarely observed even though outcrops are common in the unit. Most exposures are characterized by lack of bedding, extremely poor sorting, and highly micaceous matrix. Clasts are very angular to subrounded and are derived from gneiss and granitic rocks; maximum clast size is about $1 \mathrm{~m}$. Some lenses of unit Td are monolithologic and have characteristics similar to the lenses of sedimentary breccia in unit Tbm. A small exposure shows tuffaceous sand interbedded in unit Td near the contact with basement (unit Tdt, fig. 2), but no other volcanic material was observed in the unit. Unit Td is moderately to strongly folded and faulted, but structures were not mappable because of the lack of laterally continuous beds. The lack of continuous bedding also precludes measurement of thickness, but unit $\mathrm{Td}$ is probably greater than $100 \mathrm{~m}$ thick.

The diamictite and breccia (Td) is probably older than the Kinter Formation for several reasons. First, the contact between the upper member (Tku) of the Kinter Formation and unit $\mathrm{Td}$ in the northwestern part of figure 2 is an an- gular unconformity. At its type section (northern Gila Mountains), the upper and lower members of the Kinter Formation are conformable (Olmsted and others, 1973). Second, unit Td is more deformed than the Kinter Formation. The upper and lower members of the Kinter Formation in the northern Gila Mountains dip from $12^{\circ}$ to $43^{\circ}$ northwest to southwest (OImsted and others, 1973). In the Laguna Mountains, unit Td dips from $13^{\circ}$ to $45^{\circ}$, but planar contacts strike in all directions (fig. 2) because folding and faulting is moderate to severe in unit Td. The upper member of the Kinter Formation in the Laguna Mountains is tilted from $3^{\circ}$ to $23^{\circ}$ and exhibits southwesterly to northwesterly dips (Olmsted, 1972). These field relations indicate that substantial deformation occurred in unit Td prior to deposition of the upper member of the Kinter Formation. The degree of deformation observed in the red beds (units $\operatorname{Tr}_{1}$ through $\mathrm{Tr}_{6}$ ) is similar to the deformation observed in unit Td (fig. 2). The contrast between the folded and faulted unit $T d$ and the relatively unfolded and less tilted upper member of the Kinter Formation in the Laguna Mountains suggests that unit Td is older than both the upper and lower members of the Kinter Formation that were described at the type section (Olmsted and others, 1973) in the northern Gila Mountains.

The depositional environment of unit $\mathrm{Td}$ is difficult to interpret because of the apparent lack of original stratigraphy, the lack of sedimentary structures, and the absence of depositional contacts with adjacent Tertiary strata. Field characteristics suggest that unit $\mathrm{Td}$ may be an accumulation of fault breccia and talus breccia produced during active movement on the faults that cut the red beds and basement (fig. 2).

\section{OLIGOCENE ASH-FLOW TUFF}

Pyroclastic rocks chiefly of rhyolitic or rhyodacitic composition occur in several exposures in the Laguna Mountains (unit Tt, fig. 2, equivalent to Olmsted's, 1972, ignimbrite unit Ti), and they overlie units Tbm and Tbh of Olmsted (1972) and $\mathrm{Tr}_{6}$ with angular unconformity. East of Laguna Dam, welded and unwelded ash-flow tuff about $70 \mathrm{~m}$ thick unconformably overlies unit Tbm (of Olmsted (1972). A thin, discontinuous(?) black basal vitrophyre is observed in exposures at this locality. Two K-Ar biotite ages have been determined for rocks at the top of the tuff east of Laguna Dam. An age of $26.9 \pm 1.0$ Ma was determined by Damon and others (1965; sample No. 5-15-55A), and an age of $30.1 \pm 1.0 \mathrm{Ma}$ was determined by Shafiqullah and others (1980; sample No. UAKA-65-04) for a sample locality several hundred meters north of the first dated sample. In the southern Laguna Mountains, an ash-flow tuff about $20 \mathrm{~m}$ thick overlies units $\mathrm{Tbm}_{\mathrm{m}}$ and $\mathrm{Tr}_{6}$ with angular unconformity (fig. 2 ) and may be correlative with the dated 
tuff in the northwestern Laguna Mountains, $6 \mathrm{~km}$ away. Elsewhere in the Laguna Mountains, ash-flow tuff overlies units Tbm and Tbh of Olmsted (1972) and ranges in thickness from a few meters to $30 \mathrm{~m}$. Only one tuff outcrop is dated, and detailed correlation among discontinuously exposed outcrops of ash-flow tuff remains to be done; however, the limited age data from the unit suggests that more than $2,000 \mathrm{~m}$ of underlying sediment was deposited, then tilted $15^{\circ}$ to $45^{\circ}$ and exposed prior to late Oligocene time. The pattern of outcrop (Olmsted, 1972) indicates that parts of the ash-flow tuff (unit $\mathrm{Ti}$ of Olmsted, 1972) were tilted and removed by erosion prior to deposition of the overlying upper member of the Kinter Formation.

\section{UPPER OLIGOCENE(?) AND LOWER MIOCENE KINTER FORMATION}

The Kinter Formation at its type section in the northern Gila Mountains was divided into upper and lower members by Olmsted and others (1973). The Kinter Formation in the Laguna Mountains closely resembles the upper member of the Kinter at the type section in the northern Gila Mountains. However, for reasons outlined above, the strata mapped by Olmsted (1972) as the lower member of the Kinter Formation in the Laguna Mountains are considered here to be a stratigraphically distinct unit older than the Kinter Formation. Thus the lower member of the Kinter Formation is absent in the Laguna Mountains.

The Kinter Formation in the Laguna Mountains (unit Tku, fig. 2) is predominantly conglomerate derived from locally exposed sources. Unit Tku was deposited with angular unconformity on older Tertiary strata (units Tt, Td, and $\mathrm{Tr}_{6}$ and units $\mathrm{Tbh}$ and Tbm of Olmsted, 1972) and pre-Tertiary crystalline rocks (fig. 2; Olmsted, 1972). Sedimentary structures, sorting, and angularity suggest that the upper member of the Kinter Formation was deposited by alluvial fans (Olmsted and others, 1973). The Kinter Formation was derived mainly from gneiss lithologically similar to rocks exposed in the eastern Laguna Mountains, but it also contains clasts derived from the underlying unit of Oligocene ash-flow tuff. Biotite from a 1-m-thick bed of altered bentonitic ash (unit Tkut, fig. 2) in the lower part of the upper member of the Kinter Formation has a K-Ar age of 24.2 $\pm 1.2 \mathrm{Ma}$ (Damon and others, 1965; sample No. VAW-60-29). Although this bed is discontinuous and was probably partially removed by erosion, it is a distinctive marker bed in the western part of the area of figure 2 . The dated tuff bed in the Kinter indicates that at least part of the formation may be late Oligocene. An undated andesitic plug intrudes the Kinter Formation at the west edge of the Laguna Mountains (Olmsted, 1972).

The pattern of outcrops indicates that the upper member of the Kinter Formation filled a west-northwest-trending paleovalley that had been cut into the older tilted and folded rocks of units $T t, T d$, and $\operatorname{Tr}_{6}$ and units $T b h$ and Tbm of Olmsted (1972). The upper member dips $3^{\circ}$ to $23^{\circ}$ to the southwest, west, and northwest and has been broadly warped and folded, but it lacks the degree of deformation characteristic of underlying Tertiary rocks.

\section{TERTIARY ALLUVIUM}

Upper Miocene and Pliocene sediment of local derivation forms alluvial fans and terrace deposits as much as $\mathbf{5 0}$ $\mathrm{m}$ thick. The alluvium overlies the upper member of the Kinter Formation in the Laguna Mountains. It is very gently deformed, with dips ranging from $1^{\circ}$ to $4^{\circ}$.

\section{BOUSE FORMATION}

The Bouse Formation overlies the Kinter Formation in U.S. Geological Survey test well (C-7-22)14bcd at Laguna Dam (Olmsted and others, 1973). The Bouse Formation is $70 \mathrm{~m}$ thick in the well and consists of silty and sandy clay, micaceous silty sand with some carbonized wood, and fossiliferous silty clay.

The Bouse Formation was deposited during transgression of the proto-Gulf of California into the Yuma area and neighboring valleys in late Miocene and Pliocene time. Subsequent integration of the Colorado River drainage resulted in progradation of the ancestral Colorado River delta into the northern end of the proto-Gulf embayment (for example, Buising, this volume).

\section{PLIOCENE AND QUATERNARY ALLUVIUM}

Alluvial deposits of the Colorado and Gila Rivers and from local washes form a veneer of sediment of variable thickness and texture in and around the Laguna Mountains (Olmsted, 1972). These deposits are $63 \mathrm{~m}$ thick in U.S. Geological Survey test well (C-7-22)14bcd at Laguna Dam.

\section{STRUCTURAL FEATURES}

Several episodes of deformation are evident from the changes in style of deposition of middle Tertiary strata in the Laguna Mountains, from the folding and faulting of the strata, and from the unconformities in the section.

\section{EOCENE(?) AND OLIGOCENE FAULTING AND FOLDING}

Two or more phases of Eocene(?) and Oligocene faulting and folding occurred simultaneously with deposition. The red beds (units $T r_{1}-T r_{6}$ ) are more strongly folded and 
faulted than units Tbm and Tbh, although no unconformity separates units $\mathrm{Tr}_{6}$ and $\mathrm{Tbm}$ (fig. 2; Olmsted, 1972). The red beds have been deformed to near-vertical dips near fault contacts with basement (fig. 2). Units Tbh and Tbm of Olmsted (1972) dip $12^{\circ}$ to $39^{\circ}$. The apparent decrease of dips upsection through the Eocene(?) and Oligocene strata suggest that these units originated as syntectonic deposits.

The first phase of Eocene(?) and Oligocene faulting is indicated by faults and folds in red-bed units $\mathrm{Tr}_{1}$ through $\mathrm{Tr}_{5}$ that die out in red-bed unit $\mathrm{Tr}_{6}$ (fig. 2). East-weststriking faults with as much as $165 \mathrm{~m}$ of stratigraphic displacement placed basement rocks against Eocene(?) and Oligocene strata during this phase of faulting. Total displacement is difficult to estimate because the amount of strike-slip or oblique-slip along the faults is unknown. Renewed faulting and rapid uplift is indicated by the abrupt change from the relatively fine grained red-bed deposits (units $\mathrm{Tr}_{1}-\mathrm{Tr}_{6}$ ) to deposits of sedimentary breccia, conglomerate, and diamictite (units Tbm and Tbh of Olmsted, 1972, and unit Td). The fault contact of unit Td with units $\mathrm{Tbm}, \mathrm{Tr}_{6}$, and $\mathrm{Tr}_{5}$ may have occurred during the second episode of faulting along the east-west Oligocene faults, or it may represent a third phase of faulting (fig. 2). If unit Td is correlative with units Tbm and Tbh of Olmsted (1972), then at least $600 \mathrm{~m}$ of stratigraphic offset is indicated by the juxtaposition of units $T d$ and $\operatorname{Tr}_{5}$.

Tectonism resulted in tilting and exposure of units $\mathrm{Tr}_{1}-\mathrm{Tr}_{6}$, units Tbm and Tbh of Olmsted (1972), Td, and the basement rocks prior to the initiation of regionally extensive volcanism, which in the Laguna Mountains is signaled by the deposition of ash-flow tuff (Tt). Unit $T t$ was partially eroded and tilted as much as $30^{\circ}$ prior to deposition of the upper member (Tku, Tkut) of the Kinter Formation in the late Oligocene(?) and early Miocene.

\section{MIOCENE DEFORMATION}

Units Tku and Tkut were tilted $3^{\circ}$ to $23^{\circ}$, broadly warped, and partially eroded prior to deposition of the upper Miocene and Pliocene Bouse Formation (Olmsted, 1972; Olmsted and others, 1973). Units Tku and Tkut are cut by northwest-striking high-angle normal faults in the Laguna Mountains.

\section{OLIGOCENE AND MIOCENE PALEOGEOGRAPHIC INTERPRETATION}

During the late Eocene(?) and early Oligocene, sedimentation in the Laguna Mountains began when alluvial fans and small, bedload-dominated streams began to fill topographic depressions between rugged hills of Proterozoic basement rocks. Lacustrine mudstone, sandstone, and evaporite also were deposited in poorly drained lowlands during this time. As subsidence progressed, a regionally integrated drainage network introduced sediment of a large, bedload-dominated stream supplied by detritus from basement rocks as well as from exposures of quartzite, limestone, and metatuff that are not present in the Laguna Mountains today.

The abrupt shift to very coarse grained strata in depositional environments of catastrophic rock avalanches, alluvial fans, and debris flows indicates the initiation of rapid uplift of basement rocks close to the margins of the basin. Coarse-grained sediment more than $1,200 \mathrm{~m}$ thick accumulated as a result of rapid uplift. Continuing tectonism during deposition resulted first in folding and westward tilting in the upper Eocene(?) and lower Oligocene strata and finally in the uplift and erosion of these strata.

The first significant volcanism in the Laguna Mountains began with deposition of ash-flow tuff in late Oligocene time. The ash-flow tuff, which thins to the south, may have been erupted from a volcanic center to the north. Westward tilting of the ash-flow tuff and partial erosion resulted from continuing tectonism.

Alluvial fans derived from uplifted basement rocks, represented by the upper member of the upper Oligocene(?) and lower Miocene Kinter Formation, filled a northwest-trending paleovalley that had been formed during deformation and erosion of upper Eocene(?) and lower Oligocene strata. Continued tectonism caused additional westward tilting and broad, open folding in the Kinter Formation. The Laguna Mountains had reached their present landform configuration by late Miocene time. During the late Miocene and early Pliocene, transgression of the proto-Gulf of California resulted in marine-estuarine sedimentation at the foot of the Laguna Mountains. In the Pliocene, the newly established Colorado River began to build a channel and extensive floodplain west of the Laguna Mountains.

\section{ACKNOWLEDGMENTS}

Special thanks are owed to Errol L. Montgomery and Associates, Inc., for drafting assistance and to Jon E. Spencer of the Arizona Geological Survey for discussion and support.

\section{REFERENCES CITED}

Crowe, B.M., 1978, Cenozoic volcanic geology and probable age of inception of basin-range faulting in the southeasternmost Chocolate Mountains, California: Geological Society of America Bulletin, v. 89, no. 2, p. 251-264.

Crowell, J.C., and Sylvester, A.G., eds., 1979, Tectonics of the juncture between the San Andreas fault system and the 
Salton Trough, southeastem California: Santa Barbara, University of California Department of Geological Sciences, Guidebook, $193 \mathrm{p}$.

Damon, P.E., Titley, S.R., Giletti, B.J., Bennet, R., Bikerman, M., Eastwood, R., Erickson, R.C., Livingston, D.E., Laughlin, A.W., Mauger, R.L., and Mielke, J.E., 1965, Correlation and chronology of ore deposits and volcanic rocks: U.S. Atomic Energy Commission Annual Progress Report C00-689-50, p. 43.

Eberly, L.D., and Stanley, T.B., Jr., 1978, Cenozoic stratigraphy and geologic history of southwestern Arizona: Geological Society of America Bulletin, v. 89, no. 6, p. 921-940.

Mattick, R.E., Olmsted, F.H., and Zohdy, A.A.R., 1973, Geophysical studies in the Yuma area, Arizona and California: U.S. Geological Survey Professional Paper 726-D, 36 p.

Olmsted, F.H., 1972, Geologic map of the Laguna Dam 7.5minute quadrangle, Arizona and Califomia: U.S. Geological Survey Geologic Quadrangle Map GQ-1014, scale 1:24,000.

Olmsted, F.H., Loeltz, O.J., and Irelan, Burdge, 1973, Geohydrology of the Yuma area, Arizona and California: U.S. Geological Survey Professional Paper 486-H, 227 p.

Shafiqullah, M., Damon, P.E., Lynch, D.J., Reynolds, S.J., Rehrig, W.A., and Raymond, R.H., 1980, K-Ar geochronology and geologic history of southwestern Arizona and adjacent areas, in Jenney, J.P., and Stone, Claudia, eds., Studies in western Arizona: Arizona Geological Society Digest, v. 12, p. 201-260.

Sherrod, D.R., and Tosdal, R.M., 1991, Geologic setting and Tertiary structural evolution of southwestern Arizona and southeastem California: Journal of Geophysical Research, v. 96 , no. B7, p. $12,407-12,423$.

Smith, D.B., Tosdal, R.M., Pitkin, J.A., Kleinkopf, M.D., and Wood, R.H., 1989, Mineral resources of the Muggins Mountains wilderness study area, Yuma County, Arizona: U.S. Geological Survey Bulletin 1702-D, 16 p.

Spencer, J.E., and Reynolds, S.J., 1989, Middle Tertiary tectonics of Arizona and adjacent areas, in Jenney, J.P., and Reynolds, S.J., eds., Geologic evolution of Arizona: Arizona Geological Society Digest 17, p. 539-574.

Yarnold, J.C., and Lombard, J.P., 1989, A facies model for large rock-avalanche deposits formed in dry climates, in Colburn, I.P., Abbot, P.L., and Minch, John, eds., Conglomerates in basin analysis: a symposium dedicated to A.O. Woodford: Los Angeles, Calif., Pacific Section, Society of Economic Palentologists and Mineralogists, v. 62, p. 9-31. 


\title{
The Conglomerate of Bear Canyon (Miocene), Chocolate Mountains, Southeastern Calif.
}

\author{
By Kathleen M. Hughes ${ }^{1}$
}

\section{INTRODUCTION}

The Miocene conglomerate of Bear Canyon is a widespread stratigraphic unit exposed on the flanks of the Chocolate Mountains and adjacent ranges in southeasternmost California. Informally named by Crowe (1973, 1978), the unit was described more fully by Dillon (1975) and Hughes (1990). The conglomerate of Bear Canyon is well exposed in Bear Canyon, Carrizo Wash, Indian Pass, and Vinagre Wash (fig. 1). The upper part of the unit is undeformed by middle Tertiary detachment faulting, and its lower parts were deposited upon rocks tilted and faulted by that event.

\section{DEPOSITIONAL SETTING}

The conglomerate of Bear Canyon is a very poorly sorted cobble conglomerate deposited in proximal and medial alluvial fan environments. The unit unconformably overlies middle Tertiary volcanic rocks and Mesozoic and older crystalline rocks. Clasts in the conglomerate of Bear Canyon are angular to subrounded and restricted to rock types exposed near the site of deposition. Debris-flow deposits form most of the unit, although stream-channel deposits are common in those parts of the deposit interpreted as midfan facies. The unit was deposited rapidly, inasmuch as its sediment is only locally oxidized and no clay concentrations or caliche precipitation were observed between beds. The only soil profile seen was a poorly developed horizon exposed in the Big Chief pit of the Mesquite Mine. No fossils or other organic matter have been found in the unit.

The conglomerate of Bear Canyon is Miocene in age. Basalt that caps Black Mountain near Indian Pass is interbedded within the upper part of the unit; the basalt has $\mathrm{K}$-Ar ages of $13.4 \pm 2.6 \mathrm{Ma}$ (Crowe, 1978; age recalculated by method in Dalrymple, 1979) and $9.6 \pm 1.8 \mathrm{Ma}$ (Eberly and Stanley, 1978, their No. 121; age recalculated using

\footnotetext{
'Woodward-Clyde Consultants, 2020 E. First Street, Suite 400, Santa Ana, CA 92705
}

new decay constants). Undated basalt in the Mesquite Mine area is also interbedded in the conglomerate of Bear Canyon.

The lower part of the conglomerate of Bear Canyon is partly correlative with the upper Oligocene(?) and lower Miocene Kinter Formation (Olmsted and others, 1973; Smith and others, 1989) but lacks the siliceous tuff interbeds found in the Kinter Formation. The conglomerate of

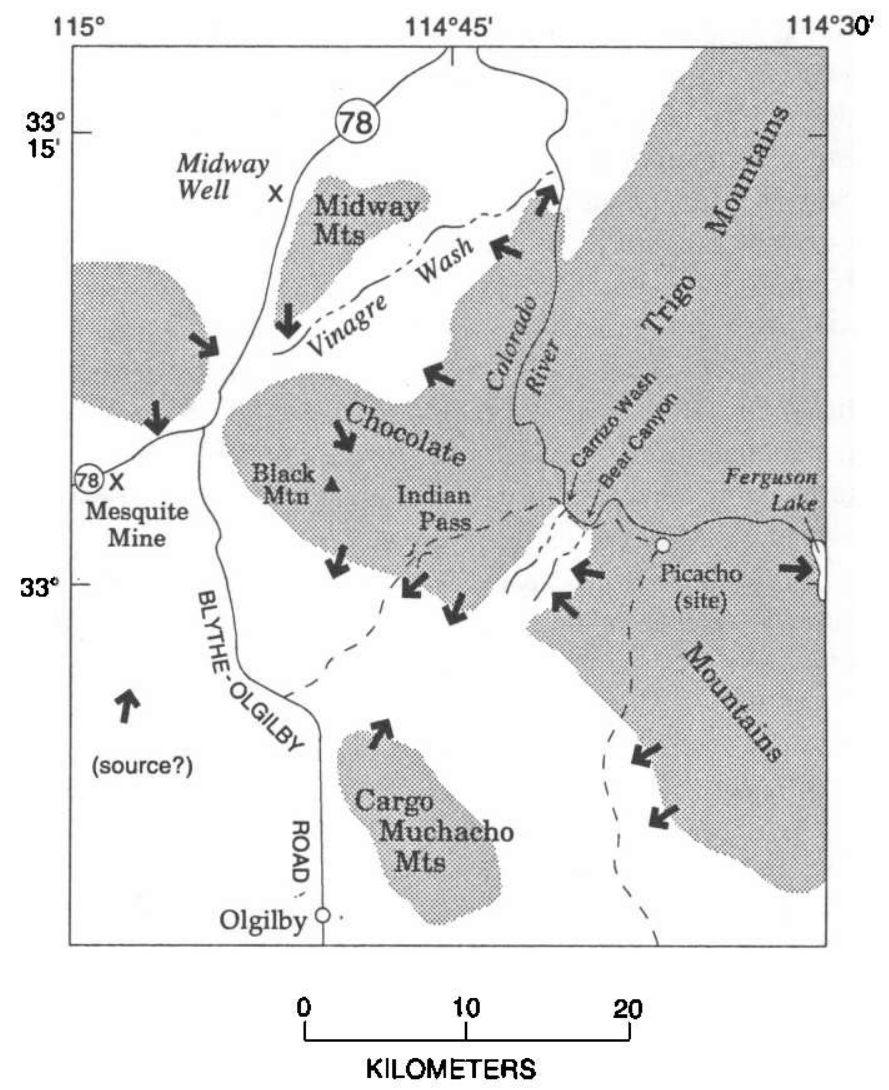

Figure 1. Map showing location of geographic features named in text. Bold arrows show paleotransport directions for detritus in conglomerate of Bear Canyon of Crowe (1978). Shaded areas show exposures of preconglomerate bedrock. "Source?" indicates no bedrock source exposed; detritus may have originated south of San Andreas fault or from sources now downfaulted and concealed by Quaternary sediment. 
Bear Canyon is conformably and unconformably overlain by the Bouse Formation and younger alluvial units.

\section{CLAST TYPES IN THE CONGLOMERATE OF BEAR CANYON}

There are four major and four minor clast types in the conglomerate of Bear Canyon. Each clast type is widely distributed, but no outcrop of the conglomerate contains clasts from all eight groups. The percentage of each clast type present in outcrop varies widely and depends mainly on the lithology of the source bedrock. Clast sizes range from very large boulder to very coarse sand.

The conglomerate of Bear Canyon is classified as a volcaniclastic litharenite; the most common clasts are volcanic rocks including rhyolitic to andesitic pyroclastic rocks, lava flows, breccia, and intrusive rocks. These clasts were derived from regionally extensive volcanic units and their intrusive equivalents that have $\mathrm{K}$ - $\mathrm{Ar}$ ages between 32 and $22 \mathrm{Ma}$ (Crowe, 1978; ages recalculated). Gneissic clasts, derived from Mesozoic (mostly Jurassic) rocks, are the second most common clasts in the conglomerate. The gneissic clasts are commonly found with granitoid clasts derived from the same source terrane. Schist, the fourth most common clast type, is derived from the Orocopia Schist. Minor constituents of the conglomerate include quartzite derived from the Orocopia Schist; basalt derived from Tertiary olivine basalt flows similar to those exposed at Black Mountain; Mesozoic gabbro from a complex found in the Midway Mountains and elsewhere; pyroclastic rocks altered to a green zeolite-facies mineral; and metaconglomerate derived either from the Jurassic(?) Winterhaven Formation or reworked from the Oligocene(?) and lower Miocene Kinter Formation.

Two distinct lithofacies may be defined by the composition of clasts in the conglomerate of Bear Canyon. One group is dominated by Tertiary volcanic rocks; the other is dominated by Mesozoic plutonic and metamorphic rocks. Mafic igneous rocks, quartzite, and metaconglomerate are minor constituents of both lithofacies. Both lithofacies were deposited throughout the study area and reflect a change in exposed bedrock over time. The two lithofacies interfinger with one another both laterally and vertically. In Bear Canyon, the volcanic lithofacies occurs at the top and bottom of the section, separated by the plutonic-metamorphic lithofacies.

\section{PALEOTRANSPORT DIRECTIONS AS INDICATED BY CLAST TYPES}

Directions of sediment transport during Bear Canyon time were determined by observing clast compositions and the variations in these compositions over a range of several kilometers, by measuring clast imbrication and channel orientation, and by interpreting Landsat thematic mapper images. Sediment was transported (1) in a south-directed fan originating in the Chocolate Mountains immediately north of the Mesquite Mine; (2) in a south-directed fan originating in the Midway Mountains; (3) in a north- and west-directed fan originating in the hills east of Vinagre Wash; (4) in west-, south-, and east-directed fans originating north of Indian Pass; and (5) in fans radiating in all directions away from the Picacho area (fig. 1). In the Ferguson Lake area, the conglomerate of Bear Canyon received sediment from both southerly and westerly sources.

\section{TECTONICS}

Seismic lines, acquired from Shell Oil Company, were shot west-southwest of the study area and depict the thickness and structure of the conglomerate of Bear Canyon and other units present in the southeastern Chocolate Mountain. One such line (fig. 2), was shot along California Highway 78 west of the Mesquite Mine (extending west of fig. 1). The conglomerate of Bear Canyon appears as many short reflectors offset by normal faults. The base of the conglomerate is shallower than about $2 \mathrm{~km}$, corresponding to 0.7 seconds of two-way travel time.

The seismic lines reveal three important aspects of the conglomerate of Bear Canyon. First, the maximum thickness of the unit is approximately $2 \mathrm{~km}$. This thickness is found in the Salton Trough approximately $55 \mathrm{~km}$ southwest of the Chocolate Mountains.

Second, the unit was deposited on a faulted Tertiary basement. This relation also is exposed in outcrops near the Midway Mountains, where steeply dipping lower Tertiary red beds underlie the more gently dipping conglomerate of Bear Canyon. The presence of dipping reflectors within the conglomerate and truncated by faults leads to the interpretation that the conglomerate fills grabens between block-faulted ranges.

Third, the conglomerate of Bear Canyon is cut by east- and west-dipping normal faults with several hundred meters of vertical offset. Similar faults are exposed in both conglomerate and microbrecciated gneiss in the Mesquite Mine.

East-west extension has been interpreted from the orientations of 32 normal faults found at the surface in the formation (Hughes, 1990). Work by Zoback and Thompson (1978) indicates a uniform S. $68^{\circ}$ W.-N. $68^{\circ}$ E. $\left( \pm 5^{\circ}\right)$ extension direction throughout much of the United States in middle Miocene time. Garner and others (1982) found that similar stress orientations resulted in detachment faulting in the Trigo Mountains. Thus, faults in the conglomerate of Bear Canyon are related to a different stress regime than that related to Miocene extension. 


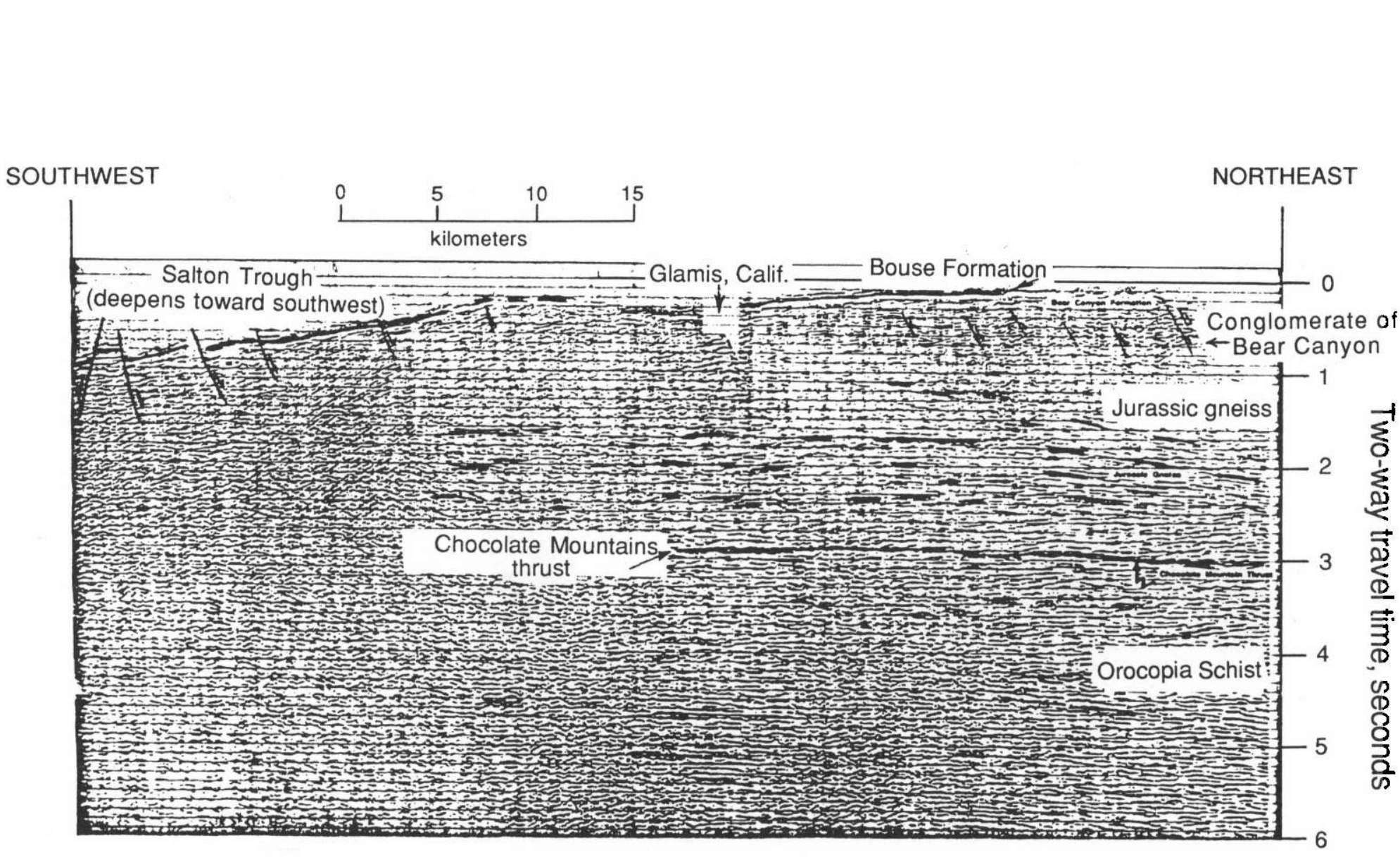

Figure 2. Seismic line along State Highway 78 southwest of Mesquite Mine. Conglomerate of Bear Canyon appears to extend to a depth of approximately $0.7 \mathrm{~s}$ (two-way travel time) and is depicted as multiple short reflectors offset by east- and west-dipping faults. 



\title{
Tertiary Basin Structure Revealed in Seismic Reflection Profiles from Milpitas Wash, Southeastern Calif.
}

\author{
By Rebecca S. Morris ${ }^{1}$
}

\section{INTRODUCTION}

Seismic refiection profiles in southeastern California have been made available to CALCRUST (California Consortium for Crustal Studies) by Exxon, U.S.A., for regional geological analysis. The reflection profiles described in this paper are from the Chocolate Mountains region, southeasternmost California, which includes Milpitas Wash (fig. 1). After reprocessing, these seismic records show the cumulative effects of deformation imposed on the Chocolate Mountains region by Mesozoic thrust faulting and possible terrane accretion, followed by middle Tertiary high- and low-angle normal faulting, and movements on Miocene to Pliocene transform faults of the San Andreas fault system. In this region, the extensional features are especially well imaged.

Mesozoic units that crop out in the southern Chocolate Mountains include the Orocopia Schist, one of the deepest structural units exposed in southern California, and components of the Chocolate Mountains thrust system (Dillon, 1975; Haxel, 1977). Major northwest-striking, northeastdipping normal faults juxtaposed the Orocopia Schist and Mesozoic gneissic rocks against Tertiary volcanic and sedimentary rocks. These faults tilted upper crustal blocks to form basins that accumulated Tertiary volcanic rocks and sedimentary strata. The rocks imaged on the seismic lines are presumed similar to those exposed in the rim of Milpitas Wash (fig. 1).

\section{FIELD AND PROCESSING PARAMETERS}

A Vibroseis source was used to generate seismic reflections in the Chocolate Mountains region. Data were collected with a receiver and shotpoint interval of $100 \mathrm{~m}$, with a split-spread recording array. The upsweep length was $11 \mathrm{~s}$ between 12 and $47 \mathrm{~Hz}$, and listening time was $4 \mathrm{~s}$. At each shotpoint a vertical stack of 20 sweeps was recorded; the nominal common midpoint fold was 24 .

\footnotetext{
'Institute of Geophysics and Planetary Physics, University of Califormia, Los Angeles, CA 90024
}

Reprocessing was performed at the Center for Computational Seismology, Lawrence Berkeley Lab, University of California, Berkeley. The extended correlation method was applied to seismic reflection profiles from the core complex corridor of southern California and western Arizona and the Salton Trough, whether collected by CALCRUST or donated by industry, in order to obtain full crustal profiles for interpretation (Okaya, 1986; Okaya and Jarchow, 1989; Okaya and Frost, 1986; Morris and Okaya, 1987; Morris, Frost, and Okaya, 1986; Spongberg and Henyey, 1987; Severson and McEvilly, 1987). The processing steps included in order: (1) extended correlation, (2) bandpass filtering, (3) spherical divergence correction, (4) trace balance, (5) elevation statics, (6) common-depth-point sorting, (7) velocity analysis, (8) normal move-out, (9) NMO stretch mute, (10) stack, (11) data plot with automatic gain, and (12) f-k migration (migration before automatic gain) for line 2 . All depths are given as two-way travel time (TWTT) in seconds.

\section{INTERPRETATION OF THE SEISMIC RECORD}

From analysis of the seismic reflection data, two large structural subbasins underlie the Milpitas Wash topographic basin (figs. 2, 3, and 4), and the upper crust is composed of a series of fault blocks tilted on high-angle normal faults. The seismic profiles were shot in a west-toeast alignment, oblique to the strike of strata; therefore, dips on the profiles are apparent dips. Trends of the western and central basins imaged on lines 2 and 5 (fig: 1) are in a northwest-southeast direction, parallel to the strike of the high-angle basin-bounding normal faults.

The basin-bounding faults dip to the northeast, which is also the dip direction of major normal faults exposed in the Chocolate Mountains (Dillon, 1975). The boundary faults extend to middle crustal depths, where they appear to join a zone of strong reflectivity. The reflective zone is interpreted to represent a penetrative extensional fabric that developed during a regional episode of middle Tertiary extension (Morris, Frost, and Okaya, 1986; Morris, Okaya, and others, 1986; McCarthy and Thompson, 1988; Frost and others, 1987). 


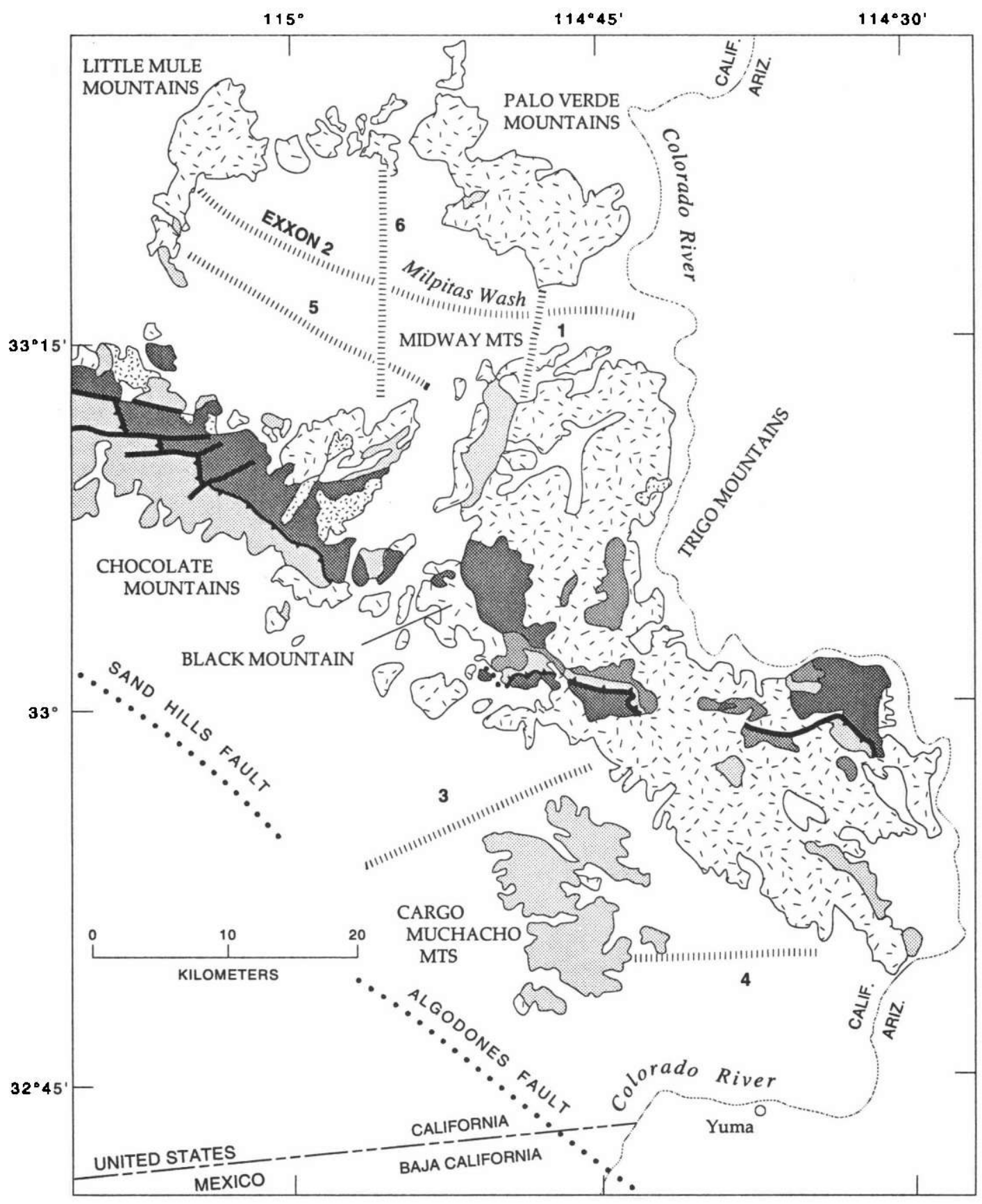

\section{EXPLANATION}

Sedimentary rocks (Holocene to Pliocene)

$\because$ : Sedimentary and volcanic rocks (late and middle Tertiary)

Plutonic rocks (middle Tertiary)

Winterhaven Formation (Jurassic?)

Granitic and gneissic rocks (Mesozoic and Proterozoic?)
Orocopia Schist (late Mesozoic)

\section{Contact}

Fault; dashed where approximately located: dotted where concealed; queried where conjectural

Chocolate Mountains thrust

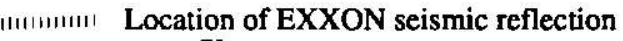
profiles

Figure 1. Surface geology and location of Exxon seismic reflection profiles (1-6) in Chocolate Mountains region (after Crowe, 1973; Dillon; 1975, Haxel, 1977; Murray, 1981; Tosdal and Sherrod, 1985). 
The strong midcrustal reflections in the Chocolate Mountains are almost identical to those imaged on reflection profiles of the more highly segmented Colorado River core complexes to the north (Frost and Okaya, 1986; Frost and others, 1987). In those terranes, middle and lower crust are characterized across all the profiles by a dense array of short, discontinuous reflections. The seismic similarity of deep-crustal reflections in the Milpitas Wash area suggests that, like the areas farther north, the Chocolate Mountains also are underlain by zones of Tertiary ductile fabric, which may be traced into surface exposures of mylonitic rocks (Frost and Okaya, 1986; Frost and others, 1989).

Thus, the structural evolution of the Milpitas Wash basins appears to have been a passive response to the mobility of the middle and lower crust during the middle Tertiary (Morris, 1990). As the middle crust extended on low-angle normal faults in the upper crust and ductile zones at greater depth, the upper crust was broken by high-angle normal faults to form synextensional basins. The basins filled with detritus from local sources and basin depocenters grew in size as displacement on the high-angle normal faults progressed. With continued extension, smaller Tertiary subbasins increased in size to that of the square- or rhomboid-shaped Milpitas Wash, which was filled later by Quatemary alluvial deposits.

\section{BASIN GEOMETRY}

Upper crustal levels, above $2 \mathrm{~s}$ on the seismic reflection profiles, are characterized by half-grabens formed by the interaction of multiple high-angle normal faults (figs. 2-6). These basins are structurally above a zone of multiple lensoidal reflections that can be identified between 2.5 and $4.0 \mathrm{~s}$. The basins are asymmetric, wedge shaped, and as deep as $4.5 \mathrm{~km}$. The deeper parts of the basins are bounded by high-angle normal faults that show large offsets. These high-angle normal faults penetrate preTertiary basement between 2 to $3 \mathrm{~s}$ (TWTT). Floors of the western and central basins, labeled WB and CB (figs. 4 and 6), tilt to the southwest.

The asymmetry of the basins seen on the reflection profiles is due to synchronous deposition of units and tilting of the upper crustal blocks on multiple high-angle normal faults (Morris, 1990). The basin structure generated by this deformation is preserved beneath a thick cover of undeformed sedimentary beds.

The strata in the large western and central basins are dissected by numerous high-angle normal faults, but the underlying fault blocks appear largely coherent on the reflection profiles. The high-angle normal faults, as well as the low-angle normal (detachment) faults, do not image as strong individual reflections but are zones of contrasting seismic fabric between reflective packages, which can be matched on the four reflection profiles (figs. 3, 5, and 7).
The crustal-scale geometry imaged on the seismic reflection profiles can be observed at the surface. Segmentation and tilting of a low-angle detachment fault by later normal faulting is preserved in the Picacho area of the southern Chocolate Mountains (Frost and others, 1986). Outcrop exposures preserve both planar and curviplanar upper-plate normal faults that join the detachment surface.

On the eastern side of profile 2, a large antiformal structure with southwesterly and northeasterly dips is interpreted (figs. 3 and 4). Crowe and others (1979) recognized this structure in surface exposures in the Chocolate Mountains, and northeast-dipping beds also have been recorded in the northern Palo Verde Mountains (Murray, 1981). The regional extent of this antiform in the Palo Verde Mountains is further disclosed in enhanced thematic mapper (TM) imagery and seismic reflection data (Blom and others, 1987). TM data indicate surface dimensions for the antiform of 10 by $11 \mathrm{~km}$, and figure 3 suggests that it extends to $1.5 \mathrm{~s}$ in the subsurface. Farther to the east in the Trigo Mountains, northeast-dipping beds are recorded in the upper-plate units above a southwest-dipping detachment fault (Garner and others, 1982; Frost and others, 1989).

\section{SEISMIC BASIN STRATIGRAPHY}

A lack of deep-well data precludes precise statements about the seismic stratigraphy. One oil test well, drilled to $640 \mathrm{~m}$ depth in Milpitas Wash, penetrated chiefly Tertiary conglomerate that overlies volcanic rocks at the base of the drill hole (Metzger and others, 1973). However, the proximity of the reflection profiles (figs. 3-9) to outcrops surrounding Milpitas Wash allows surface geology to be projected on the profiles with reasonable confidence (fig. 1). The basins are characterized by strong reflective layers separated by seismically transparent layers, and thus probably are filled with Tertiary sedimentary and volcanic rocks similar to those exposed around the rim of Milpitas Wash.

The western basin, labeled WB on figures 4 and 6 , is characterized on line 5 by three distinct sets of reflections (fig. 7), which are discontinuous on line 2 (fig. 3, 8, and 9). Such laterally discontinuous reflections are here interpreted as indicating disruption of the strata by intrabasin faults. The lowest reflections define the basin bottoms, and these basal reflections dip gently southwestward (B, fig. 6). The overall gentle dip of the basin bottom probably records an effective tilt of regional scale (Anderson, 1971) that is lower than the actual dips of each basin floor segment.

Within the westem and central basins, contrasting seismic characteristics identify a general structural layering of basement. A middle-Tertiary granodiorite laccolith intrudes Orocopia Schist (fig. 1) at Mount Barrow, which 
suggests that this layering could be produced by Mesozoic crystalline rocks and sill-like Tertiary intrusions or plutons (Dillon, 1975). These basement rocks are overlain by middle-Tertiary surface deposits, a stratigraphic relationship that is exposed in the southern part of the Little Mule Mountains (Murray, 1981).

In the western basin, the bottom reflectors are overlain by a seismically transparent layer approximately $0.3 \mathrm{~s}$ thick that likely represents tilted coarse conglomeratic deposits, such as those cropping out at the edges of Milpitas Wash in the southwestern Palo Verde and northern Midway Mountains. These units include the arkosic conglomerate of the western Palo Verde Mountains, part of which is the Tolbard Fanglomerate of Jorgensen and others
(1982). Where it is exposed in the northern Midway Mountains, the Tolbard Fanglomerate preserves midfan facies of an alluvial fan complex and is dissected by numerous conjugate faults and fractures (Jorgensen and others, 1982; Berg and others, 1982). Dips change within the Tolbard Fanglomerate, indicating progressive deformation of the unit (Morris, 1990). This is a growth-fault geometry that can be seen at crustal scale on the reflection profiles.

At approximately half the depth of the western basin (A, fig. 7), the transparent layer is overlain by laterally continuous high-amplitude reflectors, perhaps correlative with middle or upper Miocene basalt of the Chocolate Mountains region (for example, Black Mountain). This volcanic episode yielded K-Ar ages of 9-13 Ma (Eberly

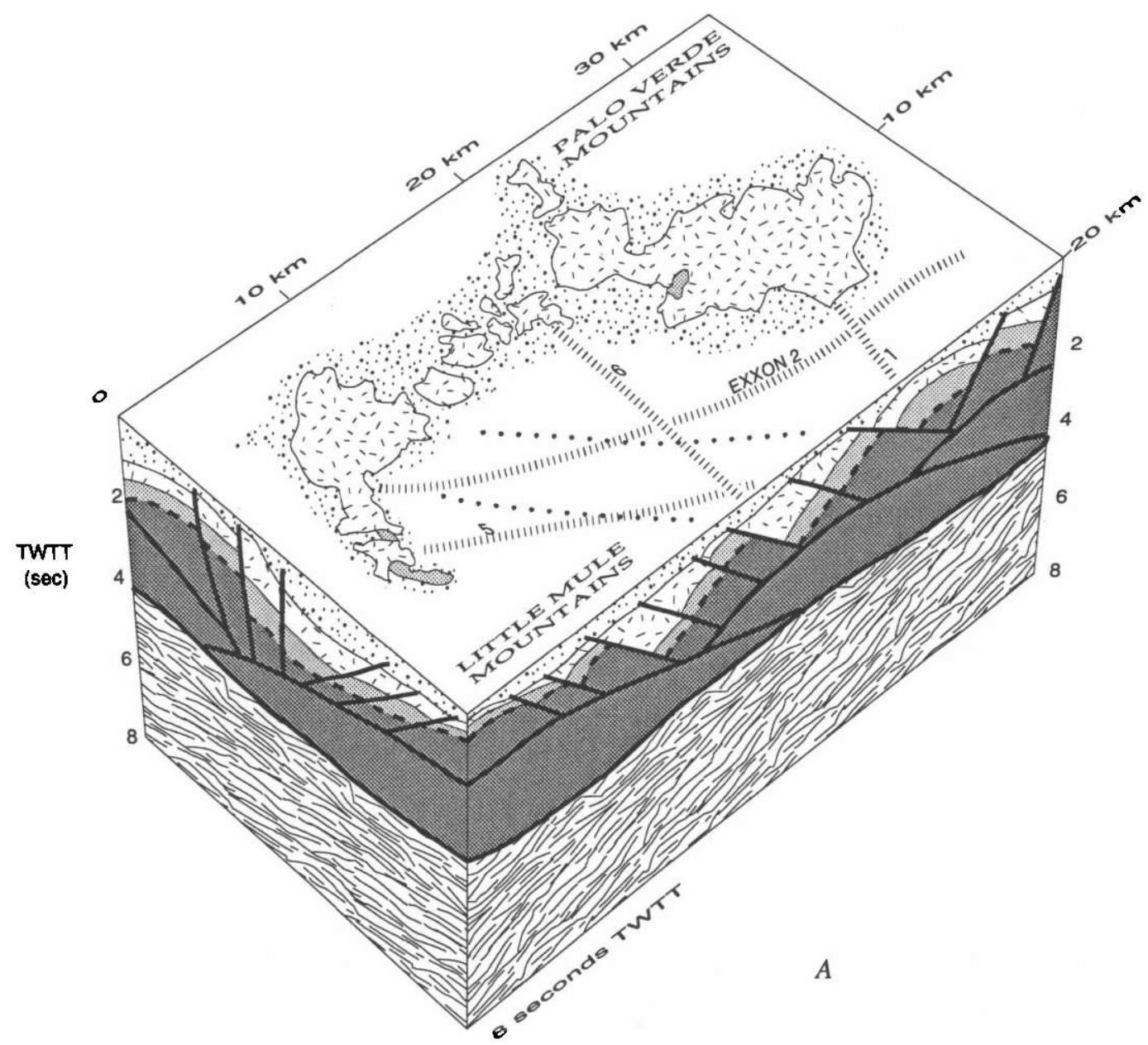

Figure 2. Isometric diagrams of upper crust in Milpitas Wash area, based on surface geology and reprocessed seismic profiles. Crustal structure interpreted from seismic line 2 is projected onto the long side of each diagram, and that of line 6 onto the short side. High-angle normal faults form halfgraben tilt blocks that are major Tertiary structural features. $A$, Interpretation 1 -lens-shaped structure on the profiles are defined by truncation of the highly reflective Mesozoic compressional fabric by Tertiary detachment faults and associated ductile zones in the middle crust. $B$, Interpretation 2-alternative shows lensoidal structure as partly due to Tertiary faulting and partly to intrusion. A zone of synkinematic sill-like plutons (shown as a single intrusion) produce lens- or lozengeshaped structures by truncation of Mesozoic fabrics and older (Mesozoic to Tertiary) faults. 
and Stanley, 1978; Crowe and others, 1979). Interpretation of the western basin on lines 2 and 5 (figs. 4 and 6), show these high-amplitude reflectors dipping southwest and overlain by another set of laterally continuous reflections that do not define distinct layers on line 5 , but show a higher degree of continuity on line 2 (fig. 8).
These reflectors could represent younger untilted conglomeratic deposits, or a change in lithology. The uppermost laterally continuous reflections with high amplitudes are approximately $0.2 \mathrm{~s}$ thick and probably define the horizontally layered, fine-grained Bouse Formation (Buising, 1990).

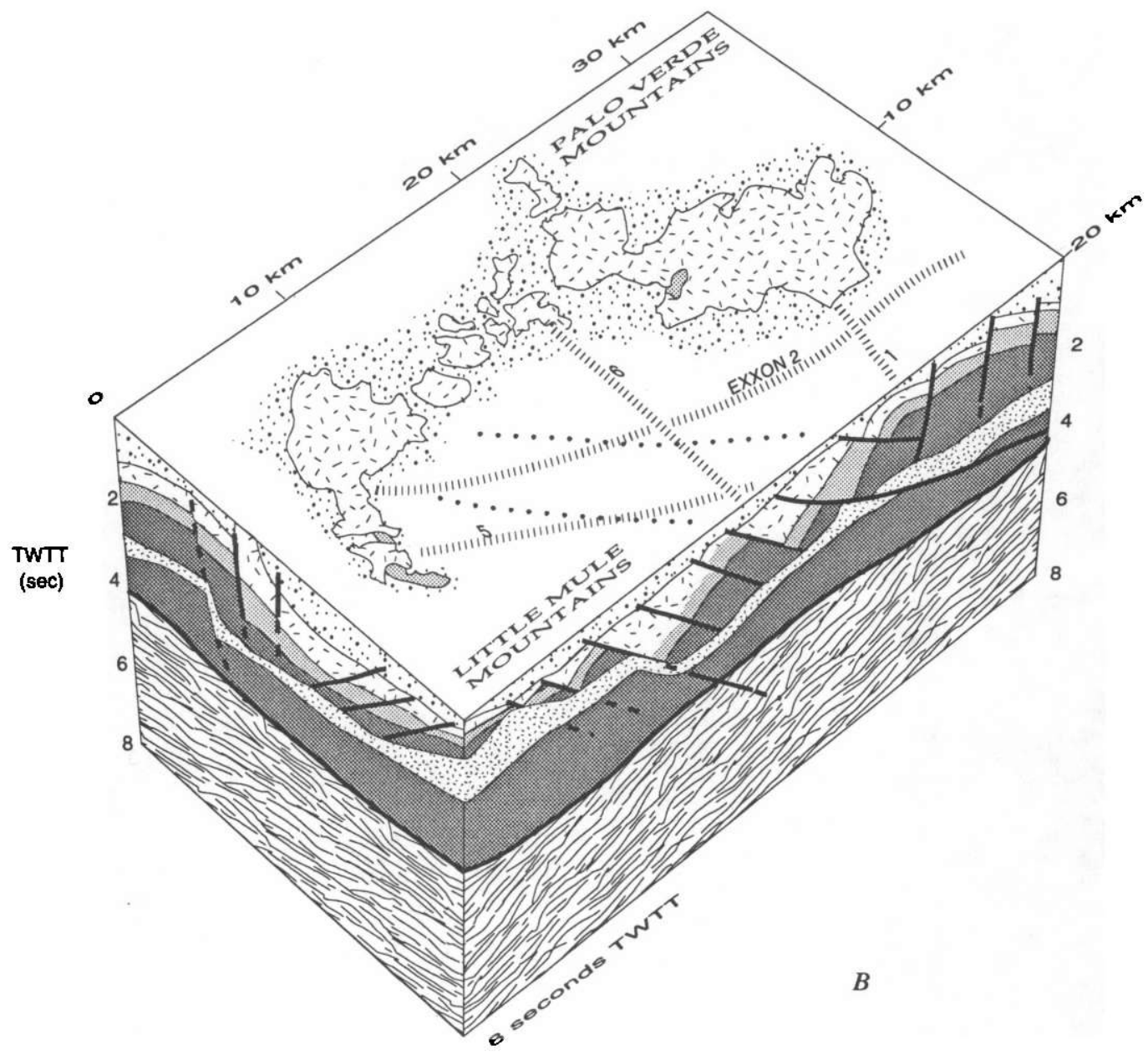

EXPLANATION

Sedimentary rocks (Holocene to Pliocene)

$\therefore \quad$ Volcanic and sedimentary rocks (late and middle Tertiary) Pre- and postextension strata

Granodioritic intrusions (late Tertiary)

Granitic and gneissic rocks (Mesozoic and Proterozoic?)

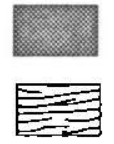

Orocopia Schist (late Mesozoic)

Basement-Rocks lying beneath the Orocopia Schist. Interpreted as zone of simple shear of the middle and lower crust

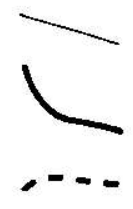

Contact

Fault-Location inferred from seismic line of figure 4

"uttiı!i" Location of EXXON seismic lines 


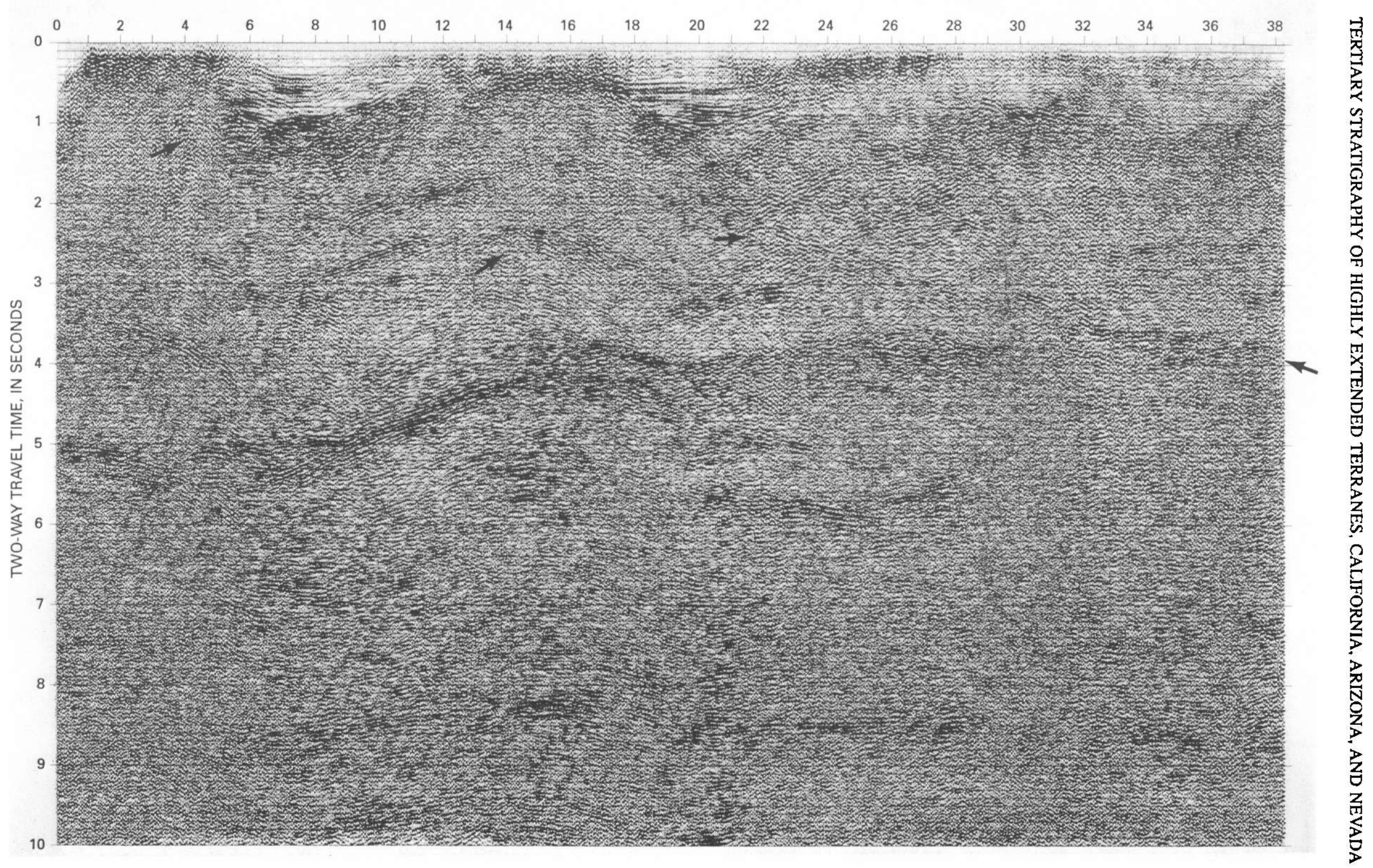

Figure 3. Reprocessed Exxon line 2; see figure 1 for location. Arrows mark locations of high-angle normal faults bounding basin margins and lensoidal structures between 2.5 to $4.0 \mathrm{~s}$ (two-way travel time). 
Rocks of the central basin (CB, figs. 4 and 8) apparently are truncated against a northeast-dipping high-angle normal fault, as are units of the westernmost basin. A strong set of gently southwest-dipping reflections define the base of deposits. A transparent layer, similar to the one imaged in the western basin, probably represents coarse conglomeratic units. However, in the central basin, the transparent layer is laterally discontinuous and grades eastward into strongly layered reflections, which are laterally continuous and probably represent units correlative with Tertiary volcanic rocks exposed in the northern rim of Milpitas Wash (fig. 1). An alternative possibility is that the reflections result from an eastward change to more uniform bedding.

Thin layers of transparent fabric are interlayered with high-amplitude reflections in the middle of the central basin. Laterally continuous reflections near the top of the basin likely represent the change from coarse-grained conglomeratic deposits to the horizontally layered Bouse Formation.

\section{BASIN SIZE}

Reflections that can be recognized on the four reprocessed reflection profiles in Milpitas Wash allow crustal structures to be matched in three dimensions and provide an estimate of the size of the two large basins within Milpitas Wash. The east-west width of the western basin ranges from $8 \mathrm{~km}$ (line 2) to $10.5 \mathrm{~km}$ (line 5); the east-west width of the central basin is $6 \mathrm{~km}$. On tie-line 6 , the northsouth length of the central basin is $10 \mathrm{~km}$. The basins extend significantly deeper than can be projected from surface geology.

\section{SUBBASIN REFLECTIONS}

The high-angle normal faults imaged on the reflection profiles appear to merge with, or to end at, a zone of anastomosing low-angle reflections between 2.5 and $4.0 \mathrm{~s}$ (figs. 3-6). These reflections bound middle-crustal lozenge- or lens-shaped zones, which can be discerned in three dimensions from the four reflection profiles in Milpitas Wash. Smaller, individual lenses can be identified within larger lenses, and their overall shape is not affected by migration (fig. 9). Short, laterally continuous reflections create a curvilinear seismic fabric within these lenses. Some of the lenses are repetitive reflections that define coherent, dense fabrics (line 2, figs. 3 and 4). Several of the lenses maintain their individual character multidimensionally on the four reflection profiles in Milpitas Wash and can be matched from one profile to the next by their internal fabric and overall shape.

Previous workers have interpreted the lensoidal reflections seen in the middle crust of southeastern California as anastomosing Tertiary detachment faults or their ductile equivalents (Adams and others, 1983; Hillemeyer, 1984; Frost and Okaya, 1986; Hamilton, 1982, 1987). If the Milpitas Wash anastomosing reflections represent faults of the same extensional system, they indicate that the low-angle normal faults are anastomosing in three dimensions. Alternatively, the reflections may represent the intersection of older fabrics with fault surfaces; therefore, some parts of lenses may be older structures. The pattern of reflections could also represent an overprinting of multiple extensional faults on preexisting structures, such as Mesozoic thrust faults.

Truncation of the highly reflective Mesozoic compressional fabric by the Tertiary detachment faults and associated ductile, middle-crustal fabric is thought to best explain the lens or lozenge shape of the profiles (figs. $2 A$, $4 A$ ). Alternatively, sill-like intrusions of Miocene granodiorite might also produce the lozenge shape by truncating the Mesozoic fabric (figs. 2B, 4B) (Dillon, 1975; Frost and others, 1989).

\section{MESOZOIC STRUCTURES}

The upper crust in the Chocolate Mountains region images as a series of tilted fault blocks on the reflection profiles from Milpitas Wash. The Chocolate Mountains are tilted to the southwest, and so high crustal levels are exposed on the southwest side and the deepest crustal levels are exposed on the northeast side. Structural components of the Late Cretaceous Chocolate Mountains thrust system crop out on the southwest side of the Chocolate Mountains (Dillon and others, 1990). In the area of Milpitas Wash, and particularly in the northeastern Chocolate Mountains, the Chocolate Mountains thrust system has been segmented and tilted by younger extensional faults. These relations are also revealed in the seismic images of the subsurface (Morris, 1990).

\section{CHOCOLATE MOUNTAINS THRUST}

The Chocolate Mountains thrust in the Chocolate Mountains (Dillon, 1975; Haxel, 1977) may be projected onto the Milpitas Wash seismic profiles because this structure is well exposed in surrounding mountain ranges. The depth of this projected contact on the seismic lines in the Chocolate Mountains is based on cross sections of Dillon (1975). The Chocolate Mountains thrust, which placed Precambrian(?) and Mesozoic gneissic rocks over the late Mesozoic Orocopia Schist (Dillon, 1975; Haxel, 1977), has been overprinted by several episodes of normal faulting (Haxel and others, 1988; Dillon and others, 1990; Jacobson, 1990). These Iater exhumation faults were localized along and in some places have 


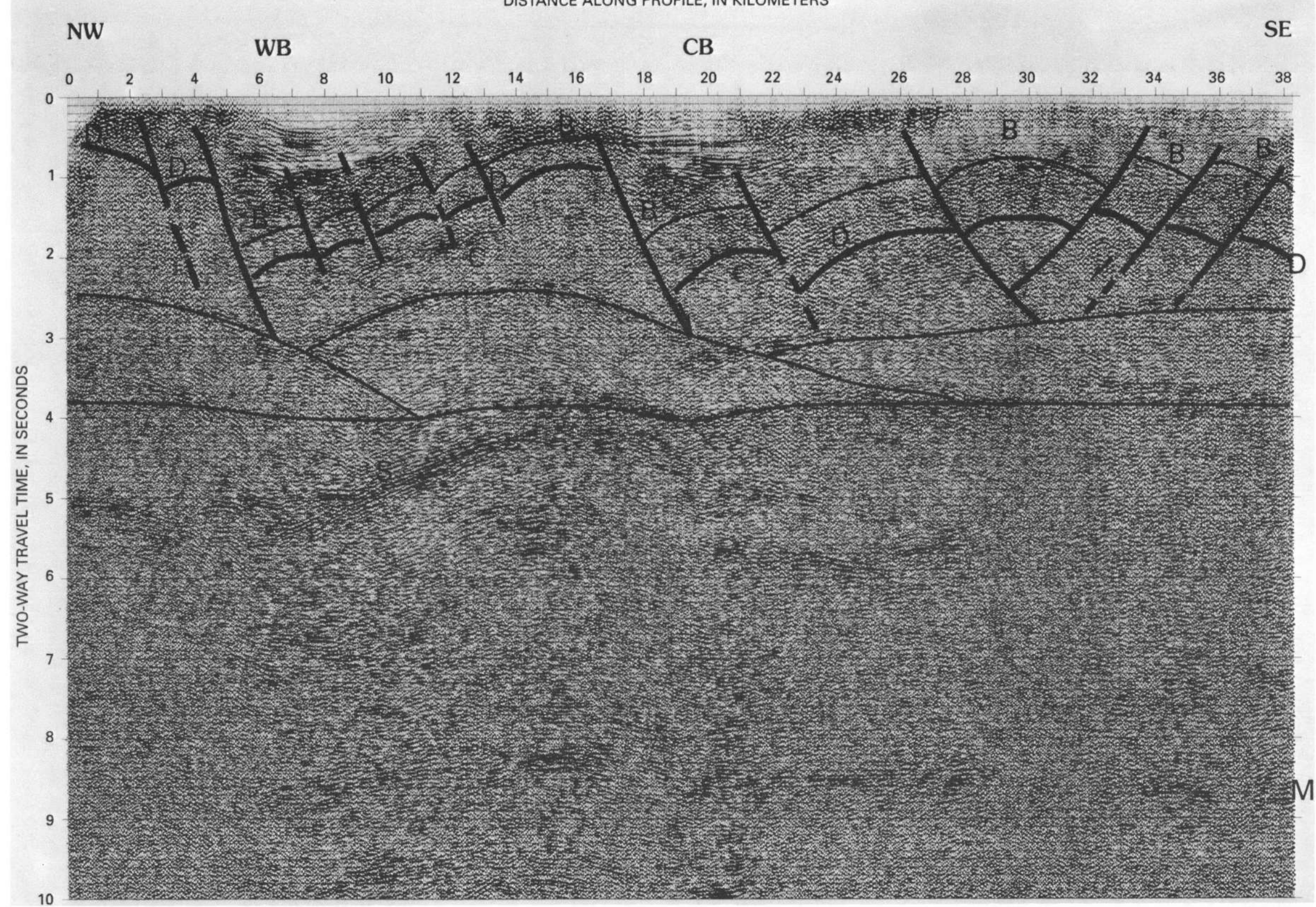

Figure 4. Interpretation of Exxon line 2. A, Interpretation 1-B, base of Tertiary basins; C, reflective crust shown as pre-Tertiary rocks offset by Tertiary high-angle normal faults; D, a flat fault that separates hanging and footwall components of the Mesozoic Chocolate Mountains thrust, which were tilted to lower angles by Tertiary high-angle normal faults. $M$, reflection Moho; S, reflection at base of Orocopia Schist.
Some high-angle normal faults appear to join a zone of anastomosing reflections between 2.5 and $4.0 \mathrm{~s}$. Faults dashed where inferred; half arrows show relative direction of movement. $B$, Interpretation $2-\mathrm{C}$ and pattern, intrusive laccoliths of Tertiary granodiorite of Mount Barrow; other symbols and labels same as $4 A$. $\mathrm{S}$, queried where uncertain. CB, central basin; WB, western basin. 
NW

WB
CB

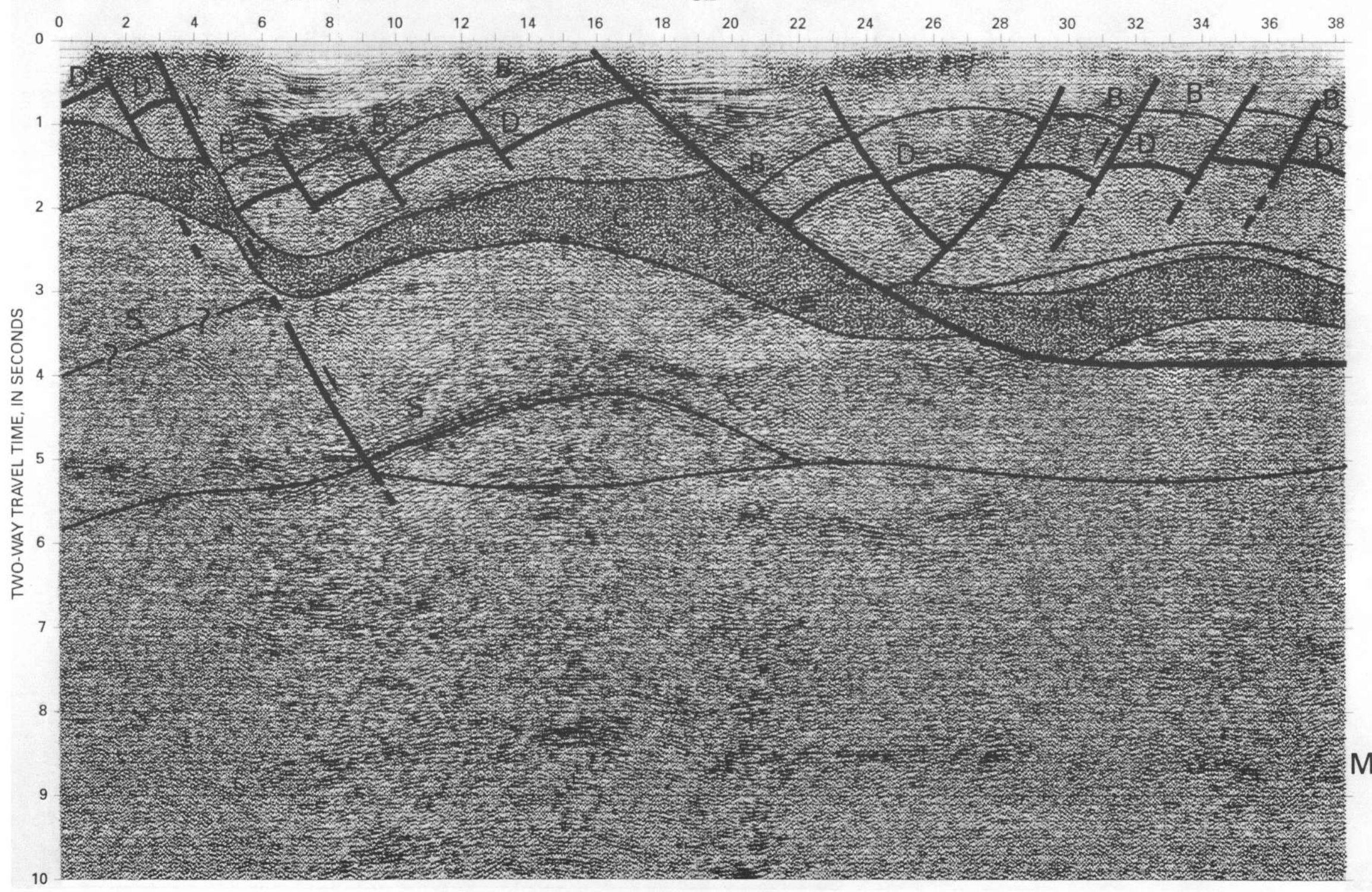


DISTANCE ALONG PROFILE, IN KILOMETERS

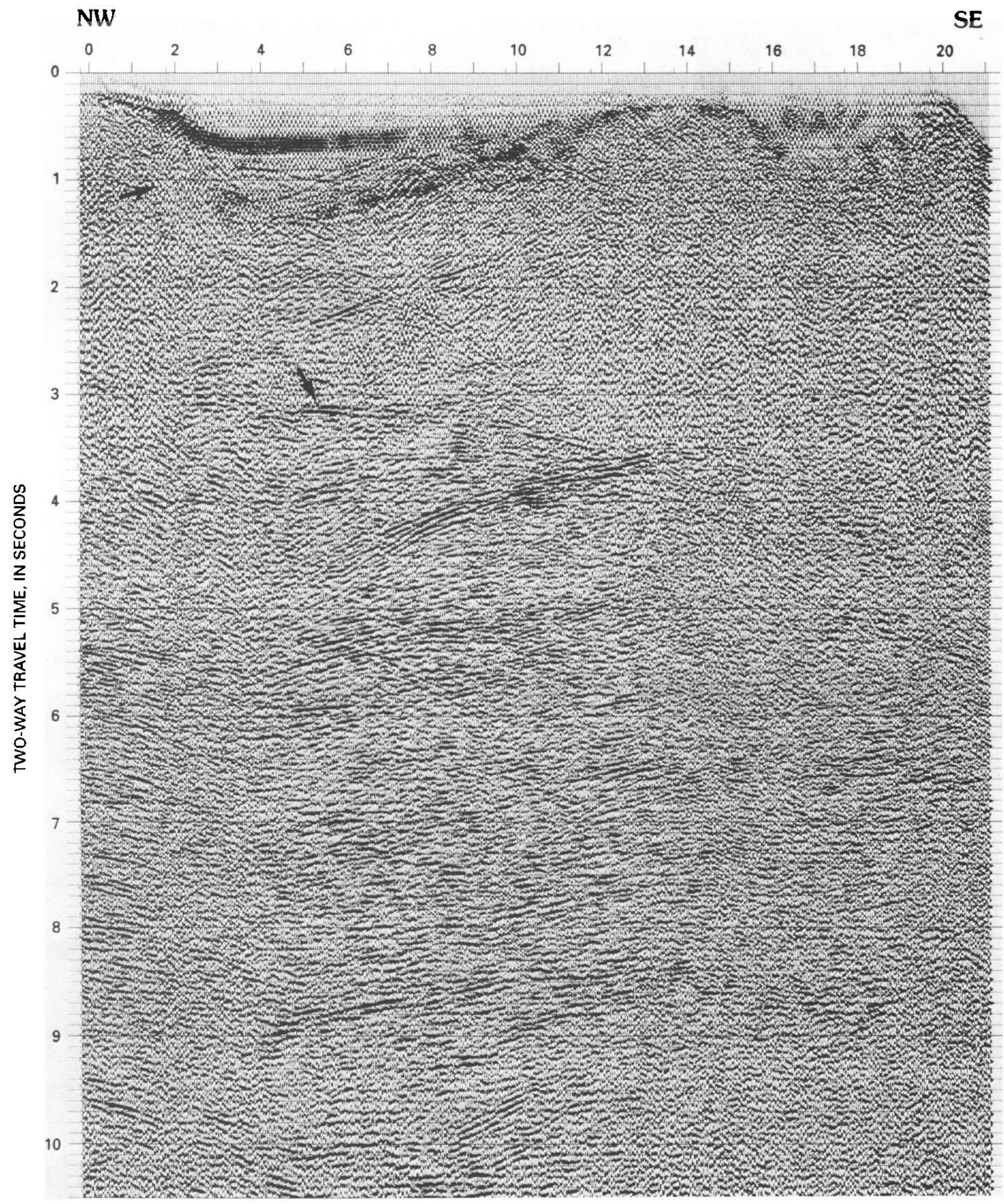

Figure 5. Reprocessed Exxon line 5. A distinctive subhorizontal seismic fabric of short, discontinuous reflections appears between 4.0 and $8.5 \mathrm{~s}$ (two-way travel time) on all ffection profiles. Fabric shows gently dipping reflectors with lateral continuity, some of which have strong imped- ance contrasts, which suggests layering. This coherent, laminar fabric has same character on all reprocessed Exxon profiles, and characterizes middle to lower crust. Arrows mark locations of high-angle normal faults and lensoidal structures. 


\section{DISTANCE ALONG PROFILE, IN KILOMETERS}

NW

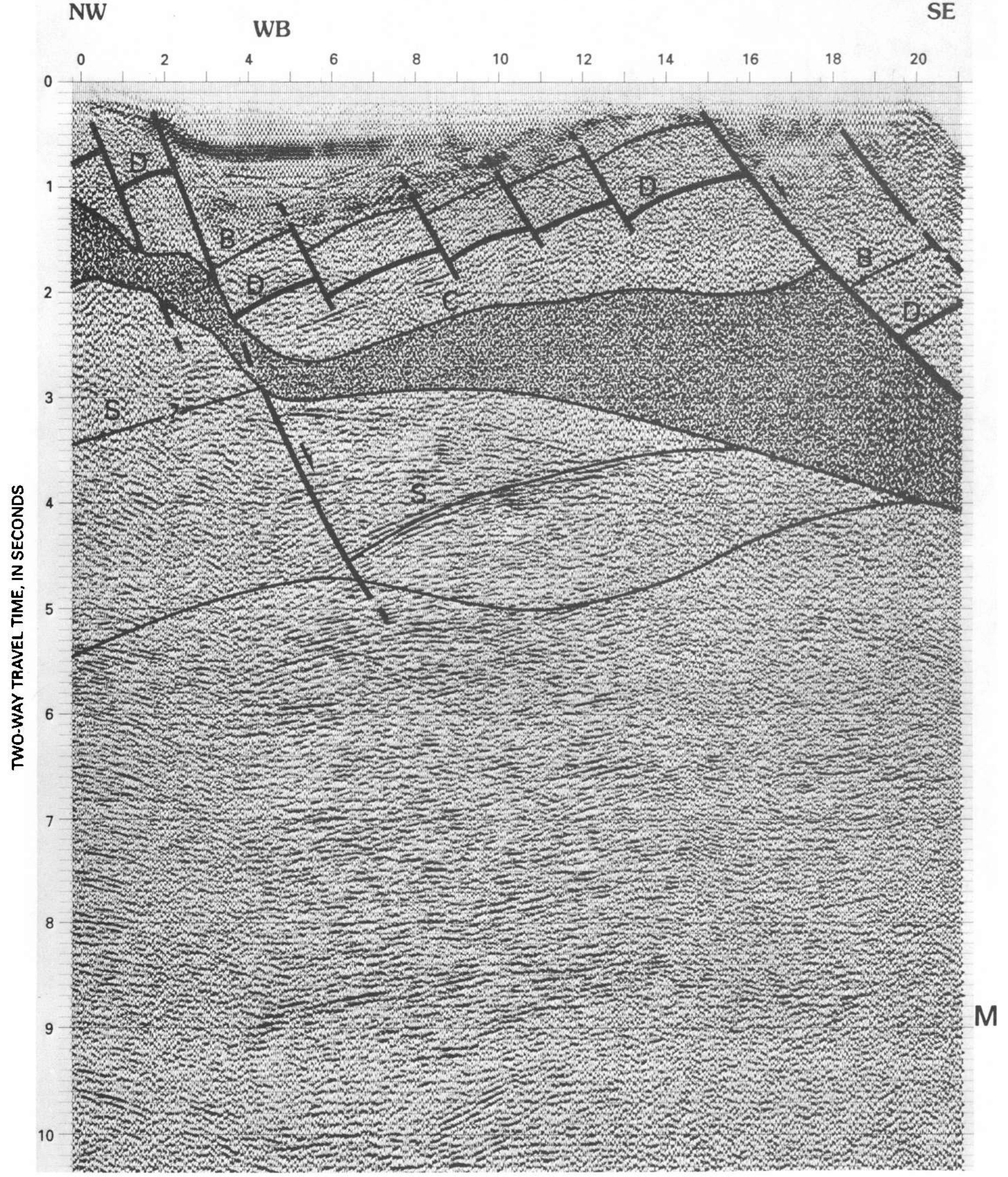

Figure 6. Interpreted Exxon line 5. Western basin (WB) identified in line 2 can be seen on west side of this profile. Reflections $\mathrm{D}, \mathrm{S}, \mathrm{B}, \mathrm{C}$, and $\mathrm{M}$ can be used to match crustal geometries between lines, and lensoidal structures can be recognized above re- flection S. Pattern, area of reflective layered middle crust interpreted as Tertiary intrusions in the Orocopia Schist, southem Chocolate Mountains. See figure 4 for explanation of other letters and symbols. 
WB

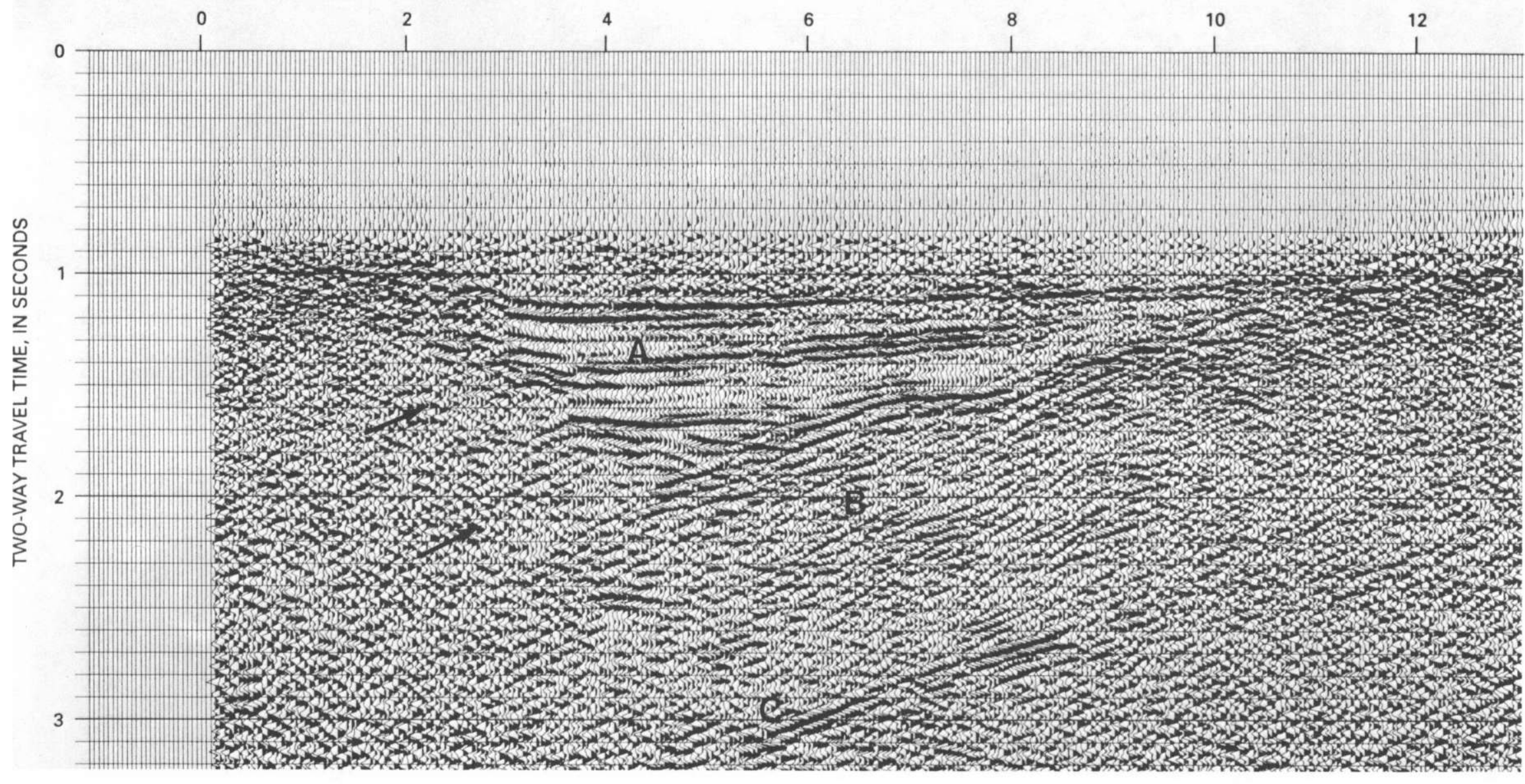

Figure 7. Detail of western basin (WB) on Exxon line 5. Arrows mark location of a northeast-dipping high-angle normal fault that bounds basin. Reflectors (A) are layered rocks of Tertiary basin fill. Lowest reflectors (B) are truncated against a lineated seismic fabric of discontinuous reflectors identified as Orocopia Schist; these define lower boundary of the basin, which dips southwestward. $\mathrm{C}$ may be interpreted as intrusive laccoliths of Mount Barrow granodiorite. 
DISTANCE ALONG PROFILE, IN KILOMETERS $\mathrm{CB}$

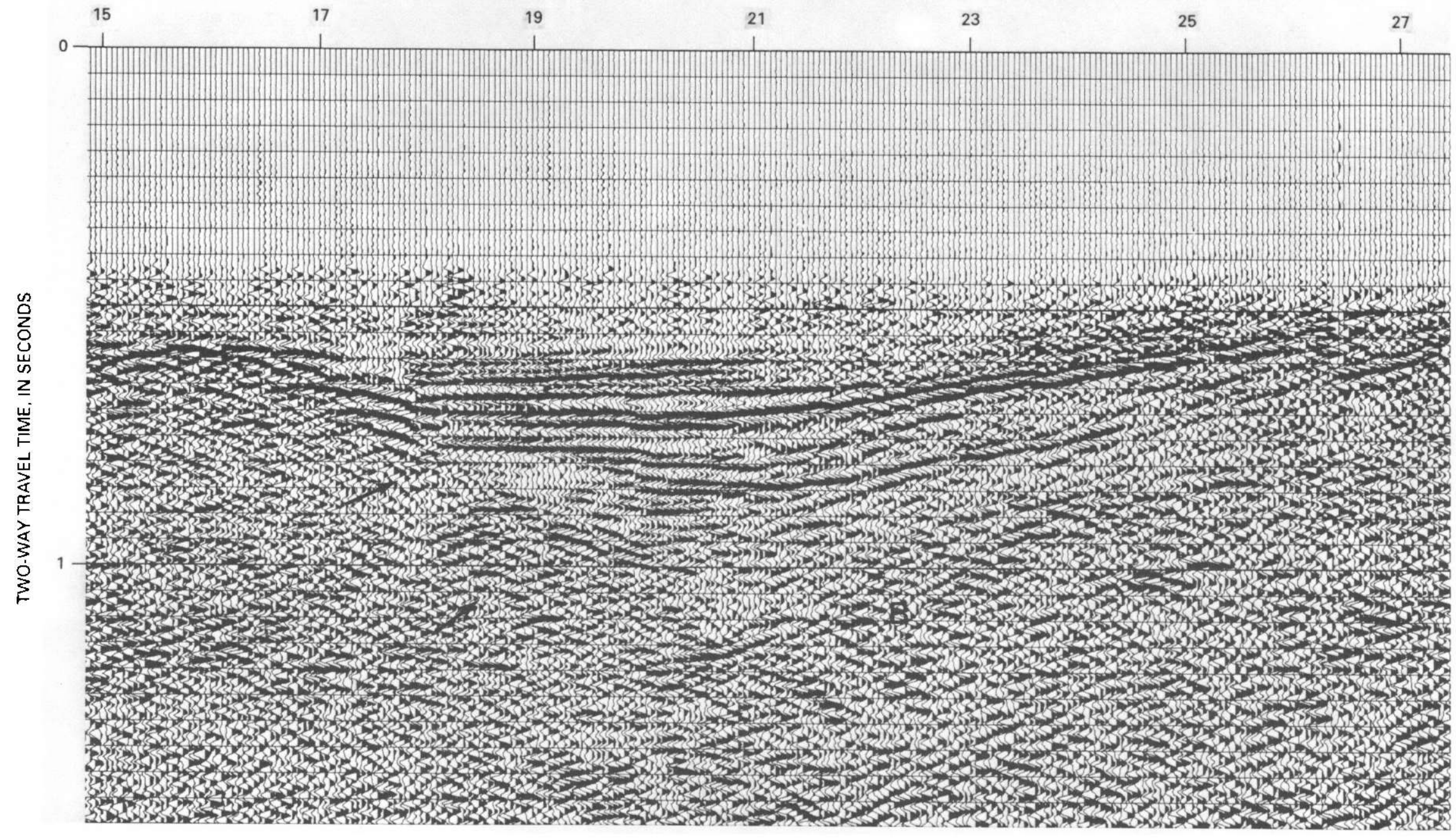

Figure 8. Detail of central basin (CB) on Exxon line 2. Arrows point to basin-bounding normal faults; B, base of Tertiary section. 


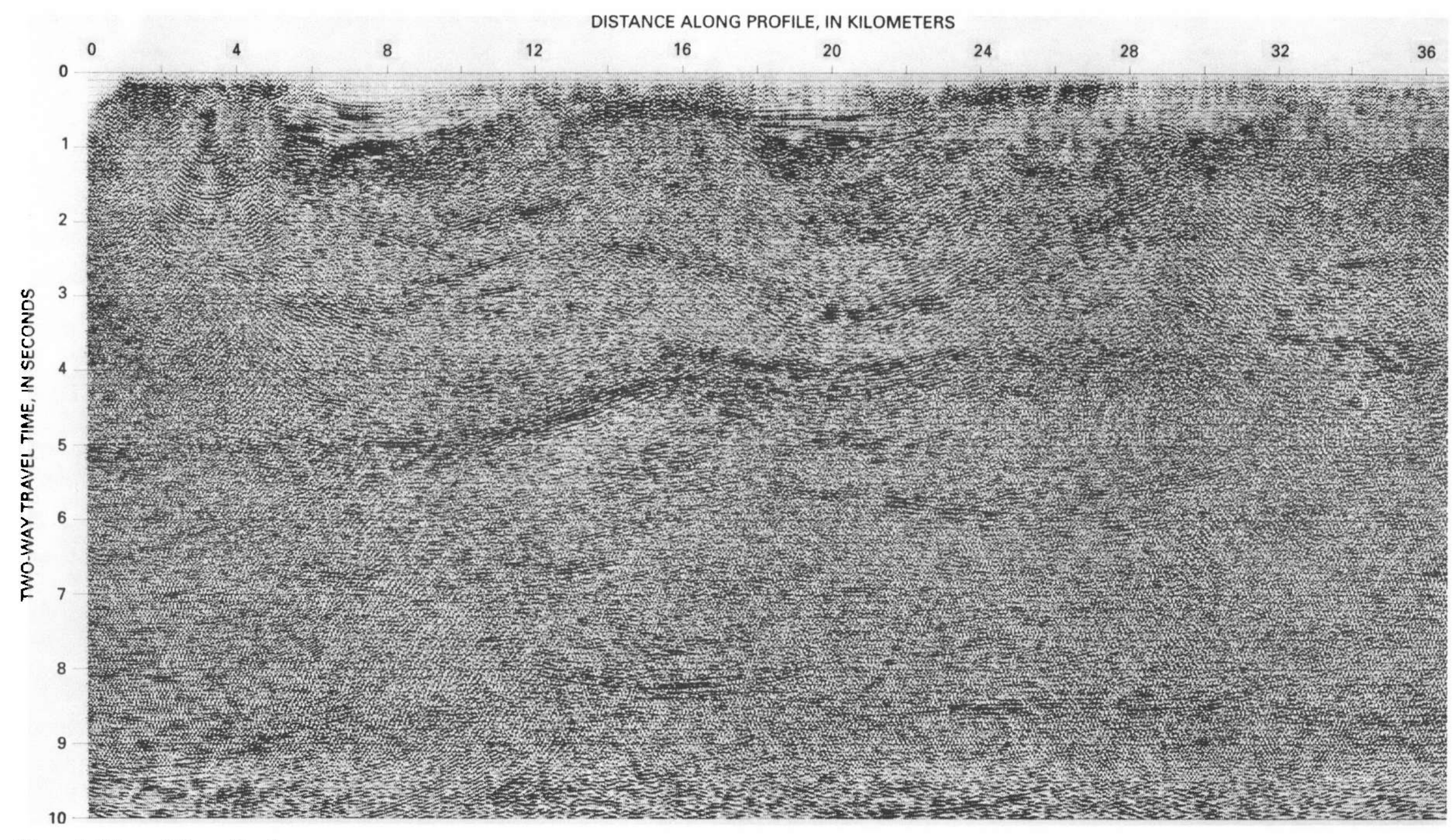

Figure 9. Migrated Exxon line 2. 
partly to completely excised the original Chocolate Mountains thrust fault.

A flat fault or fault zone (D, figs. 4 and 6) is recorded as a weakly reflective planar surface that separates the contrasting fabric of two seismic packages, likely Orocopia Schist in the footwall and gneissic rocks in the hanging wall. The depth of this projected fault zone on the reflection profiles is also based upon the geologic cross sections of Dillon (1975). The hanging-wall package of Proterozoic(?) and Mesozoic gneiss and plutonic rocks appears transparent on these seismic profiles, owing to its small-scale structural and compositional heterogeneity (Dillon, 1975). This transparent fabric contrasts with short, subhorizontal reflections that are interpreted as the Orocopia Schist of the footwall.

The fault or fault zone $D$ is thought to have a rampand-flat geometry; it was cut and extended in the Tertiary by normal faults related to regional detachment faulting. The detachment faults tilt to the northeast in the Chocolate Mountains and the southwest in the Trigo Mountains, thereby creating an intervening antiform in the upper plate (figs. 2, 3, and 4).

Exposures of low-angle faults in the Chocolate Mountains show various degrees of mylonitization (Dillon and others, 1990). Mylonitic zones are so thin (a few meters at most) that they are not directly imaged on seismic profiles, and associated faults would thus be defined by the boundary between rocks of different seismic character. In contrast, faults with a thick chlorite breccia zone do seem to be imageable (Wang and others, 1989).

Criteria for distinguishing the Mesozoic thrust surfaces from later exhumation faults are still being formulated (G.B. Haxel, oral commun., 1989; Dillon and others, 1990). Based upon surface geology, fault D could be either (1) an early Tertiary low-angle normal fault with top-to-the-northeast motion that overprinted the Chocolate Mountains thrust in the Late Cretaceous soon after it formed (Haxel and others, 1988; Simpson, 1990; Dillon and others, 1990; Richard and Haxel, 1991), (2) a later (early Tertiary?) lowangle normal fault, such as the Arrastra Wash fault and structurally higher Sortan fault in the Chocolate Mountains (Haxel and others, 1985, 1988), or (3) a Miocene detachment fault (Hamilton, 1988; Frost and others, 1987). Fault $\mathrm{D}$ is likely a hybrid structure of one, two, or all three types of the faults listed above. Adding to the complexity, different aspects of overprinted events might be observed locally (G.B. Haxel, oral commun., 1992).

\section{BASE OF THE OROCOPIA SCHIST}

In addition to the seismic fabric identified as the Orocopia Schist, a pronounced reflection interpreted as the base of the Orocopia Schist (S, figs. 4 and 6) can be identified beneath Milpitas Wash. Reflection $S$ maintains its orientation after migration (fig. 9) and can be used to match crustal structures; rocks below it have more highly reflective seismic fabrics than the Orocopia Schist. This same strong reflection can also be identified on several seismic profiles from the southwest side of the Chocolate Mountains (Morris, Frost, and Okaya 1986; Morris, Okaya, and others, 1986; Morris, 1990). The highly reflective zone beneath the Orocopia Schist could be modeled several ways: as oceanic rocks in a microcontinent collision (Haxel and Dillon, 1978, Haxel and Tosdal, 1986, Dillon and others, 1990, Tosdal and others, 1989), as subducted oceanic rocks (Crowell, 1981, Jacobson and others, 1988. Yeats, 1968), as continental North America, in which the Orocopia Schist represents a wedge between North America and overlying accreted terranes (Vedder and others, 1983), or a remnant of North American cratonal rocks preserved and tilted above a Tertiary ductile structure (E.G. Frost, oral commun., 1991).

On Milpitas Wash lines 2 and 5, reflections of greater lateral uniformity lie beneath the western basin, between 1.5 to $2.5 \mathrm{~s}$, within fabric interpreted as the Orocopia Schist. These reffections provide a structural component that can be matched multidimensionally on seismic lines 2 and 5; the interpretations shows them dipping gently to the west and terminating in diffractions (C, figs. 4 and 6). The reflections could represent contacts in the southern Chocolate Mountains between the Orocopia Schist and middleTertiary laccoliths, such as the granodiorite exposed at Mount Barrow (Dillon, 1975; Frost and others, 1987) (figs. $4 B$ and 6). The southwest-dipping reflections of both the Orocopia Schist and basal reflection $S$ continue west, where they are truncated by faults of the San Andreas fault system (E.G. Frost, oral commun., 1990).

\section{SEISMIC FABRIC OF THE MIDDLE AND LOWER CRUST}

A distinctive subhorizontal seismic fabric of short, discontinuous reflections is imaged on all the reflection profiles between 4.0 and $8.5 \mathrm{~s}$; they characterize middle to lower crust. The fabric is generally coherent, with gently dipping, laterally continuous reflectors, some with strong impedance contrasts. Short, discontinuous reflectors are also seen throughout this seismic package, which has the same character on all the reprocessed Exxon profiles in the Chocolate Mountains region (figs. 4 and 6; Morris, 1990).

Layering in the lower crust may produce this laminar seismic fabric; commonly it is interpreted to represent mylonitic zones produced by generation of new lower crust and structural reworking of older crustal components (Frost and Okaya, 1986; McCarthy and Thompson, 1988; Wang and others, 1989; McCarthy and others, 1991). In southem California, this fabric is imaged on the CALCRUST Whipple lines and on donated and reprocessed industry lines from the western Mojave (Spongberg and Henyey, 1987). 
Such discontinuous fabrics also can be seen on deep seismic profiles from other regions of extensional faulting (Brewer and Smythe, 1984; Hauge and others, 1987; Smith and Bruhn, 1984; Klemperer and others, 1986).

The southwestward dip of reflection $S$ contrasts with these short-scale, horizontal orientations of the middle and lower crustal fabrics. This contrast suggests that the reflection at the base of the Orocopia Schist is a preserved Mesozoic structure.

A strong horizontal to subhorizontal package of reflections characterizes the base of the crust between 8.5 and $9 \mathrm{~s}$ on all the profiles. It is laterally continuous on several of the lines (figs. 4 and 6). The depth to this zone of reflections translates to a crustal depth of approximately $24 \mathrm{~km}$, which closely matches the depth of the Moho in a USGS refraction survey of the Chocolate Mountains (Fuis and others, 1982).

\section{SUMMARY}

High-angle normal faults form half-grabens that are major Tertiary structural features in the upper crust. These half-graben basins overlie pronounced middle-crustal reflections, some of which seem best interpreted as zones of low-angle normal faults or ductile shear. Basin development appears to be largely the passive response of the upper-plate crust to tilting by movement along a middlecrustal zone of extensional faults. Anastomosing detachment faults, or their related ductile equivalents, appear to have overprinted Mesozoic reverse faulting of the Chocolate Mountains thrust system. Elements of the Chocolate Mountains thrust are identifiable on the records, although segmented by the extensional faults.

Sedimentary rocks that fill the half-graben basins may exhibit foldlike structures due to faulting and stratal tilting; the lower units are more strongly deformed than upper sections containing conglomerate and volcanic rocks. The reflection profiles suggest the interpretation that early formed, high-angle faults are tilted to more gentle dips by progressive deformation along younger normal faults. Apparent folds - antiforms and synforms-are produced parallel and perpendicular to the movement direction by the interaction of multiple high-angle normal faults and the shapes of the fault blocks. Tilting of the Tertiary strata and underlying crystalline rocks formed an antiform by a combination of multiple normal faults above a regional detachment fault or faults.

\section{ACKNOWLEDGMENTS}

The author would like to thank Eric Frost, John Crowell, Gordon Haxel, Dick Tosdal, Dave Sherrod, and Steve Richard for stimulating and helpful discussions, and
Tom McEvilly for allowing use of the computer facilities at the Center for Computational Seismology, University of California, Berkeley. Special thanks to David Okaya, who provided invaluable help in reprocessing the seismic reflection lines as well as imparting the fundamentals of seismic reprocessing. Thanks also to Ronald Blom and Robert Crippen of the Jet Propulsion Laboratory, Pasadena, California for providing enhanced TM images. Exxon, U.S.A., generously donated these seismic reflection profiles to CALCRUST. This study was funded in part by NSF grant No. EAR-8609247.

\section{REFERENCES CITED}

Adams, M.A., Hillemeyer, F.L., and Frost, E.G., 1983, Anastomosing shear zones-a geometric explanation for mid-Tertiary crustal extension in the detachment terrane of the Colorado River region, California, Arizona and Nevada [abs.]: Geological Society of America Abstracts with Programs, v. 15 , no. 5 , p. 375 .

Anderson, R.A., 1971, Thin skin distension in Tertiary rocks of southeastern Nevada: Geological Society of America, Bulletin, v. 82 , no. 1 , p. 43-58.

Berg, L., Leveille, G., and Geis, P., 1982, Mid-Tertiary detachment faulting and manganese mineralization in the Midway Mountains, Imperial County, California, in Frost, E.G., and Martin, D.L., eds., Mesozoic-Cenozoic tectonic evolution of the Colorado River region, California, Arizona, and Nevada (Anderson-Hamilton Volume): San Diego, Calif., Cordilleran Publishers, p. 299-311.

Blom, R.G., Morris, Rebecca, Okaya, D.A., and Frost, E.G., 1987, An anticline in the Palo Verde Mountains revealed on Landsat thematic mapper images and CALCRUST seismic reflection data [abs.]: Geological Society of America Abstracts with Programs, v. 19, no. 5, p. 591.

Brewer, J.A., and Smythe, D.K., 1984, MOIST and the continuity of crustal reflector geometry along the Caledonian-Appalachian orogeny: Geological Society of London Journal, v. 141 , no. 1 , p. $105-120$.

Buising, A.V., 1990, The Bouse Formation and bracketing units, southeastern California and western Arizona: Implications for the evolution of the proto-Gulf of California and the lower Colorado River: Journal of Geophysical Research, v. 95 , no. B12, p. 20,111-20,132.

Crowe, B.M., 1973, Cenozoic volcanic geology of the southeastem Chocolate Mountains, California: Santa Barbara, University of Califomia, Ph.D. dissertation, 117 p.

Crowe, B.M., Crowell, J.C., and Krummenacher, Daniel, 1979, Regional stratigraphy, K-Ar ages, and tectonic implications of Cenozoic volcanic rocks, southeastern California: American Journal of Science, v. 279, no. 2, p. 186-216.

Crowell, J.C., 1981, An outline of the tectonic history of southeastern California, in Ernst, W.G., ed., The geotectonic development of California (Rubey Volume 1): Englewood Cliffs, N.J., Prentice-Hall, p. 583-600.

Dillon, J.T., 1975, Geology of the Chocolate and Cargo Muchacho Mountains, southeasternmost California: Santa Barbara, University of California, Ph.D. dissertation, 405 p. 
Dillon, J.T., Haxel, G.B., and Tosdal, R.M., 1990, Structural evidence for northeastward movement on the Chocolate Mountains thrust, southeasternmost California: Journal of Geophysical Research, v. 95, no. B12, p. 19,953-19,971.

Eberly, L.D., and Stanley, T.B., Jr., 1978, Cenozoic stratigraphy and geologic history of southwestern Arizona: Geological Society of America Bulletin, v. 89, no. 6, p. 921-940.

Frost, E.G., Frost, D.M., and Houser, C.E., 1989, Mid-Tertiary ductile deformation below the Trigo Mountains detachment fault, southwestern Arizona [abs.]: Geological Society of America Abstracts with Programs, v. 21, no. 5, p. 81.

Frost, E.G., and Okaya, D.A., 1986, Crustal geometries of detachment faulting in the Colorado River extensional terrane as displayed on reprocessed industry seismic reflection data [abs.]: Geological Society of America Abstracts with Programs, v. 18, no. 5, p. 356.

Frost, E.G., Okaya, D.A., McEvilly, T.V., Hauser, E.C., Galvan, G.S., McCarthy, J., Fuis, G.S., Conway, C.M., Blom, R.G., and Heidrick, T.L., 1987, Crustal transect: Colorado Plateaudetachment terrane-Salton Trough, in Davis, G.H., and VandenDolder, E.M., eds., Geologic diversity of Arizona and its margins: excursions to choice areas: Arizona Bureau of Geology and Mineral Technology Special Paper 5, p. 398-422.

Frost, E.G., Drobeck, Peter, and Hillemeyer, Bud, 1986, Geologic setting of gold and silver mineralization in southeastem California and southwestern Arizona, in Geological Society of America, Cenozoic stratigraphy, structure, and mineralization in the Mojave Desert: GSA, Cordilleran Section, 82d, Los Angeles, Calif., March 1986, Guidebook and Volume, Field Trip nos. 5 and 6, p. 70-119.

Fuis, G.S., Mooney, W.D., Healey, J.H., McMechan, G.A., and Lutter, W.J., 1982, Crustal structure of the Imperial Valley region: U.S. Geological Survey Professional Paper 1254, p. 25-49.

Garner, W.E., Frost, E.G., Tanges, S.E., and Germinario, M.P., 1982, Mid-Tertiary detachment faulting and mineralization in the Trigo Mountains, Yuma County, Arizona, in Frost, E.G., and Martin, D.L., eds., Mesozoic-Cenozoic tectonic evolution of the Colorado River region, California, Arizona, and Nevada (Anderson-Hamilton Volume): San Diego, Calif., Cordilleran Publishers, p. 158-171.

Hamilton, W.B., 1982, Structural evolution of the Big Maria Mountains, Northeastem Riverside County, southeastem California, in Frost, E.G., and Martin, D.L., eds., MesozoicCenozoic tectonic evolution of the Colorado River region, California, Arizona, and Nevada (Anderson-Hamilton Volume): San Diego, Calif., Cordilleran Publishers, p. 1-27.

1987, Crustal extension in the Basin and Range Province, southwestern United States, in Coward, M.P., Dewey, J.F., and Hancock, P.L., eds., Continental extensional tectonics: Geological Society of London Special Publication 28, p. 155-176.

1988 , Tectonic setting and variation with depth of some Cretaceous and Cenozoic structural and magmatic systems of the western United States, in Ernst, W.G., ed., Metamorphism and crustal evolution of the western United States (Rubey Volume 7): Englewood Cliffs, N.J., Prentice-Hall, p. 1-40.

Hauge, T.A., Allmendinger, R.W., Caruso, C., Hauser, E.C., Klemperer, S.L., Opdyke, S., Potter, C.J., Sanford, W., Brown, L., Kaufman, S., and Oliver, J., 1987, Crustal structure of western Nevada from COCORP deep seismic-reflec- tion data: Geological Society of America Bulletin, v. 98 , no. 3, p. 320-329.

Haxel, G.B., 1977, The Orocopia Schist and the Chocolate Mountains thrust in the Picacho-Peter Kane Mountain area, southeastemmost Califomia: Santa Barbara, University of California, Ph.D. dissertation, 277 p.

Haxel, G.B., and Dillon, J.T., 1978, The Pelona-Orocopia Schist and Vincent-Chocolate Mountain thrust system, southern California, in Howell, D.G., and McDougall, K.A., eds., Mesozoic paleogeography of the Western United States, Los Angeles, Calif.: Society of Economic Paleontologists and Mineralogists, Pacific Section, p. 453-469.

Haxel, G.B., Jacobson, C.E., and Tosdal, R.M., 1988, Multiple low-angle faults atop the Orocopia Schist, southwestern Arizona and southeastern California [abs.]: Geological Society of America Abstracts with Programs, v. 20, no. 7, p. A383.

Haxel, G.B., and Tosdal, R.M., 1986, Significance of the Orocopia Schist and Chocolate Mountains thrust in the late Mesozoic tectonic evolution of the southeastem Californiasouthwestern Arizona region, in Beatty, Barbara, and Wilkinson, P.A.K., eds., Frontiers in geology and ore deposits of Arizona and the southwest: Arizona Geological Society Digest, v. 16, p, 52-61.

Haxel, G.B., Tosdal, R.M., and Dillon, J.T., 1985, Tectonic setting and lithology of the Winterhaven Formation, a new Mesozoic stratigraphic unit in southeasternmost California and southwestern Arizona: U.S. Geological Survey Bulletin $1599,19 \mathrm{p}$

Hillemeyer, F.L., 1984, Geometric and kinematic analysis of high- and low-angle normal faults within the Mojave and Sonoran detachment terrane: San Diego, Calif., San Diego State University, M.S. thesis, $106 \mathrm{p}$.

Jacobson, C.E., 1990, The ${ }^{40} \mathrm{Ar} /{ }^{39} \mathrm{Ar}$ geochronology of the Pelona Schist and related rocks, southern California: Joumal of Geophysical Research, v. 95, no. B1, p. 509-528.

Jacobson, C.E., Dawson, M.R., and Postlethwaite, C.E., 1988, Structure, metamorphism and tectonic significance of the Pelona, Orocopia, and Rand Schists, southern California, in Emst, W.G., ed., Metamorphism and crustal evolution of the western United States (Rubey Volume 7): Englewood Cliffs, N.J., Prentice-Hall, p. 976-997.

Jorgensen, M.R., Natenstedt, C.J., and Trumbly, P.N., 1982, Possible relationship between Miocene crustal extension/detachment faulting and the deposition of the Tolbard Fanglomerate in the Midway and western Palo Verde Mountains, Imperial County, California, in Frost, E.G., and Martin, D.L., eds., Mesozoic-Cenozoic tectonic evolution of the Colorado River region, California, Arizona, and Nevada (Anderson-Hamilton Volume): San Diego, Calif., Cordilleran Publishers, p. 313-315.

Klemperer, S.L., Hauge, T.A., Hauser, E.C., Oliver, J.E., and Potter, C.J., 1986, The Moho in the northern Basin and Range province, Nevada, along the COCORP $40^{\circ} \mathrm{N}$ seismic-reflection transect: Geological Society of America Bulletin, v. 97, no. 5 , p. 603-618.

McCarthy, Jill, Larkin, S.P., Fuis, G.S., Simpson, R.W., and Howard, K.A., 1991, Anatomy of a metamorphic core complex: seismic refraction/wide-angle reflection profiling in southeastem California and western Arizona: Journal of Geophysical Research, v. 96, no. B7, p. 12,259-12,291. 
McCarthy, Jill, and Thompson, G.A., 1988, Seismic imaging of extended crust with emphasis on the western United States: Geological Society of American Bulletin, v. 100, no. 9. p. 1,361-1,374.

Metzger, D.G., Loeltz, O.J., and Irelan, Burdge, 1973, Geohydrology of the Parker-Blythe-Cibola area, Arizona and Califomia: U.S. Geological Survey Professional Paper 486-G, $130 \mathrm{p}$.

Morris, R.S., 1990, Crustal structure of southeasternmost California: Multiple deformational events evident from industry seismic reflection profiles from the Milpitas Wash area, Chocolate Mountains: San Diego, Calif., San Diego State University, M.S. thesis, 123 p.

Morris, R.S., Frost, E.G., and Okaya, D.A., 1986, Preliminary seismic reflection interpretation of the overprint of Tertiary detachment faulting on Orocopia Schist-Chocolate Mountains thrust system, Milpitas Wash area of southeastern California, in Geological Society of America, Cenozoic stratigraphy, structure, and mineralization in the Mojave Desert: GSA, Cordilleran Section, 82d, Los Angeles, Calif., March 1986, Guidebook and Volume, Field Trip nos. 5 and 6, p. 123-126.

Morris, R.S., and Okaya, D.A., 1987, Tertiary overprint and disruption of the Chocolate Mountains thrust system and the Orocopia schist in the southern Chocolate Mountains, SE California [abs.]: Geological Society of America Abstracts with Programs, v. 19, no. 7, p. 779.

Morris, R.S., Okaya, D.A., Frost, E.G., and Malin, P.E., 1986, Base of the Orocopia Schist as imaged on seismic reflection data in the Chocolate and Cargo Muchacho Mountains region of southeasternmost California and the Sierra Pelona [abs.]: Geological Society of America Abstracts with Programs, v. 18 , no. 2 , p. 160 .

Murray, K.S., 1981, Tectonic implications of space-time pattems of Cenozoic volcanism in the Palo Verde Mountain volcanic field, southeastern California: Davis, University of California, $\mathrm{Ph}$. D. dissertation, $132 \mathrm{p}$.

Okaya, D.A., 1986, Seismic profiling of the lower crust: Dixie Valley, Nevada, in Barazangi, M., and Brown, L., eds., Reflection seismology: the continental crust: Washington, D.C., American Geophysical Union Geodynamic Series, v. 14, p. 269-279.

Okaya, D.A., and Frost, E.G., 1986, Application of seismic reflection profiles to structural analysis in mineral exploration, in Beatty, Barbara, and Wilkinson, P.A.K., eds., Frontiers in geology and ore deposits of Arizona and the Southwest: Arizona Geological Society Digest, v. 16, p. 137-152.

Okaya, D.A., and Jarchow, C.M., 1989, Extraction of deep crustal reflections from shallow Vibroseis data using extended correlation: Geophysics, v. 54, no. 5, p. 555-562.
Richard, S.M., and Haxel, G.B., 1991, Progressive exhumation of the Orocopia and Pelona Schists along a composite normal fault system, southeastern California and southwestern Arizona [abs.]: Geological Society of America Abstracts with Programs, v. 23, no. 2, p. 92.

Severson, L.K., and McEvilly, T.V., 1987, Analysis of seismic reflection data from the Imperial Valley California [abs.]: Geological Society of America, Abstracts with Programs, v. 19, no. 5, p. 449.

Simpson, Carol, 1990, Microstructural evidence for northeastward movement on the Chocolate Mountains fault zone, southeastem Califomia: Joumal of Geophysical Research, v. 95 , no. B1, p. 529-537.

Smith, R.B., and Bruhn, R.L., 1984, Intraplate extensional tectonics from the eastern Basin-Range: Inference from seismic reflection data, regional tectonics, and thermal-mechanical models of brittle-ductile deformation: Joumal of Geophysical Research, v. 89, no. B7, p. 5,733-5,762.

Spongberg, M.E., and Henyey, T.L., 1987, Crustal reflection profiling in the western Mojave Desert, California [abs.]: Geological Society of America Abstracts with Programs, v. 19. no. 6, p. 454.

Tosdal, R.M., and Sherrod, D.R., 1985, Geometry of Miocene extensional deformation, lower Colorado River region, southeastern California and southwest Arizona: evidence for the presence of a regional low-angle normal fault: Houston, Texas, Lunar and Planetary Institute, Papers presented to the Conference on Heat and Detachment in Crustal Extension on Continents and Planets, p. 147-151.

Tosdal, R.M., Haxel, G.B., and Wright, J.E., 1989, Jurassic geology of the Sonoran desert region, southern Arizona, southeastern California, and northernmost Sonora: Construction of a continental-margin magmatic arc, in Reynolds, S.J., and Jenny, J.P., eds., Geologic evolution of Arizona: Arizona Geological Society Digest 17 , p. $397-434$.

Vedder, J.G., Howell, D.G., and McLean, H., 1983, Stratigraphy, sedimentation, and tectonic accretion of exotic terranes, southern Coast Ranges, California, in Watkins, J.S., and Drake, C.L., eds., Studies in continental margin geology: American Association of Petroleum Geologists Memoir 34, p. 471-496.

Wang, Chi-Yuen, Okaya, D.A., Ruppert, Charles, Davis, G.A., Guo, Tie-Shuan, Zhong, Zengquie, and Wenk, Hans Rudolf, 1989, Seismic reflectivity of the Whipple Mountain shear zone in southern California: Journal of Geophysical Research, v. 94, no. B3, p. 2,989-3,005.

Yeats, R.S., 1968, Southern California structure, seafloor spreading, and history of the Pacific Basin: Geological Society of America Bulletin, v. 79, no. 12, p. 1,693-1,702. 


\title{
Introduction to Tertiary Rocks of the Far West Basins
}

\author{
By John C. Crowell ${ }^{1}$
}

The stratigraphic sections presented in this chapter formed in nonmarine basins from early to middle Miocene time and lie at the west and southwest edge of the Mojave Desert. These basins are the Diligencia basin, exposed in the eastern Orocopia Mountains to the northeast of the San Andreas fault zone, and the Soledad basin (Jahns and Muehlberger, 1954), exposed in the central Transverse Ranges to the southwest of the San Andreas fault zone. The Soledad basin consists of the Vasquez Rocks, Texas Canyon, and Charlie Canyon subbasins and contains unconformably overlying units. Because of their markedly similar basin history, stratal facies, and the character and inferred history of underlying and associated rocks, the two regions are considered as displaced about $330 \mathrm{~km}$ by the younger San Andreas fault system (Crowell, 1960, 1962; Crowell and Walker, 1962; Bohannon, 1975).

\section{LATEST OLIGOCENE AND EARLY MIO- CENE BASINS}

The Diligencia Formation (Crowell, 1975) of the Diligencia basin and the Tick Canyon Formation (Jahns, 1940) and Vasquez Formation of the Soledad basin are of latest Oligocene and early Miocene age. The youngest beds in the Diligencia Formation are younger than about 19 or $18 \mathrm{Ma}$, whereas those in the Vasquez Formation are probably not younger than $20 \mathrm{Ma}$. These rocks are described in greater detail in this volume (Crowell, this volume; Hendrix, this volume). Deposits of other Oligocene and eariy Miocene basins are preserved in the far-west basins region, both northeast and southwest of the San Andreas fault system, but they are not represented by stratigraphic columns in this volume and are not discussed here.

\section{MIDDLE AND UPPER MIOCENE FORMATIONS}

Nonmarine basin deposits of middle and late Miocene age, or those ranging in age between 16.2 and $5.3 \mathrm{Ma}$

\footnotetext{
'Institute for Crustal Studies and Department of Geological Sciences, University of California, Santa Barbara, CA 93106 Institute for Crustal Studies Contribution 0051-12CS-20TC
}

(Cowie and Bassett, 1989), are widespread in the far-west basins region, both northeast and southwest of the San Andreas fault zone. The Mint Canyon Formation was deposited in the Soledad basin, now lying between the San Andreas and San Gabriel faults (Hendrix, this volume). The Mint Canyon Formation and the correlative Caliente Formation in the Lockwood and Cuyama Valley areas (fig. 1) are primarily middle Miocene in age (Ehlig and others, 1975; Ehlert, 1989). Ridge basin strata were deposited between $12 \mathrm{Ma}$ (at the end of the middle Miocene) and about $3 \mathrm{Ma}$ (mid-Pliocene) (Crowell and Link, 1982), and they conformably overlie older Soledad basin beds.

\section{TECTONIC INTERPRETATIONS}

The tectonic events in the far-west basins region, which straddles the San Andreas fault system, include several distinctly different episodes and styles. The history of the Diligencia and Soledad basins suggests that extension, with presumed crustal thinning and detachment faulting, probably began in latest Oligocene time. These events occurred both to the east and west of, and are mainly older than, the San Andreas fault system in southern California. The basins enlarged and evolved in latest Oligocene and early Miocene time and were succeeded by other depositional centers with different origins and orientations that received deposits of the Barstow, Mint Canyon, and Caliente Formations and the Ridge Route Formation (Clements, 1937) in middle and late Miocene time. The complex tectonic history of the region has apparently been associated with detachment faulting, rotation, and lateral displacement of crustal blocks as the San Andreas fault system evolved. The working out of this history and the documenting of the several tectonic overprintings remains as a geologic challenge.

\section{ROTATION OF CRUSTAL BLOCKS AND DETACH- MENT FAULTING}

The concept that tectonic blocks in southern California have been rotated around vertical axes is based on paleomagnetic data (Luyendyk and others, 1985; Carter and others, 1987; MacFadden and others, 1990), which are 
supported by the reconciliation of some geological mismatches in the western Transverse Ranges (Jones and others, 1976; Link and others, 1984; Crowell, 1987). For example, paleomagnetic interpretations of data from the Vasquez Formation indicate that its strata were rotated as a whole about $53^{\circ}$ clockwise in the early Miocene and then about $16^{\circ}$ counterclockwise thereafter (Terres and Luyendyk, 1985). Strata of the Diligencia basin, on the other hand, have orientations about $45^{\circ}$ different from those of the Soledad basin (Carter and others, 1987). The lack of alignment of the rock units (Spittler and Arthur, 1973) may well be accounted for by these rotations. In addition, Terres (1984) related an apparent increase in the amount of clockwise rotation across the Diligencia basin, from about $45^{\circ}$ at the northern margin to about $170^{\circ}$ near the Clemens Well fault on the south, to increasing proximity to the San Andreas fault zone.

Such tectonic rotations would seem to require detachment of upper crustal rocks from those beneath, but as yet no detachment faults have been satisfactorily described although they have probably been identified (Morris, 1987; Robinson and Frost, 1989; Bishop and Ehlig, 1990). Because the Vasquez and Diligencia strata lie in depositional contact upon pre-Tertiary rocks, such a detachment fault (or faults) lie within the basement at depth. Moreover, Goodmacher and others (1989) recognize tilted blocks suggesting extensional deformation. In fact, throughout the region-both northeast and southwest of the San Andreas fault zone-searches are underway for the inferred detachment faults. Regional tectonic reconstructions must take into account the likelihood of rotations and detachments, much of which is associated with crustal extension (Tennyson, 1989).

\section{DISPLACEMENTS ON THE SAN GABRIEL AND SAN ANDREAS FAULT SYSTEMS}

Rocks of the Diligencia and Soledad basins are separated geographically by about $250 \mathrm{~km}$ and are found on opposite sides of the main San Andreas fault. Similarities between the stratigraphic sections include age, lithology, approximate stratigraphic sequence, abundance of volcanic rocks, distinctive rock types of limited provenance, and the character of basement rocks beneath and surrounding the Tertiary strata. In addition, the sequence of geologic events as interpreted from the rocks is similar, so it is unlikely that these events were repeated independently and

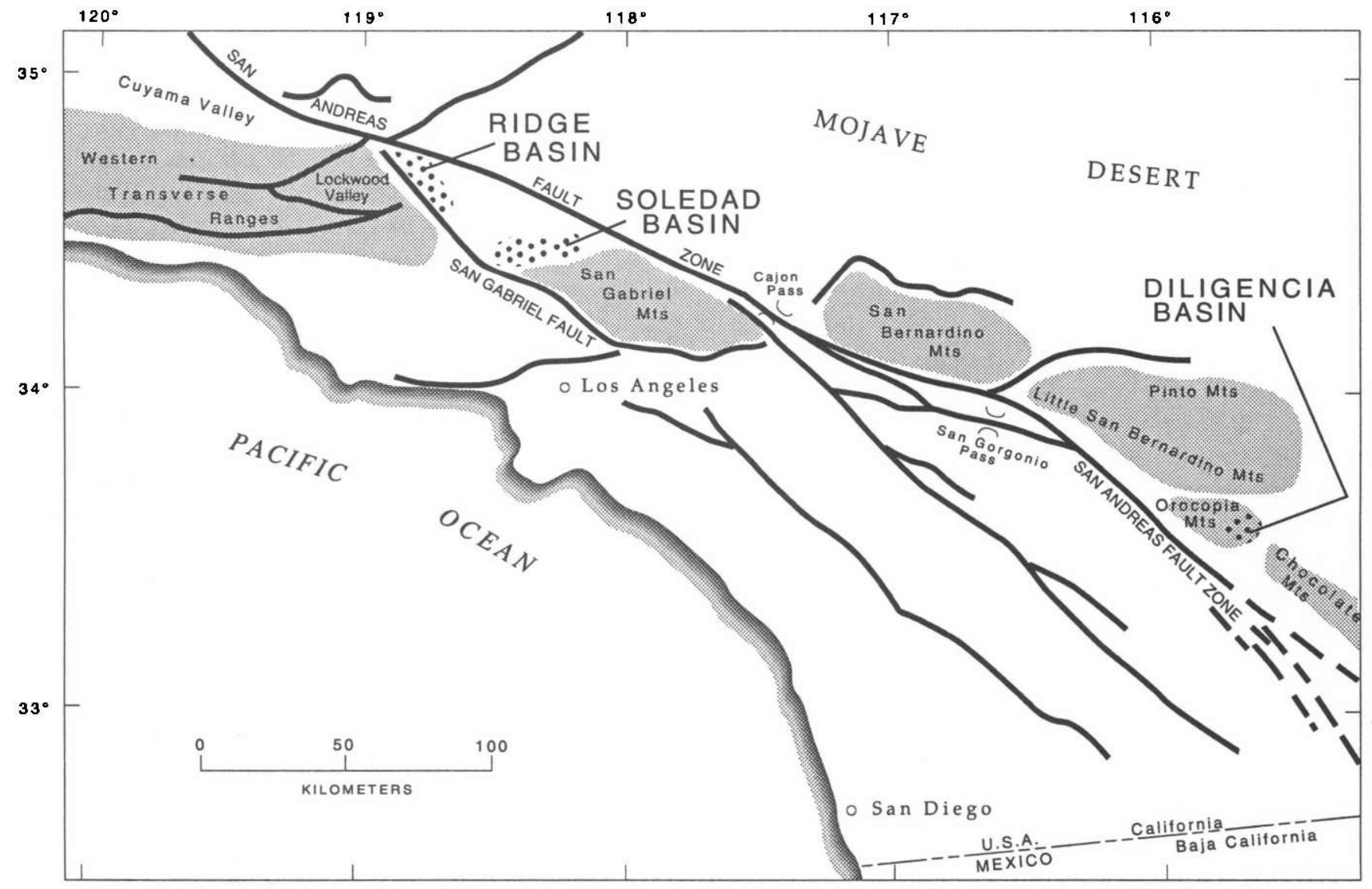

Figure 1. Map showing location of some geologic and geographic features discussed in text. Major faults generalized from Jennings (1977). 
coincidentally at great distance. I therefore have proposed that the two basins were either adjacent or part of a linear chain before displacement on the San Andreas fault (Crowell, 1960, 1962; Crowell and Walker, 1962). Although these correlations and interpretations have been controversial (Spittler and Arthur, 1973), both the stratigraphic correlation and the concept of major right slip of about $250 \mathrm{~km}$ on the main strand of the San Andreas fault zone in southeastern California have been strengthened by subsequent work (Bohannon, 1975; Ehlig and others, 1975; Powell, 1981).

West of the San Gabriel and San Andreas fault zones, in the Lockwood and Cuyama Valley areas, a stratigraphic sequence lithologically similar to the Vasquez Formation of the Soledad basin overlies lithologically similar basement rocks. The two sequences probably are correlative and have been displaced about $70 \mathrm{~km}$ by the San Gabriel fault (Crowell, 1960, 1962; Carman, 1964; Ehlig and others, 1975). The total right slip on the combined San Andreas and San Gabriel faults is therefore about $320 \mathrm{~km}$, an amount nearly equal to that recognized in central California (Stanley, 1987; Graham and others, 1989).

Major strike-slip displacement along the San Andreas fault system began about $12 \mathrm{Ma}$, although some precursor right-slip displacements may already have been underway. The San Gabriel fault scarp first spewed coarse conglomerates from its rising scarp into the oldest part of the Ridge basin sequence at about $12 \mathrm{Ma}$ (Crowell, 1982; Stitt, 1986). Inasmuch as the San Gabriel fault probably joins strands of the San Andreas fault system on the southeast in the Cajon Pass-San Gorgonio Pass region, the combined San Gabriel-San Andreas fault system is also as old as $12 \mathrm{Ma}$.

An age of $12 \mathrm{Ma}$ for the combined San Gabriel-San Andreas fault system also is indicated by reconstruction of the source region for the Mint Canyon Formation and correlative Caliente Formation (Ehlig and others, 1975; Ehlert, 1989), which are the youngest units that have been offset by $320 \mathrm{~km}$. Soledad basin paleocurrent indicators (Ehlig and others, 1975; Hendrix, this volume) suggest a source for these units to the northeast, an area now truncated and displaced by the San Andreas fault. Distinctive volcanic clasts from these units are almost certainly derived from the northern Chocolate and Orocopia Mountains region. The Caliente Formation contains lithologically similar clasts, and paleocurrent data indicate that it represents the westward continuation of Mint Canyon deposits, now offset by the San Gabriel fault. The Caliente Formation extends westward into the Cuyama Valley area and changes from terrigenous to marine facies (Lagoe, 1987; Ehlert, 1989). The Mint Canyon and Caliente Formations thus represent a throughgoing drainage from the Orocopia-Chocolate Mountains region to marine embayments along the Pacific margin, which remained intact until late in Miocene time.
Major right slip and the development of the presentday course of the San Andreas fault system is primarily a Pliocene and Quaternary event. The modern active strand of the San Andreas fault from the central Transverse Ranges to within the Salton Trough is probably no older than about $5 \mathrm{Ma}$ (Crowell, 1982). It truncates beds of this age in the northern part of Ridge basin, and its course along this stretch is viewed as related to the opening of the Gulf of California and coeval tectonic events (Crowell, 1982; Curray and Moore, 1984).

\section{REFERENCES CITED}

Bishop, K.M., and Ehlig, P.L., 1990, The Pelona fault, central Transverse Ranges, southern California: an extensional detachment fault? [abs.]: Geological Society of America Abstracts with Programs, v. 22, no. 3, p. 8.

Bohannon, R.G., 1975, Mid-Tertiary conglomerates and their bearing on Transverse Range tectonics, southern California: California Division of Mines and Geology Special Report 118 , p. $75-82$.

Carman, M.F., Jr., 1964, Geology of the Lockwood Valley area, Kern and Ventura Counties, California: California Division of Mines and Geology Special Report 81, 62 p.

Carter, J.N., Luyendyk, B.P., and Terres, R.R., 1987, Neogene clockwise tectonic rotation of the eastern Transverse Ranges, California, suggested by paleomagnetic vectors: Geological Society of America Bulletin, v. 98, no. 2, p. 199-206.

Clements, Thomas, 1937, Structure of southeastern part of Tejon quadrangle, California: American Association of Petroleum Geologists Bulletin, v. 21, no. 2, p. 212-232.

Cowie, J.W., and Bassett, M.G., 1989, International Union of Geological Sciences, 1989 Global Stratigraphic Char: Episodes, v. 12, no. 2, special insert.

Crowell, J.C., 1960, The San Andreas fault in southern California: Report of 21 st International Geological Congress, pt. 18, p. 45-63.

1962, Displacement along the San Andreas fault, California: Geological Society of America Special Paper 71, 61 p.

-1975, Geologic sketch of the Orocopia Mountains, southeastem California: California Division of Mines and Geology Special Report 118, p. 99-110.

1982, The tectonics of Ridge basin, southern California, in Crowell, J.C., and Link, M.H., eds., Geologic history of Ridge basin, southern California: Los Angeles, Calif., Pacific Section, Society of Economic Paleontologists and Mineralogists, p. $25-42$.

1987, Late Cenozoic basins of onshore southern California, in Ingersoll, R.V., and Ernst, W.G., eds., Cenozoic basin development of coastal California (Rubey Volume 6): Englewood Cliffs, N.J., Prentice-Hall, p. 207-241.

Crowell, J.C., and Link, M.H., eds., 1982, Geologic history of Ridge basin, southern Califomia: Los Angeles, Calif., Pacific Section, Society of Economic Paleontologists and Mineralogists, $304 \mathrm{p}$.

Crowell, J.C., and Walker, J.W.R., 1962, Anorthosite and related rocks along the San Andreas fault, southern California: 
University of California Publications in Geological Sciences, v. 60 , p. $219-288$.

Curray, J.R., and Moore, D.G., 1984, Geologic history of the mouth of the Gulf of California, in Crouch, J.K., and Bachman, S.B., eds., Tectonics and sedimentation along the California margin: Los Angeles, Calif., Pacific Section, Society of Economic Paleontologists and Mineralogists, p. 17-36.

Ehlert, K.W., 1989, Post-Miocene offset of the Mint Canyon and Caliente Formations along the San Andreas and San Gabriel faults, in Baldwin, E.J., Foster, J.H., Lewis, E.L., and Hardy, J.K., eds., San Andreas fault, Cajon Pass to Wallace Creek: Santa Ana, Calif., South Coast Geological Society Guidebook 17, v. 1, p. 151-167.

Ehlig, P.L., Ehlert, K.W., and Crowe, B.M., 1975, Offset of the upper Miocene Caliente and Mint Canyon Formations along the San Gabriel and San Andreas faults: California Division of Mines and Geology Special Report 118, p. 83-92.

Goodmacher, J., Barnett, L., Buckner, G., Ouachrif, L., Vidigal, A., and Frost, E., 1989, The Clemens Well fault in the Orocopia Mountains of southern California: A strike-slip or normal fault structure? [abs.]: Geological Society of America Abstracts with Programs, v. 21, no. 5, p. 85.

Graham, S.A., Stanley, R.G., Brent, J.V., and Carter, J.B., 1989 , Oligocene and Miocene paleogeography of central California and displacement along the San Andreas fault: Geological Society of America Bulletin, v. 101, no. 5, p. 711-730.

Jahns, R.H., 1940, Stratigraphy of the easternmost Ventura basin, California, with a description of a new lower Miocene mammalian fauna from the Tick Canyon Formation: Carnegie Institution of Washington Publication 514, p. 145-194.

Jahns, R.H., and Muehlberger, W.R., 1954, Geology of the Soledad basin, Los Angeles County, California: California Division of Mines and Geology Bulletin 170, v. 2, Map Sheet 6 , scale approximately $1: 85,000$.

Jennings, C.W., 1977, Geologic map of Califomia: California Division of Mines and Geology, Geologic Data Map No. 2, scale 1:500,000.

Jones, D.L., Blake, M.C., Jr., and Rangin, Claude, 1976, Four Jurassic belts of northern California and their significance to the geology of the southern California borderland, in Howell, D.G., ed., Aspects of the geological history of the California continental borderland: Los Angeles, Calif., Pacific Section, American Association of Petroleum Geologists Miscellaneous Publication 24, p. 343-362.

Lagoe, M.B., 1987, Middle Cenozoic basin development, Cuyama basin, California, in Ingersoll, R.V., and Emst, W.G., eds., Cenozoic basin development of coastal California (Rubey Volume 6): Englewood Cliffs, N.J., Prentice-Hall, p. 172-206.

Link, M.H., Squires, R.L., and Colburn, I.P., 1984, Slope and deep-sea fan facies and paleogeography of Upper Creta- ceous Chatsworth Formation, Simi Hills, California: American Association of Petroleum Geologists Bulletin, v. 68, no. 7 , p. 850-873.

Luyendyk, B.P., Kamerling, M.J., Terres, R.R., and Hornafius, J.S., 1985, Simple shear of southern California during Neogene time suggested by paleomagnetic declinations: Joumal of Geophysical Research, v. 90, no. B14, p. 12,454-12,466.

MacFadden, B.J., Swisher, C.C., III, Opdyke, N.D., and Woodburne, M.O., 1990, Paleomagnetism, geochronology, and possible tectonic rotation of the middle Miocene Barstow Formation, Mojave Desert, southern California: Geological Society of America Bulletin, v. 102, no. 4, p. 478-493.

Morris, R.S., 1987, Tertiary basin formation above middle-crustal shear zones in southern Chocolate Mountains, SE California [abs.]: Geological Society of America Abstracts with Progams, v. 19, no. 6, p. 434.

Powell, RE., 1981, Geology of the crystalline basement complex, eastern Transverse Ranges, southern California: constraints on regional tectonic interpretation: Pasadena, Calif., Institute of Technology, Ph.D. dissertation, $441 \mathrm{p}$.

Robinson, Kevin, and Frost, Eric, 1989, Orocopia Mountains detachment system: progressive ductile to brittle development of a tilted crustal slab during regional extension [abs.]: Geological Society of America Abstracts with Programs, v. 21, no. 5 , p. 135.

Spittler, T.E., and Arthur, M.A., 1973, Post-early Miocene displacement along the San Andreas fault in southem California, in Kovach, R.L., and Nur, Amos, eds., Proceedings of the conference on tectonic problems of the San Andreas fault system: Stanford University Publications in Geological Sciences, v. 13, p. 374-382.

Stanley, R.G., 1987, New estimates of displacement along the San Andreas fault in central California based on paleobathymetry and paleogeography: Geology, v. 15 , no. 2, p. 171-174.

Stitt, L.T., 1986, Structural history of the San Gabriel fault and other Neogene structures of the central Transverse Ranges, California, in Ehlig, P.L., compiler, Neotectonics and faulting in southern California: Geological Society of America, Cordilleran Section, 82d, Los Angeles, Calif., March 1986, Guidebook and Volume, Field Trip nos. 10, 12, and 18, p. 43-102.

Tennyson, M.E., 1989, Pretransform early Miocene extension in western California: Geology, v. 17, no. 9, p. 792-796.

Terres, R.R., 1984, Paleomagnetism and tectonics of the central and eastern Transverse Ranges, southern California: Santa Barbara, University of California, Ph.D. dissertation, 323 p.

Terres, R.R., and Luyendyk, B.P., 1985, Neogene tectonic rotation of the San Gabriel region, Califomia, suggested by paleomagnetic vectors: Journal of Geophysical Research, v. 90, no. B14, p. $12,467-12,484$. 


\title{
The Diligencia Formation, Orocopia Mountains, Southeastern Calif.
}

\author{
By John C. Crowell ${ }^{1}$
}

\section{INTRODUCTION}

The uppermost Oligocene and lower Miocene Diligencia Formation, consisting of as much as $2,000 \mathrm{~m}$ of irregularly interbedded nonmarine conglomerate, sandstone, siltstone, limestone, evaporite, and associated volcanic flows and intrusions, crops out in the eastern Orocopia Mountains, Riverside County, California (fig. 1). Described briefly in Crowell $(1960,1962)$, the unit was formally named and a type section designated in Crowell (1975). The formation is well exposed in rugged desert

\footnotetext{
'Institute for Crustal Studies, Department of Geological Sciences, University of Califormia, Santa Barbara, CA 93106

Institute for Crustal Studies Contribution 0052-13CS-21TC
}

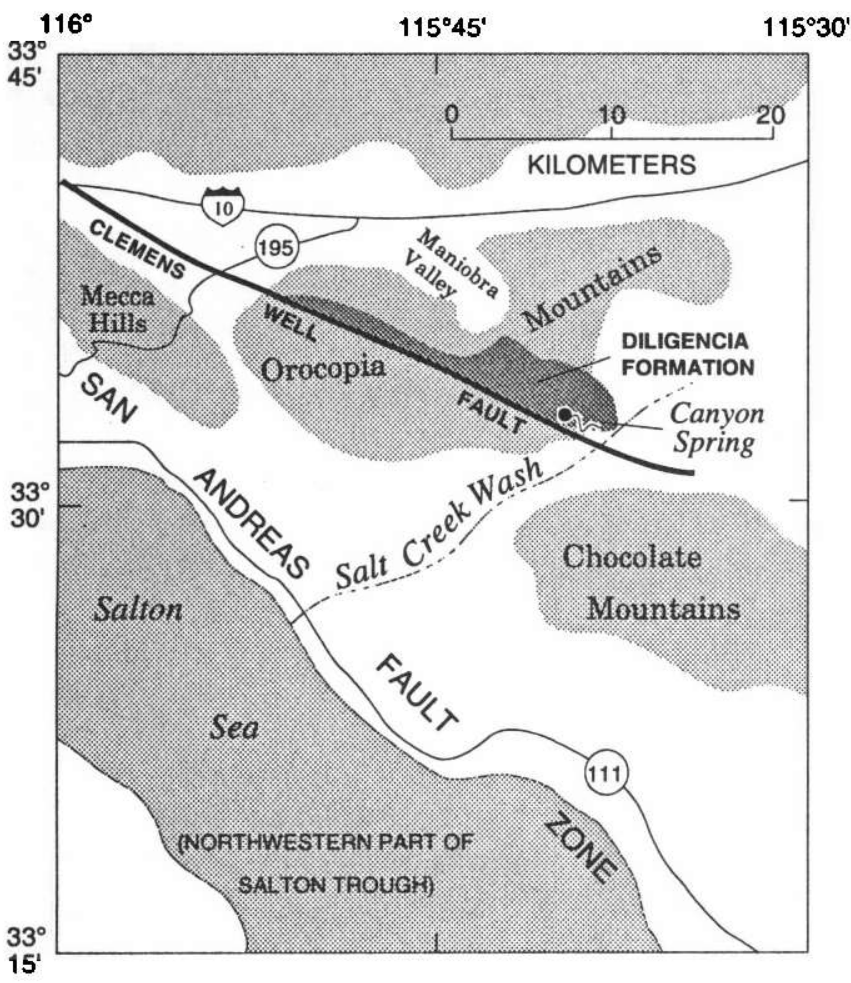

Figure 1. Map showing some geologic and geographic features discussed in text. canyons and on ridges, where steeply dipping, folded and faulted beds display marked lateral changes in facies.

Spittler and Arthur (1982) have published the most complete description of the Diligencia Formation, which is drawn on extensively here. Articles by Bohannon (1975, 1976) and Squires and Advocate (1982) have added much useful information and interpretation. Refer also to Williams (1956), Gillies (1958), Spittler and Arthur (1973), Arthur (1974), and Spittler (1974a) for further discussion of the Diligencia Formation.

My field work and investigations were conducted in 1956 and 1957, assisted by Allan G. Barrows in studying the volcanic rocks and Don E. Wilhelms in interpreting the sedimentary rocks.

\section{REGIONAL SETTING AND TECTONICS}

The rocks of the Diligencia Formation are truncated and limited on the southwest and west by the Clemens Well fault, interpreted as a major branch of the San Andreas fault system (Crowell, 1975; Smith, 1977; but see Goodmacher and others, 1989). On the north, the formation lies unconformably upon strata of the marine Eocene Maniobra Formation (Crowell and Susuki, 1959), which in turn lies unconformably upon Cretaceous and older granitic and gneissic rocks (Crowell, 1962; Crowell and Walker, 1962; Powell, 1982). On the south, near Salt Creek Wash, the Diligencia Formation lies depositionally upon a basement uplift of augen gneiss, migmatite, quartzite, and amphibolite of Proterozoic age (Silver, 1971). The unconformity here is vertical to locally overturned, and on the east the unconformity passes laterally into a steep reverse fault so that at places a few meters of the lowest conglomerate beds have been faulted out during post-middle Miocene northsouth contraction. The augen gneiss beneath the Diligencia Formation is truncated farther south by the Clemens Well fault. Because these basement rocks to the south are different from those exposed to the north, a major buried fault (suture?) is inferred to lie hidden beneath the Diligencia Formation. This hidden fault may truncate and limit the Eocene Maniobra Formation on the south and, therefore, be post-middle Eocene and pre-late Oligocene in age, or it 
may be overlapped by the Eocene beds and be pre-Eocene in age. On the east the formation is overlapped by Quaternary alluvial deposits of Salt Creek Wash, and it has not been recognized farther to the east or southeast.

The Diligencia Formation has been cut by northwesttrending faults and folds (some are markedly compressed near vertical limbs) that are crosscut by northeast-striking faults. The result is a conjugate fault pattern that is conspicuous throughout the region (Powell, 1981). Hinge lines of the folds, which form ideal piercing points where they meet the fault surfaces, are offset by the largest of the northeast-striking faults as much as $1 \mathrm{~km}$ with dominantly left slip (Crowell, 1975). Although some faults on the north may have been active during Diligencia sedimentation (Spittler and Arthur, 1982), most of the deformation is younger than middle Miocene and older than Quaternary in age.

Paleomagnetic data derived from the intercalated volcanic rocks indicate tectonic rotation around near-vertical axes (Terres, 1984; Carter and others, 1987). Inasmuch as the age of the youngest of these flows is $19.1 \pm 1.9 \mathrm{Ma}$ (Crowell, 1973, table 1), the rotations have taken place since that time. Some of the rotation probably occurred during the middle and late Miocene when extensional tectonics predominated in the region, especially in the Mojave and Colorado Deserts to the north and east (this volume); rotations may have occurred during displacement along early or middle Miocene detachment surfaces at depth (Robinson and Frost, 1989). Some of the rotations may have occurred since about $5 \mathrm{Ma}$ in association with major transform movements on the San Andreas fault system and the opening of the Gulf of California. Terres (1984) suggested that they were related to simple shear along the evolving San Andreas fault system, including the Clemens Well fault, because the clockwise rotations increase in magnitude southwestward toward the Clemens Well fault from about $100^{\circ}$ to as much as $170^{\circ}$. It is unclear, however, whether large or small tectonic units were rotated, and additional research is needed to determine the timing of rotation and size and depths of rotated units.

The Diligencia Formation and underlying basement rocks are quite similar lithologically to the Vasquez, Plush Ranch (Carman, 1964), and Simmler Formations and their underlying rocks in the central Transverse Ranges and southern Coast Ranges. This suggests that a chain of similar basins was irregularly aligned across southern California prior to dismemberment and dextral displacement of about $320 \mathrm{~km}$ by the San Andreas fault system (Crowell, 1960, 1962, 1975; Bohannon, 1975).

\section{STRATIGRAPHY AND LITHOLOGY}

The sedimentary and volcanic rocks constituting the Diligencia Formation are subdivided into interfingering mappable lithologic units of differing thickness and lateral extent. No single continuous stratigraphic section is fully representative because of marked facies changes between these units. The beds were laid down within a nonmarine basin bounded by mountains on the north, south, and southwest, as inferred from the organization of alluvial fan facies; also, paleocurrent indicators, which are mainly centripetal, indicate that the basin center migrated irregularly and laterally through time. Coarse-grained deposits, such as conglomerate and sandstone, predominate at the basin margins. Fine-grained clastic deposits and associated limestone and evaporite formed in the central part of the basin, which was occupied by an ephemeral playa lake. The strata have been disrupted by post-early Miocene deformation; as a result, the original eastern and northern extent of deposition is unknown. The uppermost units of the sequence are eroded away.

\section{BASAL CONGLOMERATE}

Conglomerate with interbedded sandstone and siltstone lies unconformably upon a terrane of augen gneiss and related rocks on the south (col. 4-A, pl. 3). Clasts are embedded in a reddish-brown earthy matrix and consist mainly of gneiss derived from underlying metamorphic rocks. Maximum clast size exceeds $2 \mathrm{~m}$ in diameter. On the north, the basal conglomerate lies unconformably upon the Eocene Maniobra Formation and consists primarily of clasts transported from granitic terranes even farther to the north, with only a minor contribution from the Eocene beds. To the northwest, monolithologic breccias composed of granitic clasts intertongue within the unit. The breccias are interpreted as debris flows from nearby rugged topography. The basal conglomerate is the lower part of unit 1 of Spittler and Arthur (1982).

\section{CONGLOMERATE AND ARKOSIC SANDSTONE}

Strata of the basal conglomerate interfinger upward into brown and red sandstone with interbedded siltstone and mudstone. Granitic clasts and feldspar-rich sandstone layers predominate. Some conglomerate lenses on the southwest contain clasts of anorthosite, syenite, and the Lowe Granodiorite of Ehlig (1981) that were apparently derived from a terrane similar to that preserved in the hanging wall of the Orocopia thrust southwest of the Clemens Well fault (Crowell, 1975). No debris derived from the Orocopia Schist, however, has yet been recognized within the Diligencia Formation. These conglomerate and arkosic sandstone beds are included in the middle and lower upper parts of unit 1 of Spittler and Arthur (1982). 


\section{TUFF AND SANDSTONE}

Green and white resistant tuff beds, interbedded with brown sandstone and siltstone layers, underlie volcanic rocks of the Diligencia Formation in the section on the northwest. In the southern part of the outcrop area, these beds are within unit 1 of Spittler and Arthur (1982).

\section{BASALT AND ANDESITE}

Basalt lava flows and slightly younger intrusions of andesite are conspicuous within the Diligencia Formation, especially on the east. More than a dozen distinct basalt flows are intercalated with thin siltstone beds. The siltstone locally contains ostracodes, indicating deposition in a lacustrine or fluvial deltaic environment. The basalt flows, which reach a maximum thickness of $160 \mathrm{~m}$, are mainly massive but some contain amygdules. Andesite crops out as sills, dikes, and irregular bulbous intrusions and load masses, suggesting intrusion into soft sediment near the top of the volcanic sequence. The chemical composition and petrography of the volcanic rocks are described by Spittler and Arthur (1982), who assigned them to their volcanic unit (between units 1 and 2).

\section{EVAPORITE BEDS}

Thin-bedded gypsum, limestone, calcareous siltstone, and minor tufa occupy the central part of the Diligencia basin. Intercalated purple siltstone and mudstone layers carry traces of borates. Gray limestone beds, characterized by jointed and reticulated surfaces, form resistant hogbacks on the northwest. The evaporitic beds and associated rocks are included in unit 2 of Spittler and Arthur (1982).

\section{BRECCIA}

Tongues of monolithologic breccia crop out in the upper parts of the formation, especially on the northwest. The breccia exhibits a mosaic structure in which angular fragments as much as $1 \mathrm{~m}$ across interlock with very little matrix. In places these mosaic rocks are massive and easily confused with shattered, in-place basement, but they are mainly interbedded with brown sandstone. The breccia lenses are interpreted as debris flows deposited in an alluvial environment or as landslides from nearby steep slopes.

\section{UPPER SANDSTONE AND SHALE}

On the northwest, bedded brown and gray sandstone, shale, and mudstone are interbedded with lenses of mono- lithologic mosaic breccia and minor beds of gray limestone. Paleocurrent structures abound, such as small-scale cross-stratification and ripple marks. These strata, including breccia lenses, are included in units 3 and 4 of Spittler and Arthur (1982).

\section{AGE}

The age of the Diligencia Formation is latest Oligocene and early Miocene on the basis of $\mathrm{K}$-Ar ages from basalt flows and an Oreodont jawbone recovered a short distance stratigraphically above the basalt. The volcanic flows, collected north of Canyon Spring in the eastem part of the outcrop area, give K-Ar ages of $23.0 \pm 2.9$,

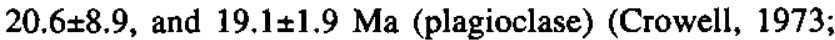
Spittler, 1974b). All ages are recalculated using modern decay constants. The extremes of the confidence limits (25.9, 29.5, and $21.0 \mathrm{Ma}$, respectively) range down into the Oligocene, which is widely accepted as ending at $23 \mathrm{Ma}$ (Cowie and Bassett, 1989). The jawbone (Merychyus sp. cf. $M$. calaminthus, Jahns), described by Woodburne and Whistier (1973), is "of late Arikareean or less possibly, early Hemingfordian age." The volcanic rocks and the fossil come from the middle part of the Diligencia Formation, so the lowest part of the formation may include Oligocene beds. Other rare fossils, such as ostracodes and fish remains and a fragment from a camel jaw (Squires and Advocate, 1982), have not yet been useful in dating.

\section{REFERENCES CITED}

Arthur, M.A., 1974, Stratigraphy and sedimentation of lower Miocene nonmarine strata of the Orocopia Mountains: constraints for late Tertiary slip on the San Andreas fault system in southern California: Riverside, University of California, M.S. thesis, $200 \mathrm{p}$.

Bohannon, R.G., 1975, Mid-Tertiary conglomerates and their bearing on Transverse Range tectonics, southern California: California Division of Mines and Geology Special Report 118, p. 75-82.

-1976, Mid-Tertiary nonmarine rocks along the San Andreas fault in southern California: Santa Barbara, University of California, Ph.D. dissertation, $311 \mathrm{p}$.

Carman, M.F., Jr., 1964, Geology of the Lockwood Valley area, Kern and Ventura Counties, California: California Division of Mines and Geology Special Report 81, 62 p.

Carter, J.N., Luyendyk, B.P., and Terres, R.R., 1987, Neogene clockwise tectonic rotation of the eastern Transverse Ranges, California, suggested by paleomagnetic vectors: Geological Society of America Bulletin, v. 98, no. 2, p. 199-206.

Cowie, J.W., and Bassett, M.G., 1989, International Union of Geological Sciences, 1989 Global Stratigraphic Chart: Episodes, v. 12 , no. 2 , special insert. 
Crowell, J.C., 1960, The San Andreas fault in southern California: Report of 21 st International Geological Congress, Part 18 , p. 45-63.

1962, Displacement along the San Andreas fault, California: Geological Society of America Special Paper 71, 61 p.

1973, Problems concerning the San Andreas fault system in southern California, in Kovach, R.L., and Nur, Amos, eds., Proceedings of the conference on tectonic problems of the San Andreas fault system: Stanford University Publications in the Geological Sciences, v. 13, p. 125-135.

1975, Geologic sketch of the Orocopia Mountains, southeastern California: California Division of Mines and Geology Special Report 118, p. 99-110.

Crowell, J.C., and Susuki, Takeo, 1959, Eocene stratigraphy and paleontology, Orocopia Mountains, southeastern California: Geological Society of America Bulletin, v. 70, no. 5, p. 581592.

Crowell, J.C., and Walker, J.W.R., 1962, Anorthosite and related rocks along the San Andreas fault, southem California: University of California Publications in Geological Sciences, v. 40 , p. $219-288$.

Ehlig, P.L., 1981, Origin and tectonic history of the basement terrane of the San Gabriel Mountains, central Transverse Ranges, in Ernst, W.G., ed., The geotectonic development of California (Rubey Volume 1): Englewood Cliffs, N.J., Prentice-Hall, p. 253-283.

Gillies, William, 1958, Geology of a portion of Cottonwood Springs quadrangle, Riverside County, California: Los Angeles, University of California, M.A. thesis, 70 p.

Goodmacher, J., Barnett, L., Buckner, G., Ouachrif, L., Vidigal, A., and Frost, E., 1989, The Clemens Well fault in the Orocopia Mountains of southem California: A strike-slip or normal fault structure? [abs.]: Geological Society of America Abstracts with Programs, v. 21, no. 5, p. 85.

Powell, R.E., 1981, Geology of the crystalline basement complex, eastern Transverse Ranges, southern California: constraints on regional tectonic interpretation: Pasadena, Califomia Institute of Technology, Ph.D. dissertation, 441 p.

1982, Crystalline basement terranes in the southem eastem Transverse Ranges, California, in Cooper, J.D., compiler, Geologic excursions in the Transverse Ranges, southern California: Geological Society of America, Cordilleran Section, 78th, Anaheim, Calif., April 1982, Volume and Guidebook, Field Trip nos. 2, 7, and 13, p. 109-151.

Robinson, Kevin, and Frost, Eric, 1989, Orocopia Mountains detachment system: Progressive ductile to brittle development of a tilted crustal slab during regional extension [abs.]: Geological Society of America Abstracts with Programs, v. 21, no. 5 , p. 135.

Silver, L.T., 1971, Problems of crystalline rocks of the Transverse Ranges [abs.]: Geological Society of America Abstracts with Programs, v. 3, no. 2, p. 193-194.

Smith, D.P., 1977, San Juan-St. Francis fault-hypothesized middle Tertiary right-lateral fault in central and southern California: California Division of Mines and Geology Special Report 129, p. 41-50.

Spittler, T.E., 1974a, Volcanic petrology and stratigraphy of nonmarine strata, Orocopia Mountains; their bearing on Neogene slip on the San Andreas fault, southem California: Riverside, University of California, M.S. thesis, 115 p.

$-1974 b$, Tertiary basaltic volcanism of the Orocopia Mountains, California [abs.]: Geological Society of America Abstracts with Programs, v. 6, no. 3, p. 260.

Spittler, T.E., and Arthur, M.A., 1973, Post-early Miocene displacement along the San Andreas fault in southern California, in Kovach, R.L., and Nur, Amos, eds., Proceedings of the Conference on tectonic problems of the San Andreas fault system: Stanford University Publications in Geological Sciences, v. 13 , p. $374-382$.

1982. The lower Miocene Diligencia Formation of the Orocopia Mountains, southern California, in Ingersoll, R.V., and Woodburne, M.O., eds., Cenozoic nonmarine deposits of California and Arizona: Los Angeles, Calif., Pacific Section, Society of Economic Paleontologists and Mineralogists, p. 83-100.

Squires, R.L., and Advocate, D.M., 1982, Sedimentary facies of the nonmarine lower Miocene Diligencia Formation, Canyon Spring area, Orocopia Mountains, southern California, in Ingersoll, R.V., and Woodburne, M.O., eds., Cenozoic nonmarine deposits of California and Arizona: Los Angeles, Calif., Pacific Section, Society of Economic Paleontologists and Mineralogists, p. 101-106.

Terres, R.R., 1984, Paleomagnetism and tectonics of the central and eastern Transverse Ranges, southern California: Santa Barbara, University of California, Ph.D. dissertation, 323 p.

Williams, J.J., 1956, Geology of part of the Orocopia Mountains, Riverside County, California: Los Angeles, University of California, M.A. thesis, 44 p.

Woodburne, M.O., and Whistler, D.P., 1973, An early Miocene oreodont (Merychyinae, Mammalia) from the Orocopia Mountains, southern California: Journal of Paleontology, v. 47 , no. 5 , p. $908-912$. 


\title{
Soledad Basin, Central Transverse Ranges, Calif.
}

\author{
By Eric D. Hendrix ${ }^{1}$
}

\section{INTRODUCTION}

The Soledad basin of Bailey and Jahns (1954) lies within the central Transverse Ranges. It is geographically and structurally bounded by the western San Gabriel Mountains crystalline basement on the south, the Liebre Mountain crystalline basement and Ridge basin to the north, the San Andreas fault zone to the east, and the San

\footnotetext{
'Department of Earth \& Space Sciences, University of Califomia, Los Angeles, CA 90024, and Applied Environmental Services Inc., 23113 Plaza Pointe Drive, Suite 100, Laguna Hills, CA 92653
}

Gabriel fault zone to the west (fig. 1). San Gabriel crystalline basement that contributed clastic material to Soledad basin sedimentary rocks includes the Proterozoic granulite-grade Mendenhall Gneiss of Oakeshott (1958) and lithologically equivalent units, a Proterozoic layered intrusion of anorthosite, syenite, and gabbro and their amphibolite-grade equivalents, the Early Triassic Lowe Granodiorite of Ehlig (1981), and mid- to Late Cretaceous granitic plutons. Stratigraphic units of the Soledad basin, from oldest to youngest, are the Vasquez Formation, Tick Canyon Formation of Jahns (1940), and Mint Canyon Formation (col. 4-B, pl. 3). The deposition of

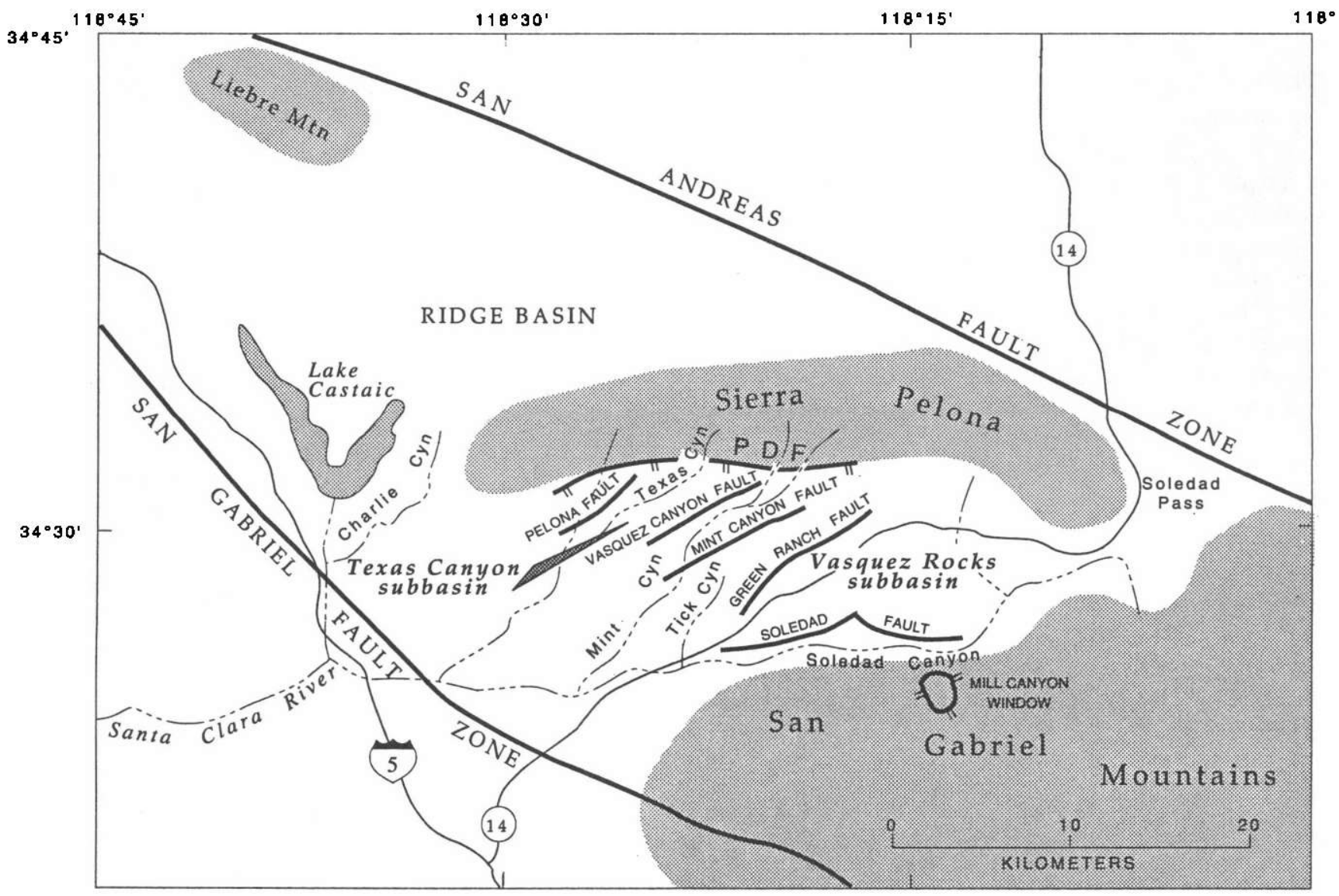

Figure 1. Map showing location of some geographic and geologic features named in text. Hachured lines are detachment faults, hachures on downdropped side; other faults are high angle. Soledad basin encompasses area between Soledad fault and Pelona detachment fault. PDF, Pelona detachment fault, is distinct from previously named high-angle Pelona fault (see text). 
these three nonmarine units spans a period of roughly 16 million years between 26 and $10 \mathrm{Ma}$. For the sake of brevity, stratigraphic data and sedimentologic interpretations are discussed together for each unit.

Best-fit palinspastic corrections for $240 \mathrm{~km}$ of Neogene San Andreas fault displacement (Crowell, 1975; this volume; Powell, 1981) place the Soledad basin immediately southwest of the Orocopia Mountains region during its inception in the latest Oligocene (approximately $26 \mathrm{Ma}$ ). Thus, it originally lay within the southwestern part of the middle Tertiary highly extended terrane. Recently, detachment faulting characteristic of other segments of the highly extended terrane has been interpreted in the Soledad basin (Bishop, 1989). Bishop and Ehlig (1990) used the name "Pelona detachment fault" for the primary detachment fault of the basin, but this name creates confusion with the previously named, geographically distinct Pelona fault (fig. 1; Muehlberger, 1958), which I interpret as a high-angle listric fault within the upper plate of the primary detachment fault. The Pelona detachment fault is interpreted as having exerted a primary control over Soledad basin evolution, in general, and Vasquez Formation sedimentation in particular.

\section{VASQUEZ FORMATION}

Representing both the earliest and thickest sedimentary accumulation within the Soledad basin, the Vasquez Formation is exposed within three geographically separate, fault-bounded subbasins (Jahns and Muehlberger, 1954; Muehlberger, 1958). Only the southern two subbasins (Vasquez Rocks and Texas Canyon subbasins) are discussed herein (Hendrix and Ingersoll, 1987; Hendrix, 1989). The northernmost subbasin (Charlie Canyon subbasin) is sedimentologically unique because it lacks (1) distinctive alluvial megacycles that can be correlated between the other two subbasins, (2) sedimentologic evidence of paleodrainage with the other two subbasins, and (3) the distinctive sedimentologic evolution observed in the other two subbasins. Owing to this uniqueness, the northern structural margin of the Soledad basin proper is considered herein to be the Pelona detachment fault of Bishop and Ehlig (1990) and the Sierra Pelona, a prominent ridge that exposes an antiform composed of the Pelona Schist immediately north of the Texas Canyon subbasin. Lithostratigraphic correlations have been established previously between the Vasquez Rocks and Texas Canyon subbasins (Hendrix and Ingersoll, 1987).

The Vasquez Formation in the Vasquez Rocks subbasin is as thick as $5,500 \mathrm{~m}$ and is depositional upon and faulted against crystalline basement along the Soledad and Mint Canyon faults (fig. 1). In the Texas Canyon subbasin the formation is slightly more than $4,000 \mathrm{~m}$ thick. As illustrated on the composite time-stratigraphic column (col
4-B, pl. 3), rocks in the Vasquez Rocks subbasin (col. 4-B, left side) are divided into four informal units (basal, volcanic, megacyclic, and upper units), whereas rocks in the Texas Canyon subbasin (col. 4-B, right side) are divided into three units (megacyclic, middle, and upper units).

\section{BASAL UNIT}

The lowest part of the Vasquez Formation, recognized only in the Vasquez Rocks subbasin, consists of coarse, clay-rich, matrix-supported breccia interpreted as debris flow deposits on small alluvial fans, with associated minor conglomeratic sandstone and limestone in the northeastern part of the subbasin. Sparse paleocurrent data suggest that sediment transport was toward the northeast, whereas the highly variable clast suites along strike imply a provenance of multiple local source areas (Hendrix and Ingersoll, 1987). The basal unit is nonconformable on crystalline basement and highly variable in thickness (range $0-330 \mathrm{~m}$ ). It exhibits general thickening toward the northwest, yet it lacks observable significant lithofacies variation either vertically or along strike. The absence of recognized fault-related sedimentologic variation suggests that the differences in outcrop thickness are the result of either infilling of original topography by small alluvial fans or deposition in small, fault-controlled basins. The facies and thickness variations along strike, coupled with the varied clast composition, indicate that the Soledad fault to the south was not yet active as the key upperplate structure controlling the geometry and depositional systems of this subbasin.

\section{VOLCANIC UNIT}

The volcanic unit is recognized only in the Vasquez Rocks subbasin and consists of subalkaline and calc-alkaline basaltic andesite and dacite lava flows and sills (Weigand, 1982). The unit thins northwest along strike from a maximum of 1,300 meters near the Soledad fault to a minimum of 400 meters in the Tick Canyon block (between the Mint Canyon and Green Ranch faults, fig. 1). Dacitic and rhyodacitic flows associated with basaltic andesite are also found in the Soledad Pass area $20 \mathrm{~km}$ east of the Vasquez Rocks subbasin (Weigand, 1982), as are volcanic domes, radial dikes and abundant volcanic breccia, features suggesting proximity to a volcanic center (Buesch and Ehlig, 1982; D.A. Buesch, oral commun., 1990).

Interstratified conglomerate and sandstone are found in the volcanic unit within the Vasquez Rocks subbasin proper but are absent from the eastern volcanic zone of the Soledad Pass area, implying a topographically positive volcanic edifice east of the principal subbasin. These interstratified epiclastic rocks reflect a homogeneous 
southern plutonic provenance, and they coarsen and thicken abruptly and uniformly southward toward the Soledad fault (fig. 1). These relationships contrast sharply with relationships observed in the basal unit and indicate that displacements on the Soledad fault and development of half-graben subbasin geometry began during volcanism (Hendrix and Ingersoll, 1987). Sedimentologic variations in the overlying megacyclic unit document the control exerted by this fault over subsequent basin evolution.

Potassium-argon ages from flows within this unit constrain the maximum age of Soledad basin inception and initial extension. Published ages are $24.9 \pm 2.1 \mathrm{Ma}$ and $23.9 \pm 0.8 \mathrm{Ma}$ (plagioclase) (Crowell, 1973) and 24.9 \pm 2.0 Ma (whole rock) (Weigand and Frizzell, 1986; V.A. Frizzell, written commun., 1986).

\section{MEGACYCLIC UNIT}

The megacyclic unit is recognized within both subbasins and comprises four allocyclic, upward-fining and upward-thinning alluvial megasequences. The megasequences were generated by prograding alluvial fans in response to episodes of displacement along the Soledad, Vasquez Canyon, and (high-angle) Pelona faults. They consist of breccia, conglomerate, sandstone, and mudstone; one megacycle contains air-fall tuff. In the Vasquez Rocks subbasin, the basal part of the unit interfingers with the uppermost part of the volcanic unit in the Vasquez Rocks subbasin, but along the eastern margin of the Texas Canyon subbasin it is faulted against retrograded mylonitic schist along a poorly exposed, low-angle normal fault (Pelona detachment fault) (Bishop, 1989). This unit attains a maximum thickness of $2,300 \mathrm{~m}$ adjacent to the Soledad fault in the Vasquez Rocks subbasin and $1,600 \mathrm{~m}$ in the Texas Canyon subbasin.

Provenance data imply that the two subbasins were structurally isolated from one another during deposition of the megacyclic unit. Paleocurrent data, conglomerate clast compositions, and facies architecture suggest that sediment was transported northward across the active Soledad fault into the Vasquez Rocks subbasin from a source area composed of the Early Triassic Lowe Granodiorite. In the Texas Canyon subbasin, gneissic and granitic clasts were transported westward with volcanic clasts derived from the Soledad Pass area. Sediment also was derived from a northerly source of granite and quartz monzonite across the active, high-angle Pelona fault (Hendrix and Ingersoll, 1987; fig. 1). Small, segmented, debris-flow- and sheetflood-dominated alluvial fans formed in response to a period of rapid fault-controlled subsidence in both subbasins, as interpreted from thickness trends, conglomerate petrofacies, and facies architecture (Hendrix and Ingersoll, in press). Typical alluvial channel-fill sequences (for example, Bull, 1977) and evi- dence for bedform migration (for example, cross-stratification) are rare. Facies and thickness trends indicate that the Vasquez Rocks subbasin formed as a half-graben with maximum subsidence along the Soledad fault, whereas the Texas Canyon subbasin formed as an asymmetric graben with maximum subsidence along its north (highangle Pelona fault) margin and subordinate subsidence along its south (Vasquez Canyon fault) margin (fig. 1). Thickness variations within stratigraphic markers, ephemeral-lacustrine lithofacies at a distal basinal position relative to the locus of maximum subsidence (Soledad fault), and an areally limited basaltic andesite flow in the Tick Canyon area of the Vasquez Rocks subbasin suggest that synsedimentary normal faulting along the Lang or Green Ranch faults occurred at a minor volcanic center in this area (Hendrix and Ingersoll, in press).

Although unfossiliferous, lithogenetic units as distinct as the tectonically generated, upward-fining alluvial sequences of the megacyclic unit were used to correlate between the otherwise physically separate Vasquez Rocks and Texas Canyon subbasins. This correlation is strengthened by the presence of distinctive Vasquez volcanic clasts in the megacyclic unit of the Texas Canyon subbasin. The clasts were derived from the Soledad Pass volcanic center to the east. Although the two subbasins were physically separate at this time, the simultaneous generation of progradational fan megasequences by faulting imply that the causative high-angle faults were somehow linked, presumably along the underlying Pelona detachment fault.

\section{MIDDLE UNIT}

A distinctive 250-m-thick sequence of breccia and sandstone defines the middle unit of the Vasquez Formation in the Texas Canyon subbasin. Its presence indicates a period of intensified activity along the Pelona (highangle) fault or perhaps decreased activity along the Vasquez Canyon fault. Stratigraphically correlative strata in the Vasquez Rocks subbasin occur in the uppermost part of the megacyclic unit and record a period of fan retrogradation and diminished relief along the Soledad fault. The middle unit and correlative strata may reflect an important episode of structural adjustment throughout the Soledad basin prior to deposition of the upper unit.

\section{UPPER UNIT}

The upper unit is characterized in both subbasins by drab-colored conglomerate and minor sandstone, which show increased textural maturity relative to underlying strata. Diagnostic sedimentary structures include well-developed clast imbrications, scour-and-fill, and normal grading, although massive bedding is equally common. The upper 
unit attains thicknesses of $1,600 \mathrm{~m}$ and $2,150 \mathrm{~m}$ in Vasquez Rocks and Texas Canyon subbasins, respectively.

The two subbasins coalesced and became integrated during deposition of this unit. Integration is documented in the Texas Canyon subbasin by the appearance of plutonic clasts that could only have been transported from a southern source in the San Gabriel Mountains. Integration probably was accomplished through erosion and partial overtopping of Mint Canyon ridge, a structural barrier of plutonic rocks (between the Vasquez Canyon and Mint Canyon faults, fig. 2) that had separated the two subbasins during deposition of the megacyclic unit (Hendrix and Ingersoll, 1987). The integration of subbasin depositional systems and the lateral uniformity of alluvial lithofacies and conglomerate sheets suggests evolution to a broad fan system, in marked contrast to the abrupt lithofacies variations of the underlying megacyclic unit. The change from localized, wedge-shaped alluvial fans to more extensive, broad fan systems has been interpreted in other basins as evidence of decreased subsidence rate (Paola, 1988; Blair and Bilodeau, 1988). Conglomerate sedimentology suggests accumulation as primarily hyperconcentrated traction deposits and more dilute streamflood deposits, in contrast to the mass flow and sheetflood deposits of the megacyclic units.

The characteristics of the upper unit of the Vasquez Formation may signal a decrease in basinal (fault-related) subsidence rate and an enlargement of the drainage basin and alluvial depositional system during progressive extension of the Soledad basin (Hendrix and Ingersoll, 1987; in press). Larger drainage basins characteristically yield lower sediment input per each event of flood discharge reaching the fan environment (for example, Hooke, 1968; Wells and Harvey, 1987). An enlarged drainage basin and concomitant increase in sediment transport distance are additionally suggested by an increasing number of subrounded to subangular clasts within the upper unit of both subbasins, in contrast to the ubiquitous angularity of clasts within the underlying megacyclic unit.

\section{TICK CANYON FORMATION}

The 300-m-thick Tick Canyon Formation of Jahns (1940) overlies the Vasquez Formation with angular discordance ranging from $30^{\circ}$ to $90^{\circ}$. The Tick Canyon Formation thins rapidly to the north-northwest along strike, eventually lapping out across plutonic rocks of Mint Canyon ridge and the southwestern corner of the Texas Canyon subbasin (Muehlberger, 1958). The subjacent unconformity cuts downsection northward and removes a significant part of the Vasquez Formation.

The Tick Canyon Formation consists of a basal volcaniclastic breccia in its southern exposures and a gneissand granite-clast breccia in its northern exposures. The southern exposures appear to occupy an east-trending, large paleochannel incised into the Vasquez Formation along the south side of the Green Ranch fault. The basal breccias fine upsection into a sequence of conglomerate, reddish to gray mudstone, and sandstone that are interpreted as fluviolacustrine deposits (Ehlert, 1982). Clast imbrications and b-axis alignments from the basal breccias suggest local derivation from the north or northeast (E.D. Hendrix, unpub. data, 1988), whereas conglomerates higher in the section suggest paleoflow from the east and northeast (Ehlert, 1982). Volcanic clasts in the basal conglomerate of the Tick Canyon Formation lithologically resemble reworked volcanic rocks of the Vasquez Formation, although a small percentage of the clasts are volcanic rocks unknown in the Soledad basin area but possibly derived from the northem Chocolate Mountains east of the San Andreas fault zone. The Tick Canyon Formation is the oldest unit in Soledad basin that contains clasts of the Pelona Schist, specifically cataclastic and greenschist-grade varieties that were derived from uplift of Sierra Pelona, northeast of Texas Canyon subbasin (Ehlert, 1982). Clasts of cataclastic and mylonitic rocks derived from the Pelona Schist decrease upsection as clasts of muscovite-albite schist increase, probably in response to erosional unroofing and exposure of the Pelona detachment fault.

A controversial vertebrate assemblage from the Tick Canyon Formation constrains the minimum age of the unconformably underlying Vasquez Formation and its preTick Canyon deformation. Originally interpreted as late Arikareean in age (21 to $20 \mathrm{Ma}$ ) (Jahns, 1940; Woodburne, 1975), oreodont fossils from the Tick Canyon Formation are now considered to represent a dwarfed variety of a species whose stratigraphic range extends into the lower part of the Hemingfordian (land mammal) Stage (Lander, 1985) and perhaps is as young as 19 or $18 \mathrm{Ma}$. This younger age assignment would permit more time, perhaps as much as $2 \mathrm{~m}$.y. or more, in which to deform and erode the Vasquez Formation prior to Tick Canyon time, thus avoiding temporal conflicts introduced by the older age determinations (Woodbume, 1975; Ehlert, 1982).

\section{MINT CANYON FORMATION}

The Mint Canyon Formation is exposed over a much greater region than the Tick Canyon Formation. It comprises between 1,300 and 1,800 meters of fluvial and lacustrine sedimentary rocks (Muehlberger, 1958; Ehlert, 1982). On the stratigraphic column (col. 4-B, pl. 3) these rocks are divided into a lower, gray-brown conglomeratic sandstone unit of braided fluvial origin and an upper sandstone, siltstone, and limestone unit of fluviodeltaic and fluviolacustrine origin (Ehlert, 1982; Saul and Wooton, 1983). Paleocurrent data suggest a large, well-integrated, 


\section{A. About $24 \mathrm{Ma}$, initial deposition of megacylic unit of Vasquez Formation}

Early Vasquez sedimentation in nonintegrated subbasins via debris-flow and sheetflood processes on small, segmented alluvial fans; subsidence rate is greater than sedimentation rate

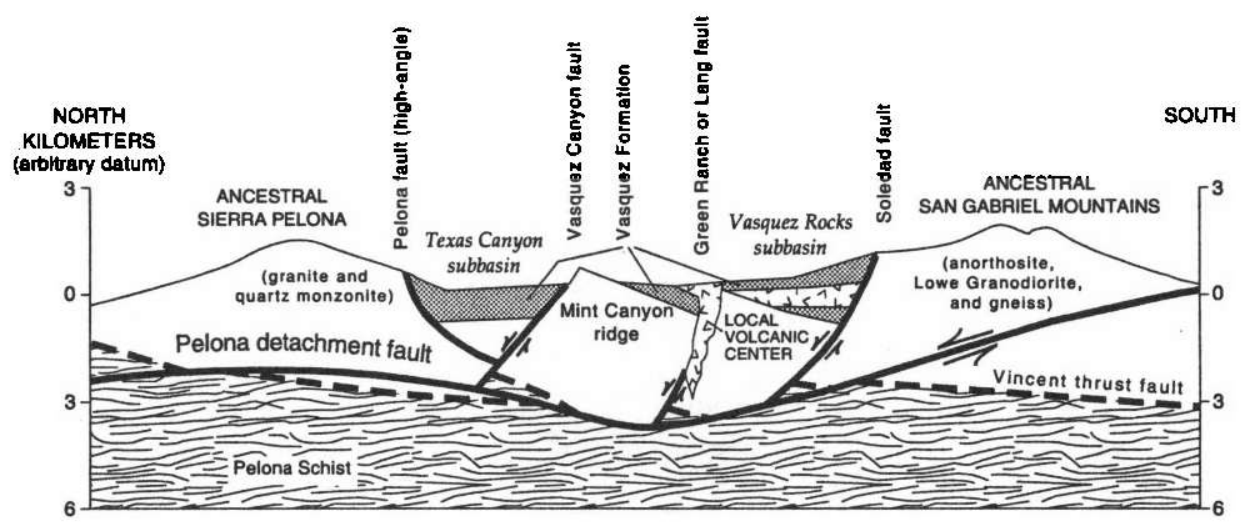

\section{B. About $21 \mathrm{Ma}$, deposition of upper unit of Vasquez Formation}

Decrease In basin subsidence rate as detachment lower plate rebounds. Sedimentation on broad alluvial fans via hyperconcentrated flood and streamflood processes within enlarged integrated subbasins

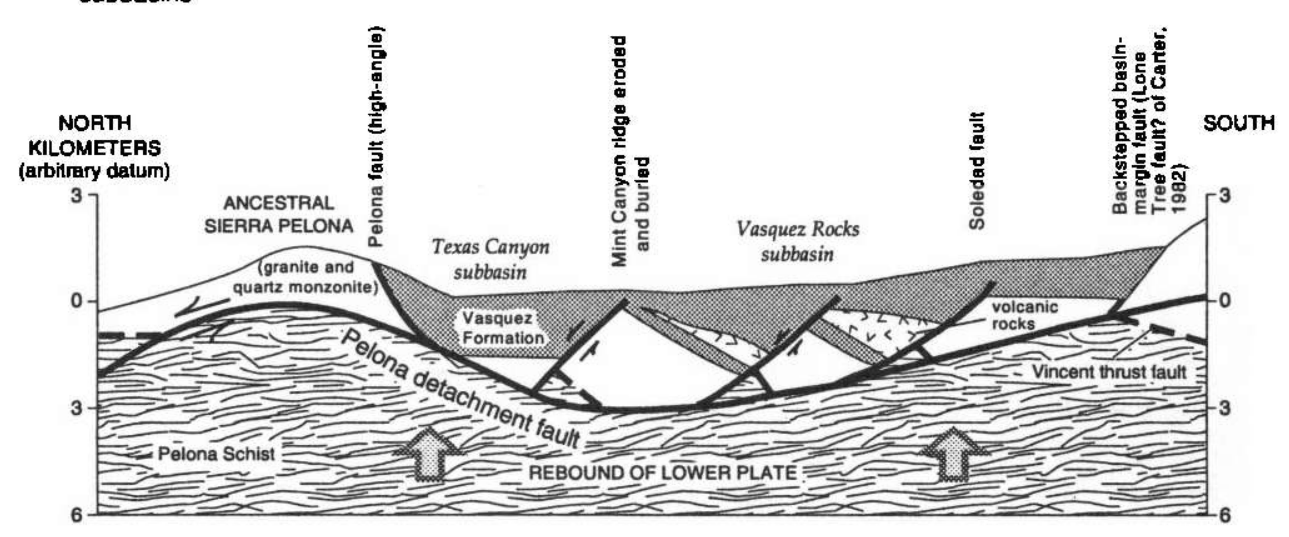

C. About $18 \mathrm{Ma}$, end of crustal extension

Flexural deformation of Vasquez Formation, growth of angular unconformity, and deposition of Tick Canyon Formation, development of angular unconformity, and deposition of Tick Caryon Formation during final stages of lower-plate rebound

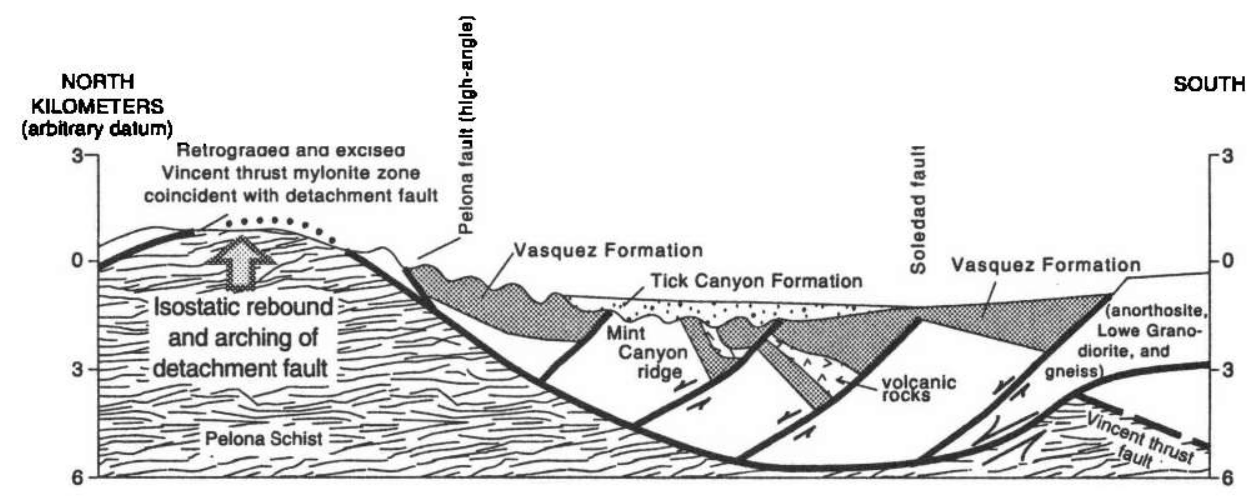

Figure 2. Schematic cross sections showing phases in structural and stratigraphic evolution of Soledad basin from about $24(A)$ to $18 \mathrm{Ma}(C)$. Between these phases, detachment lower plate is structurally denuded, leading to isostatic rebound, which profoundly affects sedimentation in upperplate alluvial basins. Vincent thrust fault shown dashed; low- and high-angle normal faults shown solid. Arrows show relative direction of movement. 
west-flowing fluvial system, and provenance data indicate that distinctive quartz latite porphyry and other volcanic and plutonic rocks from the northern Chocolate Mountains were eroded to supply sediment to this system. Clasts of pre-Tertiary plutonic and metamorphic rocks were also locally derived from the Soledad basin area. Clasts of the Pelona Schist, particularly muscovite-albite greenschist, increase in abundance upsection in the Mint Canyon Formation and are in greater abundance than in the underlying Tick Canyon Formation. Northwest of the Texas Canyon subbasin, a conglomerate (San Francisquito Canyon breccia unit of Sams, 1964) consisting exclusively of clasts derived from the Pelona Schist interfingers with the lower, braided fluvial unit of the Mint Canyon Formation. Textural maturity increases noticeably upsection between the Tick Canyon and Mint Canyon Formations.

Vertebrate assemblages within the lower, conglomeratic sandstone unit of the Mint Canyon Formation are early to middle Barstovian (middle Miocene) in age, but the lowermost part of the Mint Canyon Formation may be as old as late Hemingfordian (late early Miocene) (Durham and others, 1954; Woodburne, 1975; E.B. Lander, oral commun., 1987). Vertebrates from the upper fluviodeltaic and fluviolacustrine unit indicate a late Barstovian to early Clarendonian (late middle Miocene to late Miocene) landmammal age (Woodburne, 1975; Saul and Wooton, 1983); these ages are corroborated by a fission-track age of $10.8 \pm 0.5 \mathrm{Ma}$ (zircon) from air-fall tuff in the upper unit (Terres, 1984).

On the basis of vertebrate age assessments then in use, Jahns (1940) interpreted the contact between the Mint Canyon and underlying Tick Canyon Formations as a disconformity. The new data suggest that the two formations are much closer in age than originally believed, a conclusion consistent with conformable contacts observed by Ehlert (1982).

\section{BASIN EVOLUTION AND STRUCTURAL IMPLICATIONS}

The best evidence for kinematic association of Soledad basin evolution with detachment faulting is preserved on the northeastern margin of the Texas Canyon subbasin, where the base of the megacyclic unit of the Vasquez Formation is truncated by a fault zone defined by a 10-m-thick chloritic mylonite lying structurally above the Pelona Schist, although clasts of the Pelona Schist are absent in the overlying Vasquez Formation (Hendrix and Ingersoll, 1987; Bishop and Ehlig, 1990). The fault zone dips between $20^{\circ}$ and $45^{\circ}$ south-southwest in its present configuration and represents, at least in part, a middle Tertiary detachment fault that has excised at least $1,000 \mathrm{~m}$ of thrust-zone rocks of the Paleocene Vincent thrust fault (Ehlig, 1981; Evans, 1982). The detachment is also proba- bly exposed within the Mill Canyon window in the western San Gabriel Mountains south of the Soledad fault (fig. 1), where strongly L-tectonized, mylonitic Mesozoic granodiorite and Proterozoic(?) gneiss are in low-angle (detachment?) fault contact over brittlely sheared anorthositic rocks; both of these rock types are also commonly found in the Vincent thrust hanging wall (Ehlig, 1981; Carter, 1982). When compared to the Mill Canyon window, the structural position of the detachment fault within the Texas Canyon area suggests that the detachment fault originally extended northward to a lower structural horizon, penetrating the Pelona Schist of the original Vincent thrust footwall (fig. $2 A$ ). Similar structural localization and crosscutting relationships between Paleocene thrust and middle Tertiary detachment faults are observed in offset Soledad basin equivalents in the Orocopia Mountains (Robinson and Frost, 1989; Crowell, this volume). This structural geometry, and the antithetic sense of rotation of the upperplate block of the Vasquez Rocks subbasin, implies northward transport of the detachment's upper plate (fig. $2 A$ ). In the model proposed here, the Soledad, Green Ranch, Vasquez Canyon, and (high-angle) Pelona faults were high-angle, listric upper-plate structures which flattened into and were linked by the Pelona detachment fault.

Isostatic uplift and rebound of the detachment footwall beneath the extended upper plate (for example, Spencer, 1984; Howard and John, 1987; Davis and Lister, 1988) could have caused the net decrease in subsidence rate that is interpreted to have resulted in the sedimentologic differences between the megacyclic unit and the upper unit of the Vasquez Formation (fig. $2 B$ ). If so, then the available age constraints imply that extension was ongoing for at least 3 to 4 million years before the depositional record showed the effects of lower-plate rebound. A similar mechanism has been suggested to explain temporal variations in depositional systems in other detachment-related basins (Beratan, this volume). Uplift and doming of the detachment footwall would also have arched the detachment itself, thus explaining the present shallow southward dip of the detachment fault in the Texas Canyon area (fig. $2 C$ ). The culmination of isostatic uplift may be reflected in the deformation of the Vasquez Formation prior to Tick Canyon time, as the rising footwall flexure caused local block-rotation contraction in the upper plate. Pre-Tick Canyon deformation could not have been related to proposed clockwise rotations of the central Transverse Ranges crustal block (Terres, 1984), because regional displacement histories of units across the San Andreas fault system require that these clockwise rotations occurred no earlier than $16 \mathrm{Ma}$, or 2 million years after earliest Tick Canyon Formation deposition. The appearance of clasts of the Pelona Schist in the middle part of the Tick Canyon Formation implies that the rising footwall (Sierra Pelona anticline) of the basal detachment fault breached the surface and created a sediment source immediately after deposi- 
tion of the Tick Canyon Formation began. Fission-track retention ages of $17.5 \pm 2.1 \mathrm{Ma}$ (apatite) from upper-plate rocks of the western San Gabriel Mountains (Cummings and others, 1982), signal the culmination of a significant pretransform-fault (pre-Mint Canyon Formation) uplift and cooling event during deposition of the Tick Canyon Formation, roughly 6 to 8 million years after the initiation of Soledad basin (upper plate) extension at about $26 \mathrm{Ma}$.

Whereas the Tick Canyon Formation reflects the infilling of local depressions formed during the final phase of extension and footwall rebound, the Mint Canyon Formation reflects (1) broad integration between the Soledad basin region and areas to the east across the former volcanic center of Soledad Pass, (2) development of external drainage, and, (3) in the upper part of the Mint Canyon Formation, the effects of transform tectonics (Crowell, 1975). Onlap of the lower conglomeratic sandstone unit of the Mint Canyon Formation (approximately $16 \mathrm{Ma}$ ?) across normal faults of the detachment upper plate (Soledad, Pelona, Green Ranch, and Vasquez Canyon faults) (Jahns and Muehlberger, 1954) suggests that crustal extension had ceased in this area by early middle Miocene time.

\section{REFERENCES CITED}

Bailey, T.L., and Jahns, R.H., 1954, Geology of the Transverse Ranges province, southern Califormia: California Division of Mines and Geology Bulletin 170, p. 83-106.

Bishop, K.M., 1989, Constraints on the structural development of the Texas Canyon subbasin: Los Angeles, California State University, M.S. thesis, 104 p.

Bishop, K.M., and Ehlig, P.L., 1990, The Pelona fault, central Transverse Ranges, southern California: an extensional detachment fault? [abs.]: Geological Society of America Abstracts with Programs, v. 22, no. 3, p. 8.

Blair, T.C., and Bilodeau, W.L., 1988, Development of tectonic cyclothems in rift, pull-apart and foreland basins: sedimentary response to episodic tectonism: Geology, v. 16 , no. 6 , p. 517-520.

Buesch, D.C., and Ehlig, P.L., 1982, Structural and lower Miocene volcanic rock correlation between Soledad Pass and Salton Wash along the San Andreas fault [abs.]: Geological Society of America Abstracts with Programs, v. 14, no. 4, p. 153.

Bull, W.B., 1977, The alluvial fan environment: Progress in Physical Geography, v. 1, no. 2, p. 222-270.

Carter, B.A., 1982, Geology and structural setting of the San Gabriel anorthosite-syenite body and adjacent rocks of the western San Gabriel mountains, Los Angeles County, California, in Cooper, J.D., compiler, Geologic excursions in the Transverse Ranges, southern California: Geological Society of America, Cordilleran Section, 78th, Anaheim, Calif., April 1982, Volume and Guidebook, Field Trip nos. 5, 6, and 11, p. 1-56.

Crowell, J.C., 1973, Problems concerning the San Andreas fault system in southern California, in Kovach, R.L., and Nur,
Amos, eds., Proceedings of the Conference on Tectonic Problems of the San Andreas Fault System: Stanford University Publications in Geological Sciences, v. 13, p. 125-135.

1975, The San Andreas fault in southern California: California Division of Mines and Geology Special Report 118, p. 7-26.

Cummings, David, Weiss, J., and Haines, E.L., 1982, Cretaceous and Miocene fission-track retention ages from Precambrian rocks, and thermal history of the western San Gabriel Mountains, southern California, in Fife, D.L., and Minch, J.A., eds., Geology and mineral wealth of the California Transverse Ranges: Santa Ana, Calif., South Coast Geological Society, p. 297-303.

Davis, G.A., and Lister, G.S., 1988, Detachment faulting in continental extension: perspectives from the southwestern U.S. Cordillera, in Clark, S.P., Jr., Burchfiel, B.C., and Suppe, J., eds., Processes in continental lithospheric deformation: Geological Society of America Special Paper 218, p. 133-159.

Durham, J.W., Jahns, R.H., and Savage, D.E., 1954, Marine-nonmarine relationships in the Cenozoic section of southern California: California Division of Mines and Geology Bulletin 170 , p. $59-72$.

Ehlert, K.W., 1982, Basin analysis of the Miocene Mint Canyon Formation, southem California, in Ingersoll, R.V., and Woodburne, M.O., eds., Cenozoic nonmarine deposits of Califomia and Arizona: Los Angeles, Calif., Pacific Section, Society of Economic Paleontologists and Mineralogists, p. 51-64.

Ehlig, P.L., 1981, Origin and tectonic history of the basement terrane of the San Gabriel Mountains, central Transverse Ranges, in Emst, W.G., ed., The geotectonic development of California (Rubey Volume 1): Englewood Cliffs, N.J., Prentice-Hall, p. 253-283.

Evans, J.G., 1982, The Vincent thrust, eastern San Gabriel Mountains, California: U.S. Geological Survey Bulletin $1507,21 \mathrm{p}$.

Hendrix, E.D., 1989, Basin analysis, facies architecture and tectonic implications of the Oligo-Miocene Vasquez Formation, Soledad basin, Califomia [abs.]: American Association of Petroleum Geologists, Pacific Section, Abstracts with Programs, v. 73-74, p. 541.

Hendrix, E.D., and Ingersoll, R.V., 1987, Tectonics and alluvial sedimentation of the upper Oligocene/lower Miocene Vasquez Formation, Soledad basin, southern California: Geological Society of America Bulletin, v. 98, no. 6, p. 647-663.

$\longrightarrow$ in press, Alluvial facies architecture and sedimentologic evolution of a small terrestrial rift basin: the Oligo-Miocene Vasquez Formation, central Transverse Ranges, California: Sedimentary Geology.

Hooke, R.L., 1968, Steady-state relationships on arid region alluvial fans in closed basins: American Journal of Science, v. 266 , no. 8 , p. $609-629$.

Howard, K.A., and John, B.E., 1987, Crustal extension along a rooted system of imbricate low-angle faults, Colorado River extensional corridor, California and Arizona, in Coward, M.P., Dewey, J.F., and Hancock, P.L., eds., Continental extensional tectonics: Geological Society of London Special Publication 28, p. 299-311.

Jahns, R.H., 1940, Stratigraphy of the easternmost Ventura basin, California, with a description of a new lower Miocene 
mammalian fauna from the Tick Canyon Formation: Carnegie Institution of Washington Publication 514, p. 145-194.

Jahns, R.H., and Muehlberger, W.R., 1954, Geology of the Soledad basin, Los Angeles County, California: California Division of Mines and Geology Bulletin 170, v. 2, Map Sheet 6, scale approximately 1:85,000.

Lander, E.B., 1985, Early and middle Miocene continental vertebrate assemblages, central Mojave desert, San Bernardino County, California, in Reynolds, R.E., compiler, Geological investigations along Interstate 15 , Cajon Pass to Manix Lake, California: Redlands, Calif., San Bernardino County Museum, p. 127-144.

Muehlberger, W.R., 1958, Geology of northern Soledad basin, Los Angeles County, California: American Association of Petroleum Geologists Bulletin, v. 42, no. 8, p. 1,812-1,844.

Oakeshott, G.B., 1958, Geology and mineral deposits of San Fernando quadrangle, Los Angeles County, California: California Division of Mines Bulletin 172, 147 p.

Paola, Chris, 1988, Subsidence and gravel transport in alluvial basins, in Kleinspehn, K.L., and Paola, Chris, eds., New perspectives in basin analysis: Springer-Verlag, New York, p. 231-243.

Powell, R.E., 1981, Geology of the crystalline basement complex, eastern Transverse Ranges, southem California: constraints on regional tectonic interpretation: Pasadena, California Institute of Technology, Ph.D. dissertation, 441 p.

Robinson, Kevin, and Frost, Eric, 1989, Orocopia Mountains detachment system: Progressive ductile to brittle development of a tilted crustal slab during regional extension [abs.]: Geological Society of America Abstracts with Programs, v. 21, no. 5 , p. 135.
Sams, R.H., 1964, Geology of the Charlie Canyon area, Los Angeles County: Los Angeles, University of California, M.S. thesis, $101 \mathrm{p}$.

Saul, R.B., and Wooton, T.M., 1983, Geology of the south half of the Mint Canyon quadrangle, Los Angeles County, California: California Division of Mines and Geology Open-File Report 83-24LA, 139 p.

Spencer, J.E., 1984, Role of tectonic denudation in warping and uplift of low-angle normal faults: Geology, v. 12, no. 2, p. 95-98.

Terres, R.R., 1984, Paleomagnetism and tectonics of the central and eastern Transverse Ranges, southern California: Santa Barbara, University of California, Ph.D. dissertation, 323 p.

Weigand, P.W., 1982, Middle Cenozoic volcanism of the western Transverse Ranges, in Fife, D.L., and Minch, J.A., eds., Geology and mineral wealth of the California Transverse Ranges: Santa Ana, Calif., South Coast Geological Society, p. 170-188.

Weigand, P.W., and Frizzell, V.A., 1986, Age and geochemical data from volcanic rocks in the Plush Ranch, Vasquez and Diligencia Formations, southern California: implications for reconstruction of the San Andreas fault [abs.]: Geological Society of America Abstracts With Programs, v. 18, no. 2, p. 196.

Wells, S.G., and Harvey, A.M., 1987, Sedimentologic and geomorphic variations in storm-generated alluvial fans, Howgill Fells, northwest England: Geological Society of America Bulletin, v. 98, no. 2, p. 182-198.

Woodburne, M.O., 1975, Cenozoic stratigraphy of the Transverse Ranges and adjacent areas, southern California: Geological Society of America Special Paper 162, 91 p. 


Northerm Cotonowood Mountains,
Death Valley, Califi.

$$
\text { Sroow (his olat) }
$$

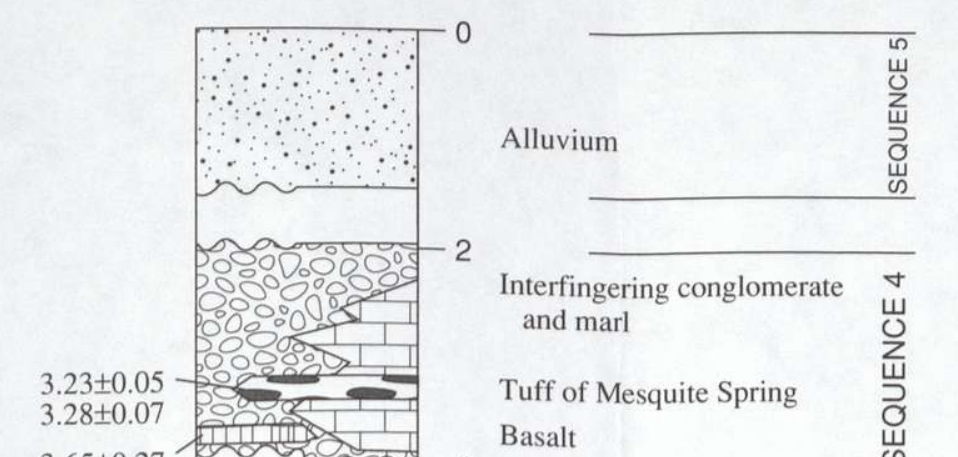

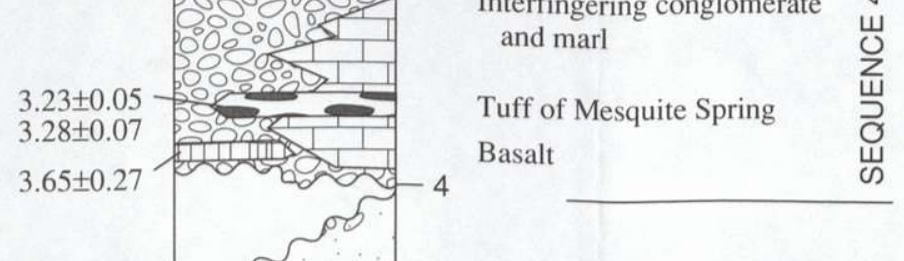
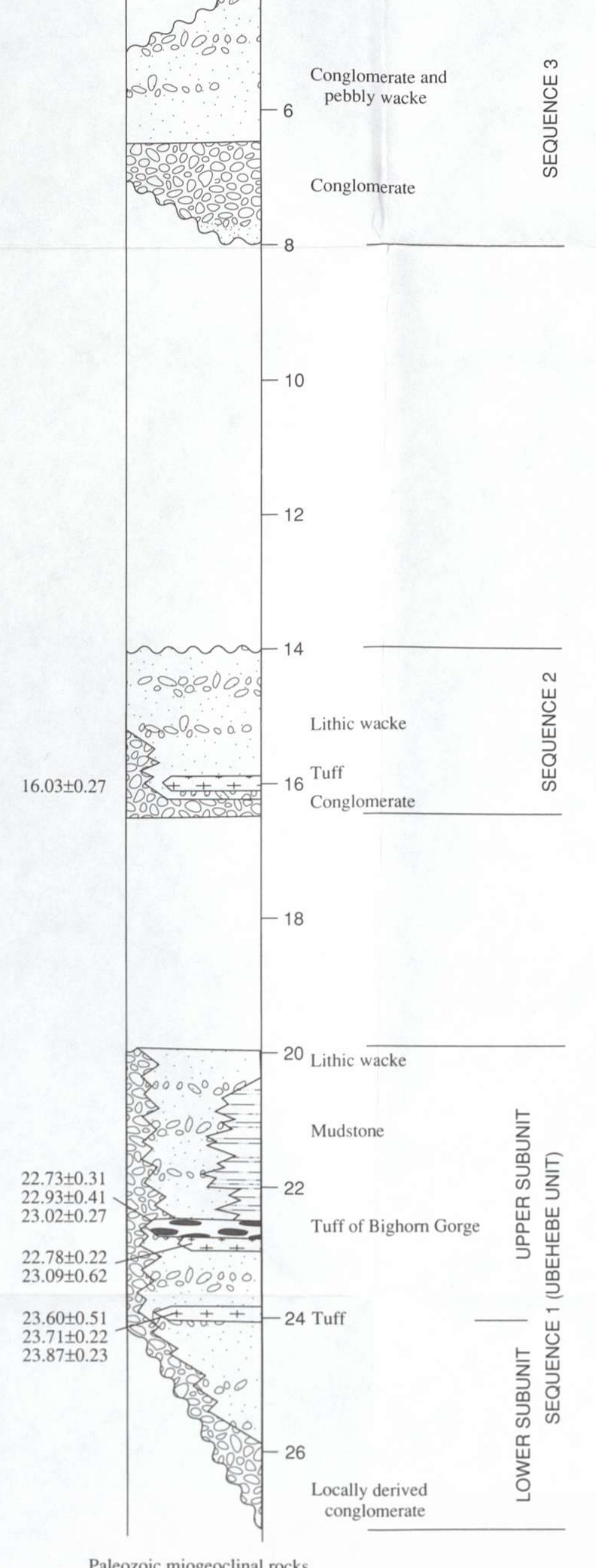

$1-\mathrm{H}$

Central Black Mountains, Ariz.

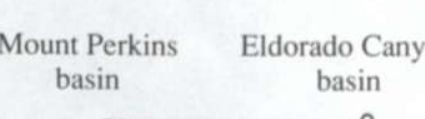

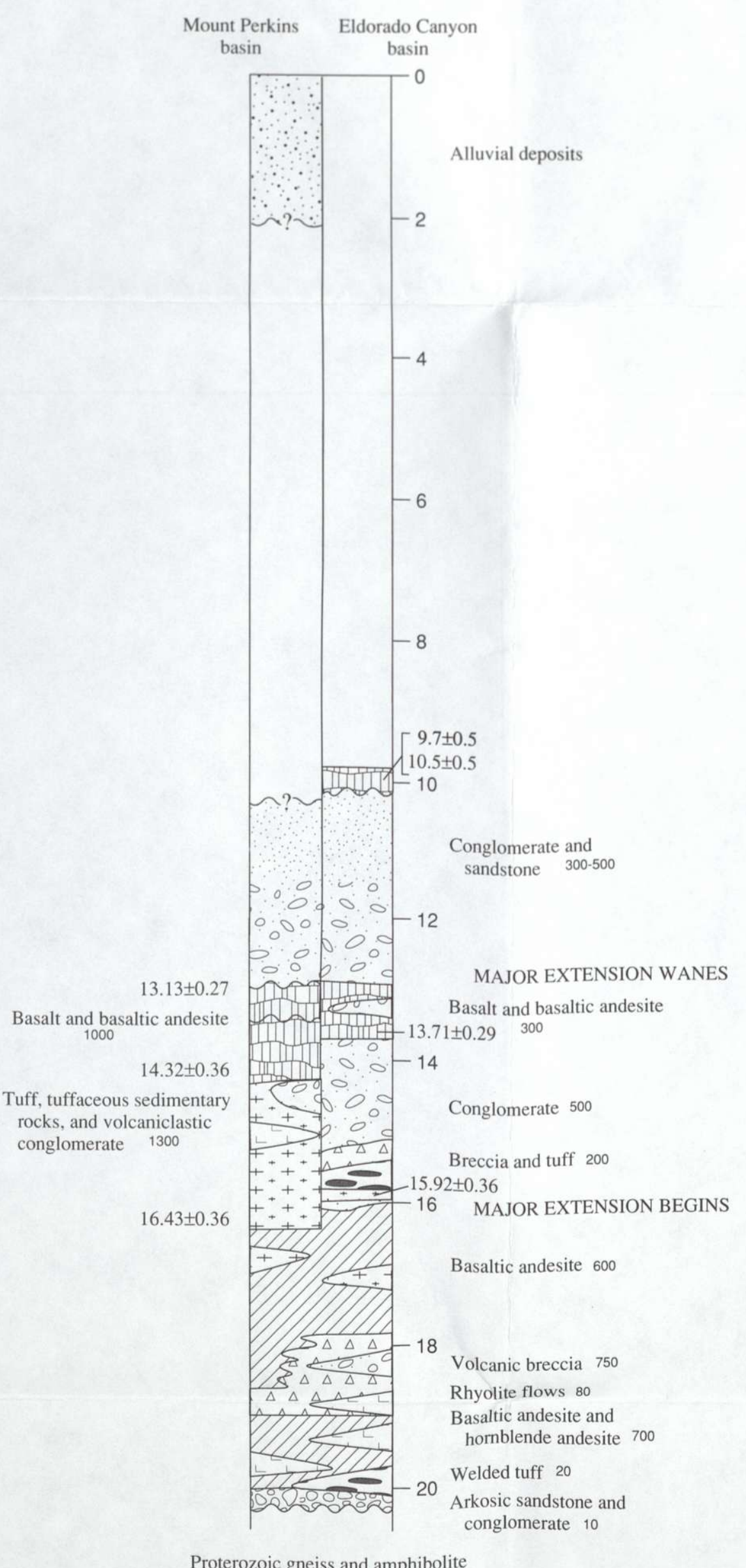

1-B

$1-\mathrm{C}$

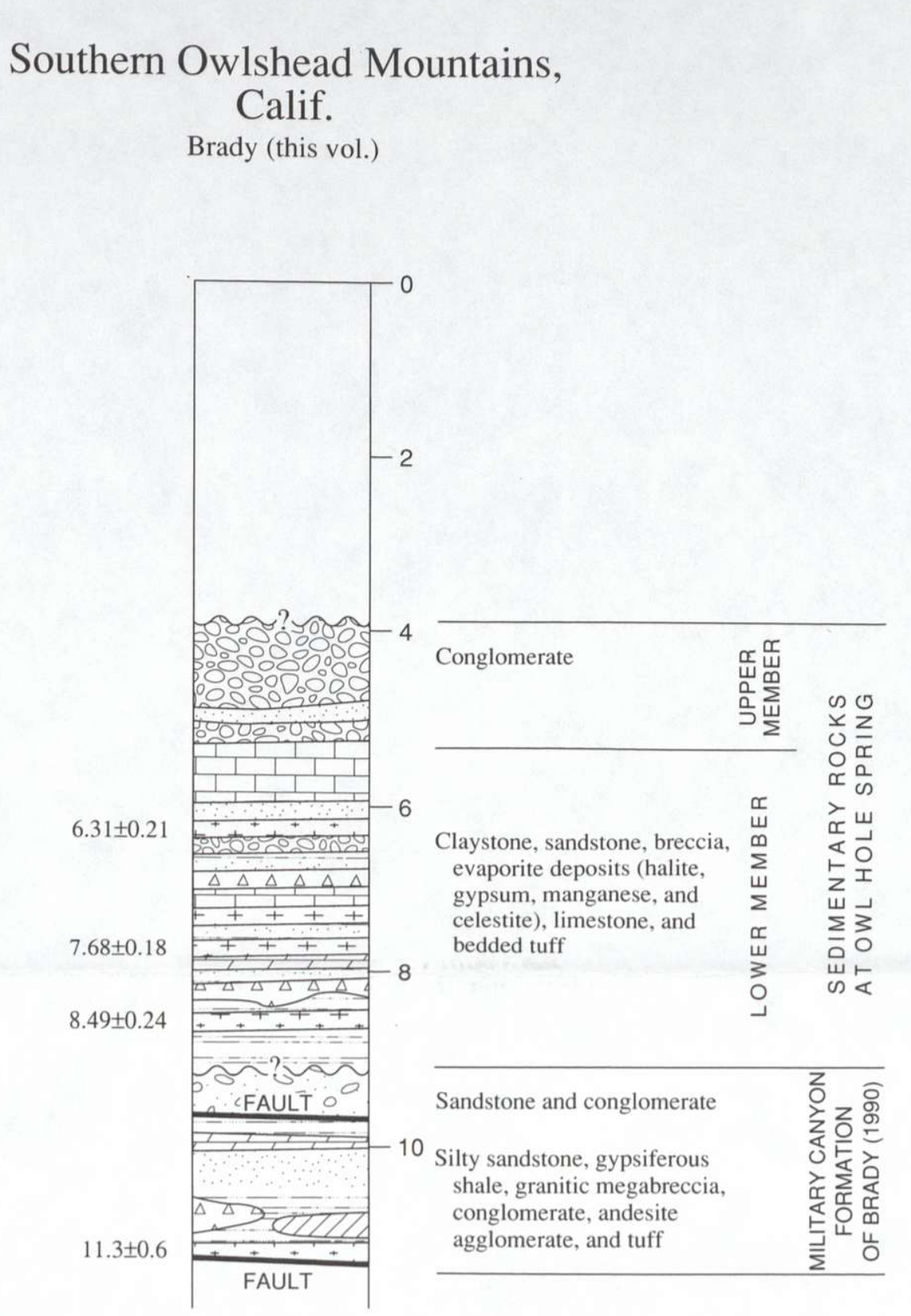

South Avawatz Mountains
Calif.
Spener (this vol.)

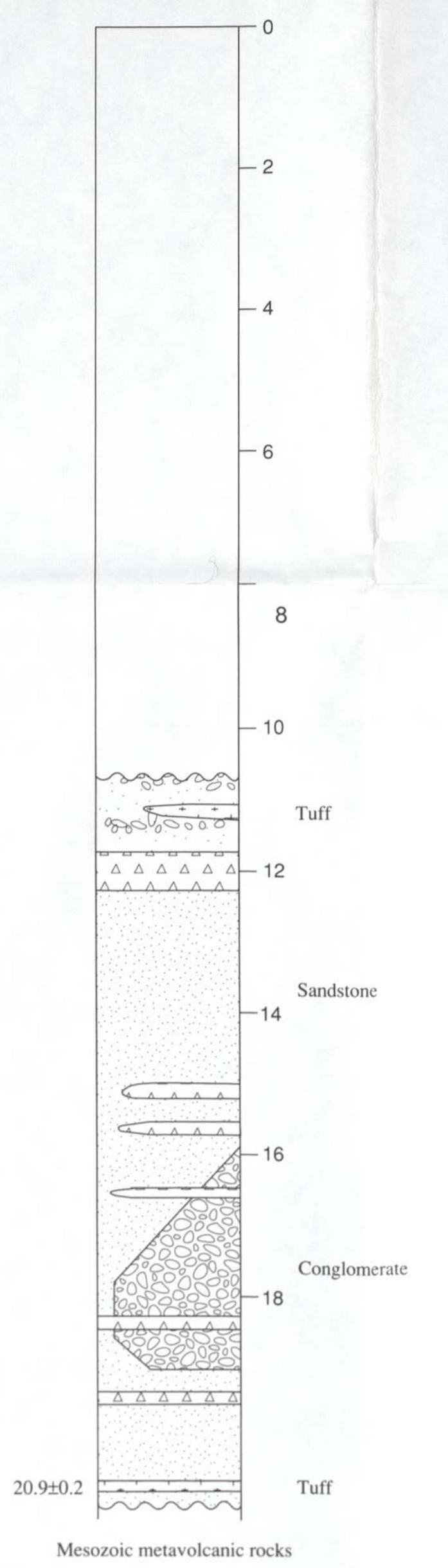

$1-\mathrm{E}$
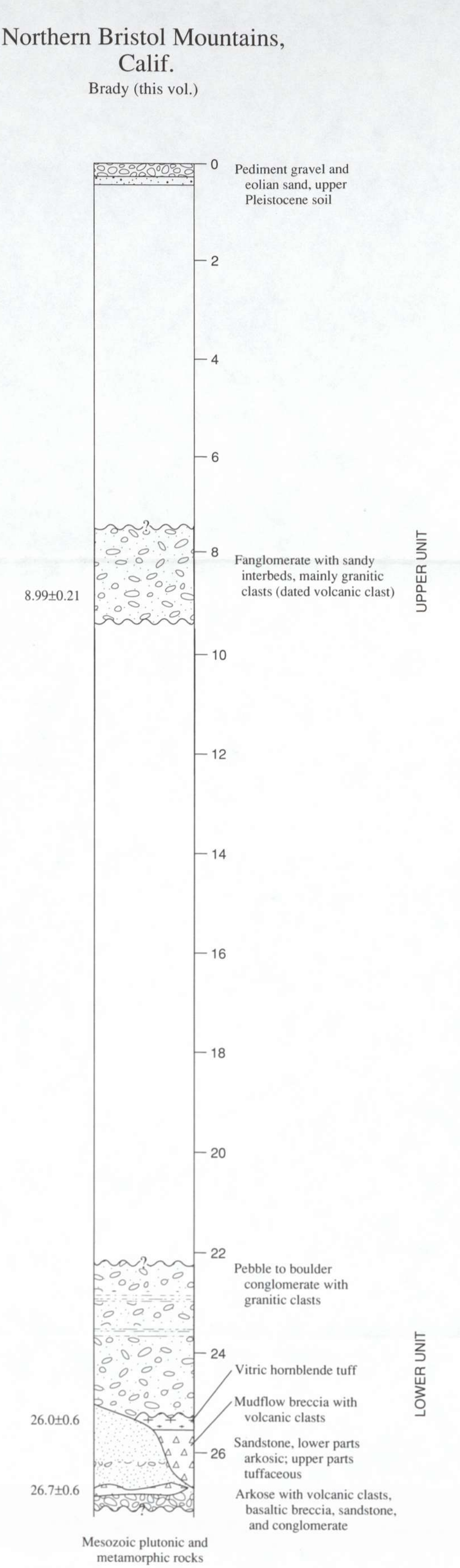

South Virgin Mountains, Nev.,
and Grand Wash Trough, Ariz

Lake Mead Area, Nev.
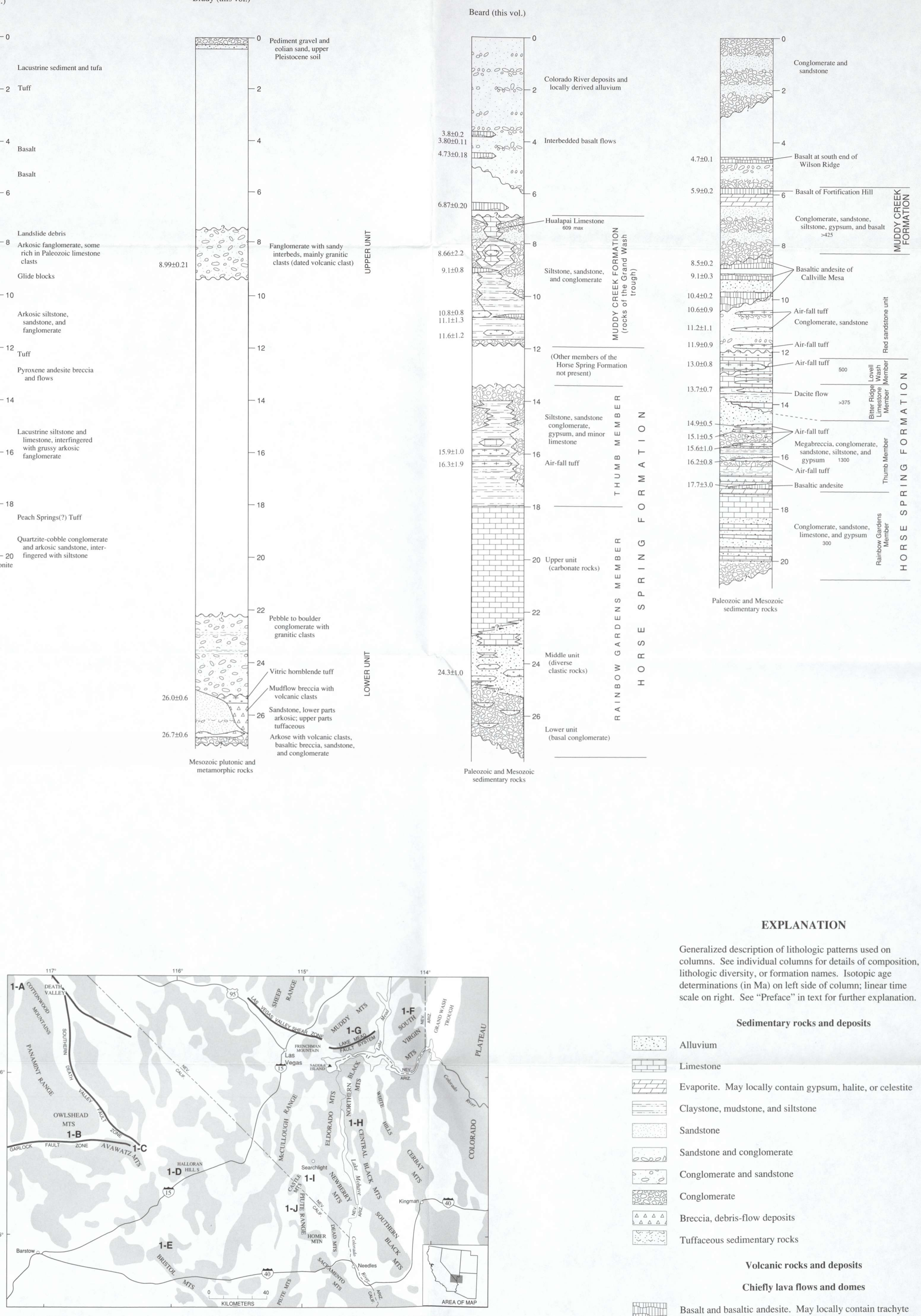

Piute Range, Calif. and Nev.
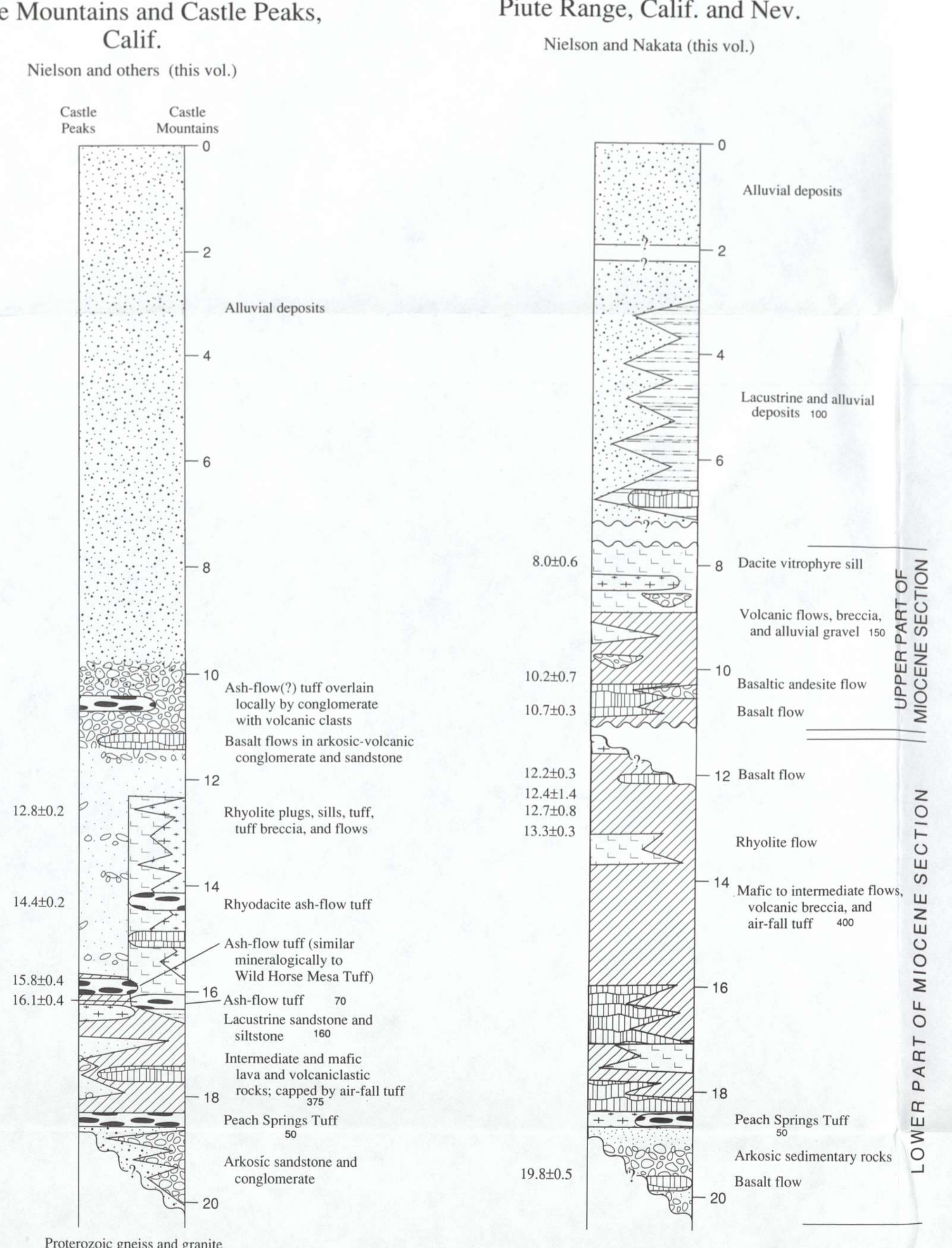

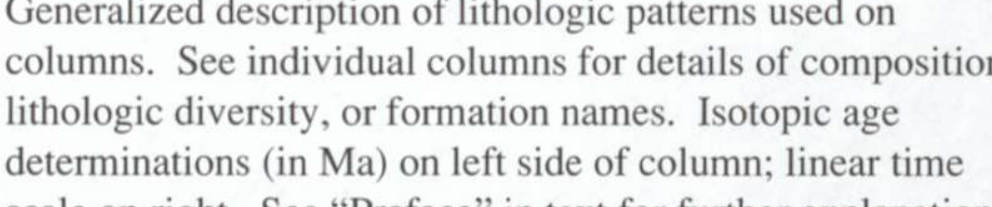
(n)

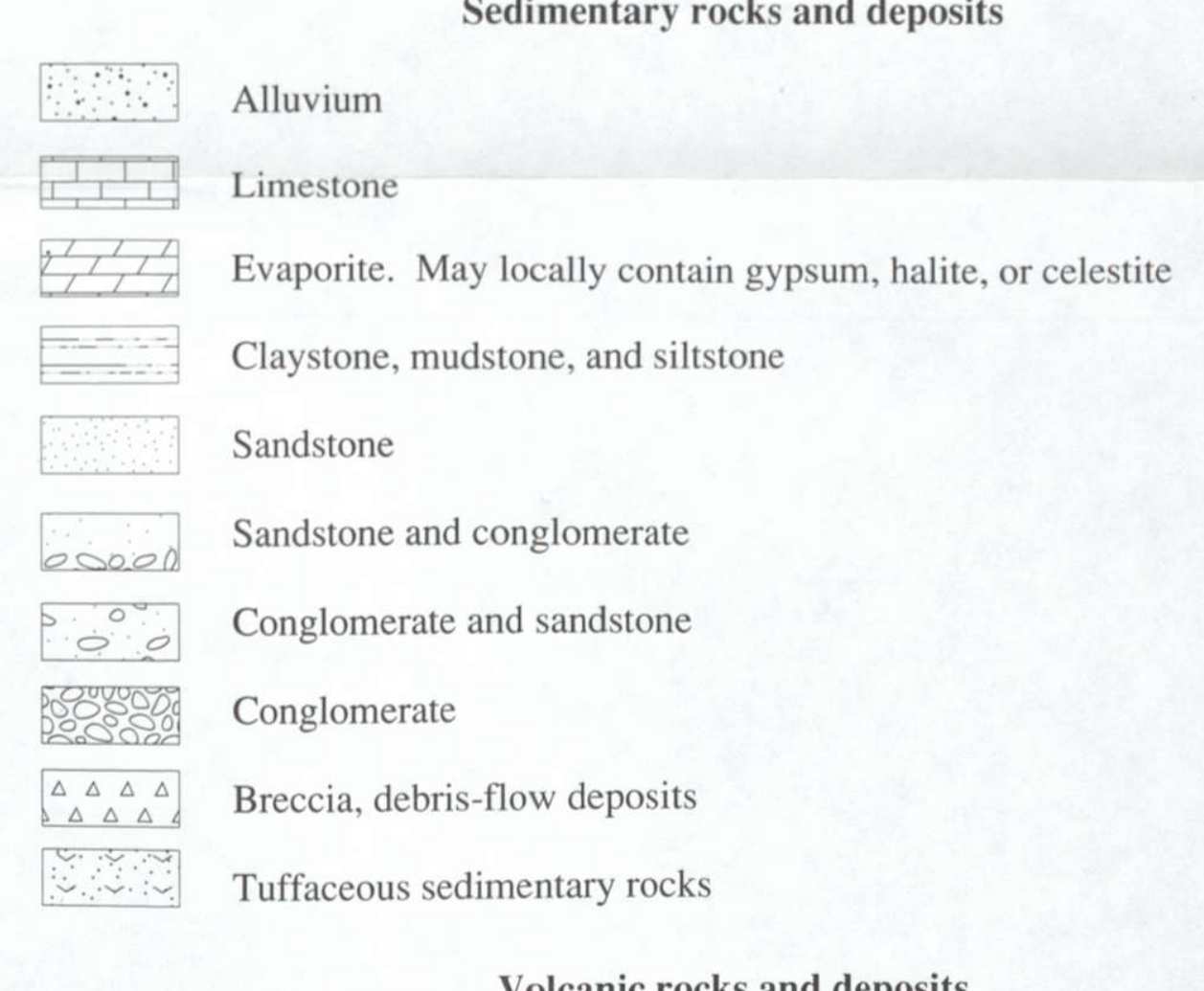

Voleanic rocks and deposits lava flows and domes

STRATIGRAPHIC COLUMNS FROM NORTHERN PART OF STUDY AREA: NORTH OF I-40 TERTIARY STRATIGRAPHY OF HIGHLY EXTENDED TERRANES, CALIFORNIA, ARIZONA, AND NEVADA David R. Sherrod and Jane E. Nielson, editors 


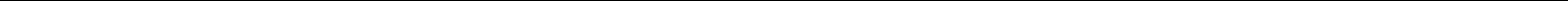



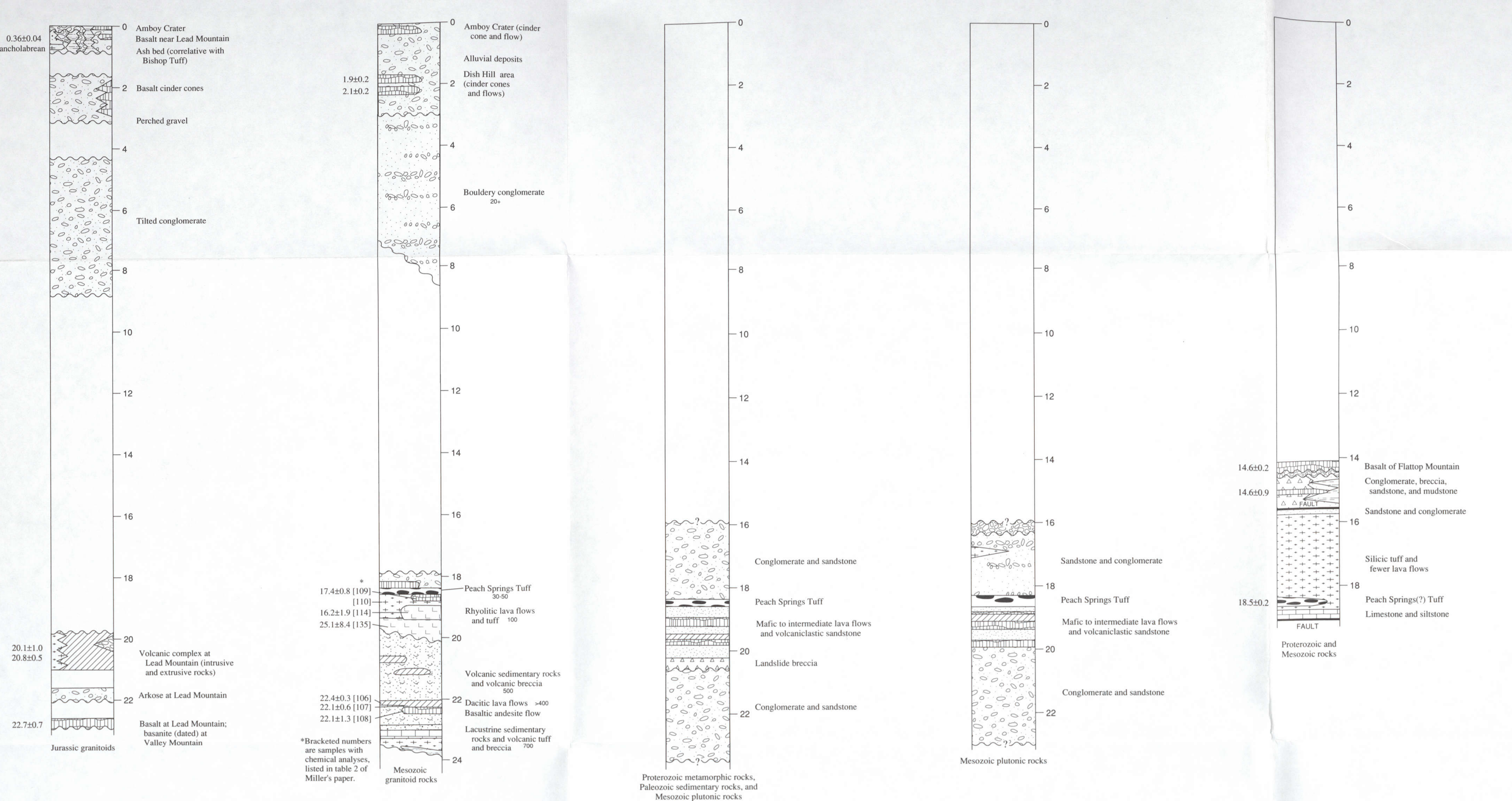

\section{Central Sacramento
Mountains Calif.
Mille nat Las Leash (this vol.)}

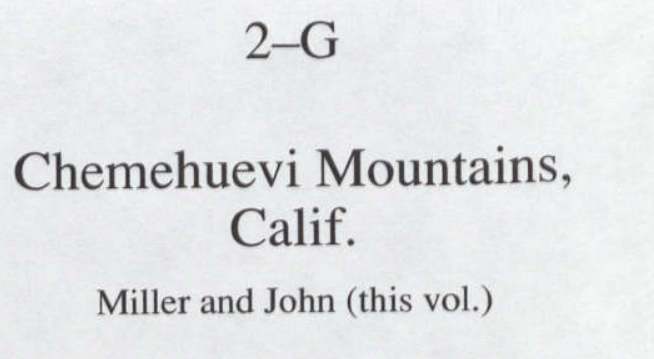

Northern Chemehuevi Valley,
Caliti., Stepladder Mountains
and Sawtooth Range)
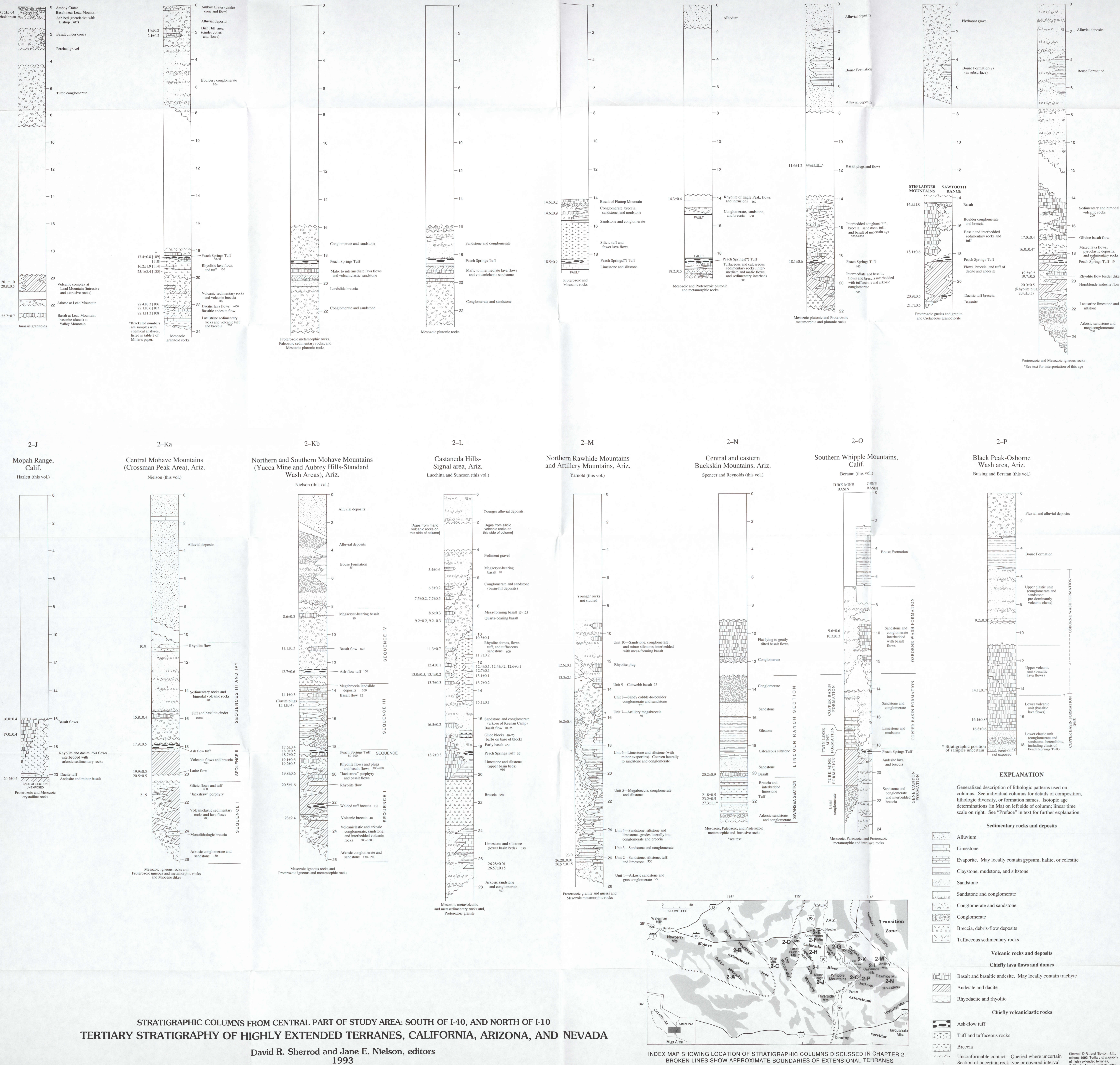

Black Peak-Osborne
Wash area, Ariz.

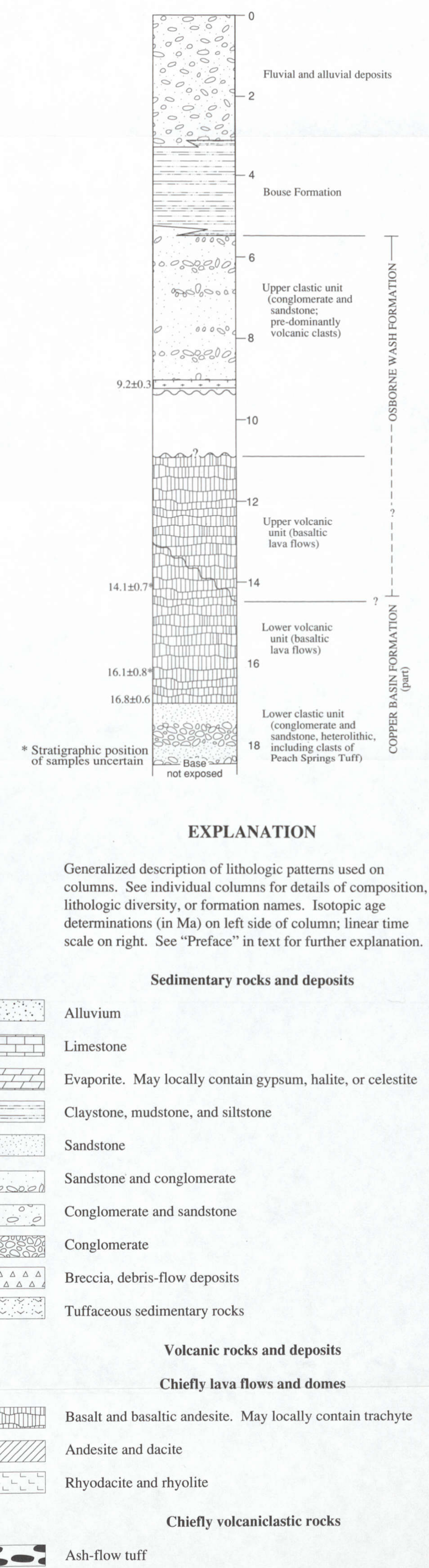

E-2. Ast

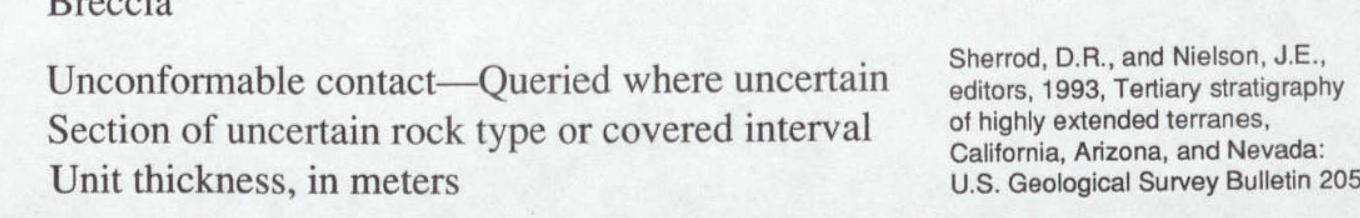





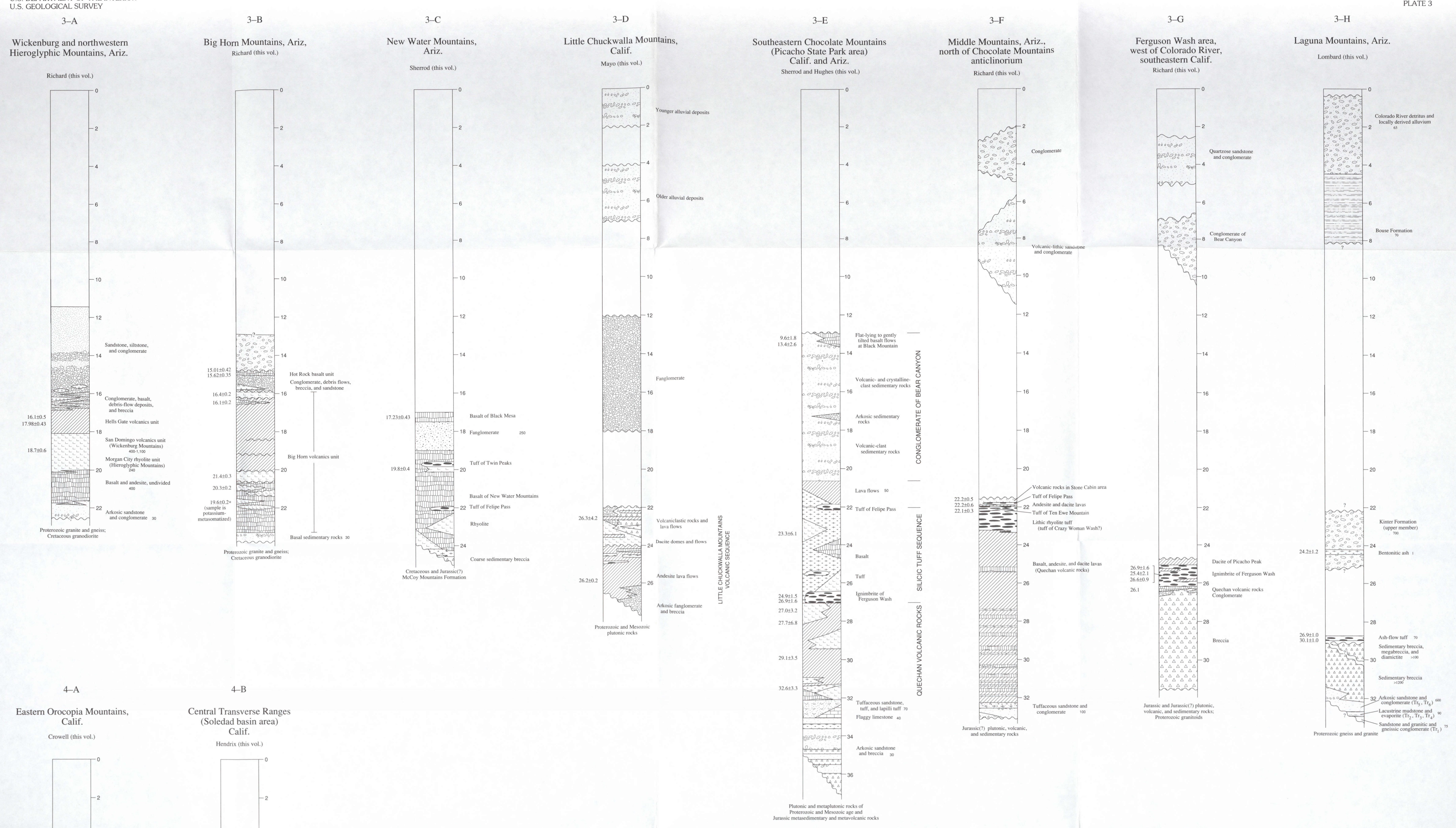

STRATIGRAPHIC COLUMNS FROM SOUTHERN AREA: SOUTH OF I-10
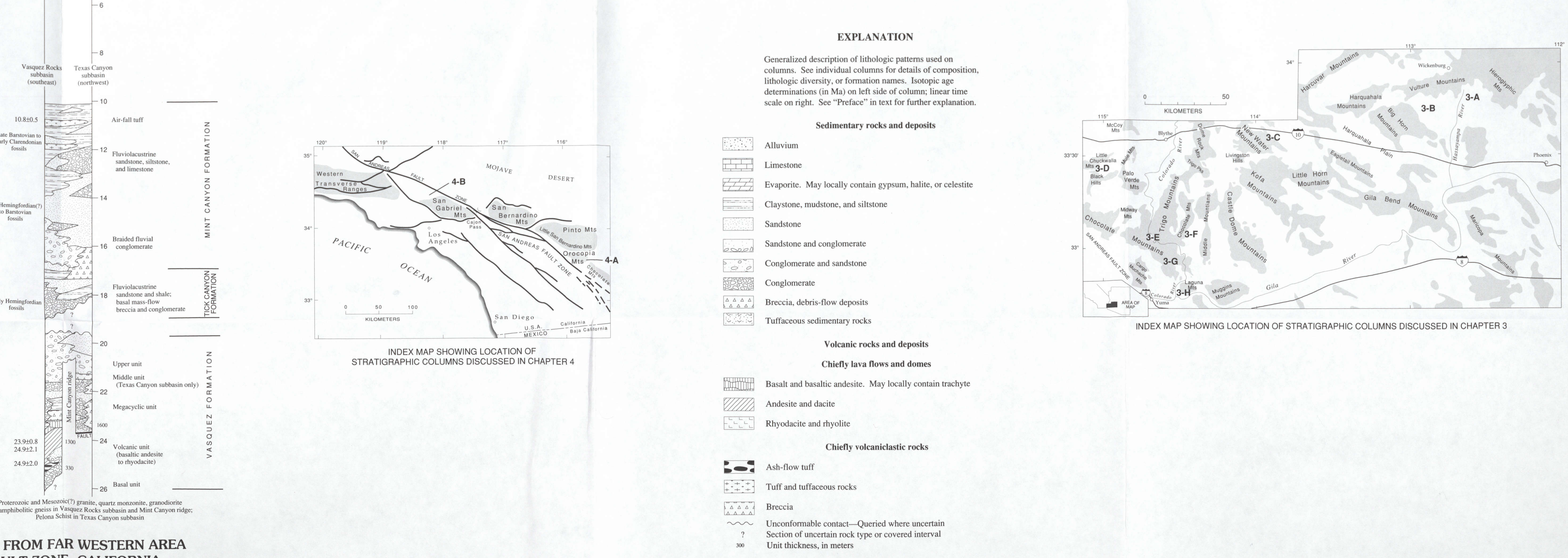
STRATIGRAPHIC COLUMNS FROM FAR WESTERN AREA
NEAR SAN ANDREAS FAULT ZONE, CALIFORNIA

TERTIARY STRATIGRAPHY OF HIGHLY EXTENDED TERRANES, CALIFORNIA, ARIZONA, AND NEVADA David R. Sherrod and Jane E. Nielson, editors 




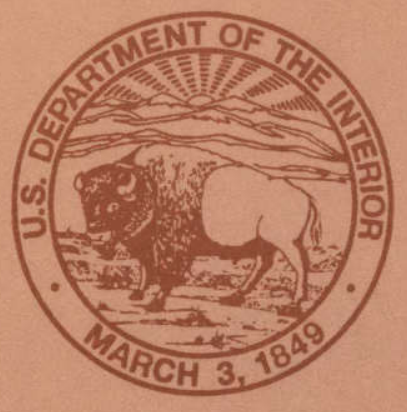

